
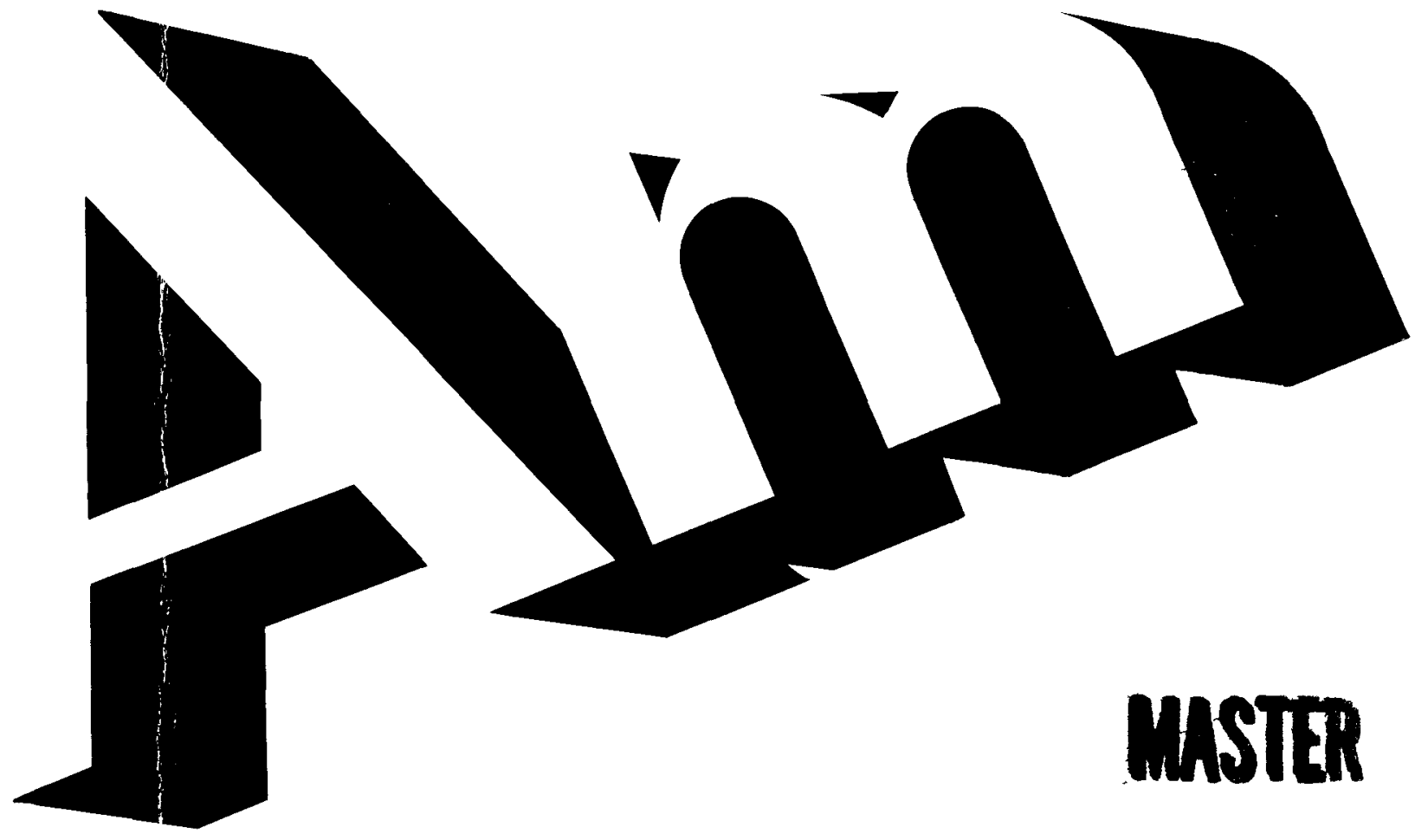

\title{
The Chemistry of
}

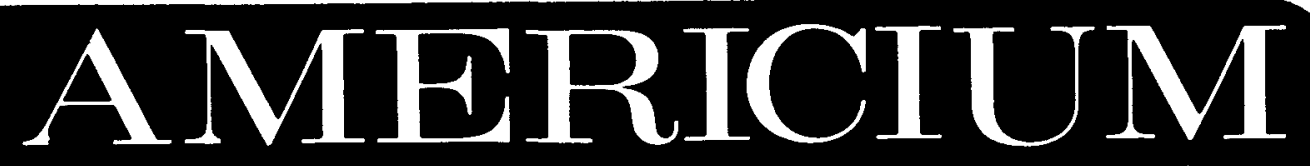

Wallace W. Schulz 


\section{DISCLAIMER}

This report was prepared as an account of work sponsored by an agency of the United States Government. Neither the United States Government nor any agency Thereof, nor any of their employees, makes any warranty, express or implied, or assumes any legal liability or responsibility for the accuracy, completeness, or usefulness of any information, apparatus, product, or process disclosed, or represents that its use would not infringe privately owned rights. Reference herein to any specific commercial product, process, or service by trade name, trademark, manufacturer, or otherwise does not necessarily constitute or imply its endorsement, recommendation, or favoring by the United States Government or any agency thereof. The views and opinions of authors expressed herein do not necessarily state or reflect those of the United States Government or any agency thereof. 


\section{DISCLAIMER}

Portions of this document may be illegible in electronic image products. Images are produced from the best available original document. 


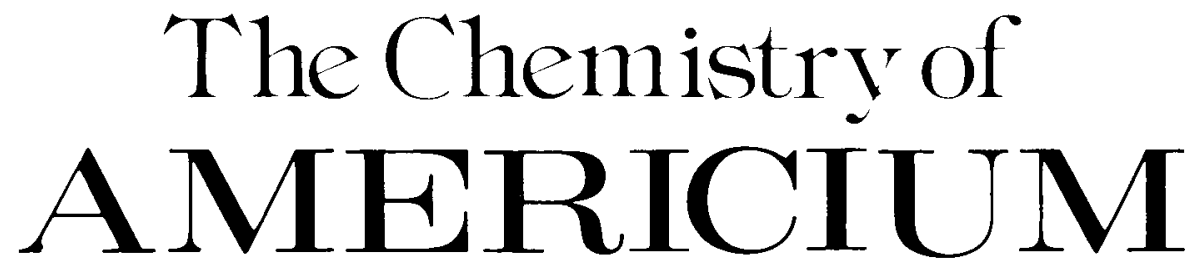

Wallace W. Schulz

Atlantic Richfield Hanford Company

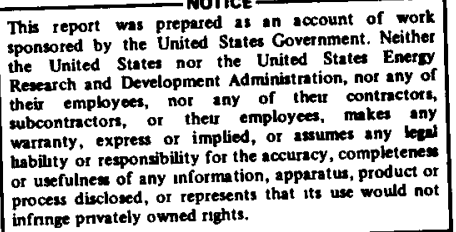

1976 
Library of Congress Cataloging in Publication Data

Schulz, Wallace $\mathrm{W}$

The chemistry of americium

(ERDA critical review series)

"TID-26971"

Includes indexes

1 Americium I Title II Series United States Energy

Research and Development Administration ERDA critical review series

QD181 A5S38 546' 441 76-25824

ISBN 0-87079-040-4

Avallable as TID-26971 for $\$ 6.00$ (foreign, $\$ 8.50$ ) from

National Technical Information Service

U.S. Department of Commerce

Springfield, Virginia 22161

\section{ERDA Distribution Category UC-4}

Printed in the United States of America

ERDA Technical Informatıon Center, Oak Rıdge, Tennessee

October 1976 


\section{FOREWORD}

The two principal americium isotopes of interest $\left({ }^{241} \mathrm{Am}\right.$ and $\left.{ }^{243} \mathrm{Am}\right)$ are both by-products of the nuclear industry and are expected to be available in relatively large quantities in the future. Americium-241, which is formed by beta decay, has been in short supply since it was first offered for sale in March 1962 at $\$ 1500$ per gram by the U.S. Atomic Energy Commission. The first material made available for sale came from the Atomic Energy Commission's Rocky Flats Plant. This source has been supplemented in recent years by the recovery of significant quantities of ${ }^{241} \mathrm{Am}$ at Richland and Savannah River reprocessing facilities.

Probably no actinide isotope has more uses than ${ }^{241} \mathrm{Am}$, which is used in nuclear gauges for numerous applications, in location sensing devices, in ${ }^{241} \mathrm{Am}-\mathrm{Be}$ neutron sources for oil well logging, etc., in static eliminators, in smoke detectors, and in many other applications. In addition, ${ }^{241} \mathrm{Am}$ has been used as a target material in nuclear reactors to produce ${ }^{242} \mathrm{Am}$, which has a number of potential uses, including its decay to ${ }^{238} \mathrm{Pu}$. Americium-243 is useful as a reactor target material for the production of ${ }^{244} \mathrm{Am},{ }^{252} \mathrm{Cf}$, and other actinides.

In 1968, Richland demonstrated the recovery of americium from high-level wastes generated from the reprocessing of the Shippingport blanket. This americium was subsequently isolated and purified by chromatographic processes. Significant quantities of ${ }^{243} \mathrm{Am}$ were produced in Savannah River production reactors as early as the late 1950s as part of special irradiations to produce transplutonium isotopes for research uses and in the ${ }^{252} \mathrm{Cf}$ production programs. Thus the Savannah River Laboratory has played an important role in the americium chemistry development programs. 
The long-range availability of americium looks attractive since increasing quantities of ${ }^{241} \mathrm{Am}$ and ${ }^{243} \mathrm{Am}$ could be expected from plutonium recycle either in light-water power reactors or fast breeder reactors. As greater quantities of these isotopes become available at reasonable prices, it can be expected that new and expanded uses will be found for them.

\section{F. P. Baranowski}

Director, Division of Nuclear Fuel Cycle and Production Energy Research and Development Administration 


\section{PREFACE}

This book has a straightforward purpose, that is, to collect and review in one place the essential features of the descriptive chemistry of americium as it is known in the mid-1970s. Highlights of this material are, of course, discussed in standard texts on the chemistry of the transuranium elements; but, because of space limitations, the coverage given americium is far from comprehensive. Other important aspects of americium chemistry are disclosed in widely scattered journal articles and in various governmental reports, both foreign and domestic, not always easily available to all the scientific community. These circumstances coupled with the great advances in our knowledge of americium chemistry during the past decade provide more than sufficient motivation for this review.

Americium chemistry is delineated here within the traditional "occurrenceproperties-compounds-uses" framework. No attempt is made to compare americium chemistry with that of other actinide elements, this task being more properly in the scope of books that discuss the chemistry of all the transuranium elements. A chapter on the analytical chemistry of americium, provisionally included in the initial outline of this review, was omitted - partly to reduce the length of the manuscript but mainly because of the recent appearance of an excellent book* that treats the subject in great detail. Missing from this text also is any discussion of the behavior of americium in biological and ecological systems; this is a vast and important segment of americium chemistry which would more fittingly be reviewed by qualified life scientists.

*B. F. Myasoedov, L. I. Guseva, I. A. Lebedev, M. S. Milyukova, and M. K. Chmutova, Analytical Chemistry of Transplutonium Elements, John Wiley \& Sons, Inc., New York, 1974. 
This book could not have been written without the cooperation and counsel of a great many talented scientists and engineers at various Energy Research and Development Administration (ERDA) laboratories and installations. Stimulating discussions of various facets of americium chemistry were held with $R$. A. Penneman and L. B. Asprey of the Los Alamos Scientific Laboratory; with W. H. Hale of the Savannah River Laboratory; with E. J. Wheelwright of the Battelle Pacific Northwest Laboratories; with R. E. Leuze of the Oak Ridge National Laboratory; and with J. B. Knighton, S. G. Proctor, and F. J. Minor at the Rocky Flats site. J. L. Ryan, Battelle Pacific Northwest Laboratories, a recognized authority on the chemistry of the transuranium elements, kindly reviewed the entire manuscript and made many helpful suggestions for its improvement. I am indebted also to T.D. Chikalla and R.P. Turcotte of the Battelle Pacific Northwest Laboratories for an expert critique of the chemistry of americium oxides.

The many drafts of the manuscript of the book were carefully typed (and retyped!) by Eleanore Earhart and Judy Foley, amanuenses of exceptional ability.

My special thanks go to my dear wife, Dorothy, and to R. F. Pigeon of ERDA's Office of Technical Information, for their encouragement and great patience while this book was being written.

Wallace W. Schulz

Atlantic Richfield Hanford Company 


\section{CONTENTS}

1 Discovery; Atomic and Nuclear Properties; Collateral Reading 1

Discovery

Isotopes and Nuclear Properties 1

Atomic Properties 4

Collateral Reading 14

2 Production and Uses 23

Introduction 23

Production of ${ }^{241} \mathrm{Am}$ by Irradiation of ${ }^{239} \mathrm{Pu}$

Production of ${ }^{243} \mathrm{Am}$ by Irradiation of ${ }^{242} \mathrm{Pu} \quad 24$

Availability of ${ }^{241} \mathrm{Am}$ and ${ }^{243} \mathrm{Am}$ from Power Reactors 27

Applications of ${ }^{241} \mathrm{Am} \quad 29$

Applications of ${ }^{243} \mathrm{Am}$

3 Chemistry in Aqueous Solution 47

Oxidation States $\quad 47$

Thermodynamic Values $\quad 55$

Electrode Potentials $\quad 55$

Autoreduction Effects $\quad 58$

Disproportionation $\quad 60$

Kinetics of Oxidation-Reduction Reactions $\quad 64$ 
$\begin{array}{ll}\text { Solution Absorption Spectra } & 72\end{array}$

Complexes of Americium lons 85

4 Metal, Alloys, and Compounds 122

$\begin{array}{ll}\text { 'Metal } & 122\end{array}$

Alloys and Intermetallic Compounds $\quad 126$

$\begin{array}{ll}\text { Compounds } & 131\end{array}$

5 Recovery; Separation; Purification 184

Introduction $\quad 184$

Pyrochemical Processes $\quad 185$

Precipitation Processes $\quad 189$

Solvent Extraction Processes $\quad 195$

Ion-Exchange Processes 233

Extraction Chromatographic Processes $\quad 255$

Miscellaneous Separation Techniques $\quad 255$

Author Index $\quad 281$

Subject Index $\quad 287$ 


\section{DISCOVERY; ATOMIC AND NUCLEAR PROPERTIES; COLLATERAL READING}

\section{DISCOVERY}

Americium, element 95, the third element past uranium, was actually the fourth transuranium element to be discovered-after curium. Working at the wartime Metallurgical Laboratory of the University of Chicago, Seaborg, Ghiorso, James, and Morgan in late 1944 and early 1945 identified ${ }^{241}$ Am produced by the reactions

$$
{ }^{239} \mathrm{Pu}(\mathrm{n}, \gamma){ }^{240} \mathrm{Pu}(\mathrm{n}, \gamma){ }^{241} \mathrm{Pu} \underset{14.3 \text { years }}{\stackrel{\beta}{\longrightarrow}}{ }^{241} \mathrm{Am}
$$

Historical details surrounding discovery and identification of ${ }^{241} \mathrm{Am}$, including the first (Nov. 11, 1945) announcement of its discovery on a national radio program, have been recounted by Seaborg and others. ${ }^{1-8}$ By analogy with the naming of its rare-earth homolog, europium, after Europe, element 95 was named (in 1946) americium after the Americas. Less than a year after it was discovered, Cunningham ${ }^{9,10}$ isolated americium in pure form as the compound $\mathrm{Am}(\mathrm{OH})_{3}$ and made the first measurements of its absorption spectrum in aqueous solution.

The longest lived americium isotope, ${ }^{243} \mathrm{Am}\left(\mathrm{t}_{1 / 2}=7400\right.$ years $)$, was identified in 1950 by Seaborg, Ghiorso, and Street ${ }^{11}$ as the product resulting from two successive neutron captures by ${ }^{241} \mathrm{Am}$. Now americium isotopes with all the mass numbers from 232 to 247 are known or at least have been tentatively identified.

\section{ISOTOPES AND NUCLEAR PROPERTIES}

Key data relative to the synthesis and radioactive decay properties of all the presently known isotopes of americium are compiled in Table 1.1. (Details of the 
Table 1.1

AMERICIUM ISOTOPES AND PROPERTIES

\begin{tabular}{|c|c|c|c|c|c|}
\hline $\begin{array}{c}\text { Mass } \\
\text { number }^{a}\end{array}$ & Half-lıfe $e^{b}$ & Decay mode ${ }^{c}$ & Principal radiations, $\mathrm{MeV}$ & $\begin{array}{l}\text { Principal synthesis } \\
\text { reactions }\end{array}$ & Refs. \\
\hline 232 & $1.4 \mathrm{~min}$ & SF isomer & & ${ }^{230} \mathrm{Th}\left({ }^{10} \mathrm{~B}, 8 \mathrm{n}\right)$ & $13-15$ \\
\hline 234 & $33 \pm 0.1 \mathrm{~min}$ & $\alpha$ & $\alpha 6.46$ & ${ }^{230} \mathrm{Th}\left({ }^{10} \mathrm{~B}, 6 \mathrm{n}\right)$ & 13,15 \\
\hline $235^{m \mathrm{~d}}$ & & & & ${ }^{237} \mathrm{~Np}\left({ }^{4} \mathrm{He}, 6 \mathrm{n}\right)$ & 16 \\
\hline $236^{m d}$ & & & & ${ }^{237} \mathrm{~Np}\left({ }^{4} \mathrm{He}, 5 \mathrm{n}\right)$ & 16 \\
\hline 237 & $75 \mathrm{~m}$ !n & $\begin{array}{l}\mathrm{EC} 99+\% \\
\alpha 0005 \%\end{array}$ & $\alpha \cdot 6.02$ & ${ }^{239} \mathrm{Pu}(\mathrm{d}, 4 \mathrm{n})$ & $17-19$ \\
\hline $237^{m}$ & $5 \mathrm{nsec}$ & SF 1somer & & ${ }^{238} \mathrm{Pu}(\mathrm{p}, 2 \mathrm{n})$ & 20 \\
\hline 238 & $186 \mathrm{hr}$ & $\mathrm{EC}, \alpha 10^{4} \%$ & $\begin{aligned} \gamma & 036,0.58,0.95,0.98 \\
& 1.35, \text { others }\end{aligned}$ & $\begin{array}{l}237 \mathrm{~Np}(\alpha, 3 \mathrm{n}) \\
239 \mathrm{Pu}(\mathrm{d}, 3 \mathrm{n})\end{array}$ & $21-24$ \\
\hline $238^{m}$ & $60 \mu \mathrm{sec}$ & SF isomer & & ${ }^{239} \mathrm{Pu}(\mathrm{p}, 2 \mathrm{n})$ & 25 \\
\hline 239 & $12.1 \mathrm{hr}$ & $\begin{array}{l}\mathrm{EC} \\
\alpha 0003-0.005 \%\end{array}$ & $\gamma 0.225,0.275$, others & $\begin{array}{l}239 \mathrm{Pu}(\mathrm{d}, 2 \mathrm{n}) \\
237 \mathrm{~Np}(\alpha, 2 \mathrm{n})\end{array}$ & $\begin{array}{l}17,21,23 \\
25-27\end{array}$ \\
\hline $239^{m}$ & $160 \mathrm{nsec}$ & $\mathrm{SF}$ 1somer & & $\begin{array}{l}240 \mathrm{Pu}(\mathrm{p}, 2 \mathrm{n}) \\
2{ }^{29} \mathrm{~Np}(\mathrm{~d}, 2 \mathrm{n})\end{array}$ & 28 \\
\hline 240 & $51.0 \mathrm{hr}$ & $\begin{array}{l}\mathrm{EC} \\
\alpha 19 \times 10^{-4} \%\end{array}$ & $\begin{array}{l}\gamma 090(23 \%) \\
1.00(77 \%) \\
1.40(<10 \%)\end{array}$ & $\begin{array}{l}240 \mathrm{Pu}(\mathrm{d}, \mathrm{n}) \\
2{ }^{39} \mathrm{Pu}(\alpha, \mathrm{p} 2 \mathrm{n}) \\
2{ }^{37} \mathrm{~Np}(\alpha, n)\end{array}$ & $\begin{array}{l}11,21,26 \\
29,30\end{array}$ \\
\hline $240^{m}$ & $0.90 \mathrm{msec}$ & SF isomer & & $\begin{array}{l}240 \mathrm{Pu}(\mathrm{d}, 2 \mathrm{n}) \\
{ }^{241} \mathrm{Pu}(\mathrm{p}, 2 \mathrm{n})\end{array}$ & 31 \\
\hline 241 & 4329 years & $\alpha$ & $\begin{array}{l}\alpha 549(85 \%), 5.44(13 \%) \\
\gamma 0.060(36 \%) \\
\text { Others see Fig. } 1.1\end{array}$ & ${ }^{241} \mathrm{Pu} \stackrel{\beta^{-}}{\longrightarrow}{ }^{21} \mathrm{Am}$ & $26,32-38$ \\
\hline $241^{m \mathrm{e}-\mathrm{h}}$ & $1.5 \mu \mathrm{sec}$ & SF 1somer & & $\begin{array}{l}241 \mathrm{Pu}(\mathrm{d}, 2 \mathrm{n}) \\
242 \mathrm{Pu}(\mathrm{p}, 2 \mathrm{n})\end{array}$ & 28 \\
\hline 242 & $16.01 \mathrm{hr}$ & $\begin{array}{l}\beta^{-}(82.8-84 \%) \\
\operatorname{EC~}(172-16 \%)\end{array}$ & 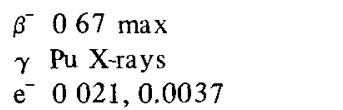 & ${ }^{241} \mathrm{Am}(\mathrm{n}, \gamma)$ & $30,39-44$ \\
\hline $242^{m 1 \mathrm{e}-\mathrm{h}}$ & 152 years & $\begin{array}{l}\text { IT } 99+\% \\
\alpha 0.48 \%\end{array}$ & $\begin{array}{lll}\mathrm{e} & 0 & 028,0.044 \\
\alpha & 5 & 21\end{array}$ & ${ }^{241} \mathrm{Am}(\mathrm{n}, \gamma)$ & $11,26,42,45$ \\
\hline
\end{tabular}




\begin{tabular}{|c|c|c|c|c|c|}
\hline $242^{m 2}$ & $14.0 \mathrm{msec}$ & SF isomer & $\begin{array}{l}\alpha 528(87 \%), 523(11.5 \%) \\
\text { Others see F1g } 12 \\
\gamma 0.044(5 \%), 0.075(61 \%) \\
\text { Others see Fig. } 12\end{array}$ & 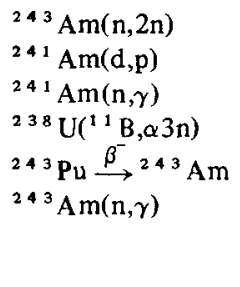 & $\begin{array}{l}11,30,33 \\
57,58\end{array}$ \\
\hline $243^{m}$ & $6.5 \mu \mathrm{sec}$ & SF isomer & & ${ }^{243} \mathrm{Am}(\mathrm{d}, \mathrm{pn})$ & 20 \\
\hline 244 & $10.1 \mathrm{hr}$ & $\beta$ & 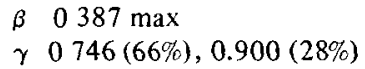 & ${ }^{243} \mathrm{Am}(\mathrm{n}, \gamma)$ & 58,59 \\
\hline $244^{m 1}$ & $26 \mathrm{~min}$ & $\begin{array}{l}\beta(99+\%) \\
\operatorname{EC}(0.039 \%)\end{array}$ & $\begin{array}{lll}\beta & 1 & 50 \max (80 \%), \text { others } \\
\gamma & 0 & 0429, \text { others }\end{array}$ & ${ }^{243} \mathrm{Am}(\mathrm{n}, \gamma)$ & $11,59-61$ \\
\hline $244^{m 2}$ & $09 \mathrm{msec}$ & SF 1somer & & ${ }^{243} \mathrm{Am}(\mathrm{d}, \mathrm{p})$ & $47,49,50$ \\
\hline 245 & $204 \mathrm{hr}$ & $\bar{\beta}$ & $\begin{array}{l}\beta 091 \mathrm{max}, \text { others } \\
\gamma\left({ }^{245} \mathrm{Cm}\right) \text { vartous }\end{array}$ & ${ }^{245} \mathrm{Pu} \stackrel{\beta^{-}}{\longrightarrow}{ }^{245} \mathrm{Am}$ & $\begin{array}{l}30,50,62, \\
63-66\end{array}$ \\
\hline $245^{m}$ & $640 \pm 60 \mathrm{nsec}$ & SF isomer & & ${ }^{244} \mathrm{Pu}(\alpha, \mathrm{p} 2 \mathrm{n})$ & 67 \\
\hline 246 & $25.0 \mathrm{~min}$ & $\beta^{-}$ & $\begin{array}{l}\beta \quad 210 \mathrm{max}(7 \%), \text { others } \\
\gamma\left({ }^{246} \mathrm{Cm}\right) \text { various }\end{array}$ & ${ }^{246} \mathrm{Pu} \stackrel{\beta}{\longrightarrow}{ }^{246} \mathrm{Am}$ & $30,65,68$ \\
\hline $246^{m 1}$ & $39 \mathrm{~min}$ & $\beta$ & $\begin{array}{l}\beta \quad 112(53 \%), 1.25(13 \%) \\
180(14 \%), 2.0(20 \%) \\
\gamma\left({ }^{24} \mathrm{Cm}\right) \text { various }\end{array}$ & $\begin{array}{l}244 \mathrm{Pu}(\alpha, \mathrm{d}) \\
244 \mathrm{Pu}\left({ }^{3} \mathrm{He}, \mathrm{p}\right) \\
244 \mathrm{Pu}(\alpha, \mathrm{pn})\end{array}$ & $58,69,70$ \\
\hline $246^{m 2}$ & $75 \pm 10 \mu \mathrm{sec}$ & SF isomer & & ${ }^{244} \mathrm{Pu}(\alpha, p n)$ & 67 \\
\hline 247 & $22 \mathrm{~min}$ & $\beta^{-}$ & $\gamma\left({ }^{24} \mathrm{Cm}\right) 0226,0.285$ & ${ }^{244} \mathrm{Pu}(\alpha, p)$ & $58,69,70$ \\
\hline
\end{tabular}

${ }^{a}$ Exact atomic masses are listed in Table 12 , specific activitıes are given in Ref 12.

${ }^{b}$ Accepted values are listed in Nuclear Data Sheets

${ }^{c_{E C}}$, electron capture, $\alpha$, alpha decay, $\mathrm{SF}$, spontaneous fission, $\beta$, negative beta decay, $\mathrm{e}^{-}$, internal conversion electron

dOnly tentatively identıfied.

érin ${ }^{241} \mathrm{Am}, 5 / 2(\operatorname{Ref} .71),{ }^{242 m 1} \mathrm{Am}, 1$ (Ref. 71), ${ }^{243} \mathrm{Am}, 5 / 2(\operatorname{Ref} 71)$

$\mathrm{f}_{\mathrm{T}_{1 / 2}}[\mathrm{SF}]{ }^{241} \mathrm{Am}, 115 \times 10^{14}$ years $(\operatorname{Ref} 72),{ }^{242 \mathrm{ml}^{1}} \mathrm{Am}, 9.50 \times 10^{11}$ years $(\operatorname{Ref} 73),{ }^{243} \mathrm{Am}, 2.00 \times 10^{14}$ years (Ref. 74).

EElectric quadrupole moment, $\mathrm{q}\left(10^{24} \mathrm{~cm}^{2}\right){ }^{241} \mathrm{Am},+49$ (Ref. 75), ${ }^{242 \mathrm{ml}} \mathrm{Am},-2.76$ (Refs $\left.75-77\right),{ }^{243} \mathrm{Am},+4.9$ (Ref 78)

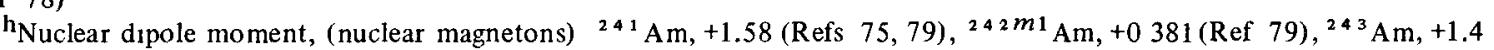
(Ref. 80). 
various decay modes and associated energies of the long-lived ${ }^{241} \mathrm{Am}$ and ${ }^{243} \mathrm{Am}$ are shown in Figs. 1.1 and 1.2.) Table 1.1 is adapted from the listing recently prepared by Hyde. $^{81}$ Hyde's article ${ }^{81}$ and the books by Hyde, Perlman, and Seaborg ${ }^{30}$ Lederer, Hollander, and Perlman $;^{82}$ and Dzhelepov and Peker ${ }^{83}$ provide exhaustive treatment of the nuclear properties of the various americium isotopes. Mughabghab and Garber $^{84}$ have recently (1973) tabulated thermal cross sections and resonance properties of ${ }^{241} \mathrm{Am},{ }^{242} \mathrm{Am},{ }^{242 m} \mathrm{Am},{ }^{243} \mathrm{Am},{ }^{244} \mathrm{Am}$, and ${ }^{243 m} \mathrm{Am}$; cross-section data for ${ }^{241}$ Am were listed earlier (1959) by Howerton. ${ }^{85}$ Wapstra and Gove ${ }^{86}$ have tabulated known nuclear systematics - masses and energetics-- of the various americium isotopes of mass numbers 234 to 248; their data are given in Table 1.2. An earlier compilation of such data was given by Viola and Seaborg. ${ }^{87}$

\section{ATOMIC PROPERTIES}

\section{Electron Configuration}

The generally accepted ${ }^{8-90}$ electron configuration of gaseous americium neutral atoms and cations, as determined from spectroscopic and atomic beam experiments, ${ }^{91}$ is shown in Table 1.3. Americium is the sixth member of the actinide series of elements; the electron configurations of americium in both its ground and ionized states are completely analogous to those of its homolog, europium, the sixth member of the lanthanide series. Recognition in 1944 of the possibility that elements 95 and 96 might be members of an actinide series led directly, as Seaborg ${ }^{3,92}$ has noted, to the identification of ${ }^{242} \mathrm{Cm}$ and ${ }^{241} \mathrm{Am}$.

\section{Atomic and Ionic Radii}

Metallic, covalent crystal, and ionic radii of americium in various oxidation states were first calculated by Zachariasen. ${ }^{93}$ His values (Table 1.4), even though 20 years old, are still cited. ${ }^{88}$ The radius of americium metal [coordination number (CN)12] is $1.73 \AA .^{94,95}$ Peterson and Cunningham, as part of their studies of berkelium compounds, calculated the ionic radius (CN 6) of several trivalent actinides in various compounds. Their results for $\mathrm{Am}^{3+}$ are $0.962 \AA$ in $\mathrm{AmF}_{3}$ (Ref. 96), $1.006 \AA$ in $\mathrm{AmCl}_{3}$ (Ref. 97), and $0.985 \AA$ in $\mathrm{Am}_{2} \mathrm{O}_{3}$ (Ref. 98). On the basis of a refined crystal structure for $\mathrm{AmCl}_{3}$, Burns and Peterson ${ }^{99}$ calculated the ionic radius (CN 6) of $\mathrm{Am}^{3+}$ in $\mathrm{AmCl}_{3}$ to be $0.984 \pm 0.003 \AA$.

\section{Ionization Potentials}

Carlson, Nestor, Wasserman, and McDowell ${ }^{100}$ have calculated ionization potentials for americium (Table 1.5) based on a simple spherical shell model using eigenvalues and mean radii from Hartree-Fock solutions for neutral atoms. 


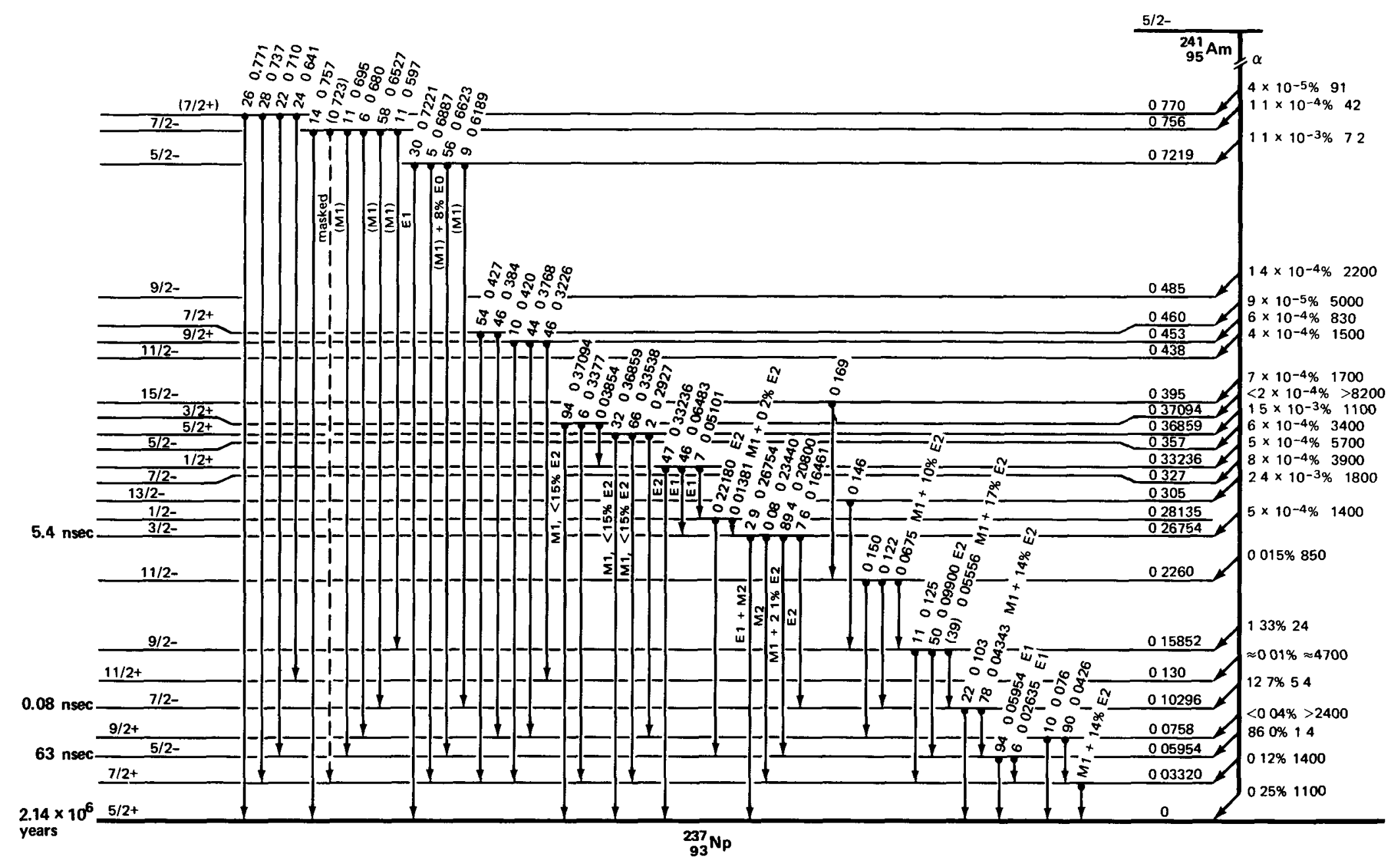

Fig. 1.1 Decay scheme for ${ }^{241}$ Am. (From C. M. Lederer, J. M. Hollander, and I. Perlman, Table of Isotopes, 6 th ed., p. 430, John Wiley \& Sons, Inc., New York, 1967.) 


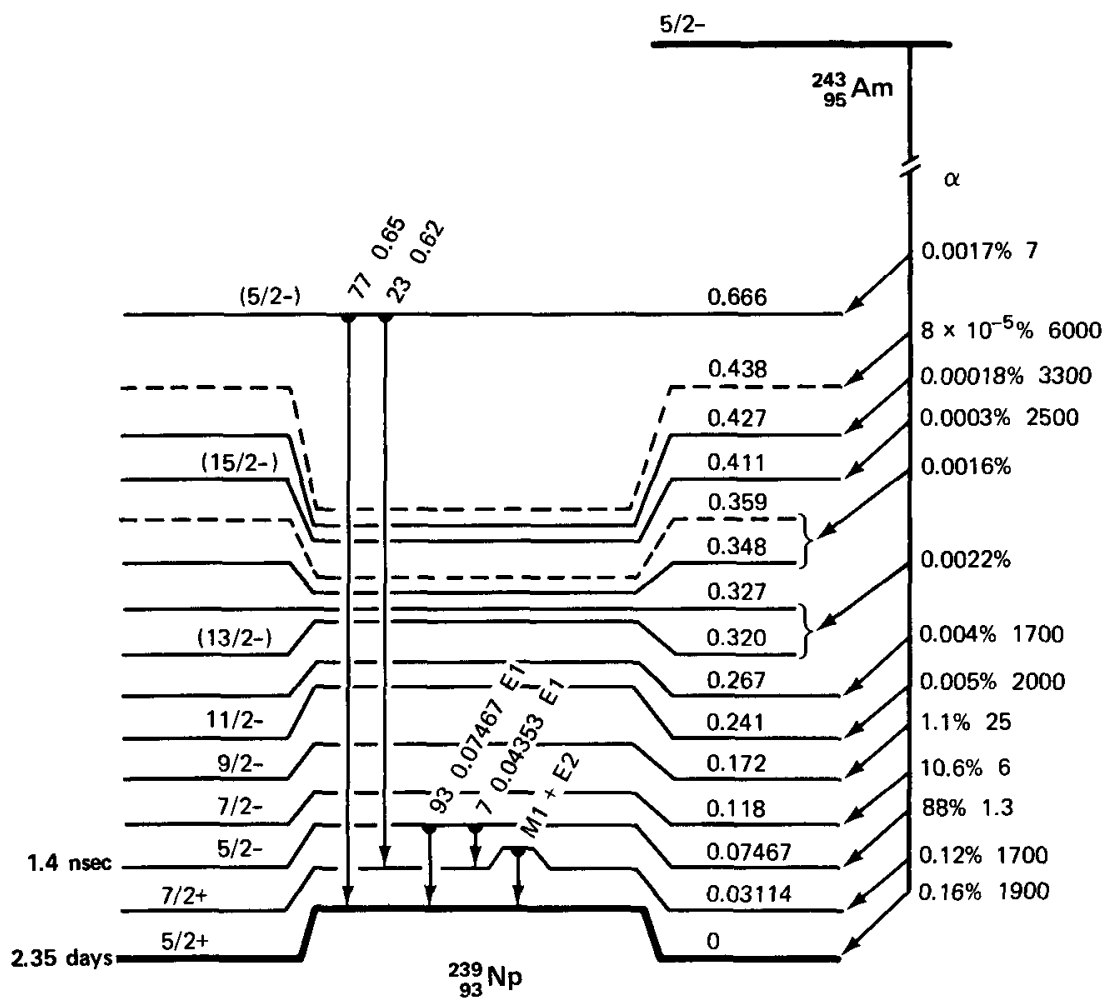

Fig. 1.2 Decay scheme for ${ }^{243} \mathrm{Am}$. (From C, M. Lederer, J. M. Hollander, and I. Perlman, Table of Isotopes, 6th ed., p. 433, John Wiley \& Sons, Inc., New York, 1967.)

\section{Emission Spectra}

Detailed studies of the arc and spark spectra of americium have been made by Tomkins and Fred, ${ }^{91,101,102}$ Thorne, ${ }^{103,104}$ and Oganov, Striganov, and Sobolev. ${ }^{105}$ Such studies identified 1000 to $2000 \mathrm{Am}$ I and Am II spectral lines. Table 1.6, compiled by Carnall, ${ }^{106}$ lists term assignments relative to the $5 f^{7} 7 \mathrm{~s}^{2}\left({ }^{8} \mathrm{~S}_{7 / 2}\right)$ ground state made by Tomkins and Fred ${ }^{102}$ for the identified even and odd parity levels of Am I. Carnall noted that the number of lines classified on the basis of the indicated terms constituted only about $10 \%$ of the Am I lines observed in the spectrum of ${ }^{241} \mathrm{Am}$ excited both in hollow cathode and electrodeless discharge sources. Term assignments for even and odd parity levels of Am II are also given in Ref. 106.

Corresponding to the absolute term value $\left(48,767 \mathrm{~cm}^{-1}\right)$ of the ground state, the ionization potential of $\mathrm{Am} \mathrm{I}$ is $6.0 \mathrm{eV}$. This value is in fair agreement with the value $5.655 \mathrm{eV}$ shown in Table 1.5. The experimental isotope shift constant $\beta C_{\exp }$ 
Table 1.2

NUCLEAR SYSTEMATICS OF AMERICIUM ISOTOPES*

\begin{tabular}{ccccccc}
\hline $\mathbf{A}$ & $\mathbf{Z}$ & $\mathbf{N}$ & $\begin{array}{c}\text { Atomic } \\
\text { mass, } \mu\end{array}$ & $\begin{array}{c}\text { Mass } \\
\text { excess, keV } \dagger\end{array}$ & $\begin{array}{c}\text { Binding } \\
\text { energy, keV } \ddagger\end{array}$ & $\begin{array}{c}\text { Beta-decay } \\
\text { energy, keV } \&\end{array}$ \\
\hline 234 & 95 & 139 & 234.04770 & 44,430 & $1,770,010$ & $-4,060$ \\
235 & 95 & 140 & 235.04796 & 44,670 & $1,777,840$ & $-1,950$ \\
236 & 95 & 141 & 236.04942 & 46,030 & $1,784,550$ & $-2,530$ \\
237 & 95 & 142 & 237.05008 & 46,650 & $1,792,010$ & -930 \\
238 & 95 & 143 & 238.05205 & 48,490 & $1,798,240$ & $-1,700$ \\
239 & 95 & 144 & 239.053039 & 49,406 & $1,805,394$ & -180 \\
240 & 95 & 145 & 240.05533 & 51,540 & $1,811,330$ & -772 \\
241 & 95 & 146 & 241.056844 & 52,951 & $1,817,992$ & 667 \\
242 & 95 & 147 & 242.059575 & 55,494 & $1,823,520$ & -7.1 \\
243 & 95 & 148 & 243.061394 & 57,189 & $1,829,897$ & 1,429 \\
244 & 95 & 149 & 244.064302 & 59,898 & $1,835,260$ & 901.6 \\
245 & 95 & 150 & 245.066475 & 61,922 & $1,841,307$ & 2,300 \\
246 & 95 & 151 & 246.06972 & 64,940 & $1,846,360$ & 1,600 \\
247 & 95 & 152 & 247.07209 & 67,160 & $1,852,220$ & 3,100 \\
248 & 95 & 153 & 248.07570 & 70,520 & $1,856,930$ & \\
\hline
\end{tabular}

*From A. H. Wapstra and N. B. Gove, The 1971 Atomic Mass Evaluation in Five Parts, Nuclear Data Tables, 9: 265 (1971).

$\dagger \mathrm{M}($ in $\mu)-\mathrm{A}$.

†Total bind ing energy $\left[\mathrm{ZM}\left({ }^{1} \mathrm{H}\right)+\mathrm{NM}\left({ }^{1} \mathrm{n}\right)-\mathrm{M}(\mathrm{A}, \mathrm{Z})\right]$.

$\S M(A, Z)-M(A, Z+1)$.

Table $1.3^{\circ}$

OUTER ELECTRON CONFIGURATION OF NEUTRAL AND CHARGED AMERICIUM ATOMS

\begin{tabular}{cll}
\hline $\begin{array}{c}\text { Ionization } \\
\text { state }\end{array}$ & $\begin{array}{c}\text { Electron } \\
\text { configuration* }\end{array}$ & $\begin{array}{c}\text { Term } \\
\text { symbol }\end{array}$ \\
\hline 0 & $5 f^{7} 7 \mathrm{~s}^{2}$ & ${ }^{8} \mathrm{~S}_{7 / 2}$ \\
$1+$ & $5 \mathrm{f}^{7} 7 \mathrm{~s}$ & ${ }^{9} \mathrm{~S}_{4}$ \\
$2+$ & $5 \mathrm{f}^{7}$ & ${ }^{8} \mathrm{~S}_{7 / 2}$ \\
$3+$ & $5 f^{6}$ & ${ }^{7} \mathrm{~F}_{0}$ \\
$4+$ & $5 f^{5}$ & ${ }^{6} \mathrm{H}_{5 / 2}$ \\
$5+$ & $5 f^{4}$ & ${ }^{5} \mathrm{I}_{4}$ \\
\hline
\end{tabular}

*All with underlying radon core configuration. 
Table 1.4

CALCULATED RADII OF AMERICIUM ATOMS AND IONS*

\begin{tabular}{cccc}
\hline \multirow{2}{*}{$\begin{array}{c}\text { Oxidation } \\
\text { state }\end{array}$} & \multicolumn{2}{c}{ Radius, $\AA$} \\
\cline { 2 - 4 } & Metallic $\dagger, \neq$ & Ionic & Covalent crystal \\
\hline+3 & 1.84 & 0.99 & \\
+4 & 1.69 & 0.89 & 1.57 \\
+5 & 1.58 & 0.86 & 1.47 \\
+6 & 1.50 & 0.80 & 1.39 \\
\hline
\end{tabular}

*Taken from W. H. Zachariasen, Crystal Chemstry of the 5 f Elements, in The Actinide Elements, G. T. Seaborg and J. J. Katz (Eds.), p. 776, McGraw-Hill Book Company, Inc., New York, 1954.

$\dagger \mathrm{CN} 12$.

$\$$ Radius expected if metal were trivalent, etc.

Table 1.5

\begin{tabular}{cc}
$\begin{array}{c}\text { CALCULATED IONIZATION POTENTIALS } \\
\text { OF AMERICIUM }\end{array}$ \\
$\begin{array}{c}\text { Atomic } \\
\text { charge }\end{array}$ & $\begin{array}{c}\text { Ionization } \\
\text { potential, eV }\end{array}$ \\
\hline Neutral & 5655 \\
$1+$ & 12.15 \\
$2+$ & 18.82 \\
$3+$ & 36.15 \\
$4+$ & 58.14 \\
$5+$ & 80.12 \\
$6+$ & 95.31 \\
$7+$ & 110.4 \\
$8+$ & 125.5 \\
$9+$ & 140.6 \\
$10^{+}$ & 162.5
\end{tabular}


Table 1.6

ENERGY LEVELS OF Am I

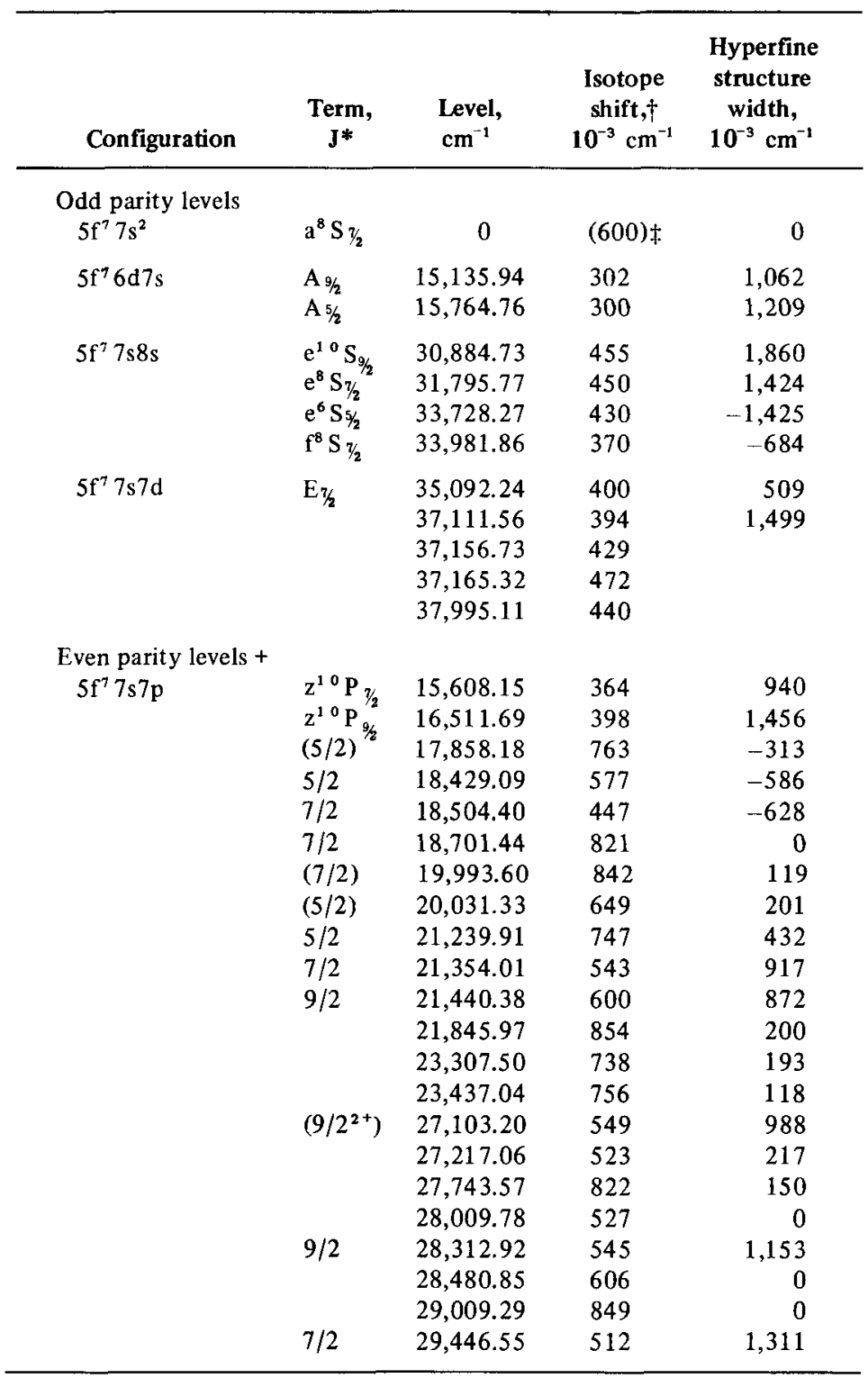

* J-values in parentheses are uncertain.

$+^{241} \mathrm{Am}-{ }^{243} \mathrm{Am}$.

$\ddagger$ Assumed. 
Table 1.7

\begin{tabular}{|c|c|}
\hline$\lambda, \AA$ & $I^{*}$ \\
\hline 28323 & \\
\hline 29206 & 10 \\
\hline 29694 & \\
\hline 31621 & \\
\hline 35101 & $>10$ \\
\hline 35692 & 10 \\
\hline 36731 & $>10$ \\
\hline 39262 & $>10$ \\
\hline 40893 & \\
\hline 45756 & $>10$ \\
\hline 46628 & 10 \\
\hline 46816 & 10 \\
\hline 54027 & 10 \\
\hline 60549 & 10 \\
\hline
\end{tabular}

*Relative intensity, Ref 92

$\left({ }^{241} \mathrm{Am}-{ }^{243} \mathrm{Am}\right)=(890 \pm 50) \times 10^{3} \mathrm{~cm}^{1}$, where $\beta \approx 1$ is the screening constant, is the average of three different calculations involving the ionization potential and experımentally observed shufts 107

Spectral lines of americium useful for analytical purposes are listed in Table $17^{105,108}$

\section{X-Ray Spectra}

The list of $\mathrm{K}$ and $\mathrm{L} \mathrm{X}$-ray energies and wavelengths for americium shown in Table 18 was compiled by Carnall ${ }^{109}$ from data gathered by Nelson and assoc1ates $^{10,111}$ (K X-rays) and from the critical literature evaluation by Bearden ${ }^{112}$ of the results of Merrill and DuMond ${ }^{13}$ and Day ${ }^{114}$ The K X-ray energies, all of which correspond to electric-dipole transitions, were measured with a Cauchois-type bent-crystal spectrometer ${ }^{110,111}$ The absorption edge of $\operatorname{Am}\left(\mathrm{L}_{\text {III }}\right)$ is $668648 \pm 0028$ X-units based on $\lambda\left(\mathrm{MoK}_{\alpha}\right)^{113}$ Atomic energy levels (binding energies) of americium have been calculated from experimental measurements of X-ray emission wavelengths, a listing of these values is given in the article by Carnall ${ }^{109}$

\section{Luminescence Spectra of Am(III)}

Accordıng to Carnall, ${ }^{15}$ "The first observation of fluorescence in a transuranium element compound was made for $\mathrm{LaCl}_{3} \quad \mathrm{Am}^{3+}$ self-excited by the intense $\alpha$-activity of 
Table 1.8

X-RAY ENERGIES OF AMERICIUM

\begin{tabular}{|c|c|c|c|c|}
\hline \multirow[b]{2}{*}{ Line } & \multirow[b]{2}{*}{ Transition } & \multicolumn{2}{|c|}{$\lambda$} & \multirow{2}{*}{$\begin{array}{c}\text { Energy, } \\
\text { keV }\end{array}$} \\
\hline & & $X$ units & $\AA$ & \\
\hline$\alpha_{2}$ & $\mathrm{~K}-\mathrm{L}_{\mathbf{I I}}$ & 121.254 & 0.121506 & 102.041 \\
\hline$\alpha_{1}$ & $\mathrm{~K}-\mathrm{L}_{\text {III }}$ & 116.194 & 0.116435 & 106.484 \\
\hline$\beta_{3}$ & $\mathrm{~K}-\mathrm{M}_{\mathrm{II}}$ & 103.749 & 0.103964 & 119.258 \\
\hline$\beta_{1}$ & $\mathrm{~K}-\mathrm{M}_{\mathrm{III}}$ & 102.834 & 0.103048 & 120.319 \\
\hline$\beta_{4}$ & $\mathrm{~L}_{\mathrm{I}^{-}-\mathrm{M}_{\mathrm{II}}}$ & 684.98 & 0.68640 & 18.0630 \\
\hline$\beta_{3}$ & $\mathrm{~L}_{\mathbf{I}}-\mathrm{M}_{\mathrm{III}}$ & 647.58 & 0.64892 & 19.1063 \\
\hline$\gamma_{2}$ & $\mathrm{~L}_{\mathrm{I}}-\mathrm{N}_{\mathrm{II}}$ & 553.3 & 0.5544 & 22.363 \\
\hline$\beta_{1}$ & $\mathrm{~L}_{\mathrm{II}}-\mathrm{M}_{\mathrm{IV}}$ & 656.305 & 0.657668 & 18.8523 \\
\hline$\gamma_{1}$ & $\mathrm{~L}_{\mathrm{II}}-\mathrm{N}_{\mathrm{IV}}$ & 560.733 & 0.561897 & 22.0655 \\
\hline$\alpha_{1}$ & $\mathrm{~L}_{\mathrm{III}}-\mathrm{M}_{\mathrm{V}}$ & 846.446 & 0.848204 & 14.6174 \\
\hline$\lambda$ & $\mathrm{L}_{\mathrm{III}}-\mathrm{M}_{\mathrm{I}}$ & 999.1 & 1.0012 & 12.383 \\
\hline$\alpha_{2}$ & $\mathrm{~L}_{\mathrm{III}}-\mathrm{M}_{\mathrm{IV}}$ & 858.500 & 0.860283 & 14.4122 \\
\hline$\beta_{5}$ & $\mathrm{~L}_{\mathrm{III}}-\mathrm{N}_{\mathrm{I}}$ & 732.67 & 0.73419 & 16.8873 \\
\hline
\end{tabular}

the ${ }^{241} \mathrm{Am} ; 34$ lines were detected. ${ }^{16}$ More complete data were taken later and interpreted in terms of transitions in which the initial state was a component of ${ }^{5} \mathrm{D}_{2}$ or ${ }^{5} \mathrm{~L}_{6}$ and the final state was a component of one of the terms of the ${ }^{7} \mathrm{~F}$ ground multiplet. ${ }^{117}$ No self-luminescence nor self-excited fluorescence was found for crystals of $\mathrm{Am}^{3+}-\beta$ diketone chelates." 118 *

\section{Mössbauer Spectra}

Israeli scientists ${ }^{19}$ and various other workers ${ }^{120-126}$ have found that ${ }^{237} \mathrm{~Np}$, formed by alpha decay of ${ }^{241} \mathrm{Am}$, is a convenient nucleus for recoilless absorption (Mössbauer effect) measurements. Gal et al., using the Mössbauer effect, determined the charge states of neptunium ions in various ${ }^{241} \mathrm{Am}$ sources. Their results are shown in Table 1.9. (Additional Mössbauer-effect data for ${ }^{241} \mathrm{Am}$ sources are given in Chap. 4 and also in an article by Keller and Randl. ${ }^{127}$ ) The Israeli workers summarized their results by stating that the neptunium charge states were $3+$ in all sources containing americium ions in frozen solutions and $4+$ and $5+$ in all oxide sources. In most other americium salts, neptunium attained the valence of the host lattice.

*References are those listed by Carnall but have been renumbered for purposes of this chapter. 
Table 1.9

MOSSBAUER STUDIES WITH ${ }^{24}{ }^{1}$ Am SOURCES*

\begin{tabular}{|c|c|c|c|c|c|}
\hline \multirow{2}{*}{$\begin{array}{l}\text { Am } \\
\text { charge } \\
\text { states }\end{array}$} & \multirow[b]{2}{*}{ Sources } & \multicolumn{3}{|c|}{$\begin{array}{c}\text { Isomer shift, } \\
\text { mm sec }{ }^{1} \\
\text { Np charge states }\end{array}$} & \multirow{2}{*}{$\begin{array}{c}\text { Temperature of } \\
\text { source and } \\
\text { absorber, } \\
{ }^{\circ} \mathbf{K}\end{array}$} \\
\hline & & $3+$ & $4+$ & $5+$ & \\
\hline \multicolumn{6}{|c|}{ Solid compounds } \\
\hline $3+$ & $\mathrm{Am}_{2} \mathrm{O}_{3}$ (cubic) & & $18 \pm 05$ & $277 \pm 05$ & 77 \\
\hline $3+$ & $\mathrm{Am}_{2} \mathrm{O}_{3}$ (hexagonal) & & $17 \pm 05$ & $280 \pm 05$ & 77 \\
\hline $3+$ & $\mathrm{AmF}_{3}$ & $446 \pm 05$ & & & 42 \\
\hline $3+$ & $\mathrm{Am}_{2}\left(\mathrm{C}_{2} \mathrm{O}_{4}\right)_{3} \cdot 6 \mathrm{H}_{2} \mathrm{O}$ & $-405+05$ & & & 42 \\
\hline $4+$ & $\mathrm{AmO}_{2}$ & & $11 \pm 05$ & $252 \pm 05$ & 77 \\
\hline $4^{+}$ & $\mathrm{AmO}_{2}$ & & $12 \pm 05$ & $251+05$ & 42 \\
\hline $4+$ & $\begin{array}{c}\mathrm{Am}(\mathrm{OH})_{4} \cdot \mathrm{H}_{2} \mathrm{O} \\
\text { (precipitate) }\end{array}$ & $409 \pm 08$ & & & 42 \\
\hline $5+$ & $\mathrm{K}_{5}\left[\mathrm{AmO}_{2}\left(\mathrm{CO}_{3}\right)_{5}\right]_{3}$ & & & $250 \pm 20$ & 42 \\
\hline \multicolumn{6}{|c|}{ Frozen solutions } \\
\hline $3+$ & $\mathrm{Am}(\mathrm{III})$ in $\mathrm{HNO}_{3}$ & $426 \pm 10$ & & & 42 \\
\hline $3+$ & Am(III) in $10 \mathrm{M} \mathrm{H}_{3} \mathrm{PO}_{4}$ & $-426 \pm 05$ & & & 42 \\
\hline $4+$ & Am(IV) in saturated & & & & \\
\hline & $\mathrm{NH}_{4} \mathrm{~F}$ & $-455 \pm 08$ & & & 42 \\
\hline $4+$ & Am(IV) in $10 M \mathrm{H}_{3} \mathrm{PO}_{4}$ & $-426 \pm 05$ & & & 42 \\
\hline $5+$ & $\begin{array}{c}\mathrm{K}_{5}\left[\mathrm{AmO}_{2}\left(\mathrm{CO}_{3}\right)_{5}\right]_{3} \\
\text { dissolved in } \mathrm{HNO}\end{array}$ & $-410 \pm 10$ & & & 42 \\
\hline $6+$ & $\mathrm{AmO}_{2}^{2+}$ in $\mathrm{H}_{3} \mathrm{PO}_{4}$ & $-426+10$ & & & 42 \\
\hline $6+$ & $\mathrm{AmO}_{2}^{2+}$ in $\mathrm{HNO}_{3}$ & $420 \pm 10$ & & & 42 \\
\hline
\end{tabular}

*Adapted from J Gal, Z Hadar, E Yanır, E R Baumınger, and S Ofer, Charge States of Np Recoll Atoms Following $\alpha$ Decay, Journal of Inorganic Nuclear Chemistry, 32: 2509 (1970)

Beta decay of ${ }^{243} \mathrm{Pu}\left(\mathrm{t}_{1 / 2}=498 \mathrm{hr}\right)$ to the $839-\mathrm{keV}$ level of ${ }^{243} \mathrm{Am}$ occurs in $276 \%$ of the disintegrations ${ }^{128}$ This excited nuclear state $\left(t_{1 / 2}=234 \mathrm{nsec}\right)$ of ${ }^{243} \mathrm{Am}$ 1s suitable for Mossbauer spectroscopy ${ }^{129}$ as evidenced by the resonance spectra of ${ }^{243} \mathrm{AmF}_{3}$ and ${ }^{243} \mathrm{AmO}_{2}$ shown in $\mathrm{F}_{1 \mathrm{~g}} 13$ These results were obtained at $42^{\circ} \mathrm{K}$ with a $50-\mathrm{mCl}^{243} \mathrm{PuO}_{2}$ source The shift of the ${ }^{243} \mathrm{AmF}_{3}$ resonance line relative to the ${ }^{243} \mathrm{AmO}_{2}$ lines is $55 \mathrm{~mm} \mathrm{sec}{ }^{1}$, the greatest shift so far observed for two oxidation states differing by one unit

\section{Critical Mass}

Bierman and Clayton ${ }^{130}$ have calculated the critical radi1 and mass of ${ }^{241} \mathrm{Am}$ and ${ }^{242} \mathrm{Am}$ metals (Table 1 10) In aqueous solution ${ }^{131}$ the minımum critical mass of ${ }^{242} \mathrm{Am} 1 \mathrm{~s} 23 \mathrm{~g}$ at a concentration of $5 \mathrm{~g}$ liter ${ }^{1}$ 


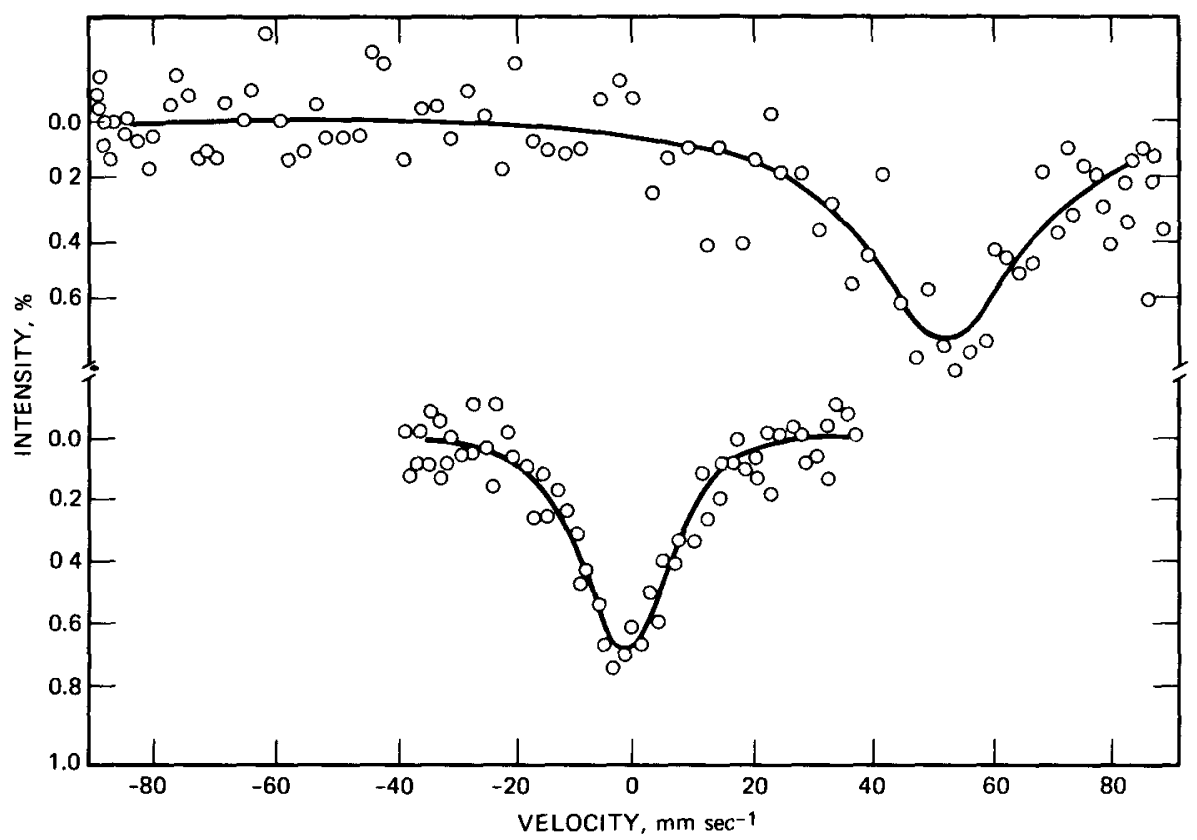

Fig. 1.3 Mossbauer spectrum of (a) ${ }^{243} \mathrm{AmF}_{3}$ and (b) ${ }^{243} \mathrm{AmO}_{2}$. [From G. M. Kalvius, S. L. Ruby, B. D. Dunlap, G. K. Shenoy, D. Cohen, and M. B. Brodsky, Mossbauer Isomer Shift in ${ }^{243}$ Am, Physics Letters, B, 29: 489 (1969).]

Table 1.10

CALCULATED CRITICAL RADII AND MASS OF AMERICIUM METAL*, $\dagger$

\begin{tabular}{|c|c|c|}
\hline & \multicolumn{2}{|c|}{ Isotope } \\
\hline & ${ }^{241} \mathrm{Am}$ & ${ }^{242} \mathrm{Am}$ \\
\hline & 11.7 & 11.7 \\
\hline \multicolumn{3}{|l|}{ Critical radius, $\mathrm{cm}$} \\
\hline Bare & 13.23 & 5.55 \\
\hline Water-reflected $\neq$ & 12.90 & 4.26 \\
\hline \multicolumn{3}{|l|}{ Critical mass, $\mathrm{kg}$} \\
\hline Bare & 113.5 & 8.4 \\
\hline Water-reflected $\ddagger$ & 105.2 & 3.8 \\
\hline
\end{tabular}

*From S. R. Bierman and E. D. Clayton, Criticality of Transuranium Actinides: Unmoderated Systems, Transactions of the American Nuclear Society, 12: 887 (1969).

$\dagger$ Spherical geometry.

$\$ 20$-cm reflector. 


\section{COLLATERAL READING}

The literature on americium chemistry is extensive and spread over many books, articles, and reports. In addition to the coverage provided here, the following sources should be consulted for further information on various aspects of americium chemistry.

\section{General Chemistry}

\section{Bibliographies}

C. E. Stuber (Comp.), Transplutonium Elements, A Bibliography, USAEC Report TID-3317, February 1968.

Ibid., Suppl. 2, October 1970.

Ibid., Suppl. 3, October 1972.

Ibid., Suppl. 4, January 1974.

Ibid., Suppl. 5, September 1975.

H. W. Miller (Comp.), Annotated Bibliography of the Chemistry and Physics of Americium, USAEC Report RFP-770, Dow Chemical Co., 1966.

Chemistry of Transplutonium Elements, Bibliographical Series No. 19, International Atomic Energy Agency, Vienna, 1968 (STI/PUB/21/19).

D. Demine, Bibliography Concerning Transplutonium Elements, European Atomic Energy Community Report EUR-2508e, September 1965.

R. W. Clarke (Comp.), Bibliography of Unclassified Reports and Published Literature on the Transplutonium Elements (1957-1964), British Report AERE-R-4761, 1964.

E. H. Smith (Comp.), Isotopic Power Sources: A Compendium Property and Processes Review. Parts I and II. USAEC Report MND-P-2581, Martin Co., Nuclear Division, 1961.

\section{Books and Monographs}

B. F. Myasoedov, L. I. Guseva, I. A. Lebedev, M. S. Milyukova, and M. S. Chmutova, Analytical Chemistry of the Transplutonium Elements (English translation), John Wiley \& Sons, Inc., New York, 1974.

A. J. Freeman and J. B. Darby, Jr. (Eds.), The Actinides: Electronic Structure and Related Properties, Vols. I and II. Academic Press, Inc., New York, 1974.

Gmelins Handbook of Inorganic Chemistry-Transuranium Elements, Verlag Chemie GmbH, Weinheim, Germany: Vol. 4, Part C, Compounds, 1972; Vol. 7a, Part A1, The Elements, 1973; Vol. 8, Part A2, The Elements, 1973.

C. Keller, Chemistry of the Transuranium Elements, Verlag Chemie GmbH, Weinheim, Germany, 1972.

K. W. Bagnall, The Actinide Elements, Elsevier Publishing Company, New York, 1972.

J. J. Katz and G. T. Seaborg, The Chemistry of the Actinide Elements, pp. 331-385, John Wiley \& Sons, Inc., New York, 1957. (Presently being revised.) 
A. F. Trotman-Dickenson (Ed.), Comprehensive Inorganic Chemistry-Actinides, Master Index, Vol. 5, Pergamon Press, Ltd., Oxford, 1973.

K. W. Bagnall (Ed.), Lanthanides and Actinides-MTP International Review of Science, Vol. 7, University Park Press, Baltimore, Md., 1972.

V. I. Gol'danskii and S. M. Polikanov, The Transuranium Elements (English translation), J. E. S. Bradley (Translator), Consultants Bureau, New York, 1969.

V. M. Vdovenko (Ed.), Chemistry of Transuranium Elements, Izdatel'stvo Nauka, Leningrad, 1967.

G. T. Seaborg, Man-Made Transuranium Elements, Prentice-Hall, Inc., Englewood Cliffs, N. J., 1963.

R. A. Penneman and T. K. Keenan, The Radiochemistry of Americium and Curium, Monograph NAS-NS-3006, National Academy of Sciences-National Research Council, 1960.

I. Perlman and K. Street, Jr., Chemistry of the Transplutonium Elements in The Actinide Elements, G. T. Seaborg and J.J. Katz (Eds.), National Nuclear Energy Series, Div. IV, Vol. 14A, McGraw-Hill Book Company, Inc., New York, 1954.

\section{Review Articles}

L. B. Asprey and R. A. Penneman, The Chemistry of the Actinides, Chem. Eng. News, 45(32): (July 31,1967$)$.

T. K. Keenan, Americium and Curium, J. Chem. Educ., 36: 27 (1959).

S. W. Rabideau, L. B. Asprey, T. K. Keenan, and T. W. Newton, Recent Advances in the Basic Chemistry of Plutonium, Americium, and Curium, in Proceedings of the Second International Conference on the Peaceful Uses of Atomic Energy, Geneva, 1958, Vol. 28, p. 361, United Nations, New York, 1959.

R. A. Penneman and L. B. Asprey, A Review of Americium and Curium Chemistry, Proceedings of the First International Conference on the Peaceful Uses of Atomic Energy, Geneva, 1955, Vol. 7, p. 355, United Nations, New York, 1956.

\section{Special Chemistry Topics}

\section{Discovery}

G. T. Seaborg, 25th Anniversary of the Discovery of Americium and Curium Elements 95 and 96: 25 Years Ago, in Proceedings of the Robert A. Welch Foundation Conference on Chemical Research. XIII. The Transuranium Elements, Houston, Tex., Nov. 17, 1969, W. O. Milligan (Ed.), Robert A. Welch Foundation, Houston, Tex., 1970.

\section{Solution Chemistry and Complexes}

J. Tostain, Solution Chemistry of the Transuranides, French Report CEA-Bib-193, May 1972. 
A. D. Gel'man, A. I. Moskvin, L. M. Zaitsev, and M.P Mefod'eva, Complex Compounds of Transuranides (English translation), Chap. IV, Israel Program for Scientific Translations, Ltd., Jerusalem, 1967.

A. D. Jones and G. R. Choppin, Complexes of Actinide Ions in Aqueous Solution, Actinides Rev., 1: 311 (1969).

Y. Marcus, M. Givon, and M. Shiloh, The Chemistry of the Trivalent Actinides in Aqueous Solutions and Their Recovery, in Proceedings of the Third International Conference on the Peaceful Uses of Atomic Energy, Geneva, 1964, Vol. 10, p. 588, United Nations, New York, 1965.

\section{Halides}

D. Brown, Halides of the Lanthanides and Actinides, John Wiley \& Sons, Inc., New York, 1968.

R. A. Penneman, R. R. Ryan, and A. Rosenzweig, Structural Systematics in Actinide Fluoride Complexes, Struct. Bonding (Berlin), 13: 1 (1973).

K. W. Bagnall, The Coordination Chemistry of the Actinide Halides, Coord. Chem. Rev., 2: 145 (1967).

J. J. Katz and I. Sheft, Halides of the Actinide Elements, in Advanced Inorganic Chemistry and Radiochemistry, Vol. 2, p. 195, H. J. Emeleus and A. G. Sharpe (Eds.), Academic Press, Inc., New York, 1960.

Recovery, Separation, and Uses

J. Ulstrup, Methods of Separating the Actinide Elements, At. Energy Rev., 4: 3 (1966).

R. E. Leuze and M. H. Lloyd, Processing Methods for the Recovery of Transplutonium Elements, in Progress in Nuclear Energy, Series III. Process Chemistry, C. E. Stevenson, E. A. Mason, and A. T. Gresky (Eds.), Vol. 4, p. 549, Pergamon Press, Inc., New York, 1970.

R. D. Baybarz, Recovery and Application of the Transuranium Elements ${ }^{237} \mathrm{~Np}$, ${ }^{241} \mathrm{Am},{ }^{242} \mathrm{Cm},{ }^{244} \mathrm{Cm}$, and ${ }^{252} \mathrm{Cf}$, At. Energy Rev., 8: 327 (1970).

B. Weaver, Solvent Extraction in the Separation of Rare Earths and Trivalent Actinides, in Ion Exchange and Solvent Extraction, A Series of Advances, Vol. 6, J. A. Marinsky and Y. Marcus (Eds.), Marcel Dekker, Inc., New York, 1974.

F. E. Levert and E. L. Helminski, Literature Review and Commercial Source Evaluation of Americium-241, Final Report, March 1, 1972-May 31, 1973, USAEC Report ORO-4333-1, Tuskegee Institute, June 1973.

\section{Analytical}

C. Ferradini, Americium and Its Analytic Properties, Chem. Anal. (Paris), 45: 647 (1963).

\section{REFERENCES}

1. G. T. Seaborg, The Synthetic Actinides-From Discovery to Manufacture, Nucl. Appl. Technol., 9: 830 (1970). 
2. G. T. Seaborg, History of the Synthetic Actınıde Elements, Actınides Rev , $1: 3$ (1967)

3 G. T. Seaborg, Man-Made Transuramum Elements, pp. 16-17, Prentice-Hall, Inc., Englewood Cluffs, N. J , 1963.

4. G. T. Seaborg and R A James, Methods of Preparation of Element 95, U.S Patent No. 3,044,944, July 1962

5. G. T Seaborg, The Transurantum Elements, pp 79-82, Addıson-Wesley Publishıng Company, Inc., Reading, Mass., 1958.

6 J. J. Katz and G. T. Seaborg, The Chemistry of the Actinide Elements, p. 250, Methuen \& Co., Ltd., London, 1957.

7. G. T. Seaborg and A. Ghorso, The Newest Synthetic Elements, Scl Amer, 195: 66 (1956).

8. M. Weeks, in Discovery of the Elements, H M. Leicester (Ed.), pp. 875-876, Journal of Chemical Education, Easton, $\mathrm{Pa}, 1956$.

9. B B Cunningham, Isolation and Chemistry of Americium, USAEC Report ANL-JJK-124, Argonne National Laboratory, February 1948.

$10 \mathrm{~J}$ C Wallmann, The First Isolations of the Transuranium Elements, $J$ Chem Educ, 26: 350 (1959)

$11 \mathrm{~K}$ Street, A. Ghiorso, and G T Seaborg, The Isotopes of Americium, Phys Rev, C, 79: 530 (1950).

12. $\mathrm{W}$ Schirmer and $\mathrm{N}$ Wächter, Table of Specific Activities of the Nuclides with $\mathrm{Z}=88$ to $\mathrm{Z}=104$, Actunides Rev., $1: 125$ (1958)

13. N. K Skobelev, Delayed Fission of Some Neutron-Deficient Nucleı, Yadern Fiz, 15: 444 (1972) through Sov $J$ Nucl Phys (Engl Transl), 15: 249 (1972), Russian Report JINR-P7-5584 through Report Np-tr-1936

14. V. I. Kuznetsov and N. K. Skobelev, Investigation of the Spontaneously Fissionable Products $\left(\mathrm{T}_{1 / 2}=1.4\right.$ minutes) in the ${ }^{230} \mathrm{Th}+{ }^{10} \mathrm{~B}$ Reaction, Russian Report JINR-P7-2984 through USAEC Report ORO-tr-3346-15.

15. J. B. Natowitz, Angular Momentum Effects in Nuclear Reactions, 1972 Progress Report, USAEC Report ORO-3924-14, Oak Rıdge Operatıons Office, 1973.

16. J. B. Natowitz and J. K. Archer, Production of Spontaneous Fission Isomers in the Reaction of ${ }^{237} \mathrm{~Np}$ with 30 to $70 \mathrm{MeV}{ }^{4} \mathrm{He}$, Phys Lett, B, 30: 463 (1969).

17. G H. Higgins, An Investigation of the Isotopes of Americium and Curium (Thesis), USAEC Report UCRL-1796, University of California Radiation Laboratory, June 1972.

18. I. Ahmad, R. F. Barnes, P. R. Fields, and R. K. Sjoblom, Electron Capture Decay of ${ }^{23}{ }^{7}$ Am, Bull Amer. Phys Soc., 15: 76 (1970).

19. Chemistry Division Annual Report, July 1971-June 1972, USAEC Report ANL-7996, pp. 29-44, Argonne Natıonal Laboratory, February 1973.

20. S. M Polikanov and G. Sletten, Spontaneously Fissioning Isomers in $\mathrm{U}, \mathrm{Pu}, \mathrm{Am}$, and $\mathrm{Cm}$ Isotopes, Nucl Phys, A, 151: 656 (1970).

21. R. A. Glass, R. J. Carr, and W. M. Gibson, Radioactive Decay Properties of ${ }^{238} \mathrm{Am}^{239}{ }^{3 \mathrm{Am}}$, ${ }^{240} \mathrm{Am},{ }^{240} \mathrm{Cm}$, and ${ }^{241} \mathrm{Cm}, J$ Inorg Nucl Chem., 13: 181 (1960).

22. I. Ahmad, R K. Sjoblom, R. F. Barnes, F. Wagner, Jr., and P. R. Fields, Electron Capture Decay of ${ }^{238} \mathrm{Am}$ and Electric Monopole Transitions in ${ }^{238} \mathrm{Pu}$, Nucl Phys, A, 186: 620 (1972).

23. J C. Post and A H. W. Aten, Decay of ${ }^{238}$ Am, Radıchım Acta, 15: 205 (1971).

24. J. C. Post and A. H. W. Aten, Decay of ${ }^{238}$ Am, Radıchım Acta, 16: 60 (1971)

25. J Borggreen, J. P. Gangrsky, G. Sletten, and S. Bjørnholm, A New Spontaneously Fissioning Isomer ${ }^{238} \mathrm{Am}$, Phys Lett, B, 25: 402 (1967).

26. G. T. Seaborg, R. A. James, and L. G. Morgan, The New Element Americium (Atomic Number 95), in The Transuranium Elements, G. T. Seaborg, J. J. Katz, and W. M. Manning (Eds ), pp. 1525-1553, McGraw-Hill Book Co., Inc., New York, 1949.

27. F. T. Porter et al, Energy Levels in ${ }^{239} \mathrm{Pu}$ Populated by Electron-Capture Decay of 11.9-h ${ }^{239}$ Am, Phys Rev, C, 5: 1738 (1972). 
28. N. Lark, J. Pederson, G. Sletten, and S Bjørnholm, Spontaneously Fissioning Isomers in U, Np, Pu, and Am Isotopes, Nucl Phys., A, 139: 481 (1969)

29. D J. Gorman and F. Asaro, Alpha Decdy of ${ }^{240}$ Am, Phys Rev , C, 2: 2406 (1970)

30 E. K Hyde, I. Perlman, and G. T Seaborg, The Nuclear Properties of the Heavy Elements, Vol II, Prentice-Hall, Inc., Englewood Cliffs, N. J., 1971.

31. S. Bృørnholm, J. Borggreen, L. Westgdard, and V. A. Karnaukhov, Excitation Energy of the Spontaneously Fissioning Isomeric State in ${ }^{240} \mathrm{Am}$, Nucl Phys , A, 95: 513 (1967)

32. J. Jove and R. Robert, Mesure de la Pérode de ${ }^{241}$ Am par Microcalorimétr ie, Radıochem Radioanal Lett, 10: 139 (1972).

33. L C. Brown and R. C Propst, A New Determination of the Half-Life of ${ }^{243} \mathrm{Am}, J$ Inorg Nucl Chem., 30: 2591 (1968).

34 F L Oettıng and S R. Gunn, A Calorimetric Determination of the Specific Power and Half-Life of Americium-241, J. Inorg Nucl Chem., 29: 2659 (1967).

35. R E Stone and E. K. Hulet, Radiochemical Determination of the Alpha Half-Life of ${ }^{241}$ Am, J Inorg Nucl. Chem, 30: 2003 (1968).

$36 \mathrm{G}$ R Hall and T. L Markın, The Alpha Half-Lıfe of Amerıcium-241, J Inorg. Nucl Chem., 4: 137 (1957).

37. J. C Wallmann, P. Graf, and L. Goda, The Specific Activities and Half-Lives of Americium-241 and Americium-243, J Inorg. Nucl. Chem, 7: 199 (1958).

38. G. R. Hall and T. L. Markın, The Alpha Half-Life of $\mathrm{Am}^{241}$, J Inorg Nucl. Chem., 2: 203 (1956) ,

39. B. M. Aleksandrov et al., The Decay of $\mathrm{Am}^{242}$, At Energ (USSR), 27: 41 (1969) through Sov At Energy (Engl Transl), 27: 724 (1969).

40 T K Keenan, R A. Penneman, and B. B. McInteer, A New Determination of the Half-Life of $\mathrm{Am}^{242 m}$, The Problem of Counting Short-Lived Activities, J Chem. Phys , 21: 1802 (1963).

41. R. W. Hoff, F. K. Hulet, and M. C. Michel, Branching Ratio of $242 m_{\text {Am Decay, } J ~ N u c l}$ Energy, 8: 224 (1959).

42. R. F. Barnes, D J. Henderson, A. L Harkness, and H. Diamond, The Alpha and Electron Capture Partial Half-Lives of ${ }^{242}$ Am, J Inorg. Nucl Chem., 9: 106 (1959).

43 R W Hoff, H Jaffe, T. O. Passell, F. S. Stephens, E. K. Hulet, and S. G. Thompson, Radioactive Decay of the Isomers of Americium-242, Phys Rev., 100: 1403 (1955).

44. R Gasteıger, G. Hohleın, and W. Weinlander, Bestımmung des Zesfallsverhaltnısses $\beta / \mathrm{EC}$ des 242 Am, Radiochim Acta, 11: 158 (1969)

45. F. Asaro, I. Perlman, J. O. Rasmussen, and S G. Thompson, Isomers of ${ }^{242}$ Am, Phys Rev, 120: 939 (1960)

46. D. S. Brenner, L. Westgdard, and S. Bjørnholm, A Study of Nuclear Isomers Which Decay by Spontaneous Fission, Nucl Phys, 89: 267 (1966)

47. S M Polikanov, Spontaneously Fissioning Isomers, Usp Fiz Nauk, 94: 43 (1968) through Sov Phys Usp (Engl Transl.), 11: 22 (1968).

48. G. N. Flerov et al., Excitation Energy of Spontaneously Fissioning Isomer $242 \mathrm{~m}_{\mathrm{Am}} \mathrm{Nucl}$ Phys., A, 97: 444 (1967).

49. S. Bృørnholm, J. Borggreen, Yu. P. Gangriskı1, and G. Sletten, Investigation of $(d, p)$ and $(d, t)$ Reactions Leading to Spontaneously Fissile Isomeric States, Yadern Fiz, 8: 459 (1968) through Sov J Nucl Phys (Engl Transl), 8: 267 (1968).

$50 \mathrm{G} \mathrm{N}$ Flerov et al., A Study of the Spontaneously-Fissionıng Isomer of ${ }^{242} \mathrm{Am}$ Through the ${ }^{241}$ Am (n, $\gamma$ ) Reaction, Nucl Phys, A, 102: 443 (1967).

51. B. N. Markov, A. A. Pleve, S. M. Polıkanov, and G. N. Flerov, Experiments on Synthesis of a Spontaneously Fissile Isomer in the Reaction ${ }^{241} \mathrm{Am}(\mathrm{n}, \gamma){ }^{241} \mathrm{Am}(\mathrm{E})$, Yadern Fiz., 3: 455 (1966) through Sov J. Nucl Phys. (Engl Transl), 3: 329 (1966).

52. Yu. P. Gangr iskı1, B. N. Markov, and Yu. M. Tsipenyuk, Invest igation of the Properties of the Spontaneously Fissioning Isomer ${ }^{241} \mathrm{Pu}$ in the Reaction $(\gamma, \mathrm{n})$, Russian Report JINR-E155071 through Nuclear Sctence Abstracts, 24: 38209 
53 Yu V. Lobanov, V. I. Kuznetsov, V P. Perelygin, S M Polıkanov, Yu Ts Oganesyan, and G N. Flerov, Spontaneous Fissile Isomer with $0.9 \mathrm{msec}$ Half-Life (E), Yadern F F , 1: 67 (1965) through Sov J Nucl Phys (Engl Transl), 1: 45 (1965).

54. A. F Linev, B. N. Markov, A. A. Pleve, and S. M. Polikanov, The Formation of a Spontaneously Fissioning Isomer in the Capture of Neutrons by Am, Nucl Phys, 63: 173 (1965)

55. S. M Polikanov et al., Spontaneous Fission with an Anomalously Short Period, $Z h$ Eksp Teor Fiz., 42: 1464 (1962) through Chemical Abstracts, 57: 93951

56. Y. A. Ellıs, A = 242 in Nuclear Data Sheets, Section B, Vol 4, p 687, Academic Press, Inc., New York, 1970.

57. A. B. Beadle, D. F. Dance, L. M. Glover, and J. Milstead, The Half-Life of Americium-243, J Inorg Nucl Chem., 12: 359 (1960).

58. Y. A Ellıs and A. H. Wapstra, A = 243-261, in Nuclear Data Sheets, Section B, Vol. 3, pp. B-3-2-6 to B-3-2-53, Academic Press, Inc., New York, 1969.

59. S E. Vandenbosch and P. Day, The Decay Scheme of 10.1-h Am ${ }^{24}$, Nucl Phys., 30: 177 (1962)

60. A Ghiorso, S G. Thompson, G R. Choppin, and B. G. Harvey, New Isotopes of Americium, Berkelıum, and Calıfornium, Phys Rev , 94: 1081 (1954).

61 P. R. Fields, J. E. Gindler, A. L. Harkness, M. H Studıer, J. R. Huizenga, and A. M. Friedman, Electron Capture Decay of $\mathrm{Am}^{244}$ and the Spontaneous Fission Half-Life of $\mathrm{Pu}^{244}$, Phys Rev, 100: 172 (1955).

62. J. P Butler, T. A Eastwood, T. L. Collıns, M. E. Jones, F M. Rourke, and R. P. Schuman, Half-Lives and Neutron Capture Cross Sections of the Heavy Plutonium Isotopes, Phys Rev, 103: 634 (1956)

63. W R. Daniels, D. C. Hoffman, F. O. Lawrence, and C. J. Orth, Decay of ${ }^{245} \mathrm{Pu}, \mathrm{Nucl} P h y s$, A, 107: 569 (1968)

64 P. R. Fields, M. H. Studier, A. M. Friedman, H. Diamond, R. Sjoblom, and P. A. Sellers, Production of $\mathrm{Pu}^{245}$ and $\mathrm{Am}^{245}$ by Neutron Irradiation of $\mathrm{Pu}^{244}, J$ Inorg Nucl Chem., 1: 262 (1955).

65. C. I. Browne et al., The Decay Chain $\mathrm{Pu}^{245}-\mathrm{Am}^{245}-\mathrm{Cm}^{245}$, J. Inorg. Nucl. Chem., 1: 254 (1955)

66. M. E. Bunker, D. C. Hoffman, C. J. Orth, and J. W. Starrer, Decay of ${ }^{245}$ Am, Nucl Phys, A, 97: 593 (1967)

67. K. L. Wolf and J. P Unık, Fissioning Isomers of Americium, Curıum, and Berkelium Isotopes, Phys Lett, B, 38: 405 (1972).

68. D Engelkemeir et al., The New Isotopes $\mathrm{Pu}^{246}$ and $\mathrm{Am}^{246}, J$ Inorg Nucl Chem, 1: 345 (1953).

69 P. R Fields, I. Ahmad, R. K. Sjoblom, R. F. Barnes, and E. P. Horowitz, Nuclear Properties of ${ }^{246} \mathrm{Am}$ and ${ }^{247} \mathrm{Am}, J$ Inorg. Nucl Chem., 30: 1345 (1968)

70. C J. Orth, W. R. Daniels, B. H. Erkkıla, F. O. Lawrence, and D. C. Hoffman, New Short-Lıved Americium Beta Emitters, Phys Rev. Lett, 19: 128 (1967)

71. G. Frielander, J. W. Kennedy, and J. M. Miller, Nuclear and Radiochemistry, John W1ley \& Sons, Inc., New York, 1964.

72. R. Gold, R. J. Armani, and J. R. Roberts, Spontaneous-Fission Decay Constant of ${ }^{241}$ Am, Phys Rev., C, 1: 738 (1970).

73. J. T. Caldwell, S. C. Fultz, C. D. Bowman, and R. W. Hoff, Spontaneous Fission Half-Life of $\mathrm{Am}^{242 m}$, Phys Rev., 155: 1309 (1967).

74. B. A. Grozdev et al., Perıod of Spontaneous Fission of Americium-243, Radıokhımıya, 8: 493 (1966) through Sov. Radochem. (Engl. Transl.), 8: 459 (1966).

75. R. Marrus and J. Winocur, Hyperfine Structure and Nuclear Moments of Americium-242, Phys Rev, 124: 1904 (1961). 
$76 \mathrm{R}$ W Hoff, J L Olsen, and L G Mann, Electron Capture and Alpha Decay of Np ${ }^{25}$, Phys Rev 102: 805 (1956)

77 J M Hollander, F Reynolds, and B B Cunningham (Eds), Nuclear Chemistry Divisıon Annual Report, 1965, USAEC Report UCRL-16580 University of California Lawrence Radiation Laboratory, January 1966

78 I Lindgren, Table of Nuclear Spins and Moments, in Alpha Beta and Gamma Ray Spectroscopy K Siegbahn (Ld), Appendix 4, North Holland Publishing Co, Amsterdam, 1964

79 L Armstrong and R Marrus, Nuclear Moments of Americium-24l and $16 \mathrm{~h}$ Americium 242 and Analysis of the Hyperfine Fields, Phys Rev 144: 994 (1966)

$80 \mathrm{~T}$ E Mannıng, $\mathrm{M}$ Fred, and $\mathrm{F} \mathrm{S}$ Tomkıns, Nucledr Moments of $\mathrm{Am}^{241}$ and $\mathrm{Am}^{243}$ Phys Rev 102: 1108 (1956)

81 E K Hyde, Properties of the Atomic Nucleı, in Gmelins Handbuch der Anorganischen Chemie Band $7 a$ Transurane Tell II G Koch (Ed), pp 1961 , Verlag Chemı GmbH, Weınheım, 1973

82 C M Lederer, J M Hollander, and I Perlman, Table of Isotopes 6th ed, John Wiley \& Sons, Inc, New York, 1967

83 B S Dzhelepov and L K Peker, Decay Schemes of Radtoactive Nuclel, English translation, D L Allan ( $\mathrm{Cd}$ ), Pergamon Press, Inc, New York, 1961

84 S F Mughabghab and D I Garber Neutron Cross Sections, Vol 1, Resonance Parameters, USAEC Report BNL 325 (Vol 1) (3rd ed ), Brookhaven Natıonal Laboratory, June 1973

85 R J Howerton, Tabulated Neutron Cross Sections Part I $0001-145 \mathrm{MeV}$, USAEC Report UCRL 5226, University of Calıfornia Lawrence Radidtion Laboratory, October 1959

86 A H Wapstra and N B Gove, The 1971 Atomic Mass Evaluation in Five Parts, Nucl Data Tables 9265 (1971)

$87 \mathrm{~V} \mathrm{E} \mathrm{Viola,} \mathrm{Jr,} \mathrm{and} \mathrm{G} \mathrm{T} \mathrm{Seaborg,} \mathrm{Nuclear} \mathrm{Systematics} \mathrm{of} \mathrm{the} \mathrm{Heavy} \mathrm{Elements} \mathrm{I} \mathrm{Energetics}$ and Masses, J Inorg Nucl Chem 28.697 (1966)

$88 \mathrm{~T}$ Moeller, Periodicity and the Lanthanides and Actınıdes, $J$ Chem Educ, $47 \cdot 417$ (1970)

89 B Kanellakopulos and R D $\Gamma$ isher, Allgemeines Eigenschaften der Atome und Ionen, in Gmeltns Handbuch der Anorganischen Chemle Band $7 a$ Transurane Tell A2 G Koch (Ed), pp 2-3, Verlag Chemie GmbH, Weinheim, 1973

90 G T Seaborg, Elements Beyond 100, Present Status and Future Prospects, Ann Rev Nucl Scl 18: 53 (1968)

91 F S Tomkıns and M Fred, The Spectra of the Heavy Elements, J Opt Soc Amer 39: 357 (1947), USAEC Report AECD 2478, December 1948

92 G T Seaborg, The Chemical and Radioactive Properties of the Heavy Elements, Chem Eng News 23: 2192 (1945)

$93 \mathrm{~W} H$ Zachariasen, Crystal Chemistry of the 5f Elements, in The Actinide Elements, G $\mathrm{T}$ Seaborg and J J Katz (Eds), pp 769-795, McGraw Hill Book Co, Inc, New York, 1954

94 D B McWhan, J C Wallmann, B B Cunningham, L B Asprey, F H Ellınger, and W H Zachariasen, Preparation and Crystal Structure of Americium Metal, J Inorg Nucl Chem 15: 185 (1960)

95 D B McWhan, B B Cunnıngham, and J C Wallmann, Crystal Structure, Thermal Expansion, and Melting Point of Americium Metal, $J$ Inorg Nucl Chem 24: 1025 (1962)

$96 \mathrm{~J} \mathrm{R}$ Peterson and B B Cunningham, Crystal Structure and Lattice Parameters of the Compounds of Berkelium IV Berkelium Trifluoride, J Inorg Nucl Chem 30: 1775 (1968)

97 J R Peterson and B B Cunningham, Crystal Structure and Lattice Parameters of the Compounds of Berkelium II Berkelium Trichloride, J Inorg Nucl Chem 30: 823 (1968)

98 J R Peterson and B B Cunnıngham, Crystal Structures and Lattice Parameters of the Compounds of Berkelium I Berkelrum Dioxide and Berkelium Sesquioxide, Inorg Nucl Chem Lett 3. 327 (1967)

$99 \mathrm{~J} \mathrm{H}$ Burns and $\mathrm{J} \mathrm{R}$ Peterson, Refinement of the Crystal Structure of $\mathrm{AmCl}_{3}, A c t a$ Crystallogr Sec B 26: 1885 (1970) 
100. T. A. Carlson, C. W. Nestor, Jr., N Wasserman, and J. D. McDowell, Comprehensive Calculations of Ionization Potentials and Bindıng Energies for Multıply-Charged Ions, USAEC Report ORNL-4562, Oak Ridge Natıonal Laboratory, July 1970.

101. M. Fred and F. S. Tomkıns, Prelımınary Term Analysis of Am I and Am II Spectra, $J$ Opt Soc. Amer, 44: 824 (1957)

102. M. Fred and F. S. Tomkıns, Prelıminary Term Analysıs of Am I and Am II Spectra. $J O p t$ Soc Amer, 47: 1076 (1957).

103. R P. Thorne, The Emission Spectra of Americium. Part I, Britısh Report AERE-CR-1309, December 1953.

104. R. P. Thorne, The Spark Spectra of Americium, Spectrochtm. Acta, 8: 71 (1956)

105. M. N. Oganov, A. R. Striganov, and Yu. P. Sobolev, The Atomic Spectrum of Americium, Opt Spektros., 1: 965 (1957), USAEC Report AEC-tr-2919, 1957.

106. W. T. Carnall, Emission Spectra, in Gmelins Handbuch der Anorganischen Chemie, Band 8, Transurane, Tell A2, G. Koch (Ed), p 42, Verlag Chem1e GmbH, Weınherm, 1973

107 J. Bla1se and A. Steudel, Isotopieverschiebungskonstanten von Th, U, Pu, und Am, Z. Phys, 209: 311 (1968)

108. C. Keller, The Chemistry of the Transuranum Elements, Verlag Chemie GmbH, Weinheim, 1971

109. W T Carnall, X-Ray Spectrd, in Gmelins Handbuch der Anorganischen Cheme, Band 8, Transurane, Tell A2, G Koch (Ed.), p. 80, Verlag Chemie GmbH, Weinheim, 1973.

110 G. C. Nelson, B. G. Saunders, and S. I. Salem, Energies of the $K \alpha_{1}, K \alpha_{2}, K \beta_{1}$, and $K \beta_{3}$ X-Rays and the K-Shell Binding Energies in Neptunium, Plutonıum, and Americium, $Z$ Phys, 235: 308 (1970).

111. G. C. Nelson, B. G. Saunders, and S. I. Salem, $K \beta_{3} / K \beta_{1}$ Transition Probabilities in Elements of Medium and High Atomic Number, Phys Rev, A, 1: 1563(1970).

112. J A. Bearden, X-Ray Wavelengths, Rev Mod Phys., 39: 78 (1967)

113. J. J. Merrill and J. W. M. DuMond, Precision Measurement of L X-Ray Wavelengths and Line Widths for $74 \leqq Z \leqq 95$ and Their Interpretation in Terms of Nuclear Perturbations, Ann. Phys. (N. Y.), 14: 166 (1961)

114. P. P. Day, Electromagnetic Spectrum of $\mathrm{Am}^{241}$, Phys Rev., 97: 689 (1955)

115. W. T. Carnall, Americium(III)-Luminescence Spectra, in Gmelins Handbuch der Anorganischen Chemie, Band 8, Transurane, Tell A2, G. Koch (Ed.), p. 59, Verlag Chemı GmbH, Weinheim, 1973.

116. D. M. Gruen, J. G. Conway, R. D. McLaughlın, and B. B. Cunnıngham, Fluorescence Spectra of $\mathrm{Am}^{3+}$ in $\mathrm{LaCl}_{3}, J$ Chem. Phys., 24: 1115 (1956).

117. J. G. Conway, Energy Levels of Am(III) in $\mathrm{LaCl}_{3}, J$ Chem Phys., 40: 2504 (1964)

118. L. J. Nugent et al., Intramolecular Energy Transfer and Sensitized Luminescence in Actınide(III) $\beta$-Diketone Chelates, J Phys Chem., 73: 1540 (1969).

119 J. Gal, Z. Hadarı, E. Yanı, E. R. Baumınger, and S. Ofer, Charge States of Np Recoll Atoms Following $\alpha$ Decay, $J$ Inorg. Nucl. Chem., 32: 2509 (1970).

120. J. A Stone and W. L Pillinger, Isomer Shifts in Neptunium Compounds, USAEC Report DP-M5-67-82, E. I. du Pont de Nemours and Company, Inc., Savannah River Laboratory, September 1967.

121. B. M. Aleksandrov, A V. Kalyamın, A S Krıvokhatskı1, B. G. Lur'e, A. N. Murın, and Yu. V. Romanov, Mossbauer Spectrum of Neptunium-237 After $\alpha$-Decay of Americium-241 in a Thorium Lattice, Fiz Tverd. Tela, 10: 1896 (1968) through Sov Phys.-Soltd State (Engl Transl), 10: 1494 (1968)

122. J. A Stone and W. L. Pillınger, Recolless Gamma-Ray Emission After Alpha Decay, Phys Rev. Lett., 13: 200 (1964)

123. V. A. Bryukhanov, V. V Ovechkın, A. I. Peryshkın, E. I. Rzhekhıma, and V S. Shpınel, The Mossbauer Effect on ${ }^{23}{ }^{7} \mathrm{~Np}$ Nuclei in Neptunium Dioxide, Fiz Tverd. Tela, 9: 1519 (1967) through Sov Phys -Solld State (Engl Transl), 9: 1189 (1967) 
124. B D. Dunlap, D. J. Lam, G. M. Kalvius, and G. K. Shenoy, Investigations of the Magnetic Behavior of Some Conductıng Am Systems, J. Appl Phys., 42: 1719 (1971).

125. B. M. Aleksandrov, A V. Kalyamın, A. S. Krıvokhatskıi, B. G. Lur'e, A. N. Murın, and Yu. F. Romanov, The Mossbauer Effect in Neptunium Compounds, Radıokhımıya, 12: 852 (1970) through Sov Radtochem. (Engl. Transl), 12: 822 (1970).

126. B. D. Dunlap, M B. Brodsky, G. M. Kalvius, and G. K. Shenoy, Magnetic Behavior of Np Metal and Dilute Np Alloys from Mossbauer Effect Studies, in Plutontum 1970 and Other Actinides, Proceedings of the 4th International Conference, Santa Fe, N. Mex., Vol. 17, Parts I and II, Nuclear Metallurgy, USAEC Report CONF-701001, 1970.

127. C. Keller and R. P. Randl, Mössbauer Spectra, in Gmelins Handbuch der Anorganischen Chemie, Band 8, Transurane, Tell A2, G Koch (Ed.), p. 88, Verlag Cheme GmbH, Weinherm, 1973.

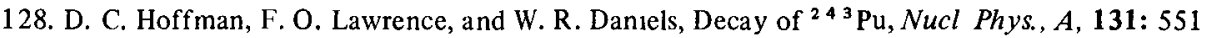
(1969)

129. G. M Kalvius, S. L. Ruby, B. D. Dunlap, G. K. Shenoy, D. Cohen, and M. B. Brodsky, Mossbauer Isomer Shift in ${ }^{243}$ Am, Phys Lett, B, 29: 489 (1969)

$130 \mathrm{~S}$. R. Bierman and E. D. Clayton, Criticality of Transuranium Actınides Unmoderated System, Trans Amer Nucl. Soc, 12: 887 (1969).

131. H. K. Clark, Critical Masses of Fissile Transplutonium Isotopes, Trans Amer Nucl Soc, 12: 886 (1969) 


\section{PRODUCTION AND USES}

\section{INTRODUCTION}

Of the isotopes of americium, only three have half-lives greater than a few hours: ${ }^{243} \mathrm{Am}\left(\mathrm{t}_{1 / 2}=7400\right.$ years $) ;{ }^{241} \mathrm{Am}\left(\mathrm{t}_{1 / 2}=433\right.$ years $)$; and ${ }^{242 \mathrm{~m}} \mathrm{Am}\left(\mathrm{t}_{1 / 2}=152\right.$ years $)$. The latter isotope is formed by irradiation of ${ }^{241} \mathrm{Am}$ with thermal neutrons and can be separated from ${ }^{241} \mathrm{Am}$ only by electromagnetic means. For all practical purposes, therefore, the chemistry and uses of americium center around the production and availability of the isotopes with mass numbers 241 and 243. In this review the discussion of the availability of ${ }^{241} \mathrm{Am}$ and ${ }^{243} \mathrm{Am}$ is limited to their production by reactor irradiation; other sources, e.g., accelerators and nuclear explosions, do not contribute substantial amounts of these isotopes to the world's supply.

\section{PRODUCTION OF ${ }^{241} \mathrm{Am}$ BY IRRADIATION OF ${ }^{239} \mathrm{Pu}$}

Neutron irradiation of ${ }^{239} \mathrm{Pu}$ produces ${ }^{241} \mathrm{Pu}$, which beta decays with a half-life of 14.0 years \pm 0.3 year to ${ }^{241} \mathrm{Am}$; a $10 \mathrm{~g}$ sample of ${ }^{241} \mathrm{Pu}$ will yield about $4 \mathrm{~g}$ of ${ }^{241} \mathrm{Am}$ after about 10 years (Ref. 1). The nuclear transformations involved in the production of ${ }^{241} \mathrm{Am}$ by irradiation of ${ }^{239} \mathrm{Pu}$ are: 


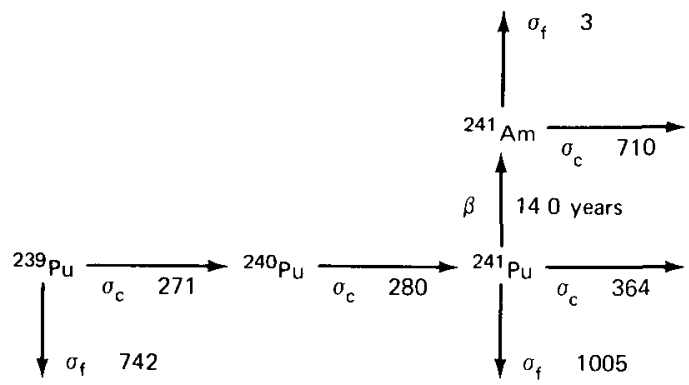

Currently at the various Energy Research and Development Administration (ERDA) sites in the United States, some 5 to $10 \mathrm{~kg}$ of ${ }^{241} \mathrm{Am}$ are recovered and purified each year as part of normal rework of aged plutonium inventories containing varying amounts of the ${ }^{241} \mathrm{Pu}$ isotope The bulk of this supply derives from the Rocky Flats site, annual availability of ${ }^{241}$ Am from this site was estimated ${ }^{2}$ at 4 to $5 \mathrm{~kg}$ in 1964 and may be higher now Additional ${ }^{241}$ Am is recovered at the Hanford and Los Alamos sites in conjunction with operation of plutonium scrap-recovery facilities (Processes used to recover and purify ${ }^{241} \mathrm{Am}$ at the ERDA sites are discussed in Chap 5 ) The purified ${ }^{241}$ Am is stockpiled at the Oak Ridge National Laboratory (ORNL), where it is marketed to various academic, governmental, and industrial customers, in 1973 alone, some $13 \mathrm{~kg}$ of ${ }^{241} \mathrm{Am}$ were sold to 13 different customers ${ }^{3}$ The ERDA price for ${ }^{241}$ Am in late 1970 was $\$ 150$ per gram, ${ }^{4}$ down from $\$ 1000$ per gram ${ }^{5}$ in 1969 and $\$ 1500$ per gram earlier

In addition to $U S$ sources, various other countries also purify and market milligram to gram amounts of ${ }^{241} \mathrm{Am}$ recovered largely from aged plutonium For example, sealed solid ${ }^{241} \mathrm{Am}$ alpha and gamma sources are avallable from the Australian AEC, ${ }^{6}$ the Radiochemical Centre, Amersham, England, ${ }^{7}$ and the French Commissariat a l'Energie Atomique ${ }^{8}$ Production statistics for the quantities of ${ }^{241} \mathrm{Am}$ recovered in these and other foreign countries have not been published

\section{PRODUCTION OF ${ }^{243} \mathrm{Am}$ \\ BY IRRADIATION OF ${ }^{24} \mathrm{Pu}$}

Nearly isotopically pure ${ }^{243} \mathrm{Am}$ results from irradiation of ${ }^{242} \mathrm{Pu}$ with thermal neutrons according to the reaction sequence

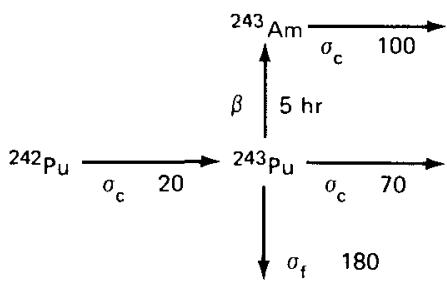


Over the last 10 years or so, Eq. 2.2 has been used in ERDA reactors to produce about $9 \mathrm{~kg}$ of ${ }^{243} \mathrm{Am}$ for use as target material in subsequent production of ${ }^{252} \mathrm{Cf}$ and for research purposes. ${ }^{9-13}$ For production of ${ }^{242} \mathrm{Pu}$ for use in Eq. 2.2, most of the ${ }^{239} \mathrm{Pu}$ in $\mathrm{Pu}-\mathrm{Al}$ alloy targets is first burned out during a preliminary irradiation in a production reactor at the ERDA Savannah River site at an average flux of about $10^{14}$ neutrons $\mathrm{cm}^{-2} \mathrm{sec}^{-1}$; the first irradiation is stopped at an exposure of $3 \times 10^{21}$ neutrons $\mathrm{cm}^{-}$(Fig. 2.1). After separation and purification (Fig. 2.2), ${ }^{242} \mathrm{PuO}_{2}$ targets are irradiated either in high-flux $\left(6 \times 10^{15}\right.$ neutrons $\left.\mathrm{cm}^{-2} \mathrm{sec}^{-1}\right)$ lattices at Savannah River $^{1-18}$ or in the High Flux Isotope Reactor (HFIR) at the ERDA Oak Ridge site at fluxes up to $3 \times 10^{15}$ neutrons $\mathrm{cm}^{-2} \mathrm{sec}^{-1}$. Figure 2.3 and Table 2.1, from Baxter, depict the production of ${ }^{243} \mathrm{Am}$ and other high mass nuclides from irradiation of

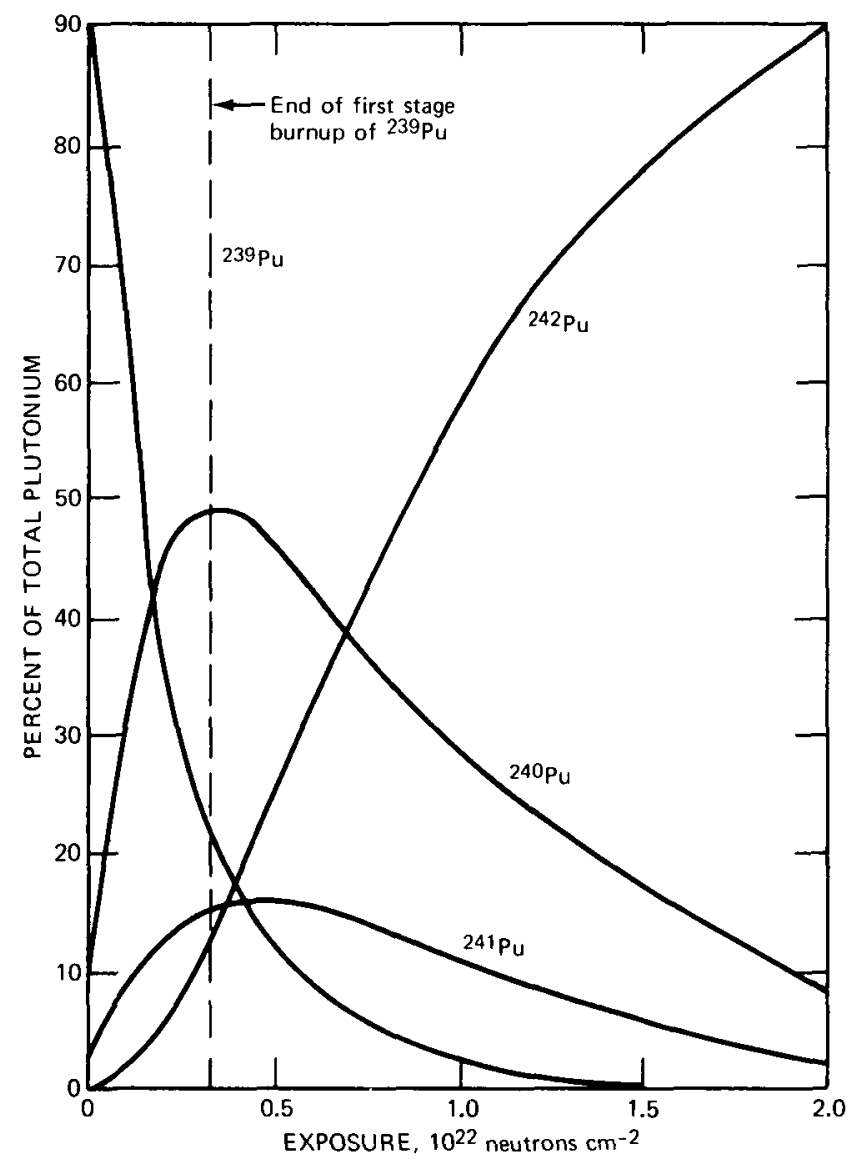

Fig. 2.1 Yield of plutonium isotopes from irradiation of ${ }^{239} \mathrm{Pu}$. 


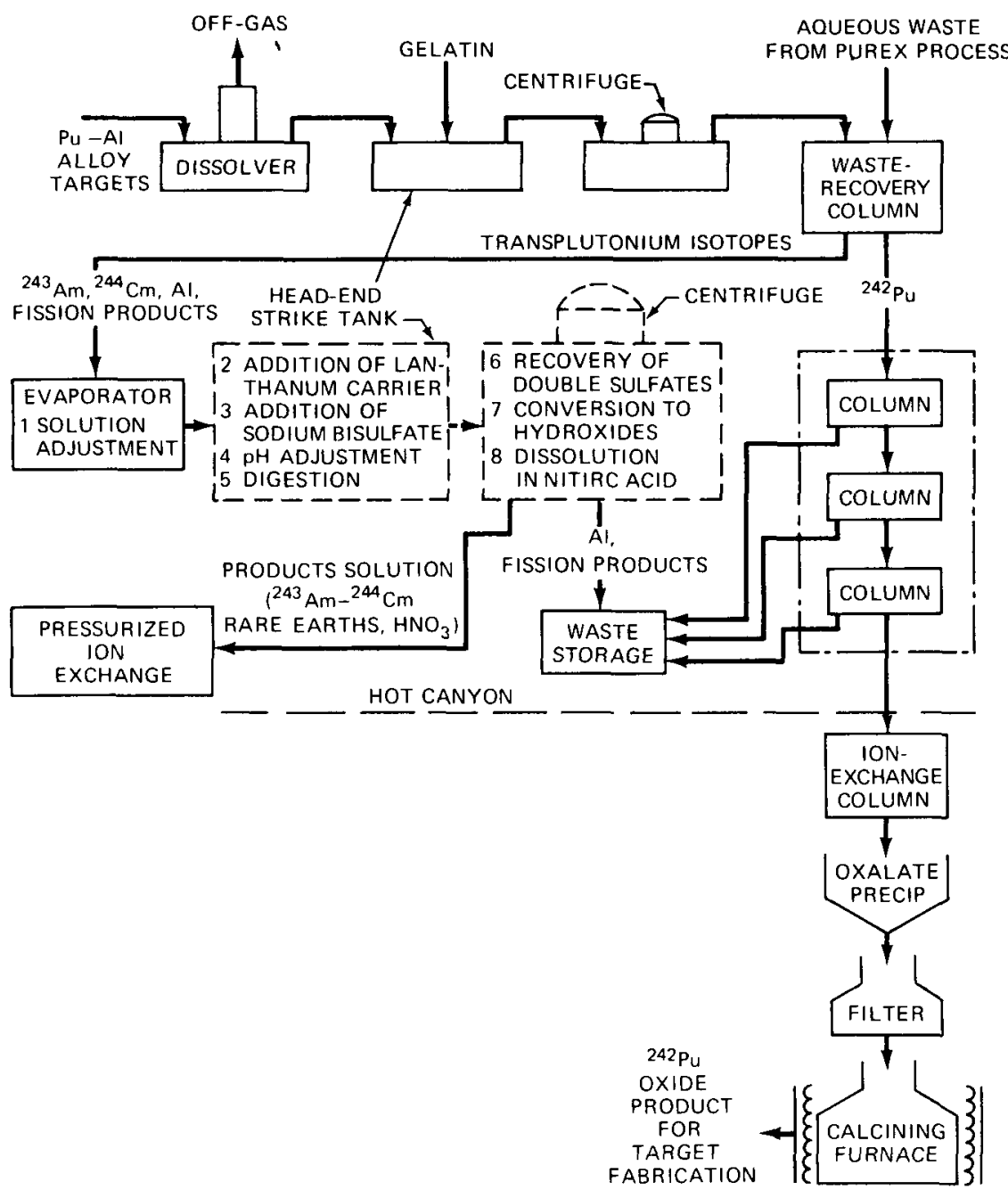

Fig. 2.2 Flow sheet of Savannah River Plant transplutonium process.

${ }^{242} \mathrm{Pu}$. Chemical procedures used to recover and purify ${ }^{243} \mathrm{Am}$ from irradiated ${ }^{242} \mathrm{PuO}_{2}$ targets are discussed in Chap. 5, and use of ${ }^{243} \mathrm{Am}$ for production of ${ }^{244} \mathrm{Cm}$ is outlined on pages 33 to 36 . Several authors ${ }^{1,10-12,19,20}$ have reviewed construction and operation of the HFIR and overall objectives of the ERDA Transplutonium Element Program. 


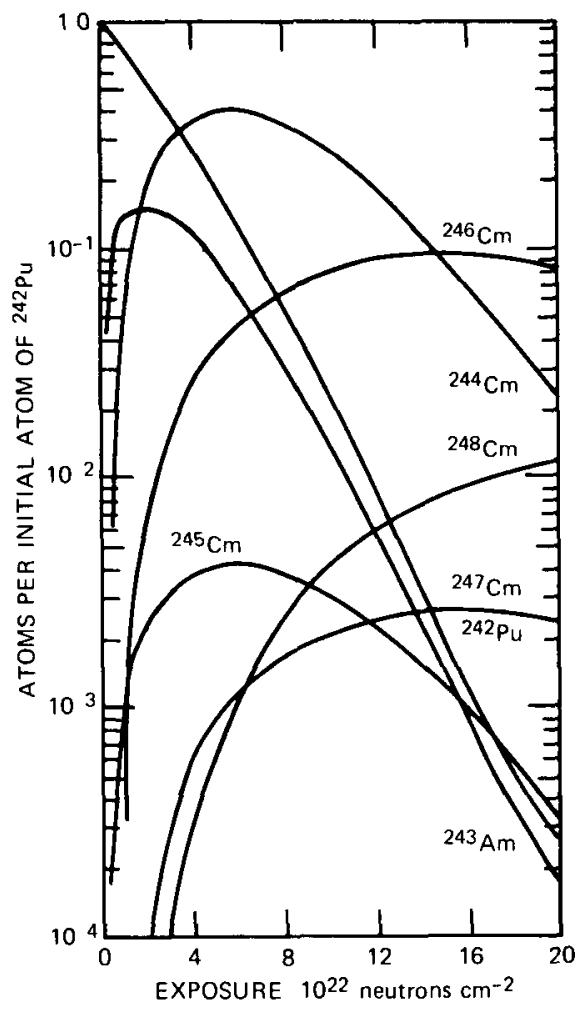

Fig. 2.3 Production of americium and curium from uradiation of ${ }^{242} \mathrm{Pu}$.

\section{AVAILABILITY OF ${ }^{241}$ Am AND ${ }^{243}$ Am FROM POWER REACTORS}

For almost 10 years now, numerous writers ${ }^{1,21-29}$ have emphasized that large quantities of ${ }^{241} \mathrm{Am}$ and ${ }^{243} \mathrm{Am}$ are being and will continue to be produced in power reactors throughout the world The exact composition of the mixture of americium 1sotopes available from this source varies with reactor exposure, at an exposure of 20,000 MWd ton ${ }^{-1}$, the mixture is essentrally 50-50 ${ }^{241} \mathrm{Am}$ and ${ }^{243} \mathrm{Am}^{21}$ Table 22 lists projections made recently by Baxter ${ }^{1}$ of the avalability of ${ }^{241} \mathrm{Am}$ and ${ }^{243} \mathrm{Am}$ from U.S commercial power reactors over the next 15 years. Of course, these estimates as well as earher ones ${ }^{2-29}$ depend very strongly on the assumptions made about reactor types and fuels and about the total U.S nuclear generating capacity. Since these bases, particularly the latter quantity, are subject to constant change, 
Table 21

PRODUCTION OF AMERICIUM ISOTOPES BY IRRADIATION OF PLUTONIUM AT A FLUX OF $3 \times 10^{15}$ neutrons $\mathrm{cm}^{2} \mathrm{sec}^{1}$

\begin{tabular}{|c|c|c|c|c|c|}
\hline \multirow{2}{*}{$\begin{array}{c}\text { Fluence, } \\
10^{22} \text { neutrons } \\
\mathrm{cm}^{2}\end{array}$} & \multirow[b]{2}{*}{ Days } & \multicolumn{4}{|c|}{ Atoms produced per atom irradiated } \\
\hline & & ${ }^{242} \mathrm{Pu}$ & ${ }^{241} \mathrm{Am}$ & $241 m_{\mathrm{Am}}$ & ${ }^{243} \mathrm{Am}$ \\
\hline 0 & 0 & 100 & 0 & 0 & 0 \\
\hline 2 & 77 & 0566 & $0547^{7} *$ & $0106^{8}$ & 0154 \\
\hline 4 & 154 & 0290 & $0121^{6}$ & $0237^{-8}$ & 0113 \\
\hline 6 & 232 & 0131 & $0139^{-6}$ & $0274^{8}$ & $0646^{1}$ \\
\hline 8 & 309 & $0542^{-1}$ & $0124^{6}$ & $0243^{-8}$ & $0313^{-1}$ \\
\hline 10 & 386 & $0214^{1}$ & $0941^{7}$ & $0185^{8}$ & $0135^{1}$ \\
\hline 12 & 463 & $0834^{2}$ & $0644^{7}$ & $0127^{8}$ & $0549^{-2}$ \\
\hline 14 & 540 & $0330^{-2}$ & $0410^{7}$ & $0809^{-9}$ & $0219^{2}$ \\
\hline 16 & 617 & $0134^{2}$ & $0247^{7}$ & $0488^{-9}$ & $0883^{-3}$ \\
\hline 18 & 694 & $0572^{3}$ & $0144^{7}$ & $0285^{9}$ & $036 T^{-3}$ \\
\hline 20 & 772 & $0255^{-3}$ & $0821^{8}$ & $0162^{-9}$ & $0159^{3}$ \\
\hline
\end{tabular}

* Exponents are powers of 10 by which the number is to be multiplied

Table 22

ESTIMATED U. S. ANNUAL PRODUCTION OF AMERICIUM FROM POWER REACTORS

\begin{tabular}{|c|c|c|c|c|c|c|}
\hline \multirow[b]{2}{*}{$\begin{array}{l}\text { Calendar } \\
\text { year }\end{array}$} & \multicolumn{2}{|c|}{$\begin{array}{c}\text { Annual availability } \\
\text { of }^{241} \mathrm{Am} \text { in } \\
\text { Am muxture, } \mathrm{kg} \text { year }\end{array}$} & \multicolumn{2}{|c|}{$\begin{array}{c}\text { Annual availability } \\
\text { of }{ }^{243} \text { Am in } \\
\text { Am mixture, kg year }\end{array}$} & \multicolumn{2}{|c|}{$\begin{array}{l}\text { Annual dvallability of } \\
241 \text { Am from processing } \\
\text { Pu stockpile, kg year }{ }^{1}\end{array}$} \\
\hline & $\begin{array}{l}\text { Case } A^{*} \\
(\text { LWR } \dagger)\end{array}$ & $\begin{array}{c}\text { Case B } \ddagger \\
\text { (LWR-U/Pu, } \\
\text { FBR } \S)\end{array}$ & $\begin{array}{l}\text { Case } A^{*} \\
(L W R \dagger)\end{array}$ & $\begin{array}{c}\text { Case B } \neq \\
(\mathrm{LWR}-\mathrm{U} / \mathrm{Pu}, \\
\text { FBR } \S)\end{array}$ & $\begin{array}{c}\text { Case A* } \\
(\mathrm{LWR} \dagger)\end{array}$ & $\begin{array}{c}\text { Case } \mathrm{B} \neq \\
(\mathrm{LWR}-\mathrm{U} / \mathrm{Pu}, \\
\text { FBR } \S)\end{array}$ \\
\hline 1975 & 38 & 39 & 50 & 53 & 118 & 119 \\
\hline 1980 & 122 & 225 & 167 & 384 & 823 & 806 \\
\hline 1985 & 237 & 568 & 312 & 913 & 2560 & 2510 \\
\hline 1990 & 377 & 695 & 462 & 645 & 6290 & 6210 \\
\hline
\end{tabular}

*Case A Light water reactors fueled with shghtly enriched uranium without plutonium or uranium $\left({ }^{236} \mathrm{U}\right)$ recycle Both cases assume $150 \times 10^{9}$ electrical watts installed by 1980

$\dagger$ LWR $=$ Light water reactors

‡Case B Light water reactors with $50 \% 236 \mathrm{U}$ recycle, limited plutonium recycle, and maximum FBR additıons beginning in 1980 PWR $-\mathrm{U} / \mathrm{Pu}$ and F BR

$\S \mathrm{FBR}=$ Fast breeder reactor includes liquid metal cooled fdst breeder reactors 
projections such as those shown in Table 22 should be regarded only as indicative of the amounts of ${ }^{241} \mathrm{Am}$ and ${ }^{243} \mathrm{Am}$ which may be avalable from power reactors Hennelly ${ }^{27}$ estimates that nuclide avalability, including that of ${ }^{241} \mathrm{Am}$ and ${ }^{243} \mathrm{Am}$, from chemical processing in the 1970s of fuels irradiated in power reactors outside the United States will be at least $50 \%$ of the U S supply in the same tıme period

Some suggested methods of using the ${ }^{241} \mathrm{Am}-{ }^{243} \mathrm{Am}$ mixture avalable from power-reactor fuels are discussed under the subheading "Applications of ${ }^{243} \mathrm{Am}$ " Because of the lack of any profit incentive, however, none of the actual or announced industrial fuel reprocessors in the United States has opted for recovery of americium isotopes (About $1 \mathrm{~kg}$ of ${ }^{241} \mathrm{Am}$ and ${ }^{243} \mathrm{Am}$ was recovered during reprocessing of Shippingport blanket fuel under ERDA aegis at the Hanford plant ${ }^{30}$ ) Certainly of interest and potentially of great significance in this latter connection is the research program $^{31}$ recently under way at several ERDA laboratories to determine if practicable ways can be found for removing all long-lived actınides from high-level Purex-process liquid waste to facilitate its subsequent treatment and storage ${ }^{32}$ Eventual success in this venture might provide the impetus for routine recovery in the United States of the ${ }^{241} \mathrm{Am}$ and ${ }^{243} \mathrm{Am}$ in power-reactor fuel

The high-level waste resulting from the reprocessing of 40 metric tons of irradiated (20.000 MWd metric ton ${ }^{1}$ ) $\mathrm{UO}_{2}$ in the West German WFK (Wiederaufarbeitungsanlage Karlsruhe) facility will contain an estumated ${ }^{33} 2 \mathrm{~kg}$ of ${ }^{241} \mathrm{Am}$ and $06 \mathrm{~kg}$ of ${ }^{243}$ Am per year As part of their "Project Actınides," German scientists are devising and testing chemical flow sheets (compare Chap 5) for recovery of the americium isotopes and subsequent irradiation to ${ }^{252} \mathrm{Cf}$

APPLICATION OF ${ }^{241}$ Am

\section{Uses Based on Characteristic Radiations}

Because of its essentially monoenergetic slpha (5 44 and $549 \mathrm{MeV}$ ) and gamma (596 keV) radiations, ${ }^{241} \mathrm{Am}$ is particularly suited for use as an X-ray excitation source and in a multitude of industrial and scientific gauging, thickness, density, and radiographic measurements Indeed, Seaborg ${ }^{34}$ states that the list of applications of ${ }^{241} \mathrm{Am}$ may well be the longest of any actinide isotope Crandall ${ }^{35}$ points out that in terms of cost, convenience, spectral purity, and lifetıme, ${ }^{241} \mathrm{Am}$ is superior to all competing radioisotopes as a low-energy gamma source

Neutron sources of various sizes which use ${ }^{241} \mathrm{Am}$ to furnish alpha particles for the reaction ${ }^{9} \mathrm{Be}(\alpha, n){ }^{12} \mathrm{C}$ find extensive use in many fields, including petroleum well logging In 1970 Baybarz $^{36}$ stated that most of the ${ }^{241}$ Am recovered worldwide was used in the manufacture of neutron sources, preparation of such sources is still (1976) the major outlet for both $\mathrm{US}$ and foreign-produced ${ }^{241} \mathrm{Am}$

Table 23 lists specific uses of ${ }^{241} \mathrm{Am}$ in various fields and industries along with the particular radiation type and property on which they are based This compilation, 
Table 2.3

CATALOG OF USES FOR ${ }^{241} \mathrm{Am}$

\begin{tabular}{|c|c|c|c|c|}
\hline \multicolumn{2}{|c|}{ Radiation } & \multicolumn{3}{|c|}{ Application } \\
\hline Type & Property & Field/ındustry & Specific use & Refs. \\
\hline \multirow[t]{14}{*}{ Gamma } & Transmission & Medicine & $\begin{array}{l}1 \text { Determine mineral } \\
\text { content of bone }\end{array}$ & $46-61$ \\
\hline & & & $\begin{array}{l}2 \text { Determine lipid } \\
\text { content of soft } t_{1} \text { ssue }\end{array}$ & 62 \\
\hline & & & $\begin{array}{l}3 \text { Evaluate regional } \\
\text { pulmonary vent } 1 \text { lation }\end{array}$ & 63 \\
\hline & & & $\begin{array}{l}\text { 4. Determine body } \\
\text { composition }\end{array}$ & 64,65 \\
\hline & & $\begin{array}{l}\text { Industral } \\
\text { gauging }\end{array}$ & $\begin{array}{l}\text { 1. Determine thickness } \\
\text { of plate glass }\end{array}$ & 66 \\
\hline & & & $\begin{array}{l}2 \text { Determine thickness } \\
\text { of metals }\end{array}$ & $67-69$ \\
\hline & & & $\begin{array}{l}3 \text { Determine thickness } \\
\text { of Al materials }\end{array}$ & 70 \\
\hline & & & $\begin{array}{l}\text { 4. Determine wire } \\
\text { thickness }\end{array}$ & 71 \\
\hline & & Soll science & $\begin{array}{l}\text { 1. Measure soll moisture } \\
\text { and density }\end{array}$ & $72-79$ \\
\hline & & Hydrology & $\begin{array}{l}1 \text { Radiation logging of } \\
\text { ground water }\end{array}$ & 80 \\
\hline & & & $\begin{array}{l}\text { 2. Sed tment concentration } \\
\text { gauge }\end{array}$ & 81 \\
\hline & & Mineralogy & $\begin{array}{l}\text { 1. Determine ore concen- } \\
\text { tration }\end{array}$ & 82 \\
\hline & & Miscellaneous & $\begin{array}{l}\text { 1. Maintain helicopter } \\
\text { flight formation }\end{array}$ & 83 \\
\hline & & & $\begin{array}{l}\text { 2. Dynamics of Freon fire } \\
\text { extinguishers }\end{array}$ & 84 \\
\hline \multirow[t]{5}{*}{ Gamma } & Backscdtter* & Meteorology & $\begin{array}{l}1 \text { Determine atmospheric } \\
\text { density }\end{array}$ & $85-86$ \\
\hline & & Coal & $\begin{array}{l}\text { 1. Determine ash content } \\
\text { of coal }\end{array}$ & $87-91$ \\
\hline & & Concrete & $\begin{array}{l}\text { 1. Determine cement } \\
\text { in concrete }\end{array}$ & 92 \\
\hline & & Mıneralogy & $\begin{array}{l}1 \text { Mineral mınıng } \\
\text { machıne }\end{array}$ & 93 \\
\hline & & & $\begin{array}{l}\text { 2. Measure ron content } \\
\text { of ores }\end{array}$ & 94 \\
\hline \multirow[t]{2}{*}{ Gamma } & $\begin{array}{l}\text { X-ray } \\
\text { excitation }\end{array}$ & Mineralogy & $\begin{array}{l}\text { 1. On-stream andlyses of } \\
\text { minerals and slurries }\end{array}$ & $95-98$ \\
\hline & source & & 2. Analysis of ores & $99-102$ \\
\hline
\end{tabular}


Table 2.3 (Contmued)

\begin{tabular}{|c|c|c|c|c|}
\hline \multicolumn{2}{|c|}{ Radiation } & \multicolumn{3}{|c|}{ Application } \\
\hline \multirow[t]{6}{*}{ Type } & Property & Field/undustry & Specific use & Refs \\
\hline & & $\begin{array}{l}\text { Analytical } \\
\text { chemistry }\end{array}$ & $\begin{array}{l}1 \text { Equipment for produc- } \\
\text { tion of X rays } \\
2 \text { Assay high purity gold }\end{array}$ & $\begin{array}{l}103-109 \\
110\end{array}$ \\
\hline & & Medicine & 1 Thyroid didgnosis & 111 \\
\hline & & Gauging & $\begin{array}{l}1 \text { Tile wear medsure } \\
\text { ments }\end{array}$ & 112 \\
\hline & & & $\begin{array}{l}2 \text { Measure thickness } \\
\text { of metal coatings on steel }\end{array}$ & $113-117$ \\
\hline & & & $\begin{array}{l}3 \text { Determine paper } \\
\text { werght density }\end{array}$ & 118 \\
\hline \multirow[t]{4}{*}{ Gamma } & $\begin{array}{l}\text { Absorption } \\
\text { radiography }\end{array}$ & Medıcıne & $\begin{array}{l}1 \text { Determine surface- } \\
\text { to-volume ratio of bone }\end{array}$ & 119 \\
\hline & & Metallurgy & $\begin{array}{l}1 \text { Radiography of thin } \\
\text { sheets of } \mathrm{Al} \text { and } \mathrm{Mg}\end{array}$ & 120 \\
\hline & & Aerospace & $\begin{array}{l}1 \text { Nondestructive testıng } \\
\text { of steel tubing }\end{array}$ & 121 \\
\hline & & Miscellaneous & $\begin{array}{l}1 \text { Development of radio- } \\
\text { graphic camera }\end{array}$ & 122 \\
\hline \multirow[t]{3}{*}{ Gamma } & $\begin{array}{l}\text { Gamma } \\
\text { source }\end{array}$ & $\begin{array}{l}\text { Radiation } \\
\text { detectors }\end{array}$ & $\begin{array}{l}1 \text { Calibration of } \\
\text { detectors }\end{array}$ & \\
\hline & & & $\begin{array}{l}2 \text { Preparation of } \\
\text { low-level gamma sources }\end{array}$ & $126-129$ \\
\hline & & Medicine & $\begin{array}{l}1 \text { Intracranial pres- } \\
\text { sure sensor }\end{array}$ & 130 \\
\hline \multirow[t]{8}{*}{ Alpha } & Ionization & Gas density & $\begin{array}{l}1 \text { Ionization gauge } \\
\text { for gas densities }\end{array}$ & $131-134$ \\
\hline & & & $\begin{array}{l}2 \text { Determine planetary } \\
\text { atmospheric density }\end{array}$ & 135 \\
\hline & & $\begin{array}{l}\text { Gas chromatog- } \\
\text { raphy }\end{array}$ & 1 Ionization detector & 136 \\
\hline & & Buildng & 1 Alr conditioning & 137 \\
\hline & & & $\begin{array}{l}2 \text { Lightnıng rods } \\
3 \text { Smoke-density detector }\end{array}$ & $\begin{array}{l}138-144 \\
145-147\end{array}$ \\
\hline & & Watchmakıng & $\begin{array}{l}1 \text { Preparation of luminous } \\
\text { paints }\end{array}$ & 148 \\
\hline & & Alpha detectors & $\begin{array}{l}1 \text { Calibration of alpha } \\
\text { spectrometer }\end{array}$ & $149-151$ \\
\hline & & Gauging & $\begin{array}{l}1 \text { Determine uniformity } \\
\text { of thin films }\end{array}$ & $152-155$ \\
\hline
\end{tabular}

(Table contınues on next page.) 
Table 2.3 (Contınued)

\begin{tabular}{|c|c|c|c|c|}
\hline \multicolumn{2}{|c|}{ Radiation } & \multicolumn{3}{|c|}{ Application } \\
\hline Type & Property & Field/Industry & Specific use & Refs. \\
\hline & & Miscellaneous & $\begin{array}{l}\text { 1. Measure relative } \\
\text { humidity of air } \\
\text { 2. Spinning disk aerosol } \\
\text { generator } \\
\text { 3. Source preparation }\end{array}$ & $\begin{array}{l}156 \\
157 \\
158-164\end{array}$ \\
\hline \multirow[t]{11}{*}{ Alpha } & $\begin{array}{l}\text { Neutron } \\
\text { source }\end{array}$ & Petroleum & 1. Well logging & $165-168$ \\
\hline & & Soll science & $\begin{array}{l}\text { 1. Determine soll density } \\
\text { and moisture content }\end{array}$ & $169-173$ \\
\hline & & Moisture meter & $\begin{array}{l}\text { 1. Moisture content } \\
\text { of coke } \\
\text { 2. Moisture content } \\
\text { of concrete }\end{array}$ & $\begin{array}{l}174,175 \\
176\end{array}$ \\
\hline & & $\begin{array}{l}\text { Activation } \\
\text { analysis }\end{array}$ & $\begin{array}{l}\text { 1. Determine carbon } \\
\text { in fly ash }\end{array}$ & 177 \\
\hline & & & $\begin{array}{l}\text { 2. Determine proteın } \\
\text { in grain }\end{array}$ & 178 \\
\hline & & & $\begin{array}{l}\text { 3. Determine fluorine } \\
\text { in ores }\end{array}$ & 179 \\
\hline & & & $\begin{array}{l}\text { 4. Determine silicon } \\
\text { in cast iron }\end{array}$ & 180 \\
\hline & & & $\begin{array}{l}\text { 5. Determine phosphorus } \\
\text { in bone }\end{array}$ & 181 \\
\hline & & Neutron counter & $\begin{array}{l}\text { 1. Thermal neutron } \\
\text { counter }\end{array}$ & 182 \\
\hline & & $\begin{array}{l}\text { Neutron-source } \\
\text { preparation }\end{array}$ & $\begin{array}{l}\text { 1. Preparation of }(a, n) \\
\text { and }(\gamma, n) \text { sources }\end{array}$ & $183-188$ \\
\hline & & & $\begin{array}{l}2 \text { Preparation of a } \\
{ }^{241} \mathrm{Am}-\mathrm{Be}-{ }^{242} \mathrm{Cm} \text { source }\end{array}$ & 189 \\
\hline
\end{tabular}

* Backscatter methods depend on Compton scatterıng of gamma rays to return degraded source gamma rays to a detector near the source

although not necessarily complete, includes examples of all the principal areas where ${ }^{241} \mathrm{Am}$ has found some actual or suggested use Applications of ${ }^{241} \mathrm{Am}$ (and, in some cases, also of ${ }^{243} \mathrm{Am}$ ) have been discussed previously by Baxter, ${ }^{1}$ Crandall, ${ }^{35}$ Baybarz, ${ }^{36}$ Rohrmann, ${ }^{37}$ Seaborg, ${ }^{13,34}$ Fowler, ${ }^{38}$ Eichholz, ${ }^{39}$ Muller, ${ }^{40}$ Keller, ${ }^{41}$ Ranschoff, ${ }^{42}$ Strain and Leddicotte, ${ }^{43}$ West ${ }^{44}$ and most recently by LeVert and Helmınski. ${ }^{45}$ The review paper by LeVert and Helminski is particularly exhaustive and provides detailed information on many of the applications mentioned in Table 2.3. In addition to those cited in Table 2.3 , references to the preparation of ${ }^{241} \mathrm{Am}-\mathrm{Be}$ neutron sources are given in Chap. 4, Sec. 4.2.2. 


\section{Use in Production of ${ }^{242} \mathrm{Cm}$}

The use of ${ }^{241} \mathrm{Am}$ as a target in nuclear reactors for the production of ${ }^{242} \mathrm{Cm}$ is potentially a very important application Alpha decay of ${ }^{242} \mathrm{Cm}$ produces ${ }^{238} \mathrm{Pu}$, a radionuclide much in demand as an isotopic power source in space and medical applications The ${ }^{238} \mathrm{Pu}$ produced by the decay of ${ }^{242} \mathrm{Cm}$ contains minimal amounts $(<002 \mathrm{ppm})^{190}$ of the undesirable ${ }^{236} \mathrm{Pu}$ contaminant, compared to the $10 \mathrm{ppm}$ or so in the ${ }^{238} \mathrm{Pu}$ produced by ${ }^{237} \mathrm{~Np}$ irradiation in a light-water-reactor spectrum, ${ }^{191}$ this is a distinct advantage for ${ }^{238} \mathrm{Pu}$ to be used in cardiac pacemakers ${ }^{192}$

Because of its high power output $\left(120 \mathrm{~W} \mathrm{~g}^{-1}\right)$ and minor shielding requirements, ${ }^{242} \mathrm{Cm}$ has been projected for use in the preparation of heat sources A $900-\mathrm{W}$ SNAP-11 generator fueled with $75 \mathrm{~g}$ of ${ }^{242} \mathrm{Cm}$ (as $\mathrm{Cm}_{2} \mathrm{O}_{3}$ ) was fabricated at ORNL, ${ }^{193}$ whereas European ${ }^{194}$ workers manufactured a thermoelectric battery contaning $400 \mathrm{mg}$ of ${ }^{242} \mathrm{Cm}$ The potentral application of ${ }^{242} \mathrm{Cm}$ as an isotopic power source is limited, as Baybarz notes, ${ }^{36}$ by its relatively short half-life (163 days), in most heat-source applications, the main criterion is that the generator supply a relatively uniform heat output for an extended period of time

The thermal-neutron-capture sequence involved in producing ${ }^{242} \mathrm{Cm}$ from pure ${ }^{241} \mathrm{Am}$ is

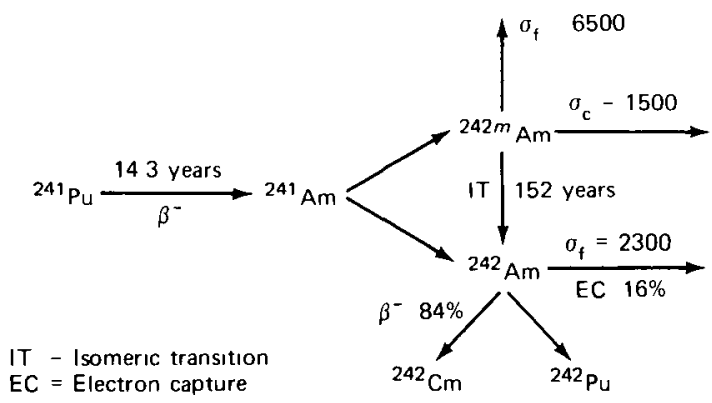

Hennelly ${ }^{27}$ notes that ${ }^{242} \mathrm{Cm}$ product is lost by ${ }^{242 m} \mathrm{Am}$ formation, by ${ }^{242} \mathrm{Am}$ fission, which is a function of neutron flux, by electron capture of ${ }^{242} \mathrm{Am}$ to form ${ }^{242} \mathrm{Pu}$, and by ${ }^{242} \mathrm{Cm}$ alpha decay giving an optimum yield of about $065 \mathrm{~g} \mathrm{of}{ }^{242} \mathrm{Cm}$ per gram of ${ }^{241} \mathrm{Am}$ burned

\section{APPLICATION OF ${ }^{243}$ Am}

Its longer half-life and lower specitic activity compared to those of ${ }^{241} \mathrm{Am}$ make ${ }^{243} \mathrm{Am}$ particularly useful in determining or redetermining basic aqueous and solid state chemistry of americium, its use in such studies is steadily increasing By far, however, the most important application of ${ }^{243} \mathrm{Am}$ is its use as a target material for the production of ${ }^{244} \mathrm{Cm}$ and, when mixed with ${ }^{244} \mathrm{Cm}$, as a target material for the manufacture of ${ }^{252} \mathrm{Cf}$ and other transuranum elements in high neutron-flux reactors 
The neutron-capture sequence involved in the production of ${ }^{244} \mathrm{Cm}$ and ${ }^{252} \mathrm{Cf}$ is shown in Fig 24

Mixed ${ }^{244} \mathrm{Cm}-{ }^{243} \mathrm{Am}$ oxide for use in fabricating targets for irradiation in the HFIR at Oak Ridge is currently prepared by calcınıng cation-exchange resin contaınıng sorbed ${ }^{244} \mathrm{Cm}$ and ${ }^{243} \mathrm{Am}{ }^{195}$ Techniques for preparing target ${ }^{244} \mathrm{Cm}-{ }^{243} \mathrm{Am}$ oxide microspheres by solgel methods have also been described 196,197 Target assemblies containing ${ }^{243} \mathrm{Am}$ and ${ }^{244} \mathrm{Cm}$ are prepared for irradiation in high-flux high-power density cores at Savannah River by uniformly mixing americium-curium oxide material with aluminum powder and pressing the material into compacts, ${ }^{14}$ several of these compacts are canned together to form 6-1n -long slugs

Curium-244, which has an 18-year half-lıfe, has been proposed as an alternative to ${ }^{238} \mathrm{Pu}$ for use in isotopic power sources Curium-244 has the advantage of a higher thermal power than ${ }^{238} \mathrm{Pu}$ but suffers from having a higher radiation level of neutrons produced by spontaneous fission The latter falling prevents its use for biomedical purposes Baybarz ${ }^{36}$ mentions that, whereas ${ }^{238} \mathrm{Pu}$ heat sources are mainly limited to the thermoelectric mode of generating electric power, the thermionic mode may be envisioned for ${ }^{244} \mathrm{Cm}$ heat sources

Americium separated from power-reactor fuel contains, as discussed previously, a mixture of ${ }^{241} \mathrm{Am}$ and ${ }^{243} \mathrm{Am}$ in varying ratios Table 24 , from Baxter, ${ }^{1}$ lists the production of high-mass nuchides obtaned by irradiating power-reactor amenicium (50-50 mixture of ${ }^{241} \mathrm{Am}$ and ${ }^{243} \mathrm{Am}$ ) at a flux of $175 \times 10^{14}$ neutrons $\mathrm{cm}^{-2} \mathrm{sec}^{-1}$

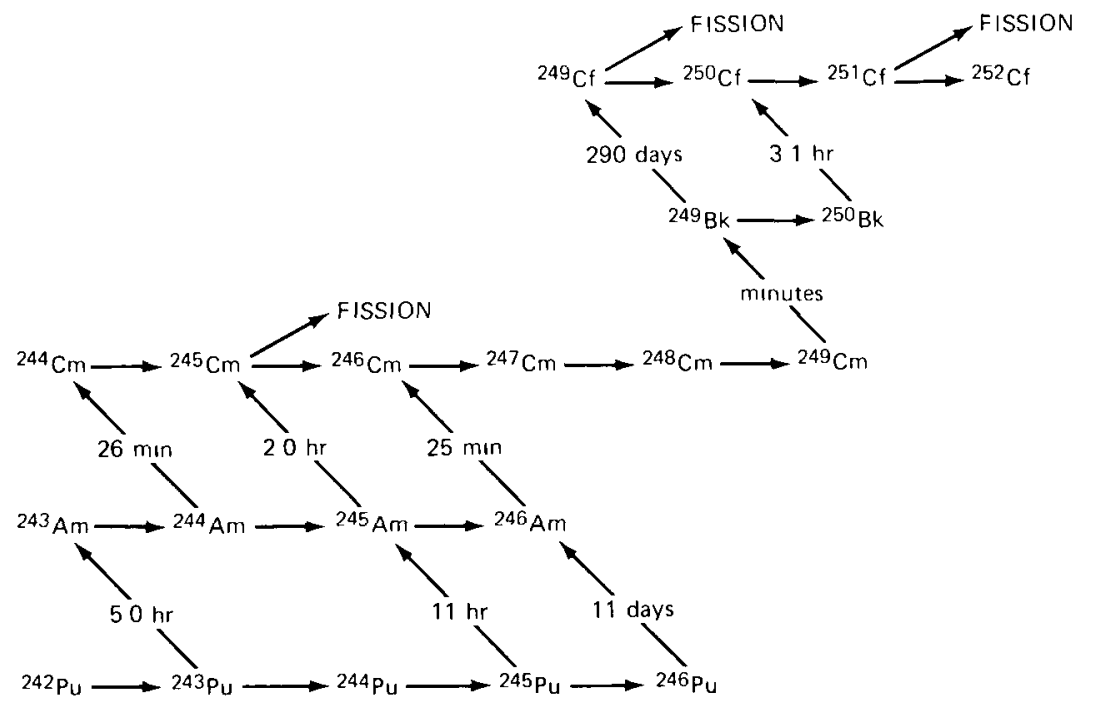

Fig. 2.4 Nucledr reactions for the production of ${ }^{252} \mathrm{Cf}$. IFrom R D. Baybarz, Recovery and Applications of the Transuranium Elements ${ }^{237} \mathrm{~Np},{ }^{238} \mathrm{Pu},{ }^{241} \mathrm{Am},{ }^{242} \mathrm{Cm},{ }^{244} \mathrm{Cm}$, and ${ }^{252} \mathrm{Cf}$, Atomic Energy Review, 8327 (1970).] 
Table 2.4

PRODUCTION OF HIGH-MASS NUCLIDES* BY IRRADIATION OF POWER-REACTOR AMERICIUM AT A FLUX OF $1.75 \times 10^{14}$ neutrons $\mathrm{cm}^{-2} \mathrm{sec}^{-1}$

\begin{tabular}{|c|c|c|c|c|c|c|c|c|c|}
\hline \multirow{2}{*}{$\begin{array}{l}\text { Fluence, } \\
10^{22} \text { neu- } \\
\text { trons } \mathrm{cm}^{-2}\end{array}$} & \multirow[b]{2}{*}{ Days } & \multicolumn{8}{|c|}{ Atoms produced per single "average atom" of ${ }^{241} \mathrm{Am}$ and ${ }^{243} \mathrm{Am}$ irradiated } \\
\hline & & ${ }^{238} \mathrm{Pu}$ & ${ }^{239} \mathrm{Pu}$ & $240 \mathrm{Pu}$ & ${ }^{241} \mathrm{Pu}$ & $242 \mathrm{Pu}$ & \multirow{2}{*}{$\begin{array}{c}{ }^{241} \mathrm{Am} \\
1.000\end{array}$} & $242 m_{A m}$ & \multirow{2}{*}{$\frac{{ }^{24} \mathrm{Am}}{1.000}$} \\
\hline 0 & & & & & & & & & \\
\hline 0.2 & 132 & $0.841^{-1} \dagger$ & $0.182^{-1}$ & $0.278^{-2}$ & $0.643^{-3}$ & $0.702^{-1}$ & 0.356 & $0.685^{-2}$ & 0.833 \\
\hline 0.4 & 265 & 0.150 & $0.540^{-1}$ & $0.132^{-1}$ & $0.437^{-2}$ & $0.906^{-1}$ & 0.124 & $0.245^{-2}$ & 0.687 \\
\hline 0.6 & 397 & 0.152 & $0.693^{-1}$ & $0.246^{-1}$ & $0.939^{-2}$ & $0.960^{-1}$ & $0.426^{-1}$ & $0.849^{-3}$ & 0.561 \\
\hline 0.8 & 529 & 0.122 & $0.640^{-1}$ & $0.307^{-1}$ & $0.127^{-1}$ & $0.978^{-1}$ & $0.147^{-1}$ & $0.293^{-3}$ & 0.457 \\
\hline 1.0 & 661 & $0.870^{-1}$ & $0.497^{-1}$ & $0.309^{-1}$ & $0.137^{-1}$ & $0.989^{-1}$ & $0.514^{-2}$ & $0.102^{-3}$ & 0.371 \\
\hline 1.2 & 794 & $0.575^{-1}$ & $0.348^{-1}$ & $0.272^{-1}$ & $0.129^{-1}$ & $0.993^{-1}$ & $0.190^{-2}$ & $0.377^{-4}$ & 0.301 \\
\hline 1.4 & 926 & $0.362^{-1}$ & $0.228^{-1}$ & $0.224^{-1}$ & $0.112^{-1}$ & $0.985^{-1}$ & $0.784^{-3}$ & $0.154^{-4}$ & 0.244 \\
\hline 1.6 & 1058 & $0.221^{-1}$ & $0.143^{-1}$ & $0.181^{-1}$ & $0.940^{-2}$ & $0.965^{-1}$ & $0.385^{-3}$ & $0.741^{-5}$ & 0.199 \\
\hline 1.8 & 1190 & $0.132^{-1}$ & $0.872^{-2}$ & $0.148^{-1}$ & $0.781^{-2}$ & $0.935^{-1}$ & $0.229^{-3}$ & $0.435^{-5}$ & 0.162 \\
\hline 2.0 & 1323 & $0.771^{-2}$ & $0.519^{-2}$ & $0.125^{-1}$ & $0.663^{-2}$ & $0.897^{-1}$ & $0.161^{-3}$ & $0.300^{-5}$ & 0.132 \\
\hline \multirow{2}{*}{$\begin{array}{l}\text { Fluence, } \\
10^{22} \text { neu- } \\
\text { trons } \mathrm{cm}^{-2}\end{array}$} & \multicolumn{9}{|c|}{ Atoms produced per single "average atom" of ${ }^{241} \mathrm{Am}$ and ${ }^{243} \mathrm{Am}$ irradiated } \\
\hline & Days & ${ }^{242} \mathrm{Cn}$ & 243 & & ${ }^{44} \mathrm{Cm}$ & ${ }^{245} \mathrm{Cm}$ & ${ }^{246} \mathrm{Cm}$ & ${ }^{247} \mathrm{Cm}$ & ${ }^{248} \mathrm{Cm}$ \\
\hline \multicolumn{10}{|l|}{0} \\
\hline 0.2 & 132 & 0.304 & 0.34 & $9^{-2}$ & 0.189 & $0.175^{-2}$ & $0.488^{-3}$ & $0.196^{-5}$ & $0.598^{-7}$ \\
\hline 0.4 & 265 & 0.277 & 0.50 & $9^{-2}$ & 0.341 & $0.305^{-2}$ & $0.188^{-2}$ & $0.149^{-4}$ & $0.984^{-6}$ \\
\hline 0.6 & 397 & 0.191 & 0.43 & $3^{-2}$ & 0.459 & $0.399^{-2}$ & $0.388^{-2}$ & $0.440^{-4}$ & $0.455^{-5}$ \\
\hline 0.8 & 529 & 0.119 & 0.30 & $0^{-2}$ & 0.549 & $0.468^{-2}$ & $0.631^{-2}$ & $0.902^{-4}$ & $0.129^{-4}$ \\
\hline 1.0 & 661 & $0.701^{-1}$ & 0.18 & $9^{-2}$ & 0.616 & $0.518^{-2}$ & $0.905^{-2}$ & $0.152^{-3}$ & $0.279^{-4}$ \\
\hline 1.2 & 794 & $0.403^{-}$ & 0.11 & $2^{-2}$ & 0.664 & $0.554^{-2}$ & $0.120^{-1}$ & $0.228^{-3}$ & $0.515^{-4}$ \\
\hline 1.4 & 926 & $0.229^{-}$ & 0.65 & $1^{-3}$ & 0.696 & $0.578^{-2}$ & $0.151^{-1}$ & $0.316^{-3}$ & $0.849^{-4}$ \\
\hline 1.6 & 1058 & $0.129^{-}$ & 0.37 & $1^{-3}$ & 0.716 & $0.594^{-2}$ & $0.182^{-1}$ & $0.412^{-3}$ & $0.129^{-3}$ \\
\hline 1.8 & 1190 & $0.729^{-}$ & 0.21 & $0^{-3}$ & 0.727 & $0.602^{-2}$ & $0.214^{-1}$ & $0.514^{-3}$ & $0.185^{-3}$ \\
\hline 2.0 & 1323 & $0.409^{-}$ & 0.11 & $9^{-3}$ & 0.730 & $0.605^{-2}$ & $0.246^{-1}$ & $0.621^{-3}$ & $0.253^{-3}$ \\
\hline
\end{tabular}

*From Ref. 3.

$\dagger$ Exponents are powers of 10 by which the number is to be multiplied. 
One method of using power-reactor ${ }^{241} \mathrm{Am}-{ }^{243} \mathrm{Am}$ mixtures is to preburn them in a thermal redctor to burn up ${ }^{241} \mathrm{Am}$, preferentially to ${ }^{242} \mathrm{Cm}$ which would decay to ${ }^{238} \mathrm{Pu}{ }^{198}$ After the ${ }^{243}$ Am-rich target mixture is chemically separated, it could be recycled to a resonance reactor for the production of ${ }^{252} \mathrm{Cf}$ An alternative, according to Christman and Cornman, ${ }^{190}$ is to irradiate the target mixture in the resonance reactor to accelerate the production of ${ }^{252} \mathrm{Cf}$ from ${ }^{243} \mathrm{Am}$ and, at the same time, to produce ${ }^{238} \mathrm{Pu}$ from ${ }^{241} \mathrm{Am}$ Figure 25 shows the production yields for ${ }^{252} \mathrm{Cf}$ and ${ }^{238} \mathrm{Pu}$ which might be realized for this latter alternative with the target management schedules that are necessary because the ${ }^{242} \mathrm{Cm}$ alpha activity limits and/or delays chemical separation and target-fabrication operations

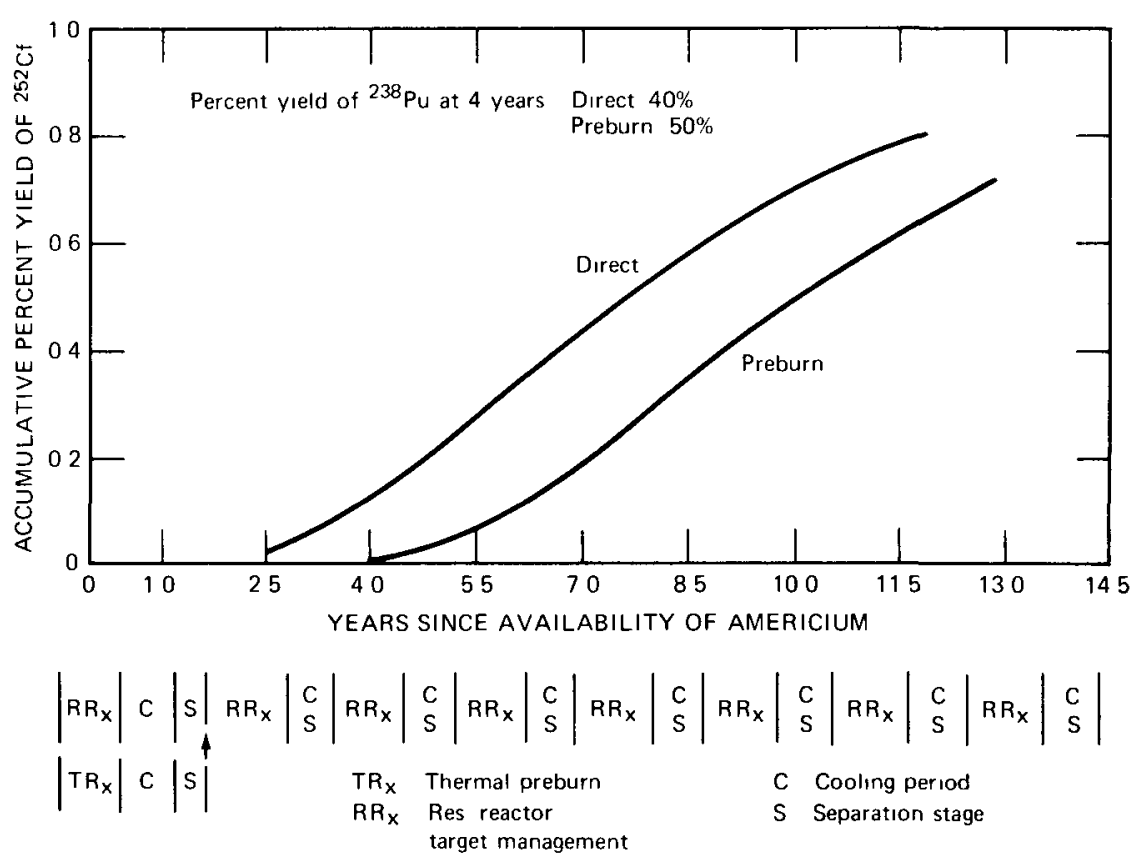

Fig. 25 Yields of ${ }^{252} \mathrm{Cf}$ and ${ }^{238} \mathrm{Pu}$ from americium [From R P. Christman and W. R. Cornman, Utulization of Power Reactor Americium for ${ }^{252} \mathrm{Cf}$ Production, Transactions of the American Nuclear Society, 1254 (1969).]

\section{REFERENCES}

1 R. G. Baxter, Actinide Properties and Methods of Production, USAEC Report DP-1269, Savannah River Laboratory, December 1972

2 A K Willams, Americuum Capability at Rocky Flats, USAEC Report RFP 349, Dow Chemical Company, 1964 
3 J L Simmons (Comp ), List of AEC Radıoisotope Customers with Summary of Radioisotope Shipments FY 1973, USAEC Report BNWL-1824, Battelle Memorial Institute, Pacific Northwest Laboratories, June 1974

4 Nuclide Price Changes, Isotop Radtat Technol, 8(2) 243 (Winter 1970-1971)

5 Prices for Two Radioisoto pes Being Lowered, Isotop Radıat Technol, 6(1) 119 (Fall 1968)

6 Australıa Supplies Solıd Radioactive Sources for Calıbration Purposes, Isotop Radiat Technol, 6(3) 338 (Spring 1969).

7. Radiochemicals Catalog 1972/73, Amersham/Searle Corporation, Arlington Heıghts, Ill

8 New French Isotope Catalog, Isotop Radiat Technol, 7(1) 123 (Fall 1969).

9. J. L. Crandall and J. A Smith, A Description of the Savannah River High-Flux Charge, Trans Amer Nucl Soc, 853 (1965).

10. G. T. Seaborg, J. L. Crandall, P. R. Fields, A. Ghiorso, O. L. Keller, Jr., and R. A. Penneman, Recent Advances in the United States of the Transuranium Elements, in Proceedings of the Fourth International Conference on the Peaceful Uses of Atomtc Energy, Geneva, 1971, Vol 7,p 487, United Nations, New York, 1972.

11. D. E. Ferguson and J. E. Bigelow, Production of ${ }^{252} \mathrm{Cf}$ and Other Transplutonium Isotopes in the United States of America, Actinides Rev, 1213 (1969)

12 D. E. Ferguson (Ed), ORNL Transuranium Program The Production of Transuranium Elements, Nucl Scl Eng, 17435 (1963).

13. G. T. Seaborg, Mass Production and Practical Applications of Actınide Elements, Isotop Radiat Technol, 6(1) 1 (Fall 1968).

14. T. C. Gorrell, Transplutonium Production, Trans Amer Nucl Soc, 14343 (1971)

15 C. J. Banick, Americium, Curium, and Plutonium Yields in SRP High-Flux Irradiations, USAEC Report DP-1 157, Savannah River Laboratory, July 1968

16. H. P. Holcomb, Yields of Transcurium Nuclides in SRP High-Flux Reactor, USAEC Report DP-1137, Savannah River Laboratory, December 1967.

17 W. P. Overbeck, C. H. Ice, and G Dessauer, Production of Transplutonium Elements at Savannah River, USAEC Report DP-1000, Savannah River Laboratory, Nove mber 1965

18 J. L. Crandall, The Sdvannah River High-Flux Demonstration, USAEC Report DP-999, Savannah River Laboratory, June 1965.

19. C. C. Winter, The High-Flux Isotope Reactor, Nucl Scl Eng, 17443 (1963)

20. J. A. Swartout, A. L. Bach, T. E. Cole, R. D. Cheverton, G. M. Adamson, and C. E. Winter, The Oak Ridge High-Flux Isotope Reactor, in Proceedings of the Third International Conference on the Peaceful Uses of Atomıc Energy, Geneva, 1964, Vol 7, p 360, United Nations, New York, 1965

21. C. A Rohrmann, Values in Spent Fuel from Power Reactors, USAEC Report BNWL-25, Battelle Memorial Institute, Pacific Northwest Laboratories, March 1965

22 E. J. Hennelly and R. R. Hood, Radioisotope Production Capabilities of U. S. Power Reactors, USAEC Report DP-1015, Savannah River Laboratory, November 1965

23. D. E Deonigı and E. A. Eschbach, Production and Indifference Pricing of Transuranium Isotopes, USAEC Report BNWL-223, Battelle Memorial Institute, Pacific Northwest Laboratones, March 196 ؛

24. R. W. McKee, D. E. Deonigi, and D R Haffner, Isotope Production Projections for the U.S. Nuclear Power Reactors, USAEC Report BNWL-SA-1529, Battelle Memorial Institute, Pacific Northwest Laboratories, March 1968

25 D. E. Deonigl, Isotope Production and Avallability from Power Reactors, USAEC Report BNWL-716, Battelle Memorial Institute, Pacific Northwest Laboratories, July 1968.

26. D. E. Deonigl, ${ }^{241} \mathrm{Am}$ and ${ }^{238} \mathrm{Pu}$ Avalability, in Pacific Northwest Laboratory Division of Isotope Development Programs, Quarterly Report, November 1968-January 1969, K. Drumheller (Ed), USAEC Report BNWL-1010, Battelle Memorial Institute, Pacific Northwest Laboratories, February 1969. 
27. E. J. Hennelly, Large-Sćale Productıon of Radıosotopes, in Radıotsotope Engıneerıng, G. G. Elchholz (Ed.), pp. 47-134, Marcel Dekker, Inc , New York, 1972

28 P. M. Wood, Isotope Production and Development, Isotop. Radiat Technol, 9(2) 129 (Winter 1971-1972).

29 L. W. Lang, D. E Deonig1, and C. A. Rohrmann, Power Cost Reduction from Isotope Revenues, $\mathrm{Nucl} \mathrm{Appl,} 3665$ (1967).

30 E. J. Wheelwright, F P. Roberts, and L. A. Bray, Simultaneous Recovery and Purification of $\mathrm{Pm}, \mathrm{Am}$, and $\mathrm{Cm}$ by the Use of Alternating DTPA and NTA Cation-Exchange Flowsheets, USAEC Report BNWL-SA-1492, Battelle Memortal Institute, Pacific Northwest Laboratories, March 1968

31. J. W. Bartlett, L. A. Bray, L. L, Burger, R. E. Burns, and J. L. Ryan, Feası Jity Evaluation and R\&D Program Plan for Transuranic Partitionıng of High-Level Fuel Reprocessing Waste, USAEC Report BNWL-1776, Battelle Memorial Institute, Pacific Northwest Laboratories, November 1973.

32 J. O. Blomeke, J. P. Nichols, and W. C. McClain, Managing Radioactive Wastes, Phys Today, 2636 (1973).

33. G. Hohleın and R. Gasteiger, Das Actınıden-Projekt der Gesellschaft fuer Kernforschung mbH, in Proceedings of Seminar on Radiation Protection Problems Relating to Transuranium Elements, Karlsruhe, 1970 (CONF-700930)

34 G. T. Seaborg, The Synthetıe Actunides From Discovery to Manufacture, Nucl Appl Technol, 9830 (1970).

35 J. L. Cranddll, Applications of Transplutonium Elements, USAEC Report DP-MS-71-52, Savannah River Laboratory, September 1971

36. R. D. Baybarz, Recovery and Application of the Transuranum Elements ${ }^{237} \mathrm{~Np},{ }^{238} \mathrm{Pu}$, ${ }^{241} \mathrm{Am},{ }^{242} \mathrm{Cm},{ }^{244} \mathrm{Cm}$, and ${ }^{252} \mathrm{Cf}$, At Energy Rev, 8327 (1970).

37 C. A. Rohrmann, Avalability and Applications of Radioactive and Stable By-Products from the Chemical Processing of Spent Nuclear Power Fuels, USAEC Report BNWL-SA-4108, Battelle Memorial Institute, Pacific Northwest Laboratories, 1971

38. E. E. Fowler, Recent Advances in Applications of Isotopes and Radiation in the United States, in Proceedings of the Fourth International Conference on the Peaceful Uses of Atomic Energy, Geneva, 1971, Vol 14, p 29, United Nations, New York, 1972

39. G. G. Eichholz, Radıotsotope Engineertng, Marcel Dekker, Inc , New York, 1972

40 W. Muller, Possible Applications of Transuranum Elements, Chem Ztg, 95285 (1971).

41. C. Keller, Preparation and Application of Transuranium Elements, Naturwiss. Rundsch, 25 331 (1972).

42 M. J. A. Ranschoff, Amer 1cium, Energ Nucl, 7246 (1965)

43. J. E. Strain and G. W. Leddicotte, The Preparation, Properties, and Uses of Americium-241 Alpha, Gamma, and Neutron Sources, USAEC Report ORNL-3335, Oak Ridge National Laboratory, September 1962, also in Nucleonics, 2090 (1962).

44. R. West, Low-Energy Gamma-Ray Sources, Nucleontcs, 1120 (1953).

45 F E LeVert and E L Helminski, Literature Review and Commercial Source Evaluation of Americium-241, USAEC Report ORO-4333-1, Tuskegee Instıtute, June 1973

46 J. R. Cameron and J. A. Sorenson, Measurement of Bone Mineral and Body Composition in Vivo, in Proceedings of the Fourth Nordic Meeting of Chemical Physics, A. Rytila and E Spring (Fds.), Helsinkı, 1966.

47 J. R. Cameron and J. Sorenson, Measurement of Bone Mineral in Vivo An Improved Method, Sclence, $142230(1963)$

48. A. J. Gilson, M J. Cohen, and F. Day, Bone Density Measurement by Means of Radioisotopic Source Photon Attenuation, presented at Society of Nuclear Medicine, 12 th Annual Meeting, Bal Harbour, Fla , 1965 
49. Bo E. R. Nilsson, Post-Traumatic Osteopenia A Quantitative Study of the Bone Mineral Mass in the Femur Following Fracture of the Tibid in Man Using ${ }^{24}$ ' Am ds d Photon Source, Acta Orthop Scand, 37 (Suppl 91) 1 (1966).

$50 \mathrm{~J}$. A. Sorenson and J R Cameron, Measurement of Bone Mineral by the Direct Photon Absorption Method Principles and Instrumentation, in Conference on Progress in Methods of Bone Mineral Measurement, Bethesda, Md, Feb 15, 1968, USAEC Report CONF-680211-1 (COO-1422-21), 1968

51 E M Davis, L H Lanzl, and A B Cox, Detection, Prevention, and Retardation of Menopausal Osteoporosis, presented at International Symposium on Osteoporosis, Bronx, N Y, June 25 26, 1969, USAEC Report CONF-690633-1

52 Bo E. Nisson, Bone Densitometry Using a Single Beam trom a Radionuclide Source, in Conference on Progress in Methods of Bone Mineral Measurements, Bethesda, Md, 1968 (CONF-680211, pp 319-328)

53 P. F. Judy, Theoretical Accuracy and Precision in the Photon Attenudtion Measurement of Bone Mineral, in Proceedings of Bone Measurement Conference, Chicago, Ill, May 22-23, 1970, J R Cameron (Ed ), USAEC Report CONF-700515, pp 1-21

54. L. H. Lanzl, A. Cox, G. Dobben, R Olson, J Toman, and A Schrodt, Additional System for Bone Densitometry Studies, in Proceedings of Bone Measurement Conference, Chicago, Ill , May 22-23, 1970, J R. Cameron (Ed ), USAEC Report CONF-700515, pp 33-47

55 A. G. Schrodt, R. E. Schavey, and J. E. Kus, Features and Performance Characteristics of the Packard Osteodensitometer, in Proceedings of Bone Measurement Conference, Chicago, Ill, May 22-23, 1970, J R. Cameron (Ed.), USAEC Report CONT-700515, pp 48-57

56 B. Roos, B. Rosengren, and H. Skoeldborn, Determination of Bone Mineral Content in Lumbar Vertebrae by a Double Gamma Ray Technique, in Proceedings of Bone Measurement Conference, Chicago, Ill, May 22-23, 1970, J R. Cameron (Ed ), USAEC Report CONF700515, pp 243-254

57. W. Burch and P. Block, Two Wavelength Techniques for the Measurement of Bone Mineral Content in Vivo, in Proceedings of Bone Measurement Conference, Chicago, Ill, May 2223 , 1970, J. R. Cameron (Ed ), USAEC Report CONF-700515, pp 263-271

58 R. B. Mazess, J. R. Cameron, R. O'Connor, and D. Knutzen, Accuracy of Bone Mineral Measurement, Sclence, 145388 (1964)

59 E. A. Spring, Sımplified Method for Bone Mineral Measurements in Vivo, Int J. Appl Radıat Isotop, 18700 (1967).

60 R. R. West and G. W. Weed, The Measurement of Bone Mineral in Vivo by Photon Beam Scannıng, Brit J. Radıl, 43886 (1970)

61, B. E. Nilsson and N E. Westlin, Bone Density in Athletes, Clin Orthop, 77179 (1971).

62 W. G. Schmonsees and L E. Preuss, Two Photon Absorptometric Analysis Using ${ }^{109} \mathrm{Cd}, \mathrm{Cl} \mathrm{n}$ Orthop, $77272-273$

63 M W Zelefsky, Evaluation of Regional Pulmonary Ventilation by Gamma Ray Densiography, Radılogy, 911208 (1968).

64. R. B Mazess, J. R. Cameron, and J. A. Sorenson, Determining Body Compositions by Radiation Absorption Spectrometry, Nature (London), 228771 (1970).

65 J. R. Cameron, Body Composition by Transmitted Gamma Rdy Measurements, Trans Amer Nucl Soc, 1542 (1972).

66 H. Langel, Thickness Measurements on Hot Glass Sheets in the Manufacture of Plate Glass, Euratom Report EUR-3269 d, February 1967.

$67 \mathrm{~J}$ F. Cameron and G. Clayton, Radiolsotope Instruments, Part 1, Pergamon Press, Ltd, Oxford, 1971

68. H. Miwa and M. Mizukoskı, Metal Thickness Gauge Usıng ${ }^{241}$ Am as the Radiatıon Source Its Performance and Examples, Genshryoku Kogyo, 1267 (1966)

69. H. Langel, Thickness and Density Medsurements with the Aid of Nuclear Radidtion, Kerntechnk, 12219 (1970). 
70. G. Boehme, Thickness Gaging by Means of ${ }^{85} \mathrm{Kr}$ Bremsstrahlung and ${ }^{241}$ Am Sources with Special Respect to Aluminum Materials, Isotopen praxis, 3262 (1967).

71 R. Plesch, Radioisotope Thickness Measurements in the Manufacture of Wire, Siemens Rev, 39223 (1972).

72. L. G. King, Gamma-Ray Attenuation for Soll-Water Content Measurements Usıng ${ }^{241}$ Am, in Isotope and Radiation Techniques in Soll Physics and Irrigation Studies, Symposium Proceedings, Istanbul, 1967, Internatonal Atomic Energy Agency, Vienna, 1967 (STI/PUB/ 158, pp 17-29).

73. J. C. Corey, S. F. Peterson, and M. A. Wakat, Measurement of Attenuation of ${ }^{137}$ Cs and ${ }^{241} \mathrm{Am}$ Gamma Rays for Soll Density and Water Content Determinations, Soll Sct Soc Amer., Proc, 35215 (1971).

74. J. G. DeSwart and P. H. Groenevelt, Column Scannıng with 60 Kev Gamma Radiation, Soll Sct, 112419 (1971).

75. W. H. Gardner and C. Calıssendorff, Gamma-Ray and Neutron Attenuation in Measurement of Soll Bulk Density and Water Content, in Isotope and Radiatıon Techniques in Soll Physics and Irrigation Studies, Symposium Proceedings, Istanbul, 1967, International Atomic Energy Agency, Vienna, 1967 (STl/PUB/158, pp 101-112)

76 G Vachaud, J Cisler, J L Thony, and L De Backer, Utilisation de l'Emission Gamma de l'Americium-241 pour la Mesure de la Teneure en Eau d'Echantillons de Sol non Saturés (1n French), in Isotope Hydrology, 1970, Symposium Proceedings, Vienna, 1970, International Atomic Energy_Agency, Vienna, 1970 (STI/PUB/255)

77. W. H. Gardner, G. S. Campbell, and C. Calissendorff, Water Content and Soll Bulk Density Measured Concurrently Using Two Gamma Photon Energies, USAEC Report RLO-1543-6, 1969

78. B. D. Soane, Dual Energy Gamma Ray Transmission for Coincident Measurement of Water Content and Dry Bulk Density of So1l, Nature, 2141273 (1967)

79. D. E. Smles, G. Vachaud, and M. Vauclin, A Test of the Uniqueness of the Soll Moisture Characteristic During Transient, Nonhysteretic Flow of Water in a Rigid Soil, Soll Scl Soc Amer., Proc., 35529 (1971).

80 W. S. Keys, Application of Radiation Logs to Groundwater Hydrology, in Isotopes in Hydrology, Symposium Proceedings, Vienna, 1966, International Atomic Energy Agency, Vienna, 1967 (STI/PUB/141, pp 477-488)

81. J. R. McHenry, N. L Coleman, J C. Willis, C. E. Murphree, G. C. Bolton, O. W. Sampson, and A. C. Gıll, Performance of Nuclear-Sediment Concentration Gages, Symposium Proceedings Vienna, 1966, International Atomic Energy Agency, Vienna, 1967 (STI/PUB/141, pp 207-225).

82. H. Fushimı, Studies on the Determination of Ore Concentration and the Water Content by Means of Radioactive ${ }^{241}$ Am, Nippon Kogyo Kalsht, 83568 (1967).

83 L. K. Hahn, C. E. Krause, and O. L. Utt, Jr., Helıcopter Close-Order Formation Keepıng System, USAEC Report COO-1471-7, Industrial Nucleonics Corp , August 1968

84. A. Notea and Y. Segal, Investigation of Freon Fire-Extınguıshing Systems with a Nucleonic Gage, Mater Eval, 30153 (1972).

85. D. B. Hakewessell, Measurement of Atmosphere Density Using Gamma Backscatter Technıques, presented at Radıosotope Applicatıons in Aerospace Symposium, Dayton, Ohı, 1966.

86 R. P. Gardner and D. R. Whitaker, Experımental and Theoretical Studies on the Gamma-Ray Scattering Techniques for Measuring Atmospheric Density, Nucl Eng Des, 7. 13 (1968).

87. A.Trost, Determination of the Ash Contents of Coal, Thickness Gauging of Glass, Plastics, and Metals with ${ }^{24}$ Am Gamma Rays, in Radiolsotope Instruments in Industry and Geophysics, Symposium Proceedings, Warsaw, 1965, International Atomic Energy Agency, Vienna, 1966 (STI/PUB/112). 
88. T. Ta nemura and H. Suita, Studies on Radioactive X-and Gamma-Ray Sources Applied to the Determination of Ash Content of Coal, Oyo Butsuri, 36: 444 (1967).

89. Coal-Ash Measurement with Two Radioisotopic Radiation Sources, Isotop. Radiat. Technol., 7(4): 464 (Summer 1970).

90. J. F. Cameron, Measurement of Ash Content and Calorific Value of Coal with Radioisotope Instrument, in Proceedings of 2nd Symposium on Low-Energy X-and Gamma Sources and Applications, Austin, Tex., March 27-29, 1967, P. S. Baker and Martha Gerrard (Eds.), USAEC Report ORNL-IIC-10, Vol. 2, pp.903-928, Oak Ridge National Laboratory, September 1967.

91. R. Crosland, D. A. Hall, and M. K. Laverick, Continuous Ash Monitoring and Coal Blending Processes, in Mineral and Extractive Metallurgy, M. J. Jones (Ed.), pp. 179-200, Institute of Mining and Metallurgy, London, 1971.

92. Nuclear Applications in Highway Research, Isotop. Radiat. Technol., 8(2): 146-165 (Winter 1970-1971).

93. L. R. Cooper and A. G. Lawrence, Mineral Mining Machine, British Patent 1,045,874, October 1966.

94. K. W. Ostrowski, K. Jelen, and E. Rulikowska, Radiometric Analyses with High-Yield Proportional X-Ray Counters and Low-Activity Sources, in Proceedings of 2nd Symposium on Low-Energy X-and Gamma Sources and Applications, Austin, Tex., March 27-29, 1967, P. S. Baker and Martha Gerrard (Eds.), USAEC Report ORNL-IIC-10, Vol. 2, pp. 944-962, Oak Ridge National Laboratory, September 1967.

95. K. G. Carr-Brion and J. R. Rhodes, On-Stream X-Ray Fluorescence Analysis of Ore Slurries with a Radioisotope X-Ray Source, Instrum. Pract., 19: 1007 (1965).

96. Yu. P. Betin, I. A. Krampit, and S. A. Pel'ts, Radioisotopic Sources ${ }^{109} \mathrm{Cd},{ }^{147} \mathrm{Pm} / \mathrm{Al}$, ${ }^{241} \mathrm{Am}$ and ${ }^{60} \mathrm{Co}$ for Roentgenometric Analysis of Minerals, Geofiz. App., 49: 55 (1972).

97. W. K. Ellis, R. A. Fookes, V. L. Gravitis, and J. S. Watt, Radioisotope X-Ray Techniques for On-Stream Analysis of Slurries. Feasibility Studies Using Solid Samples of Mineral Products, Int. J. Appl. Radiat. Isotop., 20: 691 (1969).

98. K. G. Carr-Brion, Performance of an On-Stream Radioisotope X-Ray Fluorescence Analyzer, Trans. Inst. Mining Met., 76: C94 (1957).

99. J. R. Rhodes, Some Examples of Ore and Alloy Analysis Using a Multipurpose Portable Analyzer, in Proceedings of 2nd Symposium on Low-Energy X-and Gamma Sources and Applications, Austin, Tex., March 27-29, 1967, P. S. Baker and Martha Gerrard (Eds.), USAEC Report ORNL-IIC-10, Vol, 2, p. 843, Oak Ridge National Laboratory, September 1967.

100.J. R. Rhodes, Optimization of Excitation and Detection Techniques of Silver Ores by Radioisotope X-Ray Spectrometry, in Proceedings of 2nd Symposium on Low-Energy X-and Gamma Sources and Applications, Austin, Tex., March 27-29, 1967, P. S. Baker and Martha Gerrard (Eds.), USAEC Report ORNL-IIC-10, Vol. 1, p. 442, Oak Ridge National Laboratory, September 1967.

101. J. Kuusi, M. Virtanen, and P. Jauho, Heavy Element Analysis by Isotope-Excited X-Ray Fluorescence, Nucl. Technol., 13: 216 (1972).

102. J. Charbucinski, Selective Nonspectrometric Gamma-Gamma Method of Determining the $\mathrm{Zr}$ and $\mathrm{Pb}$ Content in Polymetallic Ores, Nucleonika, 15: 563 (1970).

103. J. W. Watt, Method and Apparatus for Producing X-Rays of Particular Wave Lengths and Applications Thereof, Canadian Patent 785,195, May 1967.

104. J. DeNeef, F. Adams, and J. Hoste, Radioisotopic X-Ray Analysis. Part I. An Instrumental Configuration for the Sensitive Determination of a Number of Elements, Anal. Chim. Acta, 59: 333 (1972).

105. J. R. Rhodes, Improvements in or Relating to Apparatus for X-Ray Analysis, British Patent $1,065,918$, April 1967. 
106. J. S. Watt, Use of Gamma-Ray Excited X-Ray Sources in X-Ray Fluorescence Analysis, Int $J$ Appl Radiat. Isotop., 18383 (1967).

107. R. W. Tolmie, Portable X-Ray Fluorescence Analyzer, in Proceedings of 2nd Symposium on Low-Energy X- and Gamma Sources and Applications, Austın, Tex, March 27-29, 1967, P S. Baker and Martha Gerrard (Eds.), USAEC Report ORNL-IIC-10, Vol. 2, p 817, Oak Ridge National Laboratory, September 1967

108. J. S. Watt, Some Recent Developments in Low-Energy X-and Gamma-Ray Sources and Applications in Australia, in Proceedings of 2nd Symposium on Low-Energy X- and Gamma Sources and Applications, Austin, Tex., March 27-29, 1967, P. S. Baker and Martha Gerrard (Eds), USAEC Report ORNL-IIC-10, Vol 2, p. 665, Oak Ridge National Laboratory, September 1967.

109. J. S. Watt, Gamma-Ray Excited X-Ray Sources, Int J Appl Radiat Isotop, 15617 (1964).

110. G. C. Snyman, Rapıd Assay of High-Purity Gold by Means of Radioisotope X-Ray Fluorimetry, Int. J. Appl Radıat Isotop, 18243 (1967).

111. P. B. Hoffer, Fluorescent Thyroid Scannıng, Amer J Roentgenol, Radum Ther Nucl Med., 105721 (1969).

112. A. Kemper, Wear Measurements by Means of $\gamma$-X-Fluorescence, Eurdtom Report EUR-3627 e, 1967, also in Wear, 1255 (1968)

113. J. Cavaılles and P. Martınell, Contınuous Measurement of Galvanization Coatıngs by Means of $\mathrm{X}$-Ray Fluorescence, in Radıotsotope Instruments in Industry and Geophysics, Symposium Proceedings, Warsaw, 1965, International Atomic Energy Agency, Vienna, 1966 (STI/PUB/ 112, Vol. I, p 227).

114. S. Margolınas, X-Ray Fluorescence Applied to the Measurement of Zinc Coatıng in the Galvanızıng Industry, in Proceedings of 2nd Symposium on Low-Energy X- and Gamma Sources and Applications, Austın, Tex., March 27-29, 1967, P. S. Baker and Martha Gerrard (Eds.), USAEC Report ORNL-IIC-10, Vol. 2, p 805, Oak Ridge National Laboratory, September 1967

115. J. F. Cameron and T. Florkowskı, Radioısotope Sources of Low-Energy Electromagnet1c Radiation and Their Use in Analysis and Measurement of Coatıng Thicknesses, in Proceedings of Symposium on Low-Energy X- and Gamma Sources and Applications, Chicago, Ill., October 20-21, 1964, P S. Baker and Martha Gerrard (Eds.), USAEC Report ORNL-IIC-5, Oak Ridge National Laboratory, October 1965.

116. Y. M. Chen and B. B. Cahill, Industrial Applications of Low-Energy Gamma-Emitting Isotopes, in Applications of Low Energy $X$ and Gamma-Rays, C A Ziegler (Ed), Gordon and Breach, Science Publishers, Inc, New York, 1971

117 K. E. Duftschmid, A Versatıle Field Instrument for X-Ray Fluorescence Analysis, in Nuclear Techniques and Mineral Resources, Symposium Proceedıngs, Buenos Alres, 1968, International Atomic Energy Agency, Vienna, 1969 (STI/PUB/198, p 325)

118 J. Kuusı, M. Hıtala, H. Puolakka, and A. I. Lehtınen, A Radıossotope X-Ray Method for On-Line Measurement of Fourdrinier Machine Water Removal on the Wire Section, Tappt, 52 2378 (1969).

119. E. Lloyd, R. E. Rowland, D. Hodges, and J. H. Marshall, Surface to Volume Ratıos of Bone Determined by Computer Analysis of Microradiographs, Nature (London), 218365 (1968).

120. N. W. D. Chrımes, Low-Energy Isotopes for Industrial Radıography, At. Energy Aust, 1113 (1968).

121 G. Locher, Americium-241 as a Nondestructive Testing Tool for the Arcraft and Space Industry, in Proceedings of Symposium on Low-Energy X- and Gamma Sources and Applications, Chicago, Ill,, October 20-21, 1964, P. S. Baker and Martha Gerrard (Eds.), USAEC Report ORNL-IIC-5, Oak Ridge Natıonal Laboratory, October 1965.

122. J. H. Gillette, Review of Radioisotopes Program 1967, USAEC Report ORNL-4329, Oak Rıdge Natıonal Laboratory, November 1968. 
$123 \mathrm{~J}$ H McCrary, Use of Radıosotopes in Detector Calıbrations, Isotop Radiat Technol, 7(4) 436 (Summer 1970)

124. S. V. Damle and G. Joseph, Radioactive Pulse Light Source for In-Flight Calıbration of Scintillator Photomultıplıer Assembly, Nucl Instrum. Methods, 65123 (1968).

125 I. Ahmad and M. Wahlgren, Long-Lived Standards for the Efficiency Calibration of Ge(L1) Detectors, Nucl Instrum. Methods, 99333 (1972).

126. R. C. Milhan, The Preparation of an Americium Gamma Source, USAEC Report DP-173, Savannah River Laboratory, August 1956.

127 K. H. Ansell and E. G. Hall, Recent Developments in Low-Energy Photon Sources, in Applications of Low Energy $X$ and Gamma Rays, C A Ziegler (Ed), pp 357-371, Gordon and Breach, Science Publishers, Inc, New York, 1971

128 J. V. Boggs, Portable Low-Energy Photon Calıbration Source, Trans Amer Nucl Soc, 13 880 (1970).

129. R. S. Pressly, Design and Uses of Low-Energy Gamma- and X-Ray Sources, in Applications of Low-Energy Gamma and X-Ray Sources, C Ziegler (Ed.), p 380, Gordon and Breach, Science Publishers, Inc., New York, 1970.

130. G. Bloom, K. Murphy, and T. Cox, An Isotope-Powered, Indwelling Intracranial Pressure Sensor, Trans Amer. Nucl Soc., 13509 (1970).

131 W. Brandt, M. D. D'Agostıno, and A. J. Favale, Alpha-Particle Densitometer with Varable Response, Nucl Technol, 1199 (1971).

132 R. N. Brown, D. Balber, and G. V. Rylsky, Device for Measuring Gas Pressure by Means of Alpha Particles, U. S. Patent 3,141,970, July 1964.

133. R. P. Gardner and R. L. Ely, Jr., Radwotsotope Measurements Applications in Engineering, pp. 287-302, Reinhold Publishing Corporation, New York, 1967.

134. P. Audrieux and B. Iapteff, Improvement of Ionization Gauges Employing a Radioactive Source L'Alphavac 500, in Fourth General Meeting of International Organization for Vacuum Science and Technology, Manchester, England, 1968 (CONF-680401, p 675)

135. F. A. Hansen and B. Sellers, Feasibility Study of Alpha Particle Densitometer for Measuring Planetary Atmospheric Density, National Aeronautics and Space Administration, Report NASA-CR-66825, June 1969.

136. G. R. Shoemake, D. C. Fenımore, and A. Zlatkıs, Radiatıon Sources for Ionızation Detectors in Gas Chromatogra phy, J. Gas Chromatogr., 3285 (1965).

137. C. G. Invernizz1, lonic Conditıning of Air, in Conference on Isotope Radiation Techniques in the Building Industry, Brussels, October 28-30, 1970, USAEC Report CONF-701027-2, 1970, through USAEC Report ORNL-tr-2427, translated by Helen Warren, Oak Rudge National Laboratory, 1970.

138. C. G. Invernizz1, Aur Ionızation Used for Lightnıng Protection, Trans Amer Nucl Soc, 14 469 (1970).

139 G. Berio, The Use of Ionization in the Air for Lightning Protection, Isotop Radat. Technol., 8(2) 178 (Winter 1970-1971).

140. G. Berı, Lightning Conductor System Using Radioısotopes, in Conference on Radiation and Isotope Techniques in Civil Engineering, Brussels, Belgium, October 28, 1970, Euratom Report Eurisotop-55, Vol 2, pp, 891-908.

141. H. Baatz, Radioactive Isotopes Do Not Improve Lightnıng Protection, Elektrotech Z., A93 101 (1972).

142. K. Ritter, Lightning Rod with Ionizing Field, U. S. Patent 3,328,508, June 1967.

143. K. Ritter, Lightning Rod with Great Ionizing Power, U. S. Patent 3,350,496, October 1967.

144. Lightnıng Rods Go Radioactive, Elec World, 17336 (1970).

145. J. B. Dance, Radioisotopes Speed Fire Detection, Instrument Practice, 20975 (1966).

146. E. Me1l and T. Lamport, Ionization Fure Alarm System, U S. Patent 3,353,170, November 1967 
147 USAEC Radioisotope Licensing Changes, Smoke Detectors, Isotop Radiat Technol, 6(4) 446 (Summer 1969).

148. J. Mehl, The Choice of Radionuclides for Lumınous Paints in the Watchmaking Industry, Atomkernenergte, 10115 (1965).

149. E. K. Stepanov and N. V. Tyutıkov, Use of $\alpha$-Radiation Sources for the Calibration and Determination of the Basic Parameters of the Semiconductor Type $\alpha$ Spectrometers, Izmer Tekh, 549 (1967).

150 B M Aleksandrov, A F Belyatskı, I B Berkovich, et al, Reference Spectrometric Alpha Sources, in Standardization of Radionuclides, Symposium Proceedings, Vienna, 1966, International Atomic Energy Agency, Vienna, 1967 (STI/PUB/88).

151. M. L. Acena, Preparation of Radıoactive Sources by Electrodeposition for Alpha Spectrometry, in Standardization of Radionuclides, Symposium Proceedings, Vienna, 1966, International Atomic Energy Agency, Vienna, 1967 (STI/PUB/88).

152 F. O. Hallıday, T. O. Passell, and L. E. Balley, The Use of ${ }^{241}$ Am Alphas To Measure Properties of Thin Films, Fifth National Meeting, Society for Applied Spectroscopy, Chicago, IIl., 1966.

153. H. L. Adair, Target Thickness and Uniformity Measurements Using Charged Particles, in Proceedings of the Third International Symposium on Research Mater als for Nuclear Measurements, Gatlınburg, Tenn, October 5-8, 1971, USAEC Report CONF-711002, pp. $307-320$.

154. H. L. Anderson, Thickness Measurements Using Alpha Particles, U. S. Patent 3,193,680, July 1965.

155. K. Teranıshı, Measurements of the Thickness of Thin Polymer Films with a Semiconductor $\alpha$-Particle Detector, Nucl Eng (Tokyo), 1146 (1965).

156. H. K. Hallowes and A. E. Hodgson, An Alpha-Particle Hygrometer, in Radiotsotope Instruments in Industry and Geophysics, Symposium Proceedıngs, Warsaw, 1965, International Atomic Energy Agency, Vienna, 1966 (STI/PUB/112).

157. A. K. Postma, A Compact High-Speed Spınnıng Disc Aerosol Generator, in Pacific Northwest Laboratory Annual Report for 1966 to the USAEC Division of Biology and Medicine, Vol. II Physical Science, Part 3, Earth Sciences, D. W. Pearce and M. R. Compton (Eds.), USAEC Report BNWL-481, Battelle Memorial Institute, Pacific Northwest Laboratories, January 1968.

158. M. Bellemare, Y. Lachance, and J. C. Roy, Preparation of ${ }^{241}$ Am Sources by Surface Adsorption on Different Backings, Nucl. Instrum. Methods, 104615 (1972).

159. W. F. Riemath, G. G. Culver, and J. H. Jarrett, RF Sputtering of Thin Film Radiation Sources and Hazardous Materials, USAEC Report BNWL-SA-4392, Battelle Memorial Institute, Pacific Northwest Laboratories, September 1972.

160. R. E. Greene, R. S. Pressly, and F. N. Case, Review of Alpha Radiation Source Preparation Methods and Applications, USAEC Report ORNL-4819, Oak Ridge National Laboratory, October 1972.

$161 \mathrm{H}$ Iwınska, Preparation of Adherent ${ }^{241}$ Am Alpha Sources by Electrodeposition, $\mathrm{Nu}$ kleontka, 1769 (1972)

162. J. P. Perolat, H. Goenvec, R. Vatın, and M. Laine, Prımary Radioactivity Standards, Bull Inform. Scl. Tech. (Parts), 16319 (1971).

163. R. W. Thiele, W. P. M. Cheng, and S. Yang, Adsorption of Radioisotopes on Thm $\mathrm{Al}_{2} \mathrm{O}_{3}$ Layers Prepared by Anodic Oxidation as a Method for Source Preparation, Nucl Sci, J. (Talwan), 719 (1969).

$164 \mathrm{~J} H$ Jarrett (Comp), Pacific Northwest Laboratory, Isotope Development Program Quarterly Report February-April 1973, USAEC Report BNWL-1 308-14, Battelle Memorial Institute, Pacific Northwest Laboratories, May 1973. 
165. F. E. Armstrong and W. D Howell, Recent Advances in Radioisotope Applications for Exploitation of Petroleum and Natural-Gas Reservorrs, Isotop Radiat Technol, 3(2) 102 (Winter 1965-1966).

166. J. Tittman, H. Sherman, W A. Nagel, and R. P. Alger, The Sidewall Epithermal Neutron Porosity Log, J. Petrol Technol, 181351 (1966).

167. R. L. Caldwell and W. W. Gwens, Pulsed Neutron Source Comprising a Plurality of Alpha Sources and Assoclated Targets with a Rotatable Shutter There-Between, U.S. Patent $3,389,257$, June 1968

168. H. J. Parp and H. D. Scott, The Use of ${ }^{252} \mathrm{Cf}$ as a Neutron Source for Well Logging, in Proceedıngs of the American Nuclear Society Meeting on Neutron Sources and Applications, Augusta, Ga., Apr1l 19-21, 1971, USAEC Report CONF-710402, Vol 3, pp. III.30-42, 1971

169. L. Pospisilova-Rothscheinova, P. Klablena, J. Habarta, and A Honig (Eds), Commerctal Portable Gauges for Radiometric Determination of the Density and Moisture Content of Butding Materials A Comparative Study, Technical Reports Series, No. 130 , International Atomic Energy Agency, Vienna, 1971 (STI/DOC/10/130).

170. J. B. Rieder, Measurement with Radioactive Sources of Soll Moisture and Soll Density in Differently Treated Pastures, Bayer. Landwort Jahrb., 48259 (1971).

171 C. H. M. Van Bavel and G. B. Stırk, Soll Water Measurement with a ${ }^{241}$ Am-Be Neutron Source and an Application to Evaporimetry, J. Hydrol., 540 (1967).

172 I. F. Long and B. K. French, Measurements of Soll Moisture in the Field by Neutron Moderation, J. Soll Scl, 1849 (1967).

173. P. K. Aditya and A. K. Batia, Moisture Measurement by Neutron Moderators, Ind $J$ Pure Appl Phys, 7323 (1969)

174. K. Papez, J. F. Cameron, and B. Machaj, On-Line Neutron Moisture Gauges in the Steel Industry, in Nuclear Techniques in the Basic Metal Industries, Symposium Proceedings, Helsink1, 1972, Internationdl Atomic Energy Agency, Vienna, 1973 (STI/PUB/314)

175 K. Myagawa, I. Mishıma, T. Takeda, and Y. Tanabikı, Applications of Neutron Moisture Gauge in the Steel Industry, Trans Iron Steel Inst Jap., 9285 (1969)

176. H. Kaga, M. Yamamoto, and T Mizushına, Quality Control of Concrete Usıng a Neutron Mossture Gauge, Talsel Kensetsu Gljutsu Kenkyusho Ho, 327 (1970).

177. R. F. Stewart and W. L. Farrior, Jr., Nuclear Measurement of Carbon in Fly Ash, U.S. Bureau of Mines, Information Circular No 8348, pp 262-270, 1967.

178. P. N. Tiwarı, Rapıd and Nondestructive Determination of Protein in Grain Samples, Radıchem. Radıanal Lett., 6363 (1971).

179. P. G. Geffrey and J. M. Bakes, The Determination of Fluorine and Fluorite Ores and Concentrates by Isotope Source, Fast Neutron Activation Analysis, Analyst, 92151 (1967).

180. D. E. Wood, Activation Analysis in the Metals Industry, Nucl News, 912 (1966).

181 K. Boddy and D. Gloros, The Measurement of Phosphorus in Human Bone Using Radioactive Neutron Sources-A Technique for Partial Body in Vivo Activation Analysis, Int J. Appl. Radiat Isotop., 24147 (1973).

182 P. L. Eisenacher, Self-Calibrating Thermal Neutron Counter, USAEC Report KAPL-M-PLE-3, Knolls Atomic Power Laboratory, November 1960.

183. W. E. Downs, Properties of Isotopic $\alpha-n$ and $\gamma-n$ Neutron Sources, Canadian Report CPSR-272, June 1970.

184. R. W. Tolmie, Recent Developments in Radioisotope Neutron Sources, in Proceedings of the American Nuclear Society Meeting on Neutron Sources and Applications, Augusta, Ga., April 19-21, 1971, USAEC Report CONF-710402, Vol. 1, pp I.29-51, 1971.

185. K. H. Ansell and E. G. Hall, Recent Developments in $(\alpha, n)$ Sources in Meeting on Neutron Sources and Applications, Augusta, Ga., April 18-21, 1971, USAEC Report CONF-710402, Vol. 2, pp. 1.90-99, 1971 
186 E. A. Lorch, Neutron Spectra of ${ }^{241} \mathrm{Am} / \mathrm{B},{ }^{241} \mathrm{Am} / \mathrm{Be},{ }^{241} \mathrm{Am} / \mathrm{F},{ }^{242} \mathrm{Cm} / \mathrm{Be},{ }^{238} \mathrm{Pu} /{ }^{13} \mathrm{C}$, and ${ }^{252} \mathrm{Cf}$ Isotopic Neutron Sources, Int J Appl Radiat Isotop, 24585 (1973).

187. A. D. Vajdyd and A. Kumar, Neutron Spectrum of Am-Be Neutron Sources, Nucl Instrum Methods, 111435 (1973).

188. J. W. Cleland, Radıisotopic Sources To Study Radıation Damage in Semiconductors, Isotop Radiat Tech, 3(1) 61 (Fall 1965).

$189 \mathrm{M}$. Wahlgren, J. Wing, and D. C. Stewart, A High-Intensity ${ }^{241} \mathrm{Am}-\mathrm{Be}-{ }^{242} \mathrm{Cm}$ Neutron Source, in Modern Trends in Activation Analysis, J R DeVoe (Ed ), Vol 1, pp 501-506, National Buredu of Standards, Washington, D. C , 1969

190 R. P Christman and W. R. Cornman, Utilization of Power Redctor Americium for ${ }^{252} \mathrm{Cr}$ Production, Trans Amer Nucl Soc, 1254 (1969)

191 P. M. Wood, Isotope Production in Commercial Power Reactors, Isotop Radiat Technol, 9(2) 129 (Winter 1971-1972).

192. J D. Hixson, Comparison of Radioisotope-Fueled Energy Sources for a Prosthetic Device, Isotop Radiat Ti chnol, 9(2) 215 (Winter 1971-1972)

193 V. C. A Vaughin, W. T. McDuffee, E. Lamb, and R. A Robinson, The Preparation of Multigram Quantities of ${ }^{242} \mathrm{Cm}$ for SNAP 11, Nucl Appl, 6549 (1969)

194 Inbetriebnahme einer Isotopen Batterie mit Curnum-242, Atomwortschaft, 13415 (1968)

195 W. O. Burch, I L. Bigelow, and L J King, Transuranium Processing Plant, Semiannual Report of Production, Status, and Plans for Perıod Ending December 31, 1971, USALC Report ORNL-4767, Oak Ridge National Laboratory, May 1972

196. V. C. A Vawwen, J. D. Hoeschele, and M. H. Lloyd, Preparation of ${ }^{244} \mathrm{Cm}-{ }^{243}$ Am Oxide Microspheres by a Sol-Gel Method, Trans Amer Nucl Soc, 1255 (1969)

197 Oak Ridge Nitional Laboratory, Chemical Technology Division Annual Progress Report for Period Endina May 31, 1970, USAEC Report ORNL-4572, October 1970

198 L. J. Hennell, Production of Biomedical Grade Plutonium-238, Trans Amer Nucl Soc, 11 456 (1968) 


\section{CHEMISTRY IN AQUEOUS SOLUTION}

\section{OXIDATION STATES}

Americium in aqueous solutions is well known to exist in the III, IV, V, and VI oxidation states The hydrated ions $\mathrm{Am}^{3+} \cdot \mathrm{aq}, \mathrm{AmO}_{2}^{+} \cdot \mathrm{aq}$, and $\mathrm{AmO}_{2}^{2+} \cdot$ aq occur in the absence of complexing agents Russian workers ${ }^{1}$ a have recently announced evidence for the production of $A m(V I I)$ by oxidation of Am(VI) in cooled, strong alkali solutions Methods of producing the individual americium ions are summarized in Table 31 Some additional comments on production and stabilization of the various americium oxidation states in aqueous solution follow Recent polarographic evidence for the proposed production of Am(II) in aqueous solution is also reviewed Reference is made to the electrode-potential diagrams shown on pages 55 to 58

\section{Am(II)}

Americium is the heavy homolog of europium which has a readily attained divalent state in aqueous solution Much effort has gone into attempts to establish the existence of $\mathrm{Am}^{2+}$ in aqueous solutions and to prepare compounds containing divalent americium The latter goal was realized in 1973, as detalled in Chap 4, by the preparation of $\mathrm{AmCl}_{2}, \mathrm{AmBr}_{2}$, and $\mathrm{AmI}_{2}$ Leary and Mullins ${ }^{1 \mathrm{~b}}$ also have obtained evidence for the existence of divalent americium in molten salt-molten plutonium systems However, reduction conditions ${ }^{2}$ used successfully to prepare $\mathrm{Eu}^{2+}$ and $\mathrm{Sm}^{2+}$ 
Table 3.1

AMERICIUM IONS IN AQUEOUS SOLUTION

\begin{tabular}{|c|c|c|c|}
\hline $\begin{array}{l}\text { Oxidation } \\
\text { state }\end{array}$ & $\begin{array}{l}\text { Ionic } \\
\text { form }\end{array}$ & $\begin{array}{l}\text { Color in } \\
\text { dilute } \\
\mathrm{HClO}_{4}\end{array}$ & Methods of preparation \\
\hline III & $\mathrm{Am}^{3+} \cdot \mathrm{aq}$ & Pink red* & $\begin{array}{l}1 \mathrm{Am}(\mathrm{O})+\mathrm{HCl} \\
2 \mathrm{AmO}_{2}+\mathrm{HCl} \text { (heated) } \\
3 \mathrm{Am}(>\mathrm{III})+\mathrm{NH}_{2} \mathrm{OH}, \mathrm{I}, \mathrm{SO}_{2} \text {, } \\
\quad \text { etc } \\
4 \text { Autoreduction of } \mathrm{Am}(>\mathrm{III})\end{array}$ \\
\hline IV & & $\dagger$ & 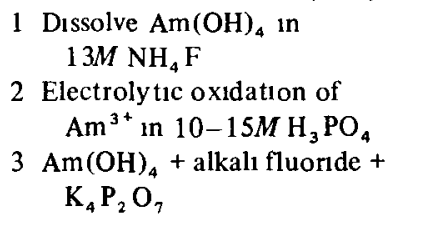 \\
\hline V & $\mathrm{AmO}_{2}^{+} \cdot \mathrm{aq}$ & Yellow & $\begin{array}{l}1 \text { Oxidation of } \mathrm{Am}^{3+} \text { in } \\
003 \mathrm{MHCO}_{3} \text { solution } \\
\text { with } \mathrm{O}_{3}, \mathrm{~S}_{2} \mathrm{O}_{8}^{2} \text { or } \mathrm{ClO} \\
2 \text { Dissolve } \mathrm{Ll}_{3} \mathrm{AmO}_{4} \text { in } \\
\text { dilute } \mathrm{HClO}_{4} \\
3 \mathrm{Electrolytic} \mathrm{oxidation} \mathrm{of} \mathrm{Am}^{3+} \text { in } 2 \mathrm{M} \mathrm{LiIO}_{3}-07 M \\
\mathrm{HIO}_{3} \text { solution }\end{array}$ \\
\hline VI & $\mathrm{AmO}_{2}^{2+} \cdot \mathrm{aq}$ & $\begin{array}{l}\text { Yellow } \\
\text { brown } \ddagger\end{array}$ & $\begin{array}{l}1 \text { Oxidation of } \mathrm{Am}^{3+} \text { in } \\
\text { dilute acid media with } \\
\mathrm{S}_{2} \mathrm{O}_{8}^{2} \text { and } \mathrm{Ag}(\mathrm{II}) \\
2 \text { Electrolytic oxidation of } \\
\mathrm{Am}^{3+} \text { in } 6 \mathrm{M} \mathrm{HClO}_{4} \text { or } \\
\text { in } 2 \mathrm{M} \mathrm{H}_{3} \mathrm{PO}_{4} \\
3 \text { Dissolve } \mathrm{Ll}_{6} \mathrm{AmO}_{6} \text { in } \\
\text { dilute } \mathrm{HClO}_{4}\end{array}$ \\
\hline VII & & $\S$ & $\begin{array}{l}1 \text { Oxidation of } \mathrm{AmO}_{2}^{2+} \text { in } 3 M-5 M \\
\mathrm{NaOH} \text { at } 0-7^{\circ} \mathrm{C} \text { with } \mathrm{O}_{3} \text { or } \mathrm{O} \\
\text { 1on radical }\end{array}$ \\
\hline
\end{tabular}

*Yellow in concentrated $\mathrm{HClO}_{4}$

$\dagger$ Pink-red $\mathrm{Am}^{4+}$ stable only in concentrated fluoride and phosphate solutions $\ddagger$ Light brown in dilute $\mathrm{HNO}_{3}$, green in fluoride solutions, dark brown in $\mathrm{H}_{2} \mathrm{SO}_{4}$ solutions, red in carbonate solutions

$\S$ Green-colored Am(VII) known only in alkalıne solutions

will not reduce $\mathrm{Am}^{3+} \cdot$ aq to $\mathrm{Am}^{2+} \cdot$ aq Also, recently Jove and Pages ${ }^{3}$ falled in attempts to reduce $\mathrm{Am}^{3+}$ in liquid ammonia either by electrolysis or with electrons furnished by dissolution of sodium metal

Results of several polarographic experiments with tracer concentrations of americium have been interpreted on the basis of the formation of divalent americium 
Thus Myasoedov and Myuzikas ${ }^{4} 5$ observed two waves in polarographic reduction of trivalent americium in $01 M$ solutions of $\left[\left(\mathrm{C}_{2} \mathrm{H}_{5}\right)_{4} \mathrm{~N}\right] \mathrm{ClO}_{4}$ in acetonitrile These scientists account for the two waves, the second of which is twice as high as the first, by the successive reductions $\mathrm{Am}^{3+}+\mathrm{e} \rightarrow \mathrm{Am}^{2+}$ and $\mathrm{Am}^{2+}+2 \mathrm{e} \rightarrow \mathrm{Am} / \mathrm{Hg}$ David ${ }^{6 \mathrm{a}}$ also observed two waves in the radiopolarograms of Am(III) in perchlorate medium at $\mathrm{pH} 1$ to 6 which he postulated to correspond to the reductions $\mathrm{Am}^{2+} \rightarrow \mathrm{Am}(0)$ and $\mathrm{Am}^{3+} \rightarrow \mathrm{Am}(0)$

Nugent ${ }^{6 \mathrm{~b}}$ disagrees with David's interpretation of his polarographic results and states that the amalgamation of $\mathrm{Am}^{3+} \cdot$ aq proceeds directly to $\mathrm{Am} / \mathrm{Hg}$ In support of this reaction mechanism, Nugent cites a linear relation developed among standard potentials, first half-wave amalgamation potentials, and the atomic radil of the crystallıne actınide metals Accordıng to Nugent, $\mathrm{Am}^{2+} \cdot$ aq is so unstable, even at tracer concentrations, as to be essentially nonexistent

\section{$\operatorname{Am}($ III)}

The stability of the higher oxidation states of the transuranium elements typically decreases with increasing atomic number In agreement with this, the trivalent state of americium is its most stable oxidation state and is the state resulting when americium metal dissolves in acids Keller ${ }^{6 \mathrm{c}}$ notes that, even though americium is the homolog of europium, the characteristics of $\mathrm{Am}^{3+}$ (radius $=099 \AA$ ) are more like those of $\mathrm{Nd}^{3+}$ (radius $=0995 \AA$ ) than those of $\mathrm{Eu}^{3+}$ The paramagnetic susceptibility ${ }^{7 \mathrm{a}}$ of $\mathrm{Am}^{3+} \cdot$ aq $1 \mathrm{~s} 700 \times 10^{6} \mathrm{~cm}^{3} \mathrm{~mol}^{-1}$ In aqueous solution, Am(III) ion is precipitated by hydroxide, fluoride, phosphate, and oxalate 1ons, properties of the resulting compounds are discussed in Chap 4

Friedman and $\mathrm{Bell}^{7 \mathrm{~b}}$ have recently discussed techniques for preparing $\mathrm{POCl}_{3}-$ $\mathrm{ZrCl}_{4}$ solutions containing $\mathrm{Am}^{3+}$ and efforts to make these solutions show laser activity Friedman and Bell ascribed fallure of these efforts to the short lifetime for the excited state of $\mathrm{Am}^{3+}$

Hydrolysis of the $\mathrm{Am}^{3+}$ ion was studied by several investigators Desire, Hussonno1s, and Gullaumont ${ }^{8}$ and Desire ${ }^{9 a}$ determined the distribution of americium between aqueous $\mathrm{HClO}_{4}-\mathrm{L}_{1} \mathrm{ClO}_{4}$ solutions and a benzene solution of thenoyltrifluoroacetone From their measurements, they calculate for the reaction

$$
\mathrm{M}^{3+} \cdot \mathrm{aq}+\mathrm{H}_{2} \mathrm{O} \rightarrow \mathrm{MOH}^{2+} \cdot \mathrm{aq}+\mathrm{H}^{+}
$$

$\mathrm{K}_{1}=\left[\mathrm{MOH}^{2+}\right]\left[\mathrm{H}^{+}\right] /\left[\mathrm{M}^{3+}\right]=12 \times 10^{-6}$ at $\mu=01 \mathrm{M}$ and $23 \pm 1{ }^{\circ} \mathrm{C}$

Hydrolysis of the $\mathrm{Am}^{3+}$ ion can also be represented by the reaction

$$
\mathrm{M}^{3+} \cdot \mathrm{aq}+\mathrm{OH} \rightarrow \mathrm{MOH}^{2+} \cdot \mathrm{aq}
$$

for which $\mathrm{K}_{2}=\left[\mathrm{MOH}^{2+}\right] /\left[\mathrm{M}^{3+}\right]\left[\mathrm{OH}^{-}\right]=\left[\mathrm{MOH}^{2+}\right]\left[\mathrm{H}^{+}\right] /\left[\mathrm{M}^{3+}\right] \mathrm{K}_{\mathrm{W}}$, where $\mathrm{K}_{\mathrm{W}}=$ $\left[\mathrm{H}^{+}\right][\mathrm{OH}]$ Marm and $\mathrm{K}_{1 k i n d a 1^{10}}$ report $\mathrm{K}_{2}=2 \pm 02 \times 10^{11}$ at $\mu=0005 \mathrm{M}$ and 
$15 \pm 1^{\circ} \mathrm{C}$ from electrophoresis measurements, whereas, from electromigration studies in $\mathrm{NH}_{4} \mathrm{ClO}_{4}$ media, Shalınets and Stepanov ${ }^{11}$ report $\mathrm{K}_{2}=5 \times 10^{10}$ at $\mu=0005 \mathrm{M}$ and $25^{\circ} \mathrm{C}$

Korotkin ${ }^{1213}$ states that, contrary to the simple representations shown in Eqs 31 and 3.2, hydrolysis of $\mathrm{Am}^{3+}$ is a complicated process that commences at pHs as low as 0.5 to 1.0 and whose mechanism is determined by the nature of other cations (e.g $\mathrm{Ll}^{+}, \mathrm{Na}^{+}$, and $\mathrm{H}^{+}$) in solution Korotkin's conclusion is based on his extensive studies $^{12-13 \mathrm{~b}}$ of the hydrolysis of $10^{-10} \mathrm{M}$ to $10^{-6} \mathrm{M}$ americium in $\mathrm{HClO}_{4}-\mathrm{L}_{1} \mathrm{ClO}_{4}$, $\mathrm{HNO}_{3}-\mathrm{L}_{1} \mathrm{ClO}_{4}, \mathrm{HNO}_{3}-\mathrm{LiNO}_{3}, \mathrm{HNO}_{3}-\mathrm{KNO}_{3}, \mathrm{HNO}_{3}-\mathrm{NaNO}_{3}$, and pure $\mathrm{HNO}_{3}$ solutions over the $\mathrm{pH}$ range 1 to 11 Using paper chromatographic methods, supplemented by 1on-exchange and electromigration procedures, Korotkin states that, in $\mathrm{HClO}_{4}-\mathrm{LiClO}_{4}(\mu=01 M)$ media, hydrolysis of $\leqslant 10 M^{6}$ americium proceeds according to the mechanism

$$
\begin{aligned}
& \mathrm{Am}^{3+} \rightarrow \mathrm{Am}(\mathrm{OH})^{2+} \rightarrow \mathrm{Am}(\mathrm{OH})_{2}^{+} \rightarrow \mathrm{Am}(\mathrm{OH})_{3} \text { or }\left[\mathrm{Am}(\mathrm{OH})_{2}\right]_{\mathrm{X}}^{\mathrm{x}^{+}} \\
& \begin{array}{llll}
\mathrm{I}(\mathrm{pH} 1) & \text { II }(\mathrm{pH} 6) & \text { III } & \text { IV }(\mathrm{pH}>85)
\end{array}
\end{aligned}
$$

In $\mathrm{HNO}_{3}-\mathrm{L}_{1} \mathrm{ClO}_{4}$ and in $\mathrm{HNO}_{3}-\mathrm{LNNO}_{3}(\mu=01 M$ to $1 M)$ solutions, hydrolysis proceeds through the forms

$$
\begin{aligned}
& \mathrm{Am}\left(\mathrm{NO}_{3}\right)^{2+} \rightarrow\left[\mathrm{Am}\left(\mathrm{NO}_{3}\right)(\mathrm{OH})\right]^{+} \rightarrow\left[\mathrm{Am}(\mathrm{OH})_{2} \mathrm{NO}_{3}\right] \\
& \text { I II( } \mathrm{pH}^{6)} \text { III } \\
& \rightarrow\left[\mathrm{Am}(\mathrm{OH})_{2}\right]_{2}^{2+} \rightarrow \mathrm{Am}(\mathrm{OH})_{3} \text { or }\left[\mathrm{Am}(\mathrm{OH})_{2}\right]_{\mathrm{x}}^{\mathrm{x}^{+}} \\
& \mathrm{IV}(\mathrm{pH}>85) \quad \mathrm{V}
\end{aligned}
$$

In $0.1 M$ solutions of $\mathrm{KNO}_{3}$ and $\mathrm{NaNO}_{3}$, the hydrolysis sequence, according to Korotkın, is

$\mathrm{Am}\left(\mathrm{NO}_{3}\right)^{2+} \rightarrow\left[\mathrm{Am}(\mathrm{OH})\left(\mathrm{NO}_{3}\right)\right]^{+} \rightarrow\left[\mathrm{Am}(\mathrm{OH})\left(\mathrm{NO}_{3}\right)\right]_{2}^{2+} \rightarrow\left[\mathrm{Am}(\mathrm{OH})\left(\mathrm{NO}_{3}\right)\right]_{2}(\mathrm{OH})^{+}$

I

II

$\rightarrow\left[\mathrm{Am}(\mathrm{OH})_{2}\right]_{2}^{2+} \rightarrow\left[\mathrm{Am}(\mathrm{OH})_{2}\right]_{\mathrm{X}}^{\mathrm{x}^{+}} \rightarrow$ negatively charged collolds
III IV

VI

Hydrolysis of $\leqslant 10^{6} M$ americium in pure $\mathrm{HNO}_{3}$ is similar to that in $\mathrm{NaNO}_{3}$ and $\mathrm{KNO}_{3}$ solutions, according to Korotkın.

Korotkin $^{13 \mathrm{C}}$ recently has extended his investigations to paper chromatographic sorption of $10^{-4} \mathrm{M}$ americium from $\mathrm{pH} 1$ to $9 \mathrm{HClO}_{4}$ solutions $\mathrm{He}$ concludes that at such conditions the hydrolysis mechanism may be represented by the following scheme 
$\mathrm{Am}^{3+} \rightarrow \mathrm{Am}(\mathrm{OH})^{2+} \rightarrow[\mathrm{Am}(\mathrm{OH})](\mathrm{OH})^{+} \rightarrow \mathrm{Am}\left[\mathrm{Am}(\mathrm{OH})_{2}\right]^{4+} \rightarrow \operatorname{Am}\left[\mathrm{Am}(\mathrm{OH})_{2}\right]_{\mathrm{n}}^{(3+\mathrm{n})^{+}}$

$\begin{array}{lllll}\text { I } & \text { II } & \text { III } & \text { IV } & \text { V }\end{array}$

It is necessary to point out that independent experiments by other scientists to confirm or refute Korotkın's speculations about the vanous hydrolytic species of amencium either have not yet been done or have not yet been published

\section{Am(IV)}

Because of the high value $(+2.4 \mathrm{~V})$ of the standard potential of the Am(IV)Am(III) couple, tetravalent americium is unstable in most mineral acid solutions with respect to disproportionation to $\mathrm{Am}(\mathrm{III})$ and $\mathrm{Am}(\mathrm{V})$ However, stable áqueous solutions of tetravalent americium in which disproportionation does not occur even at $90^{\circ} \mathrm{C}$ can be prepared ${ }^{1415}$ by dissolution of $\mathrm{Am}(\mathrm{OH})_{4}$ in concentrated solutions of $\mathrm{NH}_{4} \mathrm{~F}, \mathrm{KF}, \mathrm{RbF}$, and $\mathrm{CsF}$ The solubility of Am(IV) in $13 M \mathrm{NH}_{4} \mathrm{~F}$ at $25^{\circ} \mathrm{C}$ is $002 \mathrm{M}$. This rose-colored solution probably contans the ions $\mathrm{AmF}_{5}^{-}$and/or $\mathrm{AmF}_{6}^{2-}$. Ozone oxidizes Am(IV) in $13 M \mathrm{NH}_{4} \mathrm{~F}$ to $\mathrm{Am}(\mathrm{VI})$, whereas iodide reduces it to Am(III). Slow reduction of Am(IV) to Am(III) occurs because of alpha radiation.

Stable solutions of tetravalent Am(IV) can also be prepared by anodic oxidation (at a platinum electrode) of $\mathrm{Am}^{3+}$ in $\mathrm{H}_{3} \mathrm{PO}_{4}$ solution This method of stabilizing Am(IV) was first discovered by Yanir, Givon, and Marcus. ${ }^{16,17}$ Subsequent publications by Myasoedov and coworkers ${ }^{18 \mathrm{a}} 18 \mathrm{~b}$ have recently confirmed and extended this preparation technique. One of their papers ${ }^{18}$ a also presents detals of the construction and operation of a suitable electrolysis cell The Russian workers report $^{18 \mathrm{~d}}$ that pure Am(IV) is obtained in $10 M$ to $15 M \mathrm{H}_{3} \mathrm{PO}_{4}$ Kinetic data for the oxidation of $\mathrm{Am}$ (III) in $12 \mathrm{M} \mathrm{H}_{3} \mathrm{PO}_{4}$ (F1g. 3.1) show that complete oxidation to $\mathrm{Am}(\mathrm{IV})$ requires about an hour under the conditions used by Myasoedov et al

In their most recent paper, Myasoedov et al. ${ }^{18 \mathrm{~b}}$ discuss the influence of temperature and the concentrations of $\mathrm{H}_{3} \mathrm{PO}_{4}$ and americium on the completeness of electrochemical oxidation of $\mathrm{Am}$ (III) in $3 M$ to $15 M \mathrm{H}_{3} \mathrm{PO}_{4}$ and the stability of the resulting $\mathrm{Am}(\mathrm{IV})$. In $3 M$ to $8 M \mathrm{H}_{3} \mathrm{PO}_{4}, \mathrm{Am}(\mathrm{IV})$ disproportionates according to the scheme $3 \mathrm{Am}(\mathrm{IV}) \rightarrow 2 \mathrm{Am}(\mathrm{III})+\mathrm{Am}(\mathrm{VI})$, whereas at $\mathrm{H}_{3} \mathrm{PO}_{4}$ concentrations above $10 M, A m(I V)$ reduces to Am(III). The apparent rate constant for Am(IV) disproportionation increases with decreasing $\mathrm{H}_{3} \mathrm{PO}_{4}$ concentration, whereas that for reduction of $\mathrm{Am}(\mathrm{IV})$ to $\mathrm{Am}(\mathrm{III})$ increases with temperature and with decreasing americium and $\mathrm{H}_{3} \mathrm{PO}_{4}$ concentration ( $15 \mathrm{M}$ to $10 \mathrm{M}$ ) The activation energy for the reduction of Am(IV) to Am(III) in $12 \mathrm{M} \mathrm{H}_{3} \mathrm{PO}_{4}$ is $15.6 \pm 1.1 \mathrm{kcal} \mathrm{mol}^{-1}$ according to results obtained by Myasoedov et al ${ }^{18 \text { a }}$

Myasoedov, Lebedev, and Milyukova ${ }^{18 \mathrm{c}}$ also report that $\mathrm{Am}(\mathrm{III})$ in $\mathrm{H}_{3} \mathrm{PO}_{4}$ solutions is rapidly oxidized by $\mathrm{Ag}(\mathrm{II})$ oxide and a mixture of $\mathrm{Ag}_{3} \mathrm{PO}_{4}$ and $\left(\mathrm{NH}_{4}\right)_{2} \mathrm{~S}_{2} \mathrm{O}_{8}$ Pure Am(IV) is obtained in $9 M$ to $12 M \mathrm{H}_{3} \mathrm{PO}_{4}$. In $3 M$ to $6 M \mathrm{H}_{3} \mathrm{PO}_{4}$, depending on the oxidation tıme, pure $A m(V I)$ or a mixture of $A m(I V)$ and Am(VI) are obtained 


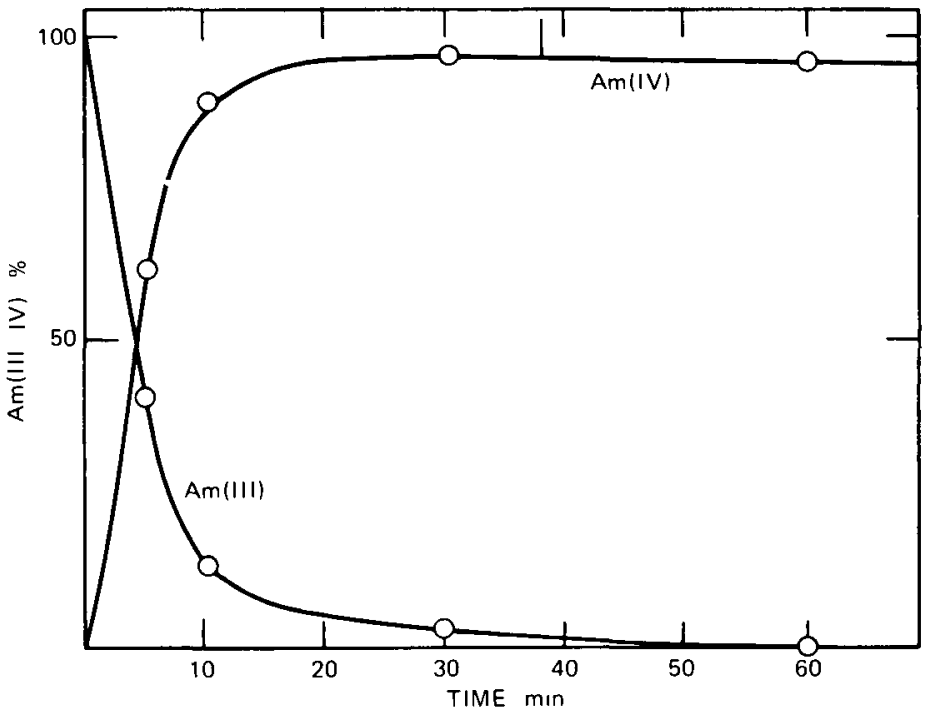

Fig. 3.1 Electrolytic oxidation of Am(III) in $12 \mathrm{M} \mathrm{H}_{3} \mathrm{PO}_{4}$ [From B F Myasoedov, $\mathrm{V} M$ Mikhalov, I A Lebedev, O E Korro, and V Ya Frenkel, Preparation and Stability of Am(IV) and Am(V) in Phosphoric Acid Solutions, Radiochemical and Radioanalytical Letters 1417 (1973) ]

A third way of stabilizing Am(IV) in aqueous solution consists of diluting a concentrated alkali fluoride solution in which $\mathrm{Am}(\mathrm{OH})_{4}$ has been dissolved with concentrated $\mathrm{K}_{4} \mathrm{P}_{2} \mathrm{O}_{7}$ solution Yanir, Givon, and Marcus ${ }^{17}$ used this approach to prepare a $03 M$ acid solution containıng Am(IV) and about $2 M \mathrm{~K}_{4} \mathrm{P}_{2} \mathrm{O}_{7}$ and $3 M$ $\mathrm{NH}_{4} \mathrm{~F}$ Americium(IV) in this solution was very stable, being reduced only $5 \%$ in $7 \mathrm{hr}$ Direct dissolution of $\mathrm{Am}(\mathrm{OH})_{4}$ in acidified pyrophosphate solutions yielded mixtures of $\mathrm{Am}(\mathrm{IV})$ and $\mathrm{Am}(\mathrm{VI})$ with $\mathrm{Na}_{4} \mathrm{P}_{2} \mathrm{O}_{7}$ and $\mathrm{Am}(\mathrm{IV})$ and $\mathrm{Am}(\mathrm{V})$ in $\mathrm{K}_{4} \mathrm{P}_{2} \mathrm{O}_{7}$ solutions

\section{$\operatorname{Am}(\mathrm{V})$}

Oxıdation of Am(III) yields Am(VI) in acid solution but both Am(V) and Am(VI) in alkaline solution This behavior is in accord with that expected from electrode potentials (see pages 55 to 58) Solutions of $\mathrm{Am}(\mathrm{V})$ are conventionally prepared by controlled oxidation of Am(III) in alkalı carbonate media with ozone, ${ }^{19-24}$ peroxydisulfate, ${ }^{192324}$ or hypochlorite 1on ${ }^{19232526}$ Various solid carbonates containing the $\mathrm{AmO}_{2}^{+}$ion (see pages 139 to 141) precipttate from the resulting solutions Dilute acid solutions of $\mathrm{AmO}_{2}^{+}$containing several percent $\mathrm{Am}^{3+}$ can be prepared by dissolution of these solid carbonates

Americium(V) solutions free of Am(III) can be prepared by intermediate preparation of $\mathrm{Am}(\mathrm{VI})$ in $2 \mathrm{M} \mathrm{Na} \mathrm{CO}_{3}$ solution ${ }^{27}$ After $5 \% \mathrm{O}_{3}$ is bubbled through the solution for $1 \mathrm{hr}$ at room temperature to oxidize Am(III) to Am(VI), 
$\mathrm{NaAmO}_{2} \mathrm{CO}_{3}$ is precipitated by heating the solution for 30 to $60 \mathrm{~min}$ at $90^{\circ} \mathrm{C}$. Solutions obtained by dissolution of the resulting $\mathrm{NaAmO}_{2} \mathrm{CO}_{3}$ contain only $\mathrm{AmO}_{2}^{+}$.

$\mathrm{Hara}^{28}$ prepared perchlorate, sulfate, and acetate solutions containing $\mathrm{AmO}_{2}^{+}$free of $\mathrm{Am}^{3+}$ by first extracting $\mathrm{AmO}_{2}^{+}$from $1 M$ acetate buffer $(\mathrm{pH}>3)$ solutions of $\mathrm{Am}(\mathrm{III})$ and $\mathrm{Am}(\mathrm{V})$ into $0.1 M$ thenoyltrifluoroacetone in isobutanol. When the organic phase containing $A m(V)$ was shaken with an aqueous phase having a proper $\mathrm{pH}$ value and composition, $A m(V)$ was selectively stripped into the aqueous phase.

Newer methods for obtaining the $\mathrm{AmO}_{2}^{+}$ion in aqueous solution include dissolution of solid $\mathrm{Li}_{3} \mathrm{AmO}_{4}$ in dilute $\mathrm{HClO}_{4}$ and electrolytic oxidation ${ }^{17}$ of $\mathrm{Am}(\mathrm{III})$ in $2 M \mathrm{LiIO}_{3}-0.7 M \mathrm{HIO}_{3}(\mathrm{pH} 1.47)$ solution. Solid $\mathrm{Li}_{3} \mathrm{AmO}_{4}$ can be prepared by the solid-state reaction: ${ }^{29}$

$$
3 \mathrm{Li}_{2} \mathrm{O}+2 \mathrm{AmO}_{2}+1 / 2 \mathrm{O}_{2} \stackrel{8 \mathrm{hr}, 600^{\circ} \mathrm{C}}{\longrightarrow} 2 \mathrm{Li}_{3} \mathrm{AmO}_{4}
$$

\section{$A m(V I)$}

Hexavalent americium can be prepared by oxidation of lower oxidation states in either acid or alkaline solutions. In dilute, nonreducing acid solutions, powerful chemical oxidants such as $\mathrm{S}_{2} \mathrm{O}_{8}^{2-}$ and $\mathrm{Ag}(\mathrm{II})$ oxidize both $\mathrm{Am}(\mathrm{III})$ and $\mathrm{Am}(\mathrm{V})$ to Am(VI). ${ }^{27.30 a}$ Peroxydisulfate, however, will not oxidize Am(III) to Am(VI) completely at acidities above about $0.5 \mathrm{M}$. In $\mathrm{HClO}_{4}$ solution, $\mathrm{Ce}(\mathrm{IV})$ oxidizes $\mathrm{Am}(\mathrm{V})$ to Am(VI) (Ref. 23) but only partly oxidizes Am(III) to Am(VI). Similarly ozone readily oxidizes $\mathrm{Am}(\mathrm{V})$ to $\mathrm{Am}(\mathrm{VI})$ in heated $\mathrm{HNO}_{3}$ or $\mathrm{HClO}_{4}$ solution ${ }^{2}$ but will not oxidize macroconcentrations of $\mathrm{Am}(\mathrm{III})$ to $\mathrm{Am}(\mathrm{VI})$ in acid media even when heated. ${ }^{30 b}$

Electrolytic oxidation of $\mathrm{Am}(\mathrm{III})$ either in $2 \mathrm{M} \mathrm{H}_{3} \mathrm{PO}_{4}$ or in $6 M \mathrm{HClO}_{4}$ produces the $\mathrm{AmO}_{2}^{2+}$ ion. ${ }^{18,27} \mathrm{Keller}^{6 \mathrm{c}}$ also states that dissolution of $\mathrm{Li}_{6} \mathrm{AmO}_{6}$ either in water or in dilute $\mathrm{HClO}_{4}$ yields a solution containing $\mathrm{AmO}_{2}^{2+} . \mathrm{Li}_{6} \mathrm{AmO}_{6}$ can be made by the solid-state reaction at $360^{\circ} \mathrm{C}$ of $\mathrm{Li}_{2} \mathrm{O}$ with $\mathrm{AmO}_{2}$ in the mol ratio of $3.5: 1$ (Ref. 29).

Ozone or peroxydisulfate oxidation of either $A m(I I I)$ or $A m(V)$ in aqueous $\mathrm{Na}_{2} \mathrm{CO}_{3}$ or $\mathrm{NaHCO}_{3}$ solution yields an intense red-brown colored solution thought to contain a carbonate complex of $\mathrm{Am}(\mathrm{VI}) .^{2.27}$ This same complex is also obtained by dissolution of solid sodium americyl acetate in $\mathrm{Na}_{2} \mathrm{CO}_{3}$ or $\mathrm{NaHCO}_{3}$ solutions. [Nugent, ${ }^{31}$ in a recent review article, speculates that an Am(VII)-carbonate complex may actually be present in such solutions and suggests that the presence of such a species would be consistent with several experimental observations.] Americium(VI) in $0.1 M$ to $0.5 M \mathrm{NaHCO}_{3}$ solution is stable at $90^{\circ} \mathrm{C}$ to reduction by $\mathrm{H}_{2} \mathrm{O}, \mathrm{Cl}^{-}$, and $\mathrm{Br}^{-}$ but is readily reduced by $\mathrm{I}^{-}, \mathrm{N}_{2} \mathrm{H}_{4}, \mathrm{H}_{2} \mathrm{O}_{2}, \mathrm{NO}_{2}^{-}$, and $\mathrm{NH}_{2} \mathrm{OH}$. Reduction by water occurs at $90^{\circ} \mathrm{C}$ in $2 \mathrm{M} \mathrm{Na}_{2} \mathrm{CO}_{3}$.

Ozone oxidation of $\mathrm{Am}(\mathrm{III})$ in $2 \mathrm{M} \mathrm{Na}_{2} \mathrm{CO}_{3}$ yields $\mathrm{AmO}_{2}^{2+}$ only if the temperature is maintained at $\sim 25^{\circ} \mathrm{C}$ or below; at $90^{\circ} \mathrm{C}$ oxidation does not proceed past $\mathrm{Am}(\mathrm{V})$. Surprisingly, $\mathrm{Am}(\mathrm{VI})$ is not produced by $\mathrm{O}_{3}$ oxidation of either $\mathrm{Am}(\mathrm{OH})_{3}$ or $\mathrm{KAmO}_{2} \mathrm{CO}_{3}$ in $0.03 M$ to $0.1 M \mathrm{KHCO}_{3}$ solution. ${ }^{22}$ Similarly $\mathrm{K}_{2} \mathrm{~S}_{2} \mathrm{O}_{8}$ will not oxidize either $\mathrm{Am}(\mathrm{OH})_{3}$ or $\mathrm{NaAmO}_{2} \mathrm{CO}_{3}$ in $0.1 \mathrm{M} \mathrm{NaHCO}_{3}$ to $\mathrm{Am}(\mathrm{VI})$, although such 
oxidation is accomplished readily with $\mathrm{Na}_{2} \mathrm{~S}_{2} \mathrm{O}_{8}$. This chemistry is explained on the basis of the lower solubility of $\mathrm{KAmO}_{2} \mathrm{CO}_{3}$ compared to that of $\mathrm{NaAmO}_{2} \mathrm{CO}_{3}$.

Alkali hydroxide solutions of $\mathrm{Am}(\mathrm{VI})$ are yellow colored ${ }^{2,32-34}$ and, according to Cohen, ${ }^{33}$ may be easily prepared by ozone oxidation of a slurry of $\mathrm{Am}(\mathrm{OH})_{3}$ in all the alkali hydroxides from lithium to cesium. An alternative procedure consists of oxidizing $\mathrm{Am}(\mathrm{III})$ in dilute $\mathrm{NaHCO}_{3}$ solution to $\mathrm{Am}(\mathrm{VI})$ with ozone, acidifying with dilute $\mathrm{HNO}_{3}$, and finally, adding the desired alkali hydroxide to neutralize the $\mathrm{HNO}_{3}$ and produce an alkaline solution. Alkali hydroxide solutions of Am(VI) are not stable, and a light-tan solid precipitates a few hours after preparation. This solid is soluble in dilute mineral acids to yield a solution containing $\mathrm{AmO}_{2}^{+}$ions.

Solid $\mathrm{Na}_{4} \mathrm{XeO}_{6}$ is reported ${ }^{34}$ to oxidize Am(III) in $12 \mathrm{M}$ to $15 \mathrm{M}$ CsF media, either with or without added HF, to Am(V) and/or Am(VI). The exact oxidation state - (V) or (VI) - of americium in the oxidized solution has not been determined.

\section{$\operatorname{Am}(\mathrm{VII})$}

In preliminary communication, Zaitseva ${ }^{35}$ indicated that a dark-violet solution containing Am(VII) could be obtained both by disproportionation of Am(VI) in $3 M$ $\mathrm{NaOH}$ and by the action of strong oxidizing agents on an alkaline solution containing $A m(V)$. Subsequent work ${ }^{36}$ showed that the claim for Am(VII) was erroneous - the dark-violet color was due to a contamination by $\mathrm{Fe}(\mathrm{VI})$. Incidentally, attempts ${ }^{\mathbf{3}}$ to prepare a solid compound containing $\mathrm{Am}$ (VII) by careful oxidation of $\mathrm{Li}_{2} \mathrm{O}-\mathrm{AmO}_{2}$ mixtures at 300 to $400^{\circ} \mathrm{C}$ in a stream of oxygen proved unsuccessful. Nugent's speculations about the existence of an Am(VII)-carbonate complex were mentioned earlier.

Krot et al. ${ }^{1 \text { a }}$ stated that aqueous solutions containing Am(VII) can be prepared by oxidation at 0 to $7^{\circ} \mathrm{C}$ of $\mathrm{Am}(\mathrm{VI})$ in alkaline solutions with either $\mathrm{O}^{-}$ion radicals or ozone. Thus passage of air containing 20 to $50 \mathrm{mg} \mathrm{liter}^{-1} \mathrm{O}_{3}$ for 30 to $60 \mathrm{~min}$ through a light-yellow $3 M$ to $4 M \mathrm{NaOH}$ solution containing $0.001 M$ to $0.002 M \mathrm{Am}(\mathrm{VI})$ at 0 to $7^{\circ} \mathrm{C}$ yields a green-colored solution containing at least some Am(VII). A similar green-colored solution results on irradiation $\left({ }^{6}{ }^{\circ} \mathrm{Co}\right)$ at $0^{\circ} \mathrm{C}$ of a $3 M \mathrm{NaOH}$ solution containing $0.001 M$ to $0.002 M$ Am(VI) and previously saturated with $\mathrm{N}_{2} \mathrm{O}$. (The $\mathrm{N}_{2} \mathrm{O}$ functions to transform hydrated electrons produced by radiolysis to $\mathrm{O}^{-}$ion radicals by the reaction $\mathrm{N}_{2} \mathrm{O}+\mathrm{e}_{\mathrm{aq}}^{-}=\mathrm{N}_{2}+\mathrm{O}^{-} ; \mathrm{S}_{2} \mathrm{O}_{8}^{2-}$ may be substituted for $\mathrm{N}_{2} \mathrm{O}$ for the same purpose.) With either oxidant the absorbance of the green-colored solution at 370 to $450 \mathrm{~nm}$ is about twice that of the original Am(VI) solution and slowly decreases with time. Stability of the Am(VII) species, according to Krot et al., is greater in $5 M \mathrm{NaOH}$ than in $3 M \mathrm{NaOH}$.

To confirm the presence of $\mathrm{Am}(\mathrm{VII})$ in the oxidized solutions, the Russian scientists made spectrophotometric studies in $1 M$ to $2 M \mathrm{NaOH}$ solutions of the reactions $\mathrm{Pu}(\mathrm{VI})+\mathrm{Am}(\mathrm{VII})=\mathrm{Pu}(\mathrm{VII})+\mathrm{Am}(\mathrm{VI})$ and $2 \mathrm{~Np}(\mathrm{VI})+\mathrm{Am}(\mathrm{VII})=$ $2 \mathrm{~Np}(\mathrm{VII})+\mathrm{Am}(\mathrm{V})$. Appearance of the characteristic spectrum of pure Pu(VII) under conditions where Am(VII) is the only oxidant provides strong evidence that the green-colored solutions prepared as described above do indeed contain some Am(VII). 
Further studies of the preparation and properties of Am(VII) in aqueous solution can surely be anticipated

\section{THERMODYNAMIC VALUES}

The heats of solution of americium metal in aqueous $\mathrm{HCl}$ solutions at $29815 \pm 005^{\circ} \mathrm{K}$ were redetermıned in 1972 by Fuger, Spirlet, and Muller ${ }^{38}$ using specially purified and characterized metal Earlier (1951) measurements were made by Lohr and Cunningham ${ }^{39}$ and Westrum and Eyring ${ }^{40}$ From their results, Fuger, Spirlet, and Muller ${ }^{38}$ calculate the standard enthalpy of formation of $\mathrm{Am}^{3+}$ aq at $298^{\circ} \mathrm{K}$ to be $-1474 \pm 03 \mathrm{kcal} \mathrm{mol}^{-1}$ This value, which is about $10 \%$ less negative than that previously accepted, ${ }^{39} 40$ confirms the preliminary data of Morss ${ }^{42}$ and is in line with arguments advanced by Ryan ${ }^{4}$ and by Nugent, Burnett, and Morss 44

Fuger and Oettıng $4 \mathrm{~b}$ have very recently carefully examined existing knowledge of the entropies of actinide ions These authors have also critically evaluated available existing enthalpy and electromotive-force data and checked them for consistency with entropy data Thermodynamic values for americium ions calculated by Fuger and Oetting are listed in Table 32 and are the most reliable data extant Some earlier thermodynamic quantities for americium ions were calculated by Fuger, Spirlet, and Muller, ${ }^{11}$ by Eyring, Lohr, and Cunningham, ${ }^{45}$ by Gunn and Cunningham, ${ }^{46}$ and by Hinchey and Cobble ${ }^{47}$

Table 32

THERMODYNAMIC QUANTITIES FOR AMERICIUM IONS

\begin{tabular}{|c|c|c|c|c|c|}
\hline \multirow[b]{2}{*}{ Ion } & \multirow[b]{2}{*}{$\begin{array}{c}-\Delta \mathbf{H}^{\circ} \mathbf{f}\left(298^{\circ} \mathrm{K}\right),{ }^{\dagger} \\
\text { kcal mol }^{1}\end{array}$} & \multirow[b]{2}{*}{$\begin{array}{l}\Delta \mathrm{G}^{\circ} \mathrm{f}\left(298^{\circ} \mathrm{K}\right), \dagger \\
\quad \mathrm{kcal} \mathrm{mol}^{1}\end{array}$} & \multirow[b]{2}{*}{$\begin{array}{l}-\mathrm{S}^{\circ}\left(298^{\circ} \mathrm{K}\right),{ }_{\dagger}^{\dagger} \\
\text { cal mol }{ }^{10} \mathrm{~K}^{1}\end{array}$} & \multicolumn{2}{|c|}{ Hydration enthalpy and entropy* } \\
\hline & & & & $\begin{array}{c}-\Delta \mathrm{H}_{\mathrm{h}}, \\
\text { kcal mol }\end{array}$ & cal $\mathrm{mol}^{-\mathrm{S}_{\mathrm{h}},}$ \\
\hline $\mathrm{Am}^{3+} \cdot \mathrm{aq}$ & $1474 \pm 03$ & $1432+09$ & $48+3$ & 832 & 918 \\
\hline $\mathrm{Am}^{4+} \cdot \mathrm{aq}$ & $1034+26$ & $892 \pm 24$ & $97+5$ & 1635 & 128 \\
\hline $\mathrm{AmO}_{2}^{+} \cdot \mathrm{aq}$ & $1924 \pm 11$ & $1777+13$ & $3+2$ & & \\
\hline $\mathrm{AmO}_{2}^{2+} \cdot \mathrm{aq}$ & $1558 \pm 05$ & $1410+08$ & $19+2$ & & \\
\hline
\end{tabular}

*Calculated values from Ref $47 \mathrm{~b}$

$\dagger$ Values from Ref $44 \mathrm{~b}$

\section{ELECTRODE POTENTIALS}

Table 33 lists electrode potentials (1969 International Union of Pure and Applied Chemistry sign convention) for americium in various aqueous media The potential dragram for amencium in $1 \mathrm{M} \mathrm{HClO}_{4}$ reflects newly estimated values for the (III)-(0), 
Table 3.3

\section{ELECTRODE POTENTIALS OF AMERICIUM*†}

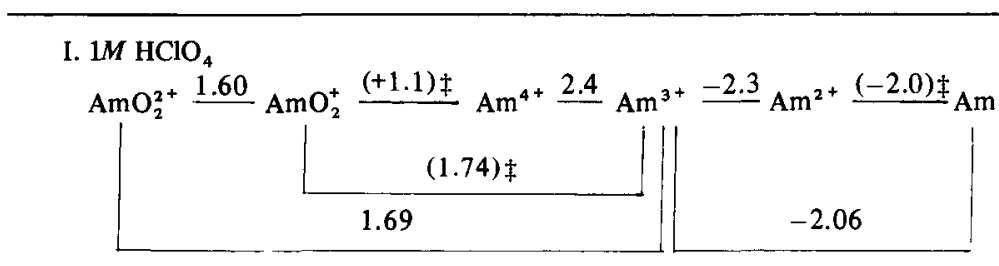

II. $1 M \mathrm{OH}^{-}$

$$
\mathrm{AmO}_{2}(\mathrm{OH})_{2} \stackrel{1.1}{=} \mathrm{AmO}_{2} \mathrm{OH} \stackrel{(0.7) \ddagger}{\longrightarrow} \mathrm{Am}(\mathrm{OH})_{4} \stackrel{0.5}{\longrightarrow} \mathrm{Am}(\mathrm{OH})_{3} \stackrel{-2.68}{\longrightarrow} \mathrm{Am}
$$

III. Phosphoric acid

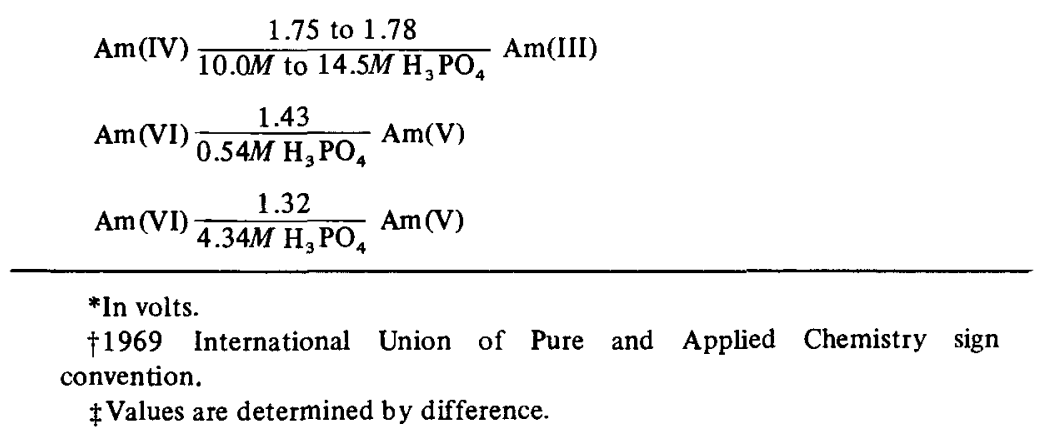

(III)-(II), and (IV)-(III) couples and differs slightly from those previously published. ${ }^{6 c, 48,49}$ Reference is made to Nugent's recent paper $^{31}$ on the chemical oxidation states of lanthanides and actinides.

\section{Potentials in $1 \mathrm{M} \mathrm{HClO}_{4}$}

The potential, $1.60 \pm 0.01 \mathrm{~V}$, of the $\mathrm{Am}(\mathrm{VI})-\mathrm{Am}(\mathrm{V})$ couple in $1 M \mathrm{HClO}_{4}$ has been directly measured. ${ }^{50}$ Potentials of all the other couples are calculated values.

Using their recently carefully determined value of $-147.4 \pm 0.3 \mathrm{kcal} \mathrm{mol}^{-1}$ for the heat of formation of $\mathrm{Am}^{3+} \cdot \mathrm{aq}$, Fuger, Spirlet, and Müller ${ }^{38}$ estimate the potential of the Am(III)-Am(0) couple in $1 M^{1} \mathrm{HClO}_{4}$ to be $-2.06 \pm 0.01 \mathrm{~V}$. Earlier, ${ }^{39,46}$ the potential of the (III) $-(0)$ couple was estimated at $-2.36 \pm 0.04 \mathrm{~V}$.

Nugent et al. $51 \mathrm{a}, 51 \mathrm{~b}$ estimate, from various theoretical considerations, that the best value for the Am(III)-Am(II) couple is $-2.3 \mathrm{~V}$. They note that this calculated value is in agreement with chemical evidence which indicates that the americium potential should be appreciably greater than the corresponding californium potential of $-1.6 \mathrm{~V}$. The standard potential of the Am(III)-Am(II) couple has previously been listed at $\leqslant-1.5 \mathrm{~V}$ (Refs. 3, 6c, 48, 52, 53). 
The standard potential of the $\mathrm{Am}(\mathrm{IV})$ - Am(III) couple in $1 M \mathrm{HClO}_{4}$ was originally estimated $^{46}$ as $244 \mathrm{~V}$ and was later revised by Cunningham ${ }^{54}$ to $28 \mathrm{~V}$ Nugent et al , ${ }^{55}$ using a variety of new calculational procedures, estimate that the standard potential of the (IV)-(III) couple lies in the range 20 to $25 \mathrm{~V}$ From their direct measurements of a value of $178 \mathrm{~V}$ for the (IV)-(III) couple in $10 \mathrm{M} \mathrm{H}_{3} \mathrm{PO}_{4}$, Stokely and Baybarz ${ }^{5}$ calculate a value of $234 \mathrm{~V}$ for the couple in $1 M \mathrm{HClO}_{4}$ An average value of $24 \mathrm{~V}$ is shown in Table 33 for the (IV)-(III) couple

Gunn, ${ }^{56}$ from measurements of the heat of reduction of Am(VI) to Am(III) by the $\mathrm{Fe}^{2+}$ 10n, estimated the potential of the Am(VI)-Am(III) couple at $170 \mathrm{~V}$ A value of $167 \mathrm{~V}$ for this couple was estimated by $\mathrm{Nigon}^{57}$ on the basis of a study of the oxidation of Am(III) to Am(VI) by the Ce(IV) ion An earlier ${ }^{27}$ estimate of $18 \mathrm{~V}$ for the (IV)-(III) couple was in error due to a misinterpretation of the effect of acidity on the oxidation of $\mathrm{Am}(\mathrm{III})$ to $\mathrm{Am}(\mathrm{VI})$ by the $\mathrm{S}_{2} \mathrm{O}_{8}^{2-}$ ion In passing 1t should be noted that the currently accepted potentials of both the (VI)-(III) and (VI)-(V) couples are based on results of measurements made 20 years ago when americlum chemistry was in its infancy Repetition of these measurements with long-lived ${ }^{243}$ Am would be helpful

Potentials shown in Table 33 for the Am(II)-Am(0), Am(V)-Am(III), and Am(V)-Am(IV) couples are calculated from those listed for the other couples The new values assigned to the (III)-(0) and (III)-(II) couples lead to a value of $-19 \mathrm{~V}$ for the (II) - ( (O) couple, which is substantially changed from the potential of $<-27 \mathrm{~V}$ customanly shown ${ }^{6 \mathrm{c}^{48}}$ Nugent $^{6 \mathrm{~b}}$ assigns a value of $-20 \mathrm{~V}$ to the (II)-(0) couple As a reflection of the change in the (IV)-(III) potential from 244 to $24 \mathrm{~V}$, the potential of the (VI)-(V) couple is calculated to be $11 \mathrm{~V}$, only slightly more positive than the value of $104 \mathrm{~V}$ previously calculated ${ }^{6 \mathrm{c} 48}$ for this potential

\section{Potentıals in $1 \mathrm{MOH}^{-}$}

Standard potentials of americium in $1 \mathrm{M} \mathrm{OH}^{-}$solution (Table 33 ) were originally calculated in 1952 by Latımer ${ }^{58 \text { a }}$ from estimates of the solubility products of $\mathrm{Am}(\mathrm{OH})_{3}$ and $\mathrm{Am}(\mathrm{OH})_{4}$ Subsequently, Penneman, Coleman, and Keenan ${ }^{32}$ suggested that the standard potential of the $\operatorname{Am}(\mathrm{OH})_{3}-\mathrm{Am}(\mathrm{OH})_{4}$ couple should be revised from $+04 \mathrm{~V}$ to at least $-05 \mathrm{~V}$ From recent studies of the reaction of $\mathrm{Am}(\mathrm{VI})$ with $\mathrm{Np}(\mathrm{VI})$ in $001 M$ to $12 M \mathrm{NaOH}$ and with $\mathrm{Pu}(\mathrm{VI})$ in $3 M$ to $14 M \mathrm{NaOH}$ Nikolaevskil, Shilov, and $\mathrm{Krot}^{58 \mathrm{~b}}$ estimate that the potential of the $\mathrm{Am}(\mathrm{VI})-\mathrm{Am}(\mathrm{V})$ couple in $1 M \mathrm{NaOH}$ is $\sim 065 \mathrm{~V}$ rather than the $11 \mathrm{~V}$ estımated by Latımer ${ }^{58 \text { a }}$ Peretrukhin, N1kolaevski1, and Shilov ${ }^{5 \mathrm{c}}$ have investigated the polarographic behavior of $\mathrm{Am}(\mathrm{V})$ and $\mathrm{Am}(\mathrm{VI})$ in $1 M$ to $10 M \mathrm{NaOH}$ From their data these authors give the following potential scheme

$19 \mathrm{M} \mathrm{NaOH} A \mathrm{NaOH}(\mathrm{VI}) \stackrel{068}{063} \mathrm{Am}(\mathrm{V}) \frac{025<\mathrm{E}_{0}<050}{017<\mathrm{E}_{0}<050} \mathrm{Am}(\mathrm{IV}) \frac{\mathrm{E}_{0}<025}{\mathrm{E}_{0}<018} \mathrm{Am}(\mathrm{III})$


Further revision of Latımer's calculated potentials for americium in alkaline solutions is in order, particularly so since there is evidence ${ }^{59}$ that the solubility product of $\mathrm{Am}(\mathrm{OH})_{3}$ is of the order of $3 \times 10^{-18}$ rather than $27 \times 10^{-20}$ as estımated by Latımer $58 \mathrm{~d}$

\section{Potentıals in $\mathrm{H}_{3} \mathrm{PO}_{4}$}

The formal potentials of the Am(IV)-Am(III) and Am(VI)-Am(V) couples in $\mathrm{H}_{3} \mathrm{PO}_{4}$ solutions which are listed in Table 33 were determined by direct potenti ometry 5560

\section{AUTOREDUCTION EFFECTS}

Species (e g, $\mathrm{H}_{2} \mathrm{O}_{2}$ and $\mathrm{HO}_{2}$; radicals) produced by alpha radiolysis of water reduce the higher oxidation states of americium in aqueous solution eventually to stable Am(III) Because of 1 ts lower specific activity, the rate of autoreduction of ${ }^{243} \mathrm{Am}(>\mathrm{III})$ is much less than that of ${ }^{241} \mathrm{Am}(>\mathrm{III})$ Autoreduction of Am(VI) has been studied in $\mathrm{HClO}_{4}$ (Refs 46, 61-64), $\mathrm{H}_{2} \mathrm{SO}_{4}$ (Refs 62-64), and $\mathrm{HNO}_{3}$ (Ref 62) solutions while autoreduction of $\mathrm{Am}(\mathrm{V})$ has been followed in $\mathrm{HClO}_{4}$ (Refs 46, 61, $63,64), \mathrm{HNO}_{3}$ (Ref 62), and $\mathrm{HCl}$ (Ref 65) media Zaitsev et al ${ }^{62}$ postulate the following reactions to account for the observed kinetics of autoreduction of $\mathrm{AmO}_{2}^{2+}$ and $\mathrm{AmO}_{2}^{+}$ions in the aqueous, arr saturated solutions

$$
\begin{aligned}
\mathrm{H}_{2} \mathrm{O} & \rightarrow \mathrm{H}+\dot{\mathrm{OH}} \\
\mathrm{H}+\mathrm{O}_{2} & \rightarrow \mathrm{HO}_{2} \\
\dot{\mathrm{O} H}+\dot{\mathrm{O}} \mathrm{H} & \rightarrow \mathrm{H}_{2} \mathrm{O}_{2} \\
\mathrm{AmO}_{2}^{2+}+\mathrm{HO}_{2} & \rightarrow \mathrm{AmO}_{2}^{+}+\mathrm{O}_{2}+\mathrm{H}^{+} \\
\mathrm{AmO}_{2}^{2+}+\mathrm{H}_{2} \mathrm{O}_{2} & \rightarrow \mathrm{AmO}_{2}^{+}+\mathrm{HO}_{2}^{+}+\mathrm{H}^{+} \\
\mathrm{AmO}_{2}^{+}+2 \mathrm{HO}_{2}^{+}+2 \mathrm{H}^{+} & \rightarrow \mathrm{Am}^{3+}+2 \mathrm{O}_{2}+2 \mathrm{H}_{2} \mathrm{O} \\
\mathrm{AmO}_{2}^{+}+\dot{\mathrm{O}} \mathrm{H} & \rightarrow \mathrm{AmO}_{2}^{2+}+\mathrm{OH}
\end{aligned}
$$

This reaction scheme assumes that $\mathrm{H}_{2} \mathrm{O}_{2}$ is consumed only in reducing Am(VI), whereas $\mathrm{Am}(\mathrm{V})$ is reduced only by $\mathrm{HO}_{2}$ radicals Americium(V) may be oxidized to $\mathrm{Am}(\mathrm{VI})$ by $\dot{\mathrm{OH}}$ radicals, and this reaction competes with that of hydrogen formation

All investigators concur that autoreduction of Am(VI) is kinetically zero order with respect to the $\mathrm{AmO}_{2}^{2+}$ ion and first order with respect to total americium concentration, $1 \mathrm{e}$, 


$$
-\frac{\mathrm{d}[\mathrm{Am}(\mathrm{VI})]}{\mathrm{dt}}=\frac{\mathrm{d}[\mathrm{Am}(\mathrm{V})]}{\mathrm{dt}}=\mathrm{k}_{1}\left[\mathrm{Am}_{\mathrm{total}}\right]
$$

In both $\mathrm{HClO}_{4}$ and $\mathrm{H}_{2} \mathrm{SO}_{4}$ media, the rate constant $\mathrm{k}_{1}$ falls off with increasing acid concentration (Table 34 ) Indeed, Zaitsev and coworkers ${ }^{62}$ did not observe any reduction of ${ }^{241} \mathrm{AmO}_{2}^{2+}$ in $12 \mathrm{M} \mathrm{HClO}_{4}$ over a period of $300 \mathrm{hr}^{\prime}$ This result is explained by Zaitsev et al on the basis that in concentrated $\mathrm{HClO}_{4}$ the predominant alpha radiolytic species are $\mathrm{Cl}_{2}$ and $\mathrm{ClO}_{2}$ which do not reduce $\mathrm{Am}(\mathrm{VI})$ or $\mathrm{Am}(\mathrm{V})$

Table 3.4

\begin{tabular}{|c|c|c|c|c|c|c|c|c|c|c|}
\hline \multicolumn{4}{|c|}{$\mathrm{HClO}_{4}$} & \multicolumn{3}{|c|}{$\mathrm{H}_{2} \mathrm{SO}_{4}$} & \multicolumn{2}{|c|}{$\mathrm{HNO}_{3}$ * } & \multicolumn{2}{|c|}{$\mathrm{HCl} \dagger$} \\
\hline$M$ & $\begin{array}{l}\mathbf{k}_{1}, \ddagger \\
\mathbf{h r}\end{array}$ & $\begin{array}{l}\mathbf{k}_{2}, \S \\
\mathbf{h r}^{1}\end{array}$ & Ref. & $M$ & $\begin{array}{l}\mathbf{k}_{\mathbf{1}}, \\
\mathbf{h r}^{1}\end{array}$ & Ref. & $M$ & $\begin{array}{l}\mathbf{k}_{1} \\
\mathbf{h r}^{1}\end{array}$ & $M$ & $\begin{array}{l}\mathbf{k}_{2} \\
\mathrm{hr}{ }^{1}\end{array}$ \\
\hline 02 & 0040 & 0020 & 46 & 01 & 0040 & 62 & 05 & 0069 & 05 & 00074 \\
\hline 02 & 0040 & & 62 & 01 & 0029 & 63 & 30 & 0086 & & \\
\hline 02 & 0030 & 0012 & 63 & 05 & 0025 & 63 & 60 & 0087 & & \\
\hline 05 & 0054 & & 61 & 10 & 00286 & 62 & 90 & 0103 & & \\
\hline 10 & 00475 & 0023 & 61 & 20 & 00251 & 62 & 143 & 0058 & & \\
\hline 20 & 0032 & & 62 & 20 & 00242 & 65 & & & & \\
\hline 40 & 0032 & & 62 & 30 & 0017 & 63 & & & & \\
\hline 90 & 0028 & & 62 & 40 & 00236 & 64 & & & & \\
\hline 90 & 001 & & 63 & 45 & 0013 & 63 & & & & \\
\hline \multirow[t]{4}{*}{120} & 00 & & 62 & 60 & 0018 & 62 & & & & \\
\hline & & & & 65 & 0012 & 63 & & & & \\
\hline & & & & 90 & 0012 & 63 & & & & \\
\hline & & & & 100 & 0022 & 62 & & & & \\
\hline
\end{tabular}

*All from Ref 62

$\dagger$ Ref 65

$\ddagger$ For $\mathrm{Am}(\mathrm{VI}) \rightarrow \mathrm{Am}(\mathrm{V})$, see Eq 311

$\S$ For $A m(V) \rightarrow A m(I I)$, see Eq 314

Zaitsev et al also state that the falloff in $\mathrm{k}_{1}$ with increasing $\mathrm{H}_{2} \mathrm{SO}_{4}$ concentration may be accounted for by the occurrence of the reactions

$$
\dot{\mathrm{OH}}+\mathrm{HSO}_{4}^{-} \rightarrow \mathrm{OH}^{-}+\mathrm{HSO}_{4}
$$

and/or

$$
\dot{\mathrm{O}}+\mathrm{H}_{2} \mathrm{SO}_{4} \rightarrow \mathrm{H}_{2} \mathrm{O}+\mathrm{HSO}_{4}
$$

which compete with Eq 36 and thereby lower the yield of $\mathrm{H}_{2} \mathrm{O}_{2}$ 
The autoreduction rate of $\mathrm{Am}(\mathrm{VI})$ in $\mathrm{HNO}_{3}$ solutions is a factor of 15 to 2 higher than the maximum rate in $\mathrm{HClO}_{4}$ and $\mathrm{H}_{2} \mathrm{SO}_{4}$ solutions Also, in contrast to the behavior noted in $\mathrm{HClO}_{4}$ and $\mathrm{H}_{2} \mathrm{SO}_{4}$ media, the reduction rate appears to increase with increasing $\mathrm{HNO}_{3}$ concentration, at least up to $9 M \mathrm{HNO}_{3}$ According to Zaitsev the increased rate of reduction of $\mathrm{Am}(\mathrm{VI})$ in $\mathrm{HNO}_{3}$ solutions is caused by radioly tically generated $\mathrm{NO}_{2}$ ions that very effectively reduce $\mathrm{Am}(\mathrm{VI})$

As regards autoreduction of $\mathrm{Am}(\mathrm{V})$ to $\mathrm{Am}(\mathrm{III})$, most investigators have stated that rate of this reaction, like that of the analogous Am(VI)-Am(V) transition, depends only on total americium concentration and is independent of $A m(V)$ concentration, $1 \mathrm{e}$,

$$
-\frac{\mathrm{d}[\mathrm{Am}(\mathrm{V})]}{\mathrm{dt}}=\frac{\mathrm{d}[\mathrm{Am}(\mathrm{III})]}{\mathrm{dt}}=\mathrm{k}_{2}\left[\mathrm{Am}_{\mathrm{total}}\right]
$$

(Values of $k_{2}$ determined in several solutions are listed in Table 34 ) Zaitsev et al ${ }^{6266}$ disagree and state that, at least under some conditions, the rate of autoreduction of $A m(V)$ to $A m(I I I)$ does depend on the concentration of $A m(V)$ In any event, autoreduction of ${ }^{241} \mathrm{AmO}_{2}^{+}$proceeds more slowly in $05 \mathrm{M} \mathrm{HCl}$ than in $02 \mathrm{M} \mathrm{HClO}_{4}$, presumably because of preferential reaction of the primary radiolysis products with chloride species rather than with $\mathrm{AmO}_{2}^{+}$ions Slow autoreduction of $\mathrm{AmO}_{2}^{+}$in $\mathrm{HNO}_{3}$ solutions has also been reported, ${ }^{62}$ the maximum reduction rate of $\mathrm{AmO}_{2}^{+}$is $\sim 1 \%$ per hour in $05 M \mathrm{HNO}_{3}$ and $08 \%$ per hour in $30 M \mathrm{HNO}_{3}$

The rate of autoreduction of ${ }^{243} \mathrm{Am}(\mathrm{VI})$ in $218 \mathrm{M} \mathrm{HClO}{ }_{4}$ solution at $757^{\circ} \mathrm{C}$ is about six times what it is at room temperature ${ }^{6}{ }^{7}$ In $4 M \mathrm{HClO}_{4}-2 M \mathrm{NaClO}_{4}$ solution, ${ }^{241} \mathrm{Am}(\mathrm{VI})$ autoreduces about four times faster at $75^{\circ} \mathrm{C}$ than at $25^{\circ} \mathrm{C}$ (Ref 62)

In $13 \mathrm{M} \mathrm{NH}_{4} \mathrm{~F},{ }^{241} \mathrm{Am}$ (IV) autoreduces at a rate of about $4 \%$ per hour, ${ }^{15}$ whereas, in $3 M$ fluoride solution, the autoreduction rate is about $10 \%$ per hour ${ }^{17}$ Self-reductıon of Am(IV) to Am(III) in phosphoric acid solution follows first-order peaction kinetics ${ }^{18}$ with a rate constant that is dependent on the concentrations of americium and $\mathrm{H}_{3} \mathrm{PO}_{4}$ (Fig 32 ) In $12 \mathrm{M} \mathrm{H}_{3} \mathrm{PO}_{4}$ solution containing initially $0008 \mathrm{M}$ Am(IV) $\left(85 \%{ }^{243} \mathrm{Am}\right), 27 \mathrm{hr}$ are required for self reduction of half the americium

\section{DISPROPORTIONATION}

\section{$A m(I V)$}

In aqueous solution, $\mathrm{Am}(\mathrm{IV})$ is stable only in concentrated $\mathrm{H}_{3} \mathrm{PO}_{4}, \mathrm{~K}_{4} \mathrm{P}_{2} \mathrm{O}_{7}$, and fluoride $\left(\mathrm{NH}_{4} \mathrm{~F}, \mathrm{KF}\right.$, etc) solutions (see pages 51 and 52) In other media, $\mathrm{Am}(\mathrm{IV})$ disproportionates to $\mathrm{Am}(\mathrm{III})$ and $\mathrm{Am}(\mathrm{V})$ in accordance with the large positive potential of the Am(IV)-Am(III) couple (see Table 3 3)

In $\mathrm{HNO}_{3}$ and $\mathrm{HClO}_{4}$ solutions, $\mathrm{Am}(\mathrm{IV})$ rapidly disproportionates according to the reaction $^{32}$

$$
2 \mathrm{Am}(\mathrm{IV}) \rightarrow \mathrm{Am}(\mathrm{III})+\mathrm{Am}(\mathrm{V})
$$




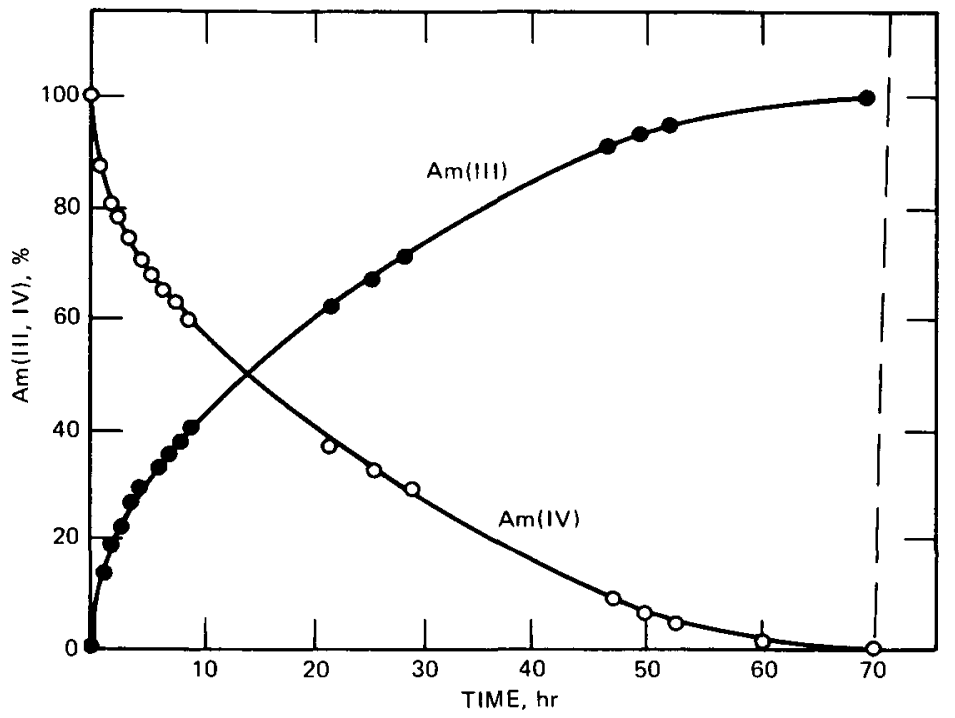

Fig. 3.2 Kinetics of the self-reduction of Am(IV) in $12 M \mathrm{H}_{3} \mathrm{PO}_{4}$. [From B. F. Myasoedov, V. M. Mikhailov, I. A. Lebedev, O. E. Koiro, and V. Ya. Frenkel, Preparation and Stability of Am(IV) and $\mathrm{Am}(\mathrm{V})$ in Phosphoric Acid Solutions, Radiochemical and Radioanalytical Letters, 14: 17 (1973).]

Assuming a reaction second order in Am(IV), Penneman, Coleman, and Keenan ${ }^{32}$ estimated $\mathrm{k}_{1}$ in the equation

$$
-\mathrm{d}[\mathrm{Am}(\mathrm{IV})] / \mathrm{dt}=\mathrm{k}_{1}[\mathrm{Am}(\mathrm{IV})]^{2}
$$

to be $>3.7 \times 10^{-4}$ liter $\mathrm{mol}^{-1} \mathrm{hr}^{-1}$ in $0.05 \mathrm{M} \mathrm{HNO}_{3}$ at $0^{\circ} \mathrm{C}$.

Conversely, dissolution of $\mathrm{Am}(\mathrm{OH})_{4}$ in $0.05 \mathrm{M}$ to $2 \mathrm{M} \mathrm{H}_{2} \mathrm{SO}_{4}$ solutions at either 0 or $25^{\circ} \mathrm{C}$ or of $\mathrm{AmO}_{2}$ in $1 M \mathrm{H}_{2} \mathrm{SO}_{4}$ yields solutions ${ }^{32,68}$ containing $\mathrm{Am}^{3+}$ and $\mathrm{AmO}_{2}^{2+}$. These results are explained on the basis of the following mechanism:

Stage 1, simple disproportionation:

$$
2 \mathrm{Am}(\mathrm{IV}) \rightarrow \mathrm{Am}(\mathrm{III})+\mathrm{Am}(\mathrm{V})
$$

Stage 2, redox reaction:

$$
\mathrm{Am}^{4+}+\mathrm{AmO}_{2}^{+} \rightarrow \mathrm{AmO}_{2}^{2+}+\mathrm{Am}^{3+}
$$

In support of this postulated mechanism, the proportion of $\mathrm{AmO}_{2}^{2+}$ increases with increasing $\mathrm{SO}_{4}^{2-}$ and $\mathrm{HSO}_{4}^{-}$concentrations at constant $\mathrm{H}^{+}$concentration. This means that $\mathrm{SO}_{4}^{2-}$ (or $\mathrm{HSO}_{4}^{-}$) catalyzes the redox reaction since this step is not observed in $\mathrm{HNO}_{3}$ or $\mathrm{HClO}_{4}$ media. 
Significantly, the average oxidation number of americium remains IV when $\mathrm{Am}(\mathrm{OH})_{4}$ is dissolved in either $\mathrm{HClO}_{4}, \mathrm{HNO}_{3}$, or $\mathrm{H}_{2} \mathrm{SO}_{4}$ media ${ }^{32}$ This result is somewhat surprising since Zaitsev et al $^{68}$ claim that the reduction of $\mathrm{Am}^{4+}$ by water 1s of increasing importance when $\mathrm{AmO}_{2}$ is dissolved in $>1 M \mathrm{H}_{2} \mathrm{SO}_{4}$, e g, 27\% reduction in $2 \mathrm{M} \mathrm{H}_{2} \mathrm{SO}_{4}$ and $64 \%$ in $6 \mathrm{M} \mathrm{H}_{2} \mathrm{SO}_{4}$

$\operatorname{Am}(\mathrm{V})$

Early studies of the disproportionation of $\mathrm{Am}(\mathrm{V}) \mathrm{in}_{\mathrm{HClO}}$ (Refs $46,63,69,72$ ), $\mathrm{H}_{2} \mathrm{SO}_{4}(\operatorname{Ref} 70 \mathrm{a}), \mathrm{HNO}_{3}$ (Ref 70a), and $\mathrm{HCl}$ (Ref 65) solutions were all made with ${ }^{241} \mathrm{Am}$ Results of these studies were greatly obscured by effects produced by alpha decay of the ${ }^{241}$ Am isotope which, in most cases, led to autoreduction of Am(VI) to $A m(V)$ at a rate which was approximately equal to that of the disproportionation This complicating effect resulted, as Coleman ${ }^{67}$ has pointed out, in general disagreement regarding both the stoichiometry and kinetics of the disproportionation reaction Thus Stephanou, Asprey and Penneman ${ }^{69}$ and, later, Hall and Markin ${ }^{63}$ concluded that the reaction $2 \mathrm{Am}(\mathrm{V}) \rightarrow \mathrm{Am}(\mathrm{VI})+\mathrm{Am}(\mathrm{IV})$ is followed by immediate reduction of $\mathrm{Am}(\mathrm{IV})$ by water, so that the apparent reaction is $2 \mathrm{Am}(\mathrm{V}) \rightarrow \mathrm{Am}(\mathrm{VI})+$ Am(III) Conversely, Gunn and Cunningham ${ }^{46}$ suggested that the storchiometry is $3 \mathrm{Am}(\mathrm{V}) \rightarrow 2 \mathrm{Am}(\mathrm{VI})+\mathrm{Am}(\mathrm{III})$, during which the average oxidation number of the americium is conserved Zaitsev et al ${ }^{70}$ a supported this latter contention

The most recent and definitive study of the kinetics of the disproportionation of $\mathrm{Am}(\mathrm{V})$ has been made by Coleman ${ }^{67}$ using the 1 sotope ${ }^{243} \mathrm{Am}$ to eliminate radiolytic complications Coleman investigated disproportionation of $\mathrm{Am}(\mathrm{V})$ in $3 \mathrm{M}$ to $8 M \mathrm{HClO}_{4}$ at $25^{\circ} \mathrm{C}$, in $1 M$ to $2 M \mathrm{HClO}_{4}$ at $757^{\circ} \mathrm{C}$, and in about $2 \mathrm{M} \mathrm{HCl}, \mathrm{H}_{2} \mathrm{SO}_{4}$, and $\mathrm{HNO}_{3}$ solutions at $757^{\circ} \mathrm{C} \mathrm{His} \mathrm{data} \mathrm{for} \mathrm{disproportionation} \mathrm{in} 6 M \mathrm{HClO}_{4}$ at $25^{\circ} \mathrm{C}$ are shown in Fig 33

In confirmation of the earlier claims of Gunn and Cunningham ${ }^{46}$ and of Zaitsev et al , ${ }^{70 a}$ Coleman ${ }^{67}$ finds that the stoichiometry of the disproportionation reaction in all media but $\mathrm{HCl}$ corresponds to

$$
3 \mathrm{Am}(\mathrm{V}) \rightarrow 2 \mathrm{Am}(\mathrm{VI})+\mathrm{Am}(\mathrm{III})
$$

In $\mathrm{HCl}$ no $\mathrm{Am}(\mathrm{VI})$ is detected, since $\mathrm{Am}(\mathrm{VI})$ is rapidly reduced by $\mathrm{Cl}$ in acid media

According to Coleman, ${ }^{67}$ the net disproportionation reaction is

$$
3 \mathrm{AmO}_{2}^{+}+4 \mathrm{H}^{+} \rightarrow 2 \mathrm{AmO}_{2}^{2+}+\mathrm{Am}^{3+}+2 \mathrm{H}_{2} \mathrm{O}
$$

At $757^{\circ} \mathrm{C}$ in $\mathrm{LiClO}_{4}-097$ to $190 M \mathrm{HClO}_{4}(\mu=20 M)$ solutions, the second order rate constant depends on $\left[\mathrm{H}^{+}\right]^{2}$ Coleman $^{67}$ and Newton ${ }^{70 \mathrm{~b}}$ note that this dependence suggests that two activated complexes are involved, one formed from two $\mathrm{AmO}_{2}^{+}$and two $\mathrm{H}^{+}$and the other from two $\mathrm{AmO}_{2}^{+}$and three $\mathrm{H}^{+}$Assuming, as Coleman did, these activated complexes are involved in parallel rate-determining steps, the rate law is given by 


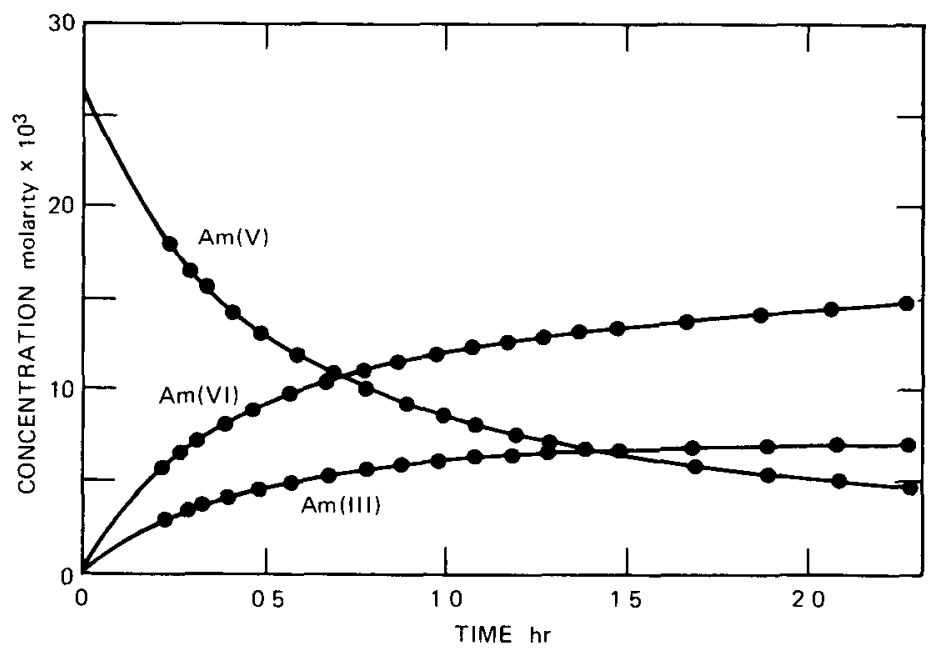

Fig. 3.3 Disproportionation of $\mathrm{Am}(\mathrm{V})$ in $6 \mathrm{M} \mathrm{HClO}_{4}$ at $25^{\circ} \mathrm{C}$ [From J S Coleman, The Kinetics of the Disproportionation of Americuum(V) Inorganic Chemistry 253 (1963)]

$$
\frac{\mathrm{d}[\mathrm{Am}(\mathrm{V})]}{\mathrm{dt}}=\mathrm{k}_{2}\left[\mathrm{AmO}_{2}^{+}\right]^{2}\left[\mathrm{H}^{+}\right]^{2}+\mathrm{k}_{3}\left[\mathrm{AmO}_{2}^{+}\right]^{2}\left[\mathrm{H}^{+}\right]^{3}
$$

with $\mathrm{k}_{2}=(694 \pm 101) \times 10^{-4} M^{-3} \sec ^{-1}$ and $\mathrm{k}_{3}=(463 \pm 071) \times 10^{4} M^{-1} \sec ^{-1}$

Newton" $70 \mathrm{~b}$ states, however "Despite the fact that the rate law above is very satisfactory, an ambiguity in interpretation remains If the same two activated complexes are formed consecutively, rather than in parallel steps, the rate law is

$$
\frac{-\mathrm{d}[\mathrm{Am}(\mathrm{V})]}{\mathrm{dt}}=\left[\mathrm{AmO}_{2}^{+}\right]\left(\frac{1}{\mathrm{k}_{2}^{\prime}\left[\mathrm{H}^{+}\right]^{2}}+\frac{1}{\mathrm{k}_{3}^{\prime}\left[\mathrm{H}^{+}\right]^{3}}\right)^{-1}
$$

This equation fits the experimental results just as well as the previous one Values for $\mathrm{k}_{2}^{\prime}$ and $\mathrm{k}_{3}^{\prime}$ are $(257 \pm 036) \times 10^{-3} M^{-4} \mathrm{sec}^{-1}$ and $(206 \pm 033) \times 10^{-3} M^{-4} \mathrm{sec}^{-1}$, respectively These values reproduce the data with a root mean square deviation of $32 \%$ and a maximum deviation of $66 \%$ In order to distınguish between the two rate laws, measurements would have to be extended at least down to $07 M \mathrm{HClO}_{4}$ where the two calculated values for the apparent second-order rate constants would differ by $10 \% "$

Using, in part, temperature-dependence data obtained by Coleman, Newton estimated thermodynamic quantities of activation for the disproportionation of Am(V) Results of his calculations are given in Table $34 \mathrm{a}$

Coleman also notes that at $757^{\circ} \mathrm{C}$ the disproportionation rates in $2 M \mathrm{HNO}_{3}, \mathrm{HCl}$, and $\mathrm{H}_{2} \mathrm{SO}_{4}$ are, respectively, 40,46 , and 24 times as great as that in $2 \mathrm{M} \mathrm{HClO}_{4}$, 
Table 3.4a

NET ACTIVATION PROCESSES AND THERMODYNAMIC QUANTITIES FOR THE DISPROPORTIONATION OF Am(V) ${ }^{\mathrm{a}}$

\begin{tabular}{ccrc}
\hline Net activation process & $\begin{array}{c}\Delta \mathrm{G}^{*}, \\
\text { kcal mol }\end{array}$ & $\begin{array}{c}\Delta \mathrm{H}^{*}, \\
\text { kcal mol }{ }^{1}\end{array}$ & $\begin{array}{c}\Delta \mathrm{S}^{*}, \\
\text { cal mol }^{1} \text { deg }^{1}\end{array}$ \\
\hline $2 \mathrm{AmO}_{2}^{+}+2 \mathrm{H}^{+}=\left[{ }^{*}\right]^{4+}$ & 2617 & $154+03$ & $31+1$ \\
$2 \mathrm{AmO}_{2}^{+}+3 \mathrm{H}^{+}-\left[{ }^{*}\right]^{5^{+}}$ & 2681 & $94+05$ & $-50+12$ \\
\hline
\end{tabular}

${ }^{a}$ Adapted from $T$ W Newton The Kinetics of the Oxidation-Reduction Reactions of Uranıum, Neptunium, Plutonium, and Americium in Aqueous Solutions, USAEC Report TID-26506, 1974

whereas at $\sim 25^{\circ} \mathrm{C}$ the reaction rate increased 450 times in going from $3 M$ to $8 M$ $\mathrm{HClO}_{4}$

Coleman also observed the reaction

$$
\mathrm{Am}^{3+}+2 \mathrm{AmO}_{2}^{2+}+2 \mathrm{H}_{2} \mathrm{O} \rightarrow 3 \mathrm{AmO}_{2}^{+}+4 \mathrm{H}^{+}
$$

the reverse of the disproportionation reaction, on addition of $\mathrm{Am}$ (III)-Am(VI) mixtures to $\mathrm{Al}\left(\mathrm{ClO}_{4}\right)_{3}$ buffer at $\mathrm{pH} 4$ and on neutralization of $\mathrm{Am}(\mathrm{III})-\mathrm{Am}(\mathrm{VI})$ mixtures with $\mathrm{NaHCO}_{3}$ Studies of the kinetics of Eq 322 have not been made

\section{KINETICS OF OXIDATION-REDUCTION REACTIONS}

A long-neglected area of americium chemistry has been the determination of the rate laws and mechanism of the various oxidation-reduction reactions of americium 1ons in aqueous solution Several recent papers by Japanese and Russian workers suggest, however, that this situation may be changing The following paragraphs summanze data for the few reactions that have been studied in detall and supplement information presented in earlier review papers by Hindman, ${ }^{71}$ by Newton and Baker, ${ }^{72}$ and by Gourisse ${ }^{73}$ An important up-to-date reference is the ERDA Critical Review by Newton $70 \mathrm{~b}$

\section{Peroxydisulfate Oxıdation of Am(III) in Acid Media}

Japanese workers ${ }^{74-76}$ have studied kinetics of oxidation of Am(III) to Am(VI) by $\mathrm{S}_{2} \mathrm{O}_{8}^{2-}$ ion, in both the presence and absence of $\mathrm{Ag}^{+}$ion, in $006 M$ to $04 M \mathrm{HNO}_{3}$ solutions at 40 to $70^{\circ} \mathrm{C}$ Kinetics of this reaction, in the absence of $\mathrm{Ag}^{+}$ion, in $009 \mathrm{M}$ to $06 \mathrm{MHNO}_{3}$ at 456 to $690^{\circ} \mathrm{C}$ have also been investigated by Russian scientists ${ }^{77}$ The general pattern of the oxidation reaction (Fig 34 ) involves (1) an induction 


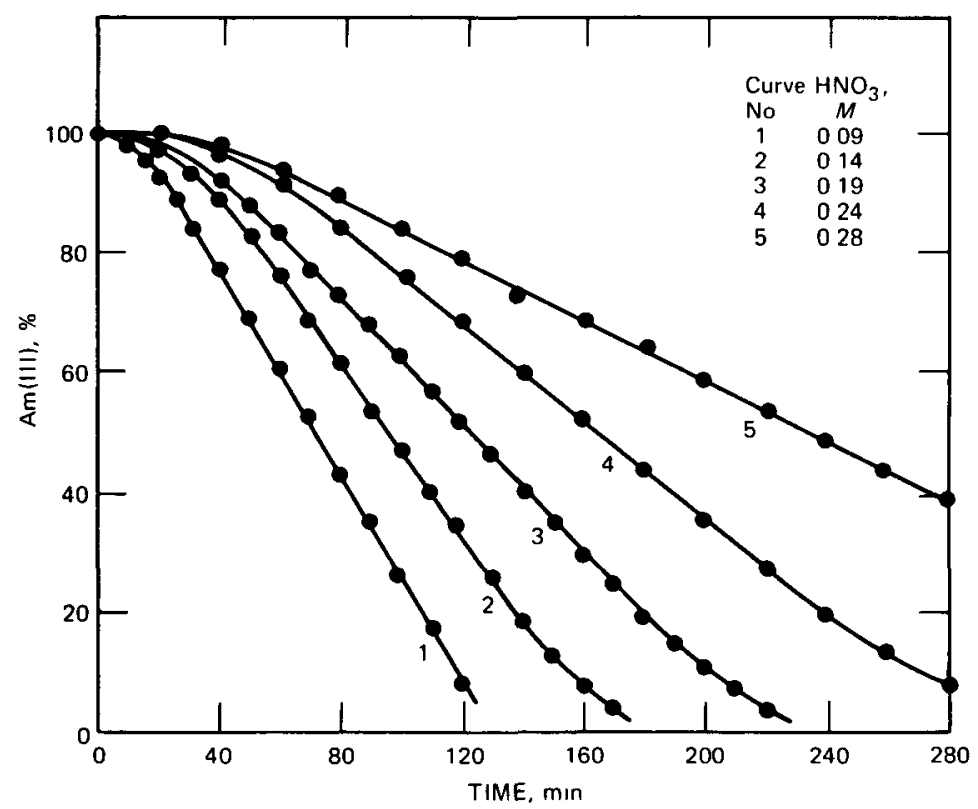

Fig. 3.4 Kinetics of oxidation of Am(III) by peroxydisulfate $\left(50.6^{\circ} \mathrm{C},\left[\mathrm{S}_{2} \mathrm{O}_{8}^{2-}\right]_{0}=0.40 M\right)$. [From V. A. Ermakov, A. G. Rykov, G. A. Timofeev, and G. N. Yakovlev, Investigation of the Kinetics and Redox Reactions of the Actınide Elements. XX. Kinetics and Mechanısms of the Interaction of Amencium(III) and (V) with Peroxydisulfate Ions in Nitric Acid Solution, Radiokhimiya, 13: 826 (1971) through Soviet Radiochemistry (English Translation), 13: 851 (1971).J

period; (2) a linear region of constant rate; and (3) a region of gradually decreasing rate, particularly at higher $\mathrm{HNO}_{3}$ concentrations. Reaction rates are dependent on temperature and on the concentrations of $\mathrm{HNO}_{3}, \mathrm{~S}_{2} \mathrm{O}_{8}^{2-}$, and, when present, $\mathrm{Ag}^{+}$. Newton ${ }^{70 b}$ states that the stoichiometry of the oxidation reaction is

$$
3 / 2 \mathrm{~S}_{2} \mathrm{O}_{8}^{2-}+\mathrm{Am}^{3+}+2 \mathrm{H}_{2} \mathrm{O} \rightarrow 3 \mathrm{SO}_{4}^{2-}+\mathrm{AmO}_{2}^{+}+4 \mathrm{H}^{+}
$$

Both the Japanese and Russian workers concur that the oxidizing agent is not the $\mathrm{S}_{2} \mathrm{O}_{8}^{2-}$ ion itself but secondary products (e.g., $\mathrm{SO}_{4}^{-}, \mathrm{OH}$, and $\mathrm{HS}_{2} \mathrm{O}_{8}^{-}$) resulting from its thermal decomposition.

Using micromolar concentrations of ${ }^{241} \mathrm{Am}(\mathrm{III})$, Ohyoshi, Jyo, and Shinohara ${ }^{76}$ found the oxidation reaction to be first order with respect to both $\mathrm{Am}^{3+}$ and $\mathrm{S}_{2} \mathrm{O}_{8}^{2-}$ concentrations and to follow the rate expression

$$
\frac{-\mathrm{d}[\mathrm{Am}(\mathrm{III})]}{\mathrm{dt}}=\mathrm{K}_{\mathrm{h}}\left(\mathrm{k}_{1}+\mathrm{k}_{2}\left[\mathrm{Ag}^{+}\right]\right)\left[\mathrm{S}_{2} \mathrm{O}_{8}^{2-}\right][\mathrm{Am}(\mathrm{III})] \cdot 1 /\left[\mathrm{H}^{+}\right]
$$


where $\mathrm{K}_{\mathrm{h}}$ is the dissociation constant of $\mathrm{H}_{2} \mathrm{~S}_{2} \mathrm{O}_{8}^{-}$and $\mathrm{k}_{1}$ and $\mathrm{k}_{2}$ refer to the silver ion uncatalyzed and catalyzed paths, respectively (Some values for $k_{1}$ and $k_{2}$ are listed in Table 35 ) The energies of activation are $333 \mathrm{kcal} \mathrm{mol}^{-1}$ for $\mathrm{k}_{1}$ and $174 \mathrm{kcal} \mathrm{mor}^{-1}$ for $k_{2}$ This activation energy for $k_{1}$ was recalculated by Newton ${ }^{70 b}$ from $k$ vs $T$ data in the original Japanese paper Newton notes that the value of $286 \mathrm{kcal} \mathrm{mol}^{1}$ reported by Ohyoshi, Jyo, and Shinohara ${ }^{76}$ for the $k_{1}$ path is clearly in error

Table 3.5

RATE CONSTANTS FOR PEROXYDISULFATE

OXIDATION OF Am(III)

\begin{tabular}{|c|c|c|}
\hline Temp., ${ }^{\circ} \mathrm{C}$ & $\begin{array}{c}\mathrm{k}_{2} \text {, 专 } \\
M^{-2} \mathrm{~mm}^{-1}\end{array}$ & $\begin{array}{c}\mathrm{k}_{1}, \S \\
M^{-1} \min ^{-1}\end{array}$ \\
\hline 40 & 162 & 0013 \\
\hline 50 & 420 & 0093 \\
\hline 60 & 915 & 036 \\
\hline 70 & 1820 & 145 \\
\hline
\end{tabular}

† Subscript zero means initial concentration \$Silver-catalyzed path Eq 323

§Uncatalyzed path Eq 323

Conversely, Ermakov et al ${ }^{77}$ on the basis of studies with millımolar amounts of ${ }^{243} \mathrm{Am}$ (III), claim that the rate of oxidation of $\mathrm{Am}(\mathrm{III})$ (in the absence of $\mathrm{Ag}^{+}$) in the linear portion of the kinetic curves does not depend on the Am(III) concentration and is given by

$$
\begin{aligned}
\frac{-\mathrm{d}[\mathrm{Am}(\mathrm{III})]}{\mathrm{dt}} & =\left(\mathrm{a}-\mathrm{b}\left[\mathrm{H}^{+}\right]\right)\left[\mathrm{S}_{2} \mathrm{O}_{8}^{2-}\right][\mathrm{Am}(\mathrm{III})]^{0} \\
& =\frac{2}{3}\left(\mathrm{k}_{1}-\frac{\mathrm{k}_{4}\left[\mathrm{H}^{+}\right]}{1+\mathrm{x}}\right)\left[\mathrm{S}_{2} \mathrm{O}_{8}^{2-}\right]_{0}=\mathrm{k}_{\mathrm{III}}
\end{aligned}
$$

At $506^{\circ} \mathrm{C}, \mathrm{a}=49 \times 10^{-5} \mathrm{~min}^{-1}$ and $\mathrm{b}=09 \times 10^{-4} M^{-1} \mathrm{~min}^{-1}$ In $\mathrm{Eq} 324,\left[\mathrm{~S}_{2} \mathrm{O}_{8}^{2-}\right]_{0}$ is the initial concentration of the peroxydisulfate ion, $x=k_{5} / k_{6}\left[H_{2} \mathrm{O}\right]$, and $k_{1}$, $\mathrm{k}_{4}-\mathrm{k}_{6}$ are rate constants for the following reactions

$$
\begin{gathered}
\mathrm{S}_{2} \mathrm{O}_{8}^{2-} \stackrel{\mathrm{k}_{1}}{\longrightarrow} 2 \mathrm{SO}_{4}^{-} \\
\mathrm{S}_{2} \mathrm{O}_{8}^{2-}+\mathrm{H}^{+} \stackrel{\mathrm{k}_{4}}{\longrightarrow} \mathrm{HSO}_{4}^{-}+\mathrm{SO}_{4}^{-} \\
\mathrm{SO}_{4}^{-} \stackrel{\mathrm{k}_{5}}{\longrightarrow} \mathrm{SO}_{3}+\mathrm{O} \\
\mathrm{SO}_{4}^{+}+\mathrm{H}_{2} \mathrm{O} \stackrel{\mathrm{k}_{6}}{\longrightarrow} \mathrm{H}_{2} \mathrm{O}_{2}+\mathrm{SO}_{3}
\end{gathered}
$$




\section{Peroxydisulfate Oxidation of $\mathrm{Am}(\mathrm{V})$ in $\mathrm{HNO}_{3}$}

Ermakov et al ${ }^{77}$ have also investigated the kınetıcs of the oxidation of $\mathrm{Am}(\mathrm{V})$ by $\mathrm{S}_{2} \mathrm{O}_{8}^{2-}$ ion in 009 to $06 \mathrm{M} \mathrm{HNO}_{3}$ media at 456 to $60^{\circ} \mathrm{C}$ According to Newton, ${ }^{70 b}$ the stoichiometry of this reaction is

$$
1 / 2 \mathrm{~S}_{2} \mathrm{O}_{8}^{2-}+\mathrm{AmO}_{2}^{+} \rightarrow \mathrm{SO}_{4}^{2-}+\mathrm{AmO}_{2}^{2+}
$$

Ermakov and his coworkers account for their results on the basis of the rate law

$$
\begin{aligned}
\frac{-\mathrm{d}[\mathrm{Am}(\mathrm{V})]}{\mathrm{dt}} & =\left(\mathrm{a}^{\prime}-\mathrm{b}^{\prime}\left[\mathrm{H}^{+}\right]\right)\left[\mathrm{S}_{2} \mathrm{O}_{8}^{2-}\right][\mathrm{Am}(\mathrm{V})]^{0} \\
& =2\left(\mathrm{k}_{1} \quad \frac{\mathrm{k}_{4}\left[\mathrm{H}^{+}\right]}{1+\mathrm{x}}\right)\left[\mathrm{S}_{2} \mathrm{O}_{8}^{2}\right]_{0}=\mathrm{kV}_{\mathrm{V}}
\end{aligned}
$$

where $\mathrm{x}, \mathrm{k}_{1}, \mathrm{k}_{4}$, and $\left[\mathrm{S}_{2} \mathrm{O}_{8}^{2-}\right]_{0}$ are defined as for Eq 324 At $506^{\circ} \mathrm{C} \mathrm{a}^{\prime}=15 \times 10^{-5}$ $\mathrm{min}^{-1}$ and $\mathrm{b}^{\prime}=27 \times 10^{-4} \mathrm{M}^{-1} \mathrm{~min}^{-1}$

From Eqs 324 and 330 , it follows that the ratio $\mathrm{k}_{V} / \mathrm{k}_{1 I I}$ should equal 3 for similar conditions of acidity and temperature This has been confirmed by Ermakov et al 77

\section{Peroxydisulfate $\mathrm{Oxıdation} \mathrm{of} \mathrm{Am}(\mathrm{III})$ in $\mathrm{K}_{2} \mathrm{CO}_{3}$ Media}

Just as in acid media, the rate of oxidation of Am(III) by peroxydisulfate in $\mathrm{K}_{2} \mathrm{CO}_{3}$ solutions is determined by the rate of thermal decomposition of the $\mathrm{S}_{2} \mathrm{O}_{8}^{2-}$ ion In contrast to behavior in acid media, however, peroxydisulfate oxidation of $\mathrm{Am}(\mathrm{III})$ in carbonate solutions proceeds through the intermediate formation of Am(V) These conclusions were established by Ermakov et al ${ }^{78}$ who studied oxidation of

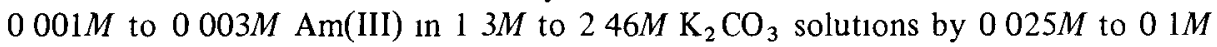
$\mathrm{S}_{2} \mathrm{O}_{8}^{2-}$ at temperatures in the range 58 to $83^{\circ} \mathrm{C}$ Under such conditions the rate of oxidation of $\mathrm{Am}(\mathrm{III})$ to $\mathrm{Am}(\mathrm{V})$ is independent of the total $\mathrm{Am}$ and $\mathrm{K}_{2} \mathrm{CO}_{3}$ concentrations and equals the rate of decomposition of $\mathrm{S}_{2} \mathrm{O}_{8}^{2-}$ ions The rate of oxidation of $\mathrm{Am}(\mathrm{V})$ to $\mathrm{Am}(\mathrm{VI})$ is directly proportional to both the total americium concentration and the $\mathrm{S}_{2} \mathrm{O}_{8}^{2-}$ concentration and is inversely proportional to the $\mathrm{K}_{2} \mathrm{CO}_{3}$ concentration

The effective activation energy of $\mathrm{S}_{2} \mathrm{O}_{8}^{2-}$ oxidation of $\mathrm{Am}(\mathrm{III})$ to $\mathrm{Am}(\mathrm{V})$ in $\mathrm{K}_{2} \mathrm{CO}_{3}$ solutions is about $339 \mathrm{kcal} \mathrm{mo \Gamma}^{1}$ which 1 s close to the activation energy (33 5 $\mathrm{kcal} \mathrm{mo \Gamma} \Gamma^{1}$ ) of the thermal decomposition of $\mathrm{S}_{2} \mathrm{O}_{8}^{2-}$ ions according to the reaction $\mathrm{S}_{2} \mathrm{O}_{8}^{2-} \rightarrow 2 \mathrm{SO}_{4}^{-}$

\section{Reduction of Am(VI) in Acıd Peroxydisulfate Solutions}

In high acid $\left(\geqslant 1 M \mathrm{HNO}_{3}\right)$ solutions at 50 to $70^{\circ} \mathrm{C}$, thermal decomposition products of the $\mathrm{S}_{2} \mathrm{O}_{8}^{2-}$ ion reduce $\mathrm{Am}(\mathrm{VI})$ to $\mathrm{Am}(\mathrm{V})$ For this reduction, Rykov et al ${ }^{79 a}$ propose the rate law 


$$
\frac{-\mathrm{d}[\mathrm{Am}(\mathrm{VI})]}{\mathrm{dt}}=\mathrm{k}_{\mathrm{VI}}\left[\mathrm{S}_{2} \mathrm{O}_{8}^{2-}\right]_{0}=2\left(\frac{\mathrm{k}_{4}\left[\mathrm{H}^{+}\right]}{1+\mathrm{x}}-\mathrm{k}_{1}\right)
$$

where $\left[\mathrm{S}_{2} \mathrm{O}_{8}^{2-}\right]_{0}$ is the initial concentration of the peroxydisulfate ion, $\mathrm{x}=$ $\mathrm{k}_{5} / \mathrm{k}_{6}\left[\mathrm{H}_{2} \mathrm{O}\right]$ and $\mathrm{k}_{1}, \mathrm{k}_{4}, \mathrm{k}_{5}$, and $\mathrm{k}_{6}$ are the rate constants for Eqs. 3.25, 3.26, 3.27, and 3.28 , respectively.

The results of Rykov et al. ${ }^{79 a}$ thus indicate that the mechanism of reduction of $\mathrm{Am}(\mathrm{VI})$ in the presence of $\mathrm{S}_{2} \mathrm{O}_{8}^{2-}$ ions is identical with that proposed (see page 67) for oxidation of $A m(V)$. The direction of the process-oxidation of $A m(V)$ or reduction of $A m(V I)-1 S$ determined by the ratio of the contributions of the primary processes of thermal decomposition of $\mathrm{S}_{2} \mathrm{O}_{8}^{2-}$ ions. At low acidities where Eq. 3.25 predominates, oxidation of $\mathrm{Am}(\mathrm{V})$ predominates. At high acidities, where the catalytic pathway of decomposition (Eq. 3.26) dominates, Am(VI) is reduced. The hydrogenion concentrations where the reaction paths change are temperature dependent.

\section{Reduction of $A m(V I)$ by Hydrogen Peroxide}

Using ${ }^{243} \mathrm{Am}$ in $\mathrm{LiClO}_{4}-\mathrm{HClO}_{4}$ media, Woods, Cain, and Sullivan ${ }^{79 \mathrm{~b}}$ studied kinetics of the reaction

$$
2 \mathrm{AmO}_{2}^{2+}+\mathrm{H}_{2} \mathrm{O}_{2} \rightarrow 2 \mathrm{AmO}_{2}^{+}+2 \mathrm{H}^{+}+\mathrm{O}_{2}
$$

These workers report that the empirical form of the rate law for Eq. 3.32 at $25^{\circ} \mathrm{C}$ and $\mu=1.00 \mathrm{M}$ is

$$
\frac{-\mathrm{d}\left[\mathrm{AmO}_{2}^{2+}\right]}{\mathrm{dt}}=\mathrm{k}\left[\mathrm{AmO}_{2}^{2+}\right]\left[\mathrm{H}_{2} \mathrm{O}_{2}\right]\left[\mathrm{H}^{+}\right]^{-0.12}
$$

Over the range of hydrogen-ion concentrations from $0.98 M$ to $0.1 M, \log$ $\mathrm{k}=4.952 \pm 0.007-0.12 \pm 0.01 \log \left[\mathrm{H}^{+}\right]$.

\section{Reduction of Am(VI) by Other Reductants*}

Shilov, Nikolaevskii, and $\mathrm{Krot}^{79 \mathrm{C}}$ have reported results of qualitative spectrophotometric studies of the reaction of $2 \times 10^{-4} M$ to $10^{3} M^{241} \mathrm{Am}$ (VI) in dilute $\mathrm{HNO}_{3}$ solutions with various reducing agents. According to their data (Table 3.5a),

*Woods and Sullivan [Inorganic Chemistry, 13: 2774 (1974)] studied the reaction between $\mathrm{AmO}_{2}^{2+}$ and $\mathrm{NpO}_{2}^{+}$in $1 \mathrm{M}(\mathrm{H}, \mathrm{Li}) \mathrm{ClO}_{4}$. The rate law is:

$$
\frac{-\mathrm{d}[\mathrm{Am}(\mathrm{VI})]}{\mathrm{dt}}=\mathrm{k}[\mathrm{Am}(\mathrm{VI})][\mathrm{Np}(\mathrm{V})]
$$

At $25^{\circ} \mathrm{C}, \mathrm{k}$ is $(2.45 \pm 0.4) \times 10^{4} M^{-1} \mathrm{sec}^{-1}$; for this reaction, $\Delta \mathrm{H}^{*}=6.66 \pm 0.08 \mathrm{kcal} \mathrm{mol}^{-1}$ and $\Delta \mathrm{S}^{*}=-16.2 \pm 0.3 \mathrm{cal} \mathrm{mol}^{-1} \mathrm{deg}^{-1}$. 
Table 3.5a

REDUCTION OF Am(VI) BY SEVERAL REDUCING AGENTS*

$\left\{[\mathrm{Am}(\mathrm{VI})]_{0}=2 \times 10^{-4}-10^{3} ; 25^{\circ} \mathrm{C}\right\}$

\begin{tabular}{|c|c|c|c|c|c|}
\hline \multicolumn{2}{|c|}{ Reductant } & \multirow[b]{2}{*}{ Medıum } & \multirow[b]{2}{*}{ Reaction rate } & \multicolumn{2}{|c|}{ Final solution } \\
\hline Reagent & Concentration, $M$ & & & $\operatorname{Am}(\mathbf{V}), \%$ & $\operatorname{Am}(\mathrm{III}), \%$ \\
\hline \multirow[t]{3}{*}{ Oxalic acid } & 0022 & $05 \mathrm{M} \mathrm{HNO}_{3}$ & Very fast & 56 & 44 \\
\hline & 015 & $05 M \mathrm{HNO}_{3}$ & Very fast & 57 & 43 \\
\hline & 015 & $\mathrm{pH}=60$ & Very fast & 57 & 43 \\
\hline \multirow[t]{2}{*}{ Tar taric acid } & 00025 & $05 M \mathrm{HNO}_{3}$ & $\mathrm{t}_{1 / 2}=3 \mathrm{~min}$ & 64 & 36 \\
\hline & 00025 & $\mathrm{pH}=40$ & $\mathrm{t}_{1 / 2}=10 \mathrm{sec}$ & 63 & 37 \\
\hline Citric acid & 00025 & $05 \mathrm{M} \mathrm{HNO}_{3}$ & $\mathrm{t}_{1 / 2}=1 \mathrm{~min}$ & 76 & 24 \\
\hline $\mathrm{HCl}$ & 009 & $05 M \mathrm{HNO}_{3}$ & $\mathrm{t}_{1 / 2}=18 \mathrm{~min}$ & 100 & 0 \\
\hline $\mathrm{HCOOH}$ & 00025 & $\mathrm{pH}=40$ & $\mathrm{t}_{1 / 2}=10 \mathrm{~min}$ & 100 & 0 \\
\hline $\mathrm{HCHO}$ & 00024 & $01 M \mathrm{HNO}_{3}$ & $\mathrm{t}_{1 / 2}=2 \mathrm{~min}$ & 100 & 0 \\
\hline $\mathrm{Li}_{2} \mathrm{SO}_{3}$ & 001 & $01 M \mathrm{HNO}_{3}$ & Very fast & 100 & 0 \\
\hline $\mathrm{NH}_{2} \mathrm{OH}$ & 00025 & $01 M \mathrm{HNO}_{3}$ & Very fast & 100 & 0 \\
\hline $\mathrm{H}_{2} \mathrm{O}_{2}$ & 00025 & $01 M \mathrm{HNO}_{3}$ & Very fast & 100 & 0 \\
\hline $\mathrm{N}_{2} \mathrm{H}_{4}$ & 00025 & $01 M \mathrm{HNO}_{3}$ & Very fast & 100 & 0 \\
\hline
\end{tabular}

*From V P Shilov, V B Nikolaevskil, and N N Krot, Some Chardcteristics of the Reaction of Amencium(V) with Reducing Agents in Aqueous Solutions, Radiokhimiya, 15: 871 (1973) through Soviet Radiochemtstry (English Translation), 15: 881 (1973)

oxalic acid and other organic compounds commonly regarded as complexing agents reduce $A m(V I)$ rapidly to approximately equal mixtures of $A m(I I I)$ and $A m(V)$, whereas other reagents $\left(\mathrm{H}_{2} \mathrm{O}_{2}\right.$, etc.) reduce $A m(V I)$ initially only to $A m(V)$. Mechanisms and rate laws involved in reduction of $\mathrm{Am}(\mathrm{VI})$ and $\mathrm{Am}(\mathrm{V})$ by $\mathrm{H}_{2} \mathrm{O}_{2}$ are discussed on pages 68 and 69-70, respectively. Detalled studies of the kinetics of reduction of $\mathrm{Am}(\mathrm{VI})$ by other reducing agents listed in Table 3 5a have not been reported

\section{Reduction of $A m(V)$ by Hydrogen Peroxide}

From their studies of the reduction of $\mathrm{AmO}_{2}^{+}$to $\mathrm{Am}^{3+}$ by $\mathrm{H}_{2} \mathrm{O}_{2}$ in $0.1 M \mathrm{HClO}_{4}$, Zaitsev et al ${ }^{80}$ deduced the rate law

$$
\frac{-\mathrm{d}\left[\mathrm{AmO}_{2}^{+}\right]}{\mathrm{dt}}=\mathrm{k}\left[\mathrm{AmO}_{2}^{+}\right]\left[\mathrm{H}_{2} \mathrm{O}_{2}\right]
$$

where $\mathrm{k}=14.8 \pm 1.5,21.6 \pm 2.2$, and $30.3 \pm 3.0$ liters $\mathrm{moT}^{-1} \mathrm{hr}^{-1}$ at 25,30 , and $35^{\circ} \mathrm{C}$, respectively. The activation energy for the reduction reaction is thus $13.2 \mathrm{kcal} \mathrm{mol}^{-1}$.

The only other reported studies of the $\mathrm{Am}(\mathrm{III})-\mathrm{Am}(\mathrm{V})-\mathrm{H}_{2} \mathrm{O}_{2}-\mathrm{HClO}_{4}$ system have been made by Damien and Pages. ${ }^{81.82 \mathrm{a}}$ They report that the rate at which 
$\mathrm{AmO}_{2}^{+}$is reduced is inversely proportional to the $\mathrm{HClO}_{4}$ concentration and also is strongly dependent on the initial $\left[\mathrm{Am}^{3+}\right]_{0} /\left[\mathrm{AmO}_{2}^{+}\right]_{0}$ and $\left[\mathrm{H}_{2} \mathrm{O}_{2}\right]_{0} /\left[\mathrm{AmO}_{2}^{+}\right]_{0}$ concentration ratios In $02 \mathrm{M} \mathrm{HClO}_{4}$ at $26^{\circ} \mathrm{C}$, the rate data could be described satisfactorily by the relation ${ }^{81}$

$$
\frac{-\mathrm{d}\left[\mathrm{AmO}_{2}^{+}\right]}{\mathrm{dt}}=\frac{\mathrm{k}\left[\mathrm{AmO}_{2}^{+}\right]_{0}\left[\mathrm{H}_{2} \mathrm{O}_{2}\right]_{0}}{1+\mathrm{k}^{\prime}\left[\mathrm{Am}^{3+}\right]_{0} /\left[\mathrm{AmO}_{2}^{+}\right]_{0}}
$$

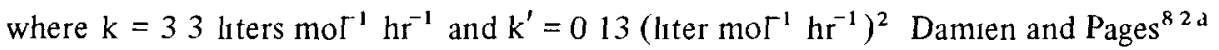
suggested that a more general rate law for this system is

$$
-\frac{\mathrm{d}\left[\mathrm{AmO}_{2}^{+}\right]}{\mathrm{dt}}=\mathrm{k}\left[\mathrm{AmO}_{2}^{+}\right]+\mathrm{k}^{\prime}\left[\mathrm{AmO}_{2}^{+}\right]^{2}
$$

where $k^{\prime}$ and $k$ are a function, respectively, of acidity and $\mathrm{H}_{2} \mathrm{O}_{2}$ concentration Damien and Pages did not attempt to determine these constants

\section{Reduction of $\mathrm{Am}(\mathrm{V})$ by $\mathrm{Np}$ (IV) in $\mathrm{HClO}_{4}$ Media}

Blokhin, Ermakov, and Rykov ${ }^{8 c}$ used a spectrophotometric procedure to study the kinetics of the $\mathrm{Np}(\mathrm{IV})-\mathrm{Am}(\mathrm{V})$ reaction in $023 \mathrm{M}$ to $197 \mathrm{M} \mathrm{HClO}_{4}$ at temperatures in the range 350 to $546^{\circ} \mathrm{C}$ Depending on the initial concentrations of $\mathrm{Np}$ (IV) and $\mathrm{Am}(\mathrm{V})$, the reaction products are either $\mathrm{Np}(\mathrm{V})$ and $\mathrm{Am}(\mathrm{III})$ or $\mathrm{Np}(\mathrm{VI})$ and $\mathrm{Am}(\mathrm{III})$ The reaction rate falls rapidly with increasing acidity Under the assumption of constant Am(IV) concentration, the kinetic data follow the rate law

$$
\frac{\mathrm{d}\left[\mathrm{Am}^{3+}\right]}{\mathrm{dt}}=\mathrm{k}_{1}^{\prime}\left[\mathrm{Np}^{4+}\right]\left[\mathrm{AmO}_{2}^{+}\right]+\mathrm{k}_{2}^{\prime}\left[\mathrm{NpO}_{2}^{+}\right]\left[\mathrm{AmO}_{2}^{+}\right]
$$

where $\mathrm{k}_{1}^{\prime}$ and $\mathrm{k}_{2}^{\prime}$ are, respectively, rate constants for Eqs 338 and 339

$$
\begin{gathered}
\mathrm{Np}^{4+}+\mathrm{AmO}_{2}^{+} \stackrel{\mathrm{k}_{1}^{\prime}}{\longrightarrow} \mathrm{NpO}_{2}^{+}+\mathrm{Am}^{4+} \\
\mathrm{NpO}_{2}^{+}+\mathrm{AmO}_{2}^{+} \stackrel{\mathrm{k}_{4}^{\prime}}{\longrightarrow} \mathrm{NpO}_{2}^{2+}+\mathrm{Am}^{4+}
\end{gathered}
$$

Values of $k_{1}^{\prime}$ and $k_{2}^{\prime}$ are given in Ref $82 c$ The authors of this reference also calculate the following standard thermodynamic activation parameters for $\mathrm{Eq} 337 \Delta \mathrm{H}^{*}=$ $30 \pm 1 \mathrm{kcal} \mathrm{mol}^{-1}, \Delta \mathrm{G}^{*}=207 \pm 10 \mathrm{kcal} \mathrm{mol}^{-1}$, and $\Delta \mathrm{S}^{*}=31 \pm 3 \mathrm{cal} \mathrm{mol}^{1} \mathrm{deg}^{-1}$

\section{Reduction of $\mathrm{Am}(\mathrm{V})$ by $\mathrm{Np}(\mathrm{V})$ in $\mathrm{HCIO}_{4}$ Medaa}

Rykov, Timofeev, and Chistyakov ${ }^{82 \mathrm{~d}}$ have determined spectrophotometrically the rate of the reaction

$$
2 \mathrm{NpO}_{2}^{+}+\mathrm{AmO}_{2}^{+}+4 \mathrm{H}^{+} \rightarrow 2 \mathrm{NpO}_{2}^{2+}+\mathrm{Am}^{3+}+2 \mathrm{H}_{2} \mathrm{O}
$$


Kinetic data were collected in perchlorate media $(\mu=20 M)$ at temperatures in the range 247 to $441^{\circ} \mathrm{C}$ According to these workers, reduction of $\mathrm{Am}(\mathrm{V})$ by $\mathrm{Np}(\mathrm{V})$ is an irreversible second-order reaction with a rate law given by

$$
\frac{-\mathrm{d}\left[\mathrm{AmO}_{2}^{+}\right]}{\mathrm{dt}}=-\frac{1}{2} \frac{\mathrm{d}\left[\mathrm{NpO}_{2}^{+}\right]}{\mathrm{dt}}=\mathrm{k}\left[\mathrm{NpO}_{2}^{+}\right]\left[\mathrm{AmO}_{2}^{+}\right]
$$

The rate of the reduction of $\mathrm{Am}(\mathrm{V})$ by $\mathrm{Np}(\mathrm{V})$ increases with acidity, at $247^{\circ} \mathrm{C}$ and $\left[\mathrm{H}^{+}\right]=053 M, \mathrm{k}=071 \mathrm{~mol}^{-1} \mathrm{~min}^{-1}$ whereas at $298^{\circ} \mathrm{C}$ and $\left[\mathrm{H}^{+}\right]=189 M, \mathrm{k}^{\prime}=610$ $\mathrm{mol}^{-1} \mathrm{~min}^{-1}$ Standard thermodynamic activation parameters calculated by Rykov, Timofeev, and Chistyakov ${ }^{8 \mathrm{~d}}$ for Eq 340 are $\Delta \mathrm{H}^{*}=152 \mathrm{kcal} \mathrm{mol}^{-1}, \Delta \mathrm{G}^{*}=200$ $\mathrm{kcal} \mathrm{mol}{ }^{-1}$, and $\Delta \mathrm{S}^{*}=-16 \mathrm{cal} \mathrm{mol}^{-1} \mathrm{deg}^{-1}$

\section{Reduction of $\mathrm{Am}(\mathrm{V})$ by $\mathrm{Np}(\mathrm{V})$ in $\mathrm{Na}_{2} \mathrm{CO}_{3}$ Meda}

Kinetics of the reduction of $\mathrm{Am}(\mathrm{V})$ by $\mathrm{Np}(\mathrm{V})$ in $\mathrm{Na}_{2} \mathrm{CO}_{3}$ solutions have been investigated spectrophotometrically by Chistyakov, Ermakov, and Rykov ${ }^{82 \mathrm{e}}$ The stoichiometry of the reduction reaction corresponds to the equation

$$
4 \mathrm{H}^{+}+\mathrm{AmO}_{2}^{+}+2 \mathrm{NpO}_{2}^{+} \rightarrow \mathrm{Am}^{3+}+2 \mathrm{NpO}_{2}^{2+}+2 \mathrm{H}_{2} \mathrm{O}
$$

Kinetics of this reaction were studied at 505 to $697^{\circ} \mathrm{C}$ in $045 M$ to $171 M \mathrm{Na}_{2} \mathrm{CO}_{3}$ solution containing $00013 M \mathrm{~Np}(\mathrm{~V})$ and $0000655 M^{243} \mathrm{Am}$ Under these conditions, kinetics of the $\mathrm{Am}(\mathrm{V})-\mathrm{Np}(\mathrm{V})$ reaction in $\mathrm{Na}_{2} \mathrm{CO}_{3}$ media follow the same rate law (Eq 341 ) as that followed in $\mathrm{HClO}_{4}$ media In $171 M \mathrm{Na}_{2} \mathrm{CO}_{3}$ at $64^{\circ} \mathrm{C}$, the rate constant, $\mathrm{k}$, is $150 \pm 15$ The effective activation energy of Eq 342 is independent of $\mathrm{Na}_{2} \mathrm{CO}_{3}$ concentration and is $145 \pm 10 \mathrm{kcal} \mathrm{mol}^{-1}$

\section{Reduction of $\mathrm{Am}(\mathrm{V})$ by $\mathrm{U}(\mathrm{IV})$ in $\mathrm{HClO}_{4}$ Media}

At 112 to $360^{\circ} \mathrm{C}$ in $051 M$ to $250 \mathrm{M} \mathrm{HClO}_{4}$, the reaction between $\mathrm{Am}(\mathrm{V})$ and $\mathrm{U}(\mathrm{IV})$ proceeds according to the reaction

$$
\mathrm{AmO}_{2}^{+}+\mathrm{U}^{4+} \rightarrow \mathrm{Am}^{3+}+\mathrm{UO}_{2}^{2+}
$$

Spectrophotometric measurements of Blokhin, Ermakov, and Rykov ${ }^{82 \mathrm{f}}$ show that the rate law for this reduction reaction is given by

$$
\frac{\mathrm{d}\left[\mathrm{Am}^{3+}\right]}{\mathrm{dt}}=\mathrm{k}\left[\mathrm{AmO}_{2}^{2+}\right]\left[\mathrm{U}^{4+}\right]
$$

In $20 \mathrm{M} \mathrm{HClO}_{4}$ at $195^{\circ} \mathrm{C}, \mathrm{k}=725 \pm 30$ Standard thermodynamic activation parameters for $\mathrm{Eq} 343$ are $\Delta \mathrm{H}^{*}=18 \pm 1 \mathrm{kcal} \mathrm{mol}^{-1}, \Delta \mathrm{G}^{*}=152 \pm 02 \mathrm{kcal} \mathrm{mol}^{-1}$, and $\Delta \mathrm{S}^{*}=9 \pm 3 \mathrm{cal} \mathrm{mol}^{-1} \mathrm{deg}^{-1}$ 


\section{Self-Reduction of $A m(V I)$ and $A m(V)$ in Acid Peroxydisulfate Solution}

Self-reduction of $A m(V I)$ and $A m(V)$,n various acid solutions is discussed on pages $\mathrm{xxx}$ to $\mathrm{xxx}$ Ermakov et al ${ }^{83}$ have now studied self-reduction of Am(VI) and $\mathrm{Am}(\mathrm{V})$ at $18^{\circ} \mathrm{C}$ in $01 \mathrm{M}$ to $02 \mathrm{M} \mathrm{HNO}_{3}$ solutions containing $010 \mathrm{M}$ to $04 \mathrm{M}$ $\left(\mathrm{NH}_{4}\right)_{2} \mathrm{~S}_{2} \mathrm{O}_{8}$ Alpha radiation doses ranged from $095 \times 10^{21}$ to $964 \times 10^{21} \mathrm{eV}$ liter ${ }^{-1} \mathrm{~min}^{-1}$ Under such conditions the rate of reduction of Am(VI) is independent of its concentration but is a function of dose rate and the concentration of $\mathrm{S}_{2} \mathrm{O}_{8}^{2-}$ ions No $A m(I I I)$ is observed until all the $A m(V I)$ is reduced to $A m(V)$ In the presence of $\mathrm{S}_{2} \mathrm{O}_{8}^{2-}$ ions, radiolytic reduction of $\mathrm{Am}(\mathrm{V})$ proceeds more slowly than that of $\mathrm{Am}(\mathrm{VI})$

\section{SOLUTION ABSORPTION SPECTRA}

\section{$A m(I I I)$}

A representative list of the various solutions in which the absorption spectra of the $\mathrm{Am}^{3+}$ in have been measured is compled in Table 36 Table 37 lists molar absorptivities at maximum absorption wavelengths for Am(III) in various media These data as well as similar results presented later for Am(IV), (V), and (VI) should be used with some caution, taking into account that the accuracy of the resolution of the narrower absorption peaks may depend on the resolving power of the instrument with

Table 3.6

ABSORPTION SPECTRUM OF AM(III)

\begin{tabular}{|c|c|c|}
\hline Media & References & $\begin{array}{r}\text { Typical } \\
\text { spectrum }\end{array}$ \\
\hline $\begin{array}{l}02 M-104 M \mathrm{HNO}_{3} \\
02 M-10 M \mathrm{HCl} \\
02 M-10 \mathrm{OM} \mathrm{H}_{2} \mathrm{SO}_{4} \\
01 M-05 M \mathrm{HClO}_{4} \mathrm{DClO}_{4} \\
4 M 137 \mathrm{M} \mathrm{LiCl}\end{array}$ & $\begin{array}{l}26,64,84 \\
64,65,85 \\
64,86 \\
2,27,48,64 \\
\quad 65,8791 \\
92\end{array}$ & $\begin{array}{l}\text { Fig } 35 \mathrm{a} \\
\text { Fig } 35 \mathrm{~b} \\
\text { Fig } 35 \mathrm{c}\end{array}$ \\
\hline 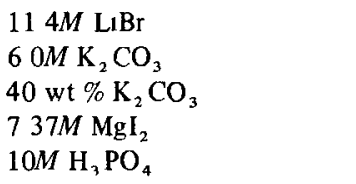 & $\begin{array}{l}84 \\
84 \\
26 \\
84 \\
18\end{array}$ & $\begin{array}{l}\text { Fig } 36 a \\
\text { F1g } 36 a\end{array}$ \\
\hline $\begin{array}{l}\text { Saturated } \mathrm{KF} \\
\text { Ethanolıc } \mathrm{HCl} \\
\text { Fused } \mathrm{LiNO}_{3}-\mathrm{KNO}_{3}\end{array}$ & $\begin{array}{l}93 \\
88,94,95 \\
96\end{array}$ & $\begin{array}{l}\text { Fig } 37 \mathrm{a} \\
\text { Fig } 37 \mathrm{~b} \\
\text { Fig } 37 \mathrm{c}\end{array}$ \\
\hline
\end{tabular}


Table 3.7

PROMINENT ABSORPTION BANDS OF AMERICIUM(III) IN VARIOUS SOLUTIONS

\begin{tabular}{|c|c|c|c|}
\hline $\begin{array}{l}\text { Absorption } \\
\text { maximum, } \\
\text { nm }\end{array}$ & $\begin{array}{c}\text { Molar } \\
\text { absorptivity, } \\
\text { liters } \mathrm{mol}^{-1} \mathrm{~cm}^{1}\end{array}$ & Media & Ref. \\
\hline 1302 & 02 & $05 \mathrm{M} \mathrm{DClO}_{4}$ & 89 \\
\hline 1050 & 77 & $05 \mathrm{M} \mathrm{DClO}_{4}$ & 89 \\
\hline 874 & 11 & $05 \mathrm{M} \mathrm{DClO}_{4}$ & 89 \\
\hline 818 & 440 & 40 wt $\% \mathrm{~K}_{2} \mathrm{CO}_{3}$ & 26 \\
\hline 815 & 619 & $10 M \mathrm{H}_{2} \mathrm{SO}_{4}$ & 64 \\
\hline 813 & 663 & $05 \mathrm{M} \mathrm{DClO}_{4}$ & 89 \\
\hline 811 & 644 & $01 M \mathrm{HClO}_{4}$ & 64 \\
\hline 811 & 430 & $10 M \mathrm{HNO}_{3}$ & 64 \\
\hline 811 & 410 & $1 M \mathrm{HNO}_{3}$ & 26 \\
\hline 510 & 1050 & $\begin{array}{l}\mathrm{LiNO}_{3}-\mathrm{KNO}_{3} \\
\text { eutectic }\end{array}$ & 96 \\
\hline 508 & 2700 & $40 \mathrm{wt} \% \mathrm{~K}_{2} \mathrm{CO}_{3}$ & 26 \\
\hline 5055 & 2600 & $1144 M \mathrm{LiBr}$ & 84 \\
\hline 505 & 700 & $137 M \mathrm{LICl}$ & 92 \\
\hline 505 & 1680 & $10 \mathrm{M} \mathrm{HNO}_{3}$ & 64 \\
\hline 503 & 3780 & $01 M \mathrm{HClO}_{4}$ & 64 \\
\hline 503 & 3790 & $12 \mathrm{MH}_{3} \mathrm{PO}_{4}$ & 18 \\
\hline 5012 & 1700 & Saturated $K F$ & 93 \\
\hline 377 & 186 & $01 M \mathrm{HClO}_{4}$ & 64 \\
\hline 360 & 155 & $01 M \mathrm{HClO}_{4}$ & 88 \\
\hline 335 & 129 & $01 M \mathrm{HClO}_{4}$ & 88 \\
\hline 235 & 27900 & $137 M \mathrm{LlCl}$ & 92 \\
\hline
\end{tabular}

which they were measured. In perchlorate media, major peaks in the absorption spectrum of $\mathrm{Am}^{3+}$ occur at 503 and $811 \mathrm{~nm}$. Shifts in the position of these peaks and/or changes in molar absorptivity which occur in other media are evidence for formation of various americium complexes.

Theoretical calculations of the electronic energy bands in the $\mathrm{Am}^{3+}$ ion have been performed by several investigators ${ }^{91}$ 97-100 $^{\text {Such calculations revealed }}{ }^{97,98}$ an unexpected ${ }^{7} \mathrm{~F}_{0} \leftrightarrow{ }^{5} \mathrm{D}_{1}$ transition at about $17,500 \mathrm{~cm}^{-1}$ which had not been observed previously Subsequently a weak band near the calculated energy level was observed in a concentrated americium solution. ${ }^{100}$ The observed intensity of this band is consistent with a weak electric dipole mechanism. ${ }^{99}$ The theoretical calculations also predict transitions between the ground ${ }^{7} \mathrm{~F}_{0}$ state and even $\mathrm{J}$-levels to be more intense than those to excited odd J-levels ${ }^{9198}$ The observed spectrum of $\mathrm{Am}^{3+}$ in $\mathrm{LINO}_{3}-\mathrm{KNO}_{3}$ eutectic is in good agreement with the latter prediction 


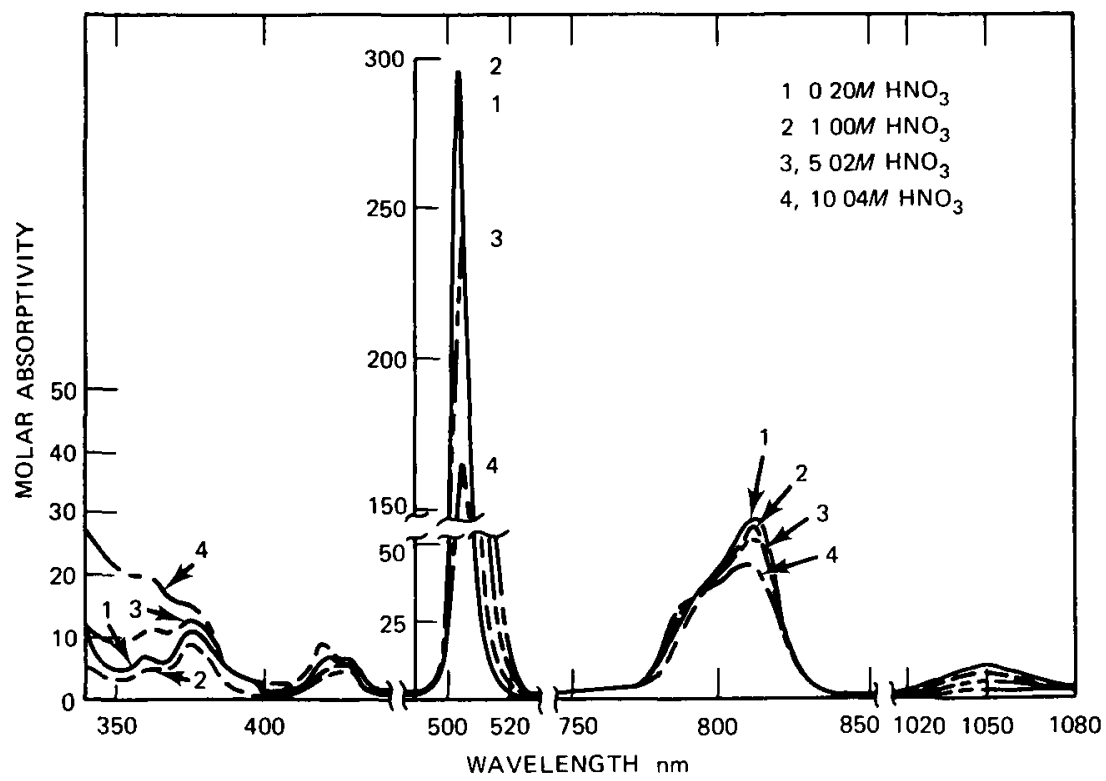

Fig. 3.5a Absorption spectrum of Am(III) in $\mathrm{HNO}_{3}$. (I rom G. N. Yakovlev and V N. Kosyakov, Spectrophotometric Studies of the Behavior of Amencium Ions in Solution, in Proceedings of the International Conference on the Peaceful Uses of Atomic Energy, Geneva, 1955, Vol. 7, p. 363, United Nations, New York, 1956 )

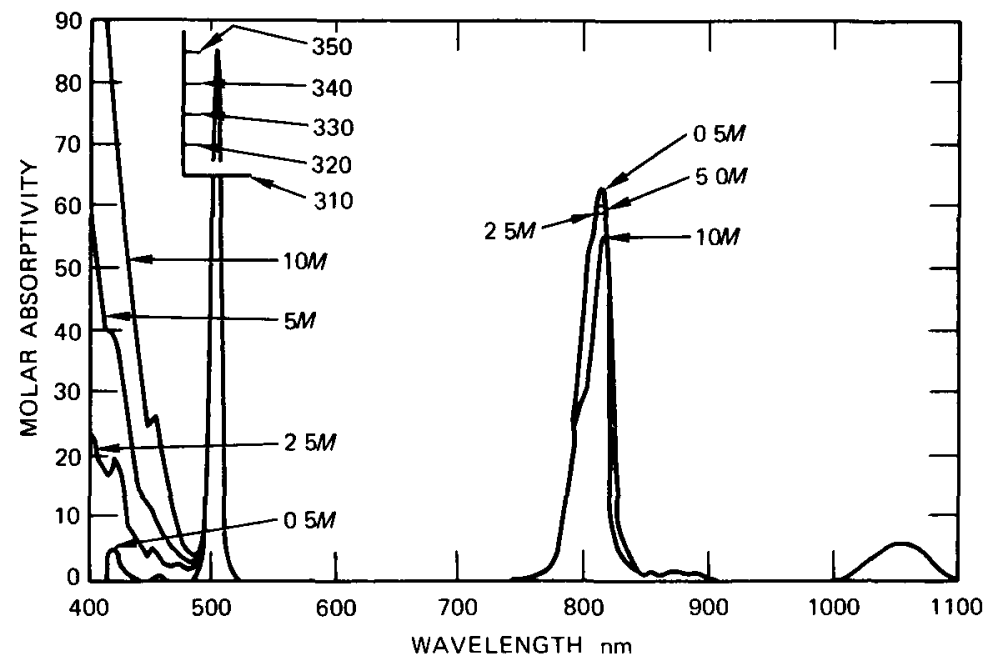

Fig. 3.5b Absorption spectrum of Am(III) in HCl [From G R Hall and P D Herniman, The Separation and Purification of Americium-241 and the Absorption Spectra of Trivalent and Quinquevalent Americium Solutions, Journal of the Chemical Society (London), p 2214 (1954)] 


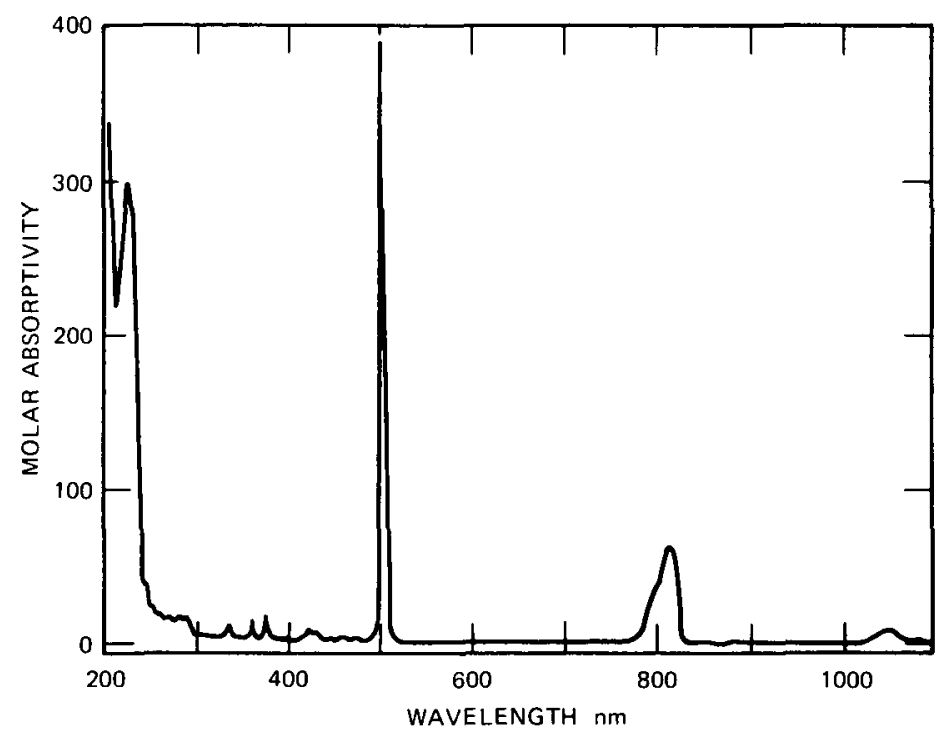

Fig. 3.5c Absorption spectrum of Am(III) in diluted $\mathrm{HClO}_{4}$. [From $\mathrm{T}$ H Keenan, Americium and Curium, Journal of Chemical Education, 36: 27 (1959).]

\section{Am(IV)}

The solution spectrum ${ }^{14}{ }^{15}$ of $\mathrm{Am}(\mathrm{IV})$ has been measured in $10 \mathrm{M}$ to $12 \mathrm{MNH}_{4} \mathrm{~F}$ (Refs. 14, 15) (Fig 3.8a) and in 12M KF (Ref. 101) (F1g $38 \mathrm{~b}$ ), in the two solutions, resemblance of the spectrum in band energy and intensity (Table 38 ) is evident The spectrum in $13 M \mathrm{NH}_{4} \mathrm{~F}$ and $12 M \mathrm{KF}$ also resembles very closely that of solid $\mathrm{AmF}_{4}$ (see pages 145 and 146).

Varga et al ${ }^{101}$ have recently published an account of the first attempts at interpretation of the absorption spectrum of $\mathrm{Am}^{4+}$ in aqueous $12 \mathrm{M} \mathrm{KF}$ and solid $\mathrm{AmF}_{4}$, including term assignments Agreement between experimental and calculated levels was generally excellent Correspondence between the calculated results obtained for $\mathrm{Am}^{4+}$ in $\mathrm{KF}$ and $\mathrm{AmF}_{4}$ was very close. Identical interpretations for the low energy levels were obtained, but some differences were found among the higher energy terms

\section{$A m(V)$}

The solution spectrum of $\mathrm{Am}(\mathrm{V})$ has been determined in $0.1 \mathrm{M} \mathrm{H}_{2} \mathrm{SO}_{4}$ (Ref 26) (Fig $39 \mathrm{a}$ ), $05 M$ to $50 M \mathrm{HCl}(\operatorname{Ref} 65)\left(\mathrm{F}_{1 \mathrm{~g}} 3.9 \mathrm{~b}\right.$ ) and in dilute $\mathrm{HClO}_{4}$ (Refs. 27, 48, 88) (Fig. $39 \mathrm{c}$ ) Molar absorptivities at maximum absorption peaks are listed in Table 38 . 


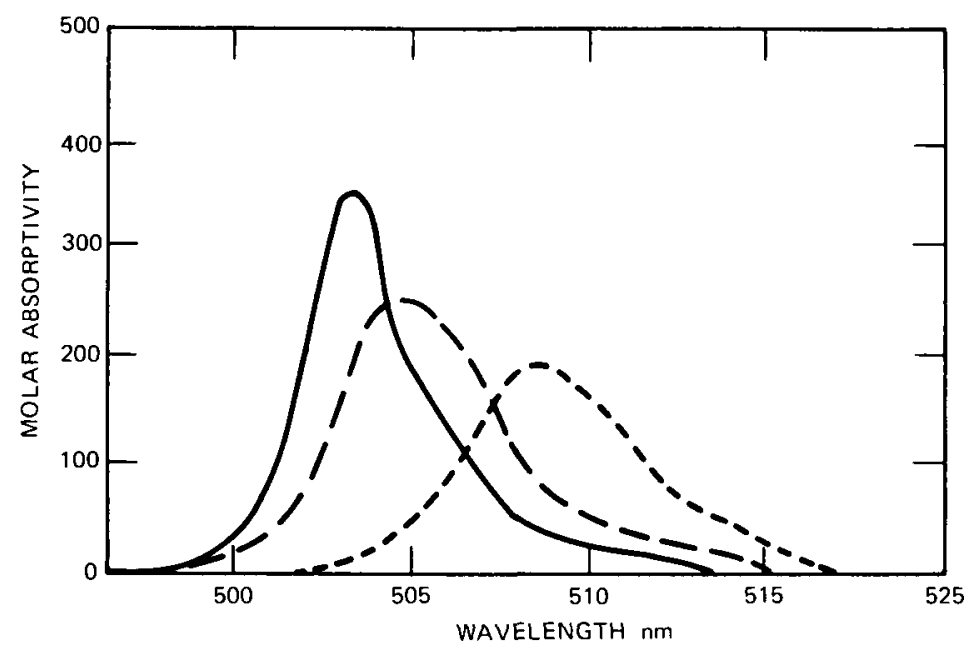

Fig. 3.6a The 503-nm band in the Am(III) spectrum - $1 M \mathrm{HClO}_{4}, \cdots, 114 M \mathrm{LiBr}, \quad \ldots$, $6 \mathrm{OM} \mathrm{K}_{2} \mathrm{CO}_{3}$ solutions [From M Shiloh, M Givon, and Y Marcus, A Spectrophotometric Study of Trivalent Actinide Complexes in Solutions III Americium with Bromide, Iodide, Nitrate, and Carbonate Ligands, Journal of Inorgantc and Nuclear Chemistry, 31: 1807 (1969) ]

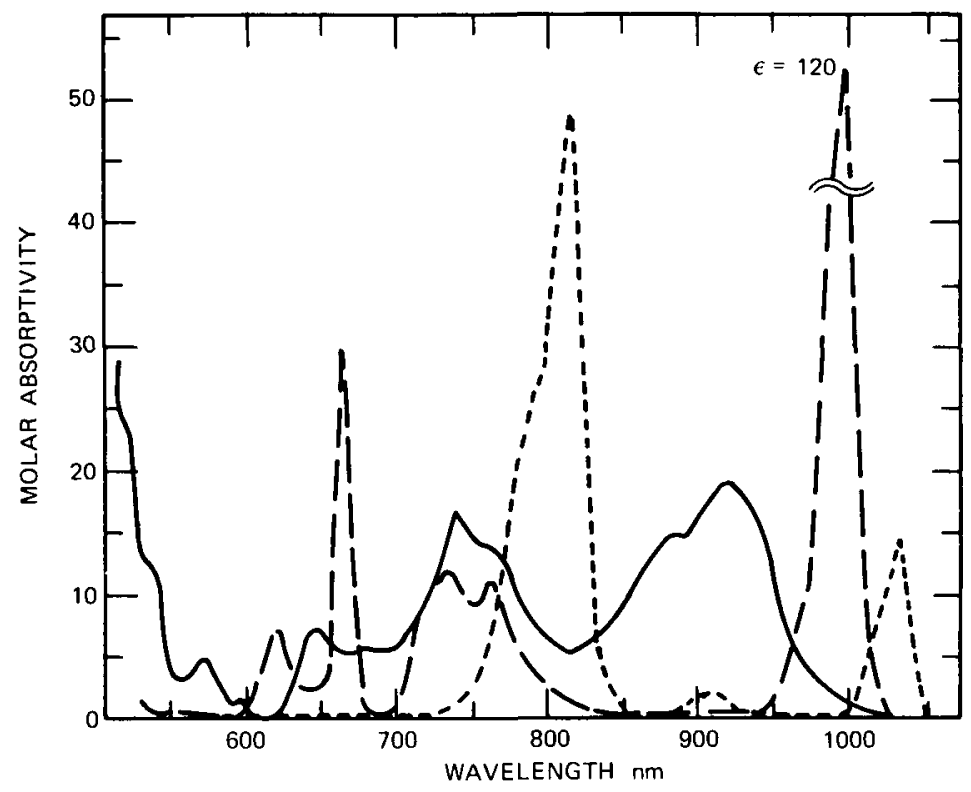

Fig. 3.6b Absorption spectrum of Am(III) in $10 M \mathrm{H}_{3} \mathrm{PO}_{4}, \cdots$, Am(IV) in $10 M \mathrm{H}_{3} \mathrm{PO}_{4}$, 一, and Am(VI) in $5 M \mathrm{H}_{2} \mathrm{PO}_{4}$, - - [From $\mathrm{E}$ Yanir and $\mathrm{M}$ Givon, Higher Oxidation States of Americium in Phosphate Solutions, Inorganic and Nuclear Chemistry Letters, Supplement to Journal of Inorganic and Nuclear Chemistry, 5: 369 (1969) ] 


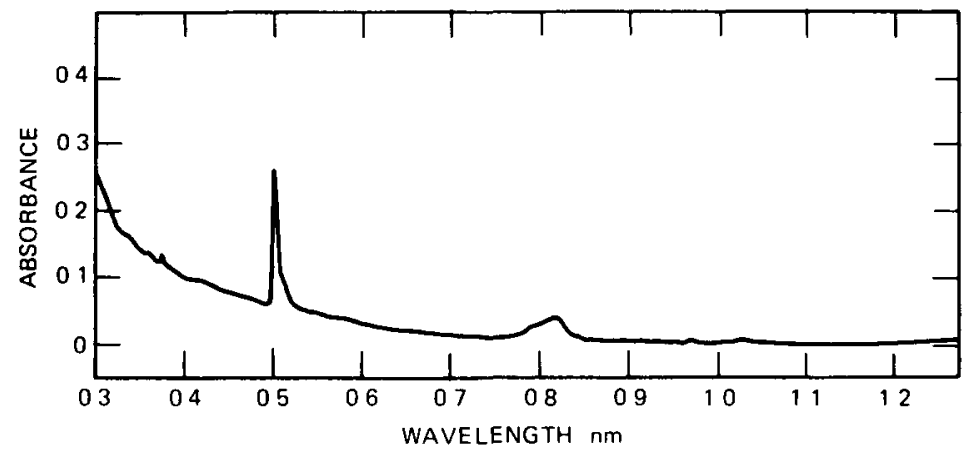

Fig. 3.7a Absorption spectrum of Am(III) in saturated KF solution. (From C. E Thalmayer and D. Cohen, Actinide Chemistry in Saturated Potassium Fluonde Solution, in Lanthantde/Actintde Chemistry, R. F. Gould (Ed.), Advances in Chemistry Serıes, p 256, 1971 )

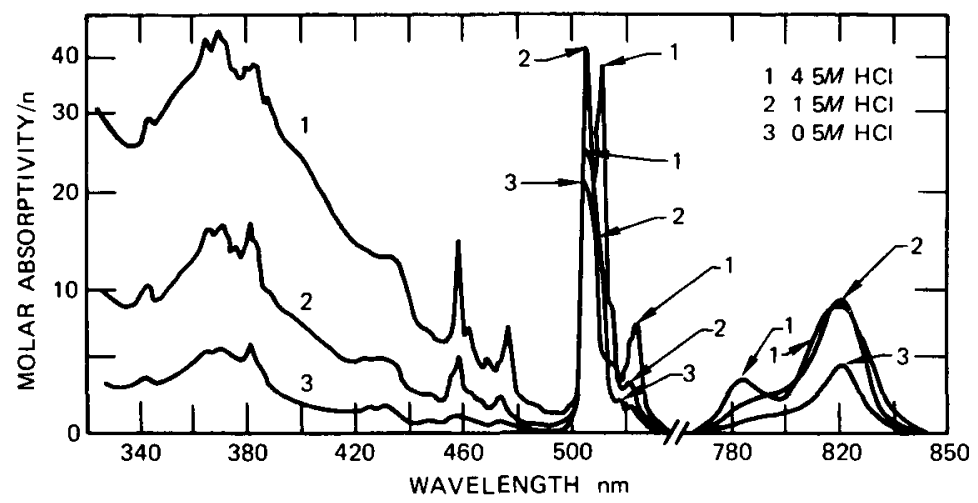

Fig. 3.7b Absorption spectrum of Am(III) in ethanolic $\mathrm{HCl}$ (for curves 1, 2, and $3 \mathrm{n}=1,10 / 3$, and 10, respectively). [From Yu. A. Barbanel, A. G. Gorskil, and V. P. Kotlin, Absorption Spectra of Am(III) in Standard Solutions of HCl, Radiokhimiya, 13: 305 (1971) through Sovlet Radiochemistry (English Translation), 13: 314 (1971).]

To interpret the spectra of the $5 f^{4} \mathrm{AmO}_{2}^{+}$1on, Varga et al ${ }^{103}$ made ab initio relativistic calculations of various spectroscopic parameters These calculated parameters were used to initiate least-squares fits to 15 electronc energy levels of aqueous $\mathrm{AmO}_{2}^{+}$in $1 \mathrm{M} \mathrm{DClO}_{4}-\mathrm{D}_{2} \mathrm{O}$. Correlation with 35 lower levels of the $\mathrm{f}^{4}$ intermediate spin-orbit coupling diagram allowed term assignments to be made to the experimental aquo-ion levels. 


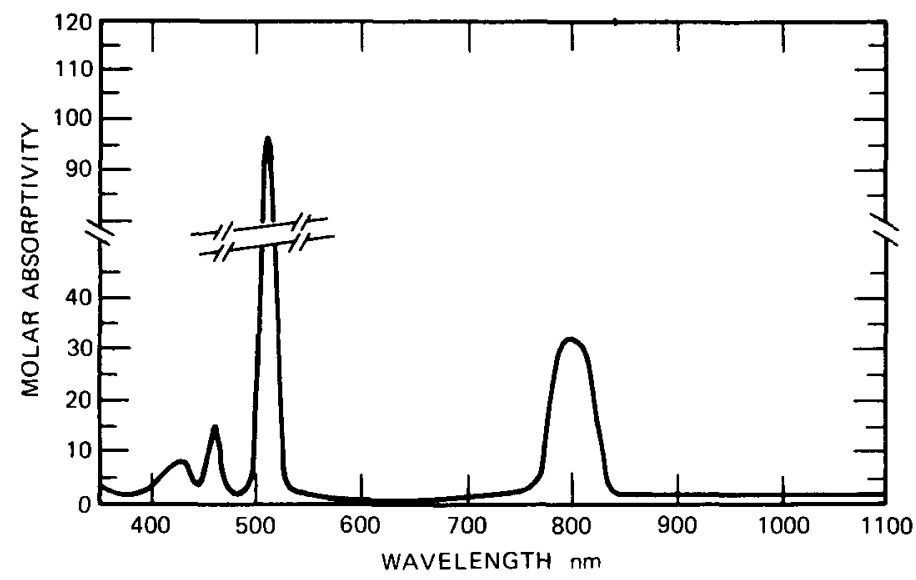

Fig. 3.7c Absorption spectrum of Am(III) $\mathrm{LiNO}_{3}-\mathrm{KNO}_{3}$ eutectıc at $170^{\circ} \mathrm{C}$. (From D. M. Gruen, S. Fried, P. Graf, and R. L. McBeth, The Chemistry of Fused Salts, in Proceedings of the Second International Conference on the Peaceful Uses of Atomic Energy, Geneva, 1958, Vol. 28, p. 112, United Nations, Geneva, 1958)

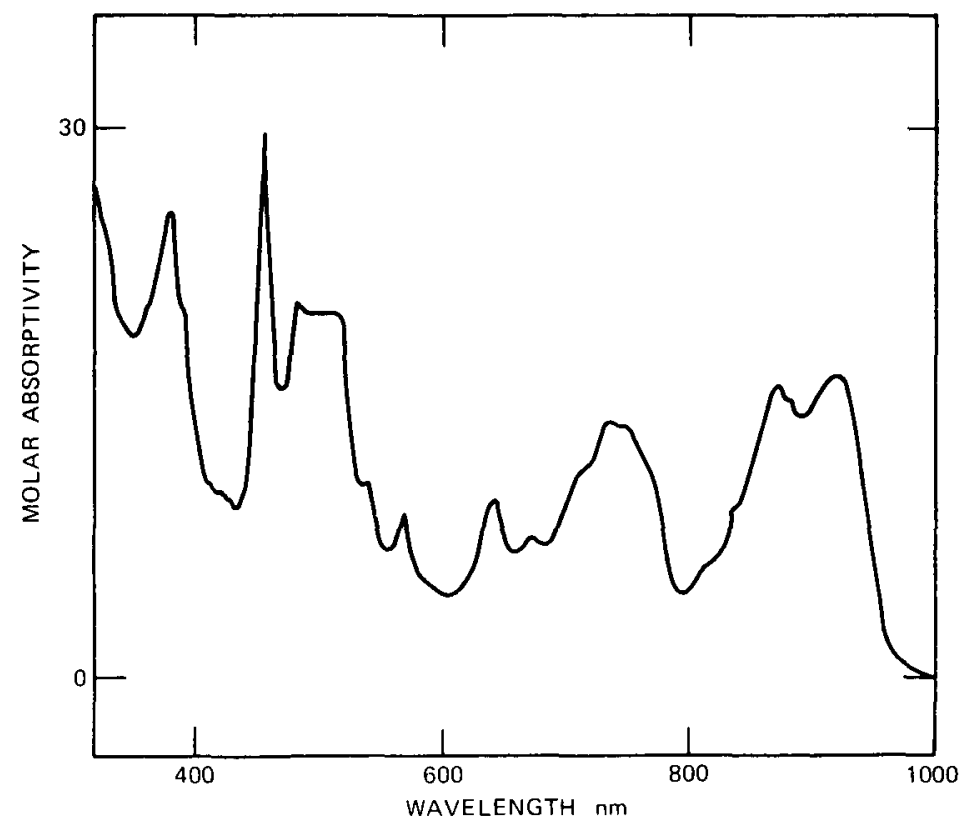

Fig. 3.8a Absorption spectrum of Am(IV) in 13M NH $\mathrm{N}_{4}$ [From L. B. Asprey and R. A. Penneman, Preparation and Properties of Aqueous Tetravalent Americium, Inorganic Chemistry, 1: 134 (1962).] 


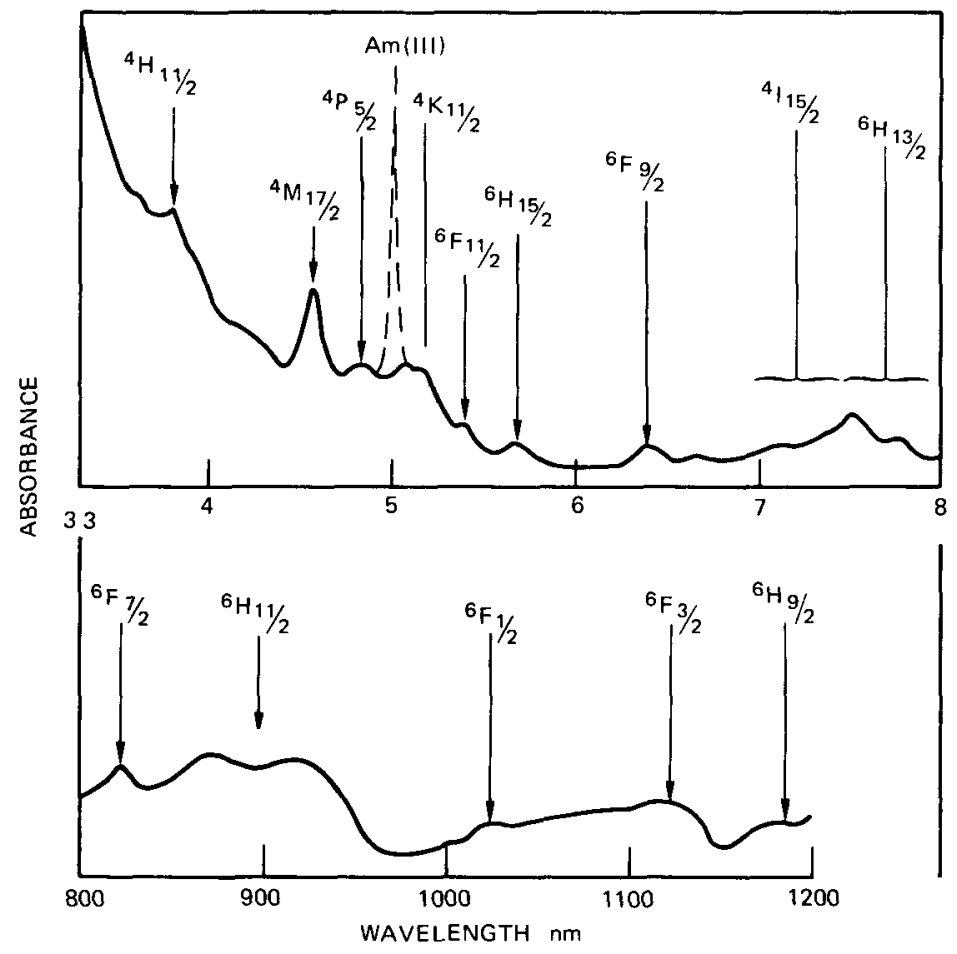

Fig. 3.8b Absorption spectrum of $\mathrm{Am}^{4+}$ in $12 M \mathrm{KF}$, room temperature, 1-cm cells The observed peak at $500 \mathrm{~nm}$ for Am(III) indicates incomplete oxidation of the sample. [From L. P. Varga, R. D. Baybarz, M. J. Reisfeld, and L. B. Asprey, Electronc Spectra of the $5 \mathrm{f}^{5}$ and $5 \mathrm{f}^{9}$ Actinides $\mathrm{Am}^{4+}, \mathrm{Pa}^{3+}, \mathrm{Bk}^{2+}, \mathrm{Cf}^{3+}$, and $\mathrm{Es}^{4+}$ Journal of Inorgantc and Nuclear Chemistry 35. 2775 (1973) ]

\section{$A m(V I)$}

Table 39 lists varıous aqueous media in which the spectrum of Am(VI) has been measured Molar absorptivity values are shown in Table 38 The spectrum of Am(VI) in acid media is not strongly affected by changes in ionic environment Only small shifts in band energies and/or intensities occur in different acids or at different acidities $^{1863104}$ The spectrum of Am(VI) in carbonate solutions (Fig $312 \mathrm{a}$ ), in $1 M$ $\mathrm{CsOH}$ (Fig 3 12b), and in acid solutions differs markedly

Varga, Reisfeld, and Asprey ${ }^{106}$ calculated the spectrum of the $\mathrm{AmO}_{2}^{2+}$ ion from the $\mathrm{f}^{3}$ intermediate spın-orbit coupling diagrams Except for the lower energy levels, agreement between calculated and observed (in $01 \mathrm{M} \mathrm{HClO}_{4}$ ) spectra was poor, however The electron delocalization associated with the covalent character of the $\mathrm{Am}-\mathrm{O}$ bond is believed ${ }^{103}$ responsible for the deviation between calculated and observed spectroscopic parameters 
Table 3.8

PROMINENT ABSORPTION BANDS OF AMERICIUM(IV)

(V), (VI), AND (VII) IONS IN V ARIOUS SOLUTIONS

\begin{tabular}{|c|c|c|c|c|}
\hline Ion & $\begin{array}{l}\text { Absorption } \\
\text { maximum, } \\
\mathrm{nm}\end{array}$ & $\begin{array}{c}\text { Molar } \\
\text { absorptivity, } \\
\text { liters mol }{ }^{1} \mathrm{~cm}^{1}\end{array}$ & Medıa & Ref. \\
\hline $\operatorname{Am}(\mathrm{IV})^{*}$ & $\begin{array}{l}920 \\
742 \\
456\end{array}$ & $\begin{array}{ll}26 & 0 \\
18 & 0 \\
30 & 0\end{array}$ & $\begin{array}{l}12 \mathrm{MH}_{3} \mathrm{PO}_{4} \\
12 M \mathrm{H}_{3} \mathrm{PO}_{4} \\
13 M \mathrm{NH}_{4} \mathrm{~F}\end{array}$ & $\begin{array}{l}18 \mathbf{a} \\
18 \mathbf{a} \\
15\end{array}$ \\
\hline$A m(V)$ & $\begin{array}{l}900 \\
720 \\
715 \\
646 \\
515 \\
514 \\
514 \\
513 \\
415\end{array}$ & $\begin{array}{rl}6 & 0 \\
66 & 0 \\
59 & 0 \\
9 & 5 \\
48 & 0 \\
44 & 4 \\
35 & 7 \\
45 & 0 \\
12 & 0\end{array}$ & $\begin{array}{l}01 M \mathrm{HClO}_{4} \\
01 M \mathrm{H}_{2} \mathrm{SO}_{4} \\
01 M \mathrm{HClO}_{4} \\
01 M \mathrm{HClO}_{4} \\
01 M \mathrm{H}_{2} \mathrm{SO}_{4} \\
05 M \mathrm{HCl} \\
5 M \mathrm{HCl} \\
01 M \mathrm{HClO}_{4} \\
01 M \mathrm{HClO}_{4}\end{array}$ & $\begin{array}{l}64 \\
26 \\
88 \\
88 \\
26 \\
65 \\
65 \\
88 \\
88\end{array}$ \\
\hline $\operatorname{Am}(\mathrm{VI})$ & $\begin{array}{l}996 \\
996 \\
995 \\
757 \\
713 \\
663 \\
619 \\
548 \\
400\end{array}$ & $\begin{array}{r}1940 \\
1200 \\
864 \\
104 \\
114 \\
305 \\
126 \\
128 \\
5000\end{array}$ & $\begin{array}{l}12 M \mathrm{H}_{3} \mathrm{PO}_{4} \\
5 M \mathrm{H}_{3} \mathrm{PO}_{4} \\
2 M \mathrm{HClO}_{4} \\
01 M \mathrm{HClO}_{4} \\
01 M \mathrm{HClO}_{4} \\
01 M \mathrm{HClO}_{4} \\
01 M \mathrm{HClO}_{4} \\
01 M \mathrm{HClO}_{4} \\
35 \mathrm{MaOH}\end{array}$ & $\begin{array}{r}18 \mathrm{a} \\
17 \\
102 \\
88 \\
88 \\
88 \\
88 \\
88 \\
1 \mathrm{a}\end{array}$ \\
\hline$A m(V I I)$ & $\begin{array}{l}740 \\
400\end{array}$ & $\begin{array}{r}3300 \\
16000\end{array}$ & $\begin{array}{l}35 M \mathrm{NaOH} \\
35 M \mathrm{NaOH}\end{array}$ & $\begin{array}{l}\text { 1a } \\
1 \mathrm{a}\end{array}$ \\
\hline
\end{tabular}

*Molar absorptivities of $\mathrm{Am}(\mathrm{IV})$ in $12 \mathrm{M} \mathrm{H}_{3} \mathrm{PO}_{4}$ at $333,357,384,416$, and $454 \mathrm{~nm}$ are, respectively, $1363 \pm 19,1029 \pm 11,701 \pm 10,365 \pm 12$, and $138 \pm 9^{13} \mathrm{~b}$

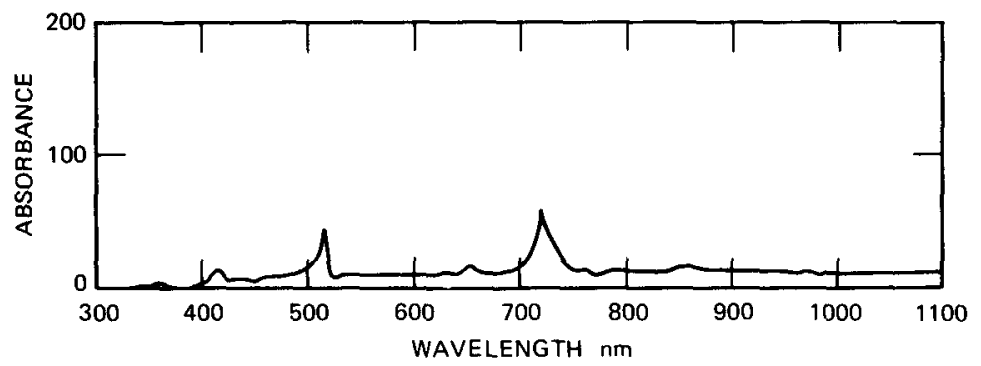

Fig. 3.9a Absorption spectrum of Am(V) in $01 \mathrm{M} \mathrm{H}_{2} \mathrm{SO}_{4}$ [From L B Werner and I Perlman, The Pentavalent State of Americium, Journal of the American Chemical Society, 73: 495 (1951) | 


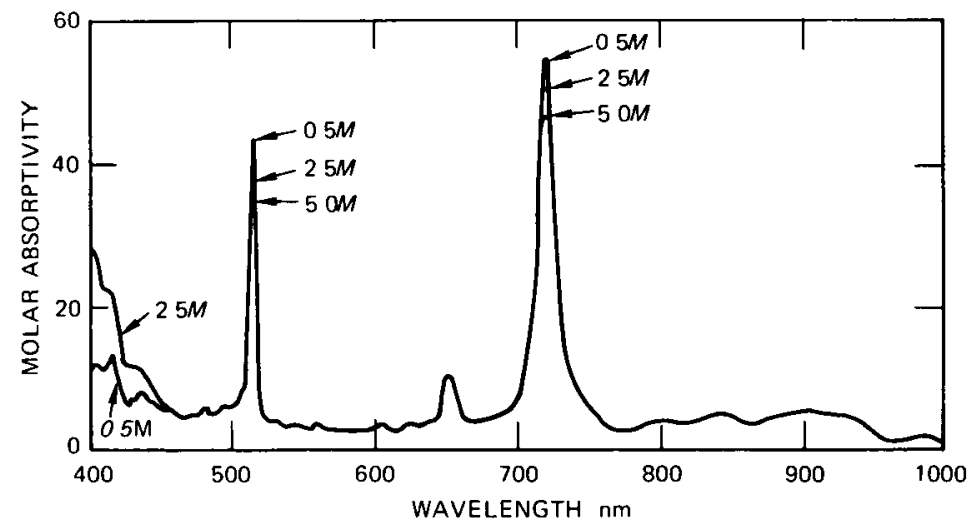

Fig. 3.9b Absorption spectrum of $A m(V)$ in $\mathrm{HCl}$ [From $G \quad R$ Hall and $P$ D Hernman, The Separation and Purification of Americium-241 and the Absorption Spectra of Tervalent and Quinquevalent Americium Solutions, Journal of the Chemical Society (London), p 2214 (1954) ]

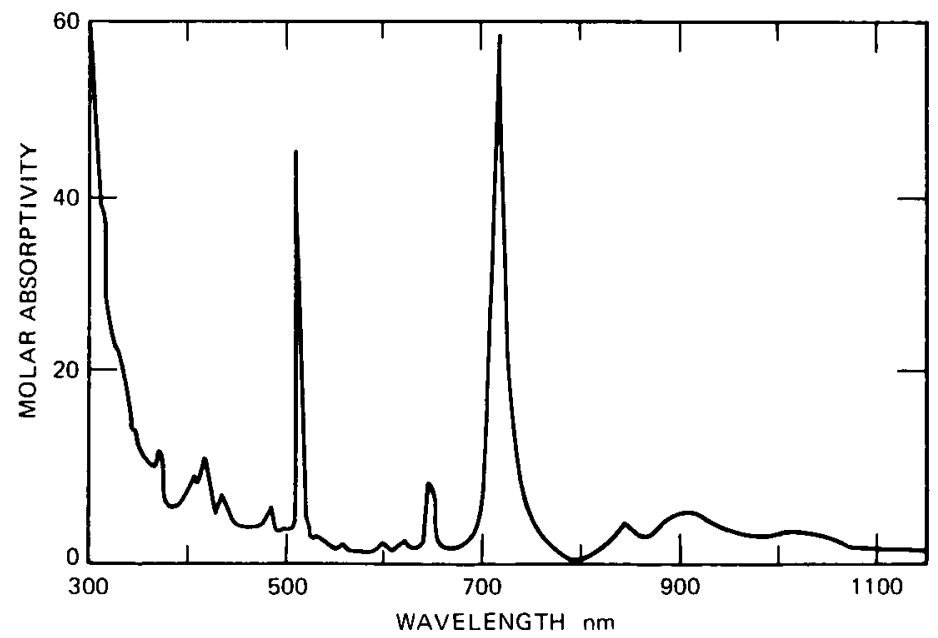

Fig. 3.9c Absorption spectrum of Am(V) in $1 \mathrm{M} \mathrm{HClO}_{4}$ (From R A Penneman and L B Asprey, A Review of Amencium and Curium Chemistry, in Proceedings of the International Conference on the Peaceful Uses of Atomic Energy Geneva, 1955, Vol 7, p 355, United Nations, New York, 1956 ) 
Bell ${ }^{107}$ has compared band positions of the transuranium actinyl spectra including those of $\mathrm{AmO}_{2}^{+}$and $\mathrm{AmO}_{2}^{2+}$ with the spacings between positions of the $\mathrm{UO}_{2}^{2+}$ bonds His results indicate that a single molecular orbitd model can represent any of the actinyl ions when the uranyl ion is assumed to have the bonding orbitals exactly filled, and the transuranium actinyl ions are represented with the uranyl core and a

Table 3.9

SOLUTION ABSORPTION SPECTRUM OF Am(VI)

\begin{tabular}{|c|c|c|}
\hline Media & References & $\begin{array}{c}\text { Typical } \\
\text { spectrum }\end{array}$ \\
\hline $02 M-143 M \mathrm{HNO}_{3}$ & 30,104 & Fig $310 \mathrm{~d}$ \\
\hline $01 M-60 M \mathrm{H}_{2} \mathrm{SO}_{4}$ & 63 & Fig $310 \mathrm{~b}$ \\
\hline $01 M-20 M \mathrm{HClO}_{4}$ & $27,48,64,88$ & Fig $311 d$ \\
\hline $50 M-120 M \mathrm{H}_{3} \mathrm{PO}_{4}$ & $17,18 \mathrm{a}$ & Fig $36 \mathrm{~b}$ \\
\hline $1 M \mathrm{HF}$ & 105 & \\
\hline $01 M \mathrm{Na}_{4} \mathrm{P}_{2} \mathrm{O}_{7}$ & 22 & Fig $311 \mathrm{~b}$ \\
\hline $01 M \mathrm{Na}_{2} \mathrm{CO}_{3}$ & 22 & Fig $312 a$ \\
\hline $10 M \mathrm{CsOH}$ & 33 & Fig $312 b$ \\
\hline
\end{tabular}

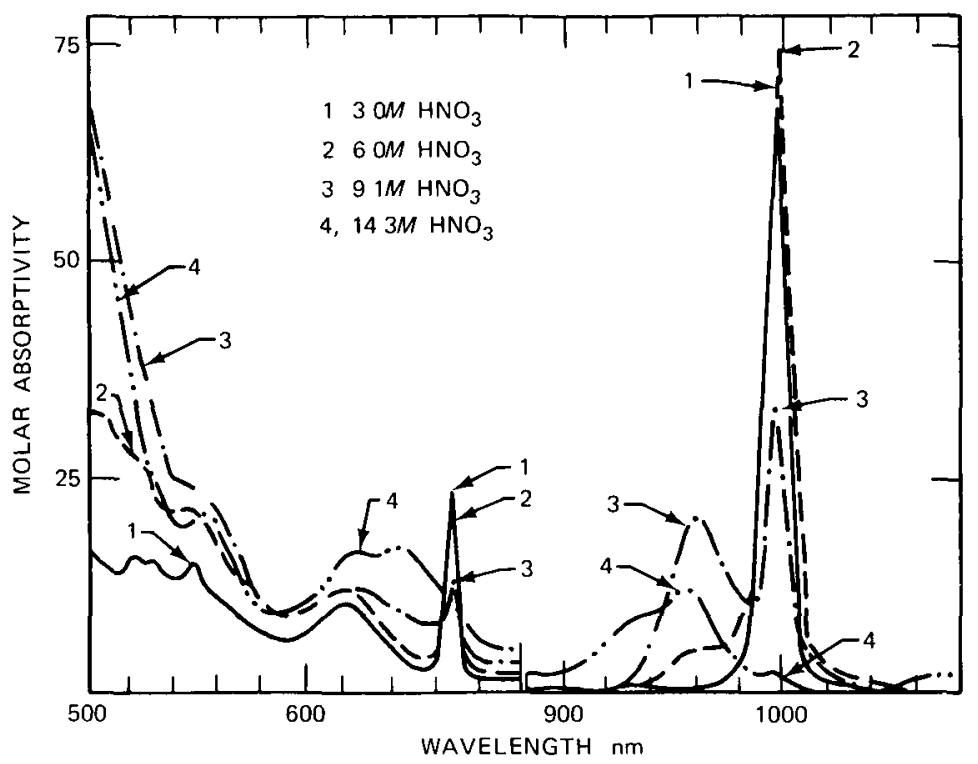

Fig. 3.10a Absorption spectrum of $\mathrm{Am}(\mathrm{VI})$ in $\mathrm{HNO}_{3}$ (From G N Yakovlev and V N Kosyakov, An Investigation of the Chemistry of Americium, in Proceedings of the Second International Conference on the Peaceful Uses of Atomic Energy, Geneva, 1955, Vol 28, p 373, United Nations, Geneva, 1956 ) 


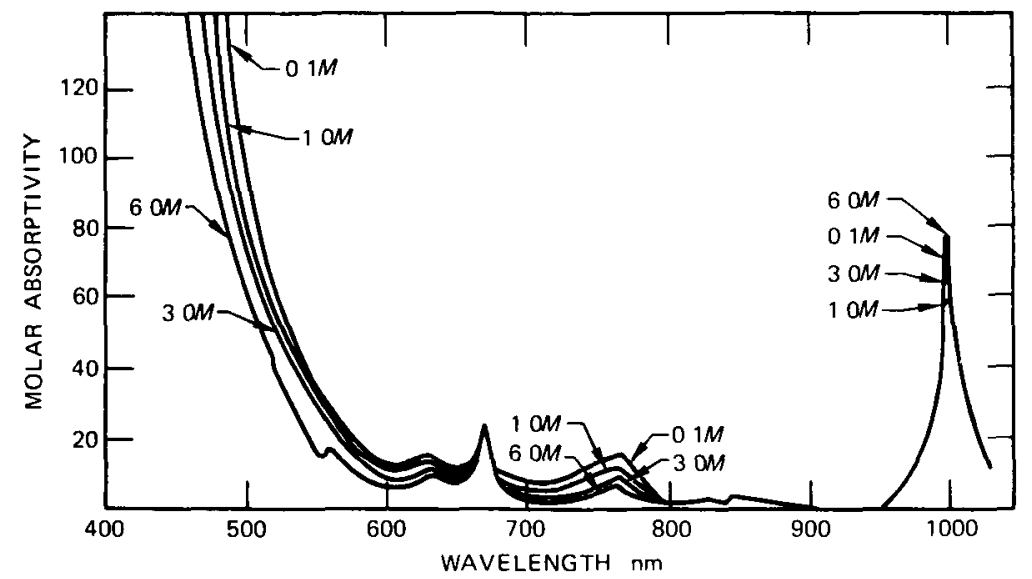

Fig. 3.10b Absorption spectrum of $\mathrm{Am}(\mathrm{VI})$ in $\mathrm{H}_{2} \mathrm{SO}_{4}$ (From $\mathrm{G} \mathrm{R}$ Hall and $\mathrm{T}$ L Markin, The Self-Reduction of Americium(V) and (VI) and the Disproportionation of Americrum(V) in Aqueous Solutions, Journal of Inorganic and Nuclear Chemistry, 4: 296 (1957) ]

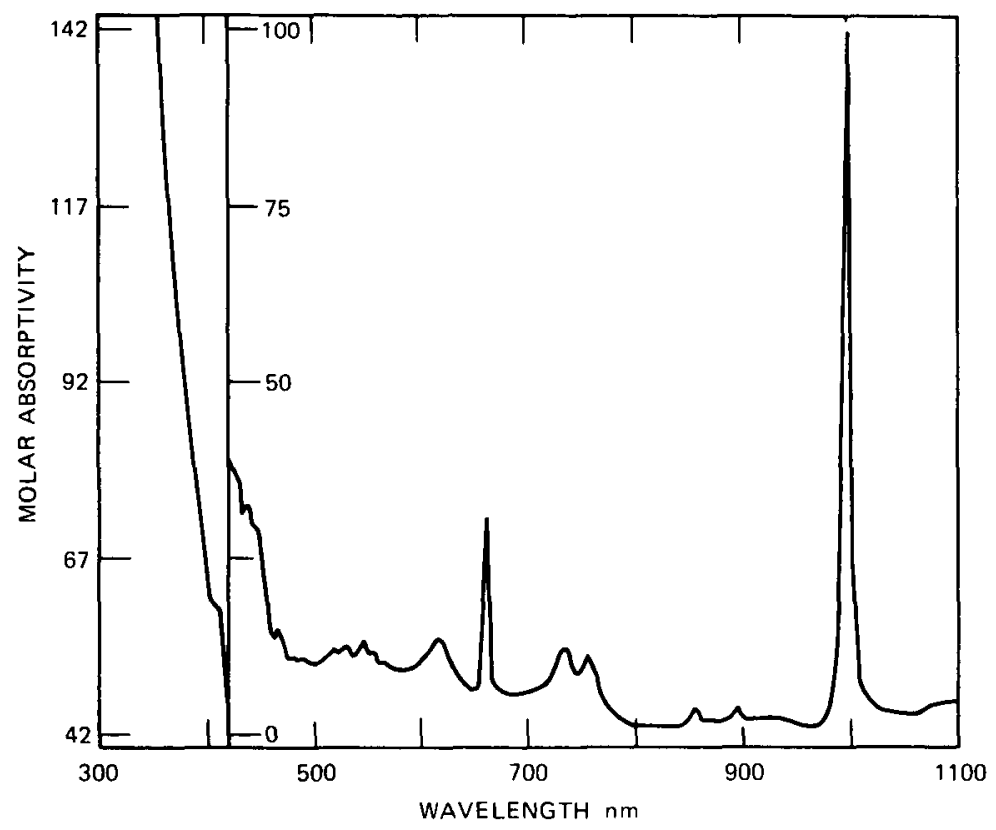

Fig. 3.11a Absorption spectrum of $\mathrm{Am}(\mathrm{VI})$ in $\mathrm{LM} \mathrm{HClO}_{4}$ (From $\mathrm{R}$ A Penneman and $\mathrm{L}$ B Asprey, A Review of Amencium and Curium Chemistry, in Proceedings of the International Conference on the Peaceful Uses of Atomic Energy, Geneva, 1955, Vol 7,p 355, United Nations, New York, 1956) 


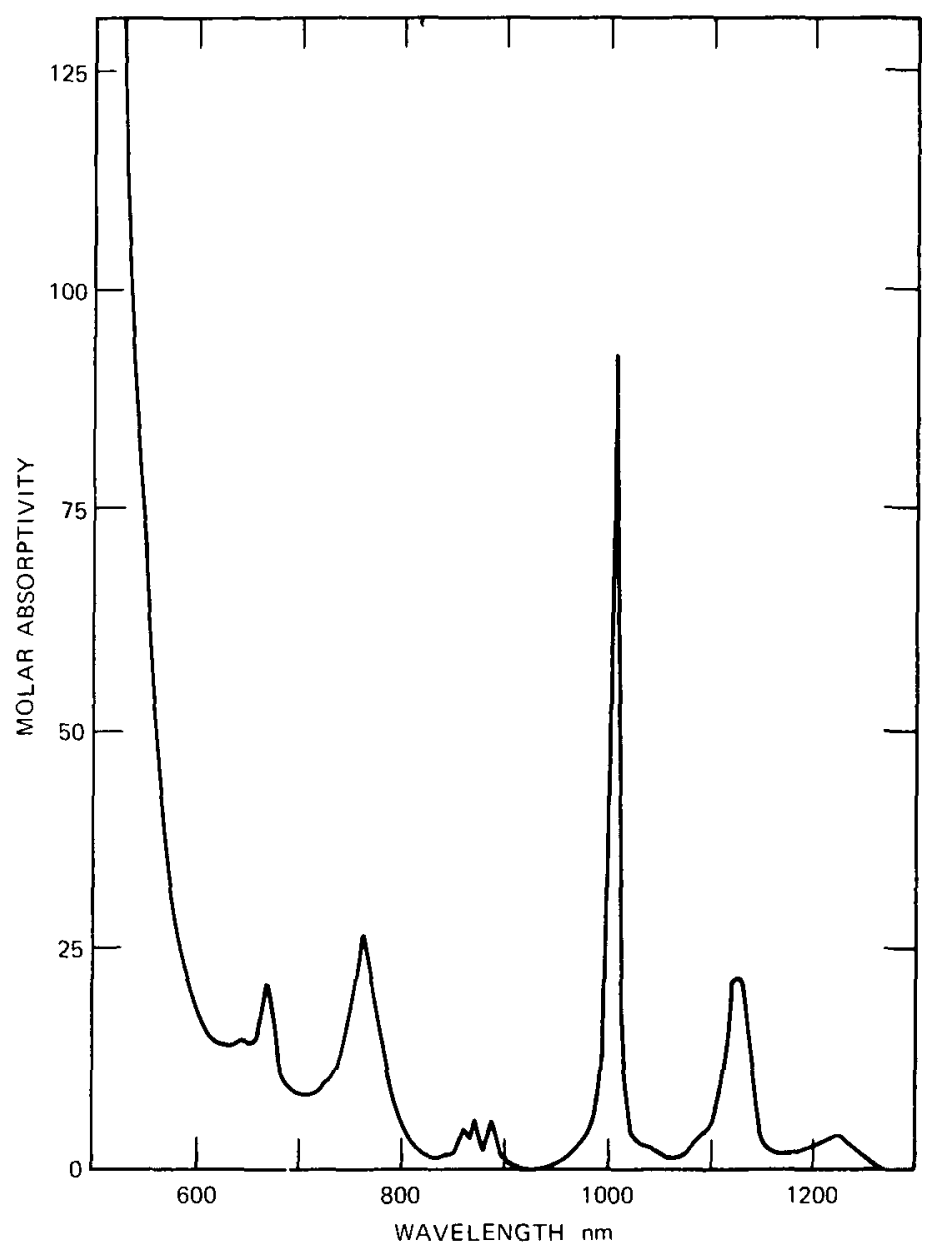

Fig. 3.11b Absorption spectrum of $\mathrm{Am}(\mathrm{VI})$ in $1 \mathrm{M} \mathrm{Na}_{4} \mathrm{P}_{2} \mathrm{O}$, [From J S Coleman, $\mathrm{T} \mathrm{K}$ Keenan, $\mathrm{L} \mathrm{H}$ Jones, $\mathrm{W} \mathrm{T}$ Carnall, and R A Penneman, Preparation and Propertes of Americium(VI) in Aqueous Carbonate Solutions, Inorganic Chemistry 1• 58 (1963) ]

progressive increase of electrons in the first two orbitals lying above the bonding orbitals

\section{$A m($ VII)}

Green-colored solutions believed to contain some Am(VII) are prepared (see pages 54 and 55) by oxidation of $\mathrm{Am}(\mathrm{VI})$ in $3 M$ to $5 M \mathrm{NaOH}$ at 0 to $7^{\circ} \mathrm{C}$ with either $\mathrm{O}_{3}$ or the $\mathrm{O}$ ion radical The absorption spectra of $\mathrm{Am}(\mathrm{VI})$ and $\mathrm{Am}(\mathrm{VII})$ in $35 \mathrm{MNaOH}$ as measured by Krot et al ${ }^{1}$ are shown in Fig $312 \mathrm{c}$ 


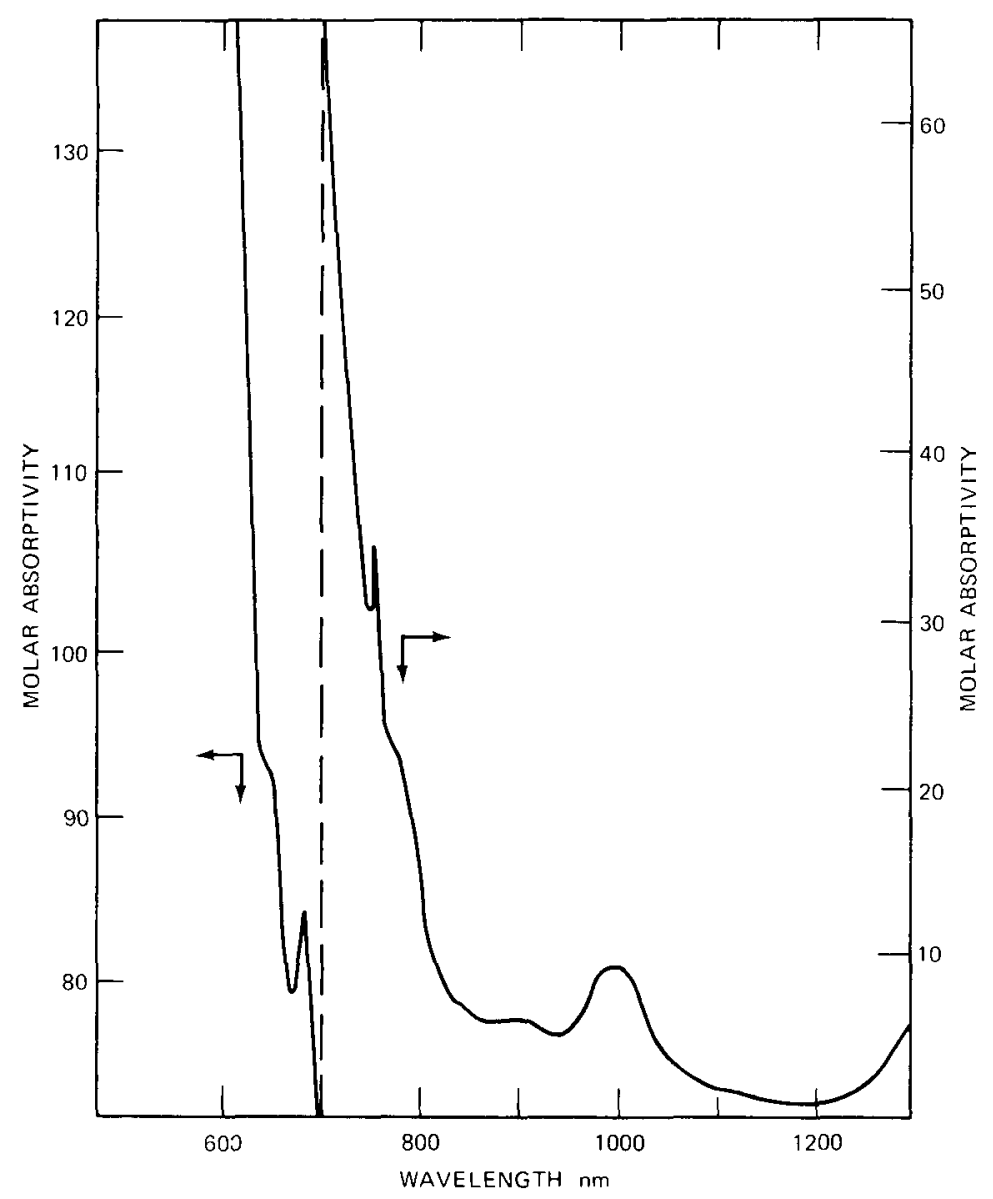

Fig. 3.12a Absorption spectrum of $\mathrm{Am}(\mathrm{VI})$ in $01 \mathrm{M} \mathrm{Na} \mathrm{CO}_{3}$ [From J $\mathrm{S}$ Coleman, $\mathrm{T} \mathrm{K}$ Keenan, L H Jones, W T Carnall, and R A Penneman, Preparation and Properties of Amencium(VI) in Aqueous Carbonate Solutions, Inorganic Chemistry, 1: 58 (1963) ]

\section{COMPLEXES OF AMERICIUM IONS}

\section{Tabulated Formation Constants}

Formation constants and pertinent experimental conditions under which they were determined are collected in Tables 310 and 311 for complexes of $\mathrm{Am}^{3+}$ with inorganic and organic ligands, respectively (A few complexes for which formation constants have not yet been measured are also cited ) This listing is believed complete

(Text continues on page 99 ) 


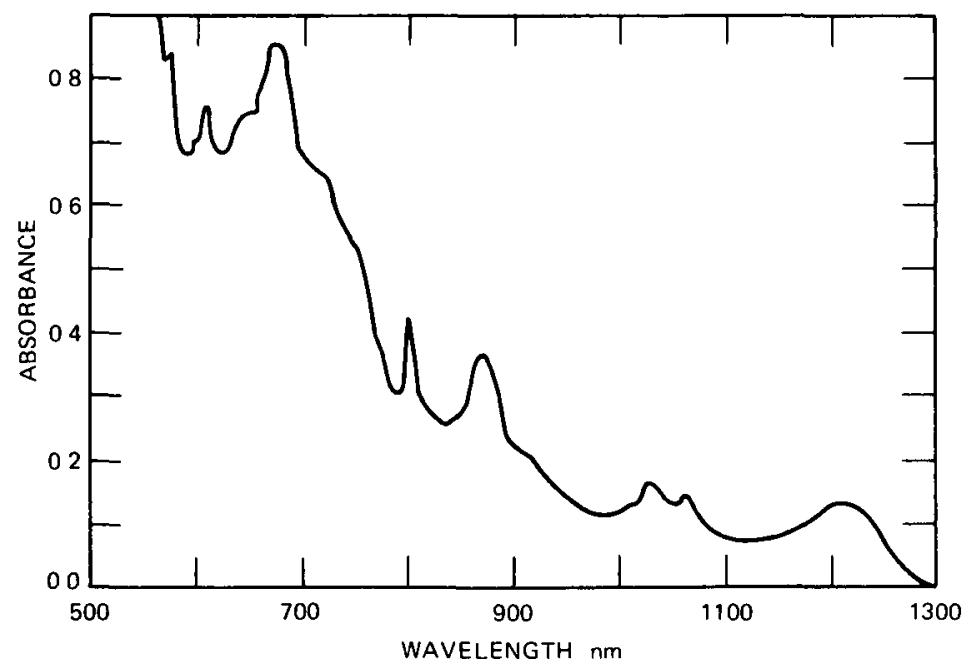

Fig. 3.12b Absorption spectrum of $\mathrm{Am}(\mathrm{VI})$ in $1 M \mathrm{CsOH}$ [From D Cohen, Americium(VI) in Basic Solution, Inorganic and Nuclear Chemistry Letters Supplement to Journal of Inorganic and Nuclear Chemistry, 8: 533 (1972) ]

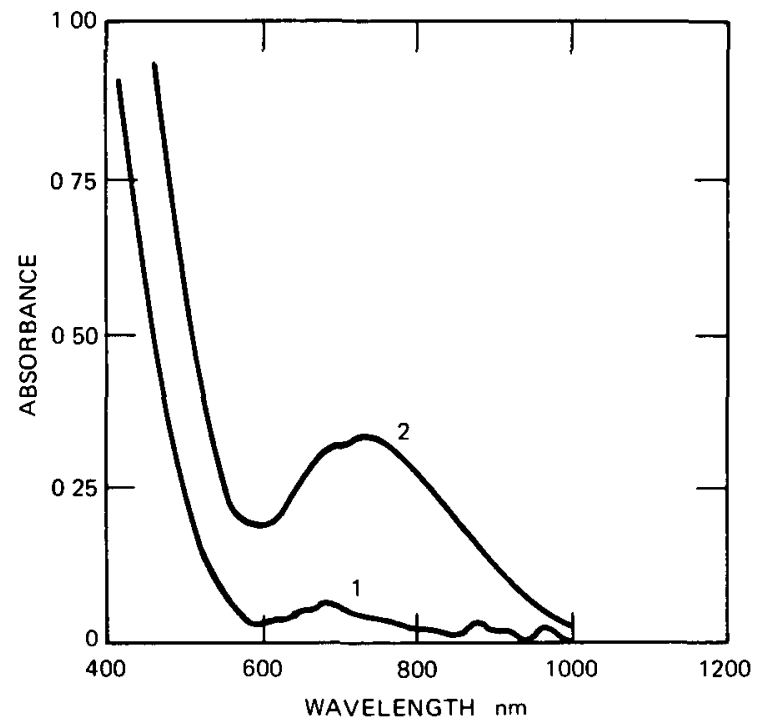

Fig. 3.12c Absorption spectra of Am(VI) and Am(VII) in $35 M \mathrm{NaOH} 1,00194 M$ Am(VI), 2, $00194 \mathrm{M}$ Am-50\% Am(VII) and 50\% Am(VI) [From N N Krot, V P Shilov, V B Nikolaevskil, A.K Nikaev, A D Gel'man, and V I Spitsyn, Preparation of Americium in Heptavalent State, Doklady Akademit Nauk SSSR (USSR), 217: 589 (1974) through USAEC Report ORNL-tr2828, Oak Ridge National Laboratory, 1974 ] 
Table 3.10

COMPLEXES OF AMERICIUM WITH INORGANIC LIGANDS

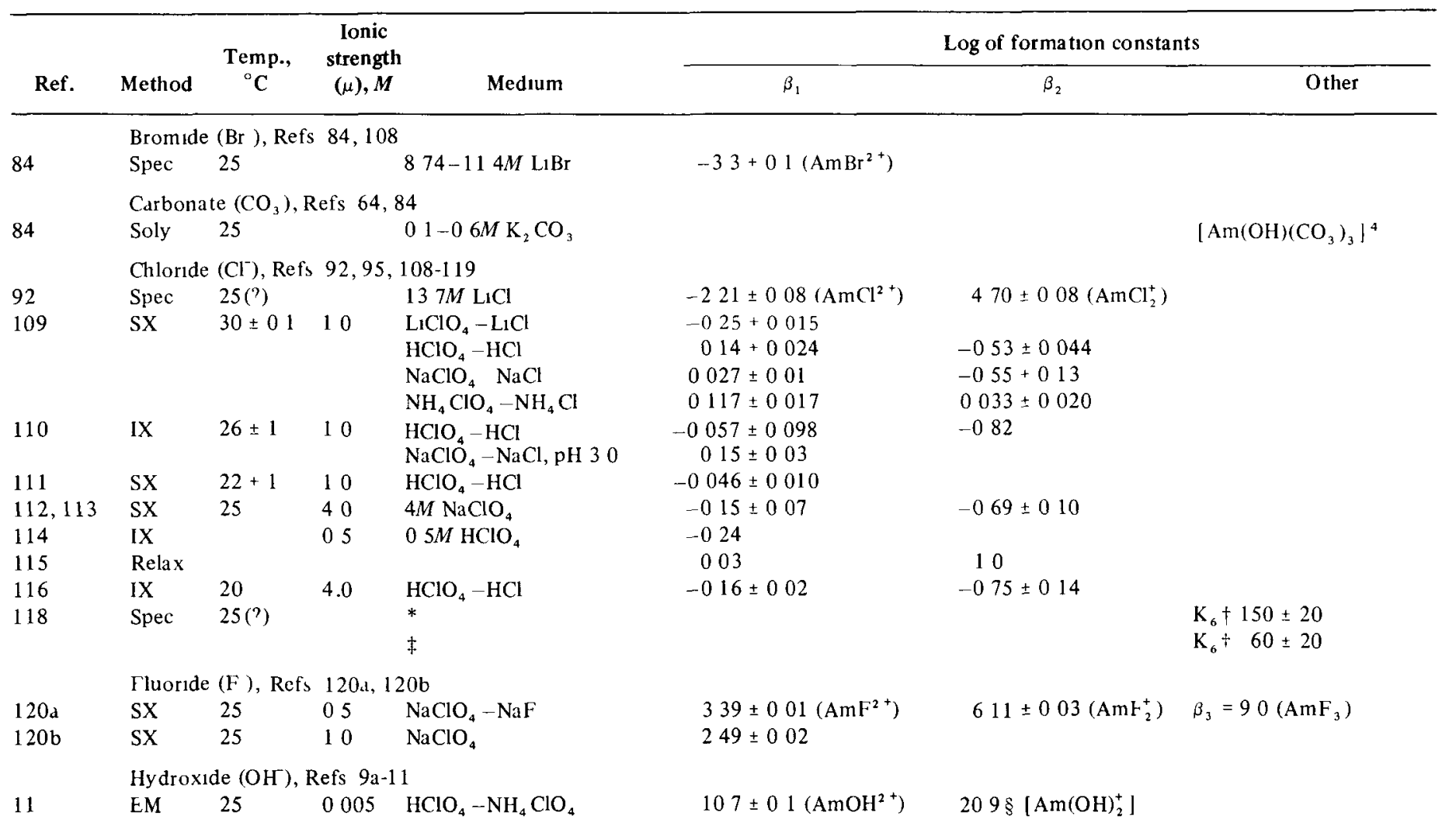


Table 3.10 (Contınued)

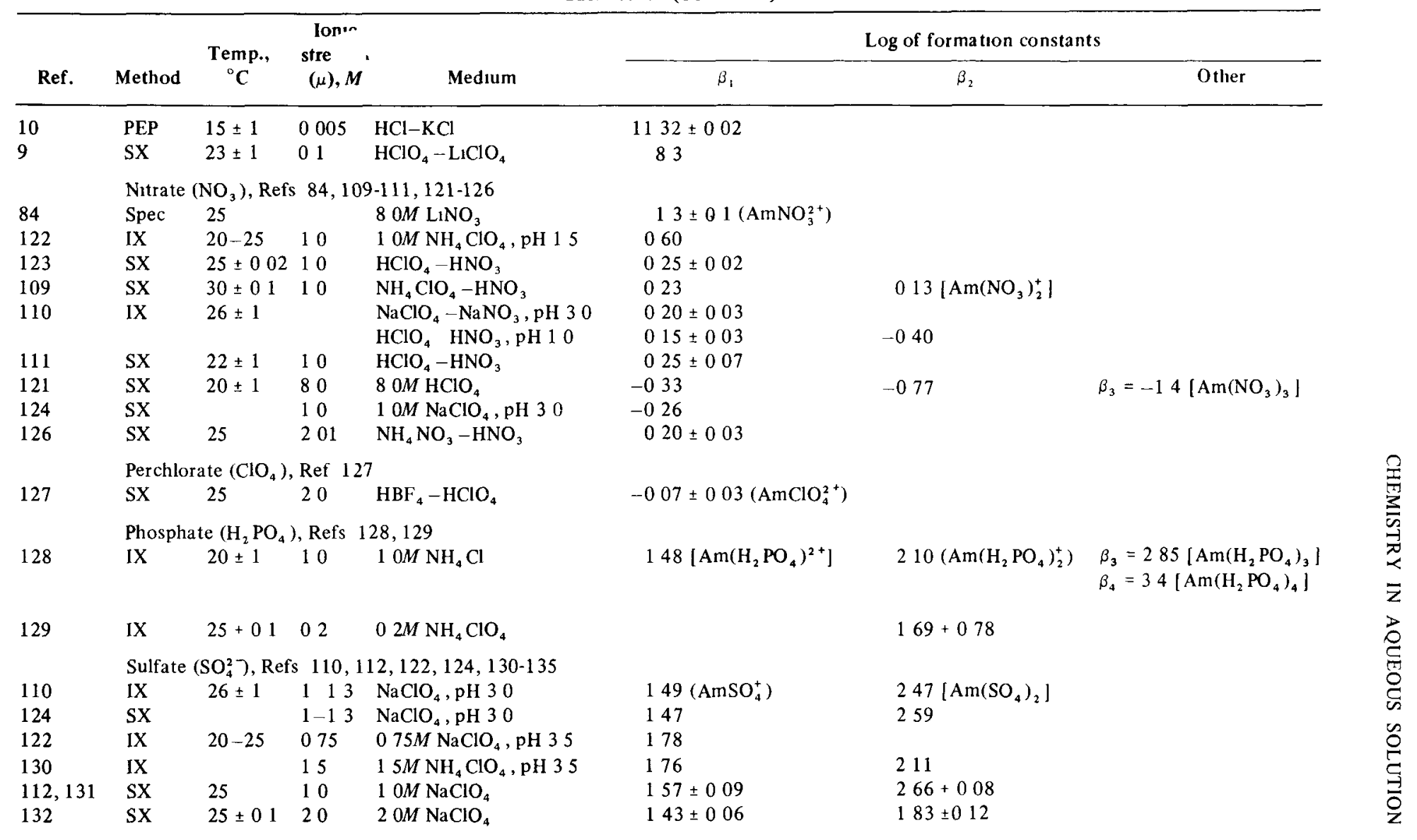






* 85 vol \% succinonitrule -15 vol \% acetonitrile

$\dagger$ Equilibrium constant for reaction $\mathrm{AmCl}_{5}^{2}+\mathrm{Cl} \rightarrow \mathrm{AmCl}_{6}^{3}$

$\$$ Propylene carbonate

$\S$ Estımated value 
TABLE 3.11

COMPLEXES OF AMERICIUM WITH ORGANIC LIGANDS

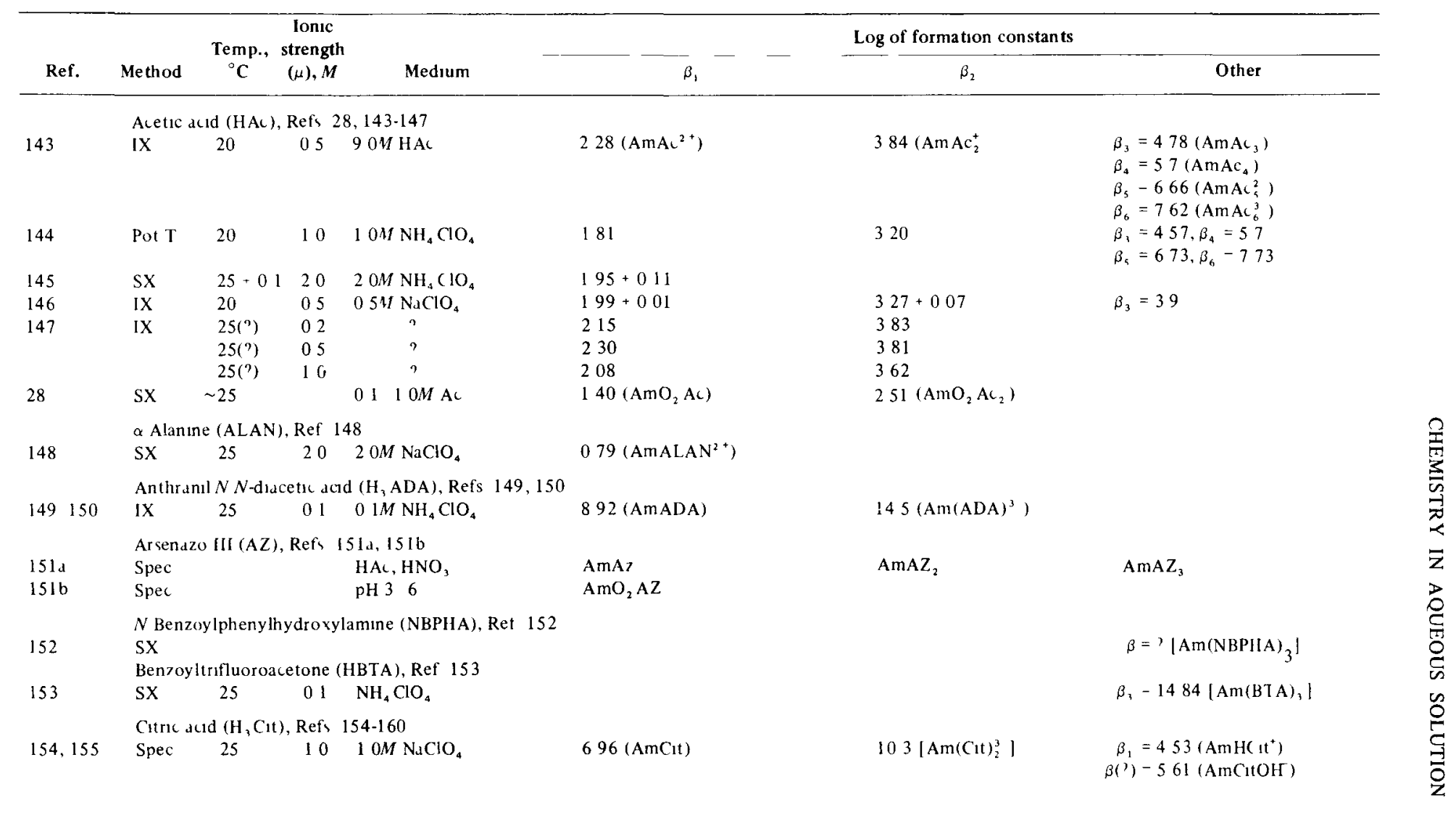




\begin{tabular}{|c|c|c|c|c|c|c|c|}
\hline \multirow{3}{*}{155} & \multirow{3}{*}{ IX } & \multirow{2}{*}{25} & 01 & $01 M \mathrm{NaClO}_{4}$ & \multicolumn{2}{|l|}{$916+003$} & $\beta_{1}^{\prime}-700$ \\
\hline & & & 05 & $05 M \mathrm{NaClO}_{4}$ & $873 \pm 0066$ & & $\beta_{1}^{\prime}=629$ \\
\hline & & \multirow{4}{*}{25} & 10 & $10 M \mathrm{NaClO}_{4}$ & $672+005$ & & $\beta_{1}^{i}=424$ \\
\hline 156 & $\mathrm{IX}$ & & 01 & $01 M \mathrm{NaH}_{2} \mathrm{Ctt}$ & 674 & 1155 & $\begin{array}{l}\beta_{1}^{\prime}=531 \\
\beta_{2}^{\prime}=823\left[\mathrm{Am}\left(\mathrm{HC}(\mathrm{t})_{2}\right]\right.\end{array}$ \\
\hline 157 & IX & & & $\mathrm{l} 0 \mathrm{M} \mathrm{NH}_{4} \mathrm{Cl}$ & 711 & 140 & $\beta_{3}^{\prime \prime}=829\left[\mathrm{Am}\left(\mathrm{H}_{2} \mathrm{Cit}\right)_{3}\right]$ \\
\hline 158 & PLP & & & $004 M$ & & 966 & \\
\hline \multirow[t]{2}{*}{161} & $\begin{array}{l}\text { Decal } \\
\text { SX }\end{array}$ & $\begin{array}{l}\text { ydroxamic } \\
20\end{array}$ & $\begin{aligned} \text { acud } \\
01\end{aligned}$ & $\begin{array}{l}\mathrm{HDHA}), \operatorname{Ref} 161 \\
01 \mathrm{M \textrm {NaClO } _ { 4 }}\end{array}$ & & & $\beta(?)=\left[\mathrm{Am}(\mathrm{DHA})_{3} \cdot 2 \mathrm{H}_{2}(\mathrm{DHA})_{2}\right.$ \\
\hline & \multicolumn{6}{|c|}{ 1,2 Dlamınocyclohexanetetradcetic acid $\left(\mathrm{H}_{4}\right.$ DCTA), Rets 162165} & \\
\hline 162 & EM & $20 \pm 05$ & 01 & $\mathrm{KCl}+\mathrm{HCl}$ & 1834 (AmDCTA) & & $\beta_{1}^{\prime}=287($ AmHDCTA $)$ \\
\hline 163 & IX & $25 \pm 1$ & 01 & $01 \mathrm{M} \mathrm{NH}_{4} \mathrm{ClO}_{4}$ & 1879 & & \\
\hline 164 & $\mathrm{IX}$ & 80 & & $\begin{array}{l}0001 M \mathrm{H}_{4} \mathrm{DCTA} \\
+002 M \text { ammonium } \\
\alpha \text { hydroxylsobuty rate }\end{array}$ & $1879 \gtreqless$ & & \\
\hline \multirow[t]{2}{*}{165} & sx & 20 & 01 & $01 M \mathrm{NH}_{4} \mathrm{Cl}$ & 1821 & & \\
\hline & \multicolumn{6}{|c|}{ 1,2 DiaminopropanetetradcetK aud (H, DTPrA), Ref 155} & \\
\hline \multirow[t]{2}{*}{155} & $\mathrm{IX}$ & 25 & 01 & $01 \mathrm{M} \mathrm{NaClO}{ }_{4}$ & $1769($ AmDTPrA $)$ & & $\beta_{1}^{\prime}=979($ AmHDTPrA $)$ \\
\hline & \multicolumn{6}{|c|}{ Dibutyl-(PP')-ethane-(1,2)-diphosphonic acid $\left(\mathrm{H}_{2} \mathrm{~B}_{2}\right.$ EDP), Ref 166} & \\
\hline \multirow[t]{2}{*}{166} & sx & 25 & 10 & $10 \mathrm{M} \mathrm{NaClO}_{4}$ & & & $\beta_{1}^{\prime}=1452\left(\mathrm{Am}\left(\mathrm{HB}_{2} \mathrm{EDP}\right)_{3}\right)$ \\
\hline & \multicolumn{6}{|c|}{ 5,7-Dichloro 8-Hy droxyquinoline (HDCO), Refs 167,168} & \\
\hline \multirow[t]{2}{*}{167} & $\mathrm{sx}$ & $25 \pm 05$ & 01 & $01 M\left(\mathrm{NH}_{4}, \mathrm{H}\right) \mathrm{ClO}_{4}$ & & & $\beta_{3}=2193\left(\mathrm{Am}(\mathrm{DCO})_{3}\right)$ \\
\hline & \multicolumn{6}{|c|}{ Deethylenetriaminepentaacetic acld ( $\mathrm{H}_{5}$ DTPA), Refs 150,169178} & \\
\hline 150 & $\mathrm{IX}$ & 25 & 01 & $01 M \mathrm{NH}_{4} \mathrm{ClO}_{4}$ & $2307\left(\mathrm{AmDTPA}^{2}\right)$ & & $\beta_{1}^{\prime}=1406$ (AmHDTPA) \\
\hline 169 & IX & 25 & 01 & $01 M \mathrm{NH}_{4} \mathrm{ClO}_{4}$ & 2292 & & \\
\hline 170 & $\mathrm{EM}$ & $25+02$ & 01 & $01 M \mathrm{KNO}_{3}$ & 2274 & & $\beta_{1}^{\prime}=143$ \\
\hline 171 & $\mathrm{sX}$ & & 01 & & 232 & & \\
\hline 172 & Spec & 25 & 01 & & 232 & & \\
\hline 173 & Spec & 25 & $0 \mathrm{l}$ & $01 M \mathrm{NH}_{4} \mathrm{ClO}_{4}$ & 2403 & & \\
\hline 174 & Spec & $20 \pm 01$ & 05 & $\mathrm{HClO}_{4}, \mathrm{HNO}_{3}$ & 2209 & & \\
\hline 175 & IX & 25 & 01 & $01 M \mathrm{NH}_{4} \mathrm{ClO}_{4}$ & 2332 & & \\
\hline \multirow[t]{2}{*}{176} & IX & 25 & 10 & $\mathrm{I} 0 \mathrm{M} \mathrm{NH}_{4} \mathrm{ClO}_{4}$ & 213 & & $\beta_{1}^{\prime}=1546$ \\
\hline & \multirow{2}{*}{\multicolumn{6}{|c|}{$\begin{array}{l}\text { Diethylphosphinylpropriontc aud (HDEPP), Ref } 17 \\
\text { IX } \quad 25 \quad 05\end{array}$}} & \\
\hline 179 & & & & & & & \\
\hline
\end{tabular}


Table 3.11 (Contınued)

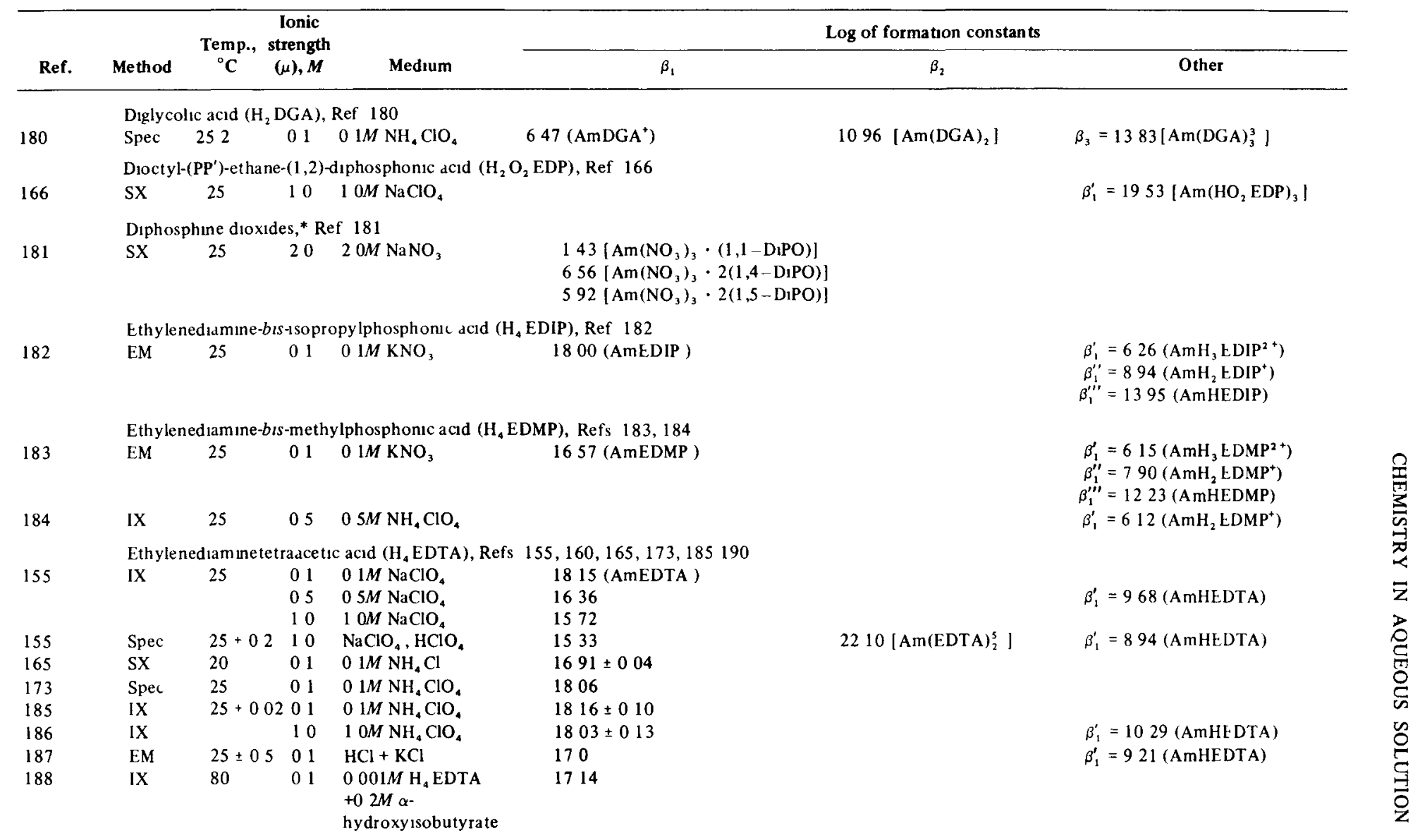


Ethylenediaminetetramethylphosphonic acid ( $\mathrm{H}_{8}$ EDTMP), Ref 19

Eth ylenediamuetetraproprionsc acid $\left(\mathrm{H}_{4}\right.$ EDTP), Ref 155

Spec $25+0210 \quad \mathrm{NaClO}_{4}, \mathrm{HClO}_{4} \quad 1884 \pm 002$ (AmLDTP)

I thyleneglycol bis 2 aminoethyltetradcetıc acid $\left(\mathrm{H}_{4}\right.$ EGTA), Ret 150

150$$
\text { IX }
$$$$
25
$$$$
0101 \mathrm{M} \mathrm{NH}_{4} \mathrm{ClO}_{4}
$$

1822 (AmEGTA)

Glycine (HGLYCN), Ref 192

192

$$
\text { SX }
$$

$$
25
$$

$2020 \mathrm{M} \mathrm{NaClO}$,

$069 \pm 002\left(\mathrm{AmGLYCN}^{2+}\right)$

Glycolk acid (HGLYC), Rets $146 \quad 155,193$
IX $\quad 20 \quad 05 \quad 05 M \mathrm{NaClO}_{4}$

$\begin{array}{lllll}\mathrm{SX} & 25 & 20 & 20 \mathrm{ONaClO}\end{array}$

Spec $25+0210 \quad \mathrm{NaClO}_{4}, \mathrm{HClO}_{4}$

IX $25 \quad 0505 \mathrm{M} \mathrm{NaClO}_{4}$

Hydrazine- $N N$-diacetic aud $\left(\mathrm{H}_{2}\right.$ Hy DA), Ret 155

IX $25 \quad 0101 M \mathrm{NaClO}_{4}$

$$
\begin{aligned}
& 282\left(\mathrm{AmGLYC}^{2+}\right) \\
& 259 \\
& 244+002 \\
& 257+002
\end{aligned}
$$

Hydrazineiminodiacetic acid ( $\mathrm{H}_{2}$ HyIDA), Ref 194
EM
25
$0101 M \mathrm{KNO}_{3}$
$1098\left(\mathrm{AmHyIDA}^{+}\right)$

$1074\left(\mathrm{AmHyDA}^{+}\right)$

2 hydroxycyclohexylethylened Iammetracets acid $\left(\mathrm{H}_{3}\right.$ HCEDTA), Ref 155

155

IX

25

$0101 M \mathrm{NaClO}$

1609 (AmHCEDTA)

$N^{*}\left(2\right.$ hydroxyethyl)ethylene- $N, N, N^{*}-$ tracetu acld $\left(H_{3}\right.$ NHEDTA), Rets $150,155173,195,196 \mathrm{~d}$

$\begin{array}{lllllll}150,195 & \mathrm{IX} & 25 & 01 & \mathrm{HClO}_{4}, \mathrm{NH}_{4} \mathrm{ClO}_{4} & 1572 \text { (AmNHEDTA) } & 2247 \text { [Am(NHEDTA) } \\ 156 & \text { Spec } & 25 \pm 02 & 10 & \mathrm{HClO}_{4}, \mathrm{NH}_{4} \mathrm{ClO}_{4} & 1484 & 2218 \\ 173 & \text { Spec } & 25 & 01 & 01 \mathrm{M} \mathrm{NH}_{4} \mathrm{ClO}_{4} & 1618 & \\ 196 \mathrm{~d} & \mathrm{IX} & 22 & 015 & \mathrm{HCl}, \mathrm{KCl} & 1534\end{array}$

196d

Hydroxyethylidenedıphosphonic acid (HEDPA), Ref 196b

$196 \mathrm{~b}$

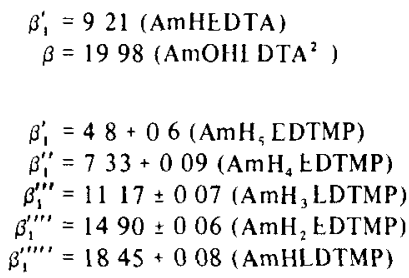

$\beta_{1}^{\prime}=921$ (AmHEDTA)

$\beta=1998$ (AmOHI DTA ${ }^{2}$ )

$\beta_{1}^{\prime}=48+06\left(\mathrm{AmH}_{4}\right.$ EDTMP $)$ $\beta^{\prime \prime}=733+009\left(\right.$ AmH $H_{4}$ EDTMP

$\begin{aligned} \beta_{1}^{\prime} & =733+009\left(\mathrm{AmH}_{4} \text { LDTMP }\right) \\ \beta_{1}^{\prime \prime \prime} & =1117 \pm 007\left(\mathrm{AmH}_{3} \text { LDTMP }\right)\end{aligned}$ $\beta_{1}^{\prime \prime \prime \prime}=1490 \pm 006\left(\mathrm{AmH}_{2}\right.$ EDTMP $)$ $\beta_{1}^{\prime \prime \prime \prime \prime}=1845+008$ (AmHLDTMP)

$\beta_{1}=1231$ (AmHEDTP)
$485\left[\mathrm{Am}(\mathrm{GLYC})_{2}^{+} \mid\right.$

$429 \pm 02$

$40 \mathrm{i}+0 \mathrm{i}$

$2020[\text { Am(Hy DA })_{2} \mid$

1997 |Am(HyIDA)

$\beta_{1}^{\prime}-413\left(\mathrm{AmHHylDA}^{2+}\right)$

$3,-744$ (AmHHC I DTA $)$ $\left.\beta_{3}={ }^{\prime} \mid \operatorname{Am}(\mathrm{H}, \operatorname{LDPA})_{3}^{3}\right) \mid$

(Table continues on next page 
Table 3.11 (Contınued)

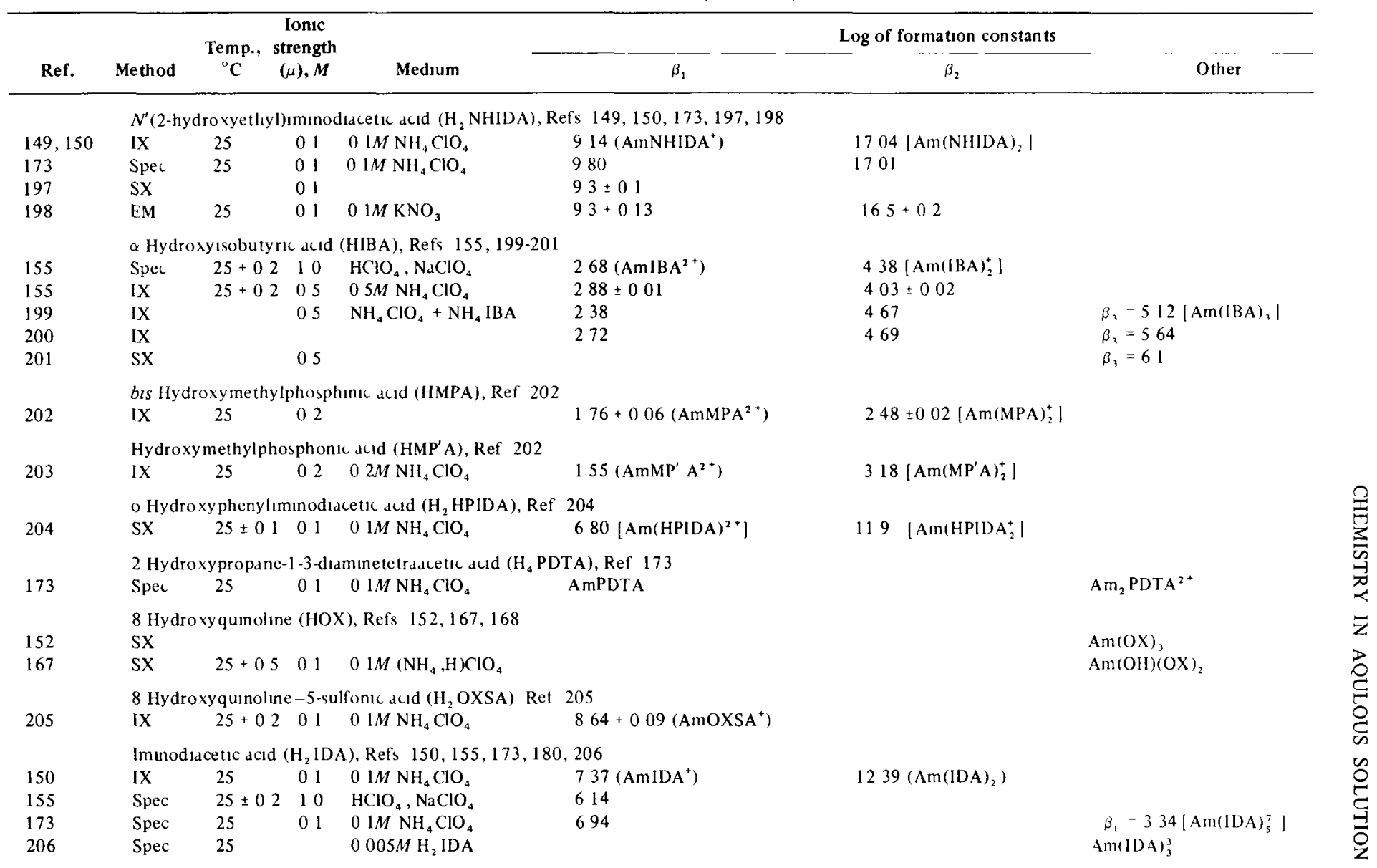


7-Iodo-8 hydroxyquinoline 5-sultonic acid ( $\mathrm{H}_{2}$ IOXSA), Ret 205

$\beta$ Isopropyltropolone (HIPT), Ref 153

$$
25 \quad 01 \quad \mathrm{NH}_{4} \mathrm{ClO}_{4}
$$

\section{Luctic dud (HLACT), Refs 148, 207-208}

$\begin{array}{llllll}148 & \mathrm{SX} & 25 & 20 & 2 \mathrm{OM} \mathrm{NH}_{4} \mathrm{ClO}_{4} & 252\left(\mathrm{AmLACT}^{2+}\right) \\ 207 & \mathrm{IX} & & 05 & 05 \mathrm{NH}_{4} \mathrm{ClO}_{4} & 277 \\ 208 \mathrm{a} & \mathrm{SX} & 20 & 05 & 05 \mathrm{NHH}_{4} \mathrm{ClO}_{4} & \\ 208 \mathrm{a} & \mathrm{IX} & 20 & 05 & 05 \mathrm{~N} \mathrm{NH}_{4} \mathrm{ClO}_{4} & \\ 208 \mathrm{~b} & \text { PEP } & 10 & 15 & \mathrm{KCl}+\mathrm{HLACT} & 257\end{array}$

$N$ Methylıminodiacefic acid ( $\mathrm{H}_{2}$ MIDA), Ref 150

$$
\text { IX } 25 \quad 0101 \mathrm{NH}_{4} \mathrm{ClO}_{4}
$$

$701\left(\right.$ AmMIDA $\left.^{+}\right)$

6 Methyl-2-picoline dud (HMAPS), Ref 205

$477\left[\mathrm{Am}(\mathrm{LACT})_{2}^{+}\right]$

464

421

$1251\left[\mathrm{Am}(\mathrm{MIDA})_{2}\right]$
$\beta_{3}=2137\left[\mathrm{Am}(\mathrm{IPT})_{3}\right]$

$\beta_{3}=598\left[\operatorname{Am}(\mathrm{LACT})_{3}\right]$

$\beta_{3}=571 \pm 003$

$\beta_{3}=573$

6-Methyl 2-picolyliminodiacetic aud ( $\mathrm{H}_{2}$ MPIDA), Ret 150

$$
25 \quad 0202 \mathrm{NH}_{4} \mathrm{ClO}_{4}
$$

(Methylphenylphosphunyl)-methylphenylphosphinic acid (HMPPA), Ret 209 $\begin{array}{lllll}\mathrm{SX} & 25 & 02 & 02 \mathrm{M} \mathrm{NH}_{4} \mathrm{ClO}_{4} & 335\left(\mathrm{AmMPPA}^{2+}\right)\end{array}$ Methylphosphinic dcid (HMPA), Ref 210

Napthoyltrifluoroacetone (HNTA), Ret 153

Nitralodiacetıcmonobutyric acid ( $H_{3}$ NDMBA), Refs 211,212

$$
\text { IX } \quad 25 \quad 01 \quad \mathrm{NH}_{4} \mathrm{ClO}_{4}
$$

Nitrilodiaceticmonoproprionic acid $\left(\mathrm{H}_{3}\right.$ NDAPA), Refs 211,212 
Table 3.11 (Contınued)

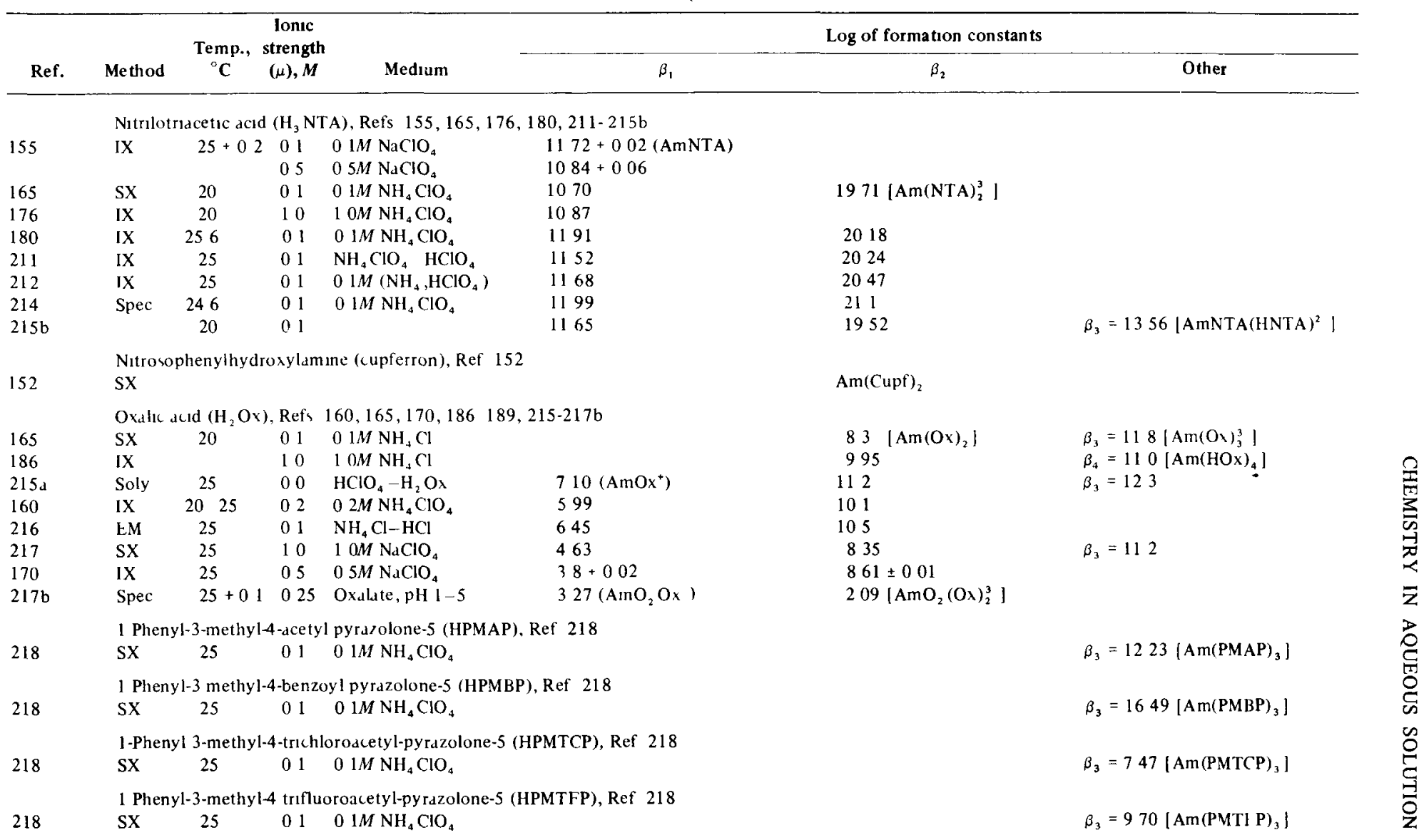


Phosphonoacetic acid ( $\mathrm{H}_{3}$ PAA), Ref 219

Pyridine-2-carbontc acud (HAPS) Ref 205

$\begin{array}{llll}25+02 & 0 \mathrm{l} & 0 \mathrm{IM} & \mathrm{NH}_{4} \mathrm{ClO}_{4}\end{array}$

205

IX $25+0201 \quad 01 M \mathrm{NH}_{4} \mathrm{ClO}_{4}$

$428+005\left(\mathrm{AmAPS}^{2+}\right)$

$309+007\left(\right.$ Am APSNO $\left.^{2+}\right)$

2-Picolyliminodiacetic acid (H, PIDA) Rets 149150

149,150

IX $25 \quad 0101 M \mathrm{NH}_{4} \mathrm{ClO}$

$896\left(\mathrm{Am}\left(\mathrm{PIDA}^{+}\right)\right)$

Propanetricarboxylic acid ( $\mathrm{H}_{3}$ PTA), Ret 154,155

154,155 Spec $25 \quad 1010 \mathrm{M} \mathrm{NaClO}_{4}$

a-Pyndylucetic aud (HAPAA) Ret 205

IX $25 \pm 0201 \quad 0 \mathrm{IM} \mathrm{NH}_{4} \mathrm{ClO}_{4}$

$561 \pm 007($ AmPTA $)$

$363+007\left(\mathrm{AmAPPA}^{2+}\right)$

Pyridine 3-carboxylk aud [Ncotinic acid] (HNIC), Ret 205

IX $25 \pm 0201 \quad 01 M \mathrm{NH}_{4} \mathrm{ClO}_{4} \quad 318+007\left(\mathrm{AmNIC}^{2+}\right)$

Pyrıdıne 2 6-dicarboxylic acid (H PDA), Ref 205

IX $25+020101 M \mathrm{NH}_{4} \mathrm{ClO}_{4} \quad 933 \pm 009$ (AmPDA ${ }^{+}$

Pyruvic acid (HPRUV), Ret 148

SX $25 \quad 20 \quad 20 \mathrm{NaClO}_{4} \quad 203$ (AmPRUV ${ }^{2+}$ )

bts 3-Methoxy-salicylıdenealdeliydee thylenedumune (B-3 MoxSCDI), Ref 220 SX $25\left(^{?}\right) \quad 0303 \mathrm{KNO}_{1}$

bıs-Salıcylıdenealdehydeethylenedımıne (BSLDI), Ref 220

SX $25(') \quad 0303 \mathrm{KNO}_{3}$

Squaric acid $\left(\mathrm{H}_{2} \mathrm{Sq}\right), \ddagger \operatorname{Ref} 221$

IX $25 \quad 10 \quad \mathrm{HClO}_{4}-\mathrm{NH}_{4} \mathrm{ClO}_{4} \quad 217\left(\mathrm{AmSq}^{+}\right)$

Tartaric dcid $\left(\mathrm{H}_{2}\right.$ TART), Refs $157,165,222$

IX $\quad 1 \mathrm{OMNH}_{4} \mathrm{Cl}$

$\begin{array}{lllll}\mathrm{SX} & 20 & 01 & 01 \mathrm{M} \mathrm{NH}_{4} \mathrm{Cl}\end{array}$

PLP (') (') (')

$39\left(\mathrm{AmTART}^{+}\right)$

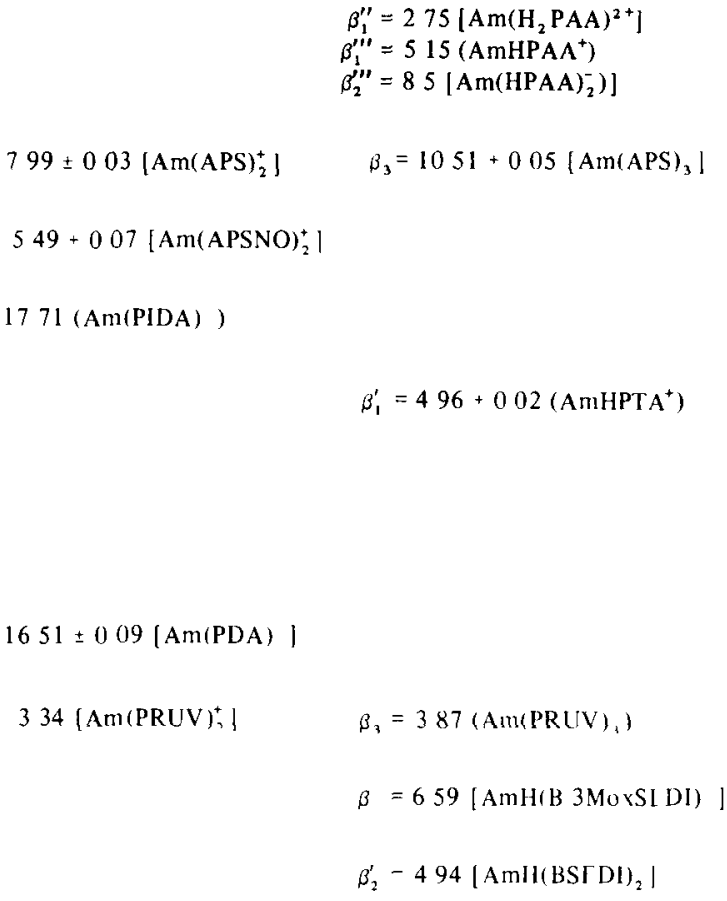

1771 (Am(PIDA)

$\beta_{1}^{\prime}=496+002\left(\right.$ AmHPTA $\left.^{+}\right)$

$1651 \pm 009(\mathrm{Am}(\mathrm{PDA})]$

334 (Am)(PRUV) $)^{+}$\}

$\beta_{3}=387$ (Amu(PRUV) $)$

$\beta=659[\mathrm{AmH}(\mathrm{B} 3 \mathrm{MorSI} \mathrm{DI})]$

$\beta_{2}^{s}-494\left[\mathrm{Amll}(\mathrm{BS} \digamma \mathrm{Dl})_{2}\right]$

$310(\mathrm{Am}(\mathrm{Sq})$,

107 [Am(TART) $_{2}$ ]

68

788 
Table 3.11 (Continued)

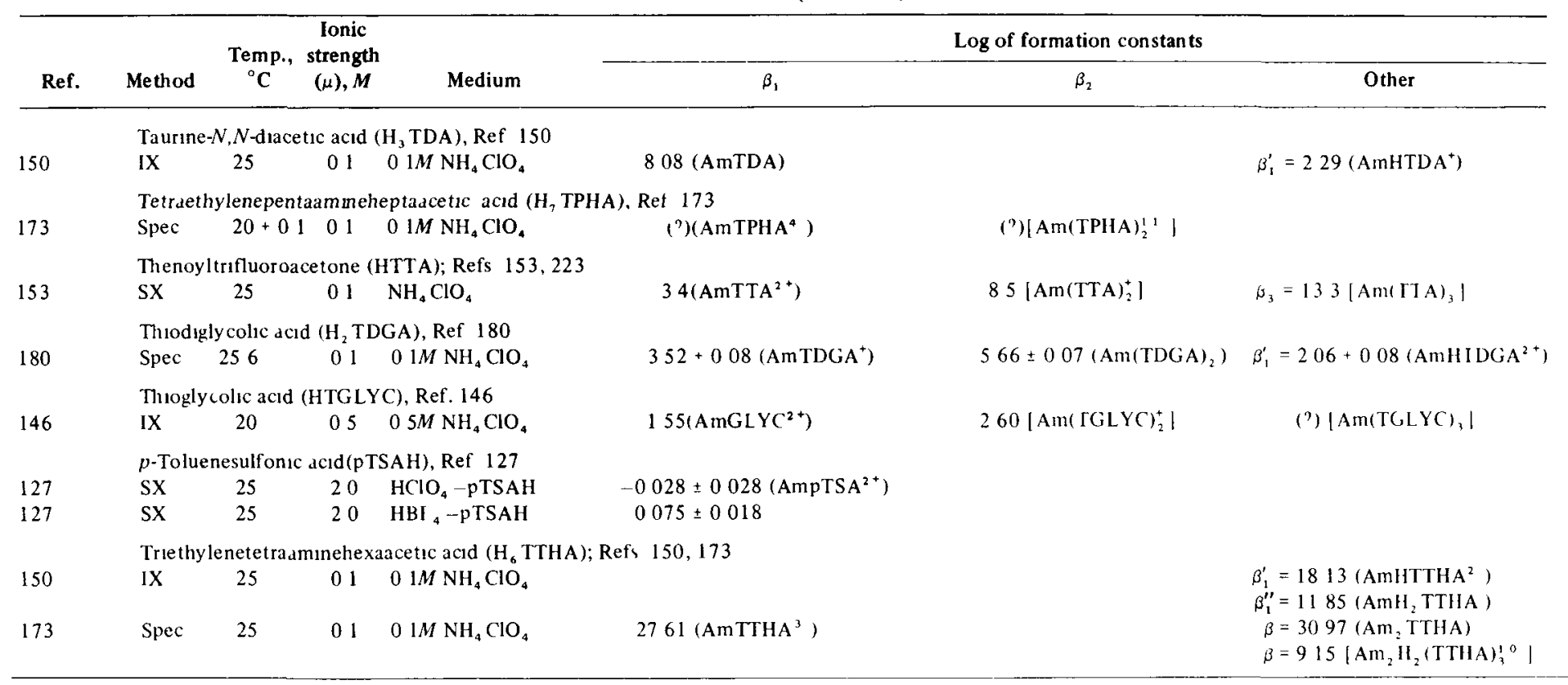

${ }^{*} 1,1-\mathrm{D} 1 \mathrm{PO}=\left(\mathrm{C}_{6} \mathrm{H}_{13}\right)_{2} \mathrm{P}(\mathrm{O}) \mathrm{CH}_{2}(\mathrm{O}) \mathrm{P}\left(\mathrm{C}_{6} \mathrm{H}_{13}\right)_{2}, 1,4 \quad \mathrm{D} 1 \mathrm{PO}=\left(\mathrm{C}_{6} \mathrm{H}_{1}\right)_{2} \mathrm{P}(\mathrm{O})\left(\mathrm{CH}_{2}\right)_{4}(\mathrm{O}) \mathrm{P}\left(\mathrm{C}_{6} \mathrm{H}_{1},\right)_{2} ; 1,5 \quad \mathrm{DiPO}=\left(\mathrm{C}_{6} \mathrm{H}_{11}\right)_{2} \mathrm{P}(\mathrm{O})\left(\mathrm{CH} \mathrm{H}_{2}\right)(\mathrm{O}) \mathrm{P}\left(\mathrm{C}_{6} \mathrm{H}_{1},\right)_{2}$

+ At $\mu=0$

$\checkmark$ Diketocyciobutenedıl

\&alculated value at $25^{\circ} \mathrm{C}$ and $\mu=01 \mathrm{M}$ 
for all data reported prior to 1974 * Earlier compilations of formation constants of americium complexes are those of Jones and Choppın, ${ }^{47 \mathrm{~b}}$ Martell and Sillen, ${ }^{24}$ Marcus, Givon, and Shiloh, ${ }^{2} 5 \mathrm{a}$ Keller, ${ }^{6 \mathrm{c}}$ and Gel'man et al $225 \mathrm{~b}$

The following abbreviations are used in Tables 310 and $311 \mathrm{Spec}$, spectrophotometry, Soly, solubility, SX, solvent extraction, IX, ion exchange, Relax, relaxation, EM, electromigration, Pot $T$, potentiometric titration, and PEP, paper electrophoresis

The constants $k_{1}$ and $\beta_{1}$ shown in Tables 310 and 311 are defined for the reaction of a cation $\mathrm{M}$ with a ligand $\mathrm{L}$ as follows

$$
\begin{gathered}
\mathrm{k}_{1}=\beta_{1}=\frac{[\mathrm{ML}]}{[\mathrm{M}][\mathrm{L}]}, \mathrm{k}_{2}=\frac{\left[\mathrm{ML}_{2}\right]}{[\mathrm{ML}][\mathrm{L}]}, \mathrm{k}_{3}=\frac{\left[\mathrm{ML}_{3}\right]}{\left[\mathrm{ML}_{2}\right][\mathrm{L}]}, \text { etc } \\
\beta_{2}=\frac{\left[\mathrm{ML}_{2}\right]}{[\mathrm{M}][\mathrm{L}]^{2}}, \beta_{3}=\frac{\left[\mathrm{ML}_{3}\right]}{[\mathrm{M}][\mathrm{L}]^{3}} \text {, etc }
\end{gathered}
$$

and

$$
\beta_{2}=k_{1} k_{2}, \beta_{3}=k_{1} k_{2} k_{3} \text {, etc }
$$

\section{Complexes with Inorganic Ligands}

All the formation constants listed in Table 310 are for complexes formed by Am(III) $\operatorname{Keller}^{6 c}$ observes that the complex formation of trivalent americium is probably better known than that of any other trivalent actınide element but that very little work has been done on complexes of Am(>III) Color changes (Table 31 ) indicate existence of $\mathrm{Am}(\mathrm{VI})$ nitrate, sulfate, and fluoride complexes There is also spectrophotometric evidence ${ }^{26}$ for the existence in $1 M \mathrm{NaOH}$ solution of a peroxide complex of Am(V) Quantitative data are lackıng for the identity of these latter complexes and their formation constants

Attempts to seek correlations within the data on formation constants of actinide complexes are largely frustrated, as pointed out by Jones and Choppin, ${ }^{47 \mathrm{~b}}$ by the wide range of ionic strengths and supporting electrolytes used However, at an ronic strength of $10 M$ to $20 M$, the stability sequence for complexes of Am( III) with monovalent inorganic ligands appears to be

$$
\mathrm{F}>\mathrm{H}_{2} \mathrm{PO}_{4}^{-}>\mathrm{SCN}^{-}>\mathrm{NO}_{3} \geqslant \mathrm{Cl}>\mathrm{ClO}_{4}^{-}
$$

*A recent paper by $E$ M Rogozına, L F Konkina, and D $\mathrm{K}$ Popov published in Radiokhimiya 16383 (1974) [Soviet Radiochemtstry (English Translation) 16. 382 (1974)] lists formation constants for complexes formed by Am(III) with various amino acids 
(The formation constant for $\mathrm{AmSCN}^{2+}$ recently determined by Chianizia, et al ${ }^{126}$ is notably out of line with values measured by other investigators ) Americium(III) forms relatively strong complexes with $\mathrm{SO}_{4}^{2-}$ and $\mathrm{P}_{3} \mathrm{O}_{9}^{3-}$ ions

The complexing behavior of $\mathrm{Am}^{3+} \cdot$ aq indicates 1 t, like other actinide and lanthanide 1ons, is a Chatt-Ahrland 227 type "A" or Pearson 228 a "hard" cation with a characteristic coordindtion number" ${ }^{118}$ of 8 or 9 in aqueous solution Association of $\mathrm{Am}^{3+}$ with inorganic ligands proceeds initially through electrostatic interactions to form outer-sphere complexes In some cases (e g, F, $\mathrm{SO}_{4}^{2}$ ), however, there is thermodynamic evidence (see pages 75 and 77 ) that the higand displaces the water of hydration, at least to some extent, to form inner-sphere complexes Spectrophotometric results of Marcus and Shiloh ${ }^{9} 108$ also provide evidence for inner-sphere complexation of chloride and nitrate to $\mathrm{Am}^{3+}$ in concentrated $\mathrm{LiCl}$ and $\mathrm{L}_{1} \mathrm{NO}_{3}$ solutions, respectively Preparation of the solid compound $\left[\left(\mathrm{C}_{6} \mathrm{H}_{5}\right)_{3} \mathrm{PH}\right]_{3}$ and $\mathrm{AmCl}_{6}$, contanning the octahedral hexahalide complex $\mathrm{AmCl}_{6}^{3-}$, has been described by Ryan ${ }^{119}$ Spectra of solutions of $\left[\left(\mathrm{C}_{6} \mathrm{H}_{5}\right)_{3} \mathrm{PH}\right]_{3}$ $\mathrm{AmCl}_{6}$ in propylene carbonate and in 15 vol \% acetonitrile $-85 \%$ vol \% succinonitrile were measured by Marcus and Bomse ${ }^{118}$

The stability of $\mathrm{Am}^{3+}$ complexes in many cases is similar to that of complexes of lanthanıdes of equal ıonic radius In some cases, however, where bonding presumably involves f electrons, the stability of the $\mathrm{Am}^{3+}$ complex is slightly greater than that of the corresponding lanthanide complex $228 \mathrm{~b}$ Advantage can be taken of this difference in stability to effect a separation of $\mathrm{Am}^{3+}$ from lanthanide elements The properties of $\mathrm{Am}^{3+}$-chloride and thocyanato complexes are particularly useful (Chap 5) for this latter purpose. Ion-exchange studies $25,229-232$ with both anion resins and long-chain amine hydrohalides show that $\mathrm{Am}^{3+}$ in concentrated $\mathrm{LiCl}$ and $\mathrm{HCl}$ solutions is complexed with the probable formation of the species $\mathrm{AmCl}_{4}$ and $\mathrm{L}_{1} \mathrm{~A}_{2} \mathrm{AmCl}_{6}$ in the organic resin and amine phases, respectively (In the $\mathrm{LiA}_{2} \mathrm{AmCl}_{6}$ species, $\mathrm{A}^{+}$is the result of the dissociation of one chloride ion from an amine hydrochlonde aggregate ${ }^{233}$ ) The predominant aqueous-phase species in the concentrated $\mathrm{LiCl}$ and $\mathrm{HCl}$ solutions is $\mathrm{AmCl}_{2}^{+}$

\section{Complexes with Organic Ligands}

Other than those for acetate, diethylenetriaminepentaacetic acid (DTPA), ethylenediaminetetraacetic acid (EDTA), and oxalate complexes of $\mathrm{Am}(\mathrm{V})$, all the data in Table 311 are for complexes of Am(III). The higher oxidation states of americium are relatively strong oxıdızing agents and are not stable in the presence of most organic complexants

For three-quarters of the approximately 80 different organic ligands listed in Table 3.11, formation constants of complexes with Am(III) have been measured only once by a single group of investigators. The accuracy of these formation constants cannot be fully determined in the absence of comparative data. In contrast, formation constants for complexes of Am(III) with hydroxycarboxylic (e.g., citric, glycolic, 
lactic, and tartanc) and aminopolycarboxylic $\left(\mathrm{H}_{5}\right.$ DTPA, $\mathrm{H}_{4}$ EDTA, $\mathrm{H}_{3} \mathrm{NTA}$, etc $)$ acids so useful in separative work have been determined by many investigators using a variety of experimental conditions and technıques. For these latter complexants, with some obvious exceptions (e.g., data for citric and tartanic acids), formation constants determined by the several investigators for a particular complex at a given ionic strength are in farly good agreement

Examination of the results in Table 3.11 reveals that aminopolycarboxylic acids complex Am(III) more strongly than do either hydroxycarboxylıc or amınoalkylpolyphosphoric acıds (e.g., ethylenediamıne-bıs-methylenephosphonic acid) Keller ${ }^{6 \mathrm{C}}$ observes that in the series of $\alpha$-hydroxycarboxylic acids (e g., glycolic and lactic) the stability of the americium complex decreases with increasing number of carbon atoms The stability of the complexes of $\mathrm{Am}^{3+}$ with aminopolycarboxylic acids increases linearly ( $F_{1 g} 313$ ) with the number of bound donor atoms of the ligand Reference has already been made to the changes in the absorption spectrum of $\mathrm{Am}^{3+}$ as the result

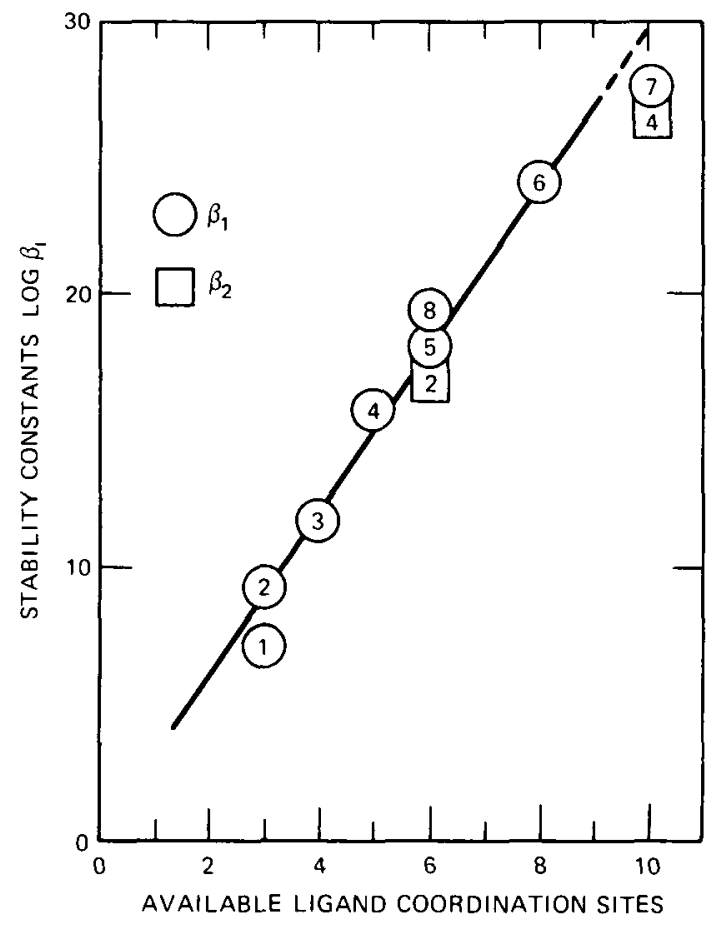

Fig. 3.13 Correlation of stability constants with number of avalable coordination sites 1 , Imınodıacetıc acıd, 2, N-hydroxyethylımınodıacetıc acid, 3, nitrlotriacetıc acıd, 4, N-hydroxyethylethylenedımınetriacetıc acid, 5, ethylenedıaminetetraacetıc acid, 6, diethylenetriaminepentaacetıc acid, 7, triethylenetetraaminehexaacetic acid, 8, diamınocyclohexanetetraacetic acid [From C Keller, The Chemistry of the Transurantum Elements, Verlag Chemie GmbH, Weinherm, 1971] 
of complex formation; illustrative of such changes is the spectrum of $\mathrm{Am}^{3+}$ in $0.1 \mathrm{M}$ $\mathrm{NaClO}_{4}-0.005 \mathrm{M} \mathrm{H}_{3} \mathrm{NTA}$ solutions at different pHs (Fig. 3.14).

Various Russian scientists ${ }^{23-238}$ are' currently seeking ways to estimate and correlate the strengths of complexes of $\mathrm{Am}^{3+}$ and other trivalent actinides and lanthanides with various organic ligands. Shalinets, ${ }^{235}$ in particular, suggests a "rule of additivity of the strength of rings" according to which, under similar steric conditions, the logarithm of the thermodynamic formation constant of the complex is proportional to the sum of the strengths of the individual rings

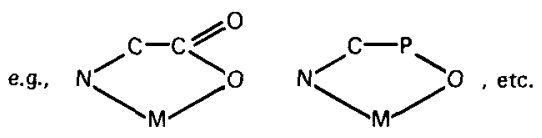

contained in it; i.e.,

$$
\log \beta_{0}^{0}=\sum_{\mathrm{i}} \mathrm{N}_{\mathrm{i}} \epsilon_{\mathrm{i}}
$$

where $\mathrm{N}_{\mathrm{i}}$ and $\epsilon_{\mathrm{i}}$ are, respectively, the number and strength of the rings in the complex and $\beta_{0}^{0}$ is the thermodynamic formation constant calculated by means of the Davies equation from the formation constant determined at a particular ionic strength. Shalinets ${ }^{235}$ has estimated $\epsilon$ values for various rings as well as discussed the influence of various factors such as the basicity of the donor atoms, the presence of substituents in the ring, and the number and size of the rings. The general utility and validity of Shalinet's approach has not been completely established, but, in a few test cases at least, formation constants of americium chelates calculated by Eq. 3.45 are in good agreement with experimental data.

Americium(III) also forms many neutral organic-phase soluble salts and chelate adducts [e.g., $\mathrm{Am}\left(\mathrm{NO}_{3}\right)_{3} \cdot 3(\mathrm{RO})_{3} \mathrm{PO}$ ] with various organophosphorus compounds and also with thenoyltrifluoroacetone. Formulas and formation constants for some of these entities are listed in Chap. 5; more complete listings are given in Refs. $6 c, 147$, and 201 .

\section{Thermodynamics and Kinetics}

Thermodynamic functions have been determined for only a few complexes of $\mathrm{Am}^{3+}$. These data, which are collected in Table 3.12, provide evidence for the structures of these complexes in aqueous solution. The thermodynamic changes on complexation of $\mathrm{Am}^{3+}$ are the result of two contributions: exothermic enthalpy and negative entropy due to the association of the cation with the ligand and endothermic enthalpy and positive entropy due to the dehydration of the cation and anion. A high positive net change of the entropy indicates inner-sphere complexing. Thus, from the magnitude of the $\Delta \mathrm{H}$ and $\Delta \mathrm{S}$ terms for $\mathrm{AmSO}_{4}^{+}$, Carvalho and Choppin ${ }^{243}$ conclude that the degree of inner-sphere complexation present is at least comparable to, and 


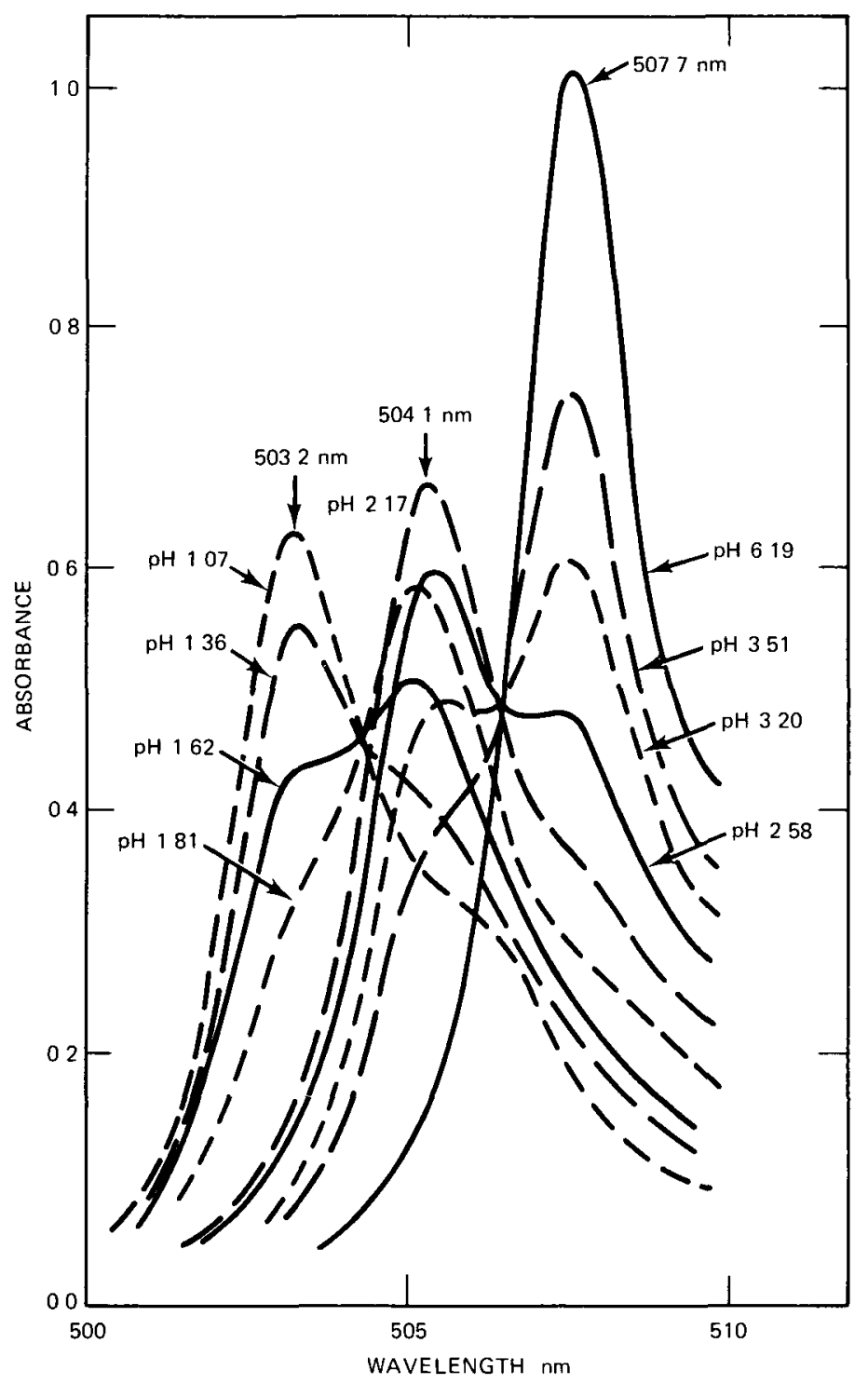

Fig. 3.14 Absorption spectrum of Am(III) in $01 M \mathrm{NaClO}_{4}-0005 M \mathrm{H}_{3}$ NTA solution at dıfferent pHs [From S H Eberle and C S Sabau, The Thermodynamics of Am(III)-Nitrilotracetic Acid Complexes, Radiochemical and Radtoanalytical Letters, 11: 77 (1972) ] 
Table 3.12

THERMODYNAMIC FUNCTIONS FOR COMPLEXES OF Am(III)

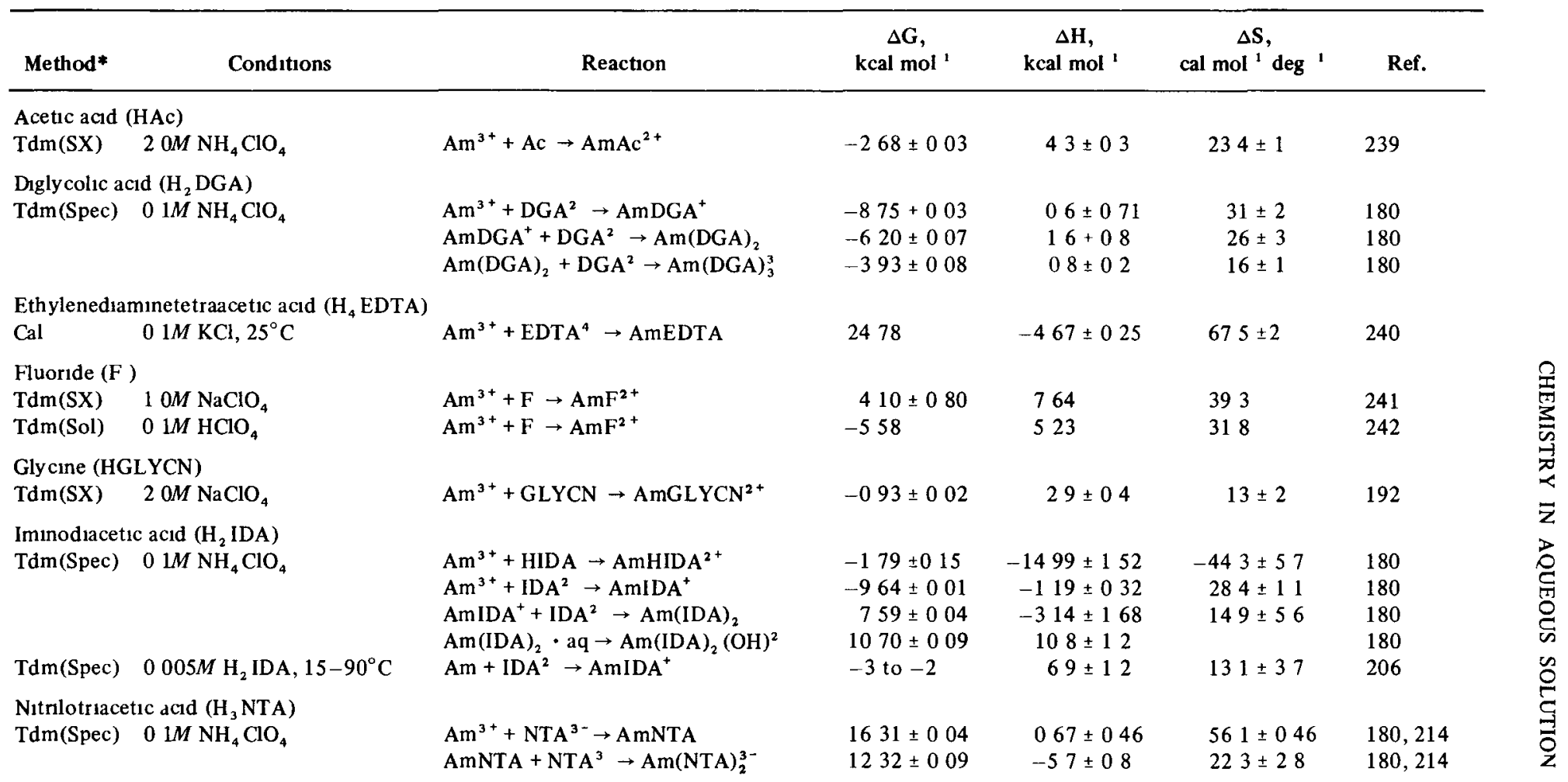


Sulfate $\left(\mathrm{SO}_{4}^{2}\right)$

\begin{tabular}{|c|c|c|c|c|c|c|}
\hline $\operatorname{Tdm}(\mathrm{SX})$ & $20 \mathrm{M} \mathrm{NaClO}_{4}$ & $\mathrm{Am}^{3+}+\mathrm{SO}_{4}^{2} \rightarrow \mathrm{AmSO}_{4}^{+}$ & -20 & 44 & 21 & 243 \\
\hline \multicolumn{7}{|c|}{ Thiocyanate (SCN) } \\
\hline $\operatorname{Tdm}(S X)$ & $10 M \mathrm{NaClO}_{4}$ & $\begin{array}{l}\mathrm{Am}^{3+}+\mathrm{SCN} \rightarrow \mathrm{AmSCN}^{2+} \\
\mathrm{Am}^{3+}+\mathrm{SCN}^{-} \rightarrow \mathrm{AmSCN}^{2+}\end{array}$ & $\begin{array}{l}-069 \pm 002 \\
-081+007\end{array}$ & $\begin{array}{r}-436 \pm 030 \\
253 \pm 029\end{array}$ & $\begin{array}{l}-123 \pm 10 \\
112\end{array}$ & $\begin{array}{l}138 \\
139\end{array}$ \\
\hline $\operatorname{Tdm}(\mathrm{SX})$ & $50 M\left(\mathrm{ClO}_{4}+\mathrm{SCN}\right) 10-55^{\circ} \mathrm{C}$ & $\begin{array}{l}\mathrm{Am}^{3+}+\mathrm{SCN} \rightarrow \mathrm{AmSCN}^{2+} \\
\mathrm{Am}^{3+}+3 \mathrm{SCN}^{-} \rightarrow \mathrm{Am}(\mathrm{SCN})_{3} \\
\mathrm{AmSCN}^{+}+2 \mathrm{SCN} \rightarrow \mathrm{Am}(\mathrm{SCN})_{3} \\
\mathrm{Am}^{3+}+3 \mathrm{SCN}^{-1} \rightarrow \mathrm{Am}(\mathrm{SCN})^{2+}\end{array}$ & $\begin{array}{r}-047 \pm 002 \\
-019 \pm 015 \\
028 \pm 016 \\
-0813+0074\end{array}$ & $\begin{array}{l}16 \pm 07 \\
-64 \\
-85 \\
281 \pm 049\end{array}$ & $\begin{aligned} 7 & \pm 2 \\
20 & \pm 15 \\
-27 & +16 \\
120 & +16\end{aligned}$ & $\begin{array}{l}140 \\
140 \\
140 \\
141 \mathrm{~b}\end{array}$ \\
\hline $\begin{array}{l}\text { Thiodiglycol } \\
\text { Tdm(Spec) }\end{array}$ & $\begin{array}{l}1 \mathrm{C} \text { acld }\left(\mathrm{H}_{2} \mathrm{TDGA}\right) \\
01 \mathrm{M} \mathrm{NH}_{4} \mathrm{ClO}_{4}\end{array}$ & $\begin{array}{l}\mathrm{Am}^{3+}+\mathrm{HTDGA}^{3} \rightarrow \mathrm{AmHTDGA}^{2+} \\
\mathrm{Am}^{3+}+\mathrm{TDGA}^{2} \rightarrow \mathrm{AmTDGA}^{+} \\
\left.\mathrm{AmTDGA}^{+}+\mathrm{TDGA}^{2} \rightarrow \mathrm{Am}^{-1} \mathrm{TDGA}\right)_{2}^{-}\end{array}$ & $\begin{array}{l}-275+019 \\
-488 \pm 009 \\
-285+012\end{array}$ & $\begin{aligned} &-708 \pm 098 \\
& 676 \pm 112 \\
& 888 \pm 066\end{aligned}$ & $\begin{array}{r}-145 \pm 39 \\
391 \pm 42 \\
394 \pm 24\end{array}$ & $\begin{array}{l}180 \\
180 \\
180\end{array}$ \\
\hline
\end{tabular}

*Tdm, temperature dependence measurements, Spec, spectrophotometry, cal, calorımetry, SX, solvent extraction, Sol, solubility 
probably exceeds, that of the outer-sphere complexation By the same criteria, monodentate complexes of $\mathrm{Am}^{3+}$ with fluoride, glycine, and ethylenediaminetetracetic, nitrilotriacetic and diglycolic acids are all also inner sphere complexes

Jones and Choppin ${ }^{46}$ emphasize the importance of the disruption of the hydration sphere of $\mathrm{Am}^{3+}$ and other actinide ions in complexing thermodynamics Their estımates of the entropy and enthalpy of hydration of $\mathrm{Am}^{3+}$ and $\mathrm{Am}^{4+}$ are listed in Table 32

On the basis of the limited data avalable, Moskvin ${ }^{244}$ has presented some generalizations of the thermodynamics of the formation of actinide ions in aqueous solutions His analysis includes discussion of the heat capacities of triply charged actinide ions and the changes in their heat capacities on hydration and when transferred from a crystal lattice to solution Moskvin concludes that further accumulation of thermochemical data for actinide ions, including those of americium, is one of the most urgent contemporary problems in actinıde chemistry

Kinetics of the exchange reaction

$$
\mathrm{EuEDTA}+\mathrm{Am}^{3+} \rightarrow \mathrm{Eu}^{3+}+\mathrm{AmEDTA}
$$

were studied in an aqueous acetate buffer solution of $\mu=01 M^{245-247}$ In the pH range 55 to 65 , Choppin and Williams ${ }^{245}$ find that the exchange obeys the overall rate law

$$
\begin{aligned}
\text { Rate }= & \left\{\frac{\mathrm{k}_{\mathrm{A}}^{1}[\text { EuEDTA }]\left[\mathrm{Am}^{3+}\right]}{\left[\mathrm{Eu}^{3+}\right]}-\mathrm{k}_{\mathrm{C}}[\text { AmEDTA }]\right\}\left[\mathrm{H}^{+}\right] \\
& +\left\{\mathrm{k}_{\mathrm{B}}^{1}\left[\mathrm{EuEDTA}^{-}\right]\left[\mathrm{Am}^{3+}\right]-\mathrm{k}_{\mathrm{D}}^{1}\left[\mathrm{Eu}^{3+}\right][\text { AmEDTA }]\right\}^{3}
\end{aligned}
$$

Equation 347 correlates with a reaction that proceeds via two pathways, the first set of braces can be associated with an acid-catalyzed mechanism, and the second set represents an acid independent reaction path The two paths have approximately equal probability at $\mathrm{pH} 64$ Activation parameters ${ }^{247}$ for the exchange reacion are $\Delta \mathrm{H}^{*}=$ $107 \mathrm{kcal} \mathrm{mol}^{-1}$ and $\Delta \mathrm{S}^{*}=-122 \mathrm{cal} \mathrm{mol}^{-1} \mathrm{deg}^{-1}$

El-Rawı, ${ }^{248}$ in a recently published thesis, reported results of studies of the kinetics of complexing of americium by the aminopolycarboxylic acids, $\mathrm{H}_{5}$ DTPA, $\mathrm{H}_{4}$ EDTA, $N$-hydroxyethylethylenediaminetriacetic acid $\left(\mathrm{H}_{3}\right.$ NHEDT A), and diaminocyclohexanetetraacetic acid $\left(\mathrm{H}_{4}\right.$ DCTA) Rates of ligand exchange between $\mathrm{Am}^{3+}$ and LaX were studied According to El Rawı, ${ }^{248}$ ligand exchange proceeds as a first-order reaction in the presence of excess $\mathrm{LaX}$ Respective rate constants for the ligand exchange increase in the order $\mathrm{H}_{3}$ NHEDTA $>\mathrm{H}_{4}$ EDTA $>\mathrm{H}_{5}$ DTPA $>\mathrm{H}_{4}$ DCTA, $\mathrm{H}_{4}$ DCTA reacts especially slowly, probably because of steric hindrance to chelate formation Two different reaction mechanisms appear operative in this system (1) direct reaction of $\mathrm{Am}(\mathrm{III})$ and $\mathrm{LaX}$ and (2) a hydrogen ion catalyzed dissociative reaction $\mathrm{LaX}-\left(\mathrm{H}^{+}\right) \rightarrow \mathrm{HX}(\mathrm{Am}) \rightarrow \mathrm{AmX}$ 


\section{REFERENCES}

1. a. N. N. Krot, V.P. Shlov, V. B. Nikolaevskı, A. K. Nikaev, A. D. Gel'man, and V. I. Spitsyn, Preparation of Americium in Heptavalent State, Dokl Akad Nauk SSSR, 217(3) 589 (1974) through USAEC Report ORNL-tr-2828, 1974.

b L J Mullins, A J Beaumont, and J A Leary, Distribution of Americium Between Liquid Plutonium and a Fused Salt Evidence for Divalent Americium, J Inorg Nucl Chem 30: 147 (1968), USAEC Report LA-3562. Los Alamos Scientific Laboratory, May 1966

2. T. H. Keenan, Amencium and Curıum, J. Chem. Educ, 36: 27 (1959).

3. J. Jove and M. Pages, Sur le Comportement de Queloues Elements $4 \mathrm{f}$ et $5 \mathrm{f}$ Dans l'Ammoniac Liquide, Radiochem. Radioanal. Lett, $11: 7$ (1972).

4. B. F. Myasoedov and K. Myuzikas, The Polarographic Reduction of Trivalent Americium in Acetonitrile Medium, Radıokhımıya, 12: 856 (1970) through Sov. Radiochem. (Engl Transl.), 12: 826 (1970).

5. B. F. Myasoedov and K. Myuzikas, Polarographic Reduction of Americium(III) in Acetonitrile, Radiochem. Radioanal. Lett., 2: 21 (1969).

6. a. F. David, Etude Polarographique de Lanthanıdes et d'Elements cls et Transurantens, Radiochem. Radioanal Lett., 5: 279 (1970).

b. L. J. Nugent, Standard Electrode Potentials and the Enthalpies of Formation of Some Lanthanide and Actinide Aquo-Ions, J. Inorg Nucl. Chem., 37: 1767 (1975).

c C Keller, The Chemistry of the Transurantum Elements, Verldg-Chemie GmbH, Weinheim, 1971

7. a. J. J. Howland and M Calvin, Paramagnetıc Susceptibilities and Electronic Structure of Aqueous Cations of Elements 92 to 95, J. Chem. Phys., 18: 239 (1950), USAEC Report UCRL-206, University of California, Lawrence Radiation Labordtory, November 1948.

b. H. A. Friedman and J. T. Bell, A Search for Laser Phenomena in the Actinides Studies of the Investigations of $\mathrm{Am}^{3+}$ in Liquid $\mathrm{POCl}_{3}$, J. Inorg. Nucl. Chem., 34: 3928 (1972).

8. B. Désiré, M. Hussonnoss, and R. Guillaumont, Determination de la Premiere Constante d'Hydrolyse l'Americium, du Curıum, du Berkelıum, et du Calıfornıum, Compt. Rend., Parls, Ser. C, 269: 448 (1969).

9. a. B. Désiré, Determination of the First Hydrolysis Constant for Trivalent Elements of the Series ' $4 \mathrm{f}$ ' and ' $5 \mathrm{f}$ ', Thesis, USAEC file No. NP-18284, 1970.

b. M. Hussonno1s, S. Hubert, L. Brillard, and R. Guillaumont, Determination de la Première Constante d'Hydrolyse de l'Einsteınıum, Radiochem. Radioanal. Lett, 15: 47 (1973).

10. B. Marın and T. Kıkında1, Étude Comparee de l'Hydrolyse de l'Europium, et de l'Americium en Milieu Chlorure par Électrophorese sur Papier, Compt. Rend, Parts, Ser C, 268: 1 (1969).

11. A. B. Shalinets and A. V. Stepanov, Investigation of Complex Formation of the Trivalent Actinide and Lanthanide Elements by the Method of Electromigration. XVII. Hydrolysis, Radiokhimiya, 14: 280 (1972) through Sov Radiochem. (Engl Transl), 14: 290 (1972).

12. Yu. S. Korotkin, Study of Transplutonium Element Hydrolysis. II Hydrolysis of Amer1cium(III) in Presence of Ions with Positive and Negative Hydration Energy, Radiokhımıya, 15: 766 (1973) through Sov Radiochem. (Engl. Transl), 15: 776 (1973).

13. a. Yu. S. Korotkin, Hydrolysis of Transuranium Elements II Hydrolysis of Americium(III) and Curium(III) in Pure Nitric Acid Solutions, Radiokhımiya, 15: 671 (1973) through Sov Radiochem (Engl Transl), 15: 677 (1973)

b Yu. S Korotkin, Hydrolysis of Transuranium Elements. IV Sorption Homogeneity of Microamounts of Americium(III), Radiokhimiya, 16: 217 (1974) through Sov Radiochem. (Engl. Transl.), 16: 218 (1974).

c. Yu. S. Korotkin, Hydrolysis of Transuranium Elements. V. Hydrolysis of Americium and Curium in Perchloric Acid Solutions, Radiokhimiya, 16: 221 (1974) through Sov Radlochem (Engl. Transl), 16: 223 (1974) 
14 L B Asprey and R A Penneman, Furst Observation of Aqueous Tetravalent Americium, $J$ Amer Chem Soc 83: 2200 (1961)

15 L B Asprey and R A Penneman, Preparation and Properties of Aqueous Tetravalent Americium, Inorg Chem, 1: 134 (1962)

16 E Yanir, Y Marcus, and M Givon, A Prediction of the Reldtive Stabilization of the Higher Oxidation States of Am in Solution, in Progress in Coordination Chemistry, M Cais (Ed), Elsevier Publishing Co, New York, 1968

17 E Yanir, $M$ Givon, and $Y$ Marcus, Higher Oxidation States of Americium in Phosphate Solutions, Inorg Nucl Chem Lett 5: 369 (1969)

18 a B F Myasoedov, V M Mikhallov, I A Lebedev, O E Koiro, and V Ya Frenkel, Prepdration and Stability of Am(IV) and Am(VI) in Phosphoric Acid Solutions, Radiochem Radioanal Lett 14: 17 (1973)

b B F Myasoedov, M S Milyukova, I A Lebedev, M N Litvina, and V Ya Frenkel, Behavior of Amencium(IV) in Phosphoric Acid Solution, J Inorg Nucl Chem, 37: 1475 (1975)

c B F Myasoedov, I A Lebedev, and M S Mlyukova, Preparation and Stability of Americium in Highest Oxidation States in Phosphoric Acid Solutions, in Transplutonium Elements Proceedings of the 4 th International Symposium, Baden-Baden, September 13-17, $1975 \mathrm{~W}$ Muller and R Lindner (Eds), North-Holland Publishing Company, Amsterdam, 1976

19 J P Nigon, R A Penneman, E Staritzky, T K Keenan, and L B Asprey, Alkalı Carbonates of $\mathrm{Np}(\mathrm{V}), \mathrm{Pu}(\mathrm{V})$, and Am(VI), J Phys Chem. 58. 403 (1954)

$20 \mathrm{~T}$ K Keenan, Latuce Constants of Some Alkalı Metal Actınyl(V) Compounds, Inorg Chem, 4: $1500(1965)$

$21 \mathrm{~T}$ K Keenan and F H Kruse, Potassium Double Carbonates of Pentavalent Neptunium, Plutonium, and Americium, Inorg Chem 3: 1231 (1964)

22 J S Coleman, T K Keenan, L H Jones, W T Carnall, and R A Penneman, Preparation and Properties of Americium(VI) in Aqueous Carbonate Solutions, Inorg Chem, 2: 58 (1963)

23 G A Burney, Separation of Americium from Curium by Precipitation of $\mathrm{K}_{3} \mathrm{AmO}_{2}\left(\mathrm{CO}_{3}\right)_{2}$, Nucl Appl 4:217(1968)

$24 \mathrm{~F} \mathrm{H}$ Ellinger and $\mathrm{W} \mathrm{H}$ Zachariasen, The Crystal Structure of $\mathrm{KPuO}_{2} \mathrm{CO}_{3}, \mathrm{NH}_{4} \mathrm{PuO}_{2} \mathrm{CO}_{3}$, and $\mathrm{RbAmO}_{2} \mathrm{CO}_{3}, J$ Phys Chem , 58: 405 (1954)

$25 \mathrm{G} \mathrm{N}$ Yakovlev and D S Gorbenko-Germanov, Coprecipitation of Amencium(V) with Double Carbonates of Uranium(VI) or Plutonium(VI) with Potassium, in Proceedings of the International Conference on the Peaceful Uses of Atomic Energy, 1955 Vol 7, p 306, United Nations, New York, 1956

26 L B Werner and I Perlman, The Pentavalent State of Americium, J Amer Chem Soc, 73: 495 (1950), USAEC Report AECD-2898, June 1950

27 L B Asprey, S E Stephanou, and R A Penneman, Hexavalent Americium, J Amer Chem Soc, 73: 5715 (1951), USAEC Report AECU-927, Los Alamos Scientific Laboratory, 1950

28 M Hara, The Chemistry of Americium I A Study of the Preparation of Am(V) and Its Behavior by Means of TTA Extraction, Bull Chem. Soc Jap , 43: 89 (1970)

29 A Keller, L Koch, and K H Walter, Die Reaktion der Transuranoxide mit Alkalioxıden-II Ternare Oxide der Funfwertigen Transurane und des Protactıniums mit Lithium and Natrium, J Inorg Nucl Chem, 27: 1225 (1965)

30 a L B Asprey, S E Stephanou, and R A Penneman, A New Valence State of Americium, Am(VI), $J$ Amer Chem Soc, 72: 1425 (1950), USAEC Reports LADC-739 and AECD-2950, Los Alamos Scientific Laboratory

b R A Penneman, Los Alamos Scientific Laboratory, personal communication, 1974

31 L J Nugent, Chemical Oxidation States of the Lanthanides and Actınides, Reviews $m$ Inorganic Chemistry Series $2 \mathrm{MTP} /$ Butterworths in press 
32 R A Penneman, J S Coleman, and T K Keenan, Alkaline Oxidation of Americium, Preparation and Reactions of Am(IV) Hydroxide, J Inorg Nucl Chem 17: 138 (1961)

33 D Cohen, Americium(VI) in Basic Solution, Inorg Nucl Chem Lett 8: 533 (1972)

$34 \mathrm{H} \mathrm{P}$ Holcomb, A Test for Oxidation of Actunides in Concentrated CsF Solution, J Inorg Nucl Chem, 29: 2885 (1967)

35 V P Zaitseva, Disproportionation of Am(VI) and Preparation of Americium(VII), Dokl Akad Nauk SSSR, 188: 826 (1969)

$36 \mathrm{~V}$ P Zaitseva, Incorrect Ident ification of Americium(VII), Radıokhımıya, 13: 658 (1971) through Sov Radiochem (Engl Transl), 13: 679 (1971)

$37 \mathrm{C}$ Keller and $\mathrm{H}$ Seiffert, $\mathrm{Li}_{5} \mathrm{NpO}_{6}$, The First Crystalline Compound with Septivalent Neptunium, and the Existence of Septivalent Plutonium and Americium, Inorg Nucl Chem Lett , 5: 51 (1969)

38 J Fuger, J C Spurlet, and W Muller, A New Determination of the Heat of Solution of Americium Metal and the Heat of Formation of Various Americium Ions and Compounds, Inorg Nucl Chem Lett 8: 709 (1972)

39 H R Lohr and B B Cunningham, The Heat of Reaction of Americium Metal with $15 M$ Hydrochloric Acid and a Note on the Hedts of Formation of $\mathrm{La}_{(\mathrm{aq})}^{+3}$ and $\operatorname{Pr}_{(\mathrm{aq})}^{+3}, J$ Amer Chem Soc, 73: 2025 (1951), USAEC Report AECD-2902, University of Calıfornia, Lawrence Radiation Laboratory, July 1950

40 E F Westrum, Jr, and L Eyring, The Preparation and Some Properties of Americium Metal, $J$ Amer Chem Soc 73: 3396 (1951)

$41 \mathrm{~J}$ Fuger and B B Cunnıngham, Heats of Formation of $\mathrm{Pu}_{(\mathrm{aq})}^{+3}, \mathrm{PuCl}_{3}(\mathrm{c}), \mathrm{PuOCl}_{(\mathrm{c})}, \mathrm{Am}_{(\mathrm{aq})}^{+}$, $\mathrm{AmCl}_{(\mathrm{c})}$, and $\mathrm{AmOCl}_{(\mathrm{c})}, J$ Inorg Nucl Chem, 25: 1423 (1963)

42 L R Morss, Crystallography and Thermochemistry of Some Chlorocomplex Compounds of the Lanthanıde and Actinide Elements, USAEC Report UCRL-18951, University of Calıfornia, Law rence Livermore Laboratory, August 1969

$43 \mathrm{~J}$ L Ryan, Evidence for Errors in the Published Enthalpies of Formation $\Delta_{\mathrm{f}} \mathrm{H}^{\mathbf{O}}\left(\mathrm{Am}^{3+}\right.$,aq) and $\Delta_{\mathrm{f}} \mathrm{H}^{\circ}\left(\mathrm{AmCl}_{3}, \mathrm{c}\right), J$ Chem Thermodyn, 5: 153 (1973)

44 a L J Nugent, J L Burnett, and L R Morss, Correlation of Some Thermodynamic Properties of the Lanthanide and Actinide Metals, J Chem Thermodyn 5: 665 (1973)

b A J Fuger and F L Detting, Present Status of the Chemical Thermodynamic Properties of the Lanthanide and Actinide Ions, in Transplutonium Elements, Proceedings of the 4 th International Symposium, Baden-Baden, September 13-17, 1975, W Muller and R Lindner (Eds ), North-Holland Publishıng Company, Amsterdam, 1976

45 L Eyring, H R Lohr, and B B Cunningham, Heats of Reactions of Some Oxides of Americium and Praseodymium with Nitric Acid and an Estimate of the Potentials of the Am(III)-Am(IV) and Pr(III)-Pr(IV) Couples, $J$ Amer Chem Soc, 74: 1186 (1952), USAEC Report AECD-2897, University of Calıfornia, Lawrence Radiation Laboratory, 1950.

$46 \mathrm{~S} R$ Gunn and B B Cunningham, The Heats of Formation of $\mathrm{AmO}_{2}^{+}(\mathrm{aq})$ and $\mathrm{AmO}_{2}^{2+}(\mathrm{aq})$ in $1 M \mathrm{HClO}_{4}, \mathrm{~J}$ Amer Chem Soc 79: 1563 (1957)

47 a R J Hinchey and J W Cobble, Thermodynamic Functions for $\mathrm{Pu}_{(\mathrm{aq})}^{+}$and the Entropies for Some Trivalent Actınıde Ions, Inorg Chem , 9: 922 (1970)

b $\mathrm{H}$ D Jones and G R Choppin, Complexes of Actinide Ions in Aqueous Solution, Actinides Rev , 1: 311 (1969)

48 R. A Penneman and L B Asprey, A Review of Amencium and Curium Chemistry, in Proceedings of the International Conference on Peaceful Uses of Atomic Energy, 1955 Vol 7,p 355, United Nations, New York, 1956

49 L B Asprey and R A Penneman, The Chemistry of the Actinides, Chem Eng News, 45(32) 75 (1967)

50 R A Penneman and L B Asprey, The Formal Potential of the Am(V)-Am(VI) Couple, USAEC Report AECU-936, Los Alamos Scientific Laboratory, September 1950. 
51 a L J Nugent, R D Baybarz, and J L Burnett, Electron-Transfer Spectra and the II-III Oxidation Potentials of Some Lanthanide and Actınide Halides in Solution, J Phys Chem 73: 1177 (1969)

b L J Nugent, R D Baybarz, J L Burnett, and J L Ryan, Electron-Transfer and f-d Absorption Bands of Some Lanthanide and Actinide Complexes and the Standard (II-III) Oxidation Potential for Each Member of Lanthanıde and Actınide Series, $J$ Phys Chem, 77: 1528 (1973)

52 F David, Polarographie de l'Actınum, Compt Rend, Parls 271: 440 (1970)

$53 \mathrm{C}$ K Jergensen, Neptunium(VII), Nobelium(II), 126(IV) and Other Unexpected Oxidation States of Transuranium Elements, Chem Phys Lett 2: 549 (1968)

54 B B Cunningham, Chemistry of the Actınide Elements, Annu Rev Nucl Scl 14: 323 (1964)

55 L J Nugent, R D Baybarz, J L Burnett, and J L Ryan, Electron-Transfer and $f \rightarrow d$ Adsorption Bands of Some Lanthanide and Actunide Complexes and the Standard (III-IV) Oxidation Potentials for Each Member of the Lanthande and Actınide Series, $J$ Inorg Nucl Chem 33: 2503 (1971)

$56 \mathrm{~S}$ R Gunn, Thermodynamics of the Aqueous Ions of Americium (Thesis), USAEC Report UCRL-254 1, University of Calıfornia, Lawrence Radiation Laboratory, 1954

57 I P Nigon, Los Alamos Scientıfic Laboratory, unpublished, cited in Ref 48

58 a W M Latımer, Oxidation Potentials 2nd ed, Prentice-Hall, Inc, Englewood Cliffs, N J, 1952

b V B Nkolaevsku, V P Shilov, and N N Krot, Estımation of Oxidation Potential of Americium(VI) in an Alkaline Medium, Radiokhımıya 16: 122 (1974) through Sov Radiochem (Engl Transl), 16: 120 (1974)

c V F Peretrukhin, V B Nikolaevsku, and V P Shilov, Electrical Properties of Americium Hydroxides in an Aqueous Alkaline Medium, Radiokhtmiya 16: 833 (1974) through Sov Radiochem (Engl Transl), 16: 813 (1974)

59 B Weaver and R R Shoun, Basicitıes of Trivalent Actınıdes and Lanthanides and Solubilities of Their Hydroxides, in Proceedings of the 9 th Rare Earth Research Conference, Blacksburg, Vurginia, October 10-14, 1971, USAEC Report CONF-711001, Vol 1, p 322, 1971

60 E Yanir, M Givon, and Y Marcus, Direct Determination of the Formal Potential of the Am(VI)-Am(II) and Am(VI)-Am(V) Couples in Phosphoric Acid, Inorg Nucl Chem Lett 6: 415 (1959)

61 L B Asprey and S E Stephanou, The Autoreduction of Am(VI) and Am(V) in Dilute Acid, USAEC Report AECU-924, Los Alamos Scientific Laboratory, November 1950

62 A A Zaitsev, V N Kosyakov, A G Rykov, Yu P Sobolov, and G N Yakovlev, Radiolytic Reduction of Am(VI) and Am(V), Sov At Energy (Engl Transl) 7:562 (1960)

$63 \mathrm{G} R$ Hall and $T \mathrm{~L}$ Markın, The Self-Reduction of Americium(V) and (VI) and the Disproportionation of Amencium(V) in Aqueous Solution, J Inorg Nucl Chem, 4: 296 (1957)

64 G N Yakovlev and V N Kosyakov, Spectrophotometric Studies of the Behavior of Americium Ions in Solutions, in Proceedings of the International Conference on the Peaceful Uses of A tomic Energy, 1955, Vol 7, p 363, United Nations, Geneva, 1956

65 G R Hall and P D Herniman, The Separation and Punfication of Americium-241 and the Absorption Spectra of Tervalent and Quinquevalent Americium Solutions, $J$ Chem Soc p 2214 (1954)

66 G N Yakovlev, A A Zaitsev, V N Kosyakov, A G Rykov, and Yu B Sobolev Coll Isotopes and Radiation in Chemistry (in Russian), Izdaniya AN SSSR, 195, p 326, cited in Ref 62

$67 \mathrm{~J}$ S Coleman, The Kinetics of the Disproportionation of Americium(V), Inorg Chem, 2: 53 (1963) 
68 A A Zaltsev, V N Kosyakov, A G Rykov, Yu P Sobolev, and G S Yakovlev, Disproportionation of Amencium(IV), USAEC Report AEC-tr-3885, 1960, from Report NP-7517

69 S E Stephanou, L B Asprey, and R A Penneman, The Disproportionation of Americium(V), USAEC Report AECU-925, Los Alamos Scientıfic Laboratory, 1950

70 a A A Zalsev, V N Kosyakov, A G Rykov, Yu P Sobolev, and G N Yakovlev, The Disproportionation of Americium(V), Radiokhtmiya 2: 339 (1960) through Radiochem (USSR) (Engl Transl) 2: 77 (1960)

b $\mathrm{T} W$ Newton, The Kinetics of the Oxidation-Reduction Reactions of Uranium, Neptunium, Plutonium, and Americium Ions in Aqueous Solutions, ERDA Critical Review Series TID 265061975

$71 \mathrm{~J}$ C Hindman, Reaction Kinetics of the Actinide Elements, in Proceedings of the Second International Conference on the Peaceful Uses of Atomic Energy Geneva 1958 Vol 28, p 349, United Nations, New York, 1958

$72 \mathrm{~T}$ W Newton and F Baker, Aqueous Oxidation-Reduction Reactions of Uranium, Neptunium, Plutonium, and Americium, in Lanthantde/Actintde Chemistry, R F Gould (Ed ), Advances in Chemistry Series, p 268, American Chemical Society, Washington, 1967

73 D Gourisse, Cinetique des Redctions d'Oxydo-Reduction des Elements Transuraniens en Solution, French Report CEA-R-3079, September 1966

74 A Ohyoshı, A Jyo, T Shinohard, and E Ohyosh1, An Attempt to Apply a Tracer Technique for the Kinetic Study of the Oxidation of Am(III), Radiochem Radioanal Lett 6. 121 (1971)

75 A Ohyoshı, A Jyo, $\mathrm{T}$ Kanaya, and $\mathrm{T}$ Shınohara, Kinetıc Studies on the Oxıdation of Am(III) with Ammonium Peroxydisulphate, Radiochem Radioanal Lett 7: 7 (1971)

76 A Ohyoshi, A Jyo, and T Shinohara, Kinetics of the Reaction of Americium(III) with Peroxydisulfate, Bull Chem Soc Jap 44: 3057 (1971)

77 V A Ermakov, A G Rykov, G A Timofeev, and G N Yakovlev, Investigations of the Kinetics of Redox Reactions of the Actinide Elements XX Kinetics and Mechanism of the Interaction of Americium(III) and (V) with Peroxydisulfate Ions in Nitric Acid Solution, Radiokhtmiya, 13: 826 (1971) through Sov Radiochem (Engl Transl), 13: 851 (1971)

78 V A Ermakov, A G Rykov, G A Timofeev, A V Dzhadav, and G N Yakovlev, Oxiddtion-Reduction Reactions of Actinide Elements XXII Kinetics and Mechanism of Americium(III) Interaction with Peroxydisulfate Ions in Potassium Carbondte Solutions, Radiokhimiya, 15: 380 (1973) through Sov Radiochem (Engl Transl) 15: 381 (1973)

79 a A G Rykov, V A Ermakov, G A Timofeev, V M Chistyakov, and G N Yakovlev, Investigations of Redox Reactions of the Actinide Elements XXI Kinetics and Mechanism of the Interaction of Americium(VI) with Peroxydisulfate Ions in Nitric Acid Solutions, Radiokhimiya, 13: 832 (1970) through Sov Radiochem (Engl Transl), 13: 858 (1970)

b M Woods, A Cain, and J C Sullivan, A Kinetic Study of the Reduction of Americium(VI) by Hydrogen Peroxide in Aqueous Perchlorate Medid, $J$ Inorg Nucl Chem, 36: 2605 (1974)

c V P Shilov, V B Nikolaevskil, and N N Krot, Some Characteristics of the Reaction of Americium(VI) with Reducing Agents in Aqueous Solutions, Radiokhımıya, 15: 871 (1973) through Sov Radiochem (Engl Transl), 15: 881 (1973)

80 A A Zaitsev, V N Kosyakov, A G Rykov, Yu P Sobolev, and G N Yakovlev, Kinetics of Americium(V) Reduction by Hydrogen Peroxide, Radlokhimlya, 3: 348 (1960) through Radlochem (USSR) (Engl Transl), 3: 86 (1960)

81 N Damien and M Pages, Etude Cinetique de ld Reduction de Am(V) par le Peroxyde d'Hydrogene, in Rapport Semestriel du Department de Chimie No 6, Juin 1968-Novembre 1968, French Report CEA-N-1148, p 407, June 1969 
82 a $^{*}$ Damien and M Pages, Etude Cinetıque de la Reduction de l'Americium Pentavalent par le Peroxyde d'Hydrogene, in Rapport Semestriel du Department de Chimı No 8, Juin 1969 Novembre 1969, French Report CEA-N-1341, p 472, July 1970

b N Damien, Reduction of Pentavalent Americium by Hydrogen Peroxide in Perchloric Solution (Thesis), French Report FRNC-Th-435, 1973

c N B Blokhın, V A Ermakov, and A G Rykov, Oxidation-Reduction Reactions of Actinide Elements XXV Kinetics of Neptunium(IV)-Americium(V) Reaction in Perchlorate Solutions, Radiokhimiva 16: 189 (1973) through Sov Radiochem (Engl Transl) 16: 191 (1973)

d A G Rykov, G A Timofeev, and V M Chistyakov, Oxidation-Reduction Reactions of Actinide Elements XXIII Kinetics of Neptunium-Americium(V) Redction in Perchlorate Solutions, Radiokhimiya 15: 872 (1973) through Sov Radiochem (Engl Transl), 15: 883 (1973)

e V M Chistydkov, V A Ermakov, and A G Rykov, Kinetics of the Reaction Neptunium(V)-Americium(V) in Sodium Carbonate Solutions, Radiokhimiya 16: 553 (1974) through Sov Radiochem (Engl Transl) 16: 545 (1974)

f $\mathrm{N}$ B Blokhin, $V$ A Ermakov, and A G Rykov, Oxidation-Reduction Reactions of Actinide Elements XXVI Kinetics of the Reaction of Uranium(IV)-Americium(V) in Perchlorate Solutions, Radiokhimiya 16: 551 (1974) through Sov Radiochem (Engl Transl) 16: 543 (1974)

83 V A Ermakov, G A Timofeev, A G Rykov, and G N Yakovlev, Kinetics of the Radiation Chemical Reduction of Americium(VI) and (V) in Aqueous Solutions in the Presence of Peroxydisulfate Ions, Radiokhimiya 13: 709 (1971) through Sov Radiochem (Engl Transl), 13: 727 (1971)

84 M Shiloh, M Givon, and Y Marcus, A Spectrophotometric Study of Trivalent Actinide Complexes in Solutions III Americium with Bromide, Iodide, Nitrate, and Carbonate Ligands, J Inorg Nucl Chem, 31: 1807 (1969)

85 D M Gruen, R L McBeth, J Kool, and W T Carnall, Oxidation States of the Elements and Their Potentials in Fused-Salt Solutions The Actinide Elements, Ann N Y Acad Sct 79: 941 (1960)

86 D S Gorbenko-Germanov, Correlations of Absorption Spectra of Americium and Europium in Crystals and Solutions, Flz Probl Spektroskopn Akad Nauk SSSR Materialy 13 go Sovesch 1: 242 (1960)

87 B J Stover, J G Conway, and B B Cunningham, The Solution Absorption Spectrum of Americium, $J$ Amer Chem Soc 73: 491 (1951)

88 S E Stephanou, J P Nigon, and R A Penneman, The Solution Absorption Spectra of Americium(III), (V), and (VI), $J$ Chem Phys, 21: 42 (1953), USAEC Report LADC-1147, Los Alamos Scientıfic Laboratory, 1952

$89 \mathrm{~W} T$ Carnall and P R Fields, The Visible and Near-Infrared Absorption Spectra of Some Trivalent Actınıde and Lanthanide Elements in $\mathrm{DCLO}_{4}$ and in Molten Nitrate Salts, Develop Appl Spectrosc, $1: 233$ (1962)

90 D C Stewart, Absorption Spectra of Lanthanide and Actınide Rare Earths II Transition Probabilities for +3 Ions in the Two Series, USAEC Report AECD-3351, Argonne National Laboratory, 1952

91 W T Carnall and P R Fields, Lanthanide and Actınide Absorption Spectra in Solutions, in Lanthanide/Actinide Chemistry, R F Gould (Ed), Advances in Chemistry Series, p 268, American Chemical Society, Washington, 1967

$92 \mathrm{Y}$ Marcus and $\mathrm{M}$ Shıloh, A Spectrophotometric Study of Trivalent Actinide Complexes in Solution IV Americium with Chloride Ligands, Israel J Chem., 7: 31 (1969)

93 C E Thalmayer and D Cohen, Actinide Chemistry in Saturated Potassium Fluoride Solution, in Lanthanide/Actinide Chemistry, R F Gould (Ed), Advances in Chemistry Series, p 256, American Chemical Society, Washington, 1967 
94 Yu A Barbanel, A G Gorskı1, and V P Kotlın, Absorption Spectra of Am(III) in Standard Solutions of $\mathrm{HCl}$, Radiokhtmiya 13: 305 (1971) through Sov Radiochem (Engl Transl) 13: 314 (1971)

95 Yu A Barbanel, V P Kotlin, and A G Gorskil, Identification of an $\mathrm{AmCl}_{6}^{3}$ Octahedral Complex from the Am(III) Absorption Spectrum in Ethanol Solutions of HCl, Dokl Akad Nauk Tadzh SSR 202: 830 (1972)

96 D M Gruen, S Fried, P Graf, and R L McBeth, The Chemistry of Fused Salts, in Proceedings of the Second International Conference on the Peaceful Uses of A tomic Energy Geneva 1958 Vol 28, p 112, United Nations, New York, 1958

$97 \mathrm{~J}$ G Conway, Energy Levels of Am(IV) in $\mathrm{LaCl}_{3}, J$ Chem Phvs 40 2504 (1964), USAEC Report UCRL-11099, University of Calıfornia, Lawrence Radiation Laboratory, November 1963

$98 \mathrm{~W}$ T Carnall and B G Wybourne, Electronıc Energy Levels of the Lighter Actinıdes $\mathrm{U}^{3+}$, $\mathrm{Np}^{3+}, \mathrm{Pu}^{3+}, \mathrm{Am}^{3+}$, and $\mathrm{Cm}^{3+}, J$ Chem Phys 40:3428 (1964)

99 J G Conway and B R Judd, Missing Band in the Spectrum of Tripositive Americium Ion, $J$ Chem Phys 41: 1526 (1964)

100 W T Carnall, P R Fields, and B G Wybourne, Low-Lying Energy Levels of Trivalent Americium, $J$ Chem Phys 41: 2195 (1964)

101 L P Varga, R D Baybarz, M J Reisfeld, and L B Asprey, Electronic Spectra of the $5 \mathrm{f}^{5}$ and $5 \mathrm{f}^{9}$ Actmides $\mathrm{Am}^{4+}, \mathrm{Pu}^{3+}, \mathrm{Bk}^{2+}, \mathrm{Cf}^{3+}$, and $\mathrm{Es}^{4+}, J$ Inorg Nucl Chem 35: 2775 (1973)

102 R A Penneman and T K Keenan, The Radiochemistry of Americium and Curium, Report NAS-NS-3006, National Academy of Sciences-National Resedrch Councli, 1960

103 L P Varga, J B Mann, L B Asprey, and M J Reisfeld, Calculated Spectroscopic Parameters and the Intermediate Spin-Orbit Coupling Diagram in the Interpretation of $5 \mathrm{f}^{4} \mathrm{AmO}_{2}^{+}$ Spectra, J Chem Phys 55: 4230 (1971)

104 G N Yakovlev and V N Kosyakov, An Investigation of the Chemistry of Americium, in Proceedings of the Second International Conference on the Peaceful Uses of Atomic Energy Geneva 1958, Vol 28, p 373, United Nations, New York, 1958

105 R A Penneman, Los A lamos Scientific Laboratory, unpublished, cited in Ref 48

106 L P Varga, M J Reisteld, and L B Asprey, Electronic Spectra of the $5 \mathrm{f}^{\mathrm{J}}$ Actinides $\mathrm{U}^{3^{+}}$, $\mathrm{Np}^{4+}, \mathrm{Pu}^{5+}$, and $\mathrm{AmO}_{2}^{2+}$ The $\mathrm{f}^{3}$ Intermediate Coupling Diagram, $J$ Chem Phys, 53. 250 (1970)

$107 \mathrm{~J} T$ Bell, Continuities in the Spectra and Structure of the Actinyl Ions, $J$ Inorg Nucl Chem, 31: 703 (1969)

$108 \mathrm{M}$ Shiloh and Y Marcus, The Chemistry of Trivalent Neptunium, Plutonıum, and Americium in Halide Solutions, Israel Report IA-924, Aprll 1964

109 P K Khopkar and P Narayanankutty, Effect of Ionıc Media on the Stability Constants of Chloride, Nitrate, and Thiocyanate Complexes of Americium(III) and Europium(III), J Inorg Nucl Chem, 33: 495 (1971)

110 B M L Bansal, S K Patıl, and H O Sharma, Chloride, Nitrate, and Sulphate Complexes of Europium(III) and Americium(III), J Inorg Nucl Chem, 26: 993 (1964)

111 D R Peppard, G W Mason, and I Hucher, Stability Constants of Certain Lanthanide(III) and Actinide(III) Chloride and Nitrate Complexes, $J$ Inorg Nucl Chem 24: 881 (1962), USAEC Report TID-14716, November 1961

$112 \mathrm{~T}$ Sekine, Complex Formation of $\mathrm{La}($ III), Eu(III), Lu(III), and Am(III) with Oxalate, Sulphate, Chloride, and Throcyanate Ions, J Inorg Nucl Chem , 26: 1463 (1964)

$113 \mathrm{~T}$ Sekıne, Solvent Extraction Study of Trivalent Actınıde and Lanthanide Complexes of $\mathrm{La}(\mathrm{III}), \mathrm{Eu}(\mathrm{III}), \mathrm{Lu}(\mathrm{III})$, and Am(III) in $4 M \mathrm{NaClO}_{4}$, Acta Chem. Scand, 19: 1435 (1965)

$114 \mathrm{M}$ Ward and G A Welch, The Chloride Complexes of Trivalent Plutonium, Americium, and Curium, J Inorg Nucl Chem 2: 395 (1965) 
115 V M Vdovenko, V B Kolokol'tsov, and O B Stebunov, Reldxation Processes in Complex I ormation I Copper and Americium Chlorides in Aqueous Solutions, Radiokhimiva, 8: 286 (1966) through Sov Radlochem (Lngl Transl) 8: 266 (1966)

116 I Grenthe, Chloride Complexes of Trivalent Americium, Acta Chem Scand 16: 2300 (1962)

117 B Marın, Behavior of Trivalent Actinide and Lanthanıde Elements in Chlorıde Solutions, I rench Report CEA R-3803, through USAI C Report ORNL tr-2342 1970

$118 \mathrm{Y}$ Marcus and $\mathrm{M}$ Bomse, Octahedral Chloride Complexes ot Trivalent Actinides and Lanthanides in Solution, Israel J Chem 8:901 (1970)

$119 \mathrm{~J} L$ Ryan, Octahedral Hexahalide Complexes of the Trivalent Actinides, in Lanthanide/ Actintde Chemistry R $\Gamma$ Gould (Ed), Advances in Chemistry Series, p 331, American Chemical Society, Washington, 1967

120 a A A7iz and S J Lyle, Equilibrium Constants for Aqueous Fluoro Complexes of Scandium, Yttrium, Americium(III), and Curium(III) by Extraction in to Di-2-Ethylhexyl Phosphoric Ac1d J Inorg Nucl Chcm 31: 3471 (1969)

b G R Choppin and P J Unrein, Thermodynamic Study of Actinide Fluoride Complexation, in Transplutonium Elemcnts Proceedings of the 4 th International Symposium, BddenBdden, September 13-17, 1975, W Muller and R Lindner (Eds), North-Holland Publushıng Company, Amsterdam, 1976

$121 \mathrm{H}$ Lahr and W Knoch, Determination of Stabilıty Constants of Some Actınde Complexes II Nitrate and Chloride Complexes of Uranium, Neptunium, Plutonium, and Americium, Radiochim Acta 13: 1 (1970), USAEC Report ORNL tr-2382, Odk Ridge National Laboratory, 1970

122 I A Lebedev, S V Prozhkov, and G N Yakovlev, Determination of the Composition and Instability Constants of the Oxalate, Nitrate, and Sulfate Complexes of Am(III) and Cm(III) by Ion Exchange, Radiokhimlya 2: 549 (1960) through Radlochem (USSR) (Engl Transl), 2(5) 39 (1960)

123 G R Choppin and W F Strazik, Complexes of Trivalent Lanthanides and Actınide Ions I Outer Sphere Ion Pars, Inorg Chem 4: 1250 (1965)

124 P K Khopkar and H D Sharma, unpublished, cited in Ref 110

125 Research Laboratories Annual Report for the Period January-December 1966, Israel Report IA-1 128, 1967

126 R Chianizld, P R Danesı, G Scibona, and L Magon, Liquid Anion Exchange of Throcyanate-Nitrate Actinide and Lanthanide Complexes, J Inorg Nucl Chem 35: 3595 (1973)

127 P A Baısden, G R Choppin, and W K Kinard, Ion Pairing of Am(III) with Perchlorate, $J$ Inorg Nucl Chem 34: 2029 (1972)

128 A I Moskvin, Investigation of the Complex Formation of Trivalent Plutonium, Americium, and Curium in Phosphate Solutions, Radiokhtmiya, 13: 668 (1971) through Sov Radiochem (Engl Transl) 13:688 (1971)

129 M S Borisov, A A Elesin, I A Lebedev, V T Filimonov, and G N Yakovlev, Investigdtion of the Complexing of Trivalent Actinides and Lanthanides in Phosphoric Acid Solutions, Radiokhimiva 8.42 (1966) through Sov Radiochem (Engl Transl) 8: 40 (1966)

130 I A Lebedev, S V Prozkhov, and G N Yakovlev, Determination of the Composition and Instability Constants of Oxalate, Nitrate, and Sulfate Complexes of Am(III) and Cm(III) by Ion Exchange, Akad Nauk SSSR through USAEC Report AEC-tr-4275, Los Alamos Scientific Laboratory, 1960

$131 \mathrm{~T}$ Sekine, Solvent Extraction Study of Trivalent Actınıde and Lanthanide Complexes in Aqueous Solutions II Sulfate Complexes of La(III), Eu(III), Lu(III), and Am(III) in $1 M$ $\mathrm{NaClO}_{4}$, Acta Chcm Scand 19: 1469 (1965)

$132 \mathrm{R} G$ Carvalho and $G \mathrm{R}$ Choppin, Lanthanide and Actinide Sulfate Complexes I Determination of Stability Constants, J Inorg Nucl Chem 29: 725 (1967) 
133 G S Nair, Amencium(III)-Sulphate Complexes, Radıchım Acta, 10 116 (1968)

134 A Azız, S J Lyle, and S J Naqvi, Chemical Equilibria in Americium and Cerium Sulphate and Oxalate Systems and an Application of a Liquid Scintillation Counting Method, J. Inorg Nucl Chem 30: 1013 (1968)

$135 \mathrm{~W} J$ McDowell and C F Coleman, The Sulfate Complexes of Some Trivalent Transplutonium Actinides and Europium, J Inorg Nucl Chem 34: 2837 (1972)

136 T Sekine, Solvent Extraction Study of Trivalent Actinides and Lanthanide Complexes in Aqueous Solutions IV Throcyanate Complexes of La(III), Eu(III), Lu(III), and Am(III) in $5 \mathrm{M} \mathrm{NaClO}_{4}$ Solutions at $25 \mathrm{deg} \mathrm{C}$, Acta Chem Scand, 19. 1519 (1965)

137 I A Lebedev and G N Yakovlev, Determination of the Composition and Instability Constants of Thiocyanate Complexes of Am(III), Cm(III), and Ce(III) by Ion Exchange, Radiokhtmiya 4· 304 (1962) through Sov Radiochem (Engl Transl) 4: 273 (1962)

138 G R Choppin and J Ketels, Thiocyanate Complexes of Some Trivalent Lanthanide and Actinide Elements, J Inorg Nucl Chem 271335 (1965)

139 G R Choppin, Thermodynamics of Complexıng of Trivalent Actınıde Ions by Thiocyanate, USAEC Report TID-25671, Florida State University, 1970

140 H D Harmon, J R Peterson, W J McDowell, and C F Coleman, The Tetrad Effect The Thiocy andte Complex Stabilıty Constants of Some Trivalent Actınıdes, J Inorg Nucl Chem 34: 1381 (1972)

141 a H D Harmon, J R Peterson, J T Bell, and W J McDowell, A Spectrophotometru Study of the Formation of Amencium Thiocyanate Complexes, $J$ Inorg Nucl Chem 34· 1711 (1972)

b W F Kinard and G R Choppin, Complexing of Trivalent Actınıde Ions by Throcyanate, $J$ Inorg Nucl Chem 36: 1131 (1974)

c P K Khopkar and J N Mathur, Thiocyanate Complexing of Some Trivalent Actinides and Lanthanides, J Inorg Nucl Chem 36. 3819 (1974)

142 A A Elesin, I A Lebedev, E M Piskunov, and G N Yakovlev, Complex Formation of Americium, Curium, and Promethium with Trimetaphosphoric Acid, Radiokhimiya 9: 161 (1967) through Sov Radiochem (Engl Transl), 9: 159 (1967)

143 A I Moskvin, Investigation of the Complex Formation of Trivalent Plutonium, Americium, and Curium in Acetate Solutions by the Ion Exchange Method, Radiokhimiya 13: 221 (1971) through Sov Radiochem (Engl Transl), 13: 220 (1971)

144 A I Moskvin, Investigation of the Complex Formation of Trivalent Plutonium and Americium in Acetate Solutions by a Potentiometric Method, Radiokhimiya 13: 224 (1971) through Sov Radlochem (Engl Transl) 13: 224 (1971)

$145 \mathrm{G}$ R Choppin and J K Schneider, The Acetdte Complexing by Trivalent Actinide Ions, $J$ Inorg Nucl Chem, 32: 3283 (1970)

146 I Grenthe, On the Stabulity of the Acetate, Glycoldte, and Thioglycolate Complexes of Tervalent Europium and Americium, Acta Chem. Scand 16: 1695 (1962)

147 E S Gureev et al, Methods of Recovery and Some Chemical Properties of Transplutonıum Elements, in Proceedings of the Third International Conference on the Peaceful Uses of Atomic Energy Geneva 1964 Vol 10,p 348, United Nations, New York, 1965

148 A Aziz and S J Lyle, Americium(III) and Europium(III) Complexes with Lactate, Pyruvate, and $\alpha$-Alaninate in Aqueous Solutions-A Comparison of Equilibrium Constants, $J$ Inorg Nucl Chem, 33: 3407 (1971)

149 S H Eberle and I Bayat, Stabilitatskonstanten und Koordınationszahlen der Chelate Dreiwertiger Transplutonıumelemente mit Imınodiacetıcacid-Derıvates, Inorg Nucl Chem Lett , 5: 229 (1969)

150 I Bayat, Uber Komplexe drelwertıger Transurane mit Amınopolykarbonsauren, German Report KFK-1291, 1970 
151 a B F Myasoedov, M S Milyukova, and L V Ryzhova, On the Reaction of Trivalent Americium and Curium with the Reagent Arsenazo III, Radiochem Radioanal I ett 5: 19 (1970)

b M S Milyukovd, B F Myasoedov, and L V Ryzhova, Spectrophotometric Study of the Reaction of Americium and Curium with Arsenazo III, Zh Anal Khtm 27: 1769 (1972)

152 E Akatsu, M Hoshi, R Ono, and $\mathrm{K}$ Ueno, Some Complexes of Americium and Curium with Oxıne, Cupferron and N-Benzoylphenylhydroxylamıne, $J$ Nucl Scl Technol (Tokyo) 5: 252 (1968)

$153 \mathrm{C}$ Keller and $\mathrm{H}$ Schreck, Die Cheldtbıldung und Extraktıon des Dreswertıgen Actınımus, Americiums, Curiums und Californiums mit Acetylaceton und Einigen Seiner Derivate, $J$ Inorg Nucl Chem, 31: 1121 (1969), West German Report KFK-672, December 1967

154 S H Eberle and F Modttar, Die Komplexe des Am(III) Mit Zitronensaure, Inorg Nucl Chem Lett, 8: 265 (1972)

155 I Moattar, Compounds of Trivalent Transuranıum Compounds Appearing in Mixtures of Complexing Agents, German Report KFK-1416, June 1971

156 E Ohyoshi and A Ohyoshi, Study of Complexes with a Polybasic Acid Am(III) Citrate Complexes, J Inorg Nucl Chem, 33: 4265 (1971)

157 A I Moskvin, G V Khalturin, and A D Gel'man, Determination of the Composition and Instability Constants of Citrate and Tartrate Complexes of Americium(III) by the Ion Exchange Method, Radiokhımiya 4: 162 (1962) through Sov Radiochem (Engl Transl) 4: 145 (1962)

$158 \mathrm{G} \mathrm{Marcu}$ and $\mathrm{K}$ Samochocka, On the Formation of Complex Combinations of ${ }^{24}{ }^{1}$ Am and ${ }^{246} \mathrm{Cm}$ in Citric Acid Media by Electrophoresis on Paper, Stud Unvv Babes Bolyal Ser Chem $1115(1966)$

159 a R Gullaumont and L Bourderie, Complexe Citrique d'Elements $4 \mathrm{f}$ et $5 \mathrm{f}$, Bull Soc Chim France, 8: 2806 (1971)

b S Hubert, M Hussonnos, L Brillard, G Goby, and R Gullaumont, Determınation Simultanee de Constante de Formation de Complexes Citrique de l'Americium, du Curıum, du Calıfornium, de l'Einsteinıum, et du Fermıum, J Inorg Chem., 36: 2361 (1974)

160 A V Stepanov, Comparative Stability of Complex Compounds of Yttrum, Some Rare Earths, and Actınıde Elements with Anıons of Oxalıc, Citric, Ethylenediaminetetraacetic, and 1,2-Diaminocyclohexanetetraacetıc Acids, Zh Neorg Khım, 16: 2981 (1971)

$161 \mathrm{~V} G$ Voden, M. E Obukhova, and M F Puchlenokov, Complex Formation of Americium with Decanohydroxyamic Acid, Radiokhimiya 11: 644 (1969) through Sov Radiochem (Engl Transl), 11:633 (1969)

162 A V Stepanov, T P Makarova, A M Maksımova, and A B Shalınets, Investigation of the Complex Formation of Ce(III), Am(III), and Cm(III) with 1,2-Diaminocyclohexanetetraacetic Acid by the Electromigration Method, Radtokhimiya, 9: 710 (1967) through Sov Radiochem (Engl Transl), 9:667 (1967)

163 R D Baybarz, Dissociation Constants of the Transplutonium Element Chelates of 1,2-Diaminocyclohexanetetraacetic Acid, J Inorg Nucl Chem., 28: 1055 (1966)

164 A A Elesin and A A Zaitsev, Complex Formation of Americium, Curium, and Promethium with 1,2-Diaminocy clohexanetetradcetic Acid, Radiokhimiya 13: 902 (1971) through Sov Radiochem (Engl Transl), 13: 931 (1966)

165 I Stary, Investigation of the Complex Formation of Americium and Promethium by the Extraction Method, Radiokhimiya, 8: 504 (1966) through Sov Radıochem (Engl Transl) 8: 467 (1966)

166 P Zur Nedden, Komplexe dreiwertiger Lanthaniden und Actiniden mit Dialkyl-(PP')-athans(1,2)-diphosphonsauren, $Z$ Anal Chem., 247: 236 (1969)

$167 \mathrm{C}$ Keller, S H Eberle, and K Mosdzelewskı, Verbındungen des drıewertigen Plutonıums, Americiums, and Curıums mit 8-Hydroxychınolin und einiger seiner Derivatıve, Radıochim Acta, 5: 185 (1966) 
168 S H Eberle, Uber die Redktionen der Elemente Neptunıum, Plutonium, und Amencium mit 8-Hydroxychınolın und Eıntger Seiner Derivate, German Report KFK-281, 1965

$169 \mathrm{R}$ D Baybarz, Dissociation Constants of the Transplutonium Element Chelates of Diethylenetriaminepentaacetic Acid (DTPA) and the Application of DTPA Chelates to Solvent Fxtraction Separations of Transplutonium Elements from the Lanthanide Elements, J Inorg Nucl Chem, 27・1831 (1965)

170 I A Lebedev, V T I Ilimonov, A B Shalınets, and G N Yakovlev, Investigation of the I ormation of Complexes of Americium, Curıum, Cerium, and Promethium with Diethylene trimmepentadcetic Acid, Radiokhimiya, 10:93(1968) through Sov Radiochem (Engl Transl) 10:87 (1968)

171 W D Burch (Comp), Transuranıum Quarterly Progress Report for Perıod Endıng F ebruary 29, 1963, USAEC Report ORNL-3651, Oak Ridge National Laboratory, 1964

172. M B Hafez, Spectrophotometric Study of the Complexes of Cerium and Uranides with Diethylenetriaminepentadcetic Acid (DTPA), French Report CEA-R-3521, 1968, USAEC Report URCL-Trans 10336C, 1968

173 A Delle Site and R D Baybarz, A Spectrophotometric Study of the Complexing of Am ${ }^{3+}$ with Aminopolydcetic Acids, J Inorg Nucl Chem, 31: 2201 (1969)

174 E M Piskunov and A G Rykov, Investigation of Complex f ormation with Diethylenetriaminepentaacetic Acid VI Americium(III), Radiokhtmiya, 14: 638 (1972) through Sov Radtochem (Engl Transl) 14:656 (1972)

175 E Brandau, Stability Constants of the Complexes Formed by Am(III), Cm(III), and Cf(III) with Diethylenetriamınepentadcetic Acid, Inorg Nucl Chem Lett, 7: 1177 (1971)

176 A I Moskvin, Investigation of the Complex Formation of Pu(III), Am(III), and Cm(III) with Nitrilotriacetic and Diethylenepentadcetic Acids, Radiokhimiya 13: 575 (1971) through Sov Radiochem (Engl Transl) 13:570 (1971)

177 A I Moskvin, Complex Formation of the Actinides with Anions of Acids in Aqueous Solution, Radiokhımiya, 11: 458 through Sov Radiochem (Engl Transl), 11: 447 (1969)

178 a I L Moore, Liquid-Liquid Extraction of Anınic Amenicium and Europium Complexes of Hydroxyethylethylenediaminetridcetic Acld and Diethylenetriaminepentacetic Acid, Anal Chem, 38: 905 (1966)

b V B Nikolaevski, V P Shulov, and N N Krot, Complex Compounds of Pentavalent Americium in Solutions of Ethylenediaminetetracetic and Diethylenetriaminepentacetic Acids, Radiokhtmiya, 16: 61 (1974) through Sov Radiochem (Engl Transl) 16:57 (1974)

179 A A Elesin and A A Zaitsev, Complex I ormation of Trivalent Americium, Curium, and Promethium Ions with Diethylphosphenylpropionic Acid, Radiokhımiya, 14: 370 (1972) through Sov Radıochem (Engl Transl), 14: 381 (1972)

$180 \mathrm{C}$ S Grigorescu-Sabau, Uber die Temperdturabhanggkeit von Komplexgleichgewichten der Transplutone, German Report KFK 1620, June 1972

181 a J Goffart and G Duyckaerts, L'Extraction des Lanthanides et des Actinides par les Oxydes d'Alkylphosphine, Anal Chım Acta, 48: 99 (1969)

b V V Vorob'eva, A A Elesin, and A A Zaitsev, Complexing of Trivalent Americium, Curıum, Calıfornium, Promethium, and Yttrium Ions with Dioxymethylphosphinic Acid, Russian Report NIIAR-P-185, 1973

182 I A Lebedev and A V Shalinets, Investigation of Complex Formation of Trivalent Lanthanide and Actınıde Elements with Ethylenediamino-bis-isopropylphosphonc Acid by the Method of Electromigration, Radiokhimiya 10: 233 (1968) through Sov Radiochem (Engl Transl), 10: 218 (1968)

183 A B Shalinets and V V Vorob'eva, Investigation of the Complex Formation of Am(III), Cm(III), and Ce(III) with Ethylenediamino-bis-methylphosphonic Acid by the Method of Electromigration, Radiokhimiya 10: 102 (1968) through Sov Radiochem (Engl Transl) 10: 97 (1968) 
184 A A Elesin, A A Zaltsev, G M Sergeev, and I I Nazarova, Complex I ormation of Trivalent Americium, Curium, and Promethium Ions with T thylenediamino bis methyl phosphonic Acid, Radtokhtmiya 15:64 (1973) through Sov Radiochem (Engl Transl) 15: 62 (1973)

$185 \mathrm{~J} I$ uger, Ion Fxchange Behavior and Dissociation Constants of Americium, Curium, and Californium Complexes with Fthylenediaminetetradetic Acid, J Inorg Nucl Chem 5: 332 (1958)

186 A I Moskvin, G V Khalturın, and A D Gel'man, Investıgation of Oxalate and EDTA Complexes of Trivalent Americium by Ion Exchange, Radiokhtmiya 1: 141 (1959)

187 I A Lebedev, A M Maksimova, A V Stepanov, and A B Shalinets, Determination of the Stability Constants of Am and Cm with EDTA by the Method of Electromigration, Radiokhimiva, 9: 707 (1967) through Sov Radiochem (Engl Transl) 9:664 (1967)

188 A A Elesin and A A Zatsev, Ion-Exchange Behavior of Trivalent Americium, Curium, and Promethium Ions in the Presence of EDTA, Radiokhtmiya 13: 775 (1971) through Sov Radiochem (Engl Transl) 13: 798 (1971)

189 A I Moskvin, Solubility and Ion Exchange Methods for Determining the Complex F ormation of Plutonrum and Americium in Aqueous Solution, Radiokhimlya 1-430 (1959)

190 A B Shalinets, Investigation of the Complex Formation of Trivalent Actinide and Lanthanide Elements by the Method of Electromigration XVI Ethylenediaminetetracetic Acid, Radiokhimiva 14: 275 (1972) through Sov Radiochem (Engl Transl), 14: 285 (1972)

191 A B Shalinets, Investigation of the Complex Formation of Trivalent Actinide and Lanthanide Elements by the Method of Electromigration XV Ethylenediammetetramethylphosphonic Acid, Radiokhimiya 14: 269 (1972) through Sov Radiochem (Engl Transl) 14: $279(1972)$

192 S P Tanner and G R Choppin, Lanthanide and Actinide Complexes of Glycine Determination of Stability Constants and Thermodynamic Parameters by a Solvent Extraction Method, Inorg Chem 7:2046 (1968)

193 G R Choppin and G Degischer, Complexing of Trivalent Actinide Ions by Glycolate, $J$ Inorg Nucl Chem, 34: 3473 (1972)

194 B I Levakov and A B Shalinets, Investigation of the Complex Formation of Trivalent Actinide and Lanthanide Elements by the Method of Electromigration XVIII Hydrazineiminodiacetıc Acid, Radiokhtmiya, 13: 295 (1971) through Sov Radiochem (Engl Transl), 13: $301(1971)$

$195 \mathrm{~S} \mathrm{H}$ Eberle and I Baydt, Die Chelatbildung Dreiwertiger Transplutonium Elements mit N-2 Hydroxy athyl-Athy ldiamen-N, $\mathrm{N}^{\prime}, \mathrm{N}^{\prime}$-Triessigsaure, Radiochim Acta, 7: 214 (1967)

196 a E Mercing and E Duyckaerts, Separation Americium-Curium Constantes de Dissociation des Complexes avec l'Acide Hydroxyéthyléne-didmınetridcétıque, Anal Lett, 1: 23 (1967)

b I A Lebedev, Yu F Mazur, and B J Myasoedov, Investigation of the Complex Formation of Americium and Europium with Hydroxylethylıdenedıphosphonic Acid, Radiokhımıya, 14: 759 (1972) through Sov Radiochem (Engl Transl), 14: 782 (1972)

197 V A Ermakov, V V Vorob'eva, A A Zartsev, and G N Yakovlev, Study of Complex-Formation by an Extraction Method II Complex-Formation of Americium, Curium, Californium, Promethium, and Europium with 2-Hydroxyethyliminodidcetic Acid, Radiokhtmiya, 13: 840 (1971) through Sov Radiochem (Engl Transl), 13: 866 (1971)

198 A B Shalinets, Investigation of the Complex Formation of Trivalent Actinide and Lanthanide Elements by the Method of Electromıgration. XIV Hydroxyethylımıno-N,N'Diacetic Acid, Radtokhtmrya, 14: 33 (1972) through Sov Radtochem (Engl Transl), 14: 30 (1972) 
199 V B Dedov, I A Lebedev, M N Ryzhov, P S Trakhlyaev, and G N Yakovlev Compler Formation Between Americium and Curıum with $\alpha$-Hydroxyısobutyric Acid, Radiokhımı a 3: 701 (1961) through Radlochem (USSR) (Engl Transl) 3(5) 197 (1961)

200 B Graus Odenheimer and G R Choppin, Stabilıty Constants of Alphahydroxyısobutyric Acid Complexes with Actinide Elements, USAEC Report UCRL-3515, University of Calıfornıa, Berkeley, Radidtion Laboratory, 1956

201 J Stary, Separation of Transplutonium Elements, Talanta 13:421 (1965)

202 V V Vorob'eva, A A Elesin, and A A Zatsev, Compleving Trivalent Americium Curium Calıfornium, and Yttrium Ions with Bts(hydroxymethyl)phosphinic Acıd, Russian Rcport SRARI-P-185, 1973, through USAEC Report AEC-tr-7474, 1973

203 A A Elesin, A A Zaitsev, N A Ivanovich, V A Karaseva, and G N Yakovlev Complex Formation of Trivalent Americium, Curtum, and Promethium Ions with Hydroxymethyl phosphonic and Methylolethylphosphinic Acids, Radiokhimiva 14. 546 (1972) through Sol Radiochem (Engl Transl) 14.563 (1972)

204 V A Ermakov, V V Vorob'eva, A A Zaitsev, and G N Yakovlev Study of Complex Formation by the Extraction Method I Complex Formation of Americium Cunum Calıfornıum, and Promethium with $\sigma$-Hydroxyphenylımınodiacetıc Acid Radiokhımı 13 692 (1971) through Sov Radiochem (Engl Transl) 13.710 (1971)

205 S Al Rifd, Complex lormation Between Trivalent Transuranium Elcments and Ligands Which Contain the Pyridine or Quinoline Ring, German Report IRCH 10/70-2, 1970

$206 \mathrm{~J}$ T Bell, R D Baybarz, and D M Helton, The Thermodynamics for the I ormation of Amencium Imınodidcetic Acid Complexes ds Determined by Spectrophotometric and $\mathrm{pH}$ Techniques, J Inorg Nucl Chem 33: 3077 (1971)

207 I A Lebedev and G N Yakovlev, Determination of the Composition and Instability Constants of the Complex Lactates of Am(III) and $\mathrm{Cm}$ (III) by the Ion Exchange Method, Radiokhtmiva 3. 455 (1961) through Radıochem (USSR) (Jerusalem) 3(3) 234 (1961)

208 a V A Ermakov and I Stary, Complex Formation of Am, Cm, Cf, and Fm with Lactic Acid Radiokhımıya 9: 197 (1967) through Sov Radıochem (Engl Transl) 9-195 (1967)

b M Sakanque and M Nakatani, Determination of the Formation Constants of Actinoid and Lanthanoid Lactate Complexes by Means of Electrophoresis Bull Chem Soc Jap 45 3429 (1972)

209 A A Elesin, A A Zaitsev, V A Karaseva, I I Nazarova, and I V Petukhova, The Synthesis of (Methylphenylphosphinyl)-methylphenylphosphonic Acid and Investigation of the Complex Formation of Trivalent Americium, Curıum, and Promethium Ions, Radiokhimiva 14. 374 (1972) through Sov Radiochem (Engl Transl) 14: 385 (1972)

210 M S Borisov, A A Elesin, I A Lebedev, E M Piskunov, V T I llimonov and G N Yakovlev, Complex Formation of Trivalent Americium, Curium and Promethium with Methylphosphinic Acid, Radıokhmmya 9: 166 (1967) through Sov Radiochem (Engl Transl) 9: 164 (1967)

$211 \mathrm{~S} \mathrm{H}$ Eberle and S Al1, Ionenaustauschverhalten und Chelatbildung drenwertiger Transplutonıumelemente bei Gegenwart von nitrilotriessigsaure und eniger ihrer Derivate, $Z$ Anorg Allg Chem 361: 1 (1968)

212 S Al, Die Chelatbibung der Drewwertigen Transplutoniumelemente mit Nitrilotriessigsaeure und Ihren Derivaten, German Report KFK-580, 1967, USAEC Report ORNL-tr-1854, 1968

$213 \mathrm{~S} \mathrm{H}$ Eberle and S Ali, Die Chelatbildung des Americiums und Curiums mit Nitrilotriessigsaure, Radiochim Acta 5: 58 (1966)

214 S H Eberle and C S Sabdu, The Thermodynamics of Am(III) Nitrilotracetic Acid Complexes, Radiochem Radioanal Lett, 11: 77 (1972)

215 a I A Lebedev, S V Prozhkov, V M Razbitnol, and G N Yakovlev, On the Complex Formation of $\mathrm{Am}^{3+}$ with Oxalates Radiokhimiva 2351 (1960) through Radiochem (USSR) (Jerusalem) $289(1960)$ 
b L I Gedeonov, I A Lebedev, A V Stepanov, A B Shalinets, and G N Yakovlev in Chemistry of the Transurantum and Fission Elements Izd, Nauka, p 140, MoscowLeningrad, 1967

216 A V Stepanov and T P Makarova, Use of the Electromigration Method to Study Complex Oxalates of Am(III), Radiokhtmiya, 7: 670 (1965) through Sov Radiochem (Engl Transl), 7: 669 (1965)

217 a $T$ Sekıne, Solvent Extraction Study of Trivalent Actınide and Lanthanide Complexes in Aqueous Solutions III Oxalate Complexes of La(III), Eu(III), Lu(III), and Am(III) in $1 M$ $\mathrm{NaClO}_{4}$, Acta Chem Scand, 19: 1476 (1965)

b V P Shilov, V B Nikoldevski, and N N Krot, Am(V) Complex Formation with Oxalate Ions, Zh Neorg Khtm 19: 469 (1974)

$218 \mathrm{~W}$ Backer and C Keller, 4-Acyl-Substıtuırte 1-Phenyl-3-Methyl-Pyrazolone-5 als Chelatbıldner fur Actınideionen, $J$ Inorg $\mathrm{NuCl}$ Chem 35: 2945 (1973), West German Report KFK-1504, December 1971

219 A A Elesın, A A Zaitsev, S S Kazdkova, and G N Yakovlev, Complex Formation of Trivalent Americium, Curıum, and Promethium Ions with Phosphonoacetic Acid, Radio khimiya 14: 541 (1972) through Sov Radiochem (Engl Transl), 14: 558 (1972)

220 I Stronskı and M Rekas, Determination of Distribution and Stability Constants of Americium and Curium Chelates with Aromatic Schift Bases XV Radiotracer Studies on the Extraction of Metal Ions, Radıochem Radıoanal Lett, 14: 297 (1973)

221 L G Cilindro, E Stadlbauer, and C Keller, Complexation of Some Actinide Ions with Squaric Acid, I Inorg Nucl Chem, 34: 2577 (1972)

222 G Marcu and K Samochockd, Paper Electrophoretic Study of the Formation of Complex Compounds of Europium, Promethium, Amencium, and Curium in a Tartaric Acid Medium, Stud Univ Babes Bolyal Ser Chem 10: 71 (1965)

$223 \mathrm{D}$ Feinauer, Formation of Chelates and Adduct Chelates in the Extraction of Trivalent Americium and Calıfornıum, German Report KFK-1298, 1970

224. A E Martell and L G Sillen, Stabultty Constants of Metal Ion Complexes, Special Publication No 17, 2nd ed, The Chemical Society, London, 1964

225 a Y Marcus, M Givon, and M Shloh, The Chemistry of the Trvalent Actınides in Aqueous. Solutions and Their Recovery, Proceedings of the Third International Conference on the Peaceful Uses of Atomic Energy Geneva 1964, Vol 10, p. 588, United Nations, New York, 1965

b A D Gel'man, A I Moskvin, L M Zd1tsev, and M P Mefod'eva, Complex Compounds of Transuranides, English translation, Israel Program for Scientific Translations, Jerusalem, 1967

226 C Musıkas, Peroxyde d'Americium Pentavalent, Radıochem Radioanal Lett, 13: 255 (1973)

227 S Ahrland, J Chatt, and N R Davies, The Relative Affinities of Ligand Atoms for Acceptor Molecules and Ions, Quart Rev (London) 12: 265 (1958)

228 a R G Pearson, Hard and Soft Acids and Bases, J Amer Chem Soc 85: 3533 (1963)

b A I Moskvin, Complex l ormation of Trivalent Plutonium, Americium, and Some Rare Earth Elements, Radiokhimlya 9: 718 (1967) through Sov Radiochem (Engl Transl), 9: 677 (1967)

229 E K Hulet, R G Gutmacher, and M S Coops, Group Separation of the Actundes from the Lanthanides by Ion Exchange, J Inorg Nucl Chem, 17: 350 (1961)

230 \& Z Welgel, Isolation of 100-mg Quantities of Americium-241 from Large Amounts of Impurities, $Z$ Anorg Allg Chem., 294: 294 (1958), USAEC Report UCRL 3934, University of Calıfornı, Berkeley, Radiation Laboratory, 1957

$231 \mathrm{~F}$ L Moore, New Techntque for the Separation of Trivalent Actinide Elements from Lanthanide Elements, Anal Chem 33: 748 (1961) 
232 R D Baybarz and B Weaver, Separation of Transplutonums from Lanthanides by Tertiary Amine Extraction, USAEC Report ORNL-3185, Oak Ridge National Laboratory, 1961

$233 \mathrm{Y}$ Marcus, Anıon Exchange of Metal Complexes XV Anıon Exchange and Amine Extraction of Lanthandes and Trivalent Actinides from Chlonde Solutions, $J$ Inorg Nucl Chem 28: 209 (1966)

234 A A Elesin and A A Zaitsev, Some Regularitıes in Complexing Trivalent lons of Americium, Curium, and Promethum with Phosphorus- and Carboxyl-Carrying Ligands, Russian Report SRARI-P-158, 1972

235 A B Shalinets, Investigation of the Complex Formation of Trivalent Actinide and Lanthanide Elements by the Method of Electromigration XII Additivity of the Strength of the Individual Rings, Radiokhimiya, 14. 20 (1972) through Sov Radiochem (Engl Transl) 14: 18 (1972)

236 A B Shalınets, Investigation of the Complex Formation of Trivalent Actinide and Lanthanide Elements by the Method of Electromigration XIII Relationship of the Structure and Selectivity of Chelate Complexes with the Additivity of the Strength of the Individual Rings, Radiokhimiya, 14: 29 (1972) through Sov Radiochem (Engl Transl) 14: 26 (1972)

237 A B Shalinets, Investigation of the Complex Formation of Trivalent Actinide and Lanthanide Elements by the Method of Electromigration XI Relationship of the Strength of Complexes to the Strength of the Acid, Radiokhimiya 13: 566 (1971) through Sov Radiochem (Engl Transl), 13: 583 (1971)

238 A I Moskvin, Relations Between Successive Stability Constants of Complex Ions of Actınıdes, Radiokhimiya, 15: 497 (1973) through Sov Radiochem (Engl Transl) 15: 504 (1973)

239 R Munze, Thermodynamische Funktionen Der Komplexbildung und Ionenradien I Bestımmung der Freien Enthalpıe, Entropie, und Enthalpie von Azetatokomplexen der Lanthanıden und Aktınıden aus Zwischenatomaren Donor-Akzeptorstanden, $J$ Inorg $\mathrm{NuCl}$ Chem, 34: 661 (1972)

$240 \mathrm{~J}$ Fuger and B B Cunnungham, Microcalorimetric Determination of the Enthalpy of Formation of the Complex Ions of Trivalent Plutonıum, Americium, and Lanthanum with EDTA, J Inorg Nucl Chem 27: 1079 (1965)

241 G R Choppin, unpublished, cited in Ref 47 b

242 D C Feay, Some Chemical Properties of Curium (Thesis), USAEC Report UCRL-2547, University of Calıfornia, Berkeley, Radiation Laboratory, 1954

243 R G De Carvalho and G R Choppin, Lanthanide and Actınide Sulfate Complexes II Determination of Thermodynamic Parameters, J Inorg Nucl Chem 29: 737 (1967)

244 A I Moskvin, Thermodynamic Characteristics of Formation of Actinide Ions in Aqueous Solutions, Radiokhimiya 15: 504 (1973) through Sov Radiochem (Engl Transl), 15: 511 (1973)

245 G R Choppin and K R Willams, The Kinetics of Exchange Between Americium(III) and Europium Ethylenediaminetetradcetate, J Inorg Nucl Chem 35: 4255 (1973)

246 W D'Olieslager and G R Choppin, The Kinetics of Exchange Between Lanthanide Ions and Lanthanum Ethylenediaminetetraacetate, J Inorg Nucl Chem 33: 127 (1971)

247 W D'Olieslager, G R Choppin, and K R Willams, The Activation Parameters for the Exchange Reactions Between EuEDTA and Eu(III) and Am(III), J Inorg Nucl Chem 32. 3605 (1970)

248 H El-Rawi, Complexing Kinetıcs of Transplutonıum Elements, German Report KFK-1927, January 1974 


\section{METAL, ALLOYS, AND COMPOUNDS}

\section{METAL}

\section{Preparation}

Americium metal is usually prepared by one of the following four methods:

1. Vapor phase reduction of $\mathrm{AmF}_{3}$ with barium (or lithium) metal

$$
2 \mathrm{AmF}_{3}+3 \mathrm{Ba} \frac{1100-1250^{\circ} \mathrm{C}}{\text { vacuum }} 2 \mathrm{Am}^{\prime}+3 \mathrm{BaF}_{2}
$$

2. Reduction of $\mathrm{AmO}_{2}$ with lanthanum metal

$$
\mathrm{AmO}_{2}+4 / 3 \mathrm{La} \frac{1500-1600^{\circ} \mathrm{C}}{\text { vacuum }} \mathrm{Am}+2_{3} \mathrm{La}_{2} \mathrm{O}_{3}
$$

3. Bomb reduction of $\mathrm{AmF}_{4}$ with calcium metal

$$
\mathrm{AmF}_{4}+\mathrm{I}_{2}+3 \mathrm{Ca} \rightarrow \mathrm{Am}+2 \mathrm{CaF}_{2}+\mathrm{CaI}_{2}
$$

4. Thermal decomposition of $\mathrm{Pt}_{5} \mathrm{Am}$

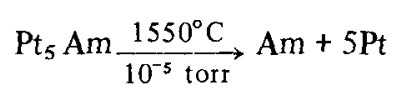


Westrum and Eynng ${ }^{1}$ and later Graf et al. ${ }^{2}$ made use of Eq. 4.1 to prepare the first microgram amounts of americium metal. Subsequently McWhan et al. ${ }^{3}$ and McWhan, Cunningham, and Wallmann ${ }^{4}$ prepared milligrams of americium metal by reduction of $\mathrm{AmF}_{3}$ with barium. These workers stress that the $\mathrm{AmF}_{3}$ be completely dehydrated, if it is not, the resulting metal will be contaminated with AmO. Also, according to McWhan, Cunnıngham, and Wallmann, ${ }^{4}$ well-agglomerated metal is obtained only when Eq. 4.1 is performed at temperatures above $1200^{\circ} \mathrm{C}$.

Lanthanum reduction of $\mathrm{AmO}_{2}$ (Eq.4.2) and subsequent distillation of the americium metal from tantalum equipment yield americium of very high $(99.9+\%)$ purity. This scheme has been used by various workers ${ }^{36}$ to prepare milligram to gram quantities of americium metal Equipment used by Wade and Wolf $\mathrm{f}^{5}$ to produce $200 \mathrm{~g}$ of metal is shown in Fig. 41 Successful production of americium by Eq. 4.2 is enhanced by the $10^{4}$-fold difference in americium-lanthanum volatilities.

The bomb method (Eq. 4.3) was applied by Conner ${ }^{7}$ to prepare americium metal on a gram scale, $\mathrm{AmF}_{4}$ for use in $\mathrm{Eq} 43$ was prepared by fluorination of $\mathrm{AmO}_{2}$ with
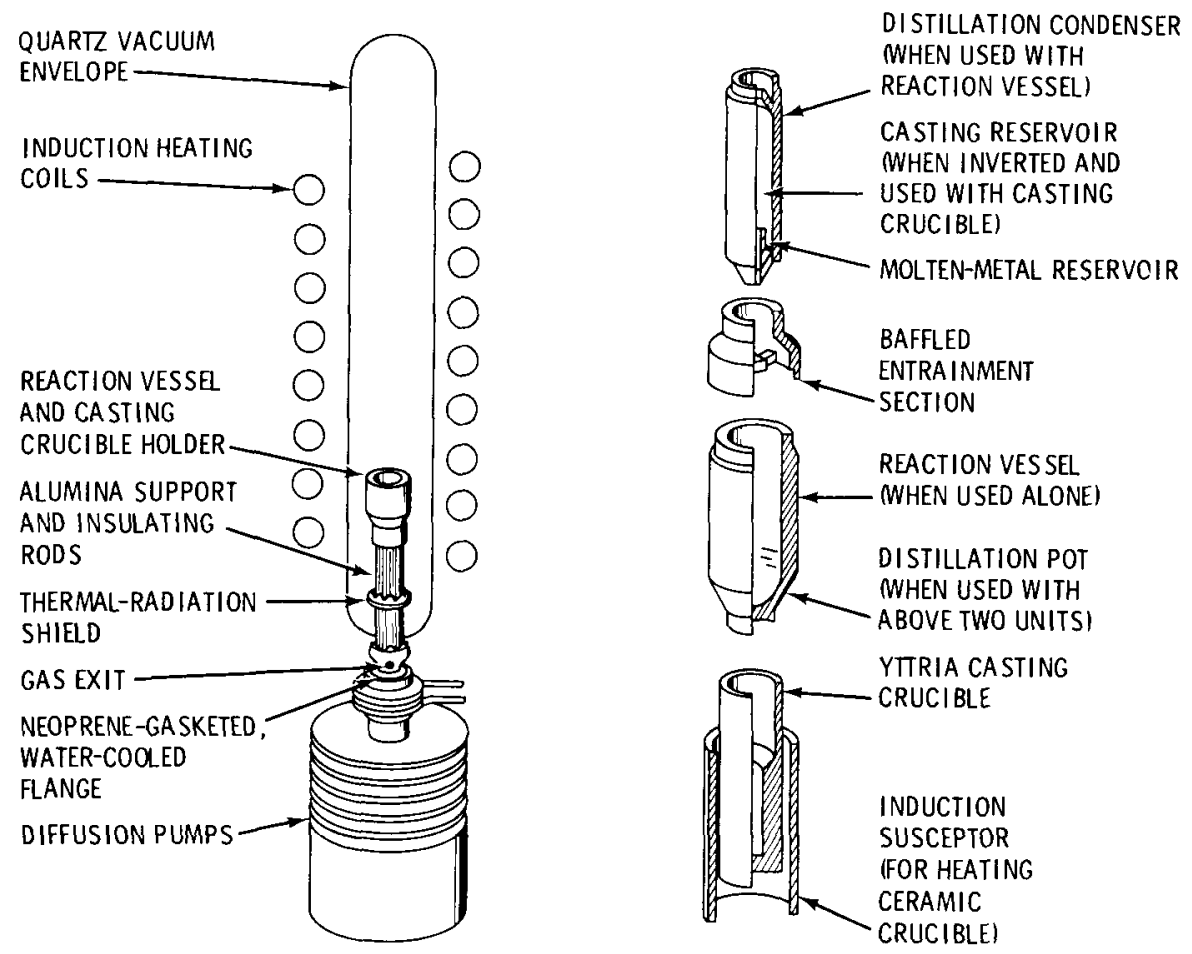

Fig. 4.1 Apparatus for preparation of americium metal by Eq 42 [From W Z Wade and $T$ Wolf, Preparation and Some Properties of Americium Metal, Journal of Inorganic and Nuclear Chemistry, 29: 2577 (1967) ] 
$\mathrm{F}_{2}$ Reductions were performed in either tantalum or $\mathrm{MgO}$ crucibles in steel pressure vessels. Reduction yields of 34 to $64 \%$ of impure amencium metal were obtained (The exothermic reaction between calcium and $I_{2}$ was used to supply the heat required for good metal coalescence) Conner believes that with further development the thermite bomb method will offer an inexpensive means for producing americium metal in good yield and of high purity

Preparation of americium metal by thermal decomposition of the intermetallic compound $\mathrm{Pt}_{5} \mathrm{Am}$ (see page 129) is a very recent development ${ }^{8} 10$ In the tests of Muller, Reul, and Spirlet, ${ }^{8} 4 \mathrm{~g}$ of $\mathrm{Pt}_{5} \mathrm{Am}$ were decomposed at $1550^{\circ} \mathrm{C}$ and $10^{6}$ torr, the resulting americium metal, after further distillation in tantalum equipment, was as pure as that obtained by $\mathrm{Eq} 42$

\section{Properties}

Amencium metal is silvery, ductile, nonmagnetic, and very malleable Selected physical properties are listed in Table 41 Of the two definitely established crystalline forms of americium metal, the double hexagonal close-packed (dhcp) phase is the stable one at room temperature and is generally the one obtained by reduction of $\mathrm{AmF}_{3}$ or by thermal dissociation of $\mathrm{Pt}_{5} \mathrm{Am}$ The reaction between $\mathrm{AmO}_{2}$ and lanthanum (Eq 42 ) has been reported vanously to yield pure dhcp phase, ${ }^{1 \text { ta }}$ pure face-centered cubic ( $\mathrm{fcc}$ ) phase, ${ }^{4}$ and a mixture of dhcp and fcc phases ${ }^{3,6}$ Workers at the European Institute for Transuranium Elements ${ }^{16 \mathrm{f}}$ recently prepared the fcc form by condensation of americium vapor on thin tungsten wires spot-welded behind a 1-mm slit in a tantalum disk The americium metal condensed on the tantalum disk showed the dhcp structure After storage at liquid-nitrogen temperatures for 3 weeks, the fcc phase started to transform into the dhcp modification $\mathrm{McWhan}$ et al ${ }^{3}$ also observed the fcc phase to transform to the dhcp on cooling the metal at dry-ice temperature

McWhan, Cunningham, and Wallmann ${ }^{4}$ originally reported that the meltıng point of americium metal is $994 \pm 7^{\circ} \mathrm{C}$ and that the $\mathrm{dhcp} \rightarrow \mathrm{fcc}$ phase transition occurs between 600 and $700^{\circ} \mathrm{C}$ Later work demonstrates that the meltung point is about $1170^{\circ} \mathrm{C}$ and that there is a solid-solid transition at about $1070^{\circ} \mathrm{C}$ Sari, Muller, and Benedict, ${ }^{16 \mathrm{a}}$ in recent metallographic and differential thermal-analysis studies with high-purity americium metal, conclude that there is no phase transition between 600 and $700^{\circ} \mathrm{C}$ Stephens, Stromberg, and Lilley ${ }^{12}$ suggest that americium metal may undergo a dhcp $\rightarrow \mathrm{fcc}$ phase transformation at 600 to $700^{\circ} \mathrm{C}$ and an $\mathrm{fcc} \rightarrow \mathrm{bcc}$ (body-centered cubic) transformation at 994 to $1070^{\circ} \mathrm{C}$ Confirmatory evidence for this hypothesis is lacking

In addition to the properties listed in Table 41 , Stephens, Stromberg, and Lilley ${ }^{12}$ have determined the phase diagram, compressibility, and electrical resistance of amencium at room temperature over the range 35 to 120 kbars. Hall et al ${ }^{16 \mathrm{e}}$ used an adiabatic technique to measure the specific heat, $C_{p}$, of vapor-deposited ${ }^{241}$ Am metal from 15 to $300^{\circ} \mathrm{K}$ According to Hall et al, ${ }^{16 \mathrm{e}}$ the temperature dependence of the 
Table 4.1

SELECTED PROPERTIES OF AMERICIUM METAL

\begin{tabular}{|c|c|c|}
\hline Property & Value(s)* & Refs. \\
\hline \multicolumn{3}{|l|}{ Crystallographic data } \\
\hline Symmetry & $\begin{array}{l}\left(<\sim 1070^{\circ} \mathrm{C}\right) \text { dhcp } \\
\left(>\sim 1070^{\circ} \mathrm{C}\right) \text { fcc }\end{array}$ & $\begin{array}{ll}2 & 4 \\
3 & 4\end{array}$ \\
\hline Space group & $P 6_{3} / m m c$ & $2-4$ \\
\hline Lattice parameters & $\begin{array}{l}\text { dhcp } a=34681 \AA, c=11241 \AA \\
\text { fcc } a=4894 \AA\end{array}$ & $\begin{array}{l}3,4 \\
3,4\end{array}$ \\
\hline Density & $\begin{array}{l}13671 \mathrm{~g} \mathrm{~cm}^{3} \text { (calculated) } \\
13671 \mathrm{~g} \mathrm{~cm}^{3} \text { (observed) } \dagger\end{array}$ & $\begin{array}{l}4 \\
5\end{array}$ \\
\hline Metallic radius (CN 12) & $173 \AA$ & 3,4 \\
\hline Meltıng point & $1176^{\circ} \mathrm{C}, 1173^{\circ} \mathrm{C}$ & 12 \\
\hline Bolling point & $2284^{\circ} \mathrm{K}$ & $11 \mathrm{a}$ \\
\hline Coefficient of thermal & $\alpha_{\mathrm{a}}=7 \mathrm{~s}+02 \times 10^{6 \circ} \mathrm{C}^{-1}$ & 4 \\
\hline expansion & $\alpha_{c}=62+02 \times 10^{60} \mathrm{C}^{-1}$ & 4 \\
\hline Compressibility at $1 \mathrm{~atm}$ & $000277 \mathrm{kbar}^{1}$ at $23^{\circ} \mathrm{C}$ & 12 \\
\hline Vapor pressure & $\begin{array}{l}\log p(a t m)=6578+0046- \\
(14,315+55) \mathrm{T}\left(9901358^{\circ} \mathrm{K}\right)\end{array}$ & $11 \mathrm{~b}, 13,14$ \\
\hline Magnetic susceptıbility & $\mathrm{x}_{20^{\circ} \mathrm{C}}=(881+46) \times 10^{6} \mathrm{~cm}^{3} \mathrm{~mol}^{1}$ & $4,15 a, 15 b$ \\
\hline Magnetic moment & 136 Bohr magnetons & $15 \mathrm{a}$ \\
\hline Microhardness (Vickers) at $25^{\circ} \mathrm{C}$ & $800 \mathrm{MN} \mathrm{m}^{2}$ & $16 \mathrm{a}$ \\
\hline Electrical resistivity & $68 \mu \Omega \mathrm{cm}\left(300^{\circ} \mathrm{K}\right), 71 \mu \Omega \mathrm{cm}\left(298^{\circ} \mathrm{K}\right)$ & $16 \mathrm{~b}, 16 \mathrm{c}$ \\
\hline Crystal entropy $\left(\mathrm{S}_{298}^{0}\right)$ & $132 \pm, 1306 \mathrm{cal} \mathrm{mol}^{10} \mathrm{~K}^{1}$ & $11 \mathrm{~b}, 16 \mathrm{~d}, 16 \mathrm{e}$ \\
\hline $\begin{array}{l}\text { Heat of vaporization at } \\
\text { bolling point } \neq\end{array}$ & $55021 \mathrm{kcal} \mathrm{mol}^{1}$ & $11 \mathrm{~b}$ \\
\hline $\begin{array}{l}\text { Entropy of vaporization at } \\
\text { bolling point } \ddagger\end{array}$ & $2408 \mathrm{cal} \mathrm{mol}{ }^{10} \mathrm{~K}^{1}$ & $11 b$ \\
\hline Transformation temperature & $\begin{array}{l}\left(600-700^{\circ} \mathrm{C}^{\circ}\right), 1079^{\circ} \mathrm{C}, 1072^{\circ} \mathrm{C} \\
10741175^{\circ} \mathrm{C}\end{array}$ & $4,5,12,16 \mathrm{a}$ \\
\hline Heat of transformation & $140 \mathrm{kcal} \mathrm{mol}^{1}$ & 5 \\
\hline Heat of fusion & $344 \mathrm{kcal} \mathrm{mol}^{1}$ & 5 \\
\hline \multicolumn{3}{|l|}{ Heat of solution in aqueous $\mathrm{HCl}$} \\
\hline $1 M \mathrm{HCl}$ & $1473 \mathrm{kcal} \mathrm{mol}^{1}$ & $11 \mathrm{a}$ \\
\hline $1.5 \mathrm{M} \mathrm{HCl}$ & $1471 \mathrm{kcal} \mathrm{mol}^{1}$ & $11 \mathrm{a}$ \\
\hline $6 M \mathrm{HCl}$ & $1477 \mathrm{kcal} \mathrm{mol}^{1}$ & $11 \mathrm{a}$ \\
\hline
\end{tabular}

*For the double hexagonal close-packed form unless otherwise indicated † By immersion in monobromobenzene $¥$ Calculated value

measured specific heat with minumum self-damage does not fit a simple Debye model However, a reasonable assumption of the electronic contribution gives a strongly temperature-dependent Debye temperature Schenkel, Schmidt, and Sprrlet ${ }^{16 \mathrm{c}}$ used a potentiometric method to measure the electrical resistivity of a $189-\mu \mathrm{m}$-thick layer of americium metal between 300 and $36^{\circ} \mathrm{K}$, up to $20^{\circ} \mathrm{K}$ the electrical resistivity varies with temperature as $\mathrm{T}^{28}$ Ward, Muller, and Kramer ${ }^{11 \mathrm{~b}}$ used the heats of transition and melting measured by Stephens et al ${ }^{12}$ to arrive at the following equation for americium liquid $\log \mathrm{p}(\mathrm{atm})=5185-13,191 / \mathrm{T}$ 
Self-1rradiation studies of ${ }^{241} \mathrm{Am}$ metal at 45 and $78^{\circ} \mathrm{K}$ were performed by Schenkel, Schmit, and Sprrlet ${ }^{16 \mathrm{c}}$ From the equation $\Delta p=1743 \mu \Omega-\mathrm{cm}\left(1-\mathrm{e}^{\alpha \mathrm{t}}\right)$, the time constant, $\alpha$, for the rate of self-damage was $00204 \mathrm{hr}^{1}$ Hall et al ${ }^{16 \mathrm{e}}$ found that, for samples of ${ }^{241} \mathrm{Am}$ self-damaged below $10^{\circ} \mathrm{K}$ for times up to $112 \mathrm{hr}$, annealıng takes place over the temperature range 50 to $250^{\circ} \mathrm{K}$ with three main stages clearly visible

Hexagonal americium metal ${ }^{17}$ shows no magnetic hyperfine coupling at tempera tures as low as $17^{\circ} \mathrm{K}$

When heated, americium metal reacts with halogens, $\mathrm{H}_{2}, \mathrm{O}_{2}, \mathrm{~N}_{2}$, carbon, boron, antimony, etc , and with $\mathrm{HgBr}_{2}$ and $\mathrm{HgI}_{2}$ These reactions are considered on pages 131 to 171 Amencium also forms alloys with a number of metals $(\mathrm{e} g$, heryllium and platinum) These are discussed on pages 127 and 129 Americium dissolves ${ }^{1,1}$ a readily in aqueous $\mathrm{HCl}$ but is insoluble ${ }^{18,19}$ in liquid $\mathrm{NH}_{3}$

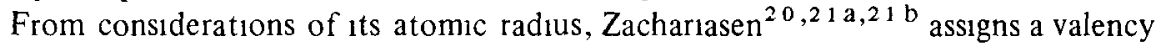
of four to americium metal-the so-called "thoride" hypothesis Hill, 2 a,2 2 b Jullien, Galleanı D'Aglıano, and Coqblın, ${ }^{2 \mathrm{c}}$ and others, however, believe there $1 \mathrm{~s}$ abundant evidence to adopt the viewpoint that americium metal is trivalent with an $f^{6}$ electronic configuration and is the first rare-earth-like metal in the transactınium series

\section{ALLOYS AND INTERMETALLIC COMPOUNDS}

Preparation and properties of alloys and intermetallic compounds formed by americlum with the metals $\mathrm{Al}, \mathrm{Be}, \mathrm{B} 1, \mathrm{Hg}, \mathrm{Ir}, \mathrm{La}, \mathrm{Np}, \mathrm{N}_{1}, \mathrm{Os}, \mathrm{Pd}, \mathrm{Pt}, \mathrm{Pu}, \mathrm{Rh}$, and Th are reviewed here * (For convenience, binary compounds of americium with the elements $\mathrm{Sb}, \mathrm{As}, \mathrm{Se}$, and Te are discussed on pages 131 and 132 and 164 to 166 ) A complete phase diagram is known only for the plutonium-americium system

\section{Alumınum-Amerıcium System}

Runnals $^{23}$ patented a method for makıng americium-alumınum alloys in which a mixture of aluminum metal and an americium halide is heated in a vacuum of $10^{3}$ torr at 700 to $1200^{\circ} \mathrm{C}$ until the americium is reduced and alloyed

Homogeneous amencium-aluminum alloys containing 2 to $53 \mathrm{wt} \%$ americium can be prepared by reaction of aluminum, $\mathrm{AmO}_{2}$, and $\mathrm{Na}_{3} \mathrm{AlF}_{6}$ (cryolite) at 1100 to $1200^{\circ} \mathrm{C}$ (Refs $24 \mathrm{a}$ and $24 \mathrm{~b}$ ) This technique is being used by German scientists at

*Preparation of the binary compounds $\mathrm{Al}_{2} \mathrm{Am}, \mathrm{\Gamma e}_{2} \mathrm{Am}, \mathrm{Co}_{2} \mathrm{Am}$, and $\mathrm{Ru}_{2} \mathrm{Am}$ has now been reported ${ }^{205}$ The first three of these compounds have the cubic $\mathrm{Cu}_{2} \mathrm{Mg}$ ty pe of structure, whereas $\mathrm{Ru}_{2} \mathrm{Am}$ is 1sostructural with $\mathrm{Os}_{2} \mathrm{Am}$, which has the $\mathrm{MgZn}_{2}$ type of structure All these compounds, except $\mathrm{fe}_{2} \mathrm{Am}$, exhibit almost temperature independent paramagnetism, $\mathrm{Fe}_{2} \mathrm{Am}$ is ferromagnetic with an estimated curle temperature of $\sim 400^{\circ} \mathrm{K}$ 
Karlsruhe, as part of their Actinide Project, to prepare gram quantities of aluminum-5 to $10 \mathrm{wt} \%$ americium alloys for irradiation in various European reactors. ${ }^{25,26}$ Equipment used for preparation of such aluminum-americium alloys is described in Refs. 25 and 26.

\section{Beryllium-Americium System}

Runnals and coworkers ${ }^{23,27,28}$ used Eq. 4.5 to prepare milligram amounts of ${ }^{241}$ Am-beryllium alloys for use as neutron sources

$$
2 \mathrm{AmF}_{3}+x \mathrm{Be} \underset{100-1200^{\circ} \mathrm{C}}{\stackrel{3}{\text { torr }}} 2 \mathrm{Am} \cdot(x-3) \mathrm{Be}+3 \mathrm{BeF}_{2}
$$

The $\mathrm{BeF}_{2}$ readily distills leaving a fluoride-free alloy. Runnals and Boucher ${ }^{28}$ prepared alloys with beryllium/amencium atomic ratios of $263 \quad 1$ and $14 \quad 1$. The intermetallic compound, $\mathrm{AmBe}_{1_{3}}$, is present in the 141 alloy, $\mathrm{AmBe}_{13}$ is fcc with a $=10.283 \AA$.

Recently, Brachet and Vasseur ${ }^{29}$ developed a method for makıng aluminumberyllium neutron sources by reduction of $\mathrm{AmO}_{2}$ with beryllium according to Eq 4.6

$$
\mathrm{AmO}_{2}+15 \mathrm{Be} \stackrel{1200-1300^{\circ} \mathrm{C}}{\longrightarrow} 2 \mathrm{BeO}+\mathrm{AmBe}_{13}
$$

Using Eq. 4.6, Brachet and Vasseur ${ }^{29}$ obtained an alloy that emitted $3.75 \times 10^{6}$ neutrons $\mathrm{g}^{-1} \mathrm{sec}^{-1}$ The yield of such a source was $2 \times 10^{6}$ neutrons $\sec ^{-1} \mathrm{C}_{1}^{-1}$ of emitter

\section{Bismuth-Americium System}

Reaction ${ }^{30}$ of metallic bismuth vapor with either americium metal or americium hydride in a sealed, evacuated quartz tube for $48 \mathrm{hr}$ at $975^{\circ} \mathrm{C}$ produces $\mathrm{AmB}$. This metallide has the $\mathrm{NaCl}$ structure with a $=6.338 \pm 00012 \AA$, after annealıng 14 days at $800^{\circ} \mathrm{C}, \mathrm{a}=6335 \pm 00019 \AA$.

\section{Mercury-Americium System}

Bouıssières and Legoux ${ }^{31 \text { a }}$ first prepared an amalgam of americium by equil1brating a sodium citrate solution of $\mathrm{AmCl}_{3}\left(10^{-12} \mathrm{M}\right.$ to $10^{-6} \mathrm{M}$ americium) for $90 \mathrm{~min}$ in an $\mathrm{H}_{2}$ atmosphere with a $0027 \mathrm{wt} \%$ lithium amalgam. The yield of americium amalgam decreased steadily as the $\mathrm{pH}$ of the initial citrate solution increased from 2 to 8 , reaching zero at the latter $\mathrm{pH}$. In this latter respect the mercury-americium system resembles the mercury-lanthanum system. ${ }^{31 \mathrm{~b}}$ David and Bouissieres ${ }^{31 \mathrm{c}}$ now find that amalgamation of americium by electrolytic reduction of $10^{-6} \mathrm{M} \mathrm{Am}^{3+}$ in a lithium citrate solution at a mercury cathode is a first-order reaction. The time required to form the americium amalgam increases with increased lithium citrate concentration. 
Reaction of $\mathrm{Am}^{3+}$ in $04 M$ to $08 M$ acetıc acid with sodium amalgam results in rapid and almost complete $\left(\geqslant 98 \%\right.$ ) amalgamation of the americium ${ }^{32}$

\section{Iridium-Americium System}

Reduction of $\mathrm{AmO}_{2}$ with highly purified $\mathrm{H}_{2}$ in the presence of iridium metal-the so-called coupled reduction ${ }^{33 \mathrm{a}-\mathrm{c}}$-yields at $1550^{\circ} \mathrm{C}$ the intermetallic compound $\mathrm{Ir}_{2}$ Am (Eq. 4.7)

$$
2 \mathrm{H}_{2}+\mathrm{AmO}_{2}+2 \mathrm{Ir} \frac{60 \mathrm{hr}}{1550^{\circ} \mathrm{C}} \mathrm{Ir}_{2} \mathrm{Am}+2 \mathrm{H}_{2} \mathrm{O}
$$

The $\mathrm{Ir}_{2} \mathrm{Am}$ phase has the cubic $\mathrm{Cu}_{2} \mathrm{Mg}$ type of structure with $\mathrm{a}=755 \AA$.

\section{Lanthanum-Americium System}

Lanthanum-americium alloys containing 092 to 237 at \% americium dissolved in fcc $\beta$-lanthanum have been produced by arc-melting the constituent metals ${ }^{34}$ The lattice parameters for these alloys deviate only slightly from the Vegard line, an indication that the effective size of americium in lanthanum is very close to that of elemental americium $(173 \AA$ radius $)$ Small amounts of americium $(<15$ at \%) dissolved in $\beta$-lanthanum produce an unusually weak depression of the superconducting transition temperature $T_{c}$ of $\beta$-lanthanum. ${ }^{35}$ To account for this latter observation, Hill et al ${ }^{35}$ suggest that americium atoms in lanthanum are likely to be trivalent and to possess the $f^{6}$ electron configuration, which has no first-order magnetıc moment

\section{Neptunium-Americium System}

Through alpha decay, ${ }^{241} \mathrm{Am}$ metal automatically becomes a neptuniumamericium alloy. The magnetic behavior of such an alloy $(\simeq 0.5 \mathrm{wt} . \%$ neptunium) was studied recently by Dunlap et al. ${ }^{36 \mathrm{a}}$ using the Mossbauer effect of the 596 -keV X-ray in ${ }^{237} \mathrm{~Np}$. A small local moment on neptunium in americium was found

\section{Nickel-Americium System}

Lam and Mitchell ${ }^{36 \mathrm{~b}}$ prepared $\mathrm{N}_{2} \mathrm{Am}$ by arc-melting the requisite amount of the pure elements in an argon-helium atmosphere for several hours at 800 to $1000^{\circ} \mathrm{C}$. Cubic $\mathrm{N}_{2} \mathrm{Am}$.has the $\mathrm{Cu}_{2} \mathrm{Mg}$ type of structure (space group $\mathrm{Fd} 3 \mathrm{~m}$ ) with a $=699 \AA$. 


\section{Osmium-Americium System}

Hexagonal $\mathrm{Os}_{2} \mathrm{Am}$ (space group $\mathrm{Pb}_{3} / m m c$ ) was prepared by Lam and Mitchell ${ }^{36 \mathrm{~b}}$ by the same method used to make $\mathrm{N}_{2} \mathrm{Am}$. Lattice constants of $\mathrm{Os}_{2} \mathrm{Am}$ are $\mathrm{a}=5.320 \AA$ and $\mathrm{c}=8849 \AA$

\section{Palladium-Americium System}

Coupled reduction of $\mathrm{Am}_{2} \mathrm{O}_{3}$ with palladium, according to the conditions of Eq. 4 8, yields the compound $\mathrm{Pd}_{3} \mathrm{Am}$, which has the ordered $\mathrm{Cu}_{3} \mathrm{Au}$ structure

$$
\mathrm{Am}_{2} \mathrm{O}_{3}+6 \mathrm{Pd}+3 \mathrm{H}_{2} \frac{13001400^{\circ} \mathrm{C}}{40-60 \mathrm{hr}} 3 \mathrm{H}_{2} \mathrm{O}+2 \mathrm{Pd}_{3} \mathrm{Am}
$$

The lattice constant of $\mathrm{Pd}_{3} \mathrm{Am}$ is $4158 \AA$

\section{Platinum-Americium System}

$\mathrm{Pt}_{2} \mathrm{Am}$. When performed at $1400^{\circ} \mathrm{C}$, Eq. 4.7 , with platinum substituted for irdium, yields pure $\mathrm{Pt}_{2} \mathrm{Am}^{33}$ This alloy phase has the cubic $\mathrm{Cu}_{2} \mathrm{Mg}$ structure with $\mathrm{a}=7.615 \AA$.

$\mathbf{P t}_{5} \mathrm{Am}$. Intermetallic $\mathrm{Pt}_{5} \mathrm{Am}$, which is obtained ${ }^{33 \mathrm{a}, 33 \mathrm{~b}}$ by Eq 4.9,

$$
\mathrm{Am}_{2} \mathrm{O}_{3}+10 \mathrm{Pt}+3 \mathrm{H}_{2} \stackrel{40 \mathrm{hr}-1200^{\circ} \mathrm{C}}{\longrightarrow} 2 \mathrm{Pt}_{5} \mathrm{Am}+3 \mathrm{H}_{2} \mathrm{O}
$$

has the orthorhombic $\mathrm{Pt}_{5} \mathrm{Sm}$ type of structure with $\mathrm{a}=5.319 \AA, \mathrm{b}=909 \AA$, and $c=26.42 \AA$ Mention has already been made (see pages 122 to 124) of the preparation of americium metal by thermal decomposition of $\mathrm{Pt}_{5} \mathrm{Am}$ in a vacuum Interestingly, for the noble metals irıdıum, palladium, platınum, and rhodium, the $\mathrm{M}_{5} \mathrm{Am}$ compound is known only for platınum.

\section{Plutonium-Americium System}

The plutonium-americium phase diagram is shown in Fig. 4.2. This diagram was constructed by Ellinger, Johnson, and Struebing ${ }^{3-39}$ from X-ray diffraction studies of plutonium-amencium alloys containing 1.48 to $95 \pm 1$ at.\% americium. The principal feature of the plutonium-americium system 1 s the continuous series of solid solutions between $\delta$-plutonium and $\beta$-americium which are stable at room temperature in the composition range from about 6 to 80 at.\% americium. In contrast to the extensive solid solubility of amencium in $\delta$-plutonium, the solubility of americium in bcc $\epsilon$-plutonium is about 8 at. $\%$ at $665 \pm 15^{\circ} \mathrm{C}$. The maximum solubility of plutonium in americium appears to be less than 5 at.\%. 


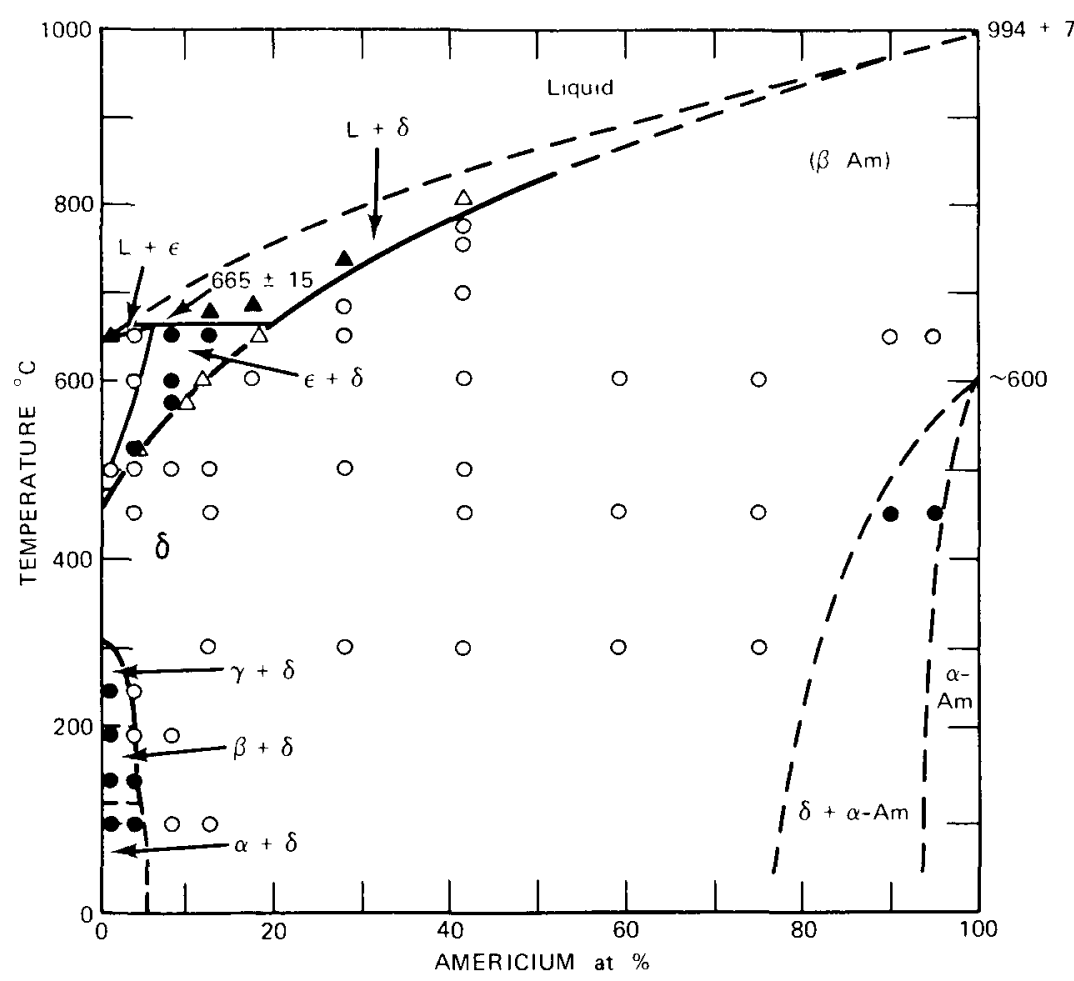

Fig. 4.2 The plutonium-dmericium phase diagram Unlabeled Greek letters refer to plutonium phases $\circ$, one-phase alloy, $\bullet$, two-phase alloy, 4 , liquid present, $\triangle, \mathrm{X}$-ray parametric [From $\mathrm{F} \mathrm{H}$ Ellınger, K A Johnson, and $\mathrm{V} O$ Struebıng, The Plutonium-Americium System, Journal of Nuclear Materials, 20: 83 (1966) ]

\section{Rhodium-Americium System}

$\mathbf{R h}_{2} \mathrm{Am}$. This intermetallic phase is prepared ${ }^{33 \mathrm{~b}}$ by the same coupled reduction technique (see Eq. 4.7) used to make $\operatorname{Ir}_{2} \mathrm{Am}$ and $\mathrm{Pt}_{2} \mathrm{Am}$. Also, $\mathrm{like}_{\mathrm{Ir}} \mathrm{Am}$ and $\mathrm{Pt}_{2} \mathrm{Am}$, the cublc $\mathrm{Rh}_{2} \mathrm{Am}$ phase has the $\mathrm{Cu}_{2} \mathrm{Mg}$ structure with $\mathrm{a}=7548 \AA$

$\mathbf{R h}_{3} \mathrm{Am}$. This intermetallic compound has the ordered $\mathrm{Cl}_{3} \mathrm{Au}$ type of structure with a $=4.098 \AA$. It is made by coupled reduction of $\mathrm{AmO}_{2}$ with rhodium for $60 \mathrm{hr}$ at $1550^{\circ} \mathrm{C}$ in a $\mathrm{H}_{2}$ atmosphere.

\section{Thorium-Americium System}

For use as Mossbauer sources, $\operatorname{Adarr}^{40}$ prepared thorlum-0 54 to $5.0 \mathrm{wt} . \%$ americium alloys by both levitation and arc melting of prepressed mixtures of 
americium and thorium metals. The high vapor pressure of americium metal at the melting point of thorium dictates that the levitation process be carried out in an inert atmosphere rather than in vacuum to avold loss of americium

\section{COMPOUNDS}

\section{Inorganic Compounds of Americium}

The known (January 1976) inorganic compounds of americium, for which compositions are established, are listed in Table 42 along with some of their properties (Compounds of americium with organic ligands including acetate and oxalate are discussed on pages 166 to 171 ) Other properties and methods of preparing these compounds are discussed in the accompanying text A few additional inorganic compounds whose compositions have not been definitely established are also mentioned

Generally, the compounds listed in Table 4.2 have been arranged in alphabetical order of the inorganic ligand. Oxyhalides are included with the corresponding binary halıdes, as are the ternary halıdes Following the practice established by Keller, ${ }^{4}$ ternary and polynary oxides of amencium containıng one or more of the elements $\mathrm{Na}$, $\mathrm{K}, \mathrm{Ba}, \mathrm{Sr}, \mathrm{Cm}, \mathrm{Zr}, \mathrm{Hf}$, Th, $\mathrm{Ta}, \mathrm{Nb}$, and $\mathrm{Pa}$ are included with the binary oxides Certain other ternary oxides $\left(\mathrm{AmAsO}_{4}, \mathrm{AmBO}_{3}, \mathrm{AmVO}_{4}\right.$, etc $)$, however, are discussed separately

Some of the compounds listed in Table 4.2 (e.g, oxides and binary halıdes) are well-characterized, gram amounts having been prepared by many investigators in several countries using both ${ }^{241} \mathrm{Am}$ and ${ }^{243} \mathrm{Am}$. Conversely, only microgram or milligram quantities of many of these compounds have been synthesized and these by a single scientist using ${ }^{241} \mathrm{Am}$. Venfication of the procedures used to prepare these latter compounds and their properties should be provided by programs currently under way both abroad and in U.S. Energy Research and Development Administration laboratories.

Aluminate. $\mathrm{AmAlO}_{3}$ Hexagonal $\mathrm{AmAlO}_{3}$ crystals ${ }^{4,42}$ are produced when coprecipitated $\mathrm{Am}(\mathrm{OH})_{3}$ and $\mathrm{Al}(\mathrm{OH})_{3}\left(\begin{array}{ll}1 & 1\end{array}\right)$ are heated in $\mathrm{H}_{2}$ for 2 to $8 \mathrm{hr}$ at $1250^{\circ} \mathrm{C}$. The crystals have the distorted perovskite structure of $\mathrm{LaAlO}_{3}$

Antimonide. $A m S b$. Mitchell and $\mathrm{Lam}^{43}$ prepared $\mathrm{AmSb}$ by heatıng equimolar amounts of ${ }^{241} \mathrm{Am}$ metal and high-punty antimony under vacuum for $1 \mathrm{hr}$ at $630^{\circ} \mathrm{C}$ The temperature was gradually rased to $850^{\circ} \mathrm{C}$, and the $\mathrm{AmSb}$ was held at this temperature for $7 \mathrm{hr}$ before cooling to room temperature Subsequently the AmSb was heat-treated at $100^{\circ} \mathrm{C}$ for $24 \mathrm{hr}$, furnace cooled, and then heated at $400^{\circ} \mathrm{C}$ for 10 days Roddy $^{30}$ also prepared AmSb by reactıng ${ }^{243} \mathrm{Am}$ metal with antımony metal for $24 \mathrm{hr}$ at 775 to $900^{\circ} \mathrm{C}$ in an evacuated quartz bulb. The lattice parameter measured by 
Roddy $(a=6.240 \AA)$ was in excellent agreement with that $(a=6.238 \AA)$ reported by Mitchell and Lam. ${ }^{43}$

Magnetic susceptibility measurements ${ }^{44}$ on AmSb give a temperature-independent value of $(1250 \pm 100) \times 10^{-6} \mathrm{emu} \mathrm{mol}^{-1}$ for the range $4.2^{\circ} \mathrm{K}<\mathrm{T}<320^{\circ} \mathrm{K}$.

$\mathrm{Am}_{4} \mathrm{Sb}_{3}$. Charvillat et al. ${ }^{4 \mathrm{~b}}$ prepared $\mathrm{Am}_{4} \dot{\mathrm{Sb}}_{3}$ by heating ${ }^{241} \mathrm{AmH}_{3}$ in a Pyrex tube at $550^{\circ} \mathrm{C}$ with a quantity of elemental antimony corresponding to the stoichiometry $4: 3$. The resulting product contained two phases, AmSb and a second phase with the bcc structure of anti-Th $\mathrm{P}_{4}$ type. The lattice parameter of $\mathrm{Am}_{4} \mathrm{Sb}_{3}$ is $\mathrm{a}=9.2392 \pm 0.0005 \AA$.

Arsenate. $\mathrm{AmAsO}_{4}$. Light-pink $\mathrm{AmAsO}_{4}$ is produced by heating at $1000^{\circ} \mathrm{C}$ the residue obtained from evaporation ${ }^{4,45}$ of a $1: 1$ solution of $\mathrm{Am}\left(\mathrm{NO}_{3}\right)_{3}$ and $\left(\mathrm{NH}_{4}\right)_{2} \mathrm{HAsO}_{4}$.

Arsenide. AmAs. Vapor-phase reaction of excess metallic arsenic with ${ }^{241} \mathrm{AmH}_{3}$ for a week at $330^{\circ} \mathrm{C}$ yields AmAs. ${ }^{4}$ The resulting product contains two phasesmetallic arsenic and a cubic NaCl-type phase that Charvillat and Damien ${ }^{46}$ label AmAs by analogy with the corresponding plutonium and neptunium monoarsenides. A single AmAs phase is obtained by heating the mixture AmAs + arsenic at $330^{\circ} \mathrm{C}$ in a high vacuum.

The lattice parameter $\left(a=5.880 \pm 0.0012 \AA\right.$ ) of AmAs prepared by Roddy ${ }^{30}$ by heating ${ }^{243} \mathrm{Am}$ metal and arsenic metal for $24 \mathrm{hr}$ at $675^{\circ} \mathrm{C}$ and then 7 days at $400^{\circ} \mathrm{C}$ was somewhat larger than the value of $5.8753 \AA$ measured by Charvillat and Damien. Roddy found that heating samples of AmAs for $10 \mathrm{hr}$ at $1000^{\circ} \mathrm{C}$ produced a slight decrease in the lattice parameters. Weak lines corresponding to AmO were observed in the X-ray pattern of the resulting material. According to Roddy, the reduction in size of the unit cell suggests the possibility of the existence of solid solution between AmAs and AmO; this phenomenon may have occurred in the preparation of Charvillat and Damien, or the slight difference in lattice parameters may be the result of isotope effects.

Kenellakopulos et al. ${ }^{15}$ a measured the magnetic susceptibility of AmAs between liquid helium and room temperature. The effective magnetic moment of AmAs is 1.14 Bohr magnetons; AmAs exhibits an antiferromagnetic transition at $13^{\circ} \mathrm{K}$.

Borate. $\mathrm{AmBO}_{3}$. Orthorhombic $\mathrm{AmBO}_{3}$ results from the solid-state reaction ${ }^{4,42}$. of stoichiometric amounts of $\mathrm{AmO}_{2}$ and $\mathrm{B}_{2} \mathrm{O}_{3}$ or $\mathrm{H}_{3} \mathrm{BO}_{3}$ for $12 \mathrm{hr}$ in air at $900^{\circ} \mathrm{C}$. The light-pink borate is soluble in concentrated mineral acids. It has the aragonite structure of the low-temperature modification of $\mathrm{LaBO}_{3}$ and $\mathrm{NdBO}_{3}$.

Borides. $A m B_{4}$. Tetragonal $\mathrm{AmB}_{4}$ forms when a mixture of americium metal and boron in the atomic ratio $33: 67$ is heated in a vacuum at 800 to $2100^{\circ} \mathrm{C}$ in a $\mathrm{ZrB}_{2}$ crucible. ${ }^{47}$ Uranium, neptunium, and plutonium all form diborides, but americium does not. Eick and Mulford ${ }^{4}$ attribute this to the large metallic radius of americium. 


\begin{tabular}{|c|c|c|c|c|c|c|c|c|c|}
\hline \multirow[b]{3}{*}{ Type } & \multirow[b]{3}{*}{ Formula } & \multirow[b]{3}{*}{ Color } & \multirow[b]{3}{*}{$\begin{array}{l}\text { Density, } \\
\mathrm{g} \mathrm{cm}^{3}\end{array}$} & \multicolumn{6}{|c|}{ Crystal structure } \\
\hline & & & & \multirow[b]{2}{*}{ Symmetry } & \multirow{2}{*}{$\begin{array}{l}\text { Space } \\
\text { group or } \\
\text { structure } \\
\text { type }\end{array}$} & \multicolumn{4}{|c|}{ Lattıce constants } \\
\hline & & & & & & a, $\AA$ & $\mathbf{b}, \AA$ & c, $\AA$ & $\begin{array}{c}\alpha(\beta) \\
\operatorname{deg}\end{array}$ \\
\hline Alumınate & $\mathrm{AmAlO}_{3}$ & Pink & 940 & Hexagonal & $R \overline{3} m$ & 5336 & & 1291 & \\
\hline Antimonide & $\mathrm{AmSb}$ & & & $\mathrm{fec}$ & $F m 3 m$ & 6239 & & & \\
\hline Arsenate & $\mathrm{AmAsO}_{4}$ & Pınk & 813 & Monoclinic & $P 2_{1} / n$ & 689 & 706 & 662 & 105.5 \\
\hline Arsenide & AmAs & & & $\mathrm{fec}$ & $F m 3 m$ & 5880 & & & \\
\hline Beryllide & $\mathrm{AmBe}_{13}$ & & 438 & $\mathrm{fcc}$ & $F m 3 c$ & 10283 & & & \\
\hline Bismuthide & $\mathrm{AmB1}$ & & & $\mathrm{fcc}$ & $F m 3 c$ & 6338 & & & \\
\hline Borate & $\mathrm{AmBO}_{3}$ & Pınk & 848 & Orthorhombic & Pnam & 5053 & 8092 & 5.738 & \\
\hline Borides & $\begin{array}{l}\mathrm{AmB}_{4} \\
\mathrm{AmB}_{6}\end{array}$ & & & $\begin{array}{l}\text { Tetragonal } \\
\text { Simple cubic }\end{array}$ & $\begin{array}{l}P 4 / m b m \\
P m 3 m\end{array}$ & $\begin{array}{l}7105 \\
4115\end{array}$ & & 4006 & \\
\hline Bromides & $\begin{array}{l}\mathrm{AmBr} \\
\mathrm{AmBr}_{3} \\
\mathrm{AmBr} \mathrm{mBr}_{3} \cdot 6 \mathrm{H}_{2} \mathrm{O} \\
{\left[\left(\mathrm{C}_{6} \mathrm{H}_{5}\right)_{3} \mathrm{PH}\right]_{3} \mathrm{AmBr}_{6}}\end{array}$ & $\begin{array}{l}\text { Black } \\
\text { White } \\
\text { Light brown }\end{array}$ & $\begin{array}{l}6.79 \\
3.51\end{array}$ & $\begin{array}{l}\text { Tetragonal } \\
\text { Orthorhombic } \\
\text { Monoclinic }\end{array}$ & $\begin{array}{l}P 4 / n \\
C c m m \\
P 2 / n\end{array}$ & $\begin{aligned} 1159 \\
1266 \\
9955\end{aligned}$ & $\begin{array}{l}4.064 \\
6783\end{array}$ & $\begin{array}{l}7121 \\
9.144 \\
8.166\end{array}$ & 92.75 \\
\hline Carbude & $\mathrm{Am}_{2} \mathrm{C}_{3}$ & Black & & bec & $I \overline{4} 3 d$ & 8276 & & & \\
\hline Carbonates & $\begin{array}{l}\mathrm{Am}_{2}\left(\mathrm{CO}_{3}\right)_{3} \cdot 2 \mathrm{H}_{2} \mathrm{O} \\
\mathrm{Am}_{2}\left(\mathrm{CO}_{3}\right)_{3} \cdot 4 \mathrm{H}_{2} \mathrm{O} \\
\mathrm{NH}_{4} \mathrm{AmO}_{2} \mathrm{CO}_{3} \\
\mathrm{CsAmO} \mathrm{CO}_{3} \\
\mathrm{KAmO}_{2} \mathrm{CO}_{3} \\
\mathrm{~K}_{3} \mathrm{AmO}_{2}\left(\mathrm{CO}_{3}\right)_{2} \\
\mathrm{~K}_{5} \mathrm{AmO}_{2}\left(\mathrm{CO}_{3}\right)_{3} \\
\mathrm{RbAmO}_{2} \mathrm{CO}_{3}\end{array}$ & $\begin{array}{l}\text { Pink } \\
\text { Pink } \\
\text { Tan } \\
\text { Light (?) } \\
\text { Tan }\end{array}$ & 606 & $\begin{array}{l}\text { Hexagonal } \\
\text { Hexagonal } \\
\text { Hexagonal } \\
\text { Orthorhombic } \\
\text { Hexdgonal }\end{array}$ & $\begin{array}{l}\mathrm{C6/mmc} \\
\mathrm{C6} / \mathrm{mmc} \\
\mathrm{C6} / \mathrm{mmc} \\
\mathrm{c} / \mathrm{mmc}\end{array}$ & $\begin{array}{l}5123 \\
5112\end{array}$ & & $\begin{array}{r}11538 \\
9740\end{array}$ & \\
\hline Chlorides & 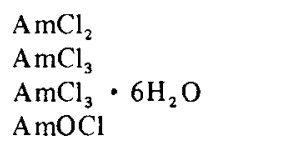 & $\begin{array}{l}\text { Black } \\
\text { Pink } \\
\text { Yellow rose } \\
\text { Pink }\end{array}$ & $\begin{array}{l}578 \\
895\end{array}$ & $\begin{array}{l}\text { Orthorhombic } \\
\text { Hexagondl } \\
\text { Monoclinic } \\
\text { Tetragonal }\end{array}$ & $\begin{array}{l}P b n m \\
P 6_{3} / m \\
P 2 / n \\
P 4 / n m m\end{array}$ & $\begin{array}{l}8963 \\
7382 \\
9702 \\
400\end{array}$ & $\begin{array}{l}7573 \\
6567\end{array}$ & $\begin{array}{l}4532 \\
4214 \\
8009 \\
678\end{array}$ & 9362 \\
\hline
\end{tabular}

(Table continues on next page) 


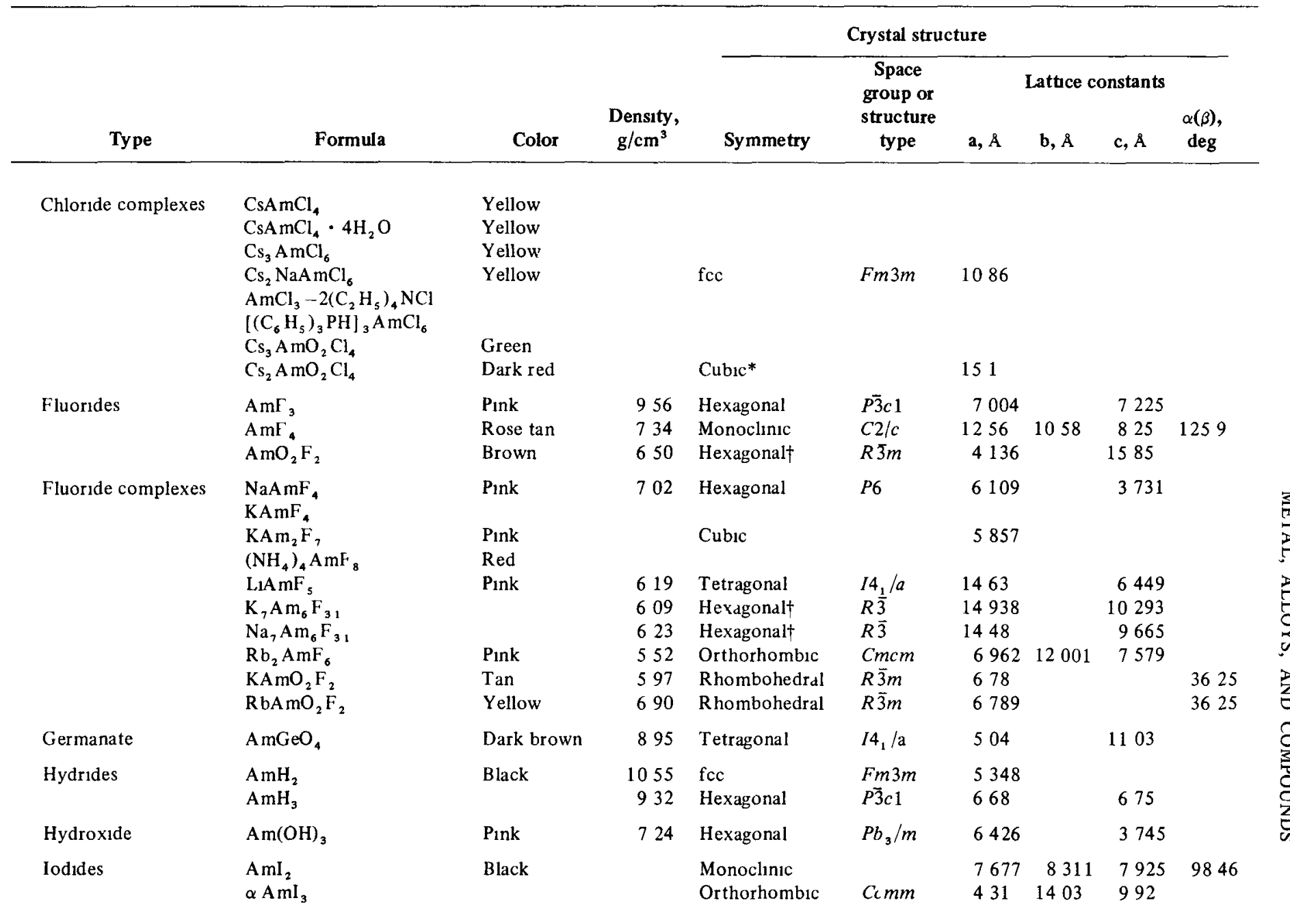


$\mathrm{B} \mathrm{AmI}_{3}$

AmOI

$\mathrm{Ir}_{2} \mathrm{Am}$

Irridium

Molybdates

$\alpha \mathrm{Am}_{2}\left(\mathrm{MoO}_{4}\right)$

$\mathrm{BAm}_{2}\left(\mathrm{MoO}_{4}\right)_{3}$

$\mathrm{LlAm}\left(\mathrm{MoO}_{4}\right)_{2}$

$\mathrm{NaAm}\left(\mathrm{MoO}_{4}\right)_{2}$

$\mathrm{Na}_{5} \mathrm{Am}\left(\mathrm{MoO}_{4}\right)_{4}$

$\mathrm{K}_{2} \mathrm{Am}_{2}\left(\mathrm{MoO}_{4}\right)_{4}$

$\mathrm{K}_{10} \mathrm{Am}_{2}\left(\mathrm{MoO}_{4}\right)_{8}$

Nickel

$\mathrm{N}_{2}$ Am

Nitride

$\mathrm{AmN}$

Osmium

$\mathrm{Os}_{2} \mathrm{Am}$

Oxıdes, binary

$\mathrm{AmO}$

$\mathrm{A}-\mathrm{Am}_{2} \mathrm{O}_{3}$

B-A m ${ }_{2} \mathrm{O}_{3}$

C-A m ${ }_{2} \mathrm{O}_{3}$

$\mathrm{AmO}_{2}$

Oxides, ternary

Lithium and sodium LiA mO

$\mathrm{L}_{2} \mathrm{AmO}_{3}$

$\mathrm{Ll}_{8} \mathrm{AmO}_{6}$

$\mathrm{Ll}_{3} \mathrm{AmO}_{4}$

$\mathrm{Ll}_{7} \mathrm{AmO}_{6}$

$\mathrm{Li}_{4} \mathrm{AmO}_{5}$

$\mathrm{Ll}_{6} \mathrm{AmO}_{6}$

$\mathrm{Na}_{2} \mathrm{AmO}_{3}$

$\mathrm{Na}_{3} \mathrm{AmO}_{4}$

$\mathrm{Na}_{4} \mathrm{AmO}_{5}$

$\mathrm{Na}_{6} \mathrm{AmO}_{6}$

Barium and

strontium

$\mathrm{BaAm}_{2} \mathrm{O}_{4}$

$\mathrm{BaAmO}_{3}$

$\mathrm{Ba}_{3} \mathrm{AmO}_{6}$
Yellow

604 Hexagonal

Cubic

Tetragonal

Orthorhombic

Tetragonal

Tetragond

Black

Black

Black

Tan

Red brown

Dark brown
$R 3$

742

4011

9204

$\mathrm{Fd} 3 \mathrm{~m} \quad 755$

I4 $1 / a \quad 524$

$\begin{array}{lll}1152 & 10527 \quad 10820\end{array}$

$14, / a$

520

525

1139

11515

11429

Fd3m 699

$\mathrm{Fm} 3 \mathrm{~m} \quad 5000$

$\mathrm{P6}_{3} / \mathrm{mmc} \quad 5320$

Fm $3 m \quad 5045$

$P \overline{3} m 1 \quad 3817$

$\mathrm{C} 2 / \mathrm{m} \quad 1438$

Ia $3 \quad 1103$

Fm $3 m \quad 5377$

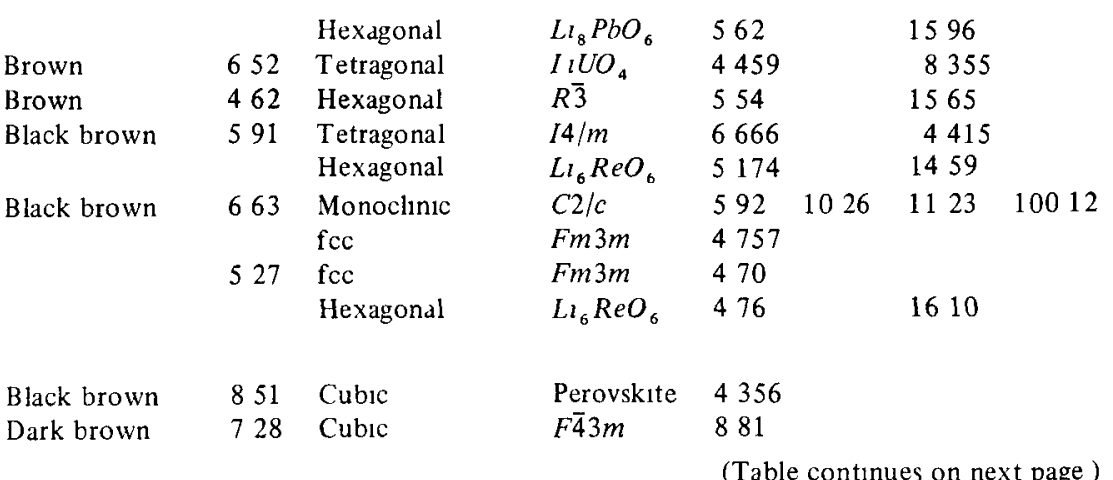




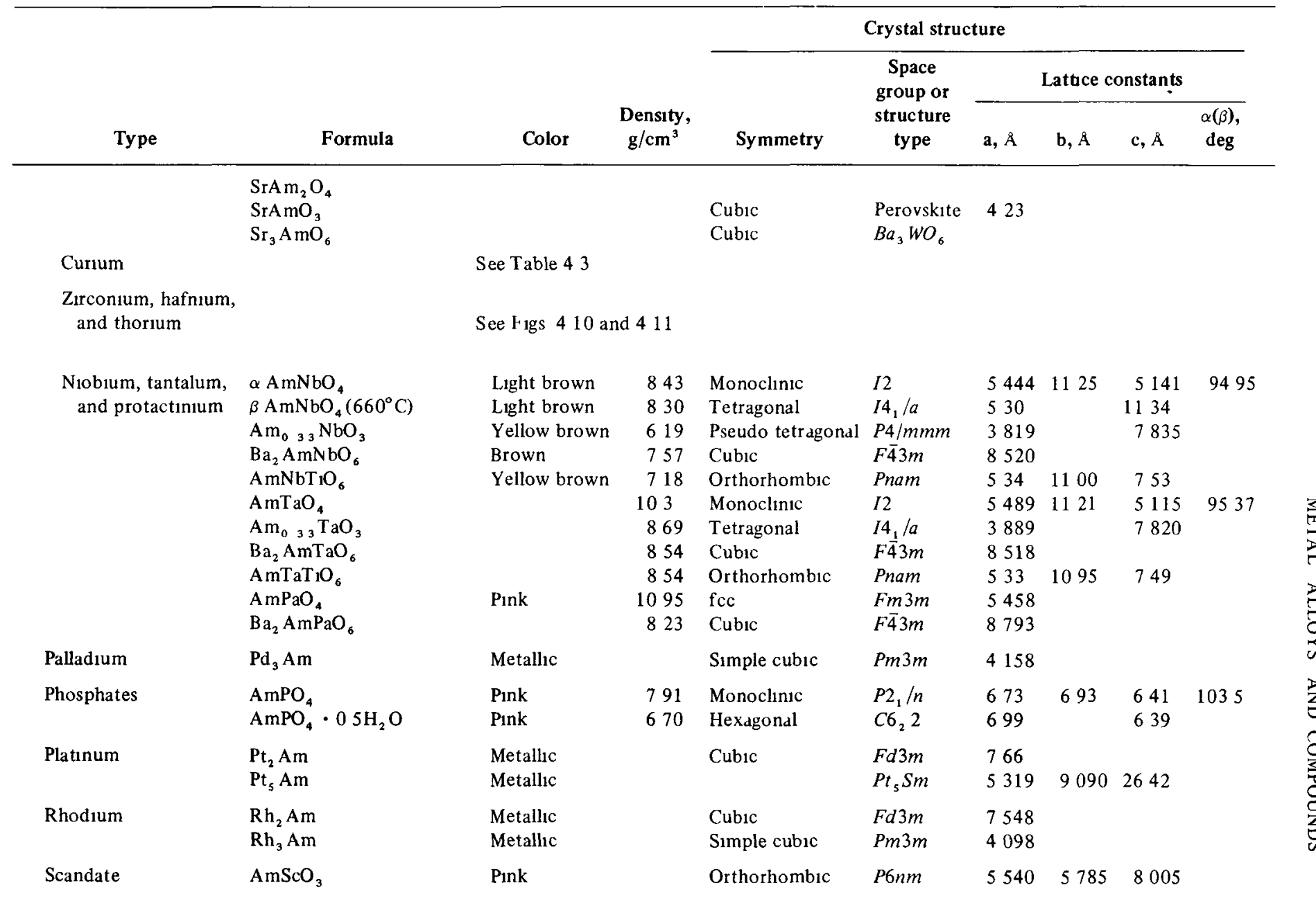




\begin{tabular}{|c|c|c|c|c|c|c|c|c|}
\hline Selenıdes & $\begin{array}{l}\mathrm{AmSe}_{1} \\
\mathrm{Am}_{3} \mathrm{Se}_{4}\end{array}$ & Black & & $\begin{array}{l}\text { Tetragonal } \\
\text { bcc }\end{array}$ & $I \overline{4} 3 d$ & $\begin{array}{l}4096 \\
8728\end{array}$ & & 8.347 \\
\hline Silicate & $\mathrm{AmSIO}_{4}$ & Dark brown & 756 & Tetragonal & $I 4, / a m d$ & 687 & & 620 \\
\hline Sulfates & $\begin{array}{l}\mathrm{Am}_{2}\left(\mathrm{SO}_{4}\right)_{3} \cdot 8 \mathrm{H}_{2} \mathrm{O} \\
\mathrm{Am} \\
\mathrm{Km}_{2}\left(\mathrm{SO}_{4}\right)_{3} \\
\mathrm{KAm}\left(\mathrm{SO}_{4}\right)_{2} \\
\mathrm{NaAm}\left(\mathrm{SO}_{4}\right)_{2} \cdot 2 \mathrm{H}_{2} \mathrm{O} \\
\mathrm{KAm}\left(\mathrm{SO}_{4}\right)_{2} \cdot \mathrm{H}_{2} \mathrm{O} \\
\mathrm{RbAm}\left(\mathrm{SO}_{4}\right)_{2} \cdot 3 \mathrm{H}_{2} \mathrm{O} \\
\mathrm{CsAm}\left(\mathrm{SO}_{4}\right)_{2} \cdot 4 \mathrm{H}_{2} \mathrm{O} \\
\mathrm{TIAm}\left(\mathrm{SO}_{4}\right)_{2} \cdot 4 \mathrm{H}_{2} \mathrm{O} \\
\mathrm{K}_{3} \mathrm{Am}\left(\mathrm{SO}_{4}\right)_{3} \cdot \mathrm{H}_{2} \mathrm{O} \\
\mathrm{K}_{8} \mathrm{Am}_{2}\left(\mathrm{SO}_{4}\right)_{7} \\
\mathrm{CS}_{8} \mathrm{Am}_{2}\left(\mathrm{SO}_{4}\right)_{7} \\
\mathrm{Tl}_{8} \mathrm{Am}_{2}\left(\mathrm{SO}_{4}\right)_{7} \\
\left\{\left[\mathrm{CO}\left(\mathrm{NH}_{3}\right)_{6}\right] \mathrm{HSO}_{4}\right\}_{2} \cdot \\
\left\{\mathrm{AmO}_{2}\left(\mathrm{SO}_{4}\right)_{3}\right\} \cdot \mathrm{nH}_{2} \mathrm{O}\end{array}$ & $\begin{array}{l}\text { Yellow pink } \\
\text { White }\end{array}$ & & Monoclinic & $C 2 / c$ & 13619 & 6837 & $18405 \quad 1027$ \\
\hline Sulfides & $\begin{array}{l}\mathrm{AmS} \\
\mathrm{AmS}_{1}{ }_{9} \\
\alpha-\mathrm{Am}_{2} \mathrm{~S}_{3} \\
\gamma-\mathrm{Am}_{2} \mathrm{~S}_{3} \\
\mathrm{Am}_{10} \mathrm{~S}_{14} \mathrm{O}_{3} \ddagger\end{array}$ & $\begin{array}{l}\text { Black } \\
\text { Black }\end{array}$ & 850 & $\begin{array}{l}\text { fcc } \\
\text { Tetragondl } \\
\text { Orthorhombic } \\
\text { bcc } \\
\text { Tetragonal }\end{array}$ & $\begin{array}{l}F m 3 m \\
\\
\text { Pnma } \\
I \overline{4} 3 d \\
I 4_{1} / a c d\end{array}$ & $\begin{array}{rl}5 & 592 \\
3 & 938 \\
3 & 98 \\
8 & 434 \\
14 & 87\end{array}$ & 739 & $\begin{array}{l}7981 \\
1536 \\
1973\end{array}$ \\
\hline Tellundes & $\begin{array}{l}\mathrm{AmTe}_{2} \\
\mathrm{AmTe}_{3} \\
\mathrm{Am}_{2} \mathrm{Te}_{3} \\
\mathrm{Am}_{3} \mathrm{Te}_{4}\end{array}$ & & & $\begin{array}{l}\text { Tetragondl } \\
\text { Orthorhombic } \\
\text { Orthorhombic } \\
\text { bec }\end{array}$ & $\begin{array}{l}\text { Bmmb } \\
P b n m \\
I \overline{4} 3 d\end{array}$ & $\begin{array}{rl}4 & 366 \\
4 & 399 \\
11 & 93 \\
9 & 394\end{array}$ & $\begin{array}{rl}4339 \\
12 & 12\end{array}$ & $\begin{array}{c}8969 \\
25.57 \\
4.33\end{array}$ \\
\hline Tungstate & $\mathrm{Am}_{2}\left(\mathrm{WO}_{4}\right)_{3}$ & & & Tetragondl & $I 4_{1} / a$ & & & \\
\hline Vanadates & $\begin{array}{l}\mathrm{AmVO}_{3} \\
\mathrm{AmVO}_{4}\end{array}$ & $\begin{array}{l}\text { Ochre } \\
\text { Red brown }\end{array}$ & $\begin{array}{l}957 \\
689\end{array}$ & $\begin{array}{l}\text { Orthorhombic } \\
\text { Tetragondl }\end{array}$ & $\begin{array}{l}\text { Pbnm } \\
\text { I4/amd }\end{array}$ & $\begin{array}{l}545 \\
731\end{array}$ & 558 & $\begin{array}{l}776 \\
642\end{array}$ \\
\hline Xendtes & $\mathrm{Am}_{4}\left(\mathrm{XeO}_{6}\right)_{3} \cdot 4 \mathrm{OH}_{2} \mathrm{O}$ & Orange & & & & & & \\
\hline
\end{tabular}

* Monoclinic form also known

† Hexagonal-rhombohedral

$\ddagger$ Also referred to as $\beta-A m_{2} S_{3}$ 
Eick and Mulford ${ }^{47}$ point out that the $\mathrm{AmB}_{4}$ phase exhibits a wide range of storchiometry.

When heated, $\mathrm{AmB}_{4}$ decomposes according to the reaction

$$
3 \mathrm{AmB}_{4}(\mathrm{~s}) \rightarrow 2 \mathrm{AmB}_{6}(\mathrm{~s})+2 \mathrm{Am}(\mathrm{g})
$$

$A m B_{6}$ Arc-melting a mixture of the elements in the americium/boron atomic ratio 1090 in an argon atmosphere produces simple cubic $\mathrm{AmB}_{6}$ (Ref. 47) This compound evaporates congruently

Bromides. The only reported solid compounds of americium with bromine are $\mathrm{AmBr}_{2}, \mathrm{AmBr}_{3}, \mathrm{AmBr}_{3} \cdot 6 \mathrm{H}_{2} \mathrm{O}$, and $\left[\left(\mathrm{C}_{6} \mathrm{H}_{5}\right)_{3} \mathrm{PH}\right]_{3} \mathrm{AmBr}_{6}$

$\mathrm{AmBr}_{2}$ Synthesis of $\mathrm{AmBr}_{2}$ can be accomplished ${ }^{48,49}$ on a multimilligram scale by oxidation of amencium metal with $\mathrm{HgBr}_{2}$ in accordance with Eq 411

$$
\mathrm{Am}+\mathrm{HgBr}_{2} \underset{\text { vacuum }}{\stackrel{300^{\circ} \mathrm{C}}{\longrightarrow}} \mathrm{AmBr}_{2}+\mathrm{Hg}
$$

Stolchiometric amounts of americium metal and $\mathrm{HgBr}_{2}$ are placed in a quartz tube, sealed in vacuum, and heated at $300^{\circ} \mathrm{C}$ for 4 days Subsequently the mercury is distilled to the opposite end of the tube and sealed off $\mathrm{The} \mathrm{AmBr}_{2}$ is then annealed 10 days at $400^{\circ} \mathrm{C} \mathrm{Black} \mathrm{AmBr}_{2}$ is 1sostructural with $\mathrm{EuBr}_{2}$ and, at room temperature, is stable in an argon atmosphere for at least 4 weeks

$\mathrm{AmBr}_{3}$ Americium(III) bromide is a high-melting solid that can be purified by vacuum sublimation at temperatures above $850^{\circ} \mathrm{C}$ It can be prepared

1 By reaction 50,51 of $\mathrm{AmO}_{2}$ with $\mathrm{AlBr}_{3}$ at $500^{\circ} \mathrm{C}$ according to Eq. 412

$$
3 \mathrm{AmO}_{2}+4 \mathrm{AlBr}_{3} \rightarrow 3 \mathrm{AmBr}_{3}+2 \mathrm{Al}_{2} \mathrm{O}_{3}+3 / 2 \mathrm{Br}_{2}
$$

2. By the metathetical reaction ${ }^{52}$

$$
\mathrm{AmCl}_{3}+3 \mathrm{NH}_{4} \mathrm{Br} \underset{\mathrm{H}_{2} \text { atmos }}{\stackrel{400-500^{\circ} \mathrm{C}}{\longrightarrow}} \mathrm{AmBr}_{3}+3 \mathrm{NH}_{4} \mathrm{Cl}
$$

3 By controlled vacuum thermal decomposition ${ }^{53}$ of $\mathrm{AmBr}_{3} \cdot 6 \mathrm{H}_{2} \mathrm{O}$

$$
\mathrm{AmBr}_{3} \cdot 6 \mathrm{H}_{2} \mathrm{O} \underset{10^{4}-10^{3} \text { torr }}{\stackrel{60-170^{\circ} \mathrm{C}}{\longrightarrow}} \mathrm{AmBr}_{3}+6 \mathrm{H}_{2} \mathrm{O}
$$

Zachanasen ${ }^{54}$ and Asprey, Keenan, and Kruse ${ }^{52}$ have determined that orthorhombic $\mathrm{AmBr}_{3}$ has the $\mathrm{PuBr}_{3}$ type of structure $\mathrm{V}_{1 \text { sible and near infrared spectra }}{ }^{51}$ have been recorded for solid $\mathrm{AmBr}_{3}$ Liquid bromine does not oxidize $\mathrm{AmBr}_{3}$ in nonaqueous solvents 55

$\mathrm{AmBr}_{3} \cdot 6 \mathrm{H}_{2} \mathrm{O}$. Anhydrous $\mathrm{AmBr}_{3}$ is hygroscopic and, when exposed to oxygen-free water vapor, takes up water corresponding to the formation of 
$\mathrm{AmBr}_{3} \cdot 6 \mathrm{H}_{2} \mathrm{O}$ (Ref 53) Vacuum evaporation of aqueous $\mathrm{HBr}$ solutions containing trivalent americium yields a product of composition close to $\mathrm{AmBr}_{3} \cdot \mathrm{H}_{2} \mathrm{O}$

$\left[/\left(\mathrm{C}_{6} \mathrm{H}_{5}\right)_{3} \mathrm{PH}\right]_{3} \mathrm{AmBr}_{6}$ The triphenylphosphonum salt of the $\mathrm{AmBr}_{6}^{3}$ ion was prepared on a microscale by precipitation from a nearly anhydrous ethanol solution of $\mathrm{AmBr}_{3}$ and $\left(\mathrm{C}_{6} \mathrm{H}_{5}\right)_{3} \mathrm{PH}$ which was almost saturated with $\mathrm{HBr}$ (Ref 56) Properties of the precipitated salt have not been determined

Carbide. $A m_{2} C_{3}$ Amencium sesquicarbide forms when americrum metal is arc melted with high-purity graphite in an argon-helium atmosphere ${ }^{57}$ The bcc crystal contains eight molecules per unit cell and is isostructural with $\mathrm{Pu}_{2} \mathrm{C}_{3}$

Nuclear gamma resonance spectra obtained using a source of $\mathrm{Am}_{2} \mathrm{C}_{3}$ show a pure quadrapole spectrum down to $18^{\circ} \mathrm{K}$ No magnetic ordering is seen 44

Carbonates. $\mathrm{Am}_{2} / \mathrm{CO}_{3} /_{3} \cdot \mathrm{x} \mathrm{H}_{2} \mathrm{O}$ Weigel and ter $\mathrm{Meer}^{58}$ report that hydrolysis of an aqueous solution of $\mathrm{Am}(\mathrm{III})$ trichloroacetate yields $\mathrm{Am}_{2}\left(\mathrm{CO}_{3}\right)_{3} \cdot 2 \mathrm{H}_{2} \mathrm{O}$ (Eq 4.15)

$2 \mathrm{Am}\left(\mathrm{CCl}_{3} \cdot \mathrm{COO}\right)_{3}+5 \mathrm{H}_{2} \mathrm{O} \rightarrow \mathrm{Am}_{2}\left(\mathrm{CO}_{3}\right)_{3} \cdot 2 \mathrm{H}_{2} \mathrm{O}+3 \mathrm{CO}_{2}+6 \mathrm{CHCl}_{3}$

Conversely, Fang ${ }^{59}$ finds that addition of a $\mathrm{CO}_{2}$-saturated solution of $\mathrm{NaHCO}_{3}$ to a solution of $\mathrm{AmCl}_{3}$ and washing the filtered precipitate with a $\mathrm{CO}_{2}$-saturated aqueous solution produce $\mathrm{Am}_{2}\left(\mathrm{CO}_{3}\right)_{3} \cdot 4 \mathrm{H}_{2} \mathrm{O}$

According to Weigel and ter Meer, ${ }^{60}$ thermal decomposition of $\mathrm{Am}_{2}\left(\mathrm{CO}_{3}\right)_{3} \cdot 2 \mathrm{H}_{2} \mathrm{O}$ in a vacuum proceeds as follows

$$
\mathrm{Am}_{2}\left(\mathrm{CO}_{3}\right)_{3} \cdot 2 \mathrm{H}_{2} \mathrm{O} \stackrel{-2 \mathrm{H}_{2} \mathrm{O}}{\longrightarrow} \mathrm{Am}_{2}\left(\mathrm{CO}_{3}\right)_{3} \stackrel{-2 \mathrm{CO}_{2}}{\longrightarrow} \mathrm{Am}_{2} \mathrm{O}_{2} \mathrm{CO}_{3} \stackrel{-\mathrm{CO}_{2}}{\longrightarrow} \mathrm{Am}_{2} \mathrm{O}_{3}
$$

Keller and Fang ${ }^{61}$ observed the following sequence for thermal decomposition of $\mathrm{Am}_{2}\left(\mathrm{CO}_{3}\right)_{3} \cdot 4 \mathrm{H}_{2} \mathrm{O}$ in alr

$$
\begin{aligned}
\mathrm{Am}_{2}\left(\mathrm{CO}_{3}\right)_{3} \cdot 4 \mathrm{H}_{2} \mathrm{O} \stackrel{-4 \mathrm{H}_{2} \mathrm{O}}{\longrightarrow} \mathrm{Am}_{2}\left(\mathrm{CO}_{3}\right)_{3} \stackrel{-\mathrm{CO}_{2}}{\longrightarrow} \mathrm{Am}_{2} \mathrm{O}\left(\mathrm{CO}_{3}\right)_{2} \\
\stackrel{+1 / 2 \mathrm{O}_{2}}{\longrightarrow} \mathrm{Am}_{2} \mathrm{O}\left(\mathrm{CO}_{3}\right)_{2} \stackrel{-2 \mathrm{CO}_{2}}{\longrightarrow} 2 \mathrm{AmO}_{2}
\end{aligned}
$$

$\mathrm{NH}_{4} \mathrm{AmO}_{2} \mathrm{CO}_{3}$ Crystals of $\mathrm{NH}_{4} \mathrm{AmO}_{2} \mathrm{CO}_{3}$ precipitate when a dilute solution of Am(III) in $1 M\left(\mathrm{NH}_{4}\right)_{2} \mathrm{CO}_{3}$ is oxidized to $\mathrm{Am}(\mathrm{V})$ with ozone or peroxydisulfate ${ }^{62}$

$\mathrm{Cs} \mathrm{AmO}_{2} \mathrm{CO}_{3} \mathrm{Keenan}^{63}$ reports that $\mathrm{CsAmO} \mathrm{CO}_{3}$ precipitates when a slurry of pink $\mathrm{Am}(\mathrm{OH})_{3}$ in $05 \mathrm{M} \mathrm{CsHCO}_{3}$ is treated with $5 \% \mathrm{O}_{3}$ in $\mathrm{O}_{2}$ for $1 \mathrm{hr}$ at $92^{\circ} \mathrm{C}$

$\mathrm{K}_{2 \mathrm{x}+1} \mathrm{AmO}_{2}\left(\mathrm{CO}_{3}\right)_{1+\mathrm{x}}$ Several different potassium $\mathrm{Am}(\mathrm{V})$ double carbonates can apparently be prepared depending on precipitation conditions of $\mathrm{pH}$ and $\mathrm{K}_{2} \mathrm{CO}_{3}$ concentration Thus $\mathrm{KAmO}_{2} \mathrm{CO}_{3}$ is precipitated ${ }^{64,65}$ from $003 \mathrm{M}$ to $01 \mathrm{M} \mathrm{KHCO}_{3}$ at $\mathrm{pH} 7$ This compound ${ }^{65}$ can be prepared most easily by $\mathrm{O}_{3}$ oxidation of $\mathrm{Am}(\mathrm{OH})_{3}$ in 
$0.03 \mathrm{M} \mathrm{KHCO}_{3}$. In an altemative synthesis, an $\mathrm{Am}(\mathrm{V})$ solution is first prepared by addition of a stoichiometric amount of $\mathrm{KI}$ to an $\mathrm{AmO}_{2}\left(\mathrm{NO}_{3}\right)_{2}$ solution After benzene extraction of the liberated $\mathrm{I}_{2}, \mathrm{KHCO}_{3}$ is added to neutralize acid and to make the final solution $0.1 M \mathrm{KHCO}_{3}$ The light-colored precipitate that forms is digested 3 to $4 \mathrm{hr}$ at $90^{\circ} \mathrm{C}$ and is then washed with $0.1 M \mathrm{KHCO}_{3}$, absolute ethyl alcohol, and acetone.

Tan, finely divided $\mathrm{K}_{3} \mathrm{AmO}_{2}\left(\mathrm{CO}_{3}\right)_{2}$ precipitates $^{66}$ when a solution of $\mathrm{Am}(\mathrm{III})$ in $35 \mathrm{M} \quad \mathrm{K}_{2} \mathrm{CO}_{3}$ is oxidized with $\mathrm{O}_{3}, \mathrm{~K}_{2} \mathrm{~S}_{2} \mathrm{O}_{8}$, or $\mathrm{KClO}_{2}$. The solubility of $\mathrm{K}_{3} \mathrm{AmO}_{2}\left(\mathrm{CO}_{3}\right)_{2}$ in $3.5 M \mathrm{~K}_{2} \mathrm{CO}_{3}$ at $23^{\circ} \mathrm{C}$ corresponds to 10 to $40 \mathrm{mg}$ Am liter ${ }^{1}$

According to Yakovlev and Gorbenko-Germanov, ${ }^{67}$ the compound $\mathrm{K}_{5} \mathrm{AmO}_{2}\left(\mathrm{CO}_{3}\right)_{3}$ precipitates when $\mathrm{Am}$ (III) in concentrated $(>5 M) \mathrm{K}_{2} \mathrm{CO}_{3}$ is oxidized with ozone, $\mathrm{K}_{2} \mathrm{~S}_{2} \mathrm{O}_{8}$, or $\mathrm{HClO}$.

Nigon et al. ${ }^{62}$ also obtained a potassium Am(V) double carbonate by heating a $\mathrm{K}_{2} \mathrm{CO}_{3}$ solution containing $\mathrm{Am}(\mathrm{III})$ and $\mathrm{KOCl}$ to $80^{\circ} \mathrm{C}$. Ne1ther the $\mathrm{K}_{2} \mathrm{CO}_{3}$ concentration nor the composition of the resulting orthorhombic bisphenords was stated.

$\mathrm{RbAmO}_{2} \mathrm{CO}_{3}$ Crystals of $\mathrm{RbAmO}_{2} \mathrm{CO}_{3}$ precipitate when a dilute solution of Am(III) in $10 M \mathrm{Rb}_{2} \mathrm{CO}_{3}$ is oxidized to $\mathrm{Am}(\mathrm{V})$ with ozone or peroxydisulfate ${ }^{62,68}$

$\mathrm{Na}_{2 \mathrm{x}+1} \mathrm{AmO}_{2}\left(\mathrm{CO}_{3}\right)_{1+\mathrm{x}}$. Werner and Perlman ${ }^{69}$ obtaned a sodium $\mathrm{Am}(\mathrm{V})$ double carbonate of unknown composition by oxidizing $\mathrm{Am}(\mathrm{III})$ in $\mathrm{K}_{2} \mathrm{CO}_{3}$ solution with $\mathrm{NaClO}$. Later, in a slightly modified procedure, Nigon et al ${ }^{62}$ also prepared a sodium $\mathrm{Am}(\mathrm{V})$ double carbonate of unknown composition by adding $\mathrm{NaClO}$ to a solution of $\mathrm{Am}$ (III) in $\mathrm{Na}_{2} \mathrm{CO}_{3}$ and digesting the resulting solution at $80^{\circ} \mathrm{C}$. The refractive index of the resulting crystals (probably belonging to the monoclinic system) was between 1.58 and 1.60. More recently, Coleman et al. ${ }^{65}$ state that, when Am(VI) in $2 M$ $\mathrm{Na}_{2} \mathrm{CO}_{3}$ (previously prepared at a lower temperature) is heated to $90^{\circ} \mathrm{C}$ even with $\mathrm{O}_{3}$ present, it is largely reduced to $A m(V)$ withın $1 \mathrm{hr}$, and sodium $\mathrm{Am}(\mathrm{V})$ carbonate precipitates. These workers did not establish the composition of the double carbonate but noted that it is readily oxidized to $\mathrm{Am}(\mathrm{VI})$ by $\mathrm{O}_{3}$ at room temperature or by $0.001 M \mathrm{Na}_{2} \mathrm{~S}_{2} \mathrm{O}_{8}$ at $90^{\circ} \mathrm{C}$ in $\mathrm{NaHCO}_{3}$ solutions $\leqslant 1 M$.

Barium Am(VI) Carbonate. Addition of $\mathrm{Ba}\left(\mathrm{NO}_{3}\right)_{2}$ to $\mathrm{Am}(\mathrm{VI})$ carbonate solution precipitates a red-brown barium amencium carbonate of undetermined composition. ${ }^{65}$

Calcium Am(VI) Carbonate. This salt precipitates when $\mathrm{Ca}\left(\mathrm{NO}_{3}\right)_{2}$ is added to Am(VI) carbonate solution, ${ }^{65}$ its composition has not been determined

Sodum Am(VI) Carbonate. A crystallıne Am(VI) carbonate forms when $1 \mathrm{ml}$ of saturated $\mathrm{Na}_{2} \mathrm{CO}_{3} \cdot \mathrm{NaHCO}_{3}$ solution is added to $0.2 \mathrm{mmol}$ of solid sodium Am(VI) acetate $^{65}$ The same compound can be prepared by adding methanol to a solution of $\mathrm{Am}(\mathrm{VI})$ in $0.1 M \mathrm{NaHCO}_{3}$. Other syntheses of sodium $\mathrm{Am}(\mathrm{VI})$ carbonates were performed by $\mathrm{O}_{3}$ oxidation of $\mathrm{Am}(\mathrm{OH})_{3}$ slurries in the presence of about 1 to 8 mols of $\mathrm{NaHCO}_{3}$ per mol of $\mathrm{Am}$ (III). Solid sodium Am(VI) carbonates were obtained ${ }^{65}$ by 
evaporation of the resulting solutions in a stream of $\mathrm{O}_{3}$ The infrared spectra of solid sodium Am(VI) carbonate establishes the presence of the oxygen-americium-oxygen group in the carbonate complex

Chlorides. $\mathrm{AmCl}_{2}$ Oxidation of americium metal with $\mathrm{HgCl}_{2}$ in a vacuum at $300^{\circ} \mathrm{C}$ produces $\mathrm{AmCl}_{2}$ (Eq 4 16) ${ }^{48,49}$

$$
\mathrm{Am}+\mathrm{HgCl}_{2} \underset{\text { vacuum }}{300^{\circ} \mathrm{C}} \mathrm{AmCl}_{2}+\mathrm{Hg}
$$

$\mathrm{AmCl}_{3} \quad$ Four methods of preparing anhydrous $\mathrm{AmCl}_{3}$ are known 1 Reaction of $\mathrm{AmO}_{2}$ with $\mathrm{CCl}_{4}$ at 800 to $900^{\circ} \mathrm{C}$ ( Refs 50, 51, and 70),

$$
\mathrm{AmO}_{2}+2 \mathrm{CCl}_{4} \stackrel{800 \quad 900^{\circ} \mathrm{C}}{\longrightarrow} \mathrm{AmCl}_{3}+2 \mathrm{COCl}_{2}+\frac{1}{2} \mathrm{Cl}_{2}
$$

2 Reaction of $\mathrm{AmO}_{2}$ with $\mathrm{HCl}$ (Refs 71 and 72),

$$
\mathrm{AmO}_{2}+4 \mathrm{HCl} \underset{500 \quad 600^{\circ} \mathrm{C}}{\rightarrow} \mathrm{AmCl}_{3}+1 / 2 \mathrm{Cl}_{2}+2 \mathrm{H}_{2} \mathrm{O}
$$

3 Evaporation to dryness of an $\mathrm{HCl}$ solution of $\mathrm{Am}^{3+}$ containıng $\mathrm{NH}_{4} \mathrm{Cl}$ and subliming $\mathrm{NH}_{4} \mathrm{Cl}$ from the residue ${ }^{52}$

4 Dehydration ${ }^{73}$ of $\mathrm{AmCl}_{3} \cdot 6 \mathrm{H}_{2} \mathrm{O}$ by heating in a stream of $\mathrm{HCl}$ followed by vacuum sublimation of $\mathrm{AmCl}_{3}$

The enthalpy of formation ${ }^{73,74}$ of $\mathrm{AmCl}_{3}$ at $209^{\circ} \mathrm{C}$ was originally reported at $-249 \pm 3 \mathrm{kcal} \mathrm{mol}^{-1}$ A more accurate value ${ }^{11}$ for the enthalpy of formation is $-2337 \pm 04 \mathrm{kcal} \mathrm{mol}^{1}$ The anhydrous trichloride sublimes at about $800^{\circ} \mathrm{C}$

Zachariasen $^{54}$ and subsequently Asprey, Keenan, and Kruse ${ }^{52}$ and Fuger ${ }^{75}$ determined the lattice constants and crystal symmetry of $\mathrm{AmCl}_{3}$ using powder methods A refined crystal structure for $\mathrm{AmCl}_{3}$ has recently been worked out by Burns and Peterson ${ }^{72}$ using single-crystal data Their lattice constants are listed in Table 42 Burns and Peterson ${ }^{72}$ calculate from their data the ionic radius of $\mathrm{Am}^{3+}$ to be $0984 \pm 0003 \AA$

The coefficients of the thermal expansion of the lattice constants ${ }^{75}$ of $\mathrm{AmCl}_{3}$ between $20^{\circ} \mathrm{C}$ and $608^{\circ} \mathrm{C}$ are $\alpha_{\mathrm{a}}=(240 \pm 01) \times 10^{5{ }^{\circ}} \mathrm{C}^{1}$ and $\alpha_{\mathrm{c}}=$ (138 \pm 01$) \times 10^{5 \circ} \mathrm{C}^{1}$

Gruber and Conway ${ }^{76}$ have measured the absorption spectrum and Zeeman effect of $\mathrm{Am}^{3+}$ in $\mathrm{LaCl}_{3}$ The absorption spectrum of $\mathrm{AmCl}_{3}$ at liquid $\mathrm{N}_{2}$ temperatures has been determuned by Pappalardo, Carnall, and Fields 51

The solubility ${ }^{77}$ of $\mathrm{AmCl}_{3}$, at either 25 or $40^{\circ} \mathrm{C}$, decreases from about $011 \mathrm{M} \mathrm{in}$ $9 M \mathrm{LiCl}$ to about $004 M$ in $13 M \mathrm{LiCl}$

$\mathrm{AmCl}_{3} \cdot 6 \mathrm{H}_{2} \mathrm{O}$ For use in single-crystal $\mathrm{X}$ ray diffraction studies, Burns and Peterson ${ }^{78}$ prepared $\mathrm{AmCl}_{3} \cdot 6 \mathrm{H}_{2} \mathrm{O}$ crystals by dissolving about $100 \mathrm{mg}$ of $\mathrm{AmO}_{2}$ in excess $6 M \mathrm{HCl}$ and allowing the solution to evaporate Stover and Conway ${ }^{79}$ 
published part of the absorption spectrum of $\mathrm{AmCl}_{3} \cdot 6 \mathrm{H}_{2} \mathrm{O}$ at room temperature and at liquid $\mathrm{N}_{2}$ temperature

$A m O C l$ Templeton and Dauben ${ }^{80}$ state that americium oxychloride was first prepared by $\mathrm{L} B$ Asprey by accidental contamination in an experiment designed to yield $\mathrm{Am}_{2} \mathrm{O}_{3}$ by $\mathrm{H}_{2}$ reduction of $\mathrm{AmO}_{2}$. Normally $\mathrm{AmOCl}$ is prepared by vapor-phase hydrolysis ${ }^{81 \text { a }}$ of $\mathrm{AmCl}_{3}$ according to Eq. 419

$$
\mathrm{AmCl}_{3}(\mathrm{~s})+\mathrm{H}_{2} \mathrm{O}(\mathrm{g}) \rightarrow \mathrm{AmOCl}(\mathrm{s})+2 \mathrm{HCl}(\mathrm{g})
$$

Koch is also reported ${ }^{81 \text { d }}$ to have prepared $\mathrm{AmOCl}$ by heating $\mathrm{Am}_{2} \mathrm{O}_{3}$ at $500^{\circ} \mathrm{C}$ in a mixture of $\mathrm{HCl}$ and $\mathrm{H}_{2} \mathrm{O}$ vapors

Equilibrium constants for Eq 4.19 at various temperatures between 682 and $800^{\circ} \mathrm{K}$ were initially measured in 1953 by Koch and Cunningham. ${ }^{81 \text { a }}$ From their results, Koch and Cunningham derived the expression $\Delta \mathrm{G}^{\circ}(\mathrm{kcal})=22.38+6.4 \mathrm{X}$ $10^{-3} \mathrm{~T} \log \mathrm{T}+1.8 \times 10^{-7} \mathrm{~T}^{2}-22 / \mathrm{T}-52.31 \times 10^{-3} \mathrm{~T}$ for the free-energy function of Eq. 4.19. Weigel, Wishnevsky, and Hauske ${ }^{81 b}$ (in 1975) redetermined equilibrium constants for Eq. 4.19 using both ${ }^{241} \mathrm{Am}$ and ${ }^{243} \mathrm{Am}$ Weigel and coworkers report the heat of formation of $\mathrm{AmOCl}$ at $298^{\circ} \mathrm{K}$ is $225.7 \mathrm{kcal} \mathrm{mol}^{1}$ This value is in excellent agreement with the value $226.0 \pm 0.2 \mathrm{kcal} \mathrm{mol}^{-1}$ calculated by Fuger, Spirlet, and Muller ${ }^{11}$ a from the earlier data of B. B. Cunningham, A. Broido, and C. W. Koch.

Chloride Complexes. Solıd chloride complexes of Am(III), (V), and (VI) were synthesized by Bagnall, Lardler, and Stewart, ${ }^{82,83 a}$ by Ryan, ${ }^{56}$ and by Marcus and Shiloh. ${ }^{84}$

$\mathrm{CsAmCl}_{4} \cdot 4 \mathrm{H}_{2} \mathrm{O}$ Hydrated cesium tetrachloroamericate(III) precipitates from concentrated solutions of $\mathrm{Am}$ (III) in $\mathrm{HCl}$ saturated with gaseous $\mathrm{HCl}$ on addition of $\mathrm{CsCl}^{83 \text { a }}$ The amencium-chlorine stretching frequencies occur at 235 and $197 \mathrm{~cm}^{-1}$. $\mathrm{X}$-ray powder results for $\mathrm{CsAmCl}_{4} \cdot 4 \mathrm{H}_{2} \mathrm{O}$ are listed in Ref. 83a but have not been interpreted.

$\mathrm{CsAmCl}_{4}$. Bagnall, Laidler, and Stewart ${ }^{83 \mathrm{a}}$ prepared $\mathrm{CsAmCl}_{4}$ by heating $\mathrm{CsAmCl}_{4} \cdot 4 \mathrm{H}_{2} \mathrm{O}$ in a stream of $\mathrm{HCl}$ at approximately $320^{\circ} \mathrm{C}$ for $1 \mathrm{hr}$. The americium-chlorine stretching frequency of the anhydrous compound occurs at 218 $\mathrm{cm}^{-1}$ Marcus and Shiloh ${ }^{84}$ also prepared $\mathrm{CsAmCl}_{4}$ by evaporatıng together aqueous $3 M \mathrm{HCl}$ solutions of $\mathrm{CsCl}$ and $\mathrm{AmCl}_{3}$ at a $11 \mathrm{~mol}$ ratio.

$\mathrm{Cs}_{3} \mathrm{AmCl}_{6}$. A compound of this composition was obtained by evaporating aqueous $3 M \mathrm{HCl}$ solutions of $\mathrm{CsCl}$ and $\mathrm{AmCl}_{3}$ at a 31 mol ratio. ${ }^{84}$ Conversely, Bagnall, Laidler, and Stewart ${ }^{83 \mathrm{a}}$ also prepared $\mathrm{Cs}_{3} \mathrm{AmCl}_{6}$ by addıng the stoichiometric amount of $\mathrm{CsCl}$ in $6 \mathrm{M} \mathrm{HCl}$ to an ethanolic solution of hydrated $\mathrm{AmCl}_{3}$ saturated with gaseous $\mathrm{HCl}$. The americium-chlorine stretching frequency of $\mathrm{Cs}_{3} \mathrm{AmCl}_{6}$ occurs at $214 \mathrm{~cm}^{-1}$. $\mathrm{X}$-ray powder results for $\mathrm{Cs}_{3} \mathrm{AmCl}_{6}$ have not been interpreted.

$\mathrm{Cs}_{2} \mathrm{NaAmCl}_{6}$. Face-centered cubic $\mathrm{Cs}_{2} \mathrm{NaAmCl}_{6}$ is obtained ${ }^{83 \mathrm{a}}$ when an $\mathrm{HCl}$ solution of $\mathrm{Am}$ (III) and a $21 \mathrm{~mol} \mathrm{mixture} \mathrm{of} \mathrm{CsCl}$ and $\mathrm{NaCl}$ is evaporated to dryness 
According to Bagnall, Laidler, and Stewart, ${ }^{83}$ a this mixed cation complex is unıque in that no other combinations of alkalı metal cations yield analogous products From 15 to $70^{\circ} \mathrm{K}, \mathrm{Cs}_{2} \mathrm{NaAmCl}_{6}$ has temperature-independent paramagnetism with $\chi_{\mathrm{m}}=$ $5400 \times 10^{-6} \mathrm{emu} \mathrm{mol}^{-1}$. Below $15^{\circ} \mathrm{K}$ the susceptibility increases slightly, presumably due to the presence of some additional paramagnetic impurity ${ }^{83 \mathrm{~b}}$

$\mathrm{AmCl}_{3} \cdot 3 \mathrm{CsCl} \cdot \mathrm{y} \mathrm{LlCl}(\mathrm{y} \simeq 20)$ Marcus and $\mathrm{Sh}_{10 h^{84}}$ prepared this solid by evaporating aqueous $3 M \mathrm{HCl}$ solutions of $\mathrm{AmCl}_{3}$ and $\mathrm{CsCl}(\mathrm{mol}$ ratio $=3$ 1) containing excess $\mathrm{LiCl}$.

$\mathrm{AmCl}_{3} \cdot \mathrm{x}\left(\mathrm{C}_{4} \mathrm{H}_{9}\right)_{4} \mathrm{NCl} \cdot \mathrm{yLlCl}(\mathrm{x} \simeq 17, \mathrm{y} \simeq 260)$ Marcus and $\mathrm{Sh}_{10 h}{ }^{84}$ find that two liquid phases are produced from ethanol solutions of hydrated $\mathrm{AmCl}_{3}$ and $\left(\mathrm{C}_{4} \mathrm{H}_{9}\right)_{4} \mathrm{NCl}$ which contain a large excess of $\mathrm{LiCl}$ A yellow solid of the abovementioned composition is formed from the upper liquid phase upon evaporation of the ethanol

$\mathrm{AmCl}_{3} \cdot 2\left(\mathrm{C}_{2} \mathrm{H}_{5}\right)_{4} \mathrm{NCl} \cdot \mathrm{yLlCl}\left(\mathrm{y} \simeq 0,1\right.$, and y) Yellow solids precipitate ${ }^{84}$ when acetone is added to ethanol solutions of hydrated $\mathrm{AmCl}_{3}$ and $\left(\mathrm{C}_{2} \mathrm{H}_{5}\right)_{4} \mathrm{NCl}$ In the absence of $\mathrm{L}_{1} \mathrm{Cl}, \mathrm{AmCl}_{3} \cdot 2\left(\mathrm{C}_{2} \mathrm{H}_{5}\right)_{4} \mathrm{NCl}$ precipitates, whereas $\mathrm{AmCl}_{3}$. $2\left(\mathrm{C}_{2} \mathrm{H}_{5}\right) \mathrm{NCl} \cdot \mathrm{LlCl}$ precipitates in the presence of stoichiometrically equal amounts of $\mathrm{LiCl}$ When excess $\mathrm{LiCl}$ is present, the yellow precipitate is $\mathrm{AmCl}_{3} \cdot 2\left(\mathrm{C}_{2} \mathrm{H}_{5}\right)_{4} \mathrm{NCl}$. $y \mathrm{LiCl}$

$\left.\mathrm{AmCl}_{3} \cdot \mathrm{x} / \mathrm{C}_{12} \mathrm{H}_{25}\right)_{3} \mathrm{NHCl}(\mathrm{x} \simeq 25)$ From a saturated solution of hydrated $\mathrm{AmCl}_{3}$ in trilaurylammonium hydrochloride in toluene, Marcus and Shloh ${ }^{84}$ obtained $\mathrm{AmCl}_{3} \cdot x\left(\mathrm{C}_{12} \mathrm{H}_{25}\right)_{3} \mathrm{NHCl}$ as a yellow waxlike solid upon evaporation of the toluene This material can be recovered unchanged after dissolution in benzene.

$\left.\left[/ \mathrm{C}_{6} \mathrm{H}_{5}\right)_{3} \mathrm{PH}\right]_{3} \mathrm{AmCl}_{6}$ Analogous to the corresponding bromide compound (see page 139), the triphenyl phosphonium salt of $\mathrm{AmCl}_{6}^{3-}$ can be prepared ${ }^{56,85}$ by precipitation from nearly anhydrous ethanol solutions of $\mathrm{AmCl}_{3}$ and $\left(\mathrm{C}_{6} \mathrm{H}_{5}\right)_{3} \mathrm{PH}$ which are almost saturated with $\mathrm{HCl}$ Quantities of $\left[\left(\mathrm{C}_{6} \mathrm{H}_{5}\right)_{3} \mathrm{PH}\right]_{3} \mathrm{AmCl}_{6}$ that contain 3 to $4 \mathrm{mg}$ of americium are stable to radiation damage for about 2 days and then turn dark yellow and char ${ }^{85}$

$\mathrm{Cs}_{3} \mathrm{AmO}_{2} \mathrm{Cl}_{4}$ * Green cesium dioxotetrachloroamericate(V), isostructural with $\mathrm{Cs}_{3} \mathrm{NpO}_{2} \mathrm{Cl}_{4}$, is precipitated by ethanol from a solution of $\mathrm{Am}(\mathrm{V})$ hydroxide and $\mathrm{CsCl}$ in $6 \mathrm{M} \mathrm{HCl}$ and also by treating $\mathrm{CsAmO}_{2} \mathrm{CO}_{3}$ with concentrated $\mathrm{HCl}$ saturated with $\mathrm{CsCl}^{83 \mathrm{a}}$ Previously, $\mathrm{Cs}_{3} \mathrm{AmO}_{2} \mathrm{Cl}_{4}$ was erroneously formulated as the trimeric cluster $\mathrm{Cs}_{8}\left(\mathrm{AmO}_{2}\right)_{3} \mathrm{Cl}_{11}$ (Ref 82) The amencium-chlorine stretching frequency for $\mathrm{Cs}_{3} \mathrm{AmO}_{2} \mathrm{Cl}_{4}$ occurs at $290 \mathrm{~cm}^{1}$

$\mathrm{Cs}_{2} \mathrm{AmO}_{2} \mathrm{Cl}_{4}$. A dark-red solid, $\mathrm{Cs}_{2} \mathrm{AmO}_{2} \mathrm{Cl}_{4}$, is obtained when $\mathrm{Cs}_{3} \mathrm{AmO}_{2} \mathrm{Cl}_{4}$ is treated with concentrated $\mathrm{HCl}^{82}$ Brown $^{86}$ states that this unusual oxidation is

*Additional studies of the preparation and properties of $\mathrm{Cs}_{3} \mathrm{AmO}_{2} \mathrm{Cl}_{4}$ have been reported recently by Vodovatov and his Russian colleagues. ${ }^{206}$ 


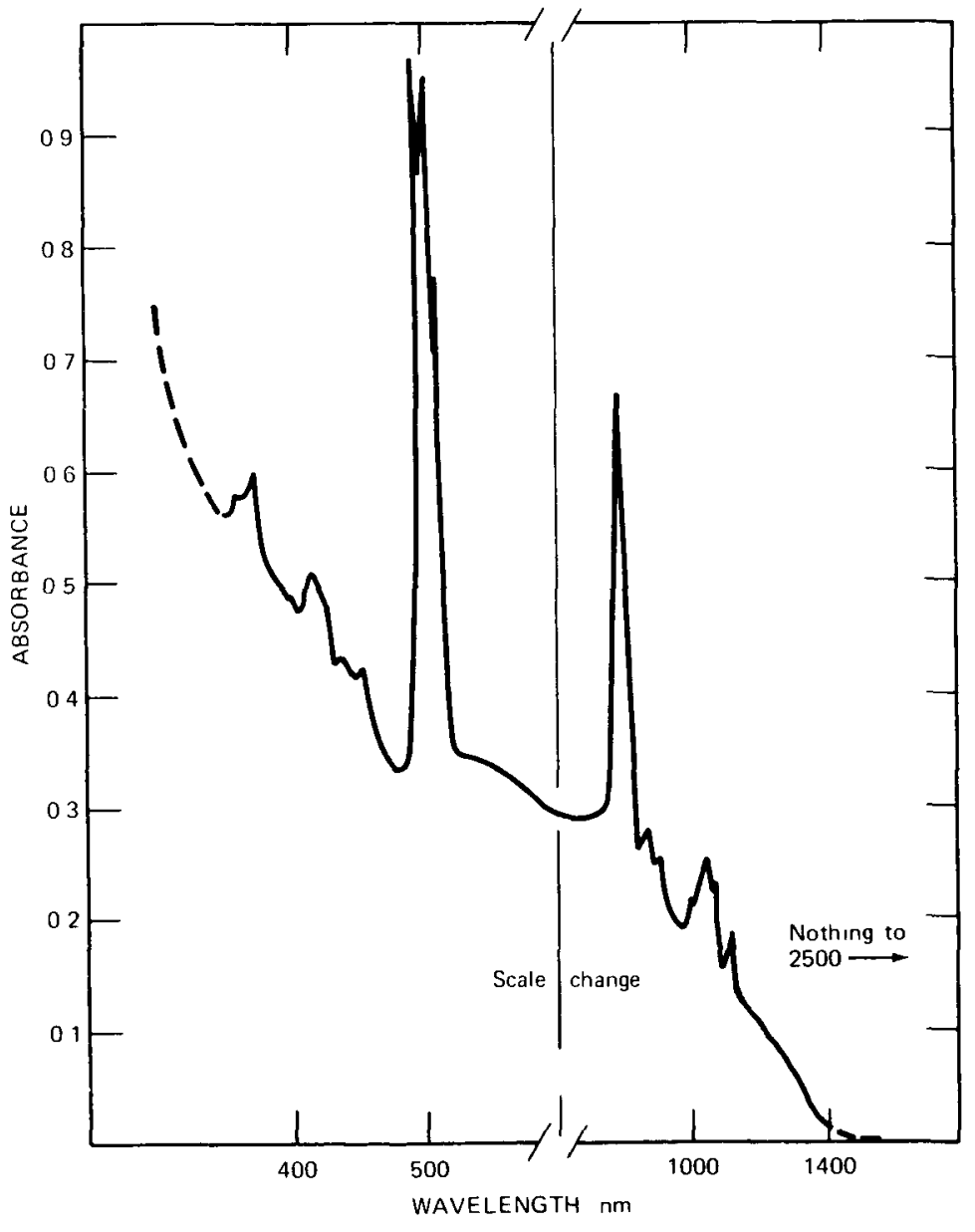

(a)

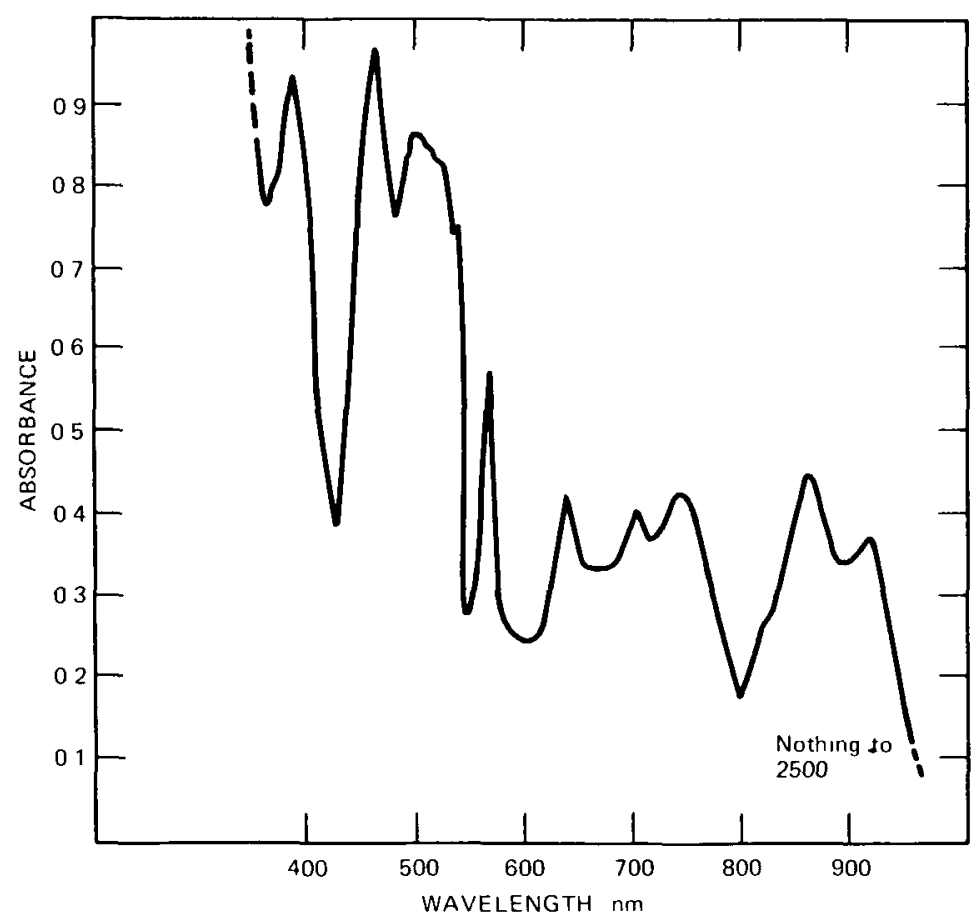

(b)

Fig. 4.3 Spectra of (d) solıd $\mathrm{AmF}_{3}$ and (b) solıd $\mathrm{AmF}_{4}$ [From L B Asprey and $T$ K Keenan, Tetravalent Americium and Curlum, The Absorption Spectra of the Tri- and Tetrafluorides of These Elements, Journal of Inorganic and Nuclear Chemistry, 7: 27 (1958)] 
probably due to the high-lattice-energy stabilization of $\mathrm{Cs}_{2} \mathrm{AmO}_{2} \mathrm{Cl}_{4}$ The cubic form of $\mathrm{Cs}_{2} \mathrm{AmO}_{2} \mathrm{Cl}_{4}$, when washed repeatedly with small volumes of concentrated $\mathrm{HCl}$, is reported $^{83 a}$ to transform to a monoclinic form

Fluorides. $A m F_{2}$ Stable $A_{m F}$ is unknown Formation of divalent americium in single crystals of $\mathrm{CaF}_{2}$ has been reported, however ${ }^{8789}$ Single crystals of $\mathrm{CaF}_{2}$ grown with 01 to $02 \mathrm{wt} \%$ Am are initially light pink, but they darken to a brown color on standing Visible and electron paramagnetic resonance spectroscopic examination of the resulting crystals indicates the presence of $\mathrm{Am}^{2+}$ in an $\mathrm{f}^{7}$ configuration Americium(III) incorporated in the $\mathrm{CaF}_{2}$ lattice may also be reduced with calcium metal or electrolytically

$A m F_{3}$ The anhydrous trifluoride can be prepared by

1 Hydrofluorination at 600 to $700^{\circ} \mathrm{C}$ for $1 \mathrm{hr}$ of either $\mathrm{Am}(\mathrm{OH})_{3}$ or $\mathrm{AmO}_{2}$ (Refs 1,50 , and 86 )

2 Drying of hydrated $\mathrm{AmF}_{3}$ precipitated from aqueous solution (Refs 4, 52, and 90)

3 Heating hydrated $\mathrm{AmF}_{3}$ precipitated from aqueous solution ${ }^{91}$ with an excess of $\mathrm{NH}_{4} \mathrm{~F} \cdot \mathrm{HF}$ at $700^{\circ} \mathrm{C}$

4 Metathesis of $\mathrm{AmCl}_{3}$ with $\mathrm{NH}_{4} \mathrm{~F}$ according to $\mathrm{Eq} 420$

$$
\mathrm{AmCl}_{3}+3 \mathrm{NH}_{4} \mathrm{~F} \underset{\mathrm{H}_{2}}{\stackrel{400}{4} 450^{\circ} \mathrm{C}} \rightarrow \mathrm{AmF}_{3}+3 \mathrm{NH}_{4} \mathrm{Cl}
$$

Hydrated $\mathrm{AmF}_{3}$ can be satisfactorly dried and dehydrated by washing with ethanol or ether and heating in air at $85^{\circ} \mathrm{C}$ under an infrared lamp ${ }^{90}$ Alternatively, dehydration can also be effected successfully by flowing $\mathrm{HF}$ or a mixture of $\mathrm{H}_{2}$ and $\mathrm{HF}$ at 400 to $500^{\circ} \mathrm{C}$ over the hydrated fluoride ${ }^{52}$

The melting point ${ }^{91}$ of $\mathrm{AmF}_{3}$ is $1393 \pm 20^{\circ} \mathrm{C}$ Americium(III) fluoride has the $\mathrm{LaF}_{3}$ structure, its crystal structure has been determined by Templeton and Dauben ${ }^{80}$ and most recently by Asprey, Keenan, and Kruse ${ }^{52}$ Magnetic susceptibilities for $\mathrm{AmF}_{3}$ at 295,199 , and $77^{\circ} \mathrm{K}_{\text {are }}{ }^{2} 1040 \times 10^{6}, 1290 \times 10^{6}$, and $1740 \times 10^{6} \mathrm{~cm}^{3}$ $\mathrm{mol}^{-1}$, respectively The solid state spectrum of $\mathrm{AmF}_{3}$, as determined by Asprey and Keenan, ${ }^{93}$ is given in $\mathrm{F}_{1} \mathrm{~g} 43$ (a) The Mossbauer spectrum for $\mathrm{AmF}_{3}$ has also been reported 94,95

Vapor-pressure data for $\mathrm{AmF}_{3}{ }^{96-98}$ are represented reliably ${ }^{97}$ by the equation

$$
\log P_{\text {torr }}=-(34628 / \mathrm{T})+34007-7048 \log \mathrm{T}\left(1126-1469^{\circ} \mathrm{K}\right)
$$

The free energy of sublimation ( $\mathrm{kcal} \mathrm{mol}{ }^{1}$ ) 1 is given by $\Delta \mathrm{G}=11265+3234 \mathrm{~T} \log$ $\mathrm{T}-155.5 \mathrm{~T} \mathrm{Ryan}^{99}$ estimates the heat of formation of solid $\mathrm{AmF}_{3}$ as $-380 \mathrm{kcal}$ $\mathrm{mol}^{-1}$.

Reduction of $\mathrm{AmF}_{3}$ to americium metal is discussed on page 122 Americium(III) trifluoride ${ }^{52}$ is stable in $\mathrm{H}_{2}$ at $500^{\circ} \mathrm{C}$ 
$A m F_{4}$ Reaction of either $\mathrm{AmF}_{3}$ or $\mathrm{AmO}_{2}$ with $\mathrm{F}_{2}$ at 400 to $500^{\circ} \mathrm{C}$ yields $\mathrm{AmF}_{4}$ (Refs 90,93, and 100) Conner ${ }^{101}$ recently used this approach to prepare multigram quantities of $\mathrm{AmF}_{4}$ Fried ${ }^{50}$ showed that $\mathrm{AmF}_{4}$ cannot be prepared by heating $\mathrm{AmF}_{3}$ in $\mathrm{O}_{2}-\mathrm{HF}$ mixtures

Lattice constants of $\mathrm{AmF}_{4}$ have been measured by Asprey, ${ }^{90}$ by Keenan and Asprey, ${ }^{102 \mathrm{a}}$ and most recently by Asprey and Hare, ${ }^{102 \mathrm{~b}} \mathrm{AmF}_{4}$ is 1somorphous with $\mathrm{UF}_{4}, \mathrm{NpF}_{4}$, and $\mathrm{PuF}_{4}$ Gas evolves when water is added to $\mathrm{AmF}_{4}$, and the tetrafluoride is converted into birefringent aggregates that give the characteristic spectrum of $\mathrm{Am}$ (III) The solid state spectrum ${ }^{93}$ of $\mathrm{AmF}_{4}$ is shown in Fig 4 3(b)

The vapor pressure of $\mathrm{AmF}_{4}$ in the range 729 to $900^{\circ} \mathrm{C}$ can be represented ${ }^{100,103}$ by the equation $\log \mathrm{P}_{\text {torr }}=-(119115 / \mathrm{T})+9337 \mathrm{AmF}_{4}$ is thermodynamically unstable above $635^{\circ} \mathrm{C}$ The estimated ${ }^{99}$ heat of formation of $\mathrm{AmF}_{4}$ is $-399 \mathrm{kcal}$ $\mathrm{mol}^{1}$

$A m F_{6}$ All attempts ${ }^{104,105}$ to prepare $\mathrm{AmF}_{6}$ have been unsuccessful

$\mathrm{AmO}_{2} \mathrm{~F}_{2}$ Keenan ${ }^{106}$ prepared amencyl fluoride by the reaction (at $-196^{\circ} \mathrm{C}$ ) of solid sodium americyl acetate with anhydrous HF containing a small amount of $\mathrm{F}_{2}$ The hexagonal $\mathrm{AmO}_{2} \mathrm{~F}_{2}$ is isostructural with other actinyl(VI) difluorides

Fluoride Complexes Various fluoride complexes of $\mathrm{Am}(\mathrm{III})\left(\mathrm{NaAmF}_{4}, \mathrm{KAmF}_{4}\right.$, and $\left.\mathrm{K}_{2} \mathrm{AmF}_{7}\right)$ and $\mathrm{Am}(\mathrm{IV})\left[\left(\mathrm{NH}_{4}\right)_{4} \mathrm{AmF}_{8}, \mathrm{~K}_{7} \mathrm{Am}_{6} \mathrm{~F}_{31}\right.$, and $\left.\mathrm{Na}_{7} \mathrm{Am}_{6} \mathrm{~F}_{31}\right]$ are known Two complexes of $\mathrm{Am}(\mathrm{V})\left(\mathrm{KAmO}_{2} \mathrm{~F}_{2}\right.$ and $\left.\mathrm{RbAmO}_{2} \mathrm{~F}_{2}\right)$ are also known

$\mathrm{NaAmF}_{4}$ Keller and Schmutz report ${ }^{107,108}$ that $\mathrm{NaAmF}_{4}$ can be synthesized by heating $\mathrm{AmO}_{2}$ with either $\mathrm{NaF}$ or $\mathrm{Na}_{2} \mathrm{CO}_{3}$ in an $\mathrm{HF}-\mathrm{H}_{2}$ mixture at 450 to $650^{\circ} \mathrm{C}$ (According to these workers, $\mathrm{NaAmF}_{4}$ is the first fluonde complex of amencium to be prepared by a high-temperature solid state reaction) Keenan ${ }^{109}$ showed later that exposure of $\mathrm{Na}_{7} \mathrm{Am}_{6} \mathrm{~F}_{31}$ to $\mathrm{H}_{2}$ for $16 \mathrm{hr}$ at $300^{\circ} \mathrm{C}$ converts it to $\mathrm{NaAmF}_{4}$ Lattice constants of hexagonal $\mathrm{NaAmF}_{4}$ have been measured, ${ }^{108}$ but other detals of the chemistry of this compound are lackıng

$\mathrm{KAmF}_{4}$ Solid-state reaction of equimolar amounts of $\mathrm{KF}$ and $\mathrm{AmF}_{3}$ at 350 to $650^{\circ} \mathrm{C}$ in an $\mathrm{HF}-\mathrm{H}_{2}$ atmosphere produces ${ }^{108} \mathrm{KAmF}_{4}$ X-ray diffraction and other properties of this compound have not been reported

$K A m_{2} F_{7}$ Pink, cubic $\mathrm{KAm}_{2} \mathrm{~F}_{7}$ is reported to result from reaction of 2 mols of $\mathrm{KF}$ with $1 \mathrm{~mol}$ of $\mathrm{AmF}_{3}$ at 350 to $650^{\circ} \mathrm{C}$ in an $\mathrm{HF}-\mathrm{H}_{2}$ atmosphere 108

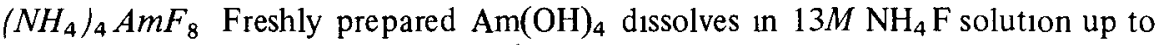
an $A m(I V)$ concentration of $5 \mathrm{~g}$ liter ${ }^{1}$ When this solubility is exceeded at room temperature, red crystals precipitate ${ }^{110}$ These crystals, by analogy with the isostructural tetravalent uranium compound, are formulated as $\left(\mathrm{NH}_{4}\right)_{4} \mathrm{AmF}_{8}$ The solubility of $\left(\mathrm{NH}_{4}\right)_{4} \mathrm{AmF}_{8}$ in $13 M \mathrm{NH}_{4} \mathrm{~F}$ is about $002 M$ No further studies of this compound have been made 
$L \imath A m F_{5}$ This compound results ${ }^{111}$ when the residue from evaporation of an $\mathrm{HCl}$ solution containing storchiometric $\left(\begin{array}{ll}1 & 1\end{array}\right)$ amounts of lithium and americium is treated with $F_{2}$ at $350^{\circ} \mathrm{C}$ for $\simeq 16 \mathrm{hr}$ Lattice constants of tetragonal $\mathrm{LiAmF}_{5}$ have been measured by Keenan, ${ }^{11} \mathrm{LIXF}_{5}$-type compounds are known for $\mathrm{X}=\mathrm{Th}, \mathrm{Pu}, \mathrm{U}, \mathrm{Np}$, $\mathrm{Pu}$, and $\mathrm{Cm}$ also ${ }^{112}$

$K_{7} A m_{6} F_{31}$ Preparation of $\mathrm{K}_{7} A m_{6} \mathrm{~F}_{31}$ is by evaporation of a 71 mixture of potassium/americium from $\mathrm{HF}$ solution, subsequently the dried residue 1 s treated ${ }^{113}$ with $\mathrm{F}_{2}$ for $16 \mathrm{hr}$ at $350^{\circ} \mathrm{C}$. (At the time of its onginal preparation, ${ }^{90} \mathrm{~K}_{7} \mathrm{Am}_{6} \mathrm{~F}_{31}$ was formulated as " $\mathrm{KAmF}_{5}$ ") Trends in the 76 potassium/actınide(IV) series for actınides from thorium to cunum inclusive are discussed by Keenan. ${ }^{113}$

$\mathrm{Na}_{7} \mathrm{Am}_{6} \mathrm{~F}_{31}$ This compound is completely analogous to the $\mathrm{K}_{7} \mathrm{Am}_{6} \mathrm{~F}_{31}$ described above and is prepared in a similar manner. ${ }^{109}$ A 76 sodium/actinide(IV) series analogous to the 76 potassium/actınıde(IV) series is also known ${ }^{109,113}$ Reduction of $\mathrm{Na}_{7} \mathrm{Am}_{6} \mathrm{~F}_{31}$ with $\mathrm{H}_{2}$, as noted earlier, produces $\mathrm{NaAmF}_{4}$.

$R b_{2} A m F_{6}$ The procedure recommended by Keenan ${ }^{114}$ for preparation of $\mathrm{Rb}_{2} \mathrm{AmF}_{6}$ involves equilibration of freshly prepared $\mathrm{Am}(\mathrm{OH})_{4}$ with aqueous $\mathrm{RbF}$ and $\mathrm{HF}$ at $0^{\circ} \mathrm{C}$. The precipitate so formed is heated for about $70 \mathrm{hr}$ at $150^{\circ} \mathrm{C}$ in $\mathrm{F}_{2}$. Synthesis of $\mathrm{Rb}_{2} \mathrm{AmF}_{6}$ from $\mathrm{RbAmO}_{2} \mathrm{CO}_{3}$ has also been accomplished ${ }^{115}$ Optical properties and the solid absorption spectrum of $\mathrm{Rb}_{2} \mathrm{AmF}_{6}$ were determined by Kruse and Asprey ${ }^{115}$ The lattice parameters of orthorhombic $\mathrm{Rb}_{2} \mathrm{AmF}_{6}$ have been measured by Keenan 114

Keenan points out that, although $\mathrm{Rb}_{7} \mathrm{Am}_{6} \mathrm{~F}_{31}$ is not known, the 76 rubidium compounds are known from thorlum to plutonium. Conversely, the $2 \quad \mathrm{ll}_{2} \mathrm{Rb}_{2} \mathrm{MF}_{6}$ series includes americium and curium but not Th(IV) and Pu(IV).

$\mathrm{KAmO}_{2} \mathrm{~F}_{2}$ Addition of a saturated solution ${ }^{116}$ of $\mathrm{KF}$ to an acid solution of $\mathrm{AmO}_{2}^{+}$(prepared by dissolution of $\mathrm{KAmO}_{2} \mathrm{CO}_{3}$ in dilute $\mathrm{HNO}_{3}$ ) precipitates tan $\mathrm{KAmO}_{2} \mathrm{~F}_{2}$ The rhombohedral crystal $\left(\mathrm{CaUO}_{4}\right.$ type) contains $\mathrm{AmO}_{2}^{+}$ions and is bult up of layers containıng $\mathrm{AmO}_{2} \mathrm{~F}_{2}^{-}$ions held together by potassium ions

$\mathrm{RbAmO}_{2} \mathrm{~F}_{2}$ Keenan ${ }^{117}$ made $\mathrm{RbAmO}_{2} \mathrm{~F}_{2}$ by addition of saturated $\mathrm{RbF}$ solution to $\mathrm{AmO}_{2}^{+}$in $001 \mathrm{M} \mathrm{HCl}$. On standing overnight in contact with an acidic $\mathrm{RbF}$ solution, $\mathrm{RbAmO}_{2} \mathrm{~F}_{2}$ is reduced to $\mathrm{Rb}_{2} \mathrm{AmF}_{6}$ (Ref. 115).

Germanate. $\mathrm{AmGeO}_{4}$ Both thermal and hydrothermal methods ${ }^{41,118}$ can be used to prepare $\mathrm{AmGeO}_{4}$ Pure, dark-brown $\mathrm{AmGeO}_{4}$ is produced when $\mathrm{Am}(\mathrm{OH})_{4}$ and excess $\mathrm{GeO}_{2}$ in a $1 M \mathrm{NaHCO}_{3}$ solution are heated 7 days at $230^{\circ} \mathrm{C}$. Bright-brown $\mathrm{AmGeO}_{4}$, contaminated with $\mathrm{AmO}_{2}$ and $\mathrm{Am}_{2} \mathrm{O}_{3}$, results when $\mathrm{AmO}_{2}$ and $\mathrm{GeO}_{2}$ are heated $8 \mathrm{hr}$ in $\mathrm{O}_{2}$ at $1000^{\circ} \mathrm{C}$.

The thermal decomposition of $\mathrm{AmGeO}_{4}$ starts at about $1050^{\circ} \mathrm{C}$. Keller ${ }^{118}$ suggests formation and decomposition of $\mathrm{AmGeO}_{4}$ can be represented by the reaction sequence 


$$
\mathrm{AmO}_{2}+\mathrm{GeO}_{2} \underset{\mathrm{I}_{1} \mathrm{~T}_{2}\left(\mathrm{H}_{2} \mathrm{O}\right)}{\longrightarrow} \alpha-\mathrm{AmGeO}_{4} \underset{\mathrm{T}_{3}}{\longrightarrow} \beta \mathrm{AmGeO}_{4} \underset{\mathrm{T}_{4}}{\longrightarrow} A m \mathrm{AmO}_{2}+\mathrm{GeO}_{2}
$$

where $\mathrm{T}_{2} \ll \mathrm{T}_{1}<\mathrm{T}_{3}>\mathrm{T}_{4} \gg \mathrm{T}_{2}$ Alpha $\mathrm{AmGeO}_{4}$ has the scheelite structure, and $\beta \mathrm{AmGeO}_{4}$ has the zircon structure

Hydrides. That americium metal reacts with $\mathrm{H}_{2}$ to form hydrides has been known almost since the discovery of americium ${ }^{1} 119$ Only recently, however, has a detaled study $^{120,121}$ of the americium-hydrogen system shown the existence of two hydride phases fcc $\mathrm{AmH}_{2+x}(0 \leqslant x \leqslant 07)$ and hexagonal $\mathrm{AmH}_{3}$ Pressure isotherms for the composition $\mathrm{AmH}_{2}$ to $\mathrm{AmH}_{3}$ are shown in Fig 44 Conversion of $\mathrm{AmH}_{2}{ }_{7}$ to $\mathrm{AmH}_{3}$ is sluggish At hydrogen to amencium $<2$, a two-phase region consisting of $\mathrm{AmH}_{2}$ and americium metal exists

According to Olson and Mulford, ${ }^{20}$ the partial pressure of $\mathrm{H}_{2}$ above $\mathrm{AmH}_{2}$ between 773 and $1073^{\circ} \mathrm{K}$ follows the relation $\log \mathrm{p}(\mathrm{atm})=7190-8812 / \mathrm{T}$ For the reaction

$$
\mathrm{Am}(\mathrm{s})+\mathrm{H}_{2}(\mathrm{~g}) \rightarrow \mathrm{AmH}_{2}(\mathrm{~s})
$$

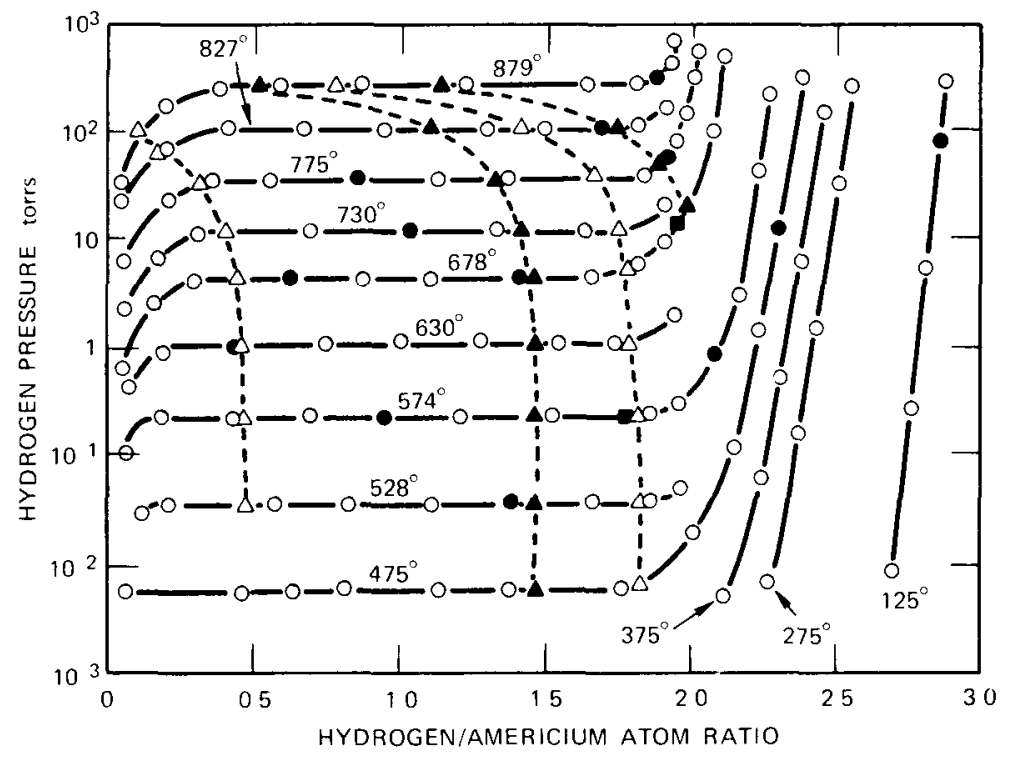

Fig. 4.4 $\Gamma$ amily of isotherms in the solid solution-dihydride-trihydride region of the americium--hydrogen system Solid lines, varying hydrogen at constant temperature $(\circ$, hydrogen added, •, hydrogen removed) Dashed lines, varying temperature with prehydrided samples $(\Delta$, increasing temperature series, 4 , decreasing temperature series) [From J W Roddy, The Actınide Hydrides The Americium-Hydrogen System, Journal of Inorgantc and Nuclear Chemistry, 354141 (1973) ] 
Olson and Mulford ${ }^{120}$ reported $\Delta \mathrm{H}=-403 \mathrm{kcal} \mathrm{mol}^{1}$ and $\Delta \mathrm{S}=-300 \mathrm{cal} \mathrm{mol}^{1}$ $\operatorname{deg}^{-1}$. Recent work ${ }^{121}$ at Oak Ridge Natıonal Laboratory puts these values at $\Delta H=$ $-45.5 \mathrm{kcal} \mathrm{mol}^{-1}$ and $\Delta S=373 \mathrm{cal} \mathrm{mol}^{-1} \mathrm{deg}^{-1}$

Utilızing the Solution Theory, Messer and Park ${ }^{122}$ have calculated the excess heat and entropies of mixing in the americium-hydrogen system.

Hydroperoxide. Slow neutralization with $\mathrm{NH}_{4} \mathrm{OH}$ of a $01 \mathrm{~N}$ acid solution of Am(III), which is also $0.2 \mathrm{~N} \mathrm{H}_{2} \mathrm{O}_{2}$, leads to a yellow-brown color at a $\mathrm{pH}$ of about 5 Further addition of $\mathrm{NH}_{4} \mathrm{OH}$ yields a yellow-brown precipitate, which, according to Buys and Louwrier, ${ }^{123}$ is quite distinct from $\mathrm{Am}(\mathrm{OH})_{3}$ and is probably a hydroperoxide of $\mathrm{Am}$ (III) The hydroperoxide is insoluble in saturated $\mathrm{NH}_{4} \mathrm{~F}$ but converts to $\mathrm{Am}(\mathrm{OH})_{4}$ when treated at $90^{\circ} \mathrm{C}$ with $10 \mathrm{~N} \mathrm{KOH}$ for 1 day

Hydroxides. $\mathrm{Am}(\mathrm{OH})_{3}$ An amorphous hydrous gel precipitates when ammonia or alkali is added to a solution of an Am(III) salt ${ }^{124-126}$ This precipitate consists of particles about 15 to $20 \AA$ in diameter ${ }^{125}$ Aging of this gel in water for 1 hr at $80^{\circ} \mathrm{C}$ yields rod-like or scroll-like particles of crystallıne $\mathrm{Am}(\mathrm{OH})_{3}$ which are isostructural with hexagonal $\mathrm{Nd}(\mathrm{OH})_{3}$ ( $\left.\operatorname{Refs} 124,126\right)$. After several months of aging in water, the $\mathrm{Am}(\mathrm{OH})_{3}$ structures disintegrate to give small amorphous particles In the solid state, $\mathrm{Am}(\mathrm{OH})_{3}$ converts to crystalline $\mathrm{AmO}_{2}$ The rate of conversion to the dioxide is dependent on storage conditions.

Weaver and Shoun ${ }^{127}$ find that $\mathrm{Am}^{3+}$ can be completely precipitated from chloride or nitrate media at an $\mathrm{NaOH} /$ americium ratio of 2.4. For this stochiometry, they calculate, at $\mathrm{NaOH} /$ americium ratios of 10 to 15 , that $\mathrm{K}_{\mathrm{SP}}$ is $\left[\mathrm{Am}^{3+}\right][\mathrm{OH}]^{2.4}=(3.4 \pm 03) \times 10^{-18}$ and that the solubility in water $1 \mathrm{~s}$ $\left(\mathrm{K}_{\mathrm{SP}} / 2.4^{24}\right)^{1 / 34}=39 \times 10^{-6} \mathrm{M}$

Figure 45 is a thermogram of a sample of $\mathrm{Am}(\mathrm{OH})_{3}$ heated in oxygen, the $\mathrm{Am}(\mathrm{OH})_{3}$ contained small amounts of nitrate and carbonate ${ }^{124}$ Although the DTA (differential thermal analysıs) peaks and TGA (thermogravımetrıc analysıs) changes are only tentatively assigned, the change at $1000^{\circ} \mathrm{C}$ is believed to be due to the decomposition of carbonate, whereas the change at about $300^{\circ} \mathrm{C}$ is thought to result from a loss of nitrate Changes below $300^{\circ} \mathrm{C}$ are assigned to loss of water The final product obtained after cooling to room temperature was confirmed by $\mathrm{X}$-ray analysis to be $\mathrm{AmO}_{2}$

$\mathrm{Am}(\mathrm{OH})_{4} \quad$ A brown-black precipitate forms when a slurry of $\mathrm{Am}(\mathrm{OH})_{3}$ is oxidized either with hypochlorite in weak base or with peroxydisulfate in strong ( $7 M)$ base ${ }^{128,129}$ This precipitate is referred to as $\mathrm{Am}(\mathrm{OH})_{4}$ by Penneman, Coleman, and Keenan ${ }^{129}$ but is perhaps better termed hydrous $\mathrm{AmO}_{2}$ Treatment ${ }^{125}$ of americium "hydroperoxide" (this page) with strong $\mathrm{KOH}$ also yields $\mathrm{Am}(\mathrm{OH})_{4}$. The estimated solubility ${ }^{129}$ product $\left(\mathrm{K}_{\mathrm{SP}}\right)$ of $\mathrm{Am}(\mathrm{OH})_{4}$ is about $10^{-56}$.

When tetravalent americium is precipitated with hydroxide, the resulting crystalline material gives election diffraction patterns identical ${ }^{125}$ to those obtained for $\mathrm{AmO}_{2}$ When a mixture of $\mathrm{Am}(\mathrm{III})$ and (IV) hydroxides is precipitated, the crystalline 


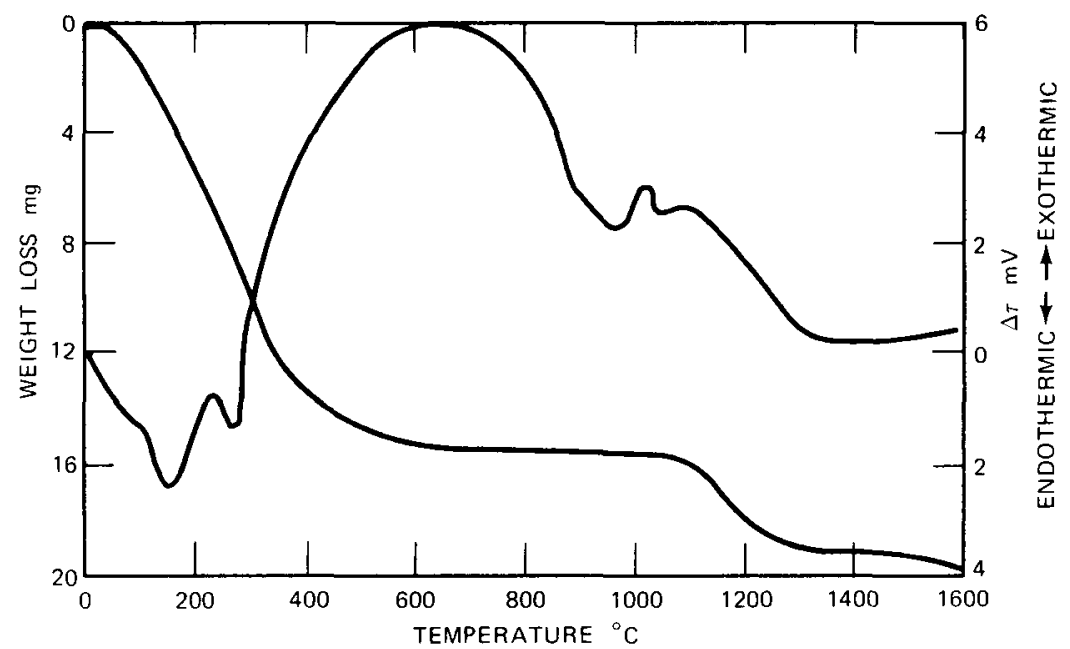

Fig. 4.5 Thermogram of $\mathrm{Am}(\mathrm{OH})_{3}$.

products consist of mixtures of rod-like $\mathrm{Am}(\mathrm{OH})_{3}$ particles and symmetrical particles of hydrous dioxide

Iodides. $A m I_{2}$. Combinıng americium metal with $\mathrm{HgI}_{2}$ according to Eq. 4.22 (Refs. 48 and 130) gives $\mathrm{AmI}_{2}$

$$
\mathrm{Am}+\mathrm{HgI}_{2} \underset{\text { vacuum }}{\stackrel{300^{\circ} \mathrm{C}}{\longrightarrow}} \mathrm{AmI}_{2}+\mathrm{Hg}
$$

Reaction conditions are 1dentical to those used to prepare $\mathrm{AmBr}_{2}$ (see page 138) except that the black granular $\mathrm{AmI}_{2}$ is annealed 3 days at $550^{\circ} \mathrm{C}$ rather than for 10 days at $400^{\circ} \mathrm{C}$. The amencium-1odine distance in $\mathrm{AmI}_{2}$ is in the range 328 to $340 \mathrm{~A}$. The only notable feature of the absorption spectrum of $\mathrm{AmI}_{2}$ is a weak, very broad band peakıng at $837 \mathrm{~nm}$. Americium(II) ıodide melts with decomposition at about $700^{\circ} \mathrm{C}$. Its effective magnetic moment is $\mu_{\mathrm{eff}}=6.7 \pm 0.7$ Bohr magnetons. ${ }^{121}$

$A m I_{3}$. What is termed $\alpha-\mathrm{AmI}_{3}$ is prepared ${ }^{51}$ by heating $\mathrm{AmO}_{2}$ at $500^{\circ} \mathrm{C}$ with either $\mathrm{AlI}_{3}$ or a mixture ${ }^{50}$ of aluminum metal and $\mathrm{I}_{2}$ and separating the reaction products by fractional sublimation Zachanasen ${ }^{54}$ found the resultıng $\mathrm{Aml}_{3}$ to have an orthorhombic structure

Americium(III) triodide can also be made by Eq. 4.23 (Refs. 52 and 131)

$$
\mathrm{AmCl}_{3}+3 \mathrm{NH}_{4} \mathrm{I} \underset{400-900^{\circ} \mathrm{C}}{\longrightarrow} \mathrm{AmI}_{3}+3 \mathrm{NH}_{4} \mathrm{Cl}
$$

where a flow system is used to sweep volatile $\mathrm{NH}_{4} \mathrm{Cl}$ from the reaction zone. The trilodide $\left(\beta-\mathrm{AmI}_{3}\right)$ made by Eq. 423 has a hexagonal structure and cannot be 
converted to an orthorhombic form even on annealıng at various temperatures. ${ }^{131}$ Treatment of $\beta-\mathrm{AmI}_{3}$ with $\mathrm{H}_{2}$ at $900^{\circ} \mathrm{Cdoes}$ not y1eld $\mathrm{AmI}_{2}$

Pappalardo, Carnall, and Fields ${ }^{51}$ have measured the visible and near infrared spectra of $\mathrm{AmI}_{3}$ at low temperatures. Maslov and Maslov ${ }^{132}$ estimate that the heat of formation for $\mathrm{AmI}_{3}$ from americium and $\mathrm{I}_{2}$ is $-146 \pm 5$ to $10 \mathrm{kcal} \mathrm{mol}{ }^{-1}$. (From recent thermochemical data, $\operatorname{Ryan}^{99}$ calculates a value of $-139 \pm 3$ to $5 \mathrm{kcal} \mathrm{mol}^{-1}$ )

AmOI Pure AmOI can be obtaned by heating $\mathrm{AmI}_{2}$ in moist atr at $400^{\circ} \mathrm{C}$ (Ref. 130). Its properties have not yet been determined.

Molybdates. $\mathrm{Am}_{2}\left(\mathrm{MoO}_{4}\right)_{3}$. Solid-state reaction ${ }^{133,134}$ between $\mathrm{MoO}_{3}$ and $\mathrm{AmO}_{2}$ at 700 to $900^{\circ} \mathrm{C}$ yields a ternary oxide of the empincal composition $\mathrm{Am}_{2} \mathrm{Mo}_{3} \mathrm{O}_{12}$. X-ray diffraction data show that the low-temperature $\left(\leqslant 850^{\circ} \mathrm{C}\right) \alpha$-form of this compound has the vacancy scheelite structure whereas the stable high-temperature $\beta$-form has an orthorhombic form.

$\mathrm{LtAm}\left(\mathrm{MoO}_{4}\right)_{2}$ The compound $\mathrm{LiAm}\left(\mathrm{MoO}_{4}\right)_{2}$ results when an equimolar mixture of $\mathrm{L}_{2} \mathrm{MoO}_{4}$ and $\mathrm{Am}_{2}\left(\mathrm{MoO}_{4}\right)_{3}$ is heated ${ }^{134}$ at $550^{\circ} \mathrm{C}$ This compound has the scheelite structure and is isostructural with $\mathrm{LiGd}\left(\mathrm{MoO}_{4}\right)_{2}$.

$\mathrm{NaAm}\left(\mathrm{MoO}_{4}\right)_{2}$ Two phases result from solid-state reaction ${ }^{134}$ of $\mathrm{Na}_{2} \mathrm{MoO}_{4}$ and $\mathrm{Am}_{2}\left(\mathrm{MoO}_{4}\right)_{3}$ at $550^{\circ} \mathrm{C}$. One of these is $\mathrm{NaAm}\left(\mathrm{MoO}_{4}\right)_{2}$ which, like $\mathrm{LiAm}\left(\mathrm{MoO}_{4}\right)_{2}$, has the scheelite structure.

$\mathrm{Na}_{5} \mathrm{Am}\left(\mathrm{MoO}_{4}\right)_{4}$ This compound, ${ }^{134}$ which also forms when $\mathrm{Na}_{2} \mathrm{MoO}_{4}$ and $\mathrm{Am}_{2}\left(\mathrm{MoO}_{4}\right)_{3}$ are heated $24 \mathrm{hr}$ at $550^{\circ} \mathrm{C}$, melts congruently at $654^{\circ} \mathrm{C}$ The crystal structure of $\mathrm{Na}_{5} \mathrm{Am}\left(\mathrm{MoO}_{4}\right)$ is the same as that of $\mathrm{Na}_{5} \mathrm{La}\left(\mathrm{WO}_{4}\right)_{4}$.

$\mathrm{K}_{2} \mathrm{Am}_{2}\left(\mathrm{MoO}_{4}\right)_{4}$ and $\mathrm{K}_{10} \mathrm{Am}_{2}\left(\mathrm{MoO}_{4}\right)_{8}$. Two homogeneous phases of the empincal composition $\mathrm{K}_{2} \mathrm{Am}_{2}\left(\mathrm{MoO}_{4}\right)_{3}$ and $\mathrm{K}_{10} \mathrm{Am}_{2}\left(\mathrm{MoO}_{4}\right)_{8}$ apparently form when $\mathrm{K}_{2} \mathrm{MoO}_{4}$ and $\mathrm{Am}_{2}\left(\mathrm{MoO}_{4}\right)_{3}$ are heated ${ }^{134}$ at $600^{\circ} \mathrm{C}$. X-ray diffraction data indicate that these compounds are not isostructural with those of sodium and lithium.

Nitrate. $\mathrm{Am}\left(\mathrm{NO}_{3}\right)_{3} \cdot \mathrm{xH}_{2} \mathrm{O}$ Several reports, e.g., Ref 70 , cite use of solid $\mathrm{Am}\left(\mathrm{NO}_{3}\right)_{3} \cdot x \mathrm{H}_{2} \mathrm{O}$ [made by thermal evaporation of a purified $\mathrm{Am}\left(\mathrm{NO}_{3}\right)_{3}-\mathrm{HNO}_{3}$ solution] as an intermediate in preparation of other americium compounds But, surprisingly, the chemical and physical properties of solid $\operatorname{Am}\left(\mathrm{NO}_{3}\right)_{3} \cdot x \mathrm{H}_{2} \mathrm{O}$, including its crystal structure, have apparently not been determıned.

Nitride. $A m N$ Akımoto ${ }^{135-137 \mathrm{a}}$ prepared micrograms of $\mathrm{AmN}$ by reacting $\mathrm{AmH}_{3}$ for $30 \mathrm{~min}$ at $800^{\circ} \mathrm{C}$ and also by direct reaction of americium metal and $\mathrm{N}_{2}$ at $750^{\circ} \mathrm{C}$. Potter and Tennery ${ }^{137 \mathrm{~b}}$ disclosed a cyclic process for the preparation of finely divided AmN which involves incrementally dehydriding $\mathrm{AmH}_{3}$ and nitriding the metal.

Milligram amounts of AmN have been recently synthesized by Charvillat et al. ${ }^{137 \mathrm{c}}$ by heating $\mathrm{AmH}_{3}$ under a high-purity $\mathrm{N}_{2}$ atmosphere in a sealed tube. The AmN thus 
produced has the cubic $\mathrm{NaCl}$ structure. Its effective magnetic moment is $136 \mathrm{Bohr}$ magnetons. ${ }^{15}$

Tagawa ${ }^{138}$ has recently reviewed the phase behavior and crystal structure of the actinide nitrides.

Binary Oxides. AmO. Zachariasen ${ }^{139}$ in a 1949 article reported the lattice constant of impure cubic AmO but did not give any details of how the compound is made. Akimoto ${ }^{135-137 a}$ claims to have prepared microgram amounts of $\mathrm{AmO}$ by reacting metallic americium at $850^{\circ} \mathrm{C}$ with the stoichiometric amount of oxygen gas generated by thermal decomposition of $\mathrm{Ag}_{2} \mathrm{O}$. He reports $\mathrm{AmO}$ is a brittle material with a grayish metallic luster. Attempts to prepare milligram to gram amounts of AmO have apparently not been made.

In connection with studies of the vaporization behavior of substoichiometric $\mathrm{PuO}_{2}$, Ackermann, Faircloth, and $\mathrm{Rand}^{140}$ found the vapor pressure of AmO between 1600 and $2200^{\circ} \mathrm{K}$ to obey the relation

$$
\log p(\operatorname{atm})=(8.19 \pm 0.41)-(25,650 \pm 760) / T
$$

$\mathrm{Am}_{2} \mathrm{O}_{3}$. Americium sesquioxide is obtained by reduction of $\mathrm{AmO}_{2}$ with $\mathrm{H}_{2}$ at 600 to $1000^{\circ} \mathrm{C}$. The crystal structure of the resulting $\mathrm{Am}_{2} \mathrm{O}_{3}$ depends on the reduction temperature. Cubic $\left(\mathrm{Mn}_{2} \mathrm{O}_{3}\right.$-type structure), red-brown C-type $\mathrm{Am}_{2} \mathrm{O}_{3}$ is produced at $600^{\circ} \mathrm{C}$ (Refs. 80 and 141 ), and hexagonal $\left(\mathrm{La}_{2} \mathrm{O}_{3}\right.$-type structure), tan A-type $\mathrm{Am}_{2} \mathrm{O}_{3}$ is obtained ${ }^{80}$ at $800^{\circ} \mathrm{C}$. The melting point of hexagonal $\mathrm{Am}_{2} \mathrm{O}_{3}$ is $2205 \pm 15^{\circ} \mathrm{C}$ (Ref. 142); the cubic-to-hexagonal transition occurs at about $800^{\circ} \mathrm{C}$ (Ref. 143). Chikalla and Eyring ${ }^{14}$ state that cubic $\mathrm{Am}_{2} \mathrm{O}_{3}$ is capable of dissolving excess oxygen and exists, at room temperature, over a wide range of stoichiometry. The upper boundary is at about $\mathrm{AmO}_{1,67}$.

It is not yet clear whether or not monoclinic sesquioxide (B-type $\mathrm{Am}_{2} \mathrm{O}_{3}$ ) can be prepared. Chikalla and Eyring ${ }^{\mathbf{1 4 4}}$ interpreted some of their X-ray data to indicate that B-type $\mathrm{Am}_{2} \mathrm{O}_{3}$ forms when oxide samples with oxygen/americium ratios between 1.51 and 1.54 are quenched from $800^{\circ} \mathrm{C}$ or above. In subsequent work, Berndt et al..$^{145 \mathrm{a}}$ and Maier ${ }^{145 b}$ were unable to confirm the earlier observations of Chikalla and Eyring. ${ }^{144}$ Their results show that only A-type $\mathrm{Am}_{2} \mathrm{O}_{3}$ exists in the range 900 to $1500^{\circ} \mathrm{C}$. Berndt et al. note, however, that in the americium-samarium-oxygen system, pure B-type $\mathrm{Am}_{2} \mathrm{O}_{3}-\mathrm{Sm}_{2} \mathrm{O}_{3}$ exists at 1250 to $1550^{\circ} \mathrm{C}$ at 8 to $10 \mathrm{~mol} \%$ $\mathrm{Sm}_{2} \mathrm{O}_{3}$. They suggest, therefore, that the diffraction lines observed by Chikalla and Eyring ${ }^{144}$ might have originated from a small amount of samarium impurity in their americium oxide sample.

On the basis of their recent studies with carefully purified ${ }^{241} \mathrm{Am}$, Keller and Berndt $^{146 a}$ state that B-type monoclinic sesquioxide with the exact stoichiometry $\mathrm{Am}_{2} \mathrm{O}_{3}$ does not exist. These workers report that hexagonal $\mathrm{Am}_{2} \mathrm{O}_{3}$ is the only stable modification for $<700^{\circ} \mathrm{C} \leqslant \mathrm{T} \leqslant 1550^{\circ} \mathrm{C}$. Keller and Berndt, ${ }^{146 \mathrm{a}}$ in agreement with the observations of Maier et al., note that a monoclinic form of $\mathrm{Am}_{2} \mathrm{O}_{3}$ can be stabilized by incorporation of small amounts of lanthanum oxides. 
Chıkalla et al. ${ }^{142}$ have drawn up a stability diagram for actınıde sesquioxides (F1g. 4.6). Their diagram includes transformation temperature data obtained by Foex and Traverse ${ }^{146 \mathrm{~b}}$ and Warshaw and Roy ${ }^{146 \mathrm{c}}$ for lanthanides Baybarz ${ }^{146 \mathrm{~d}}$ has also given a stability diagram for several of the actinide sesquioxides including $\mathrm{Am}_{2} \mathrm{O}_{3}$. Chikalla and Turcotte ${ }^{146 \mathrm{e}}$ note that the resin-bead technique used by Baybarz to obtain data for berkelium and calıfornum can result in large amounts of residual impurities and, for that reason, question the validity of Baybarz's diagram.

$\mathrm{AmO}_{2}$. Thermal decomposition in air or oxygen at 700 to $900^{\circ} \mathrm{C}$ of such americium compounds as $\mathrm{Am}\left(\mathrm{NO}_{3}\right)_{3}$ (Refs. 70 and 147), $\mathrm{Am}(\mathrm{OH})_{3}$ (Ref. 123), $\mathrm{Am}_{2}\left(\mathrm{CO}_{3}\right)_{3} \cdot 4 \mathrm{H}_{2} \mathrm{O}$ (Ref 61), or $\mathrm{Am}_{2}\left(\mathrm{C}_{2} \mathrm{O}_{4}\right)_{3}$ (Ref 141) produces dark-brown $\mathrm{AmO}_{2}$. Cubic $\mathrm{AmO}_{2}$ crystallizes with a fluorite structure. The lattice constant of ${ }^{241} \mathrm{AmO}_{2}$ has been determined by Zachariasen et al., ${ }^{139,148 \mathrm{a}}$ Dauben and Templeton, ${ }^{80}$ and most recently by Keller ${ }^{41}$ Keller and also Chıkalla and Eyrıng ${ }^{144}$ note that, because of the high alpha activity of ${ }^{241} \mathrm{Am}$, a continuous destruction of the lattice of ${ }^{241} \mathrm{AmO}_{2}$ takes place with the formation of Frenkel defects According to Keller, ${ }^{41}$ the lowest value of the lattice constant of ${ }^{241} \mathrm{AmO}_{2}$, obtained immediately after preparation, is $\mathrm{a}=5377 \AA$. After 3 months' storage, the lattice constant is $5.395 \AA$. The lattice constant of ${ }^{243} \mathrm{AmO}_{2}$ at $25^{\circ} \mathrm{C}$ is $5.3743 \AA$ (Ref. 148a). [Thermal expansion of $\mathrm{AmO}_{2}$ can be calculated from the expression $a_{t}=53733+434 \times 10^{-5} \mathrm{t}+14.3 \times 10^{-9} \mathrm{t}^{2}$, where $\mathrm{a}_{\mathrm{t}}$ is the lattice constant $(\AA) \mathrm{at}$ any temperature $\mathrm{t}\left({ }^{\circ} \mathrm{C}\right)^{148 \mathrm{~b}}$ ]

McHenry ${ }^{149}$ observed that the melting point of a composition near $\mathrm{AmO}_{2}$, when heated in helium, increased with increasing rate of heating Melting points of 1750 and $2120^{\circ} \mathrm{C}$, respectively, were noted at heating rates of 0.3 and $1.50^{\circ} \mathrm{C} \mathrm{min}^{-1}$. According to Chikalla and Turcotte, ${ }^{146 \mathrm{e}}$ McHenry's results must certainly refer to a grossly substoichiometric oxide since the oxygen dissociation pressure over $\mathrm{AmO}_{2.00}$ is $1 \mathrm{~atm}$ at about $1000^{\circ} \mathrm{C}(\operatorname{Ref} 150)$. However, on the basis of an extrapolation of other actinide dioxide data, Chikalla and Turcotte ${ }^{146 \mathrm{e}}$ state that the expected melting point of $\mathrm{AmO}_{2}$ is $2175^{\circ} \mathrm{C}$

The vapor pressure of $\mathrm{AmO}_{2}$ between 1600 and $2200^{\circ} \mathrm{K}$ is given by the relation $^{140}$

$$
\log \mathrm{p}(\mathrm{atm})=(728 \pm 0.19)-(28260 \pm 360) / \mathrm{T}
$$

The dioxide dissolves readily in aqueous $\mathrm{HCl}$ solutions with evolution of chlorine and in aqueous $\mathrm{HNO}_{3}$ and $\mathrm{H}_{2} \mathrm{SO}_{4}$ solutions with evolution of oxygen, particularly when heated Using data obtained orıginally by Eyrıng, Lohr, and Cunnıngham ${ }^{141}$ for the heat of solution of $\mathrm{AmO}_{2}$ in $602 \mathrm{M} \mathrm{HNO}_{3}-0.1 M \mathrm{HBF}_{4}$, Fuger, Sprrlet, and Muller ${ }^{11 \text { a }}$ calculate the enthalpy of formation of $\mathrm{AmO}_{2}$ at $298^{\circ} \mathrm{K}$ as $\Delta \mathrm{H}_{\mathrm{f}}^{\circ}=-2243 \pm$ $0.6 \mathrm{kcal} \mathrm{mol}^{-1}$

Chikalla and Eyring ${ }^{150}$ used a thermogravimetric isopiestic technique to measure the oxygen dissociation pressures over sto1chiometric americium dioxide Their results ( $F_{1} g$ 4.7) show that the partial pressure of oxygen above $\mathrm{AmO}_{2} \times$ increases sharply 


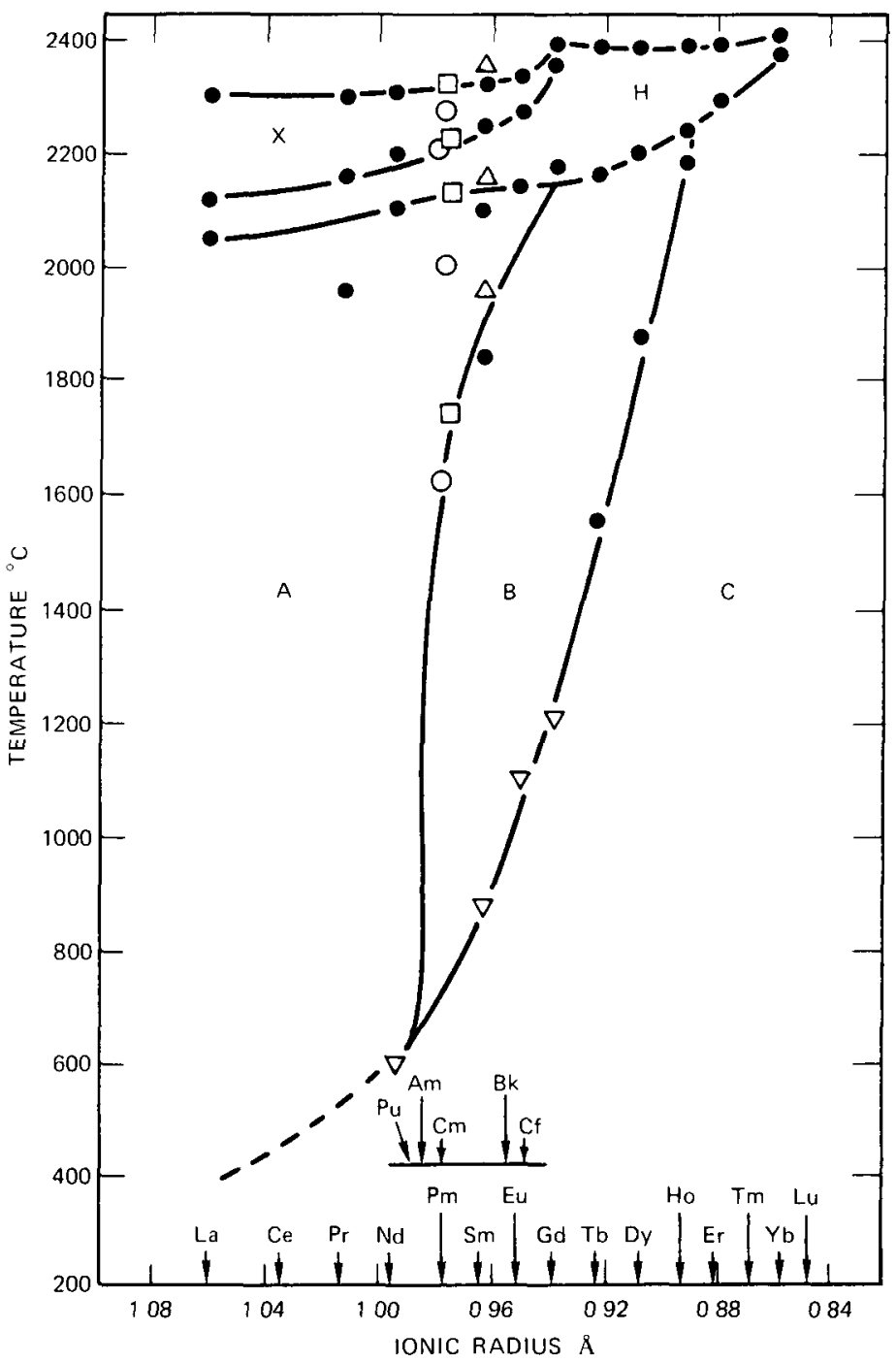

Fig. 4.6 Stability diagram of polymorphic forms of lanthanide and dctinide sesquioxides $\bullet$ and $\nabla$ are results of Foex and Traverse ${ }^{146 \mathrm{~b}}$ and Warshaw and Roy, ${ }^{16 \mathrm{C}}$ respectively 0 , $\square$, and $\Delta$ are transformation temperatures in $\mathrm{Cm}_{2} \mathrm{O}_{3}, \mathrm{Pm}_{2} \mathrm{O}_{3}$, and $\mathrm{Sm}_{2} \mathrm{O}_{3}$ found by Chikalla et al ${ }^{142}$ (from T D Chikalla, C E McNe1lly, J L Bates, and J J Rasmussen, High Temperature Phase Transformations in Some Lanthanide and Actinide Oxides, in Proceedings of the International Collquium on High Temperature Phase Transformanon, Centre National de la Recherche Scientifique, Publication No 205, 1973) 


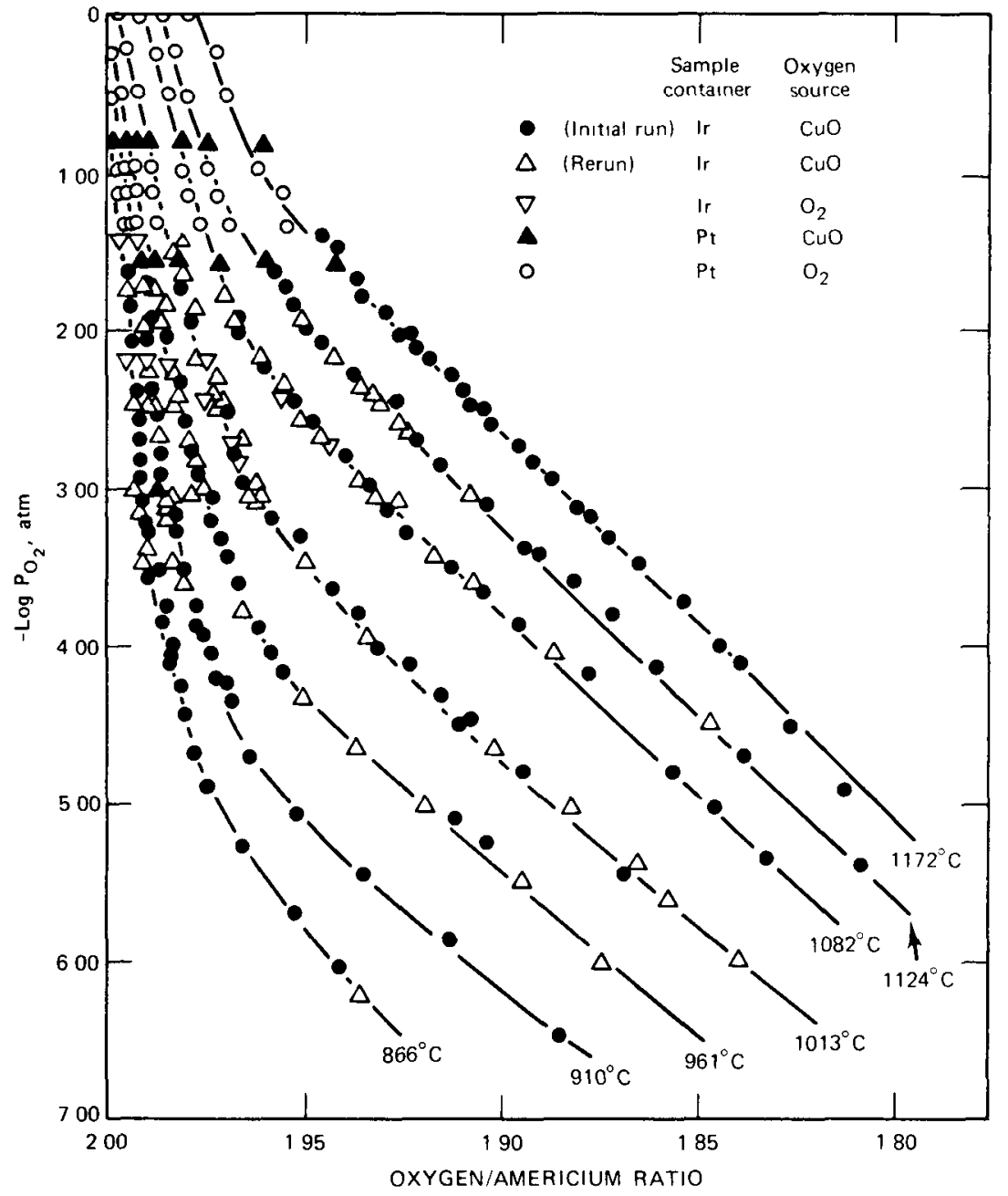

Fig. 4.7 Dissociation-pressure isotherms for $\mathrm{AmO}_{\mathrm{x}}$ [From $\mathrm{T} \mathrm{D}$ Chikalla and L Eyring Dissociation Pressures and Partial Thermodynamic Quantities for Amencium Oxides, Journal of Inorganic and Nuclear Chemistry, 29: 2281 (1967)]

both with the temperature and with the oxygen/americium ratio. Asprey and Cunningham ${ }^{151}$ also studied the thermal decomposition of $\mathrm{AmO}_{2}$ The relative partial molar enthalpy and entropy of solution of $\mathrm{O}_{2}$ in $\mathrm{AmO}_{2-x}$ calculated from the results of both sets of investigators are in reasonable agreement.

Figure 4.8 is the phase diagram for the americium-oxygen system derived by Sar1 and Zamoran1 ${ }^{152 \mathrm{a}}$ and Sarı, Tebald, and Pietra ${ }^{152 \mathrm{~b}}$ using DTA and ceramographic procedures. According to this diagram an oxygen-deficient fcc single-phase $\mathrm{AmO}_{2-x}$ 


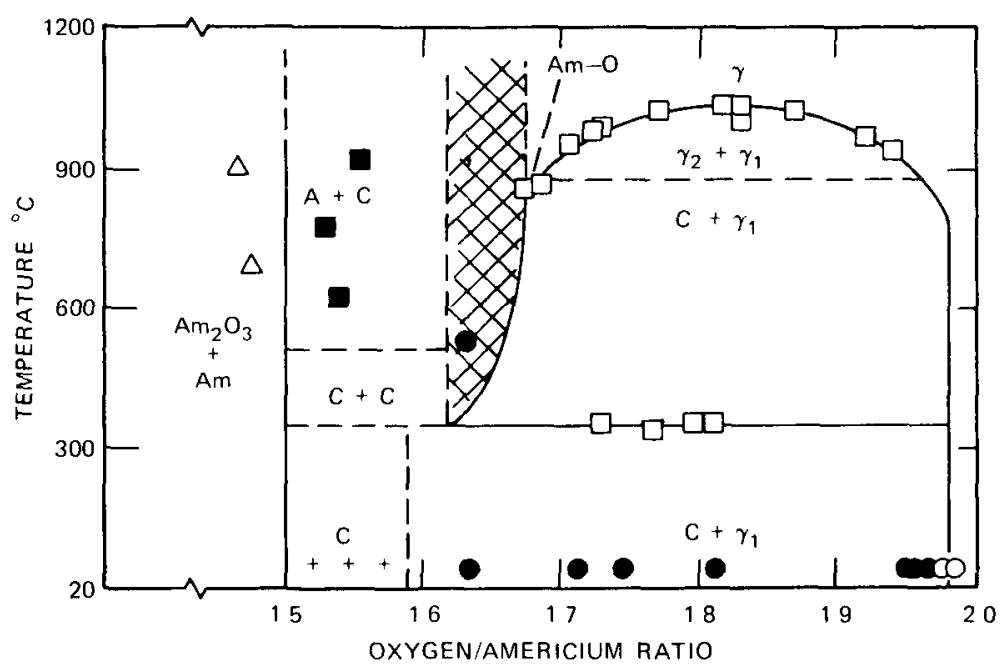

Fig. 4.8 Low-temperature americium-oxygen phase diagram $\mathrm{A}=$ hexagonal $\mathrm{Am}_{2} \mathrm{O}_{3}$, $\mathrm{C}=$ low-temperature bcc $\mathrm{Am}_{2} \mathrm{O}_{3}, \mathrm{C}^{\prime}=$ high-temperature bcc $\mathrm{Am}_{2} \mathrm{O}_{3}, \gamma, \gamma_{1}, \gamma_{2}$, = fcc $\mathrm{AmO}_{2} x \mathrm{\square}=$ results of DTA measurements All other points represent results of micrographic analysis [From C Sarı and E Zamoranı, An Investigation in the Americium Oxide System, Journal of Nuclear Materials, 37· $324(1970)]$

exists at temperatures above $1020^{\circ} \mathrm{C}$ and for $17 \leqslant$ oxygen/americium $\leqslant 20$ At room temperature the compound $\mathrm{AmO}_{1} 9_{8}$ is in equilibrium with a bcc phase of the approximate composition $\mathrm{AmO}_{159}$ The low-temperature bcc phase takes up additional oxygen at temperatures higher than $350^{\circ} \mathrm{C}$ and extends into a region of composition $163 \leqslant$ oxygen/amencium $\leqslant 168$. For higher oxygen/amencium ratios, this phase is in equilibrium with $\mathrm{AmO}_{2} x$ up to $1020^{\circ} \mathrm{C}$, whereas, for. lower oxygen/americium ratios, it is in equilibrium with a hexagonal $\mathrm{Am}_{2} \mathrm{O}_{3}$

Chikalla and Eyring ${ }^{144}$ analyzed (X-ray diffraction) quenched samples taken across the entire compositional width $150<$ oxygen/americium $<200$, their results show the formation of bcc phase $(\alpha)$ in the range $150<$ oxygen/americium $<167$ Samples annealed in the higher oxygen/americium region could not be quenched but always gave a two-phase mixture of $\mathrm{AmO}_{2} \mathrm{oo}_{0}$ and a phase of estimated composition $\mathrm{AmO}_{1} 8$ By implication it is suggested that another diphasic region must exist in the interval $167<$ oxygen/amencium $<18$

Chikalla and Turcotte ${ }^{153 a}$ have suggested that there is a greater complexity in the 167 to 180 region of the amencium-oxygen system than indicated in Fig 48 More recently, on further consideration of the Sar1-Zamoranı phase diagram for $\mathrm{AmO}_{2}$, Chikalla and Turcotte ${ }^{146 \mathrm{e}}$ state, "The partial pressure data in Fig 47 and the phase diagram suggested by Sar1 and Zamoran1 are in direct conflict The thermodynamic data suggest that the region $A_{m} O_{195}-A_{m O_{1}} 85$ is single-phased to temperatures below $900^{\circ} \mathrm{C}$, whereas the diphasic dome reported by Sart and Zamoranı 
extends to well above $1000^{\circ} \mathrm{C}$. In the other fluorite-related systems examined in this region, including plutonium, berkelium (Turcotte, unpublished), cenum, and praseodymium, there is indeed evidence of a diphasic region but only at temperatures near or below $600^{\circ} \mathrm{C}$.

"With the exception of the diphasic dome at high temperatures, which is a dome that we believe is disproved by the equilibrium thermodynamic studies, there are no real data presented which justify construction of any detaled phase diagram. That given by Sart and Zamoranı relies entirely on the hope that $\mathrm{AmO}_{x}$ is much like $\mathrm{PuO}_{x}$ "

Karraker ${ }^{153 \mathrm{~b}}$ studied the magnetic properties of $\mathrm{AmO}_{2}$, over the temperature ranges 15 to $50^{\circ} \mathrm{K}$ and 50 to $100^{\circ} \mathrm{K}, \mu_{\mathrm{eff}}=13$ and 1.53 Bohr magnetons, respectively. Karraker also notes that $\mathrm{AmO}_{2}$ is antiferromagnetıc at temperatures below about $8.5 \pm 0.5^{\circ} \mathrm{K}$.

Ternary Oxides with Lithium and Sodium. Lithium. Solid-state reaction of $\mathrm{Li}_{2} \mathrm{O}$ and $\mathrm{AmO}_{2}$ in various proportions at temperatures in the range 350 to $1000^{\circ} \mathrm{C}$ leads to a variety of brown-colored ternary oxides. ${ }^{41,154,155}$ The following compounds are known

$$
\begin{aligned}
A m(V I) & \mathrm{L}_{6} \mathrm{AmO}_{6} \text { and } \mathrm{L}_{4} \mathrm{AmO}_{5} \\
\mathrm{Am}(\mathrm{V}) & \mathrm{L}_{7} \mathrm{AmO}_{6} \text { and } \mathrm{L}_{3} \mathrm{AmO}_{4} \\
\mathrm{Am}(\mathrm{IV}) & \mathrm{L}_{8} \mathrm{AmO}_{6} \text { and } \mathrm{L}_{2} \mathrm{AmO}_{3} \\
\mathrm{Am}(\mathrm{III}) & \mathrm{L}_{1} \mathrm{AmO}_{2}
\end{aligned}
$$

Figure 49 , due to Keller, ${ }^{41}$ summarizes the thermal stability of these compounds and the conditions for their preparation.

Sodium. The following listed ternary oxides of americium with sodium can be prepared by solid-state reaction of $\mathrm{Na}_{2} \mathrm{O}$ or $\mathrm{Na}_{2} \mathrm{O}_{2}$ with $\mathrm{AmO}_{2} 41,154,155$

$$
\begin{aligned}
\mathrm{Am}(\mathrm{VI}) & \mathrm{Na}_{6} \mathrm{AmO}_{6} \text { and } \mathrm{Na}_{4} \mathrm{AmO}_{5} \\
\mathrm{Am}(\mathrm{V}) & \mathrm{Na}_{3} \mathrm{AmO}_{4} \\
\mathrm{Am}(\mathrm{IV}) & \mathrm{Na}_{2} \mathrm{AmO}_{3}
\end{aligned}
$$

Conditions for preparation of these compounds and their thermal stability were reported by Keller ${ }^{41}$ and are shown in Fig 410

Ternary Oxides with Barium and Strontium. Barum. The following ternary oxides are known in the barıum-americium-oxygen system ${ }^{41,156}$

$$
\begin{array}{ll}
\mathrm{Am}(\mathrm{VI}) & \mathrm{Ba}_{3} \mathrm{AmO}_{6} \\
\mathrm{Am}(\mathrm{IV}) & \mathrm{BaAmO}_{3} \\
\mathrm{Am}(\mathrm{III}) & \mathrm{BaAm}_{2} \mathrm{O}_{4}\left(\mathrm{BaO} \cdot \mathrm{Am}_{2} \mathrm{O}_{3}\right)
\end{array}
$$

Medium-brown $\mathrm{Ba}_{3} \mathrm{AmO}_{6}$ is obtained by heating a finely pulverized mixture of $\mathrm{BaO}$ and $\mathrm{AmO}_{2}\left(\begin{array}{ll}3.05 & 1\end{array}\right)$ in $\mathrm{O}_{2}$ for $8 \mathrm{hr}$ at 800 to $1000^{\circ} \mathrm{C}(\operatorname{Refs} 41,156)$ This compound dissolves in dilute acids 


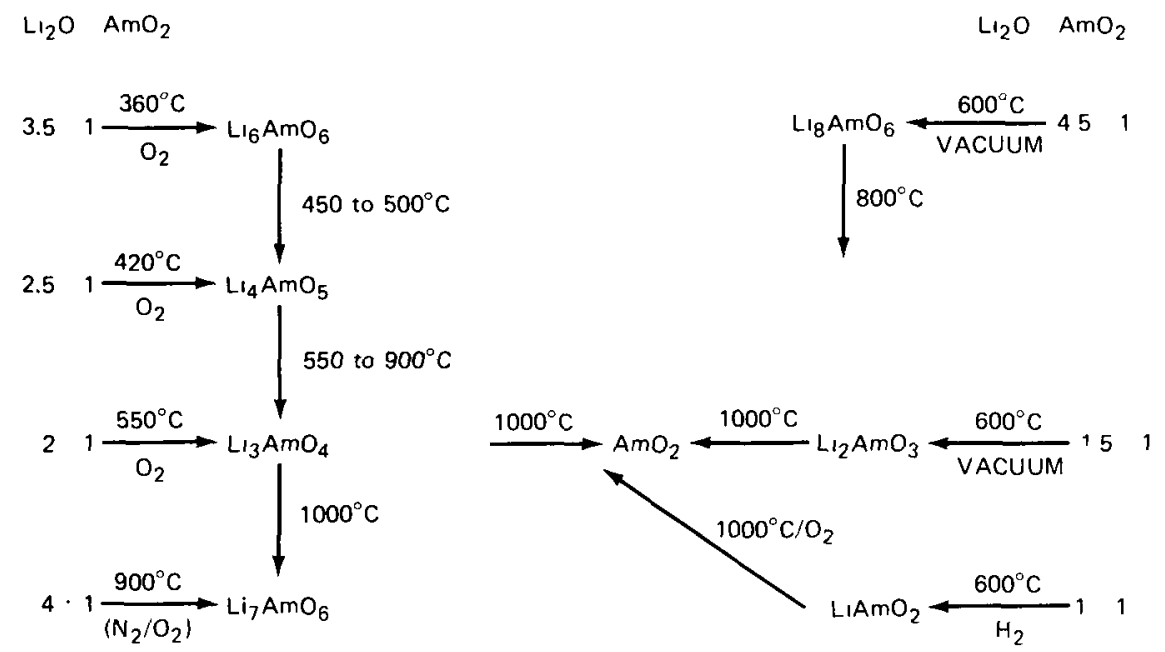

Fig. 4.9 Preparation conditions and thermal stability of compounds in the system lithium-americium-oxygen. [From C. Keller, The Solid State Chemistry of Americium Oxides, in Lanthanide/Actinide Chemistry, R. F. Gould (Ed.), Advances in Chemistry Series, American Chemical Society, Washington, 1967.]

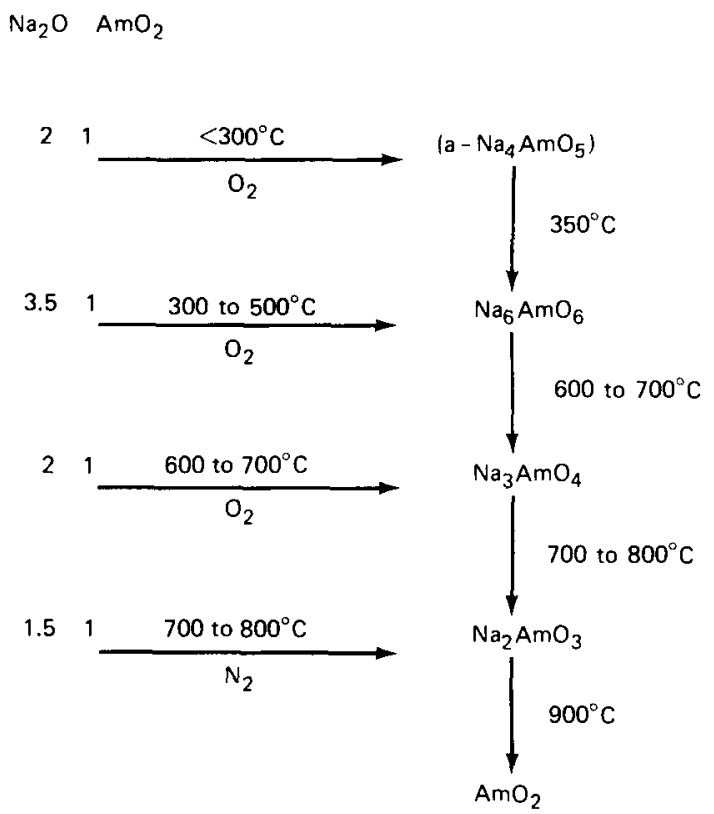

Fig. 4.10 Preparative conditions and thermal stability of compounds in the system sodium-americium-oxygen. [From C. Keller, The Solid State Chemistry of Americium Oxides, in Lanthanide/Actinide Chemistry. R. F. Gould (Ed.), Advances in Chemistry Series, American Chemical Society, Washington, 1967.] 
Dark brown $\mathrm{BaAmO}_{3}$ forms when a mixture ${ }^{41}$ of $\mathrm{BaO}$ (or $\mathrm{BaCO}_{3}$ ) and $\mathrm{AmO}_{2}$ (1 09 1) is heated in arr at $1250^{\circ} \mathrm{C}$ for $30 \mathrm{hr}$ Synthesis of $\mathrm{BaAmO}_{3}$ can also be effected by thermal decomposition of $\mathrm{Ba}_{3} \mathrm{AmO}_{6}$ at temperatures above $1100^{\circ} \mathrm{C}$ $\mathrm{BaAmO}_{3}$ dissolves in dilute acids with disproportionation of $\mathrm{Am}(\mathrm{IV})$

Reduction ${ }^{41}$ of $\mathrm{BaAmO}_{3}$ with $\mathrm{H}_{2}$ at $1250^{\circ} \mathrm{C}$ produces $\mathrm{BaAm}_{2} \mathrm{O}_{4}$ $\left(\mathrm{BaO} \cdot \mathrm{Am}_{2} \mathrm{O}_{3}\right)$, which has the structure of $\mathrm{CaFe}_{2} \mathrm{O}_{4}$

Strontium In the stiontium-americium-oxygen system, the following compounds exist 41156

$$
\begin{array}{ll}
\mathrm{Am}(\mathrm{VI}) & \mathrm{Sr}_{3} \mathrm{AmO}_{6} \\
\mathrm{Am}(\mathrm{IV}) & \mathrm{SrAmO}_{3} \\
\mathrm{Am}(\mathrm{III}) & \mathrm{SrAm}_{2} \mathrm{O}_{4}\left(\mathrm{SrO} \cdot \mathrm{Am}_{2} \mathrm{O}_{3}\right)
\end{array}
$$

These compounds are completely analogous to those in the barium-americium-oxygen system and are prepared by similar solid-state reactions

Ternary Oxides with Curium. Cunum(IV) is stabllized ${ }^{157}$ by formation of solid solutions of $\mathrm{CmO}_{x}$ in $\mathrm{AmO}_{2}$ Table 43 lists the phases known in the amenciumcurıum-oxygen system for oxygen/amencium + curıum $>15$

Ternary Oxides with Zirconium, Hafnium, and Thorium Zirconıum A one-phase solid solution with the fluorite structure exists above $18 \mathrm{~mol} \% \mathrm{AmO}_{2}$ in the $\mathrm{AmO}_{2}-\mathrm{ZrO}_{2}$ system at 1200 to $1400^{\circ} \mathrm{C}(\mathrm{F} 1 \mathrm{~g} 411)$

Figure 412 shows the phases present in the $\mathrm{AmO}_{1}{ }_{5}-\mathrm{ZrO}_{2}$ system at $1200^{\circ} \mathrm{C}$ (Refs 41,158 ) Besides the pure starting components, two one-phase regions exist a tetragonal solid solution of 0 to $6 \mathrm{~mol}^{\%} \mathrm{AmO}_{15}$ and a cubic solid solution of about 32 to 55 mol \% $\mathrm{AmO}_{15}$ According to Keller, ${ }^{41}$ "In the cubic solid solution, in whose region exists $\mathrm{Am}_{2} \mathrm{Zr}_{2} \mathrm{O}_{7}$ with the pyrochlore-type structure, a continuous transition from the fluorite phase to the pyrochlore phase can be observed"

Hafnium. The amencium-hafnum-oxygen system has not been studied as intensively as the corresponding americium-zirconıum-oxygen system Qualitatively, ${ }^{4,158}$ a one phase solid solution with the fluorite structure exists in the $\mathrm{AmO}_{2}-\mathrm{HfO}_{2}$ system, but the extent of the soldd-solution region is unknown Kelle ${ }^{41}$ reports that the $\mathrm{AmO}_{15}-\mathrm{HfO}_{2}$ system is considerably more simple than the $\mathrm{AmO}_{1}{ }_{5}-\mathrm{ZrO}_{2}$ system According to Keller, a 1 l compound $\mathrm{Am}_{2} \mathrm{Hf}_{2} \mathrm{O}_{7}$ with the pyrochlore structure exists in the $\mathrm{AmO}_{15}-\mathrm{HfO}_{2}$ system

Thorium. Thoria and $\mathrm{AmO}_{2}$ form a complete series of solid solutions 41,158 Keller ${ }^{41}$ states, "The solubility of $\mathrm{AmO}_{15}$ in $\mathrm{ThO}_{2}$ at $1300^{\circ} \mathrm{C}$ is about $50 \mathrm{~mol} \%$ In this case the pure fluorite structure remains, the lack of oxygen is bdlanced by the formation of statistically distributed oxygen holes An exact determination of the solubility of $\mathrm{AmO}_{1}$ in $\mathrm{ThO}_{2}$ is possible in practice only by quoting a large margin of error because the lattice constants of $\mathrm{ThO}_{2}(\mathrm{a}=5599 \AA)$ and those of the cublc $\mathrm{AmO}_{15}(\mathrm{a} / 2=5515 \AA)$ are relatively close to each other, and, moreover, the quality 
Table 4.3

PHASES IN THE SYSTEM AMERICIUM-CURIUM-OXYGEN

\begin{tabular}{|c|c|c|c|c|c|c|c|c|c|}
\hline & & \multirow[b]{3}{*}{ Cations present } & \multicolumn{7}{|c|}{ Phase } \\
\hline & & & \multirow[b]{2}{*}{ Formula } & \multirow[b]{2}{*}{ Symmetry } & \multicolumn{4}{|c|}{ Lattice constants, $\AA$} & \multirow[b]{2}{*}{ Conditions } \\
\hline \multicolumn{2}{|c|}{ Composition* } & & & & a & b & c & $\beta$ & \\
\hline $200 \leqslant 0$ & $M \leqslant 198$ & $\mathrm{Am}^{4+}, \mathrm{Cm}^{4+}$ & $\left(\mathrm{Am}_{030}, \mathrm{Cm}_{0}, 0\right) \mathrm{O}_{200}$ & $\mathrm{fcc}$ & 5368 & & & & $350^{\circ} \mathrm{C}$ in $\mathrm{O}_{2}$ \\
\hline $193 \leqslant 0$ & $M \leqslant 1.80$ & $\mathrm{Am}^{4+}, \mathrm{Cm}^{4+}, \mathrm{Cm}^{3+}$ & $\left(\mathrm{Am}_{030}, \mathrm{Cm}_{0}, 0\right) \mathrm{O}_{183}$ & $\mathrm{fcc}$ & 5433 & & & & $550^{\circ} \mathrm{C}$ in $\mathrm{O}_{2}$ \\
\hline $180 \leqslant 0$ & $M \leqslant 168$ & $\mathrm{Am}^{4+}, \mathrm{Cm}^{4+}, \mathrm{Cm}^{3+}$ & $\left(\mathrm{Am}_{030}, \mathrm{Cm}_{070}\right) \mathrm{O}_{1085}$ & Rhombohedral & 6687 & & & $9947^{\circ}$ & $760^{\circ} \mathrm{C}$ in $\mathrm{He}$ \\
\hline $172 \leqslant 0$ & $M \leqslant 152$ & $\begin{array}{l}\mathrm{Am}^{4+}, \mathrm{Am}^{3+} \\
\mathrm{Cm}^{4+}, \mathrm{Cm}^{3+}\end{array}$ & $\left(\mathrm{Am}_{030}, \mathrm{Cm}_{0}{ }_{70}\right) \mathrm{O}_{\mathrm{x}}$ & bcc & $\begin{array}{l}10935 \\
11004\end{array}$ & & & & $\begin{array}{l}990^{\circ} \mathrm{C} \text { in } \mathrm{He} \\
915^{\circ} \mathrm{C} \text { in } 4 \% \mathrm{H}_{2} / \mathrm{He}\end{array}$ \\
\hline $\begin{array}{l}\mathrm{O} \\
\mathrm{O}\end{array}$ & $\begin{array}{l}M=150 \\
M=150\end{array}$ & $\begin{array}{l}\mathrm{Am}^{3+}, \mathrm{Cm}^{3+} \\
\mathrm{Am}^{3+}, \mathrm{Cm}^{3+}\end{array}$ & $\begin{array}{l}\left(\mathrm{Am}_{064}, \mathrm{Cm}_{3_{36}}\right) \mathrm{O}_{15} \\
\left(\mathrm{Am}_{0_{64}}, \mathrm{Cm}_{0_{36}}\right) \mathrm{O}_{15}\end{array}$ & $\begin{array}{l}\text { Monoclinic } \\
\text { Hexagonal }\end{array}$ & $\begin{array}{r}14321 \\
3980\end{array}$ & 3665 & $\begin{array}{l}8926 \\
5980\end{array}$ & $10017^{\circ}$ & $\begin{array}{l}1100^{\circ} \mathrm{C} \text { in } 4 \% \mathrm{H}_{2} / \mathrm{He} \\
1500^{\circ} \mathrm{C} \text { in } 4 \% \mathrm{H}_{2} / \mathrm{He}\end{array}$ \\
\hline
\end{tabular}

${ }^{*} \mathrm{M}=$ amerıcıum + curnum 


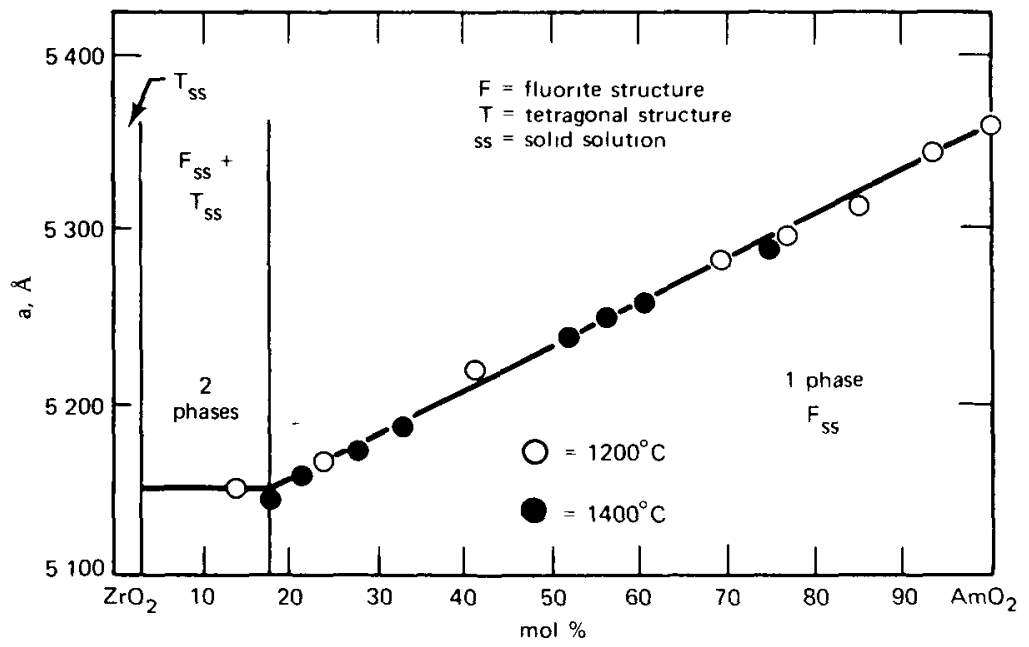

Fig. 4.11 The $\mathrm{AmO}_{2}-\mathrm{ZrO}_{2}$ system. [From C. Keller, The Solid State Chemistry of Americium Oxides, in Lanthanide/Actinide Chemistry, R. F. Gould (Ed.), Advances in Chemistry Series, American Chemical Society, Washington, 1967.]

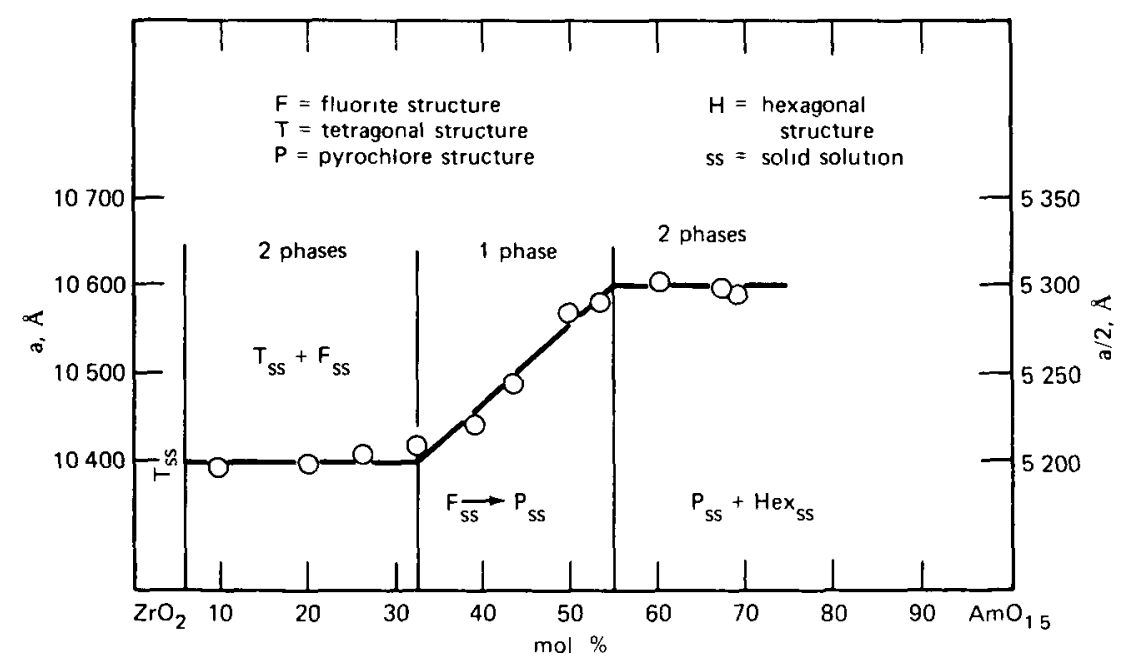

Fig. 4.12 The $\mathrm{AmO}_{1.5}-\mathrm{ZrO}_{2}$ system-lattice constants and solid solutions at $1200^{\circ} \mathrm{C}$ [From C. Keller, The Solid State Chemistry of Americium Oxides, in Lanthanide/Actinide Chemistry, R. F. Gould (Ed.), Advances in Chemistry Series, American Chemical Society, Washington, 1967.] 
of X-ray powder patterns of samples above $50 \mathrm{~mol} \% \mathrm{AmO}_{15}$ leaves much to be desired"

Oxıdes with Niobium, Tantalum, and Protactinium Noblum $\mathrm{AmNbO}_{4}$ Monoclinic $\alpha \mathrm{AmNbO}_{4}$ is produced by the solid-state reaction of $\mathrm{AmO}_{2}$ and $\mathrm{Nb}_{2} \mathrm{O}_{5}$

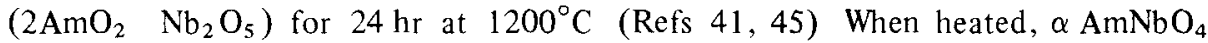
transforms to $\beta \mathrm{AmNbO}_{4}$ at $600 \pm 20^{\circ} \mathrm{C}$ (Ref 45 ), $\beta \mathrm{AmNbO}_{4}$, which has the tetragonal scheelite structure, is unstable below $660^{\circ} \mathrm{C}$ and cannot be stabilized even by fast quenching

$\mathrm{Am}_{0}{ }_{33} \mathrm{NbO}_{3}$ When mixed in the proportions $2 \mathrm{AmO}_{2} \quad 3 \mathrm{Nb}_{2} \mathrm{O}_{5}, \mathrm{AmO}_{2}$ and $\mathrm{Nb}_{2} \mathrm{O}_{5}$ react at $1200^{\circ} \mathrm{C}$ in $\mathrm{H}_{2}$, arr, or a vacuum to produce pale-rose $\mathrm{Am}_{0}{ }_{33} \mathrm{NbO}_{3}$ (Refs 41 and 42) This compound is isostructural with tetragonal $\mathrm{La}_{0}{ }_{3} \mathrm{TaO}_{3}$

$\mathrm{Ba}_{2} \mathrm{AmNbO}_{6}$ At $1300^{\circ} \mathrm{C}, \alpha-\mathrm{AmNbO}_{4}$ reacts with $\mathrm{BaO}$ to form $\mathrm{Ba}_{2} \mathrm{AmNbO}_{6}$ (Refs 41 and 45) This latter compound has the "ordered" perovskite structure This compound can also be synthesized by direct solid-state reaction of $\mathrm{AmO}_{2}, \mathrm{Nb}_{2} \mathrm{O}_{5}$, and $\mathrm{BaO}(\operatorname{Ref} 45)$

$\mathrm{AmNbT}_{1} \mathrm{O}_{6} \quad$ Yellow-brown orthorhombic $\mathrm{AmNbT}_{1} \mathrm{O}_{6}$ is easily prepared by reaction of $\alpha-\mathrm{AmNbO}_{4}$ with $\mathrm{T}_{1} \mathrm{O}_{2}$ at $1150^{\circ} \mathrm{C}$ for $24 \mathrm{hr}$ in alr ${ }^{41,45}$

Tantalum. Solid-state reactions between $\mathrm{Ta}_{2} \mathrm{O}_{5}$ and $\mathrm{AmO}_{2}$ yield $\alpha-\mathrm{AmTaO}_{4}$, $\beta$-AmTaO ${ }_{4}$, and $\mathrm{Am}_{0}{ }_{3} \mathrm{TaO}_{3}$ (Refs 41, 42, and 45), these compounds and the conditions for their preparation are completely analogous to those already described for the americium-niobium-oxygen system The compounds $\mathrm{Ba}_{2} \mathrm{AmTaO}_{6}$ and $\mathrm{AmTaT}_{1} \mathrm{O}_{6}$ are also known ${ }^{4,45}$ and are prepared like the corresponding niobium compounds

Protactinntum. $\mathrm{AmPaO}_{4}$ The solid-state reaction ${ }^{45}$ between $\mathrm{AmO}_{2}$ and $\mathrm{Pa}_{2} \mathrm{O}_{5}$ $\left(2 \mathrm{AmO}_{2} \quad \mathrm{PaO}_{2}\right)$ for $8 \mathrm{hr}$ at $1100^{\circ} \mathrm{C}$ results in a double oxide $\left[\mathrm{Am}_{0}{ }_{5}(\mathrm{III}), \mathrm{Pa}_{0}{ }_{5}(\mathrm{~V})\right] \mathrm{O}_{2}\left(=\mathrm{AmPaO}_{4}\right)$ that, according to Keller, ${ }^{4}$ I has a fluorite-type structure with a statistical distribution of metal ions The double oxide ${ }^{45}$ is insoluble in acids but can be solubilized by fusion with $\mathrm{K}_{2} \mathrm{~S}_{2} \mathrm{O}_{7}$

$\mathrm{Ba}_{2} \mathrm{AmPaO}_{6}$ At 1350 to $1400^{\circ} \mathrm{C}\left(\mathrm{Am}_{0}, \mathrm{~Pa}_{0}{ }_{5}\right) \mathrm{O}_{2}$ reacts with $\mathrm{BaO}$ or $\mathrm{BaCO}_{3}$ to form $\mathrm{Ba}_{2} \mathrm{AmPaO}_{6}$ (Refs 41, 45, 159) The latter compound has an ordered perovskite type of structure ${ }^{41}$

Phosphate $\mathrm{AmPO}_{4} \cdot \mathrm{xH}_{2} \mathrm{O}$ Light pink Am(III) phosphate precipitates when a dilute solution of either $\mathrm{H}_{3} \mathrm{PO}_{4}, \mathrm{Na}_{2} \mathrm{HPO}_{4}$, or $\left(\mathrm{NH}_{4}\right)_{2} \mathrm{HPO}_{4}$ is added to a weakly acidic $\left(\left[\mathrm{H}^{+}\right]<01 M\right) \mathrm{Am}^{3+}$ solution ${ }^{45}$ Hexagonal $\mathrm{AmPO}_{4} \cdot 05 \mathrm{H}_{2} \mathrm{O}$ is obtained when the precipitate is dried at $200^{\circ} \mathrm{C}$ or lower temperature Anhydrous $\mathrm{AmPO}_{4}$ is obtained at higher drying temperatures The anhydrous compound ${ }^{45}$ s stable up to $1000^{\circ} \mathrm{C}$ and can also be obtained by direct reaction of stoichiometric amounts of $\mathrm{AmO}_{2}$ and $\left(\mathrm{NH}_{4}\right)_{2} \mathrm{HPO}_{4}$ at 600 to $1000^{\circ} \mathrm{C}$ Dilute acid solutions readily dissolve $\mathrm{AmPO}_{4} \cdot 05 \mathrm{H}_{2} \mathrm{O}$, but monoclinic $\mathrm{AmPO}_{4}$ dissolves only in bolling acid solution 
Phosphide $A m P$ Charvillat et al ${ }^{44 \mathrm{~b}, 137 \mathrm{c}}$ synthesized $\mathrm{AmP}$ by reaction at $580^{\circ} \mathrm{C}$ of red phosphorus on $\mathrm{AmH}_{3}$ in a sealed quartz tube The monophosphide has the cubıc $\mathrm{NaCl}$ structure with $\mathrm{a}=57114 \pm 00003 \AA$

Scandate $\mathrm{AmScO}_{3}$ Pink $\mathrm{AmScO}_{3}$ forms when stolchiometric proportions of $\mathrm{AmO}_{2}$ and $\mathrm{Sc}_{2} \mathrm{O}_{3}$ are heated in highly purified $\mathrm{H}_{2}$ at 1100 to $1700^{\circ} \mathrm{C}$ (Ref 160) A convenient starting material for the solid state reaction is obtained by coprecipitation of the hydroxides of americium and scandium

According to Keller and Berndt ${ }^{146}$ oxidation of $\mathrm{AmScO}_{3}$ or the solid-state reaction of $\mathrm{AmO}_{2}-\mathrm{Sc}_{2} \mathrm{O}_{3}$ mixtures results in the formation of a fluorite phase Keller and Berndt also find that $\mathrm{AmO}_{2}$ takes up small amounts of $\mathrm{Sc}_{2} \mathrm{O}_{3}$ into solid solution, $05 \mathrm{~mol} \%$ at $1100^{\circ} \mathrm{C}$ to $47 \mathrm{~mol} \%$ at $1550^{\circ} \mathrm{C}$ But even in this system there is some loss of oxygen of $\mathrm{AmO}_{2}$ at high temperatures leading to an increased solubility of $\mathrm{Sc}_{2} \mathrm{O}_{3}$ in $\mathrm{AmO}_{2} x$

Selenides $A m S e$ Charvillat et al ${ }^{137 \mathrm{C}}$ prepared AmSe by reactıng $\mathrm{AmH}_{3}$ with a stoichiometric amount of selenium at $800^{\circ} \mathrm{C}$ in a vacuum The resulting product after pelletizing and further heating at 1100 to $1200^{\circ} \mathrm{C}$ contained two phases- $\mathrm{Am}_{3} \mathrm{Se}_{4}$ $\left(\mathrm{Th}_{3} \mathrm{Pu}_{4}\right.$ structures) and a second phase ( $\mathrm{NaCl}$ structure) that Charvillat et al identıfied as cubic AmSe

$\mathrm{AmSe}_{2} \times$ Nonstoichiometric black $\mathrm{AmSe}_{2} \times$ is prepared by heating an excess of selenium metal with $\mathrm{AmH}_{3}$ for 1 week at $400^{\circ} \mathrm{C}$ under high vacuum ${ }^{161} \mathrm{X}$ ray diffraction analyses indicate the resulting product is a nonstoichiometric compound with a composition near $\mathrm{AmSe}_{1} 8$ Roddy $^{30}$ has also prepared what appears to be tetragonal $\mathrm{AmSe}_{2}$ by heating ${ }^{243} \mathrm{Am}$ metal or hydride with selenium metal for $24 \mathrm{hr}$ at $950^{\circ} \mathrm{C}$ His results also suggest that a range of homogeneity may exist in the amenicium-selenium system

$\mathrm{Am}_{3} \mathrm{Se}_{4}$ Body-centered cubic $\mathrm{Am}_{3} \mathrm{Se}_{4}$ results when a mixture of 50 wt $\%$ americium metal and $50 \mathrm{wt} \%$ selenium metal is heated for $1 \mathrm{hr}$ at $217^{\circ} \mathrm{C}$ and then $7 \mathrm{hr}$ at $850^{\circ} \mathrm{C}$ before furnace cooling to room temperature ${ }^{43}$ Roddy $^{30}$ also prepared $\mathrm{Am}_{3} \mathrm{Se}_{4}$ by heating ${ }^{243} \mathrm{Am}$ metal with metallic selenium $24 \mathrm{hr}$ at $950^{\circ} \mathrm{C}$ X-ray diffraction measurements show that the products of such preparations contain at least two phases that persist even after heat-treating for 10 to 14 days at 750 to $800^{\circ} \mathrm{C}$ The major phase ${ }^{44}$ in the final product is $\mathrm{Am}_{3} \mathrm{Se}_{4}$, which is isostructural with $\mathrm{Th}_{3} \mathrm{P}_{4}$ and is without magnetic ordering down to $42^{\circ} \mathrm{K}$

Silicate $\mathrm{AmSlO}_{4}$ Hydrothermal reaction of $\mathrm{Am}(\mathrm{OH})_{4}$ with excess $\mathrm{S}_{2} \mathrm{O}_{2}$ in $1 M$ $\mathrm{NaHCO}_{3}$ solution for 1 week at $230^{\circ} \mathrm{C}$ yields brown $\mathrm{AmSiO}_{4}$ that has the zircon structure ${ }^{119}$ On heatıng, $\mathrm{AmSlO}_{4}$ decomposes to $\mathrm{AmO}_{2}$ and $\mathrm{SiO}_{2}$ without forming intermediate silicates $A$ process for manufacturing alpha sources has been patented $^{162}$ which consists of fixing onto a metallic or ceramic support a layer of an enamel containing ${ }^{241} \mathrm{AmSlO}_{4}$ This layer is obtained by melting an enamel powder containing ${ }^{241} \mathrm{Am}$ on the surface of the support 
Sulfates. $\mathrm{Am}_{2}\left(\mathrm{SO}_{4}\right)_{3} \cdot \mathrm{xH}_{2} \mathrm{O}$. Evaporation of a neutral solution of $\mathrm{Am}$ (III) sulfate yields thick, tabular, pale yellow-pink crystals of $\mathrm{Am}_{2}\left(\mathrm{SO}_{4}\right)_{3} \cdot 8 \mathrm{H}_{2} \mathrm{O}$ of lengths up to $05 \mathrm{~mm} .{ }^{163}$ Crystals of the octahydrate, after being dried in arr, are stable for several days.

On the basis of analyses for americium, sulfate, and water, Yakovlev et al ${ }^{164}$ assign the formula $\mathrm{Am}_{2}\left(\mathrm{SO}_{4}\right)_{3} \cdot 5 \mathrm{H}_{2} \mathrm{O}$ to the precipitate obtained by adding ethanol to a solution of $\mathrm{Am}(\mathrm{III})$ in $05 \mathrm{M} \mathrm{H}_{2} \mathrm{SO}_{4}$

Hall and Markin ${ }^{70}$ prepared white anhydrous $\mathrm{Am}_{2}\left(\mathrm{SO}_{4}\right)_{3}$ by heatıng hydrated americium sulfate to a temperature of 550 to $650^{\circ} \mathrm{C}$ in arr Thermogravimetric data obtained by these workers are shown in Fig 4.13. Anhydrous $\mathrm{Am}_{3}\left(\mathrm{SO}_{4}\right)_{3}$ does not take up water when cooled to room temperature in air

Am(III) Double Sulfates The following double sulfates ${ }^{100,164,165}$ can be prepared by addition of an alkalı metal sulfate solution to a solution of Am(III) in $05 \mathrm{M} \mathrm{H}_{2} \mathrm{SO}_{4}$

$$
\begin{array}{ll}
\mathrm{KAm}\left(\mathrm{SO}_{4}\right)_{2} & \mathrm{TlAm}\left(\mathrm{SO}_{4}\right)_{2} \cdot 4 \mathrm{H}_{2} \mathrm{O} \\
\mathrm{NaAm}\left(\mathrm{SO}_{4}\right)_{2} \cdot \mathrm{H}_{2} \mathrm{O} & \mathrm{K}_{3} \mathrm{Am}\left(\mathrm{SO}_{4}\right)_{3} \cdot \mathrm{H}_{2} \mathrm{O} \\
\mathrm{KAm}\left(\mathrm{SO}_{4}\right)_{2} \cdot 2 \mathrm{H}_{2} \mathrm{O} & \mathrm{K}_{8} \mathrm{Am}{ }_{2}\left(\mathrm{SO}_{4}\right)_{7} \\
\mathrm{RbAm}\left(\mathrm{SO}_{4}\right)_{2} \cdot 4 \mathrm{H}_{2} \mathrm{O} & \mathrm{CS}_{8} \mathrm{Am}_{2}\left(\mathrm{SO}_{4}\right)_{7} \\
\mathrm{CsAm}\left(\mathrm{SO}_{4}\right)_{2} \cdot 4 \mathrm{H}_{2} \mathrm{O} & \mathrm{Tl}_{8} \mathrm{Am}_{2}\left(\mathrm{SO}_{4}\right)_{7}
\end{array}
$$

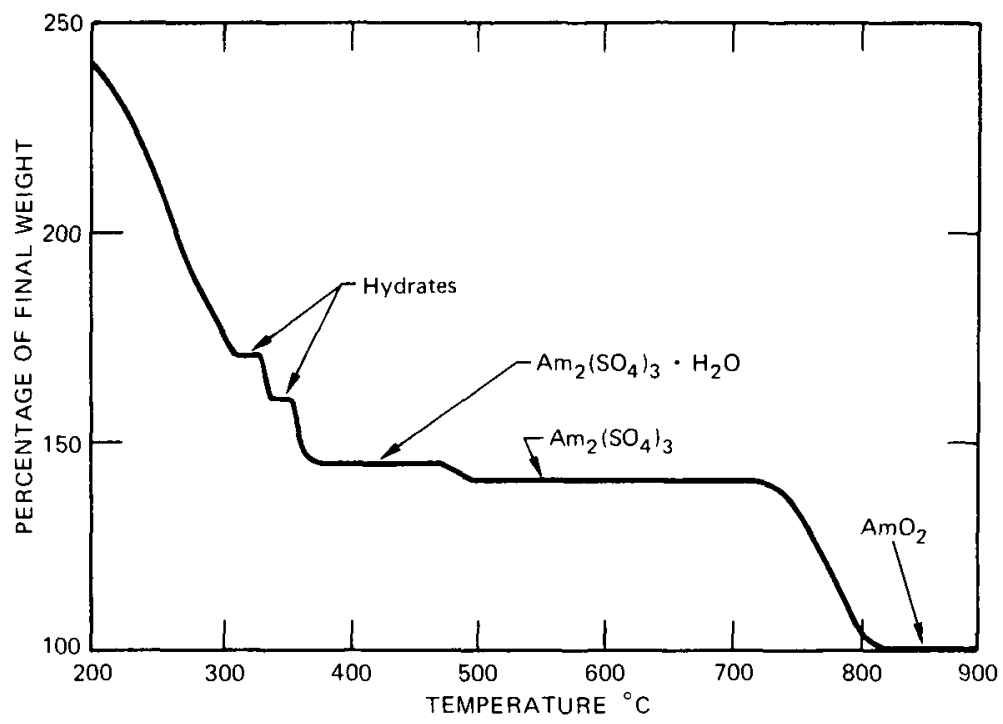

Fig. 4.13 Thermogravımetric analysis of $\mathrm{Am}_{2}\left(\mathrm{SO}_{4}\right)_{3} \cdot \mathrm{xH}_{2} \mathrm{O}$ [From $\mathrm{G} \mathrm{R}$ Hall and T. L Markın, The Alpha Half-L.,fe of Americium-241, Journal of Inorganic and Nuclear Chemistry, 4: 137 (1975) ] 
Ratios of $\left[\mathrm{M}^{+}\right] /\left[\mathrm{Am}^{3+}\right](\mathrm{M}=\mathrm{Na}, \mathrm{K}, \mathrm{Rb}, \mathrm{Cs}$, or $\mathrm{Tl})$ at which the various double sulfates precipitate are given in Ref 164 The absorption spectra of certain of the crystallıne double salts between 400 and $800 \mathrm{~nm}$ at 80,200 , and $300^{\circ} \mathrm{K}$ have also been reported, ${ }^{164}$ but, apparently, $X$ ray diffraction data for the double sulfates have not been obtained Coprecipitation of trace amounts of $\mathrm{Am}^{3+}$ with $\mathrm{K}_{2} \mathrm{SO}_{4}$ and $\mathrm{La}_{2}\left(\mathrm{SO}_{4}\right)_{3}$ has also been studied 166168

$\left.\left\{/ \mathrm{Co}\left(\mathrm{NH}_{3}\right)_{6} / \mathrm{HSO}_{4}\right\}_{2}\left\{\mathrm{AmO}_{2} / \mathrm{SO}_{4}\right)_{3}\right\} \cdot \mathrm{nH}_{2} \mathrm{O}$ Hexammine cobalt(III) americyl(VI)-sulfate is prepared by dddition of hexammine cobalt(III) ions to an aqueous sulfate solution containing $\mathrm{AmO}_{2}^{2+}$ (Ref 169) The orange cubic crystals (diamond type structure) are isostructural with the corresponding $\mathrm{UO}_{2}^{2+}$ and $\mathrm{NpO}_{2}^{2+}$ compounds No precipitate forms, however, in an ammonium sulfate solution containing Am(III) and hexammune cobalt(III) lons 170

Sulfides $A m_{2} S_{3}$ The alpha form of americium sesquisulfide is obtained ${ }^{171}$ by vapor phase reaction for 4 days of a stoichiometric amount of sulfur with $\mathrm{AmH}_{3}$ in a quartz and Pyrex tube sealed under high vacuum The quartz end of the tube is kept at $500^{\circ} \mathrm{C}$, and the Pyrex part is maintaned at $300^{\circ} \mathrm{C}$ to prevent sulfur from condensing

When heated in a vacuum ${ }^{171}$ at $1300^{\circ} \mathrm{C}, \alpha \mathrm{Am}_{2} \mathrm{~S}_{3}$ changes to pure $\gamma-\mathrm{Am}_{2} \mathrm{~S}_{3}$ Pure $\gamma-\mathrm{Am}_{2} \mathrm{~S}_{3}$ can also be prepared ${ }^{50}$ by passing a mixture of $\mathrm{H}_{2} \mathrm{~S}$ and $\mathrm{CS}_{2}$ gases over heated $\left(1400\right.$ to $\left.1500^{\circ} \mathrm{C}\right) \mathrm{AmO}_{2}$ for $5 \mathrm{~min}$ The crystal structure of $\gamma \mathrm{Am}_{2} \mathrm{~S}_{3}$ has been determined by Zacharıasen ${ }^{172}$

$A m S$ Thermal decomposition ${ }^{171}$ of $\alpha-\mathrm{Am}_{2} \mathrm{~S}_{3}$ in vacuum at $650^{\circ} \mathrm{C}$ yields $\mathrm{AmS}$ as well as $\gamma \cdot \mathrm{Am}_{2} \mathrm{~S}_{3}$ The amencium-sulfur distance in cubic AmS is $2796 \AA$

$A m S_{2}$ y Americium disulfide ${ }^{161}$ is prepared by the same procedure used to make $\mathrm{AmSe}_{2} x$-namely, by heatıng under vacuum an excess of sulfur with $\mathrm{AmH}_{3}$ for 1 week at $400^{\circ} \mathrm{C}$ Analogous to $\mathrm{AmSe}_{2} x$, the coarse black disulfide is a nonstorchiometric compound with a composition near $\mathrm{AmS}_{1}$ g The americium-sulfur distance is $293 \AA$ in good agreement with an ronic binding between $\mathrm{Am}^{3+}$ and $\mathrm{S}^{2}$

$A m_{10} S_{14} O\left(\beta A m_{2} S_{3}\right)$ When heated ${ }^{173}$ at $1100^{\circ} \mathrm{C}$ in a high vacuum, $\alpha-\mathrm{Am}_{2} \mathrm{~S}_{3}$ transforms into $\beta \mathrm{Am}_{2} \mathrm{~S}_{3}$ The formula of the $\beta-\mathrm{Am}_{2} \mathrm{~S}_{3}$, according to Damien, Marcon, and Jove, ${ }^{173}$ is more properly written $\mathrm{Am}_{10} \mathrm{~S}_{14} \mathrm{O}$ The tetragonal oxysulfide is isostructural with the rare earth and plutonium $\beta$ sesquisulfides

Tellurides $A m T e$ To prepare americium monotelluride, Charvillat et al ${ }^{137 \mathrm{c}}$ heated milligram amounts of $\mathrm{AmH}_{3}$ with a stoichiometric quantity of elemental tellurium at $800^{\circ} \mathrm{C}$ in a vacuum The resulting product after pelletizing and further heatıng at 1100 to $1200^{\circ} \mathrm{C}$ contained two phases- $\mathrm{Am}_{3} \mathrm{Te}_{4}\left(\mathrm{Th}_{3} \mathrm{Pu}_{4}\right.$ structure $)$ and a second phase $(\mathrm{NaCl}$ structure) that Charvillat et al identified as cubic AmTe

$\mathrm{AmTe}_{3}$ Americium tritelluride ${ }^{174}$ is prepared by vapor-phase reaction (120 hr at $350^{\circ} \mathrm{C}$ in a sealed tube) of excess tellurium (amencium/tellurium $=3$ 5) on $\mathrm{AmH}_{3}$ Orthorhombic $\mathrm{AmTe}_{3}$ is isostructural with the corresponding rare-earth tritellurides 
$A m T_{2}$ Thermal dissociation of $\mathrm{AmTe}_{3}$ at $400^{\circ} \mathrm{C}$ in a high vacuum $\left(<10^{5}\right.$ torr $)$ yields tetragonal $\mathrm{AmTe}_{2}$ The ditelluride is isostructural with the rare-earth ditellurides and likely has the $\mathrm{Fe}_{2}$ As type of structure Damien ${ }^{174}$ states that $\mathrm{AmTe}_{2}$ prepared as described above is a tellurium-deficient compound, $\mathrm{AmTe}_{2} x$, with a rather large homogeneity range between 400 and $600^{\circ} \mathrm{C}$

$A m_{2} \mathrm{Te}_{3}$ At temperatures ${ }^{175}$ above $600^{\circ} \mathrm{C}, \mathrm{AmTe}_{2}$ dissocidtes into $\mathrm{Am}_{2} \mathrm{Te}_{3}$ By andlogy with isostructural rare earth sesquitellurides, Damien and Charvillat ${ }^{175}$ label $\mathrm{Am}_{2} \mathrm{Te}_{3}$ as an $\eta$ form

$A m_{3} \mathrm{Te}_{4}$ The $\eta-\mathrm{Am}_{2} \mathrm{Te}_{3}$ phase is stable up to around $850^{\circ} \mathrm{C}$, at $900^{\circ} \mathrm{C}, \mathrm{Am}_{3} \mathrm{Te}_{4}$ 1s formed ${ }^{175}$ The latter compound was first prepared by Mitchell and $\mathrm{Lam}^{43}$ using experimental procedures completely identical to those already described (see page 161) for preparation of $\mathrm{Am}_{3} \mathrm{Se}_{4}$ Body-centered cubic $\mathrm{Am}_{3} \mathrm{Te}_{4}$ is isostructural with $\mathrm{Th}_{3} \mathrm{P}_{4}$ and is without magnetic ordering ${ }^{44}$ down to $42^{\circ} \mathrm{K}$

Oxytellurlde? In the pattern of $\mathrm{Am}_{3} \mathrm{Te}_{4}$, Damien and Charvillat ${ }^{175}$ assign four diffraction lines, which cannot be indexed in the bcc system, to an americium oxy telluride

Tungstate Analogous to the reaction with $\mathrm{MoO}_{3}$ (see page 151), solid-state reaction of $\mathrm{WO}_{3}$ and $\mathrm{AmO}_{2}$ at 700 to $900^{\circ} \mathrm{C}$ yields a ternary oxide of the empirical composition $\mathrm{Am}_{2} \mathrm{~W}_{3} \mathrm{O}_{12}$ (Ref 133) This compound has the scheelite structure corresponding to the formula $\mathrm{Am}_{2}\left(\mathrm{WO}_{4}\right)_{3}$

Vanadates. Red-brown $\mathrm{AmVO}_{4}$ forms when $\mathrm{AmO}_{2}$ is heated $\left(10 \mathrm{hr}\right.$ at $600^{\circ} \mathrm{C}$ followed by $10 \mathrm{hr}$ at $1000^{\circ} \mathrm{C}$ ) with $\mathrm{V}_{2} \mathrm{O}_{5}$ in air, ${ }^{41,42,45} \mathrm{AmVO}_{4}$ has the tetragonal zircon structure Reduction with $\mathrm{H}_{2}$ at $1200^{\circ} \mathrm{C}$ converts $\mathrm{AmVO}_{4}$ to ochre-colored $\mathrm{AmVO}_{3}$ with the $\mathrm{GdFeO}_{3}$ structure

Xenate. Addition of solid sodium perxenate to $\mathrm{K}_{2} \mathrm{CO}_{3}$ and $\mathrm{Na}_{2} \mathrm{CO}_{3}$ solutions of $\mathrm{Am}(\mathrm{III})$ precipitates $\mathrm{Am}(\mathrm{III})$ perxenate, $\mathrm{Am}_{4}\left(\mathrm{XeO}_{6}\right)_{3} \cdot 40 \mathrm{H}_{2} \mathrm{O}$ (Ref 176). The color of the precipitate is orange when wet and orange tan when dried under vacuum at room temperature The compound can be water washed without decomposition or loss by solubilization. Its solubility in distilled water at $\simeq 23^{\circ} \mathrm{C}$ is $46 \times 10^{5} \mathrm{M}$ Americium perxenate dissolves in acids with evolution of gas to form $\mathrm{Am}(\mathrm{V})$ and $\mathrm{Am}(\mathrm{VI})$ Marcus and Cohen ${ }^{176}$ report that Am(III) perxenate shows the characteristic absorption bands of $A m(I I I)$ in the visible and near-infrared regions, as well as the characteristic infrared absorption at 650 to $680 \mathrm{~cm}^{1}$ for the xenon-oxygen vibration in perxenate

\section{Compounds of Americium with Organic Ligands}

Relatively few solid compounds of americium with organic ligands have yet been prepared, those known as of January 1976 are listed in Table 44 As revealed in the 
Table 4.4

COMPOUNDS OF AMERICIUM WITH ORGANIC LIGANDS

\begin{tabular}{|c|c|c|c|}
\hline \multirow[b]{2}{*}{ No. } & \multirow{2}{*}{$\begin{array}{c}\text { Organtc } \\
\text { reagent ligand }\end{array}$} & \multicolumn{2}{|c|}{ Compound } \\
\hline & & Formula & Color \\
\hline 1 & Acetate & $\mathrm{NaAmO}_{2}\left(\mathrm{OOCCH}_{3}\right)_{3}$ & Lemon yellow \\
\hline 2 & Acetylacetone & $\mathrm{Am}\left(\mathrm{C}_{5} \mathrm{H}_{7} \mathrm{O}_{2}\right)_{3} \cdot \mathrm{H}_{2} \mathrm{O}$ & Pale rose \\
\hline 3 & Benzoyltrifluorodcetone & $\mathrm{Am}\left(\mathrm{C}_{10} \mathrm{H}_{6} \mathrm{I}_{3} \mathrm{O}_{2}\right)_{3} \cdot 3 \mathrm{H}_{2} \mathrm{O}$ & Pale rose \\
\hline 4 & Cyclooctatetraene & $\mathrm{KAm}\left(\mathrm{C}_{8} \mathrm{H}_{8}\right)_{2} \cdot 2 \mathrm{THF}^{*}$ & Yellow \\
\hline 5 & Cyclopentadiene & $\operatorname{Am}\left(\mathrm{C}_{5} \mathrm{H}_{5}\right)_{3}$ & I lesh \\
\hline 6 & Dipivaloylmethane & $\mathrm{Am}\left(\mathrm{C}_{1}, \mathrm{H}_{1}, \mathrm{O}_{2}\right)_{3}$ & \\
\hline 7 & Formate & $\mathrm{Am}(\mathrm{HCOO})_{3} \cdot 02 \mathrm{H}_{2} \mathrm{O}$ & Pink \\
\hline 8 & Hexafluorodcetylacet one & $\operatorname{CsAm}\left(\mathrm{C}_{5} \mathrm{HF}_{6} \mathrm{O}_{2}\right)_{4} \cdot \mathrm{H}_{2} \mathrm{O}$ & Yellow \\
\hline 9 & 8-Hydroxyquinoline & $\mathrm{Am}\left(\mathrm{C}_{9} \mathrm{H}_{6} \mathrm{NO}\right)_{3}$ & Yellow green \\
\hline 10 & 5-chloro-8-hydroxyquinoline & $\mathrm{Am}\left(\mathrm{C}_{9} \mathrm{H}_{5} \mathrm{ClNO}\right)_{3}$ & Dark green \\
\hline 11 & 5,7-dichloro-8-hyd roxyquinoline & $\mathrm{Am}\left(\mathrm{C}_{9} \mathrm{H}_{4} \mathrm{Cl}_{2} \mathrm{NO}\right)_{3}$ & Green \\
\hline 12 & Oxalate & $\mathrm{Am}_{2}\left(\mathrm{C}_{2} \mathrm{O}_{4}\right)_{3} \cdot 10 \mathrm{H}_{2} \mathrm{O}$ & Pınk \\
\hline 13 & Phthalocyanine & $\operatorname{Am}\left(\mathrm{C}_{32} \mathrm{H}_{16} \mathrm{~N}_{2}\right)_{2}$ & Dark violet \\
\hline 14 & Pyridine-2-carboxylic acid & $\mathrm{AmO}_{2}\left(\mathrm{C}_{5} \mathrm{H}_{4} \mathrm{NCOO}\right)_{2}$ & Red brown \\
\hline 15 & Pyridine 2-carboxylic acid & $\mathrm{HAmO}_{2}\left(\mathrm{C}_{5} \mathrm{H}_{4} \mathrm{NCOO}_{3}\right.$ & Red brown \\
\hline 16 & Pyridine $N$ oxide carboxylic acid & $\mathrm{AmO}_{2}\left[\mathrm{C}_{5} \mathrm{H}_{4} \mathrm{~N}(\mathrm{O}) \mathrm{COO}\right]_{2}$ & \\
\hline 17 & Thenoyltrifluorodcetone & $\mathrm{Am}\left(\mathrm{C}_{8} \mathrm{H}_{4} \mathrm{~F}_{3} \mathrm{O}_{2} \mathrm{~S}\right)_{3} \cdot 3 \mathrm{H}_{2} \mathrm{O}$ & Pale rose \\
\hline
\end{tabular}

$* \mathrm{THF}=$ tetrahyd rofuran

ensuing discussion, aside from $\mathrm{Am}_{2}\left(\mathrm{C}_{2} \mathrm{O}_{4}\right)_{3}$ which is well characterized, very little is known about elther the preparation or properties of compounds of americium with organic ligands This situation will surely change in the future as ${ }^{243} \mathrm{Am}$ becomes more avalable and as interest in the bonding parameters of americium in compounds with cyclopentadiene and similar ligands continues to buld

Acetate. Sodium $\mathrm{Am}(\mathrm{VI})$ acetate $\left[\mathrm{NaAmO}_{2}\left(\mathrm{OOCCH}_{3}\right)_{3}\right]$ precipitates when sodium acetate is added to an acid solution of Am(VI) (Refs 177-179) The lattice constant of the lemon-yellow cubic crystals (space group $=P 2_{1} / 3$ ) is $10653 \pm 0002 \AA$, and their refractive index is $1528 \pm 0002$ (Ref 178) From infrared measurements, Jones ${ }^{180}$ has determined the force constant of the americium-oxygen bond in $\mathrm{NaAmO}_{2}\left(\mathrm{OOCCH}_{3}\right)_{3}$ to be 612 megadynes $\AA^{-1}$

Acetylacetone Dropwise addition of ammonia to an aqueous $\mathrm{Am}^{3+}$ solution containing a small excess of acetylacetone precipitates at pH 6 to 63 pale-rose $\operatorname{Am}\left(\mathrm{C}_{5} \mathrm{H}_{7} \mathrm{O}_{2}\right)_{3} \cdot \mathrm{H}_{2} \mathrm{O}(\operatorname{Ref} 181 \mathrm{a})$ The crystallıne precipitate obtained after stirring for $24 \mathrm{hr}$ is recrystallized from ethanol and dried in air over silica gel or $\mathrm{P}_{2} \mathrm{O}_{5}$ It decomposes to $\mathrm{AmO}_{2}$ when heated in air at 200 to $400^{\circ} \mathrm{C}$ 
Benzoyltrifluoroacetone. To prepare $\mathrm{Am}\left(\mathrm{C}_{10} \mathrm{H}_{6} \mathrm{~F}_{3} \mathrm{O}_{2}\right)_{3} \cdot 3 \mathrm{H}_{2} \mathrm{O}$, an aqueous Am(III) solution adjusted to $\mathrm{pH} 45$ is added dropwise, with warming, to slightly less than the storchiometric amount of $\mathrm{NH}_{4} \mathrm{C}_{10} \mathrm{H}_{6} \mathrm{~F}_{3} \mathrm{O}_{2}$ (Ref 181a) The pale-rose precipitate is recrystallized from ethanol and dried in air When heated in air at 200 to $400^{\circ} \mathrm{C}, \mathrm{Am}\left(\mathrm{C}_{10} \mathrm{H}_{6} \mathrm{~F}_{3} \mathrm{O}_{2}\right)_{3} \cdot 3 \mathrm{H}_{2} \mathrm{O}$ decomposes directly to $\mathrm{AmO}_{2}$

Cyclooctatetraene. Karraker ${ }^{181 \mathrm{~b}}$ has recently announced preparation of potassium bis(cyclooctatetraenyl)Am(III) by the reaction of $\mathrm{K}_{2} \mathrm{C}_{8} \mathrm{H}_{8}$ in tetrahydrofuran (THF) solution with ${ }^{241} \mathrm{AmI}_{3}$ Metal analysis of the solid is consistent with the formula $\mathrm{KAm}(\mathrm{COT})_{2} \cdot 2 \mathrm{THF}$, whereas X-ray powder-diffraction patterns show it to be 1 sostructural with $\mathrm{KPu}(\mathrm{COT})_{2} \cdot 2 \mathrm{THF}$ The compound $\mathrm{KAm}(\mathrm{COT})_{2} \cdot 2 \mathrm{THF}$ decomposes in water and burns when exposed to alr The absorption spectrum of $\mathrm{KAm}(\mathrm{COT})_{2} \cdot 2 \mathrm{THF}$ in THF solution shows the characteristic spectrum of $\mathrm{Am}^{3+}$

Cyclopentadiene. Tr(cyclopentadienide)Am(III), $\operatorname{Am}\left(\mathrm{C}_{5} \mathrm{H}_{5}\right)_{3}$, is prepared by reacting elther $\mathrm{AmCl}_{3}$ (Refs 182,183a, and 183b) or $\mathrm{AmF}_{3}$ (Ref 183c) with molten $\mathrm{Be}\left(\mathrm{C}_{5} \mathrm{H}_{5}\right)_{2}$ according to Eqs 424 and 425

$$
\begin{gathered}
2 \mathrm{AmCl}_{3}+3 \mathrm{Be}\left(\mathrm{C}_{5} \mathrm{H}_{5}\right)_{2} \stackrel{65^{\circ} \mathrm{C}}{\longrightarrow} 2 \mathrm{Am}\left(\mathrm{C}_{5} \mathrm{H}_{5}\right)_{3}+3 \mathrm{BeCl}_{2} \\
2 \mathrm{AmF}_{3}+3 \mathrm{Be}\left(\mathrm{C}_{5} \mathrm{H}_{5}\right)_{2} \stackrel{70^{\circ} \mathrm{C}}{\longrightarrow} 2 \mathrm{Am}\left(\mathrm{C}_{5} \mathrm{H}_{5}\right)_{3}+3 \mathrm{BeF}_{2}
\end{gathered}
$$

Baumgartner et al ${ }^{182}$ state that pure $\mathrm{Am}\left(\mathrm{C}_{5} \mathrm{H}_{5}\right)_{3}$ can be obtained by fractional sublimation at $10^{5}$ torr and 160 to $205^{\circ} \mathrm{C}$ The flesh-colored compound does not melt below $330^{\circ} \mathrm{C}$ when heated in argon but darkens at higher temperatures. Unlike $\mathrm{Pu}\left(\mathrm{C}_{5} \mathrm{H}_{5}\right)_{3}, \mathrm{Am}\left(\mathrm{C}_{5} \mathrm{H}_{5}\right)_{3}$ is not pyrophoric, it decomposes only slowly in air ${ }^{182}$ In water or dilute acids, the compound decomposes, with evolution of gas and deposition of white flocks, to give a rose-colored Am(III) solution

The infrared spectrum of $\mathrm{Am}\left(\mathrm{C}_{5} \mathrm{H}_{5}\right)_{3}$ shows characteristic absorption bands at $768 / 795 \mathrm{~cm}^{-1}, 841 \mathrm{~cm}^{-1}, 1007 \mathrm{~cm}^{-1}, 1448 \mathrm{~cm}^{-1}$, and $3078 \mathrm{~cm}^{-1}$ (Ref 184) The room-temperature absorption spectrum of $\mathrm{Am}\left(\mathrm{C}_{5} \mathrm{H}_{5}\right)_{3}$ between $4455 \mathrm{~cm}^{-1}$ and $40,000 \mathrm{~cm}^{-1}$ has been measured ${ }^{185}$ On the basis of the published absorption spectrum, Nugent et al ${ }^{186}$ estımate that the organometallic bonding in $\mathrm{Am}\left(\mathrm{C}_{5} \mathrm{H}_{5}\right)_{3}$ is highly ionic with a covalency only about $28 \pm 02 \%$ relative to the corresponding bands of $\mathrm{Am}_{\mathrm{dq}}^{3+}$ For this reason they state that $\mathrm{Am}\left(\mathrm{C}_{5} \mathrm{H}_{5}\right)_{3}$ should be designated as a tricyclopentadienide rather than as a tricyclopentadienyl

The magnetic moment of $\mathrm{Am}\left(\mathrm{C}_{5} \mathrm{H}_{5}\right)_{3}$ is reported ${ }^{187}$ to be 174 Bohr magnetons

Dipivaloylmethane. Danford et al ${ }^{188}$ at Oak Ridge Natıonal Laboratory precipltate $\mathrm{Am}\left(\mathrm{C}_{1}, \mathrm{H}_{1}, \mathrm{O}_{2}\right)_{3}$ by adding aqueous $\mathrm{Am}$ (III) sulfate to a solution of dipivaloylmethane (dpm) (2,2,6,6-tetramethyl-3,5-heptanedione) and $\mathrm{NaOH}$ in $70 \%$ aqueous ethanol Following the precipitation step, two-thirds of the mother liquor is removed by vacuum evaporation The precipitate is extracted with ethanol, one-quarter volume 
of water is added to the alcohol extracts, and the ethanol is evaporated in a stream of nitrogen to reprecipitate the complex The precipitate, after drying in vacuo at room temperature, is purified by sublimation at 124 to $135^{\circ} \mathrm{C}$ at $10^{5}$ torr for $15 \mathrm{hr}$ It melts at 215 to $218^{\circ} \mathrm{C}$ after softening at $205^{\circ} \mathrm{C}$ (Ref $183 \mathrm{c}$ ) Monoclinic unit-cell dimensions are ${ }^{183 \mathrm{C}} \mathrm{a}=122(2) \AA, b=283(3) \AA, c=224(3) \AA, \beta=1064(9)^{\circ}$

Sakanoue and Amano ${ }^{189}$ have recently determıned the volatility of $\mathrm{Am}\left(\mathrm{C}_{1}{ }_{1} \mathrm{H}_{1} \mathrm{O}_{2}\right)_{3} \quad\left[\mathrm{Am}(\mathrm{dpm})_{3}\right]$ and various lanthanide dipivaloylmethanato complexes at $180^{\circ} \mathrm{C}$ and $10^{-3}$ torr Their results yield the following order for the volatilities

$$
\mathrm{La}(\mathrm{dpm})_{3}<\underset{\mathrm{Am}(\mathrm{dpm})_{3}}{\operatorname{Pr}(\mathrm{dpm})_{3}}<\underset{\mathrm{Gd}(\mathrm{dpm})_{3}}{\operatorname{Eu}(\mathrm{dpm})_{3}}<\mathrm{Sc}(\mathrm{dpm})_{3}
$$

Sakanoue and Amano ${ }^{189}$ also determined that $\mathrm{Am}(\mathrm{dpm})_{3}$ was less volatile than $\mathrm{Th}(\mathrm{dpm})_{3}, \mathrm{Pu}(\mathrm{dpm})_{3}$, or $\mathrm{Cf}(\mathrm{dpm})_{3}$

Formate Hydrated $\mathrm{Am}(\mathrm{III})$ formate $\left[\mathrm{Am}(\mathrm{HCOO})_{3} \cdot 02 \mathrm{H}_{2} \mathrm{O}\right.$ ] crystals form when $\mathrm{Am}(\mathrm{OH})_{3}$ is dissolved in concentrated formic acid at $50^{\circ} \mathrm{C}$ and the excess acid is evaporated ${ }^{58}$ The lattice constants of the hexagonal pink crystals are a $=1055 \AA$ and $\mathrm{c}=407 \AA$

Weigel and ter Meer $^{60}$ report that thermal decomposition of $\mathrm{Am}(\mathrm{HCOO})_{3}$ proceeds according to the following reaction sequence

$$
\begin{gathered}
\mathrm{Am}(\mathrm{HCOO})_{3} \stackrel{300-350^{\circ} \mathrm{C}}{\longrightarrow} \mathrm{AmO}(\mathrm{HCOO})+\mathrm{H}_{2}+\mathrm{CO}+\mathrm{CO}_{2} \\
2 \mathrm{AmO}(\mathrm{HCOO}) \stackrel{400-500^{\circ} \mathrm{C}}{\longrightarrow} \mathrm{Am}_{2} \mathrm{O}_{3} \mathrm{CO}_{3}+\mathrm{H}_{2}+\mathrm{CO} \\
\mathrm{Am}_{2} \mathrm{O}_{2} \mathrm{CO}_{3} \stackrel{520^{\circ} \mathrm{C}}{\longrightarrow} \mathrm{Am}_{2} \mathrm{O}_{3}+\mathrm{CO}_{2}
\end{gathered}
$$

Hexafluoroacetylacetone. Yellow $\mathrm{CsAm}\left(\mathrm{C}_{5} \mathrm{HF}_{6} \mathrm{O}_{2}\right)_{4} \cdot \mathrm{H}_{2} \mathrm{O}$ precipitates when an excess of $\mathrm{CsC}_{5} \mathrm{HF}_{6} \mathrm{O}_{2}$ in 50 vol \% ethanol is added to an $\mathrm{AmCl}_{3}$ solution and the solution is evaporated to half its volume ${ }^{\mathbf{1 8 8 , 1 9 0}}$ A product melting at 189 to $191^{\circ} \mathrm{C}$ results when the yellow crystals are washed with water and dried in air The melting point increases to 193 to $194^{\circ} \mathrm{C}$ after vacuum sublimation at 130 to $140^{\circ} \mathrm{C}$ at $10^{6}$ torr (Ref 188) According to Ref 191, "It is not clear whether this increase in melting point is due to dehydration, for the pale-rose, anhydrous compound is obtained when the monohydrate is recrystallized from 1 butanol "

Hydroxyquinoline 8 Hydroxyquinoline Keller, Eberle, and Mosdzelewski ${ }^{192}$ report that yellow-green $\mathrm{Am}\left(\mathrm{C}_{9} \mathrm{H}_{6} \mathrm{NO}\right)_{3}$ precipitates when an $\mathrm{Am}(\mathrm{III})$ solution is added dropwise to a pH 55 to 65 solution of 8-hydroxyquinoline in $01 M$ ammonium acetate At $25^{\circ} \mathrm{C}, \mathrm{Am}\left(\mathrm{C}_{9} \mathrm{H}_{6} \mathrm{NO}\right)_{3}$ is soluble in ether, acetone, methanol, dioxane, and chloroform to the extent of only $25 \times 10^{5}$ to $7 \times 10^{5}$ mols liter $^{-1}$ 
5-Chloro-8-Hydroxyquinoline. Dark-green $\mathrm{Am}\left(\mathrm{C}_{9} \mathrm{H}_{5} \mathrm{ClNO}\right)_{3}$ precipitates on addition of an $\mathrm{Am}$ (III) solution to a $\mathrm{pH} 5.1$ to $5.9,30$ vol.\% dioxane solution of 5-chloro-8-hydroxyquinoline in $0.1 M$ ammonium ace tate. ${ }^{192}$

5,7-Dichloro-8-Hydroxyquinoline. Addition of an Am(III) solution to a 65 vol.\% dioxane solution of 5,7-dichloro-8-hydroxyquinoline in $0.1 M$ ammonium acetate at $\mathrm{pH} 5.7$ to 6.0 precipitates green $\mathrm{Am}\left(\mathrm{C}_{9} \mathrm{H}_{4} \mathrm{Cl}_{2} \mathrm{NO}\right)_{3}$ (Ref. 192). This compound and also $\mathrm{Am}\left(\mathrm{C}_{9} \mathrm{H}_{5} \mathrm{ClNO}\right)_{3}$ are about 1000 -fold more soluble in ether, acetone, methanol, dioxane, and chloroform than is $\mathrm{Am}\left(\mathrm{C}_{9} \mathrm{H}_{6} \mathrm{NO}\right)_{3}$. The absorption spectrum of $\mathrm{Am}\left(\mathrm{C}_{9} \mathrm{H}_{6} \mathrm{Cl}_{2} \mathrm{NO}\right)_{3}$ in $\mathrm{CHCl}_{3}$ exhibits a band at $3900 \AA$ characteristic of tris chelates.

Oxalate. Pink, monoclinic $\mathrm{Am}_{2}\left(\mathrm{C}_{2} \mathrm{O}_{4}\right)_{3} \cdot 10 \mathrm{H}_{2} \mathrm{O}$ precipitates from a slightly acidic or neutral solution of $\mathrm{Am}^{3+}$ on addition of oxalic acid or suitable alkali oxalate solution (Refs. 100,141, 150, 193, and 194). Lattice constants of the crystalline hydrate are $\mathrm{a}=11.19 \AA, \mathrm{b}=9.63 \AA$, and $\mathrm{c}=10.24 \AA$ with $\beta=114.4^{\circ}$. The space group $^{58}$ is $P 2 / b$. The solubility product ${ }^{195}$ of $\mathrm{Am}(\mathrm{III})$ oxalate in $0.2 M$ to $0.3 \mathrm{M}$ $\mathrm{HClO}_{4}$ is $2.2 \times 10^{-3 \mathrm{i}}$. Attempts to measure the solubility product in water were unsuccessful. The solubility of Am(III) oxalate in nitric acid-oxalic acid solutions has been measured by Burney and Porter. ${ }^{196}$

From their recent $\mathrm{X}$-ray diffraction studies, Weigel and ter $\mathrm{Meer}^{58}$ conclude that the value of $x$ in $\mathrm{Am}_{2}\left(\mathrm{C}_{2} \mathrm{O}_{4}\right)_{3} \cdot x \mathrm{H}_{2} \mathrm{O}$ is 10 . [Previously the number of water molecules in hydrated Am(III) oxalate was thought to vary with the conditions of precipitation and drying; values of $x=7$ (Ref. 197), 9 (Ref. 100), and 11 (Ref. 193) were reported.] Weigel and ter $\mathrm{Meer}^{58}$ note that $\mathrm{Nd}^{3+}$ and $\mathrm{Am}^{3+}$ have nearly the same ionic radius. Ollendorff ${ }^{198}$ has shown that $\mathrm{Nd}(\mathrm{III})$ oxalate is $\mathrm{Nd}_{2}\left(\mathrm{C}_{2} \mathrm{O}_{4}\right)_{3} \cdot 10 \mathrm{H}_{2} \mathrm{O}$. Plutonium(III) and $\mathrm{Cm}(\mathrm{III})$ are also decahydrates. ${ }^{199}$

Weigel and ter Meer ${ }^{60}$ studied the thermal decomposition of $\mathrm{Am}_{2}\left(\mathrm{C}_{2} \mathrm{O}_{4}\right) \cdot 10 \mathrm{H}_{2} \mathrm{O}$ in air using mass spectrometric identification of gaseous decomposition products and $\mathrm{X}$-ray identification of solid residues. Their results, listed in Table 4.5, extend and modify those reported earlier by Markin ${ }^{197}$ for decomposition of the "heptahydrate." Radiolytic decomposition of ${ }^{241}$ Am(III) oxalate to yield first anhydrous Am(III) carbonate (15 to 20 days) and then its pentahydrate (50 to 60 days) is a first-order reaction with a rate constant of $0.22 \mathrm{~d}^{-1}$ (Ref. 200).

Phthalocyanine. Weighable amounts of $\operatorname{Am}\left(\mathrm{C}_{32} \mathrm{H}_{16} \mathrm{~N}_{8}\right)_{2}$ have been prepared by reaction of $\mathrm{AmI}_{3}$ at $200^{\circ} \mathrm{C}$ with phthalodinitride in 1-chloronapthene. ${ }^{201}$ According to $\mathrm{Lux},{ }^{202} \mathrm{Am}\left(\mathrm{C}_{32} \mathrm{H}_{16} \mathrm{~N}_{8}\right)_{2}$ is the first $\mathrm{Am}$ (IV) compound with organic ligands to be prepared. Dark-violet $\mathrm{Am}\left(\mathrm{C}_{32} \mathrm{H}_{16} \mathrm{~N}_{8}\right)_{2}$ sublimes without decomposition at $550^{\circ} \mathrm{C}$ at $10^{-5}$ torr and is stable in air. ${ }^{202}$ Spectroscopic evidence also indicates ${ }^{202}$ that americium also forms a mono(phthalocyaninato) compound which sublimes at 450 to $500^{\circ} \mathrm{C}$ at $10^{-5}$ torr.

Pyridine Carboxylates. Pyridine-2-Carboxylates. Addition of pyridine-2-carboxylic acid $\left(\mathrm{C}_{6} \mathrm{H}_{5} \mathrm{NCOOH}\right)$ to a solution of $\mathrm{AmO}_{2}^{2+}$ precipitates either americyl(VI) 
Table 4.5

THFRMAL DECOMPOSITION OF

$\mathrm{Am}_{2}\left(\mathrm{C}_{2} \mathrm{O}_{4}\right)_{3} \cdot 10 \mathrm{H}_{2} \mathrm{O}$

\begin{tabular}{|c|c|c|}
\hline Initial phase & $\begin{array}{c}\text { Temperature } \\
\text { interval }\end{array}$ & Final phase \\
\hline $\begin{array}{l}\mathrm{Am}_{2}\left(\mathrm{C}_{2} \mathrm{O}_{4}\right)_{3} \cdot 10 \mathrm{H}_{2} \mathrm{O} \\
\mathrm{Am}_{2}\left(\mathrm{C}_{2} \mathrm{O}_{4}\right)_{3} \cdot 6 \mathrm{H}_{2} \mathrm{O}\end{array}$ & $\begin{array}{c}2550^{\circ} \mathrm{C} \\
50340^{\circ} \mathrm{C} \\
\text { (over } 4 \\
\text { hydrate } \\
\text { forms) }\end{array}$ & $\begin{array}{l}\mathrm{Am}_{2}\left(\mathrm{C}_{2} \mathrm{O}_{4}\right)_{3} \cdot 6 \mathrm{H}_{2} \mathrm{O} \\
\mathrm{Am}_{2}\left(\mathrm{C}_{2} \mathrm{O}_{4}\right)_{3}\end{array}$ \\
\hline $\begin{array}{l}\mathrm{Am}_{2}\left(\mathrm{C}_{2} \mathrm{O}_{4}\right)_{3} \\
\mathrm{Am}_{2}\left(\mathrm{CO}_{3}\right)_{3} \\
\mathrm{Am}_{2} \mathrm{O}\left(\mathrm{CO}_{3}\right)_{2} \\
\mathrm{Am}_{2} \mathrm{O}_{2} \mathrm{CO}_{3}\end{array}$ & $\begin{array}{l}390-430^{\circ} \mathrm{C} \\
430 \quad 470^{\circ} \mathrm{C} \\
470-520^{\circ} \mathrm{C} \\
520 \quad 610^{\circ} \mathrm{C}\end{array}$ & $\begin{array}{l}\mathrm{Am}_{2}\left(\mathrm{CO}_{3}\right)_{3} \\
\mathrm{Am}_{2} \mathrm{O}\left(\mathrm{CO}_{3}\right)_{2} \\
\mathrm{Am}_{2} \mathrm{O}_{2} \mathrm{CO}_{3} \\
\mathrm{Am}_{2} \mathrm{O}_{3}\end{array}$ \\
\hline
\end{tabular}

pyridine-2-carboxylate $\left[\mathrm{AmO}_{2}\left(\mathrm{C}_{6} \mathrm{H}_{5} \mathrm{NCOO}\right)_{2}\right]$ or a complex acid of the composition $\mathrm{H}\left[\mathrm{AmO}_{2}\left(\mathrm{C}_{6} \mathrm{H}_{5} \mathrm{NCOO}\right)_{3}\right]$ (Refs 203, 204) The particular compound precipitated depends, as discussed in Ref 203, upon solution $\mathrm{pH}$ and the concentration of the pyridine carboxylic acid Both compounds are crystalline red-brown powders soluble in pyridine The $\mathrm{H}\left[\mathrm{AmO}_{2}\left(\mathrm{C}_{6} \mathrm{H}_{5} \mathrm{NCOO}\right)_{3}\right]$ compound decomposes to $\mathrm{AmO}_{2}$ at about $340^{\circ} \mathrm{C}$

Pyndine-N-Oxıde-2-Carboxylate Amencyl(VI) pyndine- $N$-oxide-2-carboxylate, $\mathrm{AmO}_{2}\left[\mathrm{C}_{6} \mathrm{H}_{5} \mathrm{~N}(\mathrm{O}) \mathrm{COO}\right]_{2}$, precipitates when pyridine- $N$-oxide-2-carboxylic acid is added to an aqueous $\mathrm{AmO}_{2}^{2+}$ solution ${ }^{204}$ The precipitate is soluble in pyridine and dımethyl sulfoxıde and, when heated, dehydrates at $100^{\circ} \mathrm{C}$ and decomposes at temperatures above $200^{\circ} \mathrm{C}$

Thenoyltrifluoroacetone Preparation of Am(III) thenoyltrifluoroacetone $\left[\mathrm{Am}\left(\mathrm{C}_{8} \mathrm{H}_{4} \mathrm{~F}_{3} \mathrm{O}_{2} \mathrm{~S}\right)_{3} \cdot 3 \mathrm{H}_{2} \mathrm{O}\right]$ is accomplished in exactly the same way (see pages $\mathrm{xxx}$ to $\mathrm{xxx}$ ) as the benzoyltrifluoroacetone complex ${ }^{181}$ The pale-rose precipitate decomposes directly to $\mathrm{AmO}_{2}$ when heated in air at 200 to $400^{\circ} \mathrm{C}$

\section{REFERENCES}

1 E F Westrum, Jr, and L Fyring, The Preparatıon and Some Properties of Americium Metal, $J$ Amer Chem Soc 733396 (1951), USAEC Report UCRL 1055, University of California Radiation Laboratory, March 1951

2 P Graf, B B Cunningham, C H Dauben, J C Wallmann, D H Templeton, and H Ruben, Crystal Structure and Magnetic Susceptibility of Americium Metal, J Amer Chem Soc 78 2340 (1956)

3 D B McWhan, J C Wallmann, B B Cunningham, L B Asprey, I H Lllinger, and W H Zachariasen, Preparation and Crystal Structure of Americium Metal, J Inorg Nucl Chem 15185 (1960) 
4 D. B McWhan, B. B. Cunningham, and J. C. Wallmann, Crystal Structure, Thermal Expansion, and Melting Point of Americium Metal, J Inorg Nucl. Chem., 24: 1025 (1962)

5 W. Z. Wade and T. Wolf, Preparation and Some Properties of A mericium Metal, $J$ Inorg Nucl Chem., 29: 2577 (1967).

6. K. W. R. Johnson and J. A. Leary, Preparation of Americium Metal, USAEC Report LA-2992, Los Alamos Șcientific Labordtory, Oc tober 1963

$7 \mathrm{~W}$. V Conner, Bomb Reduction of Americium Tetrafluoride to Metal, USAEC Report RFP-1188, Dow Chemical Co, November 1968

8. W. Muller, J. Reul, and J. C. Spirlet, Herstellung von Reinem Americium und Curium durch Zersetzen Intermetallischen Verbindungen, Atomwirtschaft, 17: 415 (1972)

9 d. J. C Spirlet and W Muller, Gram-Scale Preparation of Americium, Angew Chem, 83: 932 (1971) through Angew Chem Int Ed Engl, 10:857 (1971)

b J. C. Spirlet and $W$ Muller, The Preparation and Purification of Americium Metal by Fvaporation, J Less-Common Metals, 31: 35 (1973).

10. U Berndt, B. Erdmann, and C Keller, Preparation of Non-Noble Metals (L1, Ca, Sr, Ba, Am, C) by Reduction of Their Oxides and I luorides with Hydrogen, Angew Chem. Int Ed. Engl., 11: $515(1972)$

11. a. J. Fuger, J. C. Spırlet, and W. Muller, A New Determination of the Heat of Solution of Americium Metal and the Hedt of Formation of Various Americium Ions and Compounds, Inorg. Nucl. Chem. Lett., 8: 709 (1972).

b. J. W Ward, W. Muller, and G F Kramer, The Vapor Pressure of High-Purity Solid Americium, in Transplutonium Elements, Proceedings of the 4th International Symposlum, Baden-Baden, Sept. 13-17, 1975, W. Muller and R. Lindner (Eds), North-Holland Publishing Company, Amsterdam, 1976.

12. D. R. Stephens, H. D. Stromberg, and E. M. Lilley, Phase Dragram, Compressibility and Resistance of Americium ds a Function of Pressure, $J$ Phys Chem. Sollds, 29: 815 (1968)

13 S. C Carnigla and B. B. Cunnıngham, The Vapor Pressure of Americium Metal, J. Amer Chem Soc., 77: 1502 (1955)

14. N D. Erway and O. C. Simpson, The Vapor Pressure of Amencium, $J$ Chem. Phys., 18: 953 (1950).

15. a. B. Kanellakopulos, J. P. Charvillat, F. Maıno, and W. Muller, The Magnetic Susceptibility of A mericium and Curium Metals and Pnictides, in Transplutontum Elements, Proceedings of the 4 th International Symposium, Baden-Baden, Sept. 13-17, 1975, W. Muller and R. Lindner (Eds.), North-Holland Publishing Company, Amsterdam, 1976

b. W. J. Nellis and M. B. Brodsky, Magnetic Properties, in The Actmides Electronic Structure and Related Properties, A J Freeman and J B Darby, Jr. (Eds.), Vol. II, Academic Press, Inc., New York, 1974.

16. a. C Sarı, W. Muller, and U Benedict, Phase Transition of Americium Metal, J. Nucl Mater, 45: 73 (1972/1973).

b. M. B Brodsky, A. J. Arko, A. R. Harvey, and W. J. Nellis, Transport Properties, in The Actinides Electronic Structure and Related Properties, A. J. Freeman and J B. Darby, Jr. (Eds.), Vol. II, Academic Press, Inc., New York, 1974.

c. R. Schenkel, H. E. Schmidt, and J. C. Spirlet, The Electrical Resistivity of ${ }^{241}$ Americium Metal, in Transplutonium Elements, Proceedings of the 4 th International Symposium, Baden-Baden, Sept. 13-17, 1975, W. Muller and R. Lindner (Eds.), North-Holland Publishing Company, Amsterdam, 1976.

d. J. W. Ward and H. H Hill, An Entropy Correlation for the $4 \mathrm{f}$ and $5 f$ Metals Correlation of Electronic Properties to Metallic Rad11, Magnetic Transformations and Thermodynamics of Vaporization, in Transplutonium Elements, Proceedings of the 4 th International Symposlum, Baden-Baden, Sept. 13-17, 1975, W. Muller and R. Lindner (Eds.), North-Holland Publıshing Company, Amsterdam, 1976.

e. R. O. A. Hall, M. J. Mortımer, D. L. McElroy, W. Muller, and J. C. Spırlet, The Specifıc Heat of Americium-241 Metal from 15 to $300^{\circ} \mathrm{K}$, in Transplutonum Elements, Proceedings 
of the 4 th International Symposium, Baden-Baden, Sept. 13-17, 1975, W. Muller and R Lindner (Eds.), North-Holland Publishing Company, Amsterdam, 1976.

f. R. D. Baybarz et al., Preparation and Structure Studies of Less-Common Actinide Metals, in Transplutonium Elements, Proceedings of the 4 th International Symposium, Baden-Baden, Sept 13-17, 1975, W Muller and R Lindner (Eds), North-Holland Publıshıng Company, Amsterdam, 1976.

17. B. D. Dunlap, M. B. Brodsky, G M. Kalvius, G. K. Shenoy, and D. J. Lam, Hyperfine Interaction and Susceptibulity in Some Actınide Metals and Intermetallic Compounds, $J$ Appl. Phys., 40: 1495 (1969).

18. J. C. Warf and W. L. Korst, Solutions of Europium and Ytterbium Metals in Liquid Ammonia, $J$ Phys Chem, 60: 1950 (1956).

19. S. R. Gunn and R. J Morrow, Insolublity of Amencium in Liquid Ammonia, Inorg Nucl Chem. Lett., 4: 137 (1968).

20. W H. Zachariasen, The Metal Plutonum, A S. Coffinberry and W N Mıner (Eds), p 99, University Chicago Press, Chicago, 1961.

21. a. B. T. Matthias, W. H. Zachariasen, G. W. Webb, and J. J. Engelhardt, Meltıng-Point Anomalies, Phys. Rev. Lett, 18: 781 (1967).

b. W. H. Zachariasen, Metallıc Radı1 and Electron Configurations of the $5 \mathrm{f} 6 \mathrm{~d}$ Metals, $J$ Inorg. Nucl. Chem., 35: 3487 (1973).

22. a. H. H. Hill, Superconductivity in the 'Actinide' Elements, Physica, 55: 186 (1971)

b. H. H Hill, The Early 'Actınides'. The Periodic System's $f$ Electron Transition Metal Series, in Plutontum 1970 and Other Actinides, Proceedings of the 4th International Conference on Plutonium and Other Actinides, Santa Fe, N Mex, Oct 5-8, 1970, W H Miner (Ed), Nuclear Metallurgy, Vol 17, USAEC Report CONF-701001 (Pts I and II), 1970

c. R Jullen, E Galleanı D'Agliano, and B Coqblin, Hybridized Nondegenerate $6 \mathrm{~d}$ and $5 \mathrm{f}$ Virtual-Bound-States Model for Actinide Metals, Phys Rev., B, 6: 2139 (1972)

23.O. J. C Runnals, Method of Alloying Reactive Metals with Aluminum or Beryllum, U S Patent No 2,809,887, October 1975, Britısh Patent No. 741,441, 1956

24 a. U. Wede, Herstellung von Americium-Alumunum-Legierung, Radıchım Acta, 15: 102 (1971)

b U. Wede, Application of Americium-Aluminum Alloys for the Production of Transuranium Nuclides and Method for the Production of Americium-Aluminum Alloys, German Patent No. 2,051,923, April 1972.

25. S. H. Eberle, W. Robel, W. Jung, and I Bayat, in Projekt Actınıden Erster Halbjahresberıcht 1971, West German Report KFK-1456, July 1971

26 W. Robel and W Jung, in Projekt Actıniden 2. Halbjahresberıcht 1971, West German Report KFK-1544, January 1972

27 O J C. Runnals, Method of Making Alloys of Beryllum with Plutonium and the Like, U.S Patent No. 2,875,041, 1951, Canadian Patent No 615,734, 1961.

28. O. J C Runnals and R R Boucher, Neutron Yields from Americium-Beryllum Alloys, Nature, 176: 1019 (1955), Can J Phys., 34: 949 (1956)

$29 \mathrm{G}$ Brachet and C. Vasseur, Reduction of Americium Oxide by Beryllium for Neutron-Source Production, French Report CEA-R-3875, October 1969

30. J W. Roddy, Americium Metallides AmAs, $\mathrm{AmSb}, \mathrm{AmBl}, \mathrm{Am}_{3} \mathrm{Se}_{4}, \mathrm{AmSe}_{2}, J$ Inorg Nucl Chem, 36: 2531 (1974)

31. a G. Bouıssières and Y. Legoux, Amalgams of Actunide Elements, Bull. Soc. Chim. Fr, 386 (1965).

b. G. Bouıssières, M Hassinsky, and Y. Legoux, Formation of Actınıum Amalgam and the Question of Bivalent Actinium, Bull. Soc. Chim. Fr., 1028 (1961).

c. F. David and G. Bousssieres, Comparative Formation of Amalgams of Transuranium Elements and Rare Earths by Electrolysis, Inorg. Nucl. Chem. Lett., 4: 153 (1968) 
32. Y. Kobayashı and A. Saito, The Extraction of Thorium, Neptunium, Plutonıum, and Americium with Sodium Amalgam from Aqueous Solution, J. Inorg. Nucl. Chem., 35: 3605 (1973).

33. a. B. Erdmann, Darstellung von Actınıden/Lanthanıden-Edelmetall (Pt, Pd, Ir, Rh) Legrerungsphases durch Gekoppelte Reduktion, West German Report KFK-1444, October 1971

b. B. Erdmann and C. Keller, The Preparation of Actınide (+ Zirconıum and Hafnum)Noble Metal Alloy Phases by Coupled Reductions, Inorg. Nucl Chem. Lett, 7: 675 (1971)

c. B. Erdmann and C Keller, Actinıde (Lanthanide)-Noble Metal Alloy Phases, Preparation and Properties, J. Solld State Chem., 7: 40 (1973).

34. H. H. Hill and F. H. Ellinger, Effective Size of Americium Dissolved in Lanthanum, $J$. Less-Common Metals, 23: 92 (1971).

35. H. H. Hill, J. D. G. Lindsay, R W. White, L B. Asprey, V. O. Struebing, and B T. Matthias, 5f Electrons and Superconductivity Dilute Alloys Formed Between Lanthanum and the Actınide Metals, Physica, 55: 615 (1971).

36. a. B. D. Dunlap, M. B. Brodsky, G. M Kalvius, and G. K. Shenoy, Magnetıc Behavıor of Np Metal and Dilute Np Alloys from Mossbauer Effect Studies, in Plutonium 1970 and Other Actinides, Proceedings of the 4 th Internationd Conference on Plutonium and Other Actinides, Santa Fe, N. Mex, Oct. 5-8, 1970, W. N. Miner (Ed.), Nuclear Metallurgy, Vo1. 17, USAEC Report CONF-701001 (Pts I and II), 1970.

b. D. J. Lam and A W Mitchell, Laves Phases of Actınide Elements, J. Nucl. Mater., 44: 279 (1972).

37. F H Ellinger, K. A. Johnson, and V. O Struebing, The Plutonium-Americium System, $J$. Nucl. Mater., 20: 83 (1966); USAEC Report LA-DC-7095, Los Alamos Scientific Laboratory, 1964.

38. Quarterly Status Report on Advanced Reactor Technology (ART) for Perıod Endıng April 30, 1965, USAEC Report LA-3316, Los Alamos Scientific Laboratory, May 1965.

39. I. H. Ellınger, C. C. Land, and K. A Gschneider, Jr., Alloying Behavior of Plutonıum, in Plutonium Handbook, A Gutde to the Technology, O J. Wick (Ed.), Vol. I, p 197, Gordon and Bredch, Science Publishers, New York, 1967

40. $\mathrm{H}$ L Ada1r, Levitation-Meltıng and Americium-Reduction Techniques for Preparation of Thorium-Amencium Alloys, J. Inorg. Nucl. Chem., 32: 1173 (1970).

41. C. Keller, The Solid-State Chemistry of Americium Oxides, in Lanthanide/Actintde Chemistry, R F Gould (Ed), p. 228, Advances in Chemistry Series, American Chemical Society, Washington, 1967

42. C. Keller and K. H. Walter, Ternare Oxide des Americiums und Einger Seltener Erden vom Typ $\mathrm{A}_{\mathrm{x}}^{\mathrm{III}} \mathrm{BO}_{3}$, J Inorg. Nucl. Chem., 27: 1247 (1965).

43. A. W Mitchell and D J. Lam, Crystal Structures of Am-Sb, Am-Se, and Am-Te Alloys Near the Equiatomic Composition, J. Nucl. Mater., 37: 349 (1970).

44. a. B D. Dunlap, D. J. Lam, G M. Kalvıus, and G. K. Shenoy, Investigation of the Magnetic Behavior of Some Conducting Am Systems, J. Appl. Phys., 42: 1719 (1971).

b. J. P. Charvillat, U. Benedict, D. Damien, and W Muller, Preparation et Parametres de Maille de Quelques Pnictures d'Americium et de Curıum, Radiochem. Radioanal. Lett., 20: 371 (1975).

45. C Keller and $\mathrm{K} \mathrm{H}$. Walter, Darstellung, Gitterkonstanten and Chemische Eigenschaften Einigen Ternarer Oxide des Plutoniums, Americiums, und Cunums vom Typ $\mathrm{Me}^{\mathrm{IIl}} \mathrm{X}_{\mathrm{O}_{4}}, J$. Inorg. Nucl. Chem., 27: 1253 (1965)

46. J. P. Charvillat and D. Damien, Americium Monoarsenide, Inorg. Nucl. Chem. Lett., 9: 559 (1973).

47. H. A. Eick and R. N R. Mulford, Americium and Neptunium Borides, J. Inorg. Nucl. Chem, 31: 371 (1969). 
48 J. R Peterson, Compounds of Divalent Lanthanides and Actinides, in Proceedings of the Tenth Rare Earth Research Conference, Carefree, Ar1z., Apr 30-May 3, 1973, C J Kevane and T. Moeller (Eds.), USAEC Report CONF-730402, Pt. 1, 1973.

49. R D. Baybarz, The Preparation and Crystal Structures of Americium Dichloride and Dibromide, J. Inorg. Nucl. Chem., 35: 483 (1973).

50. S. Fried, The Preparation of Anhydrous Americium Compounds, J. Amer. Chem. Soc, 73: 416 (1951)

51. R G. Pappalardo, W T. Carnall, and P. R Fields, Low-Temperature Optical Absorption of Americium Halides, J. Chem. Phys., 51: 1182 (1969)

52 L B. Asprey, T K Keenan, and I H Kruse, Crystal Structures of the Trifluorides, Trichlondes, Tribromides, and Truodides of Americium and Curıum, Inorg Chem, 4: 985 (1965)

53 D. Brown, S Fletcher, and D G Holah, The Preparation and Crystallographic Properties of Certain Lanthanide and Actinide Tribromides and Tribromide Hexahydrates, J. Chem Soc, $A$, p 1889 (1968).

54. W. H. Zacharıasen, Crystal Chemical Studies of the $5 \mathrm{f}$ Series of Elements I. New Structure Types, Acta Crystallogr., 1: 265 (1948)

55 D Brown, D G Holah, and C E. F Rickard, Stabilization of Plutonium Tetrabromide and Uranum Pentabromide, Chem. Commun, 11: 651 (1968)

56 J L Ryan, Octahedral Hexahalide Complexes of the Trivalent Actinides, in Lanthantde/ Actinide Chemistry, R. F. Gould (Ed.), p. 331, Advances in Chemistry Series, American Chemical Society, Washington, 1967.

57. A. W Mitchell and D J. Lam, The Crystal Structure of Amencium Sesquicarbide, J. Nucl. Mater., 36: $110(1970)$.

$58 \mathrm{~F}$ Weigel and $\mathrm{N}$ ter Meer, The Unit Cells of Some Americium(III)-Salts with Organıc Anıons, Inorg. Nucl Chem. Lett., 3: 403 (1967)

59. D. Fang, Karlsruhe, Dissertation, 1967, cited in Ref 61

60. F. Weigel and N. ter Meer, Der Thermische Abbau von Amencium(III)-Oxalat, -formiat und -Carbonate, Z Naturforsch., B, 26: 504 (1971).

$61 \mathrm{C}$ Keller and D Fang, Uber Karbondtokomplexe des driewertigen Americiums sowie des Vier--und Sechswertigen Urans und Plutoniums, Radıochım Acta, 11: 123 (1969).

62. J P. Nigon, R. A. Penneman, E Staritzky, T K. Keenan, and L B Asprey, Alkalı Carbonates of $\mathrm{Np}(\mathrm{V}), \mathrm{Pu}(\mathrm{V})$, and Am(VI), J Phys. Chem., 58: 403 (1954)

63 T. K. Keenan, Lattice Constants of Some Alkalı Metal Actinyl(V) Compounds, Inorg. Chem , 4: 1500 (1965)

64. T K. Keenan and F. H Kruse, Potassium Double Carbonates of Pentavalent Neptunium, Plutonium, and Americium, Inorg. Chem., 3: 1231 (1964).

65. J. S Coleman, T. K. Keenan, L H. Jones, W. T. Carnall, and R. A. Penneman, Preparation and Properties of Americium(VI) in Aqueous Carbonate Solutions, Inorg. Chem., 2: 58 (1963).

66. G. A. Burney, Separation of Americium from Curium by Precipitation of $\mathrm{K}_{3} \mathrm{AmO}_{2}\left(\mathrm{CO}_{3}\right)_{2}$, Nucl. Appl., 4: 217 (1968).

67 G. N. Yakovlev and D S. Gorbenko-Germanov, Coprecipitation of Americium(V) with Double Carbonates of Uranium(VI) or Plutonium(VI) with Potassium, in Proceedings of the International Conference on the Peaceful Uses of Atomic Energy, Geneva, 1955, Vol 7, p. 306, United Nations, New York, 1956.

68. F. H. Ellinger and W. H. Zachariasen, The Crystal Structure of $\mathrm{KPuO}_{2} \mathrm{CO}_{3}, \mathrm{NH}_{4} \mathrm{PuO}_{2} \mathrm{CO}_{3}$, and $\mathrm{RbAmO}_{2} \mathrm{CO}_{3}$, J. Phys. Chem., 58: 405 (1954)

69. L B Werner and I Perlman, The Pentavalent State of Americium, J Amer Chem Soc, 73: 495 (1951)

70. G. R. Hall and T. L Markın, The Alphd Half-Life of Amencium-241, J. Inorg. Nucl. Chem , 4: 137 (1957). 
71. A. Broldo and B. B. Cunnıngham, Heat and Free Energy of the Reaction $\mathrm{AmCl}_{3}(\mathrm{c})+$ $\mathrm{H}_{2} \mathrm{O}_{(\mathrm{g})}=\mathrm{AmOCl}_{(\mathrm{c})}+2 \mathrm{HCl}_{(\mathrm{g})}$, USAEC Report AECD-2918, University of California, Radiation Laboratory, July 1950.

72. J. H. Burns and J. R Peterson, Refinement of the Crystal Structure of $\mathrm{AmCl}_{3}$, Acta Crystallogr., B, 26: 1885 (1970).

73. J. Fuger and B. B. Cunningham, Heats of Formation of $\mathrm{Pu}_{(\mathrm{aq})}^{3+}, \mathrm{PuCl}_{3}(\mathrm{c}), \mathrm{PuOCl}_{(\mathrm{c})}, \mathrm{Am}_{(\mathrm{aq})}^{3+}$, $\mathrm{AmCl}_{3}(\mathrm{c})$, and $\mathrm{AmOCl}_{(\mathrm{aq})}, J$ Inorg Nucl. Chem., 25: 1423 (1963).

74. H. R. Lohr and B. B. Cunningham, The Heat of Reaction of Americium Metal with $1.5 M$ Hydrochloric Acid and a Note on the Heats of Formation of $\mathrm{La}_{(\mathrm{aq})}^{+3}$ and $\mathrm{Pr}_{(\mathrm{aq})}^{+3}, J . A$ mer. Chem. Soc., 73: 2025 (1951); USAEC Report AECD-2902, University of California Radiation Laboratory, July 1950.

75. J. Fuger, Thermal Expansion Coefficients of the Anhydrous Trichlorides of Cerium, Plutonum, and Americium, J Inorg. Nucl. Chem., 28: 3055 (1966).

76. J. B. Gruber and F. G. Conway, The Absorption Spectrum and Zeeman Effect of $\mathrm{Am}^{3+}$ in $\mathrm{LaCl}_{3}, J$ Chem. Phys., 36: 191 (1962)

$77 \mathrm{Y}$ Marcus, The Solubility of Americium(III) Chloride in Concentrated Lithium Chloride Solutions, Radlochım. Acta, 8: 212 (1967)

78. J. H. Burns and J R. Peterson, The Crystal Structures of Americium Trichlonde Hexahydrate and Berkelium Trichlonde Hexahydrate, Inorg. Chem., 10: 147 (1971).

79. B. J. Stover and J. G. Conway, The Absorption Spectrum of Hydrated Americium Chlonde, $J$. Chem. Phys., 20: 1490 (1952), USAEC Report UCRL-1778, University of California Radiation Laboratory, May 1952.

80. D. H Templeton and C. H. Dauben, Crystal Structure of Americium Compounds, $J$ Amer Chem. Soc., 75: 4560 (1953), USAEC Report UCRL-2101, University of California Radiation Laboratory, February 1953.

81. a. C. W. Koch and B. B. Cunningham, The Vapor Phase Hydrolysis of the Actinide Halides. I. Heat and Free Energy of the Reaction $\mathrm{AmCl}_{3}(\mathrm{~s})+\mathrm{H}_{2} \mathrm{O}_{(\mathrm{g})}=\mathrm{AmOCl}_{(\mathrm{s})}+2 \mathrm{HCl}_{(\mathrm{g})}, J$ Amer. Chem. Soc., 76: 1470 (1954); USAEC Report UCRL-2006, University of California Radiation Laboratory, November 1952

b. F. Weigel, V Wishnevsky, and H. Hauske, The Vapor Phase Hydrolysis of ${ }^{241} \mathrm{AmCl}_{3}$ and ${ }^{243} \mathrm{AmCl}_{3}$, Heats of Formation of ${ }^{241} \mathrm{AmOCl}$ and ${ }^{243} \mathrm{AmOCl}$, in Transplutonium Elements, Proceedings of the 4th International Symposium, Baden-Baden, Sept. 13-17, 1975, W. Muller and R. Lindner (Eds.), North-Holland Publıshing Company, Amsterdam, 1976.

82. K. W. Bagnall, J. B. Laıdler, and M. A. A. Stewart, Americyl(V) and (VI) Chloro-Complexes, Chem. Commun., 24: (1967).

83. a. K. W. Bagnall, J. B. Laidler, and M. A. A. Stewart, Americium Chloro-Complexes, $J$ Chem Soc., $A$, p. 133 (1968).

b. M E. Hendricks, E. R. Jones, Jr., J. A. Stone, and D. G. Karraker, Magnetic Properties of Trivalent Actinides in the Octahedral Compounds $\mathrm{Cs}_{2} \mathrm{NaMCl}_{6}, J$. Chem. Phys., 60: 2095 (1974).

84. Y. Marcus and M. Shiloh, A Spectrophotometric Study of Trivalent Complexes in Solution. IV. Amencium with Chloride Ligands, Israel J Chem., 7: 31 (1969).

85. Y. Marcus and M. Bomse, Octahedral Chloride Complexes of Trivalent Actinides and Lanthanides in Solution. Israel J. Chem., 8: 901 (1970)

86. D. Brown, Halıdes of the Lanthan York, 1968.

87. N. Edelstein, W. Easley, and R. McLaughlın, Formation and Characterization of Divalent Americium in $\mathrm{CaF}_{2}$ Crystals, J. Chem. Phys., 44: 3130, 1966.

88. N. Edelsteın, W. Easley, and R. McLaughlin, Optical and Electron Paramagnetic Resonance Spectroscopy of Actınide Ions in Single Crystals, in Lanthantde/Actinide Chemistry, $\mathrm{R}$ F. 
Gould (Ed), p 203, Advances in Chemistry Serıes, American Chemical Society, Washington, 1967

$89 \mathrm{~N}$ Edelstein and $\mathrm{W}$ Edsley, Zero Field Splittıngs of $\mathrm{Am}^{2+}$ and $\mathrm{Cm}^{3+}$ in Cubic Symmetry Sites in $\mathrm{CaF}_{2} J$ Chem. Phys 48: 2110 (1968)

$90 \mathrm{~L}$ B Asprey, New Compounds of Quadrivalent Americium, $\mathrm{AmF}_{4}, \mathrm{KAmF}_{5}, J \mathrm{Amer}$ Chem Soc 76: 2019 (1954)

$91 \mathrm{~J} \mathrm{~L}$ Burnett, Melting Points of $\mathrm{CmF}_{3}$ and $\mathrm{AmF}_{3}, J$ Inorg Nucl Chem, 28: 2454 (1966), Trans Amer Nucl Soc, 8: 335 (1965)

$92 \mathrm{~W}$ W T Crane, J C Wallmann, and B B Cunningham, The Magnetic Susceptibilities of Some Compounds of Amencium and Curıum, USAEC Report UCRL 846, University of Californı Radidtion Laboratory, August 1950

93 L B Asprey and T K Keenan, Tetravalent Americium and Curum, The Absorption Spectra of the Tr1- and Tetrafluondes of These Elements, J Inorg Nucl Chem, 7: 27 (1958)

94 J A Stone and W L Pillinger, Mossbauer Effect with ${ }^{241}$ Am Sources, USAEC Report CONF-661208-3, Savannah River Laboratory, November 1966

95 G M Kdlvius, S L Ruby, B D Dunlap, G K Shenoy, D Cohen, and M B Brodsky, Mossbauer Isomer Shift in ${ }^{243}$ Am, Phys Lett, B 25•489 (1969)

96 M E Jones, The Vapor Pressure of Americium Trifluoride (Thesis), USAEC Report UCRL-1438, Unıversity of Calıfornıa Radıatıon Laboratory, August 1951

97 S C Carnglıa, Vapor Pressures of Americium Trifluoride and Americium Metal, USAEC Report UCRL 2389, University of California Radiation Laboratory, 1953

98 S C Carniglia and B B Cunningham, Vapor Pressures of Americium Trifluoride and Plutonium Trifluoride, Heats and Free Energies of Sublimation, J Amer Chem Soc, 77: 1451 (1955)

99 J L Ryan, Battelle Pacific Northwest Labordtories, personal communcation, 1974

$100 \mathrm{G} \mathrm{N}$ Yakovlev and V N Kosyakov, An Investıgation of the Chemistry of Americium, Proceedings of the Second International Conference on the Peaceful Uses of Atomic Energy, Geneva, 1958, Vol 28, p 373, United Nations, New York, 1958

$101 \mathrm{~W} \mathrm{~V}$ Conner, Conversion of Mult1-Gram Quantities of ${ }^{241} \mathrm{AmO}_{2}$ to ${ }^{241} \mathrm{AmF}_{4}, J$ Less Common Metals 25: 379 (1971), USAEC Report RГP-1188, Dow Chemical Co, Rocky Flats, November 1968

102 a T K Keenan and L B Asprey, Lattıce Constants of Actinide Tetrafluorıdes Including Berkelıum, Inorg Chem., 8: 235 (1969)

b L B Asprey and R G Harre, On the Actınıde Tetrafluoride Lattice Parameters, Inorg Nucl Chem. Lett 9: 1121 (1973)

103 E G Chudinov and D Ya Choporov, Sublimation of Amencium Tetrafluoride, At Energ (USSR), 28: 62 (1970) through Sov At Energy (Engl Transl) 28: 71 (1970)

104 B Weinstock and J G Malm, The Properties of Plutonium Hexafluoride, $J$ Inorg Nucl Chem., 2: 380 (1956)

105 S Tsujımura, D Cohen, C L Chernick, and B Weınstock, The Attempted Preparation of $\mathrm{AmF}_{6} \mathrm{~J}$ Inorg Nucl Chem., 25: 226 (1963)

$106 \mathrm{~T} \mathrm{~K}$ Keenan, Lattice Constants of $\mathrm{AmO}_{2} \mathrm{~F}_{2}$ Inorg Nucl Chem Lett, 4: 381 (1968)

$107 \mathrm{C}$ Keller and $\mathrm{H}$ Schmutz, Uber Doppelfluoride der dreiwertigen Lanthaniden und einiger Actuniden des typs $\mathrm{NaMeF}_{4}, Z$ Naturforsch $B$ 19: 1080 (1964)

$108 \mathrm{H}$ Schmutz, Untersuchungen in den Systemem Alkalıfluorı--Lanthanıden/Actınıdenfluorıd (Li, Na, K, Rb-La, S E, Y/Np, Pu, Am), West Germany Report KFK-431, July 1966

109 T K Keenan, Lattıce Constants of 76 Sodıum-Actınıde(IV) Fluorides, Inorg Nucl Chem Lett., 2: 211 (1966)

110 L B Asprey and R A Penneman, Preparation and Properties of Aqueous Tetravalent Amencium, Inorg Chem., 1: 134 (1962)

$111 \mathrm{~T}$ K Keenan, Lattice Constants of 11 Lithium Tetravalent Actınide Pentafluondes (1) Inorg Nucl Chem. Lett, 2: 153 (1966) 
112 R A Penneman, T K Keenan, and B Asprey, Tetra and Pentavalent Actınide Hluoride Compleses, in Lanthantde/Actintde Chemistry P F Gould (Ed), p 248, Advances in Chemistry Series, American Chemical Society, Washungton, 1967

$113 \mathrm{~T} \mathrm{~K}$ Keenan, Lattice Constants of $\mathrm{K}_{7} \mathrm{Cm}_{6} \mathrm{~F}_{31}$, Trends in the 11 and 76 Alkali Metal-Actinide(IV) Series, Inorg Nucl Chem Lett, 3391 (1967)

$114 \mathrm{~T} \mathrm{~K}$ Keenan, Lattice Constants of $\mathrm{Rb}_{2} \mathrm{MI}_{6} \mathrm{M}=$ Uranum Through Curum Inorg Nucl Chem I ett 3:463(1967)

115 1. H Kruse and L B Asprey, A Crystalline 1 luoride Comples of Tetravalent Amencium, Inorg $\mathrm{Chcm}, 1: 137$ (1962)

116 L B Asprey, 1 H Ellinger, and W H Zachariasen, Preparation, Identification, and Crystal Structure of a Pentavalent Americum Compound, $\mathrm{KAmO}_{2} \Gamma_{2}, J$ Amer Chem Soc, 76: 5235 (1954)

117 T K Keenan, Lattıce Constants of Some Alkalı Metal Actinyl(V) Compounds, Inorg Chem, 4. 1500 (1965)

$118 \mathrm{C}$ Keller, Untersuchungen uber die Germanate und Silıkate des Typs $\mathrm{ABO}_{4}$ der Vierwertigen Elemente Thorium bis Amencium, Nukleonk 5: 41 (1963)

$119 \mathrm{~J} \mathrm{~J} \mathrm{Katz}$ and G T Sedborg, The Chemistry of the Actinide Elements p 349, Methuen \& Co , Ltd , London, 1957

120 W M Olson and R N R Multord, The Americium-Hydrogen System, J Phys Chem, 70: 2934 (1966)

$121 \mathrm{~J}$ W Roddy, The Actinide Hydrides The Americum-Hydrogen System, J Inorg Nucl Chem, 35: 4141 (1973)

122 C E Messer and M K Park, Dissociation Pressures and Related Thermodynamic I unctions and Hydrogen Solution Parameters in The System $\mathrm{PrH}_{2}-\mathrm{PrH}_{3}, \mathrm{NdH}_{2}-\mathrm{NdH}_{3}$, and $\mathrm{SmH}_{2}-\mathrm{SmH}_{3}$ General Considerations for the Related Lanthanide and Actinide Hydnde Systems, J Less Common Metals, 26: 235 (1972)

$123 \mathrm{~K}$ Buyss and K P Louwrier, Peroxides of Am(III) and the Oxidation of Am(III) to Am(IV) by Hydrogen Peroxıde, J Inorg Nucl Chem 28: 2463 (1966)

124 Chemical Technology Division Annual Progress Report for Penod Ending May 31, 1968, USAEC Report ORNL-4272, Oak Ridge National Laboratory, September 1968

125 W O Miligan, M L Beasley, M H Lloyd, and R G Haire, Crystallıne Americium Hydroxide, Acta Crystallogr Sect B, 24: 978 (1968)

126 W O Milligan, Crystal Structure and Morphology of Hydrous Oxides and Hydroxides in the Lanthanide and Actınide Serıes, Final Report, June 1, 1969-May 31, 1972, USAEC Report ORO 3955-3, Odk Ridge National Laboratory, 1972

127. $\mathrm{B}$ Weaver and $\mathrm{R} R$ Shoun, Basucities of Trivalent Actunides and Lanthandes and Solubilities of Their Hydroxides, in Proceedings of the 9th Rare Earth Research Conference, Oct 10 14, 1971, Blacksburg, Vd, USAEC Report CONF-711001-(Vol 1), p 322, 1971

128 B B Cunningham, The Frrst Isolation of Americium in the Form of Pure Compounds, Microgram-Scale Observations on the Chemistry of Amencium, in The Transuranium Elements, G T Seaborg and J J Katz (Eds.), p 1363, National Nuclear Energy Series, Div IV, Vol 14B, McGraw-Hill Book Company, Inc, New York, 1949.

129 R A Penneman, J S Coleman, and T H Keenan, Alkalıne Oxıdation of Americium, Preparation and Reactions of Am(IV) Hydroxide, J Inorg. Nucl Chem, 17: 138 (1961)

130 R Bdybdrz, L B Asprey, C E Strouse, and E Fukushima, Divalent Americium The Crystal Structure and Magnetic Susceptibility of $\mathrm{AmI}_{2}, J$ Inorg Nucl Chem., 34: 3427 (1972)

131 L B Asprey, T K Keenan, and F H Kruse, Preparation and Crystal Data for Lanthanide and Actinide Truodides, Inorg Chem., 3: 1137 (1964)

132. R G Maslov and Yu P Maslov, Heat of Formation of Some Thorium, Protactinium, Uranıum, Neptunium, and Amencium Halıdes, J Gen. Chem. USSR (Engl Transl.), 35: 2100 (1965) 
133. W. Freundlıch and M. Pages, Oxydes Terndıres de Neptunium(VI) et Americium(III) dvec Molydene ou Tungstène $\mathrm{NpM}_{2} \mathrm{O}_{8}, \mathrm{Am}_{2} \mathrm{M}_{3} \mathrm{O}_{12}(\mathrm{M}=\mathrm{Mo}, \mathrm{W})$, Compt Rend, Ser. C, 269: 392 (1969).

134. A. Tabuteau, M. Pages, and W. Freundlich, Molybdate d'Amencium(III) $\mathrm{Am}_{2}\left(\mathrm{MoO}_{4}\right)_{3}$ et Reactions avec les Molybdates Alcalıns, Radıochem. Radıoanal. Lett., 12: 139 (1972)

135. Y. Akimoto, A Note on AmN and AmO,J. Inorg. Nucl. Chem., 29: 2650 (1967).

136. Chemistry Division Semiannual Report [for] December 1958 Through May 1959, USAEC Report UCRL-8867, University of California Radiation Laboratory, May 1959

137. a. Chemistry Division Semiannual Report for June Through December 1959, USAEC Report UCRL-9093, University of California Radiation Laboratory, I ebruary 1960.

b. R. A. Potter and V. J. Tennery, Process for the Preparation of Uranium Nitride, U S. Patent No 3,758,669, September 1973.

c. J. P. Charvillat, U. Benedict, D. Damien, Ch. de Novion, A. Wojakowskı, and W Muller, Preparation and Lattice Parameters of Actınide Monochalcogenides and Monopnictides, in Transplutonum Elements, Proceedings of the 4th International Symposum, Baden-Baden, Sept. 13-17, 1975, W Muller and R. Lindner (Eds.), North-Holland Publıshing Company, Amsterdam, 1976

138. H. Tagawa, Phase Behavior and Crystal Structure of Actinide Nitrides, Nippon Genshırvoku Gakkalshi, 5: 267 (1971).

139. W. H. Zachariasen, Crystal Chemical Studies of the 5 f-Series of Elements XII New Compounds Representing Known Structure Types, Acta. Crystallogr., 2: 288 (1949), Phys Rev., 73: 1104 (1948).

140. R. J. Ackermann, R. L. Faucloth, and M H. Rand, A Thermodynamic Study of the Vaporization Behavior of the Substo1chiometric Plutonium Dioxide Phase, J. Phys. Chem., 70: 3698 (1966).

141. L. Eyring, H. R. Lohr, and B. B. Cunningham, Heat of Reaction of Some Oxides of Amencium and Praseodymum with Nitric Acid and an Estimate of the Potentials of the Am(III)-Am(IV) and $\operatorname{Pr}(I I I)-P r(I V)$ Couples, $J$ Amer. Chem. Soc., 74: 1186 (1952), USAEC Report UCR L-327, University of Californı Radiation Laboratory, 1949

142. T. D. Chikalla, C E. McNeilly, J. L Bates, and J. J. Rasmussen, High-Temperature Phase Transformations in Some Lanthanide and Actinde Oxides, in Proceedings of the Intemational Colloquium on High Temperature Phase Transformations, Centre National de la Recherche Screntıfique, Publication No. 205, 1973.

143. J. C. Wallmann, A Structural Transformation of Curium Sesquioxide, J. Inorg. Nucl. Chem., 26: 2053 (1964).

144. T. D. Chikalla and L Eyring, Phase Relationships in the Americium-Oxygen System, $J$. Inorg. Nucl, Chem., 30: 133 (1968).

145. a. U. Berndt, R Tanamas, D. Maır, and C. Keller, Zur Stabilitat der Monoklinen Modifıkation der Sesquioxide von Americium und Europıum, Inorg. Nucl. Chem. Lett., 10: 315 (1974).

b. D. Maier, Polymorphy of Americium Sesquioxide and Contributions to the Stability of the Modifications of the Rare Earth Oxides, West Germany Report KFK-1844, July 1973.

146. a. C Keller and U. Berndt, The Reaction of Americium Oxides with Trivalent Metal Oxides, in Transplutonium Elements, Proceedings of the 4th International Symposium, BadenBaden, Sept. 13-17, 1975, W Muller and R. Lindner (Eds), North-Holland Publishing Company, Amsterdam, 1976.

b. M. Foex and J. P. Traverse, Polymorphism of Rare Earth Sesquioxides at High Temperatures, Bull. Soc, Fr. Miner. Crist, , 89: 184 (1966).

c. I. Warshaw and R. Roy, Polymorphism of the Rare Earth Sesquioxides, J. Phys. Chem., 65 : 2048 (1961).

d. R. D. Baybarz, High-Temperature Phases, Crystal Structures, and the Melting Points for Several of the Transplutonum Sesquioxides, J Inorg. Nucl Chem., 35: 4149 (1973). 
e T D Chikalla and R P Turcotte, Battelle Pactic Northwest Ldboratories, personal communication 1974

147 G R Hall and T L Markin, The Alphd Half Lufe of ${ }^{241}$ Am J Inorg Nucl Chem 2202 (1955)

148 d L B Asprey, F H Ellinger, S I ried, and W H Zachariasen, Evidence for Quadrivalent Cunum X Ray Data on Cunum Oxudes J Amer Chem Soc 771707 (1965)

b J A Fahey, R P Turcotte, and $\Gamma \mathrm{D}$ Chikalla, Thermal Expansion of the Actinide Dioxides, Inorg Nucl Chem. I ett 10: 459 (1974)

149 R E McHenry, Melting Points of Curium and Americium Oxides, Trans Amer Nucl Soc 8. 75 (1965)

150 T D Chıkalla and L Eyrıng, Dissociation Pressures and Partıd Thermodynamic Quantities for Americium Oxides, J Inorg Nucl Chem. 29. 2281 (1967)

151 L B Asprey and B B Cunningham, Equilibria in the Oxide Systems of Praesodymium and Americium, USAEC Report UCRL 329, University of California Radiation Laboratory, April 1949

152 a C Sarı and E Zamoranı, An Investıgation in the Amerıcium Oxide System, $J$ Nucl Mat 37324 (1970)

b C Sarı, V Tebaldı, I D Pietra, Ceramography of Amencium Oxıdes, Report EUR-4413, September 1969

153 a T D Chikalla and R P Turcotte, Oxygen Dissocidtion Pressures and Phase Behavior in the Transplutonium Oxides, in Soltd State Chemistry National Bureau of Standards, Publication No 364, Superintendent of Documents, U S Government Printing Office, Washington, 1972

b D G Karraker, Magnetic Susceptibility of ${ }^{243} \mathrm{AmO}_{2}$, USERDA Report DP-MS-75-1, E I du Pont de Nemours and Company by Savannah River Laboratory, 1975

$154 \mathrm{C}$ Keller, L Koch, and $\mathrm{K} \mathrm{H}$ Walter, Die Redktion der Oxıde der Transurane mit Alkalioxiden I Ternare Oxıde der Sechswertigen Transurane mit Lithium and Natrium, $J$ Inorg Nucl Chem 271205 (1965)

155 C Keller, L Koch, and K H Walter, Die Reaktıon der Transuranoxide mit Alkalıoxiden-II Ternare Oxide der I unfwertigen Transurane und des Protactiniums mit Lithium und Natrum, J Inorg Nucl Chem. 27·1225 (1965)

156 C Keller, Uber die Festkorperchımıe der Actınıdes Oxıde, (The Solıd State Chemistry of the Actinıde Oxides), West Germany Report KFK 225, Hebruary 1964

$157 \mathrm{~W} C$ Mosley, Studies of Mixed Actinide Oxides $\mathrm{Am}_{y} \mathrm{Cm}_{1-y} \mathrm{O}_{x}$ and $\mathrm{Pu}_{y} \mathrm{Cm}_{1-y} \mathrm{O}_{x}$, in Plutonium 1970 and Other Actinides Proceedings of the 4th International Conference on Plutonium and Other Actinides, Santa I e, N Mex, Oct 5-9, 1970, W N Miner (Ed), Nuclear Materials, Vol 17, USAEC Report CONF-701001 (Pts I and II), 1970

$158 \mathrm{H}$ Radzewitz, I estkorperchemische Untersuchungen uber die Systeme $\mathrm{SeO}_{1}{ }_{5}-\mathrm{ZrO}_{2}\left(\mathrm{HfO}_{2}\right)$, $\mathrm{AmO}_{1} 5-\mathrm{ZrO}_{2}\left(\mathrm{HfO}_{2}, \mathrm{ThO}_{2}\right) \mathrm{O}_{2}$ und $\mathrm{TlO}_{2}-\mathrm{NpO}_{2}\left(\mathrm{PuO}_{2}\right)$, [Solid Chemical Investigations of the Systems $\mathrm{SeO}_{15}-\mathrm{ZrO}_{2}\left(\mathrm{HfO}_{2}\right), \mathrm{AmO}_{1},-\mathrm{ZrO}_{2}\left(\mathrm{HfO}_{2} \mathrm{ThO}_{2}\right) \mathrm{O}_{2}$, and $\mathrm{TiO}_{2}$ $\mathrm{NpO}_{2}\left(\mathrm{PuO}_{2}\right)$ ] West Germany Report KFK 433 July 1966

$159 \mathrm{C}$ Keller, Ternare and Polynare Oxıdes des Protactınıums mit Perowskitstruktur, $J$ Inorg Nucl Chem 27. 321 (1965)

$160 \mathrm{C}$ Keller U Berndt, M Debbabi, and H Engerer, Phasengleichgewichte in den Systemen Scandiumoxid Oxide der Actiniden (Th Am), J Nucl Mat 42-23 (1972)

161 D Damien and I Jove, Americium Disulfide and Diselenide, Inorg Nucl Chem Lett 7685 (1971)

162 C Cimetiere, J Desroches and C Routier, Process for Fabncation of Alpha Sources rrench Patent No 2,041 947, 1971

$163 \mathrm{~J}$ H Burns and R D Baybarz, Crystal Structure of Amencium Sulfate Octahydrate, Inorg Chem 112233 (1972) 
164. G. N. Yakovlev, D S Gorbenko-Germanov, R. A. Zenkova, V. L. Rdzbitno1, and K S Kazansku, Study of Double Sulfates of Americium by Absorption Spectra in Crystals, $J$ Gen. Chem. USSR (Engl. Transl.), 28: 2653 (1958).

165. E Staritzky and D I. Walker, Optical Properties of Some Compounds of Urantum, Plutonum, and Related Elements, USAEC Report LA-1439, Los Alamos Scientific Laboratory, June 1952.

166. V I Grebenshchikova and V. N. Babrova, Coprecipitation of Lanthanum, Cerium, and Americium, Zhur. Neorg. Khtm., 3: 400 (1958)

167. V. I. Grebenshchikova and V. N. Babrova, Coprecipitation of Plutonium and Americium with Potassium Sulfate, Radiokhimiya, 3: 544 (1961) through Radıochemistry USSR 3: 32 (1961)

168. V I Grebenschchikova and N. B. Cheinyavskaya, Isolation of $\mathrm{Np}^{4+}, \mathrm{Pu}^{4+}$, and $\mathrm{Am}^{3+}$ from Solutions by the Sulfate Method, Radiokhimiya, 4: 232 (1961) through Sov. Radiochem (Engl. Transl), 4: 207 (1962)

169. K. Ueno and M. Hoshi, Precipitation of Some Actinide Element Complex Ions by Using Hexammine Cobalt (III) Cation III. The Precipitation of Neptunum(VI) and Americium(VI) Sulfate Complexes with Hexammine Cobalt(III) Cation, J. Inorg. Nucl. Chem., 33: 2631 (1971).

170. K. Ueno and M. Hoshı, II. The Precipitation of Thorıum, Uranium(VI), and Plutonum(IV), (VI) Sulfate Complex Ions with Hexammine Cobalt (III) Cation, J Inorg. Nucl. Chem., 33: 1765 (1971)

171. D. Damien, $\alpha$ f orm of Americium Sesquisulfide and Amencium Monosulfide, Inorg. Nucl. Chem. Lett., 7: 291 (1971).

172. W H. Zachariasen, Crystal Chemical Studies of the $5 \mathrm{f}$-Series of Elements. VI The $\mathrm{Ce}_{2} \mathrm{~S}_{3}-\mathrm{Ce}_{3} \mathrm{~S}_{4}$ Type of Structure, Acta Crystallogr , 2: 57 (1949)

173. D Damien, J. P. Marcon, and J. Jove, The $\beta$ form of Americium Sesquisulfide, Inorg Nucl. Chem. Lett., 8: 317 (1972)

174. D. Damien, Americium Tritelluride and Ditelluride, Inorg. Nucl. Chem. Lett., 8: 501 (1972)

175. D. Damien and J P. Charvillat, Amencium Sesquitellurides, Inorg. Nucl. Chem. Lett., 8: 705 (1972).

176. Y. Marcus and D Cohen, Americium(III) Perxenate,Inorg. Chem., 5: 1740 (1966).

177. L. B. Asprey, S. E. Stephanou, and R. A. Penneman, A New Valence State of Americrum, Am(VI), J. Amer. Chem. Soc., 72: 1425 (1950)

178. L. B. Asprey, S. E. Stephanou, and R A. Penneman, Hexdvalent Americium, J Amer Chem Soc., 73: 5715 (1951)

179. L B. Asprey, S. E. Stephanou, and R. A. Penneman, Compounds of the Element Americium, U.S Patent No 2,681,924, June 1954.

180. L L Jones, Infrared Spectra and Structure of the Crystalline Sodium Acetate Complexes of U(VI), Np(VI), Pu(VI), and Am(VI). A Comparison of Metal-Oxygen Bond Distance and Bond Force Constant in This Series, J. Chem. Phys., 23: 2105 (1953)

181.d.C Keller and H. Schrock, Die Chelatbildung und Extraktion des Dreiwertige Actınıums, Amenciums, Curıums, und Californıums mit Acetylacetone und Einiger Seiner Derivate, $J$. Inorg. Nucl, Chem., 31: 1121 (1969).

b. D. G Karraker, Potassium Bis(Cyclooctatetraenyl) Americium(II), in Transplutonium Elements, Proceedings of the 4th International Symposium, Baden-Baden, Sept. 13-17, 1975, W. Muller and R. Lındner (Eds.), North-Holland Publıshıng Company, Amsterdam, 1976

182. I Baumgartner, E. O I ssher, B. Kanellakopulos, and P. Laubereau, Tri(Cyclopentadienyl)Americium(111), Angew. Chem., 78: 112 (1966), Angew. Chem. Int. Ed Engl., 5: 134 (1966)

183. d. G. T. Seaborg, Recent Advances in the Chemistry of Organometallic Compounds of the Actınıde Elements, Pure Appl. Chem., 30: 539 (1972) 
b. B Kanellakopulos, Cyclopentadienyl-Complexes of the Actınide Elements, in Sympostum on the Transuranum Elements, Liege, Belgium, Apr 21-22, 1969, Report CONF-690426, 1969

c G. E. Moore (Ed), Chemistry Division Annual Progress Report for Period Ending May 20, 1970, USAEC Report ORNL-4581, Oak Ridge National Laboratory, September 1970

184 B Kanellakopulos, E O Fisher, E Dornberger, and F Baumgartner, Uber Tricyclopentadienyluran (III) und Seine Addukte mit Tetrahydrofuran, Cyclohexylisonitril, und 1-Nicotın, J. Organometal. Chem. (Amsterdam), 24: 507 (1970)

185. R. Pappalardo, W. T Carnall, and P R Fields, Absorption Spectrum of Americium Trichloropentadienide, $J$ Chem. Phys., 51: 842 (1969)

186. L. J. Nugent, P G. Laubereau, G K Werner, and K. L Vander Slus, Noncovalent Character In the Chemical Bonds of the Lanthanıde(III) and the Actınıde(III) Tricyclopentadienides, $J$. Organometal. Chem. (Amsterdam), 27: 365 (1971)

187. R D Fischer, P. Laubereau, and B. Kanellakopulos, in Third International Transplutonium Element Symposium, Argonne, Ill, Oct 20-22, 1971, Report CONF-711078 (Abstracts), 1971.

188 M D Danford, J H Burns, C E Higgins, J R Stokeley, Jr, and W H Baldwin, Preparation and Properties of Some Rare Earth and Americium Chelates, Inorg Chem 9: 1953 (1970)

189 M Sakanoue and R Amano, Preparation of Americium and Californium Dipivaloylmethanato Complexes and Therr Volatilities as Compared with Plutonium and Lanthanold Complexes, in Transplutontum Elements, Proceedings of the 4th International Symposium, Baden-Baden, Sept 13-17, 1975, W Muller and R Lindner (Eds), North-Holland Publishing Company, Amsterdam, 1975

190 J H Burns and M D Danford, The Crystal Structure of Cesium Tetrakıs(hexafluoroacetylacetylacetonato)europate and -americlate Isomorphism with the Yttrate, Inorg Chem 8: 1780 (1969)

191 K W Bagnall, Complex Compounds with Neutral and Chelating Ligands, in Transuranium Elements Part C Compounds, G Koch (Ed ), Gmelins Handbook of Inorganic Chemistry, New Supplement Senes, Vol 4, Verlag Cheme GmbH, Weinherm, Germany, 1972, p 264

192 C Keller, S H Eberle, and K Mosdzelewskı, Die Verbındungen des Dreiwertigen Plutonıums, Americium, und Curiums mit 8-Hydroxychinoline und einıger Seiner Derviate, Radıochım Acta , 4: 141 (1965)

193 E Staritzky and A L Truitt, Optıcal Properties of Some Compounds of Uranium, Plutonium, and Related Elements. In The Actınde Elements, G T Seaborg and $\mathrm{J} \mathbf{J}$ Katz (Eds), Chap 19, National Nuclear Energy Series, Div IV, Vol 14A, McGraw-H1ll Book Company, Inc, New York, 1954

194 R D Baybarz, Preparation of Amencium Dioxide by Thermal Decomposition of Americium Oxalate in Air, USAEC Report ORNL-3003, Oak Ridge National Laboratory, December 1960

195 I A Lebedev, S V Pirozhkov, V M Razbitno1, and G N Yakovlev, Studies on Complex Formation Between $\mathrm{Am}^{3+}$ and Oxalate Ions, Radiokhimiya 2: 351 (1960) through Sov Radlochem (Engl Transl), 2: 89 (1960)

196. G. A. Burney and J A Porter, Solubilities of Pu(III), Am(III), and Cm(III) Oxalates, Inorg Nucl Chem. Lett, 3: 79 (1967)

197 T L Markin, The Thermal Decomposition of Americium(III) Oxalate, $J$ Inorg Nucl Chem, 7: 290 (1958)

198 F Weigel, W Ollendorff, V Scherer, and R Hagenbruch, Structure Investigations on Lanthanide Oxalates I Single-Crystal Investigatıons on Neodymum(III) Oxalate Decahydrate and Samanum(III) Oxalate Decahydrate The Elementary Cell of Promethum Oxalate Decahydrate, $Z$ Anorg Allg Chem, 345: 119 (1966)

199 C Keller, Chemistry of the Transuranium Elements, pp. 503 and 542, Verlag Chemie GmbH, Weinheım, Germany, 1970 
200 I A Lebedev, S V Prozhkov, V M Razbitno1, and G N Yakovlev, Investigation of the Decomposition of Americium Oxdate Under the Action of Its Own $\alpha$ Radiation, Radio khımiya 4: 308 (1962) through Sov Radiochem (Engl Transl) 4. 276 (1962)

201 W Hagenberg, Dissertation, Technische Universitat Munchen, 1973

202 I Lux, Lanthanide and Actınide Phthalocyaninato Complexes, in Proceeding of the Tenth Rare Earth Research Conference, Carefree, Arız, Apr 30 May 3, 1973, C J Kevane and T Moeller, (Fds ), p 871, USAFC Report CONI -730402(Pt 2), 1973

203 S H Eberie and W Robel, Normale und Solvatısierte Cheldte Sechswertiger Actınıden mit $a$ Picolinsaure, Inorg Nucl Chem Lett 6: 369 (1970)

204 W Robel, Complex Compounds of Hexavalent Actinides with Pyridine Carboxylic Acids, West Germany Report KГK-1070, December 1970

205 A T Aldred, B D Dunlap, D J Lam, and G K Shenoy, Crystal Structure and Magnetic Properties of Americium Phases, in Transplutonum Elements Proceedings of the 4th International Symposıum, Baden-Baden, Sept 13-17, 1975, W Muller and R Lindner (Eds), North Holland Publishing Company, Amsterdam, 1976

206 V A Vodavatov, V G Kolokoltsov, T V Kovaleva, L G Mashirov, D N Suglobov, and V G Sles, Coordinatıng Properties of Actınıde(V) Dioxocations, in Transplutonum Elements Proceedings of the 4th International Symposium, Baden-Baden, Sept 13-17, 1975, W Muller and R Lindner (Eds), North-Holland Publıshing Company, Amsterdam, 1976 


\section{RECOVERY; SEPARATION; J PURIFICATION}

\section{INTRODUCTION}

Present-day technology for recovery and purification of americium involves principally aqueous ion exchange and solvent extraction methods supplemented, in some cases, by precipitation processes. Using the chemistry discussed in Chaps. 3 and 4, these procedures are applied not only to recover and separate americium from a variety of aqueous feedstocks, including high-level Purex-process waste, but also to purify it from curium and lanthanides. Although methods used primarily for analytical purposes or tested only on a laboratory-scale are cited, emphasis in this review is on those aqueous procedures used either currently or previously to recover and purify gram to kilogram amounts of americium.

Only little use has thus far been made of nonaqueous methods for separating and purifying americium - a notable exception is the pyrochemical process used at the Energy Research and Development Administration (ERDA) Rocky Flats Plant to remove ${ }^{241} \mathrm{Am}$ from molten plutonium metal. The pyrochemical process, as well as significant features of americium chemistry in other nonaqueous processes, is described in the first part of this chapter. 


\section{PYROCHEMICAL PROCESSES}

\section{Rocky Flats Americium Extraction Processes}

Currently at the ERDA Rocky Flats Plant, a countercurrent molten-salt extraction process is used to purify multikilogram amounts of plutonium metal from ${ }^{241} \mathrm{Am}$ which grows in by beta decay of ${ }^{241} \mathrm{Pu}$ (Refs. 1 to 4 ). This two-stage batch purification scheme, which is based partly on earlier molten salt-molten metal studies at Los Alamos Scientific Laboratory (LASL) ${ }^{5}$ and Argonne National Laboratory (ANL), ${ }^{6}$ removes about $90 \%$ of the americium from plutonium metal typically contaminated with 200 to $2000 \mathrm{ppm}{ }^{241} \mathrm{Am}$.

The charge to the first stage of this Rocky Flats process (Fig. 5.1) consists of plutonium metal contaminated with ${ }^{241} \mathrm{Am}$ and gram quantities of $\mathrm{PuO}_{2}$ and a salt initially composed of $\mathrm{KCl}-47.1 \mathrm{~mol} \% \mathrm{NaCl}-5.8 \mathrm{~mol} \% \mathrm{MgCl}_{2}$ which has previously been contacted in Stage 2 with plutonium metal partially depleted in americium.* This charge, contained in a tantalum crucible, is heated under an argon atmosphere in a resistance furnace at $750^{\circ} \mathrm{C}$; the molten phases are stirred 1 hour at $750^{\circ} \mathrm{C}$ with a flat-bladed tantalum stirrer and then cooled to room temperature. [A specially designed tilt-pour furnace is being tested for use in the molten-salt extraction

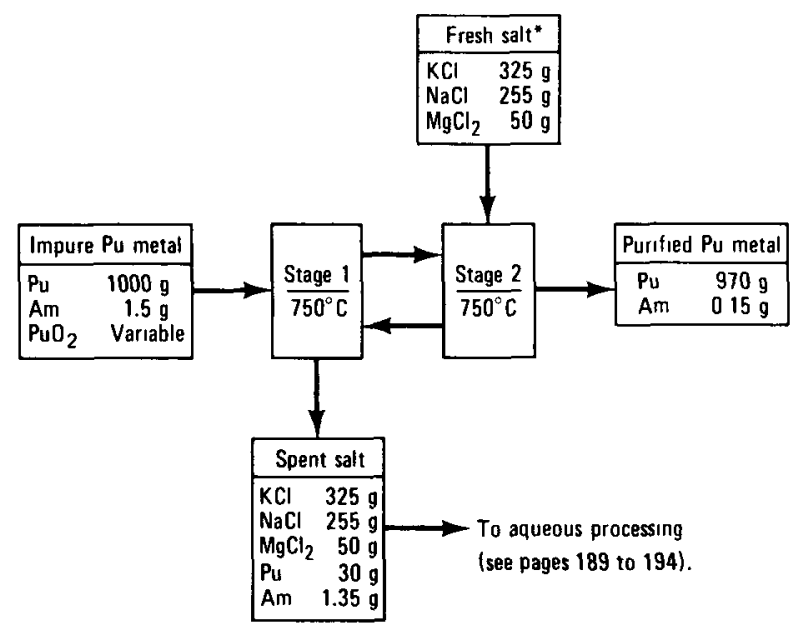

*Salt/metal ratıo varıable, depending on 241 Am content of Pu metal

Fig. 5.1 Rocky Flats molten-salt amencium extraction process.

*According to Knighton et al., ${ }^{382}$ the $\mathrm{MgCl}_{2}$ content of the salt has been increased from 8 to $30 \mathrm{~mol} \%$, whereas the salt/metal ratio has been decreased from 0.56 to 0.056 . 
process. ${ }^{7}$ ] Plutonium metal resulting from Stage 1 is contacted in Stage 2 with fresh $\mathrm{KCl}-\mathrm{NaCl}-\mathrm{MgCl}_{2}$ salt under the same conditions as in Stage 1. The particular salt/metal ratio used depends on the ${ }^{241} \mathrm{Am}$ content of the feed plutonium and is chosen to ensure removal of about $90 \%$ of the americium; a typical salt $/$ metal ratio is ${ }^{2}$ 0.56* Salt from Stage 1, which has had two contacts with plutonium metal, is currently processed by aqueous methods (see pages 190 to 194) for recovery of americium and plutonium values. Originally ${ }^{3,4}$ the process was operated in a cross-current mode with a salt composed of $\mathrm{KCl}-49.1 \mathrm{~mol} \% \mathrm{NaCl}-1.8 \mathrm{~mol} \% \mathrm{MgCl}_{2}$. Countercurrent operation with a salt phase containing $5.8 \mathrm{~mol} \% \mathrm{MgCl}_{2}$ reduces the amount of americium-bearing salt which must be subsequently processed.

In the Rocky Flats process, americium is oxidized by $\mathrm{MgCl}_{2}$ and $\mathrm{PuCl}_{3}$ by the following reactions:

$$
\begin{gathered}
\mathrm{Am}^{0}+\frac{3}{2} \mathrm{MgCl}_{2} \rightarrow \mathrm{AmCl}_{3}+\frac{3}{2} \mathrm{Mg}^{0} \\
\mathrm{Am}^{0}+\mathrm{PuCl}_{3} \rightarrow \mathrm{AmCl}_{3}+\mathrm{Pu}^{0}
\end{gathered}
$$

Knighton ${ }^{8}$ notes that distribution of americium between metal and salt phases correlates with the $3 / 2$ power of the $\mathrm{MgCl}_{2}$ mole fraction. This indicates that americium in the salt phase is present in the trivalent state (Eq. 5.1) rather than as $\mathrm{Am}^{2+}$, which might be expected from the work of Mullins, Beaumont, and Leary. ${ }^{9 \mathrm{a}, 9 \mathrm{~b}}$ Plutonium oxide has also been shown to extract americium from plutonium metal; ${ }^{\mathrm{c}}$ the side reaction between $\mathrm{PuO}_{2}$ and americium in Stage 1 (Fig. 5.1) enhances removal of americium from the metal phase.

Current research effort by personnel at the Rocky Flats Plant on the americium extraction process is centered on reducing still further the salt/metal ratio and in developing nonaqueous methods of recovering americium and plutonium values from spent salt. ${ }^{*}$ With respect to the former objective, recent tests ${ }^{8}$ (Table 5.1) show that, at corresponding $\mathrm{MgCl}_{2}$ contents, the value of the americium distribution coefficient is much higher with an $\mathrm{NaCl}-\mathrm{CaCl}_{2}-\mathrm{MgCl}_{2}$ salt than with the $\mathrm{NaCl}-\mathrm{KCl}-\mathrm{MgCl}_{2}$ mixture. In verification of these distribution data, countercurrent, two-stage production-scale tests with a $45 \mathrm{~mol} \% \mathrm{NaCl}-50 \mathrm{~mol} \% \mathrm{CaCl}_{2}-5 \mathrm{~mol} \% \mathrm{MgCl}_{2}$ salt demonstrated satisfactory $(>90 \%)$ removal of americium from plutonium metal containing about $1500 \mathrm{ppm}^{241} \mathrm{Am}$ at a salt/metal ratio of 0.2 .

A potential disadvantage of substituting $\mathrm{CaCl}_{2}$ for $\mathrm{KCl}$ is that the aqueous methods (see pages 190 to 194 and 233 to 243 ) currently used to process spent extraction salt will not easily separate americium from large amounts of calcium. A pyrochemical procedure involving reduction with calcium metal appears suitable, however, for recovery of americium and plutonium values from both spent $\mathrm{NaCl}-\mathrm{CaCl}_{2}-\mathrm{MgCl}_{2}$ and $\mathrm{NaCl}-\mathrm{KCl}-\mathrm{MgCl}_{2}$ salts. ${ }^{8}$ In addition to a metal button containing plutonium and americium contaminated with magnesium and calcium, the

*See footnote on page 185 . 
Table 5.1

\begin{tabular}{|c|c|c|}
\hline \multirow{2}{*}{$\begin{array}{l}\mathrm{MgCl}_{2} \\
\mathrm{~mol} \%\end{array}$} & \multicolumn{2}{|c|}{ Americium distribution coefficient $\left(\mathrm{K}_{\mathrm{d}}\right)^{*}$} \\
\hline & $\overrightarrow{\mathrm{NaCl}}-\mathrm{KCl}-\mathrm{MgCl}_{2}$ & $\mathrm{NaCl}-\mathrm{CaCl}_{2}-\mathrm{MgCl}_{2}$ \\
\hline 5 & 3.1 & 13 \\
\hline 10 & 8.7 & 20 \\
\hline 15 & 15.9 & 29 \\
\hline 20 & 24.5 & 39 \\
\hline 30 & 45.0 & 60 \\
\hline 40 & 69.2 & 85 \\
\hline 50 & 97.0 & 112 \\
\hline
\end{tabular}

$* \mathrm{~K}_{\mathrm{d}}=\mathrm{wt} . \%$ Am in salt/wt.\% Am in metal.

products of the reduction reaction are a white salt (four parts) and a black salt (one part) with some metallic modular inclusions. Preliminary indications are that the white salt contains sufficiently small amounts of americium and plutonium (typically $10^{-4}-10^{-3} \mathrm{~g} \mathrm{Pu} / \mathrm{g}$ salt and $10^{-5} \mathrm{~g} \mathrm{Am} / \mathrm{g}$ salt) that it can be discarded without further processing or, possibly, reused. Hydroxide precipitation methods (pages 190 to 194) can be used to recover and purify americium and plutonium from acid solutions of the metal button and black salt.

Also under development for removing plutonium and americium from chloride melts is a pyrochemical process that involves scrubbing the molten salt with an $\mathrm{Mg}-90$ wt.\% $\mathrm{Zn}$ alloy. The resulting scrub alloy buttons can be satisfactorily dissolved in $4 M$ $\mathrm{HNO}_{3}-0.2 M \mathrm{HF}$ solution to prepare feedstock for further aqueous processing.

\section{Americium Chemistry in Other Pyrochemical Systems}

Mullins and Leary ${ }^{10}$ patented a method of separating americium from plutonium which involves bubbling a mixture of oxygen and argon gas in to a molten salt containing both elements. Plutonium precipitates as $\mathrm{PuO}_{2}$, whereas americium stays in solution. ${ }^{11}$

In connection with their studies of salt transport processes, ${ }^{12}$ ANL investigators ${ }^{13}$ determined distribution coefficients of americium and other actinides between molten $\mathrm{MgCl}_{2}$ and liquid zinc-magnesium alloys at $800^{\circ} \mathrm{C}$. On the basis of these and other data, pyrochemical processes for separating americium from curium have been patented. ${ }^{14,15}$ These processes involve contacting a molten halide salt containing americium, curium, and at least $50 \mathrm{wt} . \% \mathrm{MgCl}_{2}$ with either magnesium-zinc or a magnesium-cadmium alloy; curium is taken up by the alloy, whereas americium remains in the salt phase. 
Studies in support of the development of a Molten Salt Breeder Reactor (MSBR) are currently under way in the United States ${ }^{1618}$ One method considered for the processing of MSBR fuel involves selective reduction of protactınıum and rare earths from the molten fluonde salt into liquid bismuth, followed by the preferential transfer of the rare earths into an acceptor salt, such as $\mathrm{LiCl}$ or $\mathrm{LiBr}$ Ferris and his coworkers ${ }^{19} 22$ in their studies of this process have determined the equilibrium distribution of americium (and other transuranium elements) between liquid bismuth and molten $\mathrm{L} \mathrm{Cl}_{1} \mathrm{LBBr}$, and several $\mathrm{L} \mathrm{L}_{1}-\mathrm{BeF}_{2}-\mathrm{ThF}_{4}$ solutions at temperatures in the range 600 to $750^{\circ} \mathrm{C}$ At each temperature the distribution coefficients (mole fraction in the bismuth phase divided by mole fraction in the salt phase) for most of the solutes obeyed the relation $D_{M}=\left(N_{L_{1}}^{n}\right)\left(K_{M}\right)$, in which the superscript $n$ is the oxidation number of solute $\mathrm{M}^{\mathrm{n}+}$ in the salt phase and $\mathrm{N}_{\mathrm{L}_{1}}$ is the mole fraction of lithium in the bismuth phase For $\mathrm{N}_{\mathrm{L}_{1}}$ ranging from $10^{-5}$ to 03 , the oxidation number of americium in the salt varied between $3+$ and $2+$, depending on temperature and salt-phase composition In molten $\mathrm{LiCl}$ and in $667 \mathrm{~mol} \% \mathrm{LiF}-333 \mathrm{~mol}_{\%} \mathrm{BeF}_{2}$ at $600^{\circ} \mathrm{C}$, however, a significant fraction of the americium appears to be present in the divalent state This evidence for existence of $\mathrm{Am}^{2+}$ parallels the observations of Mullins, Beaumont, and Leary ${ }^{9}$ a for the $\mathrm{Am}-\mathrm{PuCl}_{3}$ system

The distribution coefficient, $\mathrm{D}=(\mathrm{g} A \mathrm{~m} / \mathrm{g}$ metal phase) ( $\mathrm{g} \mathrm{Am} / \mathrm{g}$ salt phase), of americium between molten aluminum metal and molten $\mathrm{AlCl}_{3}-\mathrm{KCl} 1 \mathrm{~s}^{23} 196$ * McKenzie, Fletcher, and Bruce ${ }^{24}$ measured the distribution of plutonium, americium, and certain fission products between neutron-1rradiated aluminum-plutonium alloys and molten bismuth An equal volume of bismuth extracts $75 \%$ of the plutonium and 93\% of the amencium

Foos, Guillaumont, and Mesplede have measured the partition of amencium at 150 to $160^{\circ} \mathrm{C}$ between molten $\mathrm{LiNO}_{3}-\mathrm{KNO}_{3}$ phases and solutions of either tri- $n$-butyl phosphate (TBP), ${ }^{2-27}$ triphenyl phosphonate (TPPO), ${ }^{25-27}$ tr1-n-octylphosphine oxide (TOPO), ${ }^{28}$ or a series of diphenyldiphosphine dioxides ${ }^{28} 29$ $\left[\left(\mathrm{C}_{6} \mathrm{H}_{5}\right)_{2} \mathrm{PO}\left(\mathrm{CH}_{2}\right)_{n} \mathrm{PO}\left(\mathrm{C}_{6} \mathrm{H}_{5}\right)_{2}=\mathrm{n}-\mathrm{DPO}\right.$, where $\mathrm{n}=2,3,4$, and 6] in a eutectic of polyphenyls (The spectrum of $\mathrm{Am}^{3+}$ in molten $\mathrm{LiNO}_{3}-\mathrm{KNO}_{3}$ is shown in Chap 3, Fig $37 \mathrm{c}$ ) From logarithmic plots of distribution ratio vs organophosphorus extractant concentration, the following organic species were identified $\mathrm{Am}\left(\mathrm{NO}_{3}\right)_{3} \cdot 2 \mathrm{TBP}, \mathrm{Am}\left(\mathrm{NO}_{3}\right)_{3} \cdot 2 \mathrm{TPPO}, \mathrm{Am}\left(\mathrm{NO}_{3}\right)_{3} \cdot \mathrm{TOPO}, \mathrm{Am}\left(\mathrm{NO}_{3}\right)_{3} \cdot 2-\mathrm{DPO}$, $\mathrm{Am}\left(\mathrm{NO}_{3}\right)_{3} \cdot 2(3-\mathrm{DPO})$, and $\mathrm{Am}\left(\mathrm{NO}_{3}\right)_{3} \cdot 2(4-\mathrm{DPO})$ For the diphenyldiphosphine dioxides, the following order of extractant strength was observed

$$
6 \mathrm{DPO} \ll 4-\mathrm{DPO}<3-\mathrm{DPO}<2-\mathrm{DPO}
$$

In this system, 6 DPO does not extract americium Foos, Gullaumont, and Mesplede ${ }^{2529}$ note that TOPO extracts lanthanides very well from fused $\mathrm{LiNO}_{3}-\mathrm{KNO}_{3}$ but $\mathrm{Am}^{3+}$ only poorly, suggesting an effective separation scheme

*At $275^{\circ} \mathrm{C}$ and an $\mathrm{AlCl}_{3} \quad \mathrm{KCl}$ mole ratio of 114 
Polish workers investigated the distribution at $180^{\circ} \mathrm{C}$ of uranium, plutonium, and americium between a $\mathrm{KCl}-\mathrm{CuCl}$ eutectic melt and solutions of $\mathrm{TBP}$, dibutylphosphoric acid (HDBP), and tri- $n$-octylamine in biphenyl. ${ }^{30}$ Absorption spectra of $\mathrm{Am}(\mathrm{III})$ in molten pyridinium and some alkali metal chlorides indicate americium is present as the octahedral complex $\mathrm{AmCl}_{6}^{3-}$ (compare Chap. 3, pages 99 and 100) in such systems. ${ }^{31}$

\section{PRECIPITATION PROCESSES}

For the first 15 years or so after its discovery, many different precipitation processes were used extensively to recover and purify microgram to gram amounts of americium. Highlights of these processes, which are now primarily only of historical interest, are presented here; amplified discussion of several early precipitation schemes is given in articles by Penneman and Keenan ${ }^{32}$ and by Thompson et al. ${ }^{33}$ Nowadays, of course, ion exchange and solvent extraction technology have largely supplanted precipitation processes for recovering americium. Even so, for special purposes, precipitation processes still find applications, and these are discussed on pages 190 to 194. Attention is also directed to the discussion in Chap. 4 of the properties of $\mathrm{AmF}_{3}$, $\mathrm{Am}_{2}\left(\mathrm{C}_{2} \mathrm{O}_{4}\right)_{3}, \mathrm{~K}_{3} \mathrm{AmO}_{2}\left(\mathrm{CO}_{3}\right)_{2}$, and other insoluble compounds of Am(III) and $\mathrm{Am}(\mathrm{V})$.

\section{Precipitation Processes: Historical}

Important contributions in the very early days of americium chemistry were made by Cunningham, ${ }^{34}$ Wallman, ${ }^{35}$ Werner, ${ }^{36-38}$ and Thompson. ${ }^{39}$ Cunningham isolated the first pure americium by precipitation of $\mathrm{AmF}_{3}$ and $\mathrm{Am}(\mathrm{OH})_{3}$, and Werner and Thompson devised various schemes for isolation of trace quantities of americium including its precipitation as an insoluble $\mathrm{Am}(\mathrm{V})$ carbonate and by carrying on $\mathrm{Ta}_{2} \mathrm{O}_{5} \cdot \mathrm{xH}_{2} \mathrm{O}$ precipitated by heating a carbonate solution containing $\mathrm{Ta}(\mathrm{V})$ and $\mathrm{Am}(\mathrm{V})$.

Subsequently workers in several countries used precipitation methods to purify milligram and even gram amounts of ${ }^{241} \mathrm{Am}$ from plutonium and other contaminants. For example, Milsted, Herniman, and $\mathrm{Hall}^{4^{-42}}$ in England devised methods for the separation of 10 to $25 \mathrm{mg}{ }^{241} \mathrm{Am}$ from aged plutonium stocks; their isolation scheme included steps in which americium was concentrated and purified by precipitation of $\mathrm{AmF}_{3}$ and $\mathrm{Am}_{2}\left(\mathrm{C}_{2} \mathrm{O}_{4}\right)_{3} \cdot 10 \mathrm{H}_{2} \mathrm{O}$. Later, in 1956, Butler and Merritt ${ }^{3}$ in Canada combined precipitation $\left[\mathrm{Am}(\mathrm{OH})_{3}\right.$ and $\left.\mathrm{AmF}_{3}\right]$ and ion-exchange techniques to separate and purify $0.8 \mathrm{~g}$ of ${ }^{241} \mathrm{Am}$ from $2 \mathrm{~kg}$ of aged plutonium; as in the earlier British work, a gross separation from plutonium was first made by precipitating plutonium peroxide from acid solution. Yakovlev and Kosyakov ${ }^{44}$ reported on the separation of a gram of ${ }^{241} \mathrm{Am}$ from plutonium and other impurities by precipitation of $\mathrm{K}_{8} \mathrm{Am}_{2}\left(\mathrm{SO}_{4}\right)_{7}$ and $\mathrm{K}_{3} \mathrm{AmO}_{2}\left(\mathrm{CO}_{3}\right)_{2}$. American scientists ${ }^{4-47}$ in the 1950 s also 
devised and tested several precipitation schemes for isolation and purification of macro amounts of americium The precipitation process developed by LASL workers to concentrate americium from impure feedstocks is shown in Fig 52

Also in this early period, results obtaned during the development of analytical procedures for and the fundamental chemistry of americium established that micro concentrations of Am(III) coprecipitate quantitatively with $\mathrm{LaF}_{3}$ (Refs 48 to 51), $\mathrm{CeF}_{3}$ (Refs 32 and 51 to 53), $\mathrm{La}_{2}\left(\mathrm{C}_{2} \mathrm{O}_{4}\right)_{3}$ (Refs 54 to 57), $\mathrm{CaC}_{2} \mathrm{O}_{4}$ ( $\operatorname{Ref} 46$ ), $\mathrm{K}_{2} \mathrm{SO}_{4}(\operatorname{Ref} 58), \mathrm{KLa}\left(\mathrm{C}_{2} \mathrm{O}_{4}\right)_{2}$ (Refs 59 and 60), and $\mathrm{B}_{1} \mathrm{PO}_{4}(\operatorname{Refs} 32,61$, and 62) Yakovlev and Gorbenko-Germanov ${ }^{63}$ also showed that $\mathrm{Am}(\mathrm{V})$ in alkalıne medium is quantitatively coprecipitated with $\mathrm{K}_{4} \mathrm{UO}_{2}\left(\mathrm{CO}_{3}\right)_{3}$ and $\mathrm{K}_{4} \mathrm{PuO}_{2}\left(\mathrm{CO}_{3}\right)_{3}$ Hermann $^{56}$ also reported that a partial separation of amencium from lanthanum could be obtained by fractional precipitation of $\mathrm{La}_{2}\left(\mathrm{C}_{2} \mathrm{O}_{4}\right)_{3}$ from homogeneous solutions involving the slow hydrolysis of dimethyl oxalate to generate the precipitant, americium is enriched in the precipitate

Pressly ${ }^{64}$ devised an interesting precipitation process for separatıng Am(III) from $\mathrm{Pm}$ (III) In this scheme $\mathrm{Am}^{3+}$ and $\mathrm{Pm}^{3+}$ are coprecipitated as fluorides, which are then dissolved in a mixture of boric and nitric acids The resulting solution is made $3 M$ $\mathrm{H}_{2} \mathrm{SiF}_{6}$, on heating, $\mathrm{H}_{2} \mathrm{~S}_{1} \mathrm{~F}_{6}$ partially decomposes in to volatile $\mathrm{HF}$ and $\mathrm{S}_{1} \mathrm{~F}_{4}$, whereby $\mathrm{PmF}_{3}$ precipitates while $\mathrm{Am}^{3+}$ stays in solution Earlier, Werner ${ }^{38}$ and Thompson ${ }^{39}$ also used to advantage the soluble complex formed by $\mathrm{Am}^{3+}$ with fluosilicate ions to isolate micrograms of americium from rare earths

Kuznetsov and Akimova ${ }^{6}$ found that microgram amounts of Am(III) coprecipitate with the black solids precipitated by the addition of the dyes methyl violet, crystal violet, or methylene blue to solutions containing americium and one of the compounds benzene-2 arsonic acid $<1$-azo-7 $>1$,8-dihydroxynaphthalene-3,6-disulfonic acid (Arsenazo), 2-hydroxy-5-nitro-naphthalene-4-sulfonic acid-<1-azo-2>-1-hydroxynaphthalene (Eriochrome black T), or benzene-2-carboxyl-<1-azo-7>-1,8-dihydroxynaphthalene-3, 6-disulfonic acid The extent of coprecipitation of $\mathrm{Am}^{3+}$ varies with $\mathrm{pH}$ but is essentially $100 \%$ at $\mathrm{pH}$ 's $\geqslant 60$ Americium(III) is also carried by the precipitate formed by addition of 1,8-diaminonaphthalene chloride to a solution containing ammonium oxalate and oxalic acld ${ }^{65}$

\section{Present-Day Precipitation Processes}

Flow sheets currently used ${ }^{66}$ at the Transuranium Processing Plant at Oak Ridge National Laboratory (ORNL) to purify the ${ }^{243} \mathrm{Am}-{ }^{244} \mathrm{Cm}$ fraction recovered from both High Flux Isotope Reactor (HFIR) and Savannah River reactor $\mathrm{PuO}_{2}$ and/or $\mathrm{AmO}_{2}-\mathrm{CmO}_{2}$ targets include two cycles of oxalate precipitation to remove miscellaneous metallic impunties European workers ${ }^{6768}$ have also used an oxalate precipitation process to purify amencium and cunum separated from irradiated ${ }^{243}$ Am targets

A precipitation process for separating gram to kılogram amounts of curium from amencium is still used occasionally 686974 In this process (Fig 53 ), Am(III) in 


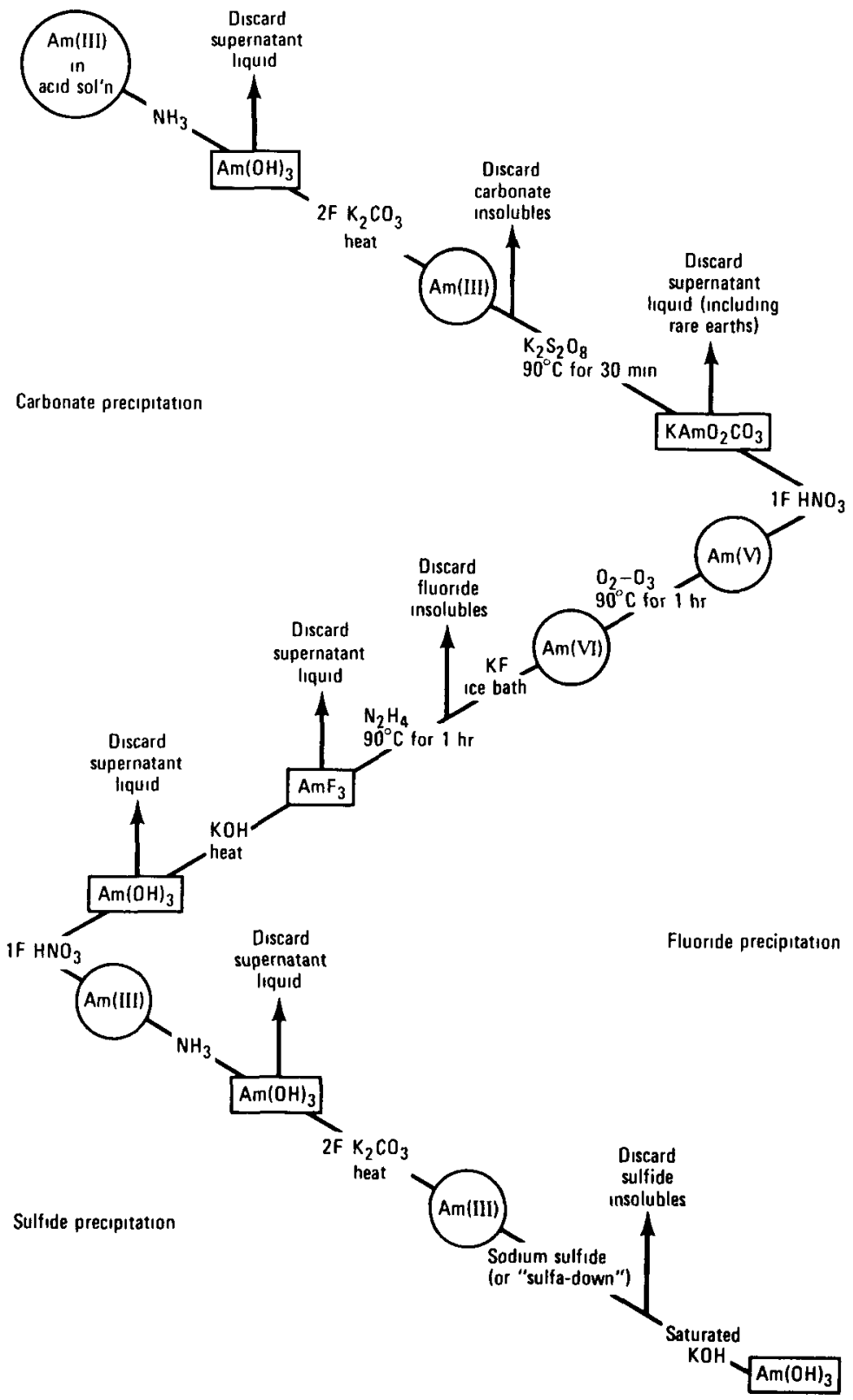

Fig. 5.2 Typical precipitation process developed for the recovery and purification of gram amounts of americium. ${ }^{47}$ 


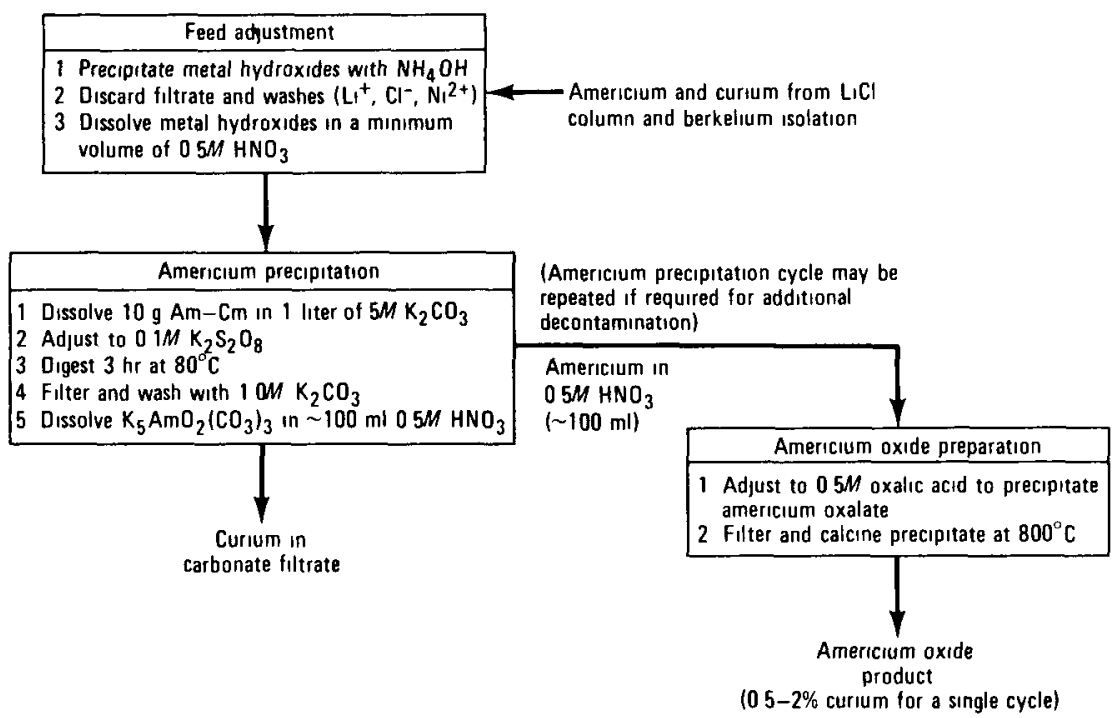

Fig. 5.3 Americium-curium separation by precipitation of $\mathrm{K}_{5} \mathrm{AmO}_{2}\left(\mathrm{CO}_{3}\right)_{3}$. [From R. E. Leuze and M. H. Lloyd, ${ }^{76}$ Processing Methods for the Recovery of Transplutonium Elements, in Progress in Nuclear Energy, Process Chemistry, Series III, C. E. Stevenson, E. A. Mason, and A. T. Gresky (Eds.), Vol. 4, page 549, Pergamon Press, Inc., New York, 1970.]

concentrated $(\geqslant 3 M) \mathrm{K}_{2} \mathrm{CO}_{3}$ solution is oxidized to $\mathrm{Am}(\mathrm{V})$ at $80^{\circ} \mathrm{C}$ with ozone, $\mathrm{NaOCl}$, or $\mathrm{K}_{2} \mathrm{~S}_{2} \mathrm{O}_{8}$ and subsequently precipitated as $\mathrm{K}_{5} \mathrm{AmO}_{2}\left(\mathrm{CO}_{3}\right)_{3} ; \mathrm{Cm}$ (III) is not oxidized and remains as a soluble complex in the carbonate solution. [As early as 1952, Stephanou and Penneman ${ }^{49}$ found that $\mathrm{Cm}$ (III) could be separated from americium by oxidizing the latter to $\mathrm{Am}(\mathrm{VI})$ with $\mathrm{K}_{2} \mathrm{~S}_{2} \mathrm{O}_{8}$ and precipitating $\mathrm{CmF}_{3}$.] Equipment used at the Savannah River Plant for large-scale precipitation separation of americium and curium has been described by Kishbaugh et al. ${ }^{73}$

A process based on precipitation of the double sulfate $\mathrm{Am}_{2}\left(\mathrm{SO}_{4}\right)_{3} \cdot \mathrm{Na}_{2} \mathrm{SO}_{4} \cdot$ $\mathrm{H}_{2} \mathrm{O}$ (compare pages 164 and 165) with lanthanum as carrier was successfully used $^{75,76}$ at the Savannah River Plant to recover $200 \mathrm{~g}$ of americium and curium from the aqueous raffinate remaining after solvent extraction recovery of plutonium from highly irradiated plutonium--aluminum alloy (see Chap. 2, Fig. 2.2). Solutions of $\mathrm{NaHSO}_{4}, \mathrm{NaOH}$, and $\mathrm{La}\left(\mathrm{NO}_{3}\right)_{3}$ were added to the nitrate-based raffinate to adjust its composition to approximately $5.5 M \mathrm{Na}^{+}, 0.5 \mathrm{M} \mathrm{Al}^{3+}, 1 M \mathrm{SO}_{4}^{2-}, 5 M \mathrm{NO}_{3}^{-}, 0.5 \mathrm{~g} \mathrm{La}^{3+}$ liter $^{-1},<25 \mathrm{mg} \mathrm{Am}^{3+}$ liter $^{-1}$, and $<25 \mathrm{mg} \mathrm{Cm}^{3+} \operatorname{liter}^{-1}$ at $\mathrm{pH} 0.5$. Best results for recovering americium and curium were obtained by adding $\mathrm{La}\left(\mathrm{NO}_{3}\right)_{3}$ carrier and then adjusting the sulfate concentration to $1.0 \mathrm{M}$ to $1.5 \mathrm{M}$ by addition of $\mathrm{NaHSO}_{4}$. Subsequently the solution was adjusted to $\mathrm{pH} 0.5$ to 1.0 by adding $50 \mathrm{wt} . \% \mathrm{NaOH}$ and digested $6 \mathrm{hr}$ at $70^{\circ} \mathrm{C}$ to form the double sulfates. After centrifugation, the sulfate precipitate was washed with dilute $\mathrm{Na}_{2} \mathrm{SO}_{4}$ solution and then metathesized to hydroxides by treatment with $\mathrm{NaOH}$ solution. The resulting hydroxides were washed 
and dissolved in $\mathrm{HNO}_{3}$ to provide a concentrated americium-curium fraction for further purification at the Oak Ridge Transuranium Processing Plant.

Variables affecting carrier precipitation of americium and curium double sulfates were studied by Burney; his results, including data for solubility of carrier-free americium and curium double sulfates, have been summarized by Leuze and Lloyd. ${ }^{76}$ On the basis of experience at the Savannah River Plant, the double sulfate precipitation process provides an adequate way of concentrating americium and purifying it from gross amounts of such impurities as iron and aluminum. Its principal disadvantage, as noted by Leuze and Lloyd ${ }^{76}$ is that the americium-curium product is contaminated with gross amounts of lanthanum which must be removed in further purification steps.

Until very recently when it was replaced by a cation-exchange process, a hydroxide precipitation process was routinely used at the Rocky Flats Plant to recover americium and plutonium values from the spent $\mathrm{NaCl}-\mathrm{KCl}-\mathrm{MgCl}_{2}$ mixture obtained from pyrochemical extraction of ${ }^{241} \mathrm{Am}$ from aged plutonium metal (pages 185-187). ${ }^{77}$ The chloride salt residue was dissolved in hot $1 M \mathrm{HCl}$, and the plutonium and americium precipitated as hydroxides with $3 M \mathrm{KOH}$. After the precipitate was washed with $0.5 M \mathrm{KOH}$, it was filtered and then dissolved in $3 M \mathrm{HNO}_{3}$ in preparation for separating americium and plutonium by an ion-exchange process. This precipitation process had several deficiencies: (1) slow filtration because of the gelatinous nature of the precipitate, (2) carry-over of magnesium that caused inefficiency in subsequent processing, and (3) a high carry-over of chloride ion that caused equipment corrosion. To circumvent these difficulties, Miner and Hogan ${ }^{78}$ developed a new selective, hydroxide precipitation process based on the slow decomposition of urea; the precipitate formed from the slow release of hydroxyl ions is fairly crystalline, easily filtered, and substantially free of magnesium and chloride. This latter homogeneous precipitation process has not been operated under plant-scale conditions.

Proctor et al. ${ }^{79-81}$ at the Rocky Flats Plant use precipitation processes to purify gram quantities of production-grade $\mathrm{AmO}_{2}$ from cerium and other rare earths. In one process, adopted from the work of Zaozerskii and Patkin, ${ }^{82}$ an americium solution of $30 \mathrm{~g} \mathrm{liter}^{-1}$ is prepared by dissolving the impure $\mathrm{AmO}_{2}$ in $6 \mathrm{M} \mathrm{HCl}$. After the addition of $20 \mathrm{vol} . \% \mathrm{NH}_{4} \mathrm{OH}$ to adjust the solution $\mathrm{pH}$ to $5, \mathrm{Ce}(\mathrm{IV})$ peroxide is precipitated by adding $2 \mathrm{M} \mathrm{H}_{2} \mathrm{O}_{2}$. Subsequently $\mathrm{Am}_{2}\left(\mathrm{C}_{2} \mathrm{O}_{4}\right)_{3}$, precipitated from the peroxide filtrate, is digested $16 \mathrm{hr}$ at $60^{\circ} \mathrm{C}$, washed, dried, and calcined to $\mathrm{AmO}_{2}$. Two cycles of peroxide precipitation and supplemental oxalate precipitation reduce the cerium content of the $\mathrm{AmO}_{2}$ from as much as $50,000 \mathrm{ppm}$ to $<500 \mathrm{ppm}$. A more general precipitation process patented by Proctor ${ }^{81}$ for preparing high-purity $\mathrm{AmO}_{2}$ is depicted in Fig. 5.4. This scheme makes use of the fact that Am(VI) is soluble in the hydrofluoric acid solution used to precipitate rare earths. Coupling of the fluoride precipitation step with tail-end precipitation of $\mathrm{Am}_{2}\left(\mathrm{C}_{2} \mathrm{O}_{4}\right)_{3}$ to remove lead and silver impurities yields $\mathrm{AmO}_{2}$ containing only 500 to $600 \mathrm{ppm}$ total impurities. The scheme shown in Fig. 5.4 was used by Proctor ${ }^{83}$ recently to purify $57 \mathrm{~g}$ of americium from $200 \mathrm{~g}$ of a composite of aluminum metal; in this case aluminum was first separated by dissolution in an $\mathrm{NaOH}-\mathrm{NaNO}_{3}$ solution. 


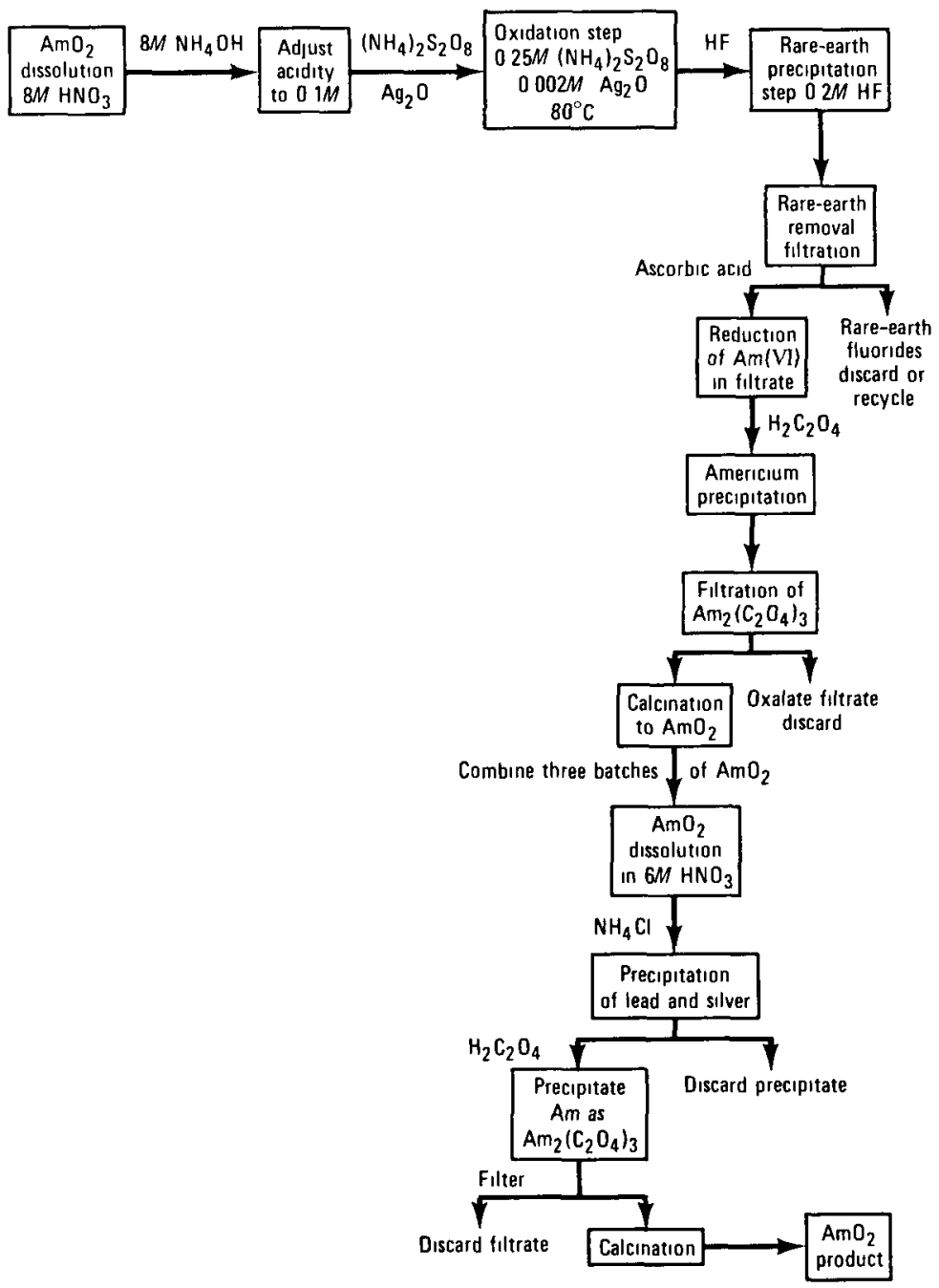

Fig. 5.4 Precipitation process used at Rocky Flats Plant to make high-purity $\mathrm{AmO}_{2}$.

Precipitation processes still figure prominently in new analytical methods for the determination of trace amounts of americium in process and environmental samples. Iyer and Kamath ${ }^{84}$ have developed a novel method of analyzing for americium in urine which involves coprecipitation of $\mathrm{Am}^{3+}$ with $\mathrm{BiOCl}$. Sill and Williams ${ }^{85}$ carry $\mathrm{Am}^{3+}$ and other actinides on $\mathrm{BaSO}_{4}$ to analyze for trace amounts of these elements in various matrices; recent physicochemical studies of coprecipitation of americium with $\mathrm{BaSO}_{4}$ and with $\mathrm{BaC}_{2} \mathrm{O}_{4}$ have been reported by Ginzburg, Karantsevich, and Maksimov ${ }^{86}$ and by Bykhovskii and Petrova, ${ }^{87}$ respectively. 


\title{
SOLVENT EXTRACTION PROCESSES
}

\author{
Introduction
}

Solvent extraction technology is widely used for the recovery, separation, decontamination, and analysis of both trace and macro amounts of americium. In particular, solvent extraction processes and systems using amine and organophosphorus extractants are extensively used for the initial recovery and separation of gram amounts of americium from a wide variety of aqueous solutions; the discussion here is restricted primarily to their technology. Weaver ${ }^{88}$ has recently published an excellent up-to-date general review of the solvent extraction chemistry of trivalent americium; Weaver's paper includes much information previously reviewed earlier by other authors. ${ }^{8-94}$ Solvent extraction systems for the analysis of americium have been discussed by Myasoedov et al. ${ }^{95}$

\section{Organophosphorus Extractants}

Tri- $n$-Butyl Phosphate, Extraction of $\mathrm{Am}^{3+}$ from nitrate media by tri- $n$-butyl phosphate (TBP) conforms to the reaction: ${ }^{8,96-100}$

$$
\mathrm{Am}_{(\mathrm{aq})}^{3+}+3 \mathrm{NO}_{(\mathrm{aq})}^{-}+3 \mathrm{TBP}_{(\mathrm{org})} \rightleftharpoons \mathrm{Am}\left(\mathrm{NO}_{3}\right)_{3} \cdot 3 \mathrm{TBP}_{(\text {org })}
$$

The value of the equilibrium constant, $\mathrm{K}_{\mathrm{ex}}=\left[\mathrm{Am}\left(\mathrm{NO}_{3}\right)_{3} \cdot 3 \mathrm{TBP}\right] /\left[\mathrm{Am}^{3+}\right]\left[\mathrm{NO}_{3}^{-}\right]^{3}$ $[\mathrm{TBP}]^{3}$, for Eq. 5.3 at zero ionic strength is ${ }^{100} 0.4$. [Russian investigators ${ }^{101}$ have compiled a list of equilibrium constants for the extraction of americium by several neutral organophosphorus compounds; Table 5.2 is abstracted from their compilation.]

Tri- $n$-butylphosphate, even undiluted, extracts americium only weakly from strong $\mathrm{HNO}_{3}$ solutions (Fig. 5.5). [Throughout this book the americium distribution ratio, $\mathrm{D}_{\mathrm{Am}} \equiv$ concentration of americium in organic phase/concentration of americium in aqueous phase.] However, TBP extracts americium quite strongly from neutral (or low-acid), highly salted nitrate solutions as shown by results listed in Table 5.3 and the more extensive data tabulated in Refs. 102 and 103. Highly hydrated ions such as $\mathrm{Al}^{3+}$ and $\mathrm{Li}^{+}$are particularly effective as salting agents. Reflecting its low TBP extractability from $\mathrm{HNO}_{3}$ solutions, $\mathrm{Am}^{3+}$ in Purex-type extraction processes reports to the high-level aqueous waste stream; this latter solution then constitutes a valuable and important feedstock for recovering americium by the various solvent extraction processes described here and elsewhere in this chapter.

Batch TBP solvent extraction procedures have been successfully used recently at both the Hanford and Savannah River plants to recover hundreds of grams of ${ }^{241} \mathrm{Am}$ and ${ }^{243} \mathrm{Am}$ from fuel-reprocessing waste solutions. The Savannah River application involved isolating $\sim 10 \mathrm{~kg}$ of ${ }^{243} \mathrm{Am}$ and ${ }^{244} \mathrm{Cm}$ from the aqueous solution remaining after dissolving an irradiated plutonium-aluminum alloy (see Chap. 2, Fig. 2.2) in 
Table 5.2

EQUILIBRIUM CONSTANTS FOR THE EXTRACTION OF Am(III) BY SOME NEUTRAL ORGANOPHOSPHORUS COMPOUNDS*

\begin{tabular}{lc}
\multicolumn{1}{c}{ Reagent } & $\mathrm{K}_{\text {ex }} \dagger$ \\
\hline$\left(\mathrm{C}_{4} \mathrm{H}_{9} \mathrm{O}\right)_{3} \mathrm{PO}$ & $0.4 \ddagger$ \\
$\left(\mathrm{C}_{4} \mathrm{H}_{9} \mathrm{O}\right)_{2}\left(\mathrm{C}_{4} \mathrm{H}_{9}\right) \mathrm{PO}$ & 74 \\
$\left(\mathrm{C}_{4} \mathrm{H}_{9} \mathrm{O}\right)\left(\mathrm{C}_{4} \mathrm{H}_{9}\right)_{2} \mathrm{PO}$ & 1800. \\
$\left(\mathrm{C}_{4} \mathrm{H}_{9}\right)\left(\mathrm{C}_{6} \mathrm{H}_{5}\right)\left(\mathrm{C}_{4} \mathrm{H}_{9} \mathrm{O}\right) \mathrm{PO}$ & 45 \\
$\left(\mathrm{C}_{8} \mathrm{H}_{17} \mathrm{O}\right)_{3} \mathrm{PO}$ & 0.3 \\
$\left(l \mathrm{C}_{8} \mathrm{H}_{17} \mathrm{O}\right)_{3} \mathrm{PO}$ & 02 \\
$\left(\mathrm{C}_{8} \mathrm{H}_{17} \mathrm{O}\right)_{2}\left(\mathrm{C}_{8} \mathrm{H}_{17}\right) \mathrm{PO}$ & 42 \\
$\left(\mathrm{C}_{8} \mathrm{H}_{17} \mathrm{O}\right)\left(\mathrm{C}_{8} \mathrm{H}_{17}\right)_{2} \mathrm{PO}$ & 580. \\
$\left(\mathrm{C}_{8} \mathrm{H}_{17}\right)_{3} \mathrm{PO}$ & 3000 \\
$\left(l-\mathrm{C}_{8} \mathrm{H}_{17}\right)_{3} \mathrm{PO}$ & 100. \\
\hline
\end{tabular}

*[I rom F. S Gureev, V. B Dedov, S. M. Karpacheva, I. K. Shvetsov, M N Ryhzov, P S Trukchlayev, G. N Ydkovlev, and I. A. Lebedev, ${ }^{101}$ Methods of Recovery and Some Chemical Properties of the Transplutonium Elements, in Progress in Nuclear Energy, Process Chemistry, Series III, C. E. Stevenson, F A Mdson, and A. T. Gresky (Eds.), Vol. 4, p. 631, Pergamon Press, Inc., New York, 1970]

$\dagger K_{\text {ex }}=\left[\mathrm{Am}\left(\mathrm{NO}_{3}\right)_{3} \cdot 30\right]_{\mathrm{org}} /\left[\mathrm{Am}^{3+}\right]_{\mathrm{dq}}\left[\mathrm{NO}_{3}\right]_{\mathrm{aq}}^{3}[\mathrm{O}]_{\text {org }}^{3}$, where $\mathrm{O}$ is the organophosphorus es tractant, values listed are for zero ionic strength.

$\uparrow$ Value from Ref. 100

$\mathrm{HNO}_{3}$ and recovering the plutonium by TBP extraction. The solution was adjusted to $65 \mathrm{M}$ to $6.8 \mathrm{M}$ inextractable nitrate $\left[\sim 0.67 \mathrm{M} \mathrm{Al}\left(\mathrm{NO}_{3}\right)_{3}-4.5 \mathrm{M} \mathrm{NaNO} \mathrm{N}_{3}\right]$ and $0.10 M$ to $035 \mathrm{M} \mathrm{HNO}_{3}$ before extracting the americium and curnum with two successive equal volume portions of $50 \mathrm{vol} \% \mathrm{TBP}$ in a hydrocarbon diluent. Subsequently the amencium and curnum were stripped into $0.2 \mathrm{MHNO}_{3}$. Recovery was greater than $95 \%$ with 5680-liter batches on a plant scale, essentially no aluminum or fission products other than lanthanides, ${ }^{95} \mathrm{Zr}$, and ${ }^{106} \mathrm{Ru}$ were extracted. Detals of the Savannah River experience have been recounted by Henry ${ }^{74}$ and others ${ }^{104-105} \mathrm{~b}$

At Hanford, batch TBP extraction was used to recover about $1100 \mathrm{~g}$ of americium, $60 \mathrm{~g}$ of curlum, and $200 \mathrm{~g}$ of promethium from the aqueous waste produced when Shippingport reactor fuel was processed in the Redox plant. ${ }^{106-109}$ This waste solution, after concentration, contained, typically, $16 \mathrm{M} \mathrm{Al}\left(\mathrm{NO}_{3}\right)_{3}-1.5 M \mathrm{NaNO}_{3}-$ $02 \mathrm{M} \mathrm{Na}_{2} \mathrm{Cr}_{2} \mathrm{O}_{7}$ and $06 \mathrm{M} \mathrm{NaF}$. Feed (16,500 liters) for the batch TBP extraction step was prepared by reducing $\mathrm{Cr}$ (VI) to $\mathrm{Cr}$ (III) by adding $\mathrm{NaNO}_{2}$ and adjusting the $\mathrm{pH}$ to the range 00 to 0.5 . The solvent, 50 vol. $\%$ TBP in $n$-paraffin hydrocarbon (NPH) diluent, was contacted with successive equal-volume amounts ( 2650 to 3800 liters) of feed until excessive aqueous raffinate waste losses indicated the need to reduce the product loading. The loaded organic phase was then contacted with one-half of its 


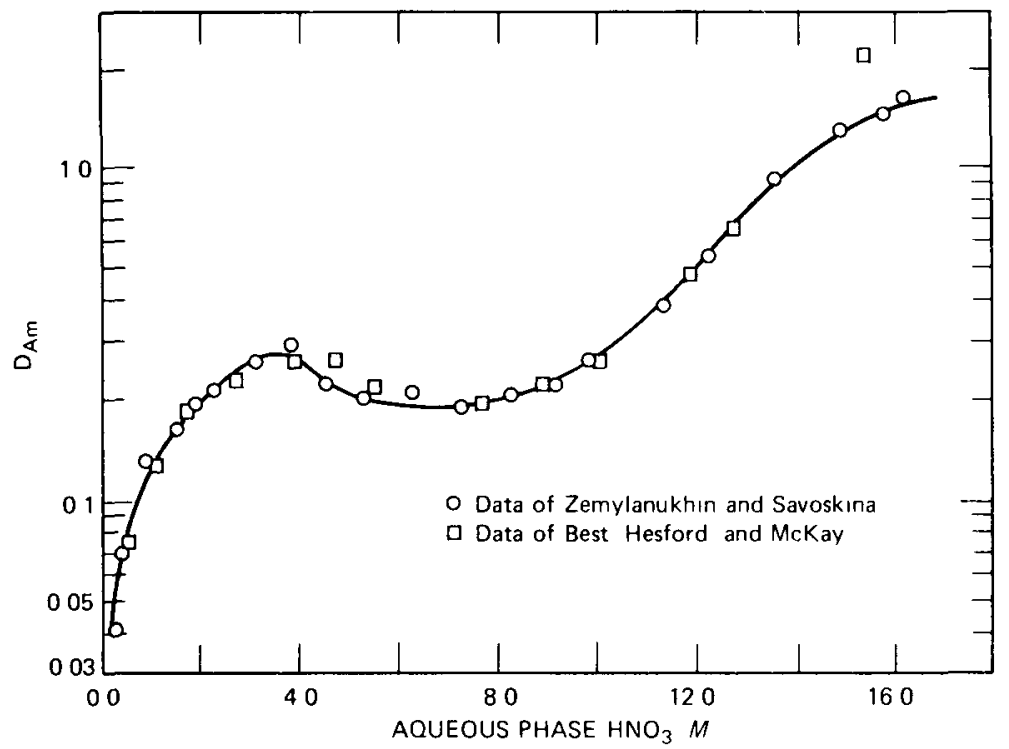

Fig. 5.5 Extraction of Am(III) by undiluted TBP [From V I Zemlyanukhin and G P Savoskina, ${ }^{99}$ I xtraction of Americium by Tributyl Phosphate, Radiokhimiya 3411 (1961) through Radiochemistry (USSR) (English Translation) 3(4) 182 (1961), and G F Best, E Hesford, and H A C McKay, ${ }^{9}$ Tri $n$ Butyl Phosphate as an Extracting Agent for Inorganic Nitrates VII, The Trivalent Actinide Nitrates Journal of Inorganic and Nuclear Chemistry, 12 136 (1959) ]

volume of $1 M \mathrm{HNO}_{3}$ to strip the americium and curium The resulting aqueous product solution (Table 54 ) was scrubbed with NPH diluent to remove entrained TBP, recovery and punfication of americium and cunum from this crude concentrate by extraction with bis(2-ethylhexyl)phosphoric acid is described on pages 208 to 220 The TBP process recovered about $92 \%$ of the amencium and curlum in the Shippingport waste Excessively long phase disengagement times encountered in some extraction contacts were attributed to the high solids content of the Shippingport waste solution These solids were believed to be $\mathrm{ZrO}_{2}$ fines left in the dissolver vessel after the decladding step and those formed during evaporation of the waste to a high salt concentration

Batch TBP extraction procedures have also been developed and applied in France $^{71}$ and Japan ${ }^{10}$ to recover small amounts of americium and curium from nuclear fuel-processing waste solutions A continuous counter current TBP extraction process for the recovery of grams of amencium from Hanford slag and crucible waste was developed by Ranney ${ }^{111}$ Following the dissolution of the slag and crucible in $\mathrm{HNO}_{3}-\mathrm{HF}$ media, $\mathrm{Pu}(\mathrm{IV})$ was first recovered by extraction with $30 \%$ TBP In Rainey's process, excess $(5 M) \mathrm{HNO}_{3}$ in the aqueous waste from the plutonium extraction step was neutralized to $001 M$ with gaseous $\mathrm{NH}_{3}$ The resulting feed 
Table 5.3

DISTRIBUTION OF Am(III) BETWEEN 30 VOL.\% TBP- $n$-PARAFFIN AND AQUEOUS Al(NO $)_{3}-\mathrm{LiNO}_{3}-\mathrm{NaNO}_{3}$ SOLUTIONS*

\begin{tabular}{cccccc}
\hline \multirow{2}{*}{$\mathbf{A l}\left(\mathrm{NO}_{3}\right)_{3}}$, & $\mathrm{LiNO}_{3}$, & $\mathrm{NaNO}_{3}$, & \multicolumn{2}{c}{$\mathrm{HNO}_{3}, M$} & \\
\cline { 5 - 6 } & $M$ & $M$ & Aqueous & Organic & D \\
\hline 0.73 & 3.15 & 0 & 0.055 & 0.355 & 21.0 \\
0.73 & 3.15 & 0 & 0.135 & 0.565 & 7.57 \\
0.73 & 3.15 & 0 & 0.285 & 0.710 & 3.05 \\
0.73 & 3.15 & 0 & 0.345 & 0.745 & 2.26 \\
1.05 & 0 & 3.23 & 0.050 & 0.360 & 10.1 \\
1.05 & 0 & 3.23 & 0.145 & 0.555 & 4.07 \\
1.05 & 0 & 3.23 & 0.320 & 0.675 & 1.69 \\
1.05 & 0 & 3.23 & 0.375 & 0.715 & 1.21 \\
0 & 3.09 & 2.99 & 0.040 & 0.370 & 8.49 \\
0 & 3.09 & 2.99 & 0.160 & 0.540 & 4.14 \\
0 & 3.09 & 2.99 & 0.345 & 0.650 & 1.76 \\
0 & 3.09 & 2.99 & 0.431 & 0.659 & 1.38 \\
0.75 & 2.07 & 1.93 & 0.025 & 0.385 & 24.8 \\
0.75 & 2.07 & 1.93 & 0.125 & 0.575 & 6.55 \\
0.75 & 2.07 & 1.93 & 0.280 & 0.685 & 2.66 \\
0.75 & 2.07 & 1.93 & 0.372 & 0.718 & 1.95 \\
\hline
\end{tabular}

*Irom Ref. 103.

solution, which contained large amounts of $\mathrm{Ca}^{2+}, \mathrm{Mg}^{2+}$, and $\mathrm{Al}^{3+}$, was contacted with a $30 \%$ TBP solution to extract the americium. Subsequently the organic extract was scrubbed with $3 M \mathrm{NH}_{4} \mathrm{NO}_{3}$ solution to remove any extracted calcium and magnesium, and the americium was then stripped into water. This process was satisfactorily tested in pulse column runs with actual slag and crucible waste solution but was never used at Hanford (compare pages 202 to 205).

Reflecting their chemical similarity, Am(III) and trivalent lanthanides extract about equally well from $\mathrm{HNO}_{3}$ solutions into TBP solvents. ${ }^{12,113}$ Thus considerable effort has been expended to devise TBP extraction processes for purifying americium from lanthanum and other rare-earth elements. One such process (Fig. 5.6) developed by Lewis ${ }^{114}$ takes advantage of the fact that, in $17 M \mathrm{HNO}_{3}, \mathrm{D}_{\mathrm{Am}}$ is 10 -fold higher than $\mathrm{D}_{\mathrm{La}}$ (Fig. 5.7). In the flow sheet of Lewis, undiluted TBP is used to extract the americium from the $17 M \mathrm{HNO}_{3}$ feed. Small amounts of coextracted lanthanum and cerium are scrubbed with a small volume of $13.5 M \mathrm{HNO}_{3}$, and the americium is then stripped into $6 M \mathrm{HNO}_{3}$. In pilot-plant-scale tests of this flow sheet, americium recoveries were $99.5 \%$, and the recovered americium contained less than $1 \%$ of the lanthanum and cerium in the feed. Satisfactory $17 M \mathrm{HNO}_{3}$ feedstock containing only americium and rare earths can be prepared by preliminary TBP extraction from an $\mathrm{Al}\left(\mathrm{NO}_{3}\right)_{3}$-salted low-acid feed. A TBP extraction process similar to that shown in 
Table 5.4

PRODUCT FROM TBP BATCH EXTRACTION

OF AMERICIUM AND CURIUM FROM

SHIPPINGPORT REACTOR FUEL-PROCESSING WASTE

(Estimated Volume 1040 liters)

\begin{tabular}{|c|c|}
\hline Component & Concentratıon \\
\hline $\begin{array}{l}\mathrm{HNO}_{3} \\
\mathrm{Al}\left(\mathrm{NO}_{3}\right)_{3} \\
\mathrm{NaNO}_{3} \\
\mathrm{Cr}\left(\mathrm{NO}_{3}\right)_{3} \\
\mathrm{Ie}\left(\mathrm{NO}_{3}\right)_{3}\end{array}$ & $\begin{array}{ll}2 & 2 M \\
0 & 3 M \\
0 & 2 M \\
0 & 1 M \\
0 & 08 M\end{array}$ \\
\hline $\begin{array}{l}\mathrm{F} \\
\mathrm{UO}_{2}\left(\mathrm{NO}_{3}\right)_{2} \\
\text { Totdl rare edrths* } \\
{ }^{21} \mathrm{Am} \\
{ }^{243} \mathrm{Am}\end{array}$ & $\begin{array}{l}006 M \\
006 M \\
346 \mathrm{~g} \text { liter }^{1} \\
087 \mathrm{~g} \mathrm{liter}^{1} \\
025 \mathrm{~g} \mathrm{liter}^{1}\end{array}$ \\
\hline $\begin{array}{l}242 \mathrm{Cm} \\
24{ }^{4} \mathrm{Cm} \\
\mathrm{Np} \\
\mathrm{Pu} \\
1{ }^{47} \mathrm{Pm}\end{array}$ & $\begin{array}{l}000045 \text { g liter } \\
0061 \mathrm{~g} \mathrm{liter}^{1} \\
0024 \mathrm{~g} \mathrm{liter}^{1} \\
0016 \mathrm{~g} \mathrm{liter}^{-1} \\
238 \mathrm{Cl} \text { liter }\end{array}$ \\
\hline $\begin{array}{l}144 \mathrm{Ce}{ }^{144} \mathrm{Pr} \\
154 \mathrm{Lu} \\
106 \mathrm{Ru}-{ }^{106} \mathrm{Rh} \\
137 \mathrm{Cs}\end{array}$ & $\begin{array}{r}235 \mathrm{C}_{1} \text { liter }^{1} \\
12 \mathrm{C}_{1} \text { liter }^{-1} \\
55 \mathrm{C}_{1} \text { liter }^{1} \\
21 \mathrm{C}_{1} \text { hiter }^{1}\end{array}$ \\
\hline
\end{tabular}

*As oxıdes

Fig 56 was proposed by Leuze ${ }^{115}$ for the recovery and purification (from rare earths) of americium and curium from irradiated plutonium-aluminum alloy fuel Neither this process nor that of Lewis has been used in routine plant-scale operation

Both French ${ }^{116}$ and American workers ${ }^{117}$ have studied the effects of aminopoly carboxylic acids on TBP extraction of americium from low-acid $\mathrm{LiNO}_{3}$ and $\mathrm{Al}\left(\mathrm{NO}_{3}\right)_{3}$ solutions Formation constants of complexes formed by Am(III) with aminopolycarboxylic acids (compare Table 3 11) are higher than those of complexes of the light lanthanides ( $Z=57$ to 61$)$ with these ligands Thus, addition of an aminopolycarboxylic acid to an $\mathrm{L}_{1} \mathrm{NO}_{3}\left[\right.$ or $\left.\mathrm{Al}\left(\mathrm{NO}_{3}\right)_{3}\right]-\mathrm{Am}(\mathrm{III})$-rare earth (RE) solution enhances TBP extraction of the lanthanides relative to that of americium Separation factors $\left(D_{R L} / D_{A m}\right)$ measured by Koehly and coworkers ${ }^{116}$ for some typical aminopolycarboxylic acids are histed in Table 55 McKibben et al ${ }^{117}$ at the Savannah River Plant devised a TBP extraction process (Fig 5 8) for separating americium and curium from large amounts of light lanthanides Feedstock for this process is prepared by adding $\mathrm{LiNO}_{3}$ and diethylenetriaminepentaacetic acid (DTPA) to the product solution obtained, as described earlier, by batch TBP extraction of americium and 


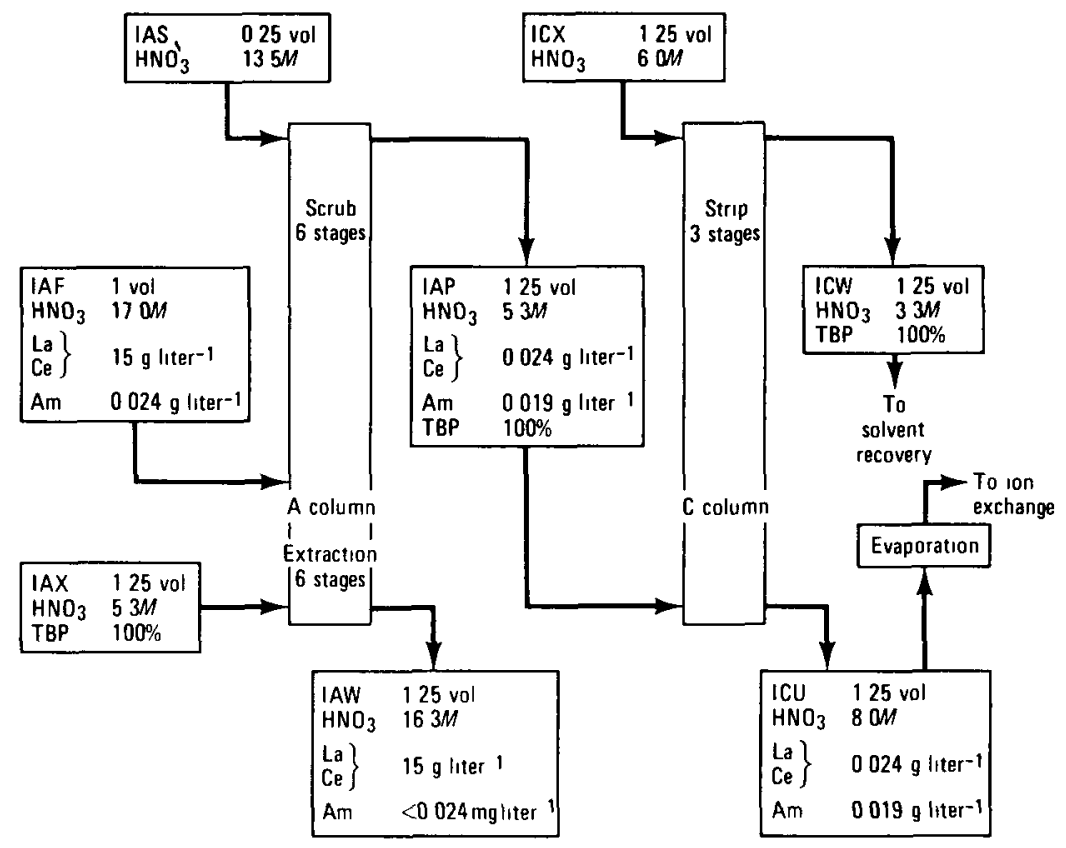

Fig. 5.6 TBP extraction flow sheet for the separation of americium from lanthanum and cerium (From $\mathrm{W} \mathrm{H}$ Lewis, ${ }^{14}$ Americium and Neptunium Recovery Processes, in Proceedings of the Second United Nations International Conference on the Peaceful Uses of Atomic Energy Geneva, 1958, Vol 17, page 236, United Nations, New York, 1958)

curium from the waste solution resulting from the processing of irradiated ${ }^{239} \mathrm{Pu}$ fuel Maleic acid is added to the extraction column via a scrub stream to buffer the aqueous phase and thereby decrease the sensitivity of the process to changes in aqueous acidity The aqueous raffinate containing the actinides and residual lanthanides can be further processed by extraction with $30 \% \mathrm{TBP}$ solvent to remove interfering salts $\left(\mathrm{L}_{1} \mathrm{NO}_{3}\right.$ and DTPA) prior to final separation and purification of ${ }^{243} \mathrm{Am}$ and ${ }^{244} \mathrm{Cm}$ by high-pressure 1on-exchange procedures (compare pages 245 to 252) The lanthande rejection process ( $F_{1} g$ 5 ) has been satisfactorily demonstrated in miniature mixersettler runs, but so far no production-scale use has been made of it

An in tensive effort was mounted at the Oak Ridge site in the 1960s to develop and demonstrate processes for separatıng and purifying transplutonum elements from highly irradiated HFIR (compare Chap 2) fuel elements Various methods of separating americium and curium from lanthanides were investigated as part of this activity One such scheme which provided reasonably good separation of the two actinides from europium and other rare earths involved preferential extraction of americium and curium from a $10 \mathrm{M} \mathrm{L1Cl}-01 M \mathrm{HCl}$ solution into $30 \% \mathrm{TBP}$ solvent ${ }^{11} 8$ Subsequent tests led, as described on pages 220 to 222 , to the development of a more 


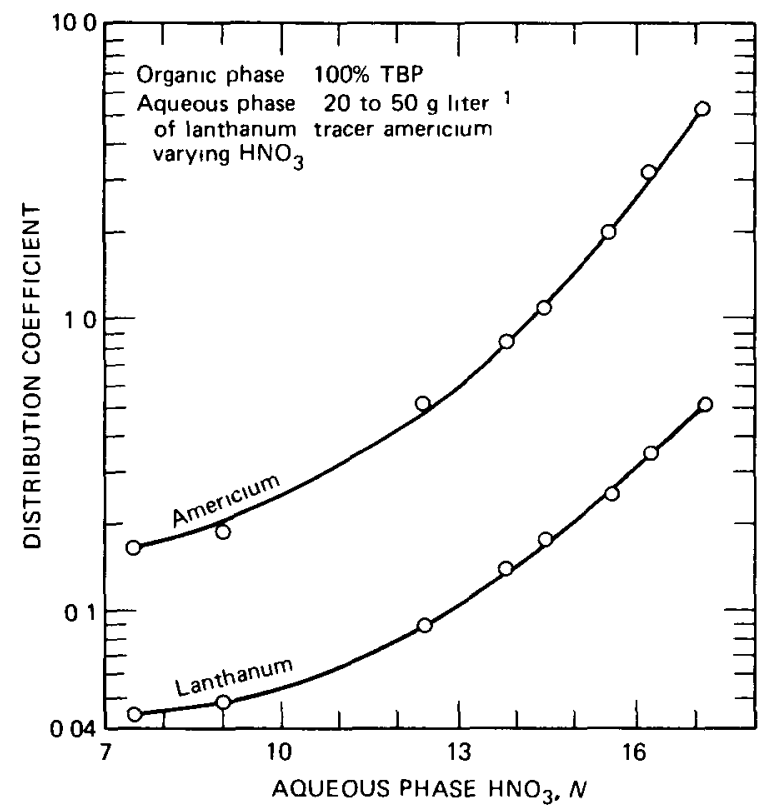

Fig. 5.7 TBP extraction of americium and lanthanum from concentrated $\mathrm{HNO}_{3}$ solutions (From W H Lewis, ${ }^{114}$ Americum and Neptunium Recovery Processes, in Proceedings of the Second United Nations International Conference on the Peaceful Uses of Atomic Energy, Geneva, 1958, Vol 17, page 236, United Nations, New York, 1958 )

efficient amine extraction process (Tramex process) for purifying americium and curium from rare earths

Penneman and Keenan ${ }^{32}$ report that Am(III) can be separated from rare earths by TBP extraction from $1 M \mathrm{NH}_{4} \mathrm{SCN}$ solutions The mechanism of extraction of Am(III) and $\mathrm{Eu}(\mathrm{III})$ from $1 \mathrm{M} \mathrm{NH}_{4} \mathrm{SCN}$ media by TBP both in the presence and in the absence of a quaternary ammonium thiocyanate was recently investigated by Indian scientists $^{119}$ Thiocyanate-TBP systems have not been used in production-scale recovery or punfication of amencium, thocyanate solutions have been much used, however, in large-scale 1on-exchange purification of americium from lanthanides and other contaminants (compare pages 234 to 237)

Chemistry involved in TBP extraction of Am(III) from molten $\left(120^{\circ} \mathrm{C}\right) \mathrm{KNO}_{3}-$ $\mathrm{L}_{1} \mathrm{NO}_{3}$ mixtures has been studied by Foos and Gullaumont, ${ }^{25} 27$ Isaak, Fields, and Gruen, ${ }^{120}$ and Borkowska, Mielcarsk1, and Taube ${ }^{121}$, some of their results are discussed on pages 187 to 189 No large-scale application of this separation technology has been made

Conflicting evidence has been obtained for TBP extraction of $\mathrm{Am}(\mathrm{VI})$ from $\mathrm{HNO}_{3}$ solutions Zangen ${ }^{122}$ found that $\mathrm{TBP}-\mathrm{CCl}_{4}$ solutions extract $\mathrm{Am}(\mathrm{VI})$ much more 
Table 5.5

EFFECT OF COMPLEXANTS ON TBP EXTRACTION OF AMERICIUM AND RARE EARTHS*

(Aqueous Phase: $4 M \mathrm{LiNO}_{3}-0.1 \mathrm{M}$ Al(NO$\left.)_{3}\right)_{3}-0.1 M$ Complexant, pH 2.5 to 3.0 ; Organic Phase: $40 \%$ TBP in Dodecane)

\begin{tabular}{|c|c|c|c|c|c|c|}
\hline \multirow[b]{3}{*}{ Lanthanide } & \multicolumn{6}{|c|}{ Separation factor $D_{R E} / D_{A m}$} \\
\hline & \multirow{2}{*}{$\begin{array}{l}\text { In absence of } \\
\text { complexant }\end{array}$} & \multicolumn{5}{|c|}{ With complexant $\dagger$ present } \\
\hline & & EDTA & DTPA & TTHA & DACTA & HPDTA \\
\hline $\mathrm{Ld}$ & & 20.5 & 1200 & 52 & 45 & \\
\hline $\mathrm{Ce}$ & 0.9 & 10.3 & 51 & 26 & 15 & \\
\hline $\operatorname{Pr}$ & 1.07 & 3.81 & 12.5 & 7.8 & 3.5 & \\
\hline $\mathrm{Pm}$ & 1.15 & 3.1 & 5.8 & 6.4 & 2.3 & \\
\hline I u & 1.35 & 2.9 & 1.96 & 3.1 & & 1.44 \\
\hline $\mathrm{Tb}$ & 1.55 & 0.62 & 1.03 & 1.5 & 0.80 & \\
\hline $\mathbf{E r}$ & 1.03 & 0.04 & 1.00 & 0.62 & 0.55 & \\
\hline $\mathrm{Tm}$ & 0.93 & 0.037 & 1.01 & 0.36 & 0.41 & \\
\hline $\mathrm{Yb}$ & 0.73 & 0.006 & 1.07 & 0.23 & 0.32 & \\
\hline
\end{tabular}

* I rom G. Koehly and I. Hoffert, ${ }^{116}$ Separation of the Actınide Group from That of the Lanthanides in Nitric Medium, in Semiannual Report of the Chemistry Department, Center for Nuclear Studies at I ontenay-Aux-Roses, December 1966-May 1967, I rench Report CEA-N-856, through USAI C Report ANL-Trans-628, Argonne National Laboratory, 1967.]

$\lceil$ LDTA = ethylenedidminetetracefic acid

DTPA = die thylenetriamınepentaacetic acıd

TTHA = triethylenetetramınehexacetıc acid.

DACTA $=1,2$-diaminocyclohexane te traacetic acid.

HPDTA $=$ 2-hydroxypropanediaminetetraacetic acid.

strongly than Am(III) from 0.05M $\mathrm{HNO}_{3}$. Conversely, other workers ${ }^{41.123}$ report that TBP rapidly reduces $\mathrm{Am}(\mathrm{VI})$ to inextractable $\mathrm{Am}(\mathrm{III})$.

Dibutyl butylphosphonate. Dibutyl butylphosphonate [DBBP $=\left(\mathrm{C}_{4} \mathrm{H}_{9} \mathrm{O}\right)_{2}$ $\left(\mathrm{C}_{4} \mathrm{H}_{9}\right) \mathrm{PO}$ ] extracts $\mathrm{Am}(\mathrm{III})$ from nitrate media according to the reaction:

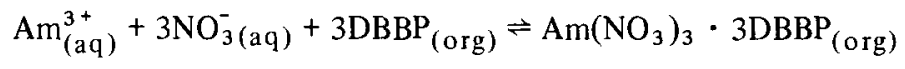

This reaction stoichiometry is similar to that followed by TBP (compare Eq. 5.3) and other monofunctional neutral organophosphorus extractants.

Distribution data plotted in Fig. 5.9 show that DBBP extracts Am(III) more strongly than TBP from nitrate solutions (compare also Table 5.2); DBBP is a powerful extractant for Am(III) from low-acid highly salted nitrate solutions. Distribution ratio data for DBBP extraction of $\mathrm{Am}(\mathrm{III})$ from $\mathrm{HNO}_{3}$ - metal nitrate solutions are listed in Refs. 100, 102, 125, and 126.

A production-scale countercurrent DBBP solvent extraction process (Fig. 5.10) is currently operated at Hanford to recover plutonium and americium values from the acid aqueous waste (CAW) solution produced in the operation of the Hanford 
Plutonium Reclamation Facility (PRF). [The PRF uses a reflux-type $20 \% \mathrm{TBP}-\mathrm{CCl}_{4}$ solvent extraction process to recover and purify plutonium from $\mathrm{HNO}_{3}$ and $\mathrm{HNO}_{3}-\mathrm{HF}$ solutions of a wide variety of metallurgical scrap. ${ }^{127.128}$ ] The present Hanford DBBP americium-plutonium recovery process evolved from an earlier batch extraction process devised by Kingsley. ${ }^{129,130}$ Important contributions to the development of the flow sheet shown in Fig. 5.10 were made by Lorenzen and Speakman, ${ }^{131}$ Taylor, $^{132}$ and Richardson. ${ }^{133}$

Feed for the Hanford DBBP americium extraction process is prepared by adding $\mathrm{NaOH}$ to the PRF aqueous waste to adjust its acidity from $\sim 2 M$ to $0.1 M \mathrm{HNO}_{3}$. Americium(III) and $\mathrm{Pu}(\mathrm{IV})$ in the adjusted feed are coextracted in to the $30 \%$ $\mathrm{DBBP}-\mathrm{CCl}_{4}$ solvent. Subsequently the americium is preferentially stripped into dilute $0.1 M \mathrm{HNO}_{3} ; \mathrm{Pu}(\mathrm{IV})$ and residual americium are stripped with an $\mathrm{HNO}_{3}-\mathrm{HF}$ solution. The latter solution is recycled to the mainline TBP process in the PRF, whereas the americium is concentrated and purified by the ion-exchange process described on pages 245 to 252 .

The Hanford DBBP americium extraction process is performed in three packed pulse columns; for the conditions shown in Fig. 5.10, the extraction column is

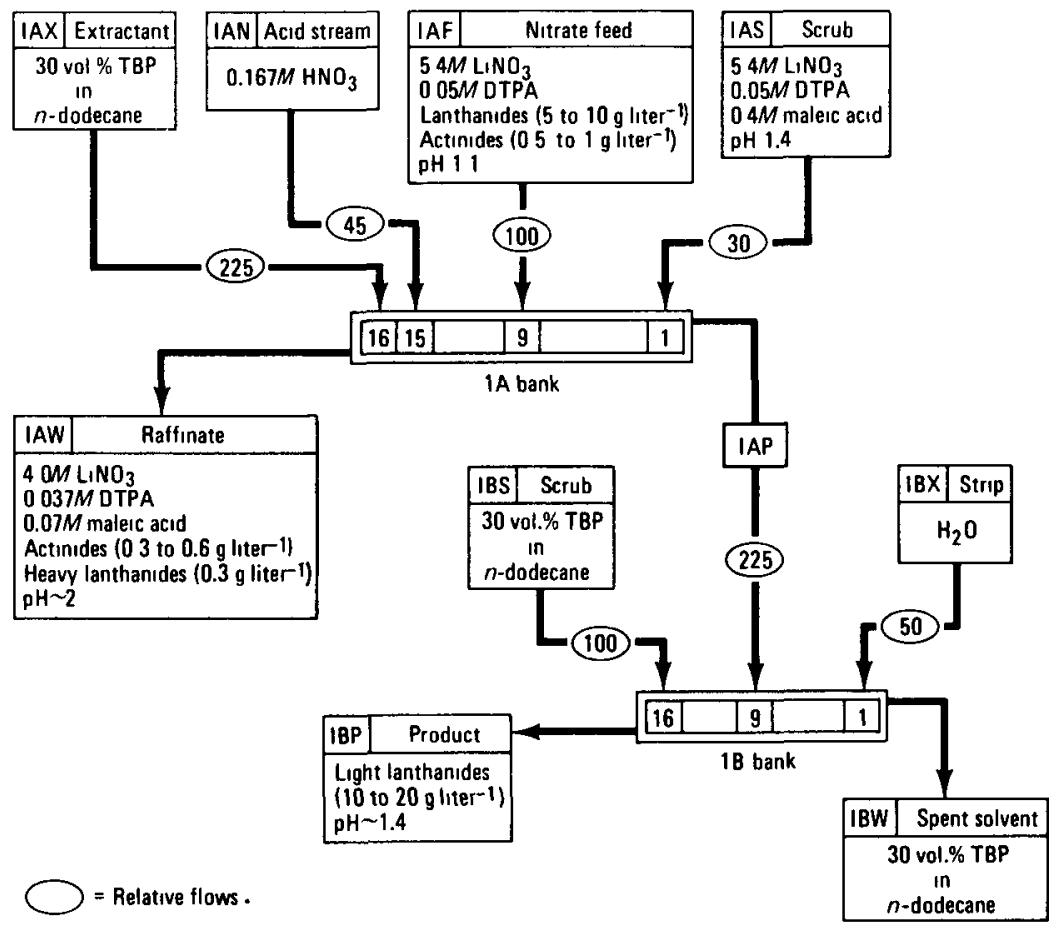

Fig. 5.8 Lanthanide rejection flow sheet-TBP extractıon process for separating americium and curium from light rare earths. ${ }^{17}$ 


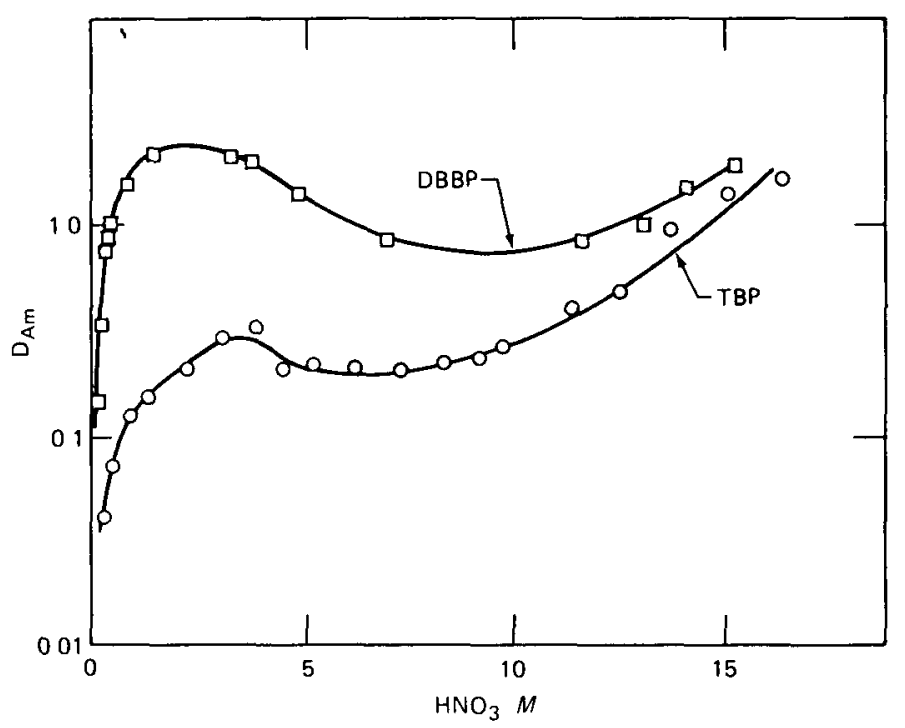

Fig. 5.9 Extraction of Am(III) from $\mathrm{HNO}_{3}$ by TBP and DBBP lAdapted from V.I. Zemlyanukhın, G P Savoskına, and M I Pushlenkov, ${ }^{124}$ Complex Formation of Nitrates of Transuranıum Elements with Neutral Organophosphorus Compounds, Radiokhımıya, 6: 714 (1964), through Soviet Radiochemistry (English Translation), 6: 690 (1964).]

calculated to operate with one to two extraction stages and one scrub stage, and the partition and plutonium strip columns each operate with three stages Overall, amenicium recovery in typical plant-scale operation with the DBBP extraction process ranges from 60 to $80 \%$, the relatively poor americium recovery is attributed primarily to improper in-line neutralization of $\mathrm{HNO}_{3}$ in the unbuffered CAW solution and to inadequate extraction-column equipment. The DBBP extraction process recovers essentally all the soluble plutonium in the feed to the process, however, any insoluble plutonium (e g, finely divided $\mathrm{PuO}_{2}$ ) is not recovered. The Hanford americium extraction process is operated with a small inventory of $30 \% \mathrm{DBBP}-\mathrm{CCl}_{4}$ solvent which is replaced frequently, for this reason the process operates satisfactorily without routine washıng of the solvent with $\mathrm{Na}_{2} \mathrm{CO}_{3}$ or $\mathrm{NaOH}$ solutions

Aside from the Hanford application, no other plant-scale use has been made of DBBP (or any other neutral phosphonate) for the recovery of americium. From time to tıme, however, workers in several countries have proposed conceptual phosphonate solvent extraction processes for the recovery and/or purification of amencium. For example, Schulz and Richardson ${ }^{134}$ suggested a DBBP solvent extraction process for the recovery of amencium and other actinide elements from the high-level aqueous waste stream resulting from the processing of irradiated $\mathrm{UO}_{2}-\mathrm{PuO}_{2}$ fuel in the Liquid Metal-Cooled Fast Breeder Reactor. The application of DBBP and other phosphonates 


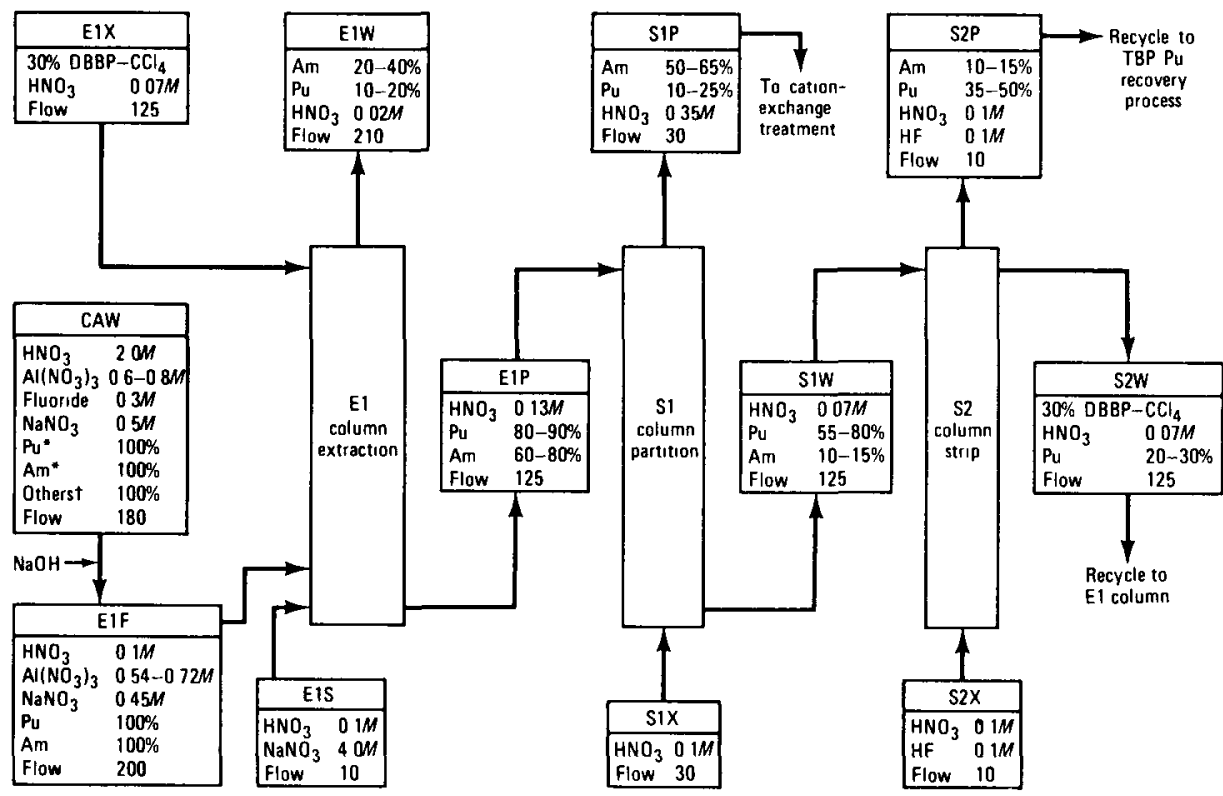

"CAW solution contains, typically, 0005 to $001 \mathrm{~g}$ liter-1 each of americium and plutonium tIncludes small concentrations of calcium, magnesium, iron, chromium, nickel, etc

Fig. 5.10 Hanford DBBP americium extraction process flow sheet.

for extracting americium and curium from $\mathrm{LiCl}-\mathrm{HCl}$ solutions was studied at Oak Ridge National Laboratory. ${ }^{18}$ Russian scientists ${ }^{101,135}$ have studied the extraction of $\mathrm{Am}$ (III) from $\mathrm{HNO}_{3}$ and $\mathrm{LiCl}$ solutions by diisoamyl methylphosphonate, and Koehly and Hoffert ${ }^{116}$ have investigated the extraction of $\mathrm{Am}$ (III) from $\mathrm{HNO}_{3}$ media by methyldibutylphosphonate.

Neutral Bifunctional Organophosphorus Compounds. Siddall ${ }^{136,137}$ in two papers published in the early 1960 s reported that certain neutral bifunctional organophosphorus compounds effectively extract trivalent lanthanides and actinides from strong $\mathrm{HNO}_{3}$ solutions. [This behavior contrasts sharply (Fig. 5.11) with that of such neutral monofunctional organophosphorus reagents as TBP and DBBP, which, as already noted, extract $\mathrm{Am}$ (III) only weakly from strong $\mathrm{HNO}_{3}$ media.] In particular, Siddall synthesized various methylenediphosphonates

$$
\begin{array}{cc}
\mathrm{O} & \mathrm{O} \\
\| & \| \\
{\left[(\mathrm{RO}-)_{2}\right.} & \left.\mathrm{P}-\mathrm{CH}_{2}-\mathrm{P}(-\mathrm{OR})_{2}\right]
\end{array}
$$


carbamyl phosphonates

$$
\left[\begin{array}{cl}
\mathrm{O} & \mathrm{O} \\
\| & \| \\
\left.[\mathrm{RO}-)_{2} \mathrm{P}-\mathrm{C}-\mathrm{N}(-\mathrm{R})_{2}\right]
\end{array}\right.
$$

and carbamyl methylenephosphonates

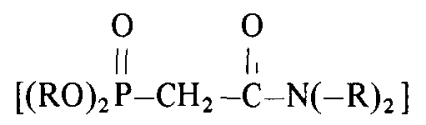

and determined their ability to extract $\mathrm{Am}^{3+}, \mathrm{Ce}^{3+}$, and $\mathrm{Pm}^{3+}$ from $01 M$ to $12 M$ $\mathrm{HNO}_{3}$ solutions $\mathrm{On}$ the basis of the favorable results of his exploratory studies, Siddall suggested such bidentate extractants could be used to remove trivalent lanthanıdes and actinides from high-level Purex process waste, this idea was eventually patented 138

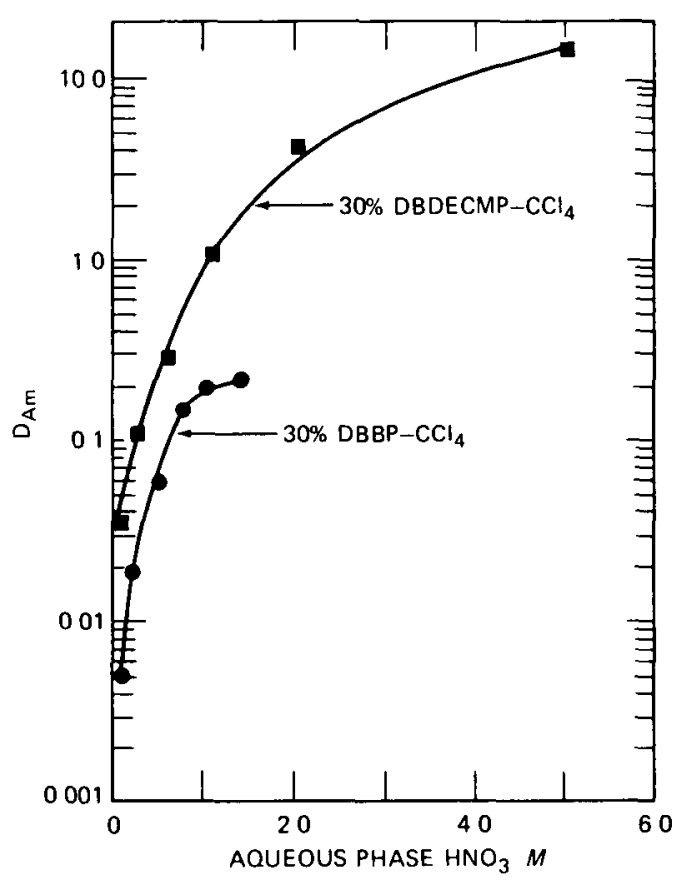

Fig. 5.11 Extraction of Am(III) by typical neutral monodentate and bidentate extractants DBBP $=$ dibutyl butylphosphonate, $\quad$ DBDECMP $=$ dibutyl $-N N$ diethylcarbamyl methylenephosphonate 
Schulz ${ }^{139}$ and McIsaac ${ }^{140}$ at the Hanford and Idaho Falls sites, respectively, have recently revived interest in plant-scale application of neutral bidentate organophosphorus extractants, particularly dihexyl- $N, N$-diethylcarbamyl methylenephosphonate (DHDECMP) and dibutyl- $N, N$-diethylcarbamyl methylenephosphonate (DBDECMP). McIsaac and coworkers are concerned with developing a bidentate solvent extraction scheme to remove small amounts of neptunium, plutonium, americium, and other actinides from the high-level waste resulting from processing of irradiated ${ }^{235} \mathrm{U}$-enriched fuels at the Idaho Chemical Processing Plant.

At Hanford, work is in progress to develop a solvent extraction process to replace the DBBP process (pages 202 to 205) presently used to recover americium and plutonium from neutralized $(\mathrm{pH} \mathrm{1})$ aqueous waste (CAW solution) produced in operation of the Hanford Plutonium Reclamation Facility. A conceptual flow sheet for DBDECMP (or DHDECMP) extraction of Am(III) and Pu(IV) directly from the acid $\left(\sim 2 \mathrm{M} \mathrm{HNO}_{3}\right)$ CAW stream is presented in Fig. 5.12 ; this flow sheet has been siccessfully demonstrated in miniature mixer-settler runs with an actual CAW solution.

Major deterrents to large-scale applications of carbamyl methylenephosphonate extractants include their current limited availability and high cost ( $\$ 50$ to $\$ 100$ per liter) and the need to purify them before use. As prepared by the Arbuzov or Michaelis reactions, ${ }^{136.137}$ both commercially available DHDECMP and DBDECMP contain an

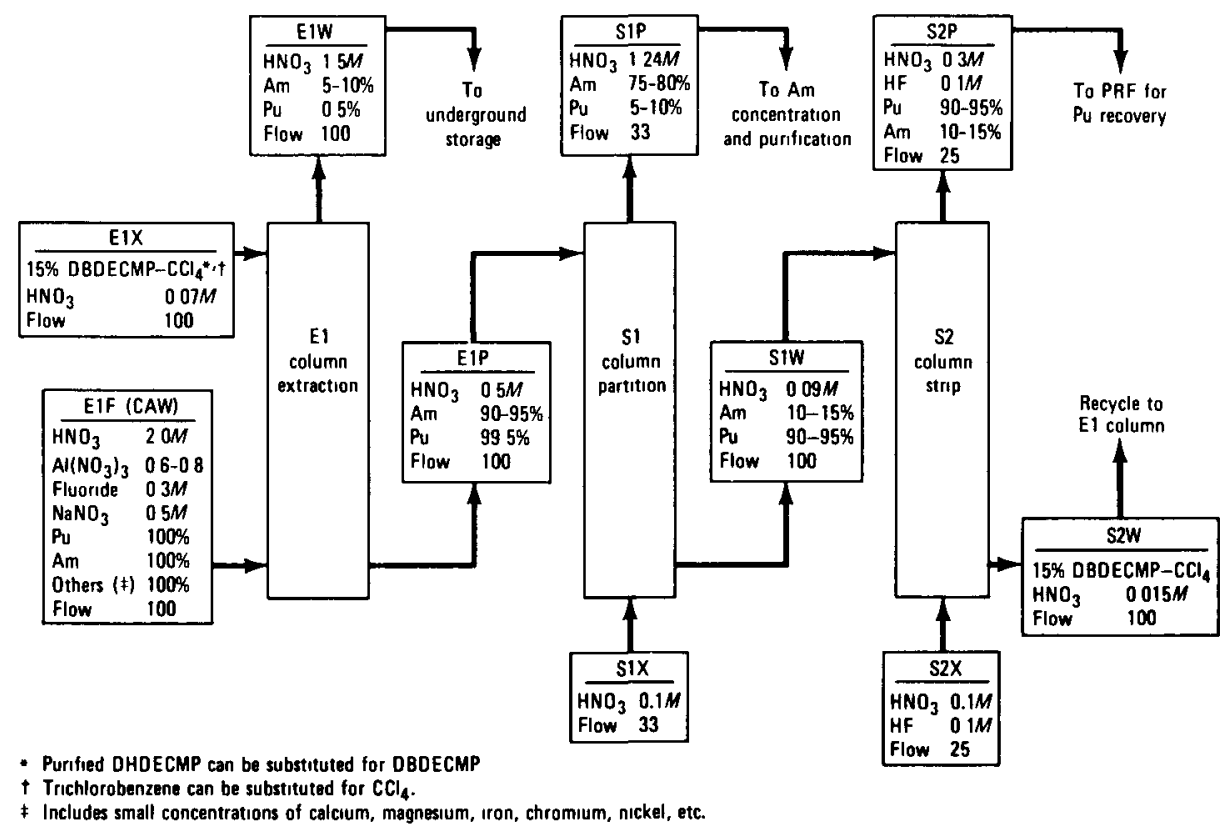

Fig. 5.12 A conceptual bidentate organophosphorus extraction process for the recovery and separation of americıum and plutonium from Hanford CAW solution. 140 
unidentified impuriły with a very strong affinity for $\mathrm{Am}^{3+}$ at low aqueous-phase $\mathrm{HNO}_{3}$ concentrations (Fig. 5.13); this impurity must be removed to permit the use of dilute aqueous acid solutions to strip americium and partition it from coextracted $\mathrm{Pu}(\mathrm{IV})$. Pure DBDECMP (Fig. 5.13) can be prepared by vacuum distillation of the technical-grade material at $\sim 180^{\circ} \mathrm{C}$ and 0.1 torr. Schulz ${ }^{139}$ claims that a satisfactorily pure DHDECMP extractant can be prepared from the commercially available material by contacting DHDECMP- $\mathrm{CCl}_{4}$ solutions for $24 \mathrm{hr}$ at $60^{\circ} \mathrm{C}$ with $6 \mathrm{M} \mathrm{HCl}$ and subsequent washing of the organic solvent with $\mathrm{NaOH}$ and $\mathrm{HNO}_{3}$ solutions.

Butler and Hall ${ }^{141}$ recommend the bidentate extractant, dibutyl- $N, N$-diethylcarbamyl phosphonate for use in determination of americium and other actinides in biological samples.

Bis(2-ethylhexyl)phosphoric Acid. Chemistry involved in the extraction of $\mathrm{Am}^{3+}$ by bis(2-ethylhexyl)phosphoric acid<smiles>[R]O[PH3](=O)O</smiles>

has been intensively studied by scientists in many countries. This extractant is commercially available in large quantities, can be readily purified, and has been much used for both analytical and plant-scale recovery and purification of americium.

Ferraro, Mason, and Peppard ${ }^{142,143}$ at ANL have established that HDEHP, like other organophosphorus acids, exists as a dimer in nonpolar solvents and predominantly as the monomer in polar diluents. Extraction of small concentrations of trivalent americium by monomeric and dimeric HDEHP, respectively, conforms to the following equations: ${ }^{144,145}$

$$
\begin{gathered}
\mathrm{Am}_{(\mathrm{aq})}^{3+}+3 \mathrm{HDEHP}_{(\mathrm{org})} \rightleftharpoons \mathrm{Am}(\mathrm{DEHP})_{3(\mathrm{org})}+3 \mathrm{H}_{(\mathrm{aq})}^{+} \\
\mathrm{Am}_{(\mathrm{aq})}^{3+}+3(\mathrm{HDEHP})_{2(\mathrm{org})}
\end{gathered}
$$

Mason, Lewey, and Peppard ${ }^{146}$ state that monomeric HDEHP may also extract $\mathrm{Am}^{3+}$ in the form of the species [Am(DEHP) $\left.{ }_{3}(\mathrm{HDEHP})_{3}\right]_{(\mathrm{org})}$. Letting HX stand for HDEHP, the equilibrium constants for Eqs. 5.6 and 5.7 can be written as

$$
\mathrm{K}_{\mathrm{ex}}=\frac{\left[\mathrm{AmX}_{3}\right] \cdot\left[\mathrm{H}^{+}\right]^{3}}{\left[\mathrm{Am}^{3+}\right] \cdot[\mathrm{HX}]^{3}} \text { and } \mathrm{K}_{\mathrm{ex}} \frac{\left[\mathrm{Am}\left(\mathrm{HX}_{2}\right)_{3}\right] \cdot\left[\mathrm{H}^{+}\right]^{3}}{\left[\mathrm{Am}^{3+}\right] \cdot\left[(\mathrm{HX})_{2}\right]^{3}}
$$

respectively. For Eq. 5.6, $\mathrm{K}_{\mathrm{ex}}=0.27$ (Ref. 144), whereas for Eq. 5.7, $\mathrm{K}_{\mathrm{ex}}=0.033$ (Ref. 112).

Data in Table 5.6 illustrate the profound effect of the nature of the carrier solvent on HDEHP extraction of Am(III). Corresponding to the inverse third-power 


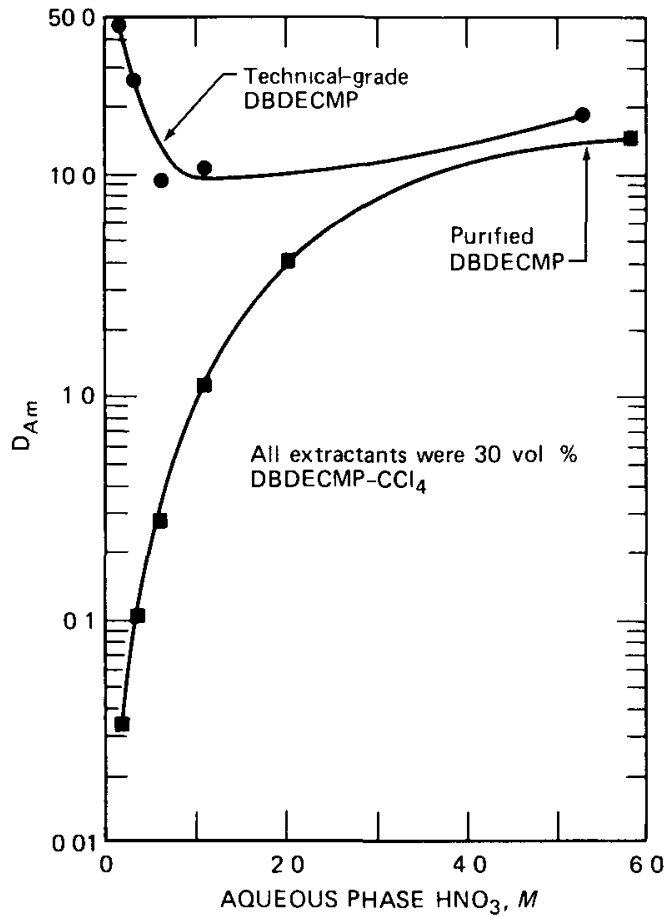

Fig. 5.13 Extraction of Am(III) by purified and unpurffed DBDECMP 140

Table 5.6

EFFECT OF DILUENT TYPE ON HDEHP EXTRACTION OF Am(III)* (Organic Phase: 0.5M HDEHP; Aqueous Phase: $0.5 \mathrm{MHNO}_{3}$ )

\begin{tabular}{lll}
\hline \multicolumn{1}{c}{ Diluent } & D Am \\
\hline Isooctane & 21.1 \\
Decane & 17.7 \\
Cyclohexane & 4.5 \\
CCl$_{4}$ & 0.49 \\
Toluene & 0.15 \\
Benzene & 0.092 \\
Chloroform & 0.0167 \\
\hline
\end{tabular}

*[From E. S. Gureev, V. N. Kosyakov, and G N Yakovlev, ${ }^{144}$ Extraction of Actinide Elements of Dialkylphosphoric Acids, Radiokhimiya, 6: 655 (1964), through Soviet Radiochemistry (English Translation), 6: 639 (1964).] 
dependency on hydrogen concentration (Eqs. 5.6 and 5.7), relatively dilute ( $1 M$ to 2M) $\mathrm{HNO}_{3}$ solutions readily strip $\mathrm{Am}^{3+}$ from HDEHP extractants (Fig. 5.14).

Kinetics of extraction of $\mathrm{Am}^{3+}$ from $\mathrm{HClO}_{4}$ solutions by HEDHP- $n$-decane solutions follow the rate law:

$$
\frac{\mathrm{d}\left[\mathrm{Am}^{3+}\right]}{\mathrm{dt}}=\frac{\mathrm{k}\left[\mathrm{Am}^{3+}\right]_{(\mathrm{aq})} \cdot[\mathrm{HDEHP}]_{(\mathrm{org})}^{1.5}}{\left[\mathrm{H}^{+}\right]_{(\mathrm{aq})}^{2}}
$$

At $25^{\circ} \mathrm{C}$ and $\mu=0.2 M, \mathrm{k}=0.137 \pm 0.02(\mathrm{~mol})^{0.5} \mathrm{sec}^{-1}$. According to Karpacheva and Ilozheva, ${ }^{147}$ the limiting step in the extraction process is

$$
\mathrm{AmDEHP}_{2}^{+}+\mathrm{HDEHP} \rightarrow \mathrm{Am}(\mathrm{DEHP})_{3}+\mathrm{H}^{+}
$$

which most likely takes place in the aqueous phase.

A countercurrent HDEHP extraction process was used at Hanford in the late 1960s as part of the processing sequence for recovering and purifying some $1000 \mathrm{~g}$ of $\mathrm{Am}$ and $50 \mathrm{~g}$ of $\mathrm{Cu}$ from irradiated Shippingport reactor fuel. ${ }^{106-109,148}$ This is by far the largest plant-scale application of HDEHP extraction technology for americium recovery and purification yet reported. Feed for the HDEHP extraction process used at Hanford was the crude concentrate (Table 5.4) obtained in prior TBP batch extractions. The crude concentrate was adjusted to $\mathrm{pH} 4$ by the addition of $\mathrm{NaOH}$. Hydroxyacetic acid and sodium nitrilotriacetate were added to complex aluminum, iron, and various other metallic impurities and to provide buffering capacity. Americium, curium, and lanthanides were extracted into a $0.4 M \mathrm{HDEHP}-0.2 M$ TBP-NPH (Normal Paraffin Hydrocarbon, a mixture of $\mathrm{C}_{10}-\mathrm{C}_{14}$ normal paraffins) solvent using countercurrent equipment (pulse columns installed in the Hanford Semiworks). The actinide-lanthanide mixture was stripped in to $2 \mathrm{MHNO}_{3}$; the strip

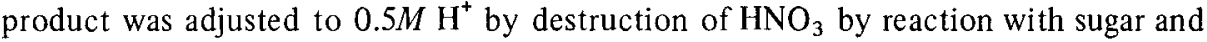
thermally concentrated to a volume of about 570 liters. [Follow-on chromatographic ion-exchange procedures used to separate the americium from lanthanides and curium are described on pages 245 to 252.] This HDEHP extraction process proceeded extremely well; americium and curium recoveries exceeded $95 \%$. A chemical flow sheet for the recovery-purification scheme is given in Fig. 5.15.

A simple HDEHP extraction-strip process (Dapex process) was also devised and used in the Curium Recovery Facility at Oak Ridge. ${ }^{76,149}$ This process was used to convert nitrate solutions containing americium, curium, and lanthanides to chloride media for subsequent amine extraction separations; it was also used with chloride feeds to separate americium and curium from aluminum. A flow sheet for the latter purpose is shown in Fig. 5.16; this flow sheet features coextraction of the americium, curium, and lanthanides into an 0.7M HDEHP solvent, scrubbing out of impurities with dilute $\mathrm{HCl}$, and stripping of the actinides and lanthanides with $2 \mathrm{M} \mathrm{HCl}$. Leuze and Lloyd" ${ }^{76}$ state, "Plant operation of this process was satisfactory at a feed power density of $20 \mathrm{~W} / 1$; extraction losses were low, and decontamination factors of 540 and 24 were obtained for ${ }^{106} \mathrm{Ru}$ and ${ }^{95} \mathrm{Zr}-{ }^{95} \mathrm{Nb}$, respectively." 


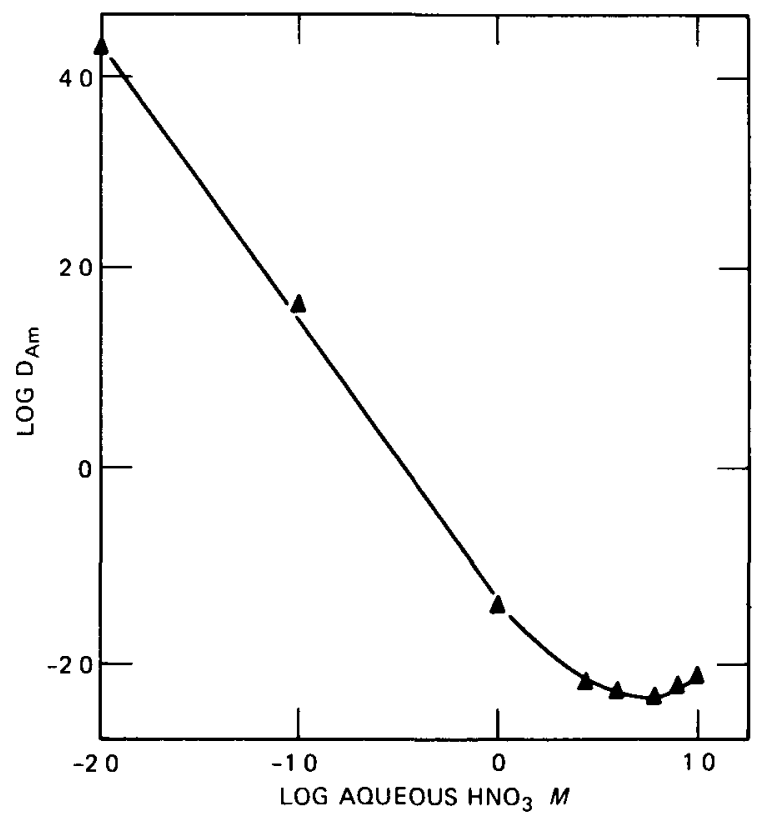

Fig. 5.14 Extraction of Am(III) by $05 M$ HDEHP in 1sooctane [From $E S$ Gureev, V N Kosyakov, and G N Yakovlev, ${ }^{144}$ Extraction of Actınide Elements by Dialkylphosphoric Acids, Radıokhtmiya, 6: 655 (1964), through Soviet Radiochemistry (English Translation), 6: 639 (1964) ]

Another simple HDEHP batch extraction-strip process (Cleanex process) is routınely used in the Transuranium Processing Plant at the Oak Ridge National Laboratory to reclaim amencium, curum, and other transplutonium elements from rework solutions and/or to convert from nitrate to chloride media ${ }^{150}$ The Cleanex process is so named because it will clean up transplutonium elements from a great variety of corrosion products, floor sweepings, and other assorted contaminants. It involves extraction of the transplutonium elements from a dilute acid $(<01 M)$ feed into a $1 M$ HDEHP-Amsco 125-82 solvent, the metallic impunties are left in the aqueous phase, which is discarded Subsequently a $6 \mathrm{~N} \mathrm{HCl}$ solution is used to strip the actinides from the HDEHP phase Advantages of the batch Cleanex process have been cited by Bigelow, Chattin, and Vaughen 150

Various HDEHP extraction processes have been proposed and, in some instances, used to separate gram amounts of americium (and, usually, associated curium) from large quantities of lanthanides These processes ${ }^{151-156}$ take advantage of the results of Weaver and Kappelmann, who were the first to show that HDEHP extracts lanthanides much more strongly than actinides from aqueous carboxylic acid solutions containing an amınopolycarboxylic acid chelating agent. [Weaver and Kappelmann coined the acronym Talspeak (Trivalent $A$ ctinide Lanthanide Separation by Phos- 


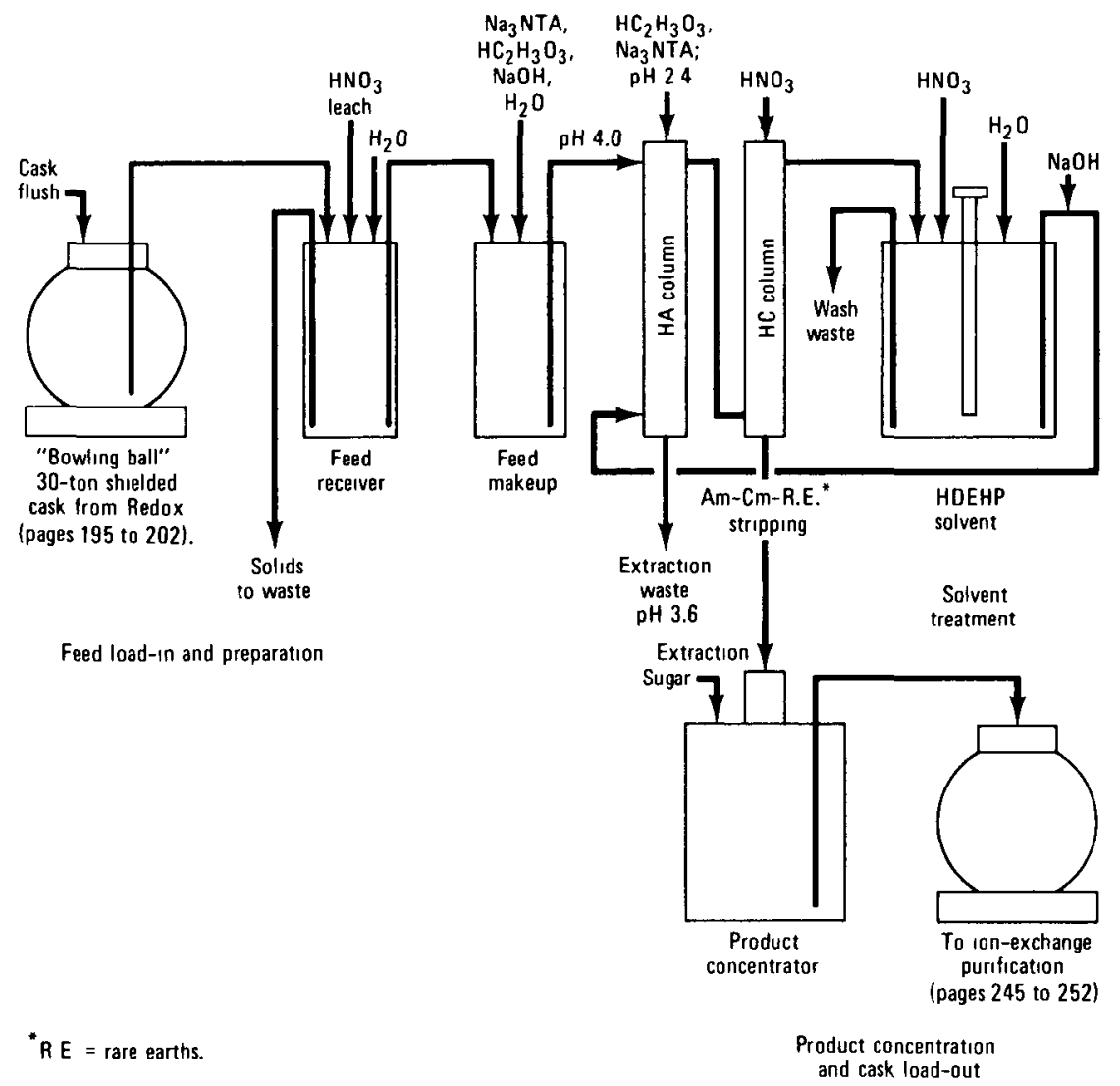

Fig. 5.15 Simplified HDEHP extraction process used at Hanford in recovering americium and curium from Shippingport reactor fuel. ${ }^{106}$

phorus Reagent Extraction from Aqueous Komplexes) for this type of separation scheme.] Data in Table 5.7 and Fig. 5.17 are llustrative of the actinide-lanthanide separations that can be achieved by Talspeak-type processes. The actinides are so much more strongly complexed by diethylenetriaminepentaacetic acid (DTPA), the preferred complexing agent, that even the most extractable heavy actinides are only about one-tenth as extractable as the least extractable lanthanides.

Lactic acid is preferred for use in the Talspeak process over the other carboxylic acids listed in Table 5.7 because, of the hydroxyacids, it alone has a high enough solubility of its lanthanide salts to be useful in the separation of actinides from high concentrations of lanthanides. Lunichkina and Renard ${ }^{157}$ have recently studied HDEHP extraction of lanthanum and neodymium from $1.0 \mathrm{M}$ lactic acid $-0.5 \mathrm{M} \mathrm{NaNO}_{3}$ solutions containing $10 \mathrm{~g} \mathrm{liter}^{-1} \mathrm{La}$ or $\mathrm{Nd}$. Their results confirm earlier observations of Weaver and Kappelmann ${ }^{151}$ that the HDEHP phase resulting from contact with such 


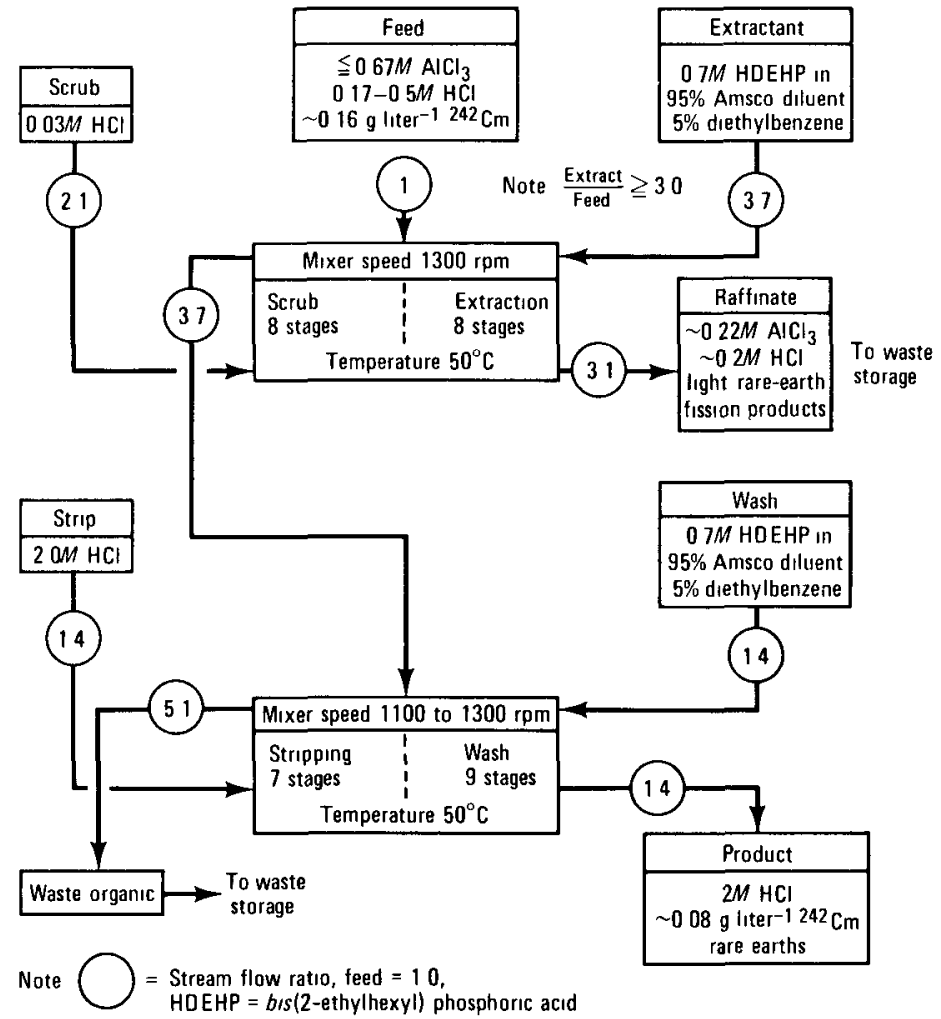

Fig. 5.16 Dapex process used at Oak Ridge to separate americium and curıum from alumınum ${ }^{149}$

aqueous solutions contains both metal and lactate species. Lunichkina and Renard suggest that HDEHP extraction of lanthanides ( $\mathrm{Ln}$ ) from lactate (L) media probably proceeds by the reaction:

$$
\mathrm{LnL}^{2+}+(\mathrm{HDEHP})_{2} \rightleftharpoons \mathrm{Ln}(\mathrm{DEHP})_{2} \mathrm{~L}+2 \mathrm{H}^{+}
$$

Fardy and Pearson ${ }^{158}$ found that the purity of HDEHP markedly influences the separation of cerium from americium in a lactic acid-DTPA solution but does not significantly affect separation of americium from europium or promethium. No explanation for this different behavior has been advanced.

No plant-scale application of the Talspeak process in the form originally devised by Weaver and Kappelmann has yet been made. The Tramex process (compare pages 224 to 230) is currently used at Oak Ridge in the processing of HFIR targets for the separation of americium and curium from fission-product lanthanides. In this respect, Weaver ${ }^{88}$ believes that the Talspeak process, although it gives a smaller intergroup separation factor than the Tramex process, has a distinct advantage in that its aqueous 
Table 5.7

\section{HDEHP EXTRACTION OF AMERICIUM AND LANTHANIDES FROM MIXTURES OF DTPA AND CARBOXYLIC ACIDS*}

(Organic Phase: 0.2M HDEHP in Disopropylbenzene; Aqueous Phase: $1 M$ Carboxylic Acid-0.05 $M$ DTPA, pH 3.0)

\begin{tabular}{|c|c|c|c|c|}
\hline \multirow[b]{2}{*}{ Acid } & \multirow{2}{*}{$\begin{array}{l}\text { Distribution } \\
\text { coefficient } \\
\text { for americium }\end{array}$} & \multicolumn{3}{|c|}{ Separation factor } \\
\hline & & $\mathrm{La} / \mathrm{Am}$ & $\mathrm{Ce} / \mathrm{Am}$ & $\mathrm{Eu} / \mathrm{Am}$ \\
\hline Formic & 00102 & 270 & 147 & 19 \\
\hline Acetic & 0.0086 & 430 & 163 & 24 \\
\hline Propionic & 0.0052 & 770 & 190 & 29 \\
\hline Butyric & 0.0009 & & 190 & 10 \\
\hline Gly colıc & 0.0124 & 145 & 97 & 84 \\
\hline Lactic & 00085 & 380 & 140 & 91 \\
\hline Citric & 00102 & 73 & 84 & 105 \\
\hline Malonic & 0.0087 & 290 & 184 & 57 \\
\hline$\alpha$-Hydroxy isobutyric & 00132 & 370 & 144 & 62 \\
\hline Glycine $-\mathrm{HNO}_{3}$ & 00111 & 270 & 144 & 16 \\
\hline
\end{tabular}

* [F rom B. Weaver and $\mathrm{F}$ A Kappelmann, ${ }^{151}$ Preferential Extraction of Lanthanides over Trivalent Actınides by Monoacidıc Organophosphates from Carboxylic Acids and from Mixtures of Carboxylic and Aminopolyacetic Acids, Journal of Inorgantc and Nuclear Chemistry, 30: 263 (1968) ]

medium is sufficiently noncorrosive that it does not require special construction materıals.

Berger et al,$^{159}$ and other French investigators have applied a Talspeak-like process as part of a scheme for recovenng milligrams of americium and curium from highly irradiated $\mathrm{Al}-10 \mathrm{wt} . \% \mathrm{Pu}$ alloys. Following dissolution of the irradiated targets, two trilaurylamine extraction cycles were used to recover plutonium from an $\mathrm{HNO}_{3}$ solution The plutonium-free raffinate was adjusted to $15 M \mathrm{Al}\left(\mathrm{NO}_{3}\right)_{3}$ and $1 M$ to $2 M$ $\mathrm{HNO}_{3}$ and batch contacted with $025 \mathrm{M}$ DHEHP- $n$-dodecane to extract fission-product zirconium and ruthenium. Finally, two HDEHP extraction cycles (Fig 5 18) were used to recover the amencium and curnum and to punfy them from fission-product lanthanides. A distinguishing feature of the French flow sheet is the use of a concentrated $\mathrm{LiNO}_{3}$ solution containıng DTPA to selectively strip americium and curum from the HDEHP extract. Weaver ${ }^{88}$ points out that $3 M \mathrm{LiNO}_{3}-005 M$ DTPA solutions are less effective than carboxylic acid-DTPA solutions in separating transplutonium elements from rare earths Anon-exchange procedures used for the final purification and separation of americium from curum are described on pages 239 to 243 


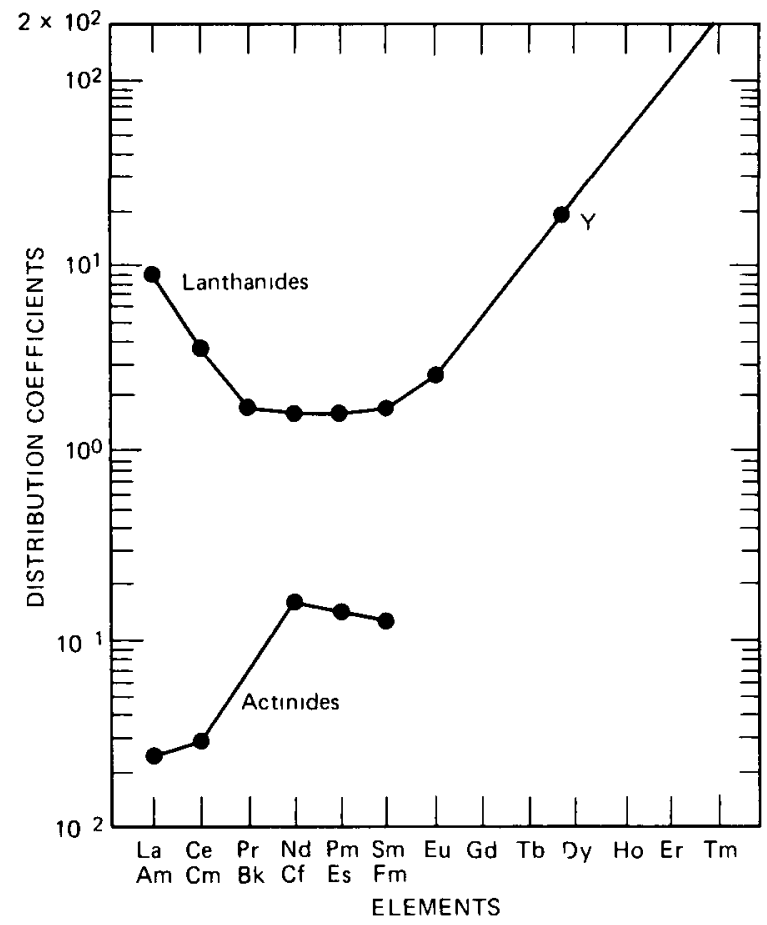

Fig. 5.17 Separation of actınides and lanthanides in the Talspeak process Organic phase, $03 M$ HDEHP in disopropylbenzene, aqueous phase, $1 M$ lactic acid-0 005M DTPA at $\mathrm{pH} 20$ [From B Weaver and F A Kappelmann, ${ }^{151}$ Preferential Extraction of Lanthanides over Trivalent Actinides by Monoacidic Organophosphates from Carboxylic Acids and from Mixtures of Carboxylic and Aminopolyacetıc Acids, Journal of Inorganic and Nuclear Chemistry, 30: 263 (1968) ]

Koch, Kolarik, and coworkers in West Germany have been developing for some tıme now an HDEHP extraction scheme for the removal and separation of americium and curium from Purex-process high-level waste that incorporates both normal and "reverse" Talspeak processes ${ }^{160-163}$ A simplified schematic of their current flow sheet is presented in Fig 5 19, with pertinent stream compositions listed in Table 58 [An earlier HDEHP solvent extraction flow sheet ${ }^{164165}$ had to be abandoned since it produced a citrate-complexed waste in which vigorous and potentially explosive exothermic reactions occurred on calcination] The initial process step involves denitration of the high-level waste (1WW solution) by reaction with formic acid Conditions are maintained in this step under which americium and curium remain in solution while part of the fission and corrosion products are coprecipitated The denitrated waste solution, which contains the amencium, curium, fission-product rare earths, strontium, and cesium, is adjusted to extraction conditions 


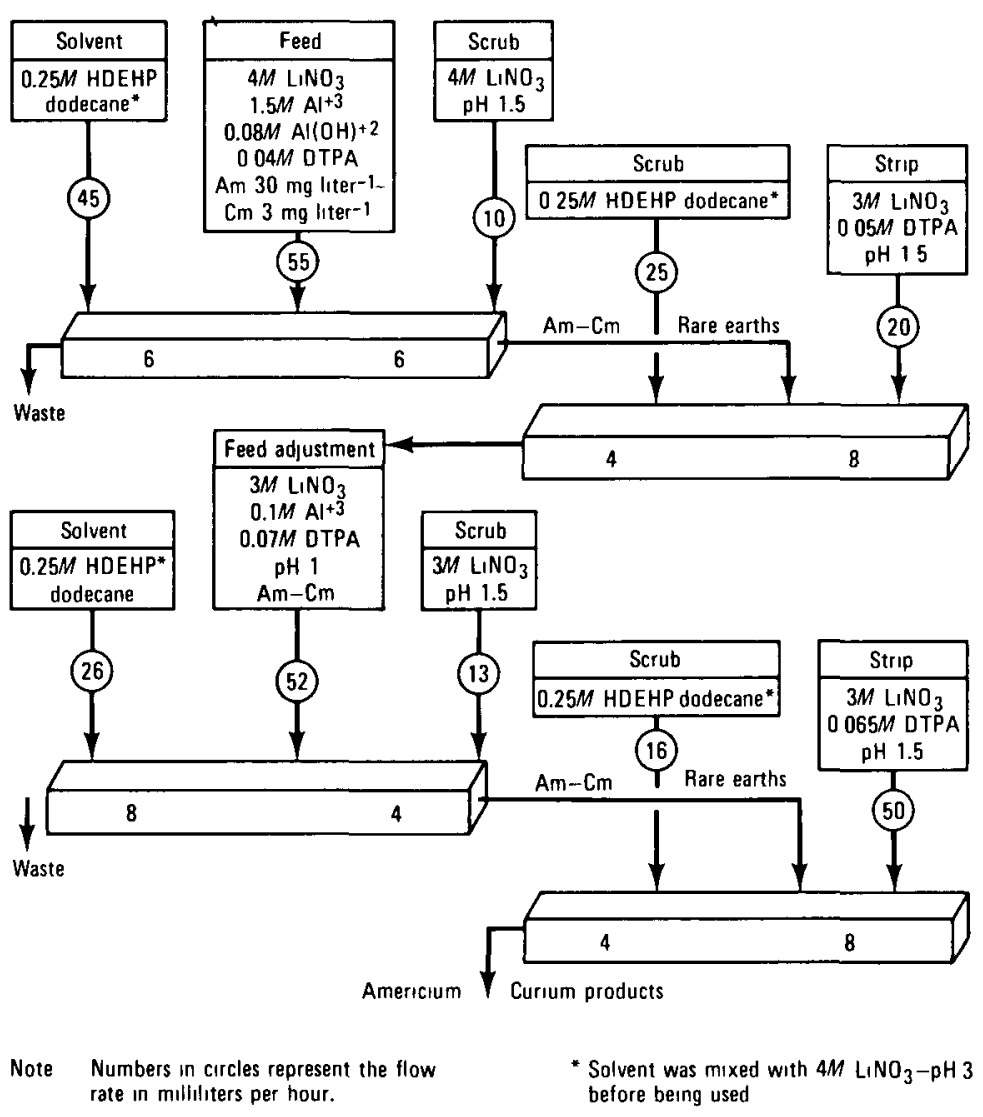

Fig. 5.18 HDEHP extraction process used in France in the recovery and purification of americium and curium from irradiated plutonium-aluminum alloy. [From R. Berger, G. Koehly, C. Musikas, R. Pottier, and R. Sontag, ${ }^{159}$ Processing of Highly Irradıated Al-Pu Alloy, Nuclear Applications and Technology, 8: 371 (1970).]

The extraction cycle (Fig. 5.19) in the German process involves (1) coextraction of the americium, curium, and rare earths into an $0.3 M \mathrm{HDEHP}-0.2 M \mathrm{TBP}-\mathrm{NPH}$ solvent (WA mixer-settler bank); (2) partitioning of americium and curium from rare earths (WB bank) using a $1 M$ lactic acid-0.05M DTPA solution to preferentially strip the actinides (reverse Talspeak-type process); (3) stripping of rare earths with $5 M \mathrm{HNO}_{3}$ (WC bank); and (4) further purification of the americium and curium by a normal Talspeak process (WD bank). The rare-earth-loaded solvent (WDW solution) from the WD bank is recycled to the WA bank. The spent solvent (WCW solution) from the WC bank after cleanup is recycled as extractant to the WA and WD banks and as organic scrub solution to the WB bank. The dilute americium and curium product from the WD bank is a $1 M$ lactic acid-0.05M DTPA solution that is concentrated and purified further by the cation-exchange resin process discussed on pages 245 to 252 . 


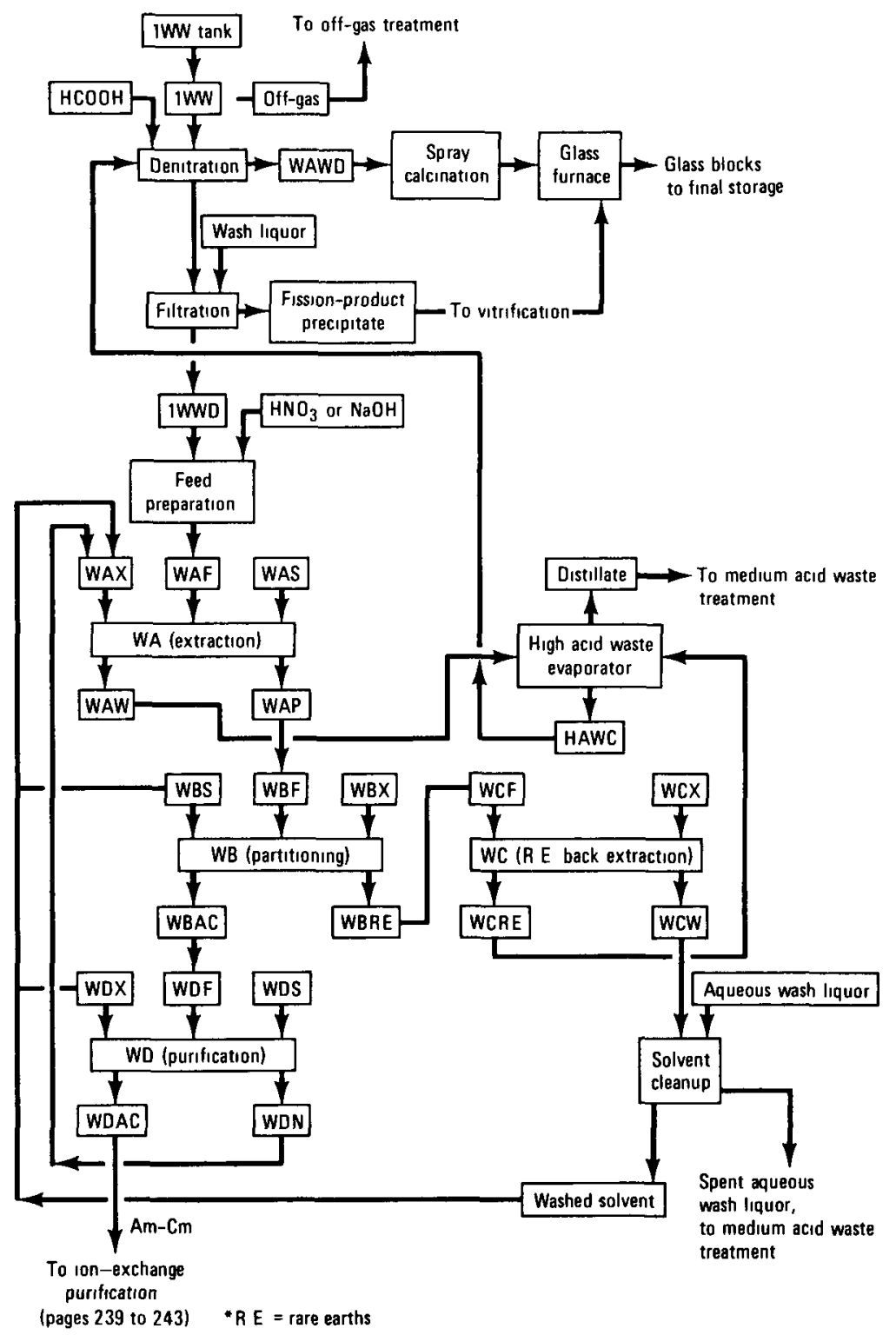

Fig. 5.19 German HDEHP extraction process for recoverıng amencium and curnum from high-level Purex-process waste (Stream compositions are listed in Table 58) [From G. Koch, Z. Kolarık, H Haug, W. Hild, and S. Drobnık, ${ }^{161}$ Recovery of Transplutonium Elements from Fuel Reprocessing High-Level Waste Solutions, in Symposium on the Management of Radioactive Wastes from Fuel Reprocessing, Paris, France, November 27-December 1, 1972 (CONF-721107, pp. 1081-1110), also, German Report KFK-1651, November 1972.] 
Table 5.8

GERMAN HDEHP AMERICIUM-CURIUM RECOVERY PROCESS: STREAM FLOWS AND COMPOSITION*

\begin{tabular}{|c|c|c|c|c|c|c|c|c|c|c|c|c|c|c|}
\hline \multirow{2}{*}{$\begin{array}{l}\text { Stream } \\
\text { desig- } \\
\text { nation } \neq\end{array}$} & \multicolumn{12}{|c|}{ Composition } & \multirow[b]{2}{*}{$\mathbf{p H}$} & \multirow[b]{2}{*}{ Flow } \\
\hline & $\begin{array}{c}\text { Am } \\
\text { g luter ' }\end{array}$ & $\underset{\mathrm{g} \text { liter }^{-1}}{\mathrm{Cm}}$ & $\begin{array}{c}\mathrm{HNO}_{3} \\
M\end{array}$ & $\begin{array}{c}\mathrm{RE}_{\ddagger} \\
\mathrm{g} \text { liter }^{-1}\end{array}$ & $\begin{array}{c}\mathbf{F P} \& \\
\text { g liter }{ }^{-1}\end{array}$ & $\begin{array}{c}\mathrm{NaNO}_{3} \\
M\end{array}$ & $\begin{array}{c}\mathrm{N}\left(\mathrm{NO}_{3}\right)_{2} \\
M\end{array}$ & $\begin{array}{c}\text { CPA } \\
\text { g liter }\end{array}$ & $\begin{array}{c}\mathrm{H}_{5} \mathrm{DTPA}^{* *} \\
M\end{array}$ & $\begin{array}{c}\text { HLAC }+\dagger \\
M\end{array}$ & $\begin{array}{c}\text { HDEHP } \ddagger \ddagger \\
M\end{array}$ & $\begin{array}{c}\text { TBP } \$ \& \\
M\end{array}$ & & \\
\hline 1WWD & 0.12 & 0.01 & 4 & & 27 & 0.22 & & 4 & & & & & & 100 \\
\hline WAF & 0.06 & 0.005 & & 5 & $39 \pi$ & 0.11 & 0.004 & & & & & & 2 & 200 \\
\hline WAX & & & & 0.002 & & & & & & & 0.3 & 0.2 & & 500 \\
\hline WAS & & & 0.22 & & & & & & & & & & & 134 \\
\hline WAW & & & & & 18 & 0.07 & 0.002 & & & & & & 1.1 & 334 \\
\hline WBt & 0.024 & 0.002 & & 2 & & & & & & & 0.3 & 0.2 & & 500 \\
\hline WBX & & & & & & & & & 0.05 & 1 & & & 3.0 & 166 \\
\hline WBS & & & & & & & & & & & 0.3 & 0.2 & & 166 \\
\hline WDF & 0.072 & 0.006 & & 0.006 & & & & & 0.05 & 1 & & & 3.0 & 166 \\
\hline WCF & & & & 1.5 & & & & & & & 0.3 & 0.2 & & 666 \\
\hline WCX & & & 5 & & & & & & & & & & & 166 \\
\hline WCRE & & & 4.9 & 6 & & & & & & & & & & 166 \\
\hline WCW & & & & & & & & & & & 0.3 & 0.2 & & 166 \\
\hline WDX & & & & & & & & & & & 0.3 & 0.2 & & 125 \\
\hline WDS & & & & & & & & & 0.05 & 1 & & & 3.0 & 42 \\
\hline WDAC & 0.058 & 0.0048 & & & & & & & 0.05 & 1 & & & 3.0 & 208 \\
\hline WDW & & & & 0.008 & & & & & & & 0.3 & 0.2 & & 125 \\
\hline
\end{tabular}

*[From G. Koch, Z. Kolank, H. Haug, W. Huld, and S. Drobnik, ${ }^{61}$ Recovery of Transplutonium Elements from I uel Reprocessing High-Level Waste Solutions, in Symposium on the Management of Radioactive Wastes from Fuel Reprocessing. Pans, France, November 27-December 1, 1972 (CONF-721107, pp. 1081-1110), also, German Report KFK-1651, November 1971.]

† See Fig. 5.19.

$\ddagger$ Rare-earth fission products.

$\S$ Other fission products.

Corrosion products.

**Diethylenetriaminepentaacetic acid.

++ Lactic acid.

$\ddagger \ddagger B i s$ (2-ethylhexyl)phosphoric acid

\& \& Trt-n-butyl phosphate.

19 Essentrally rubidum, strontum, cesum, and barum. 
Thus far the German HDEHP americium-curium extraction process has been demonstrated only on a laboratory-scale with simulated Purex-process waste containing added radioisotopes. Although process performance was excellent under such conditions, it is clear, as $\operatorname{Koch}^{161}$ notes, that pilot-plant-scale tests with actual high-level waste are needed to determine fully the utility of this americium-curium recovery scheme.

HDEHP extraction processes that make use of the differences in stability of the chloride and thiocyanate complexes of the lanthanides and actinides (compare Chap. 3) have been proposed $95,101,166,167$ for separating americium and curium from the rare earths. Such processes use concentrated $\mathrm{LiCl}$ (or $\mathrm{CaCl}_{2}$ ) and $\mathrm{NH}_{4} \mathrm{SCN}$ aqueous feedstocks. Gureev et al. ${ }^{166}$ have described laboratory-scale mixer-settler tests in which an $0.74 M$ HDEHP-dodecane solvent was used with either a $6 M$ $\mathrm{NH}_{4} \mathrm{SCN}$ or a $11 M \mathrm{LiCl}-0.4 M \mathrm{HCl}$ aqueous feed to extract rare earths away from americium. Decontamination factors of americium from rare earths of $\sim 10\left(\mathrm{Cl}^{-}\right.$ system) and $\sim 1000$ ( $\mathrm{SCN}^{-}$system) were realized in these tests. No industrial-scale application of such processes is anticipated, since they are less efficient than the Talspeak process (or modifications thereof) ${ }^{101}$ and involve the use of more corrosive and/or difficult-to-handle aqueous-phase compositions.

Similar to results with TBP (compare pages 201 and 202), there is conflicting evidence regarding $\mathrm{HDEHP}$ extraction of $\mathrm{Am}(\mathrm{VI})$ from $\mathrm{HNO}_{3}$ solutions. Zangen ${ }^{122}$ states that HDEHP- $-\mathrm{CCl}_{4}$ solutions extract $\mathrm{Am}(\mathrm{VI})$ from $0.05 M \mathrm{HNO}_{3} \sim 1000$ times better than Am(III). Penneman and Asprey ${ }^{32}$ also found that an $0.3 M$ HDEHPtoluene solution extracts Am(VI) quantitatively from $0.1 M \mathrm{HNO}_{3}-0.1 M \mathrm{Na}_{2} \mathrm{~S}_{2} \mathrm{O}_{8}$ solution and suggest this procedure for separating macro amounts of americium from $\mathrm{Cm}$ (III). On the other hand, workers at ORNL observe that HDEHP extracts Am(III) considerably better than Am(VI). ${ }^{156,168}$ Myasoedov et al. ${ }^{95}$ suggest this latter result may have been obtained because of the reduction of $A m(V I)$ to inextractable $A m(V)$. Penneman and Keenan ${ }^{32}$ note tracer concentrations of americium are difficult to maintain in the hexavalent state. Definitive experiments are needed to resolve this conflict.

Watanabe and Sagawa ${ }^{169}$ have devised an HDEHP extraction process for separating curium and plutonium from americium. This procedure involves reduction of $\mathrm{Am}(\mathrm{VI})$ to $\mathrm{Am}(\mathrm{V})$ with $\mathrm{H}_{2} \mathrm{O}_{2}$ in $0.1 M \mathrm{HNO}_{3}$ solution, and extraction of plutonium and $\mathrm{Cm}(\mathrm{III})$ into a 50 vol.\% HDEHP-xylene (or dodecane) solvent. A decontamination factor of ${ }^{241} \mathrm{Am}$ from ${ }^{242} \mathrm{Cm}$ of $30 \pm 10$ is obtained in one cycle of solvent extraction. It is not clear why $\mathrm{H}_{2} \mathrm{O}_{2}$ does not reduce $\mathrm{Am}(\mathrm{V})$ to $\mathrm{Am}(\mathrm{III})$, nor is it clear whether plutonium is in the +4 or the +3 state. Lee ${ }^{170}$ has reported on a study of the Am(III)-Cm(III) separation factors in HDEHP extraction systems.

Myasoedov et al. ${ }^{171,172}$ report that a $3: 1$ mixture of HDEHP and $\mathrm{P}_{2} \mathrm{O}_{5}$ in cyclohexane extracts $\mathrm{Am}^{3+}$ quantitatively from $1 M$ to $12 M \mathrm{HNO}_{3}$ solution (Fig. 5.20). Large concentrations of $\mathrm{Al}\left(\mathrm{NO}_{3}\right)_{3}$ do not interfere in the extraction of $\mathrm{Am}^{3+}$ by an $0.3 M$ HDEHP- $-1 M \mathrm{P}_{2} \mathrm{O}_{5}$ solution. The Russian investigators postulate that an entity with a great affinity for trivalent transplutonium elements forms when $\mathrm{P}_{2} \mathrm{O}_{5}$ is dissolved in HDEHP solutions. Myasoedov and coworkers also report that the 


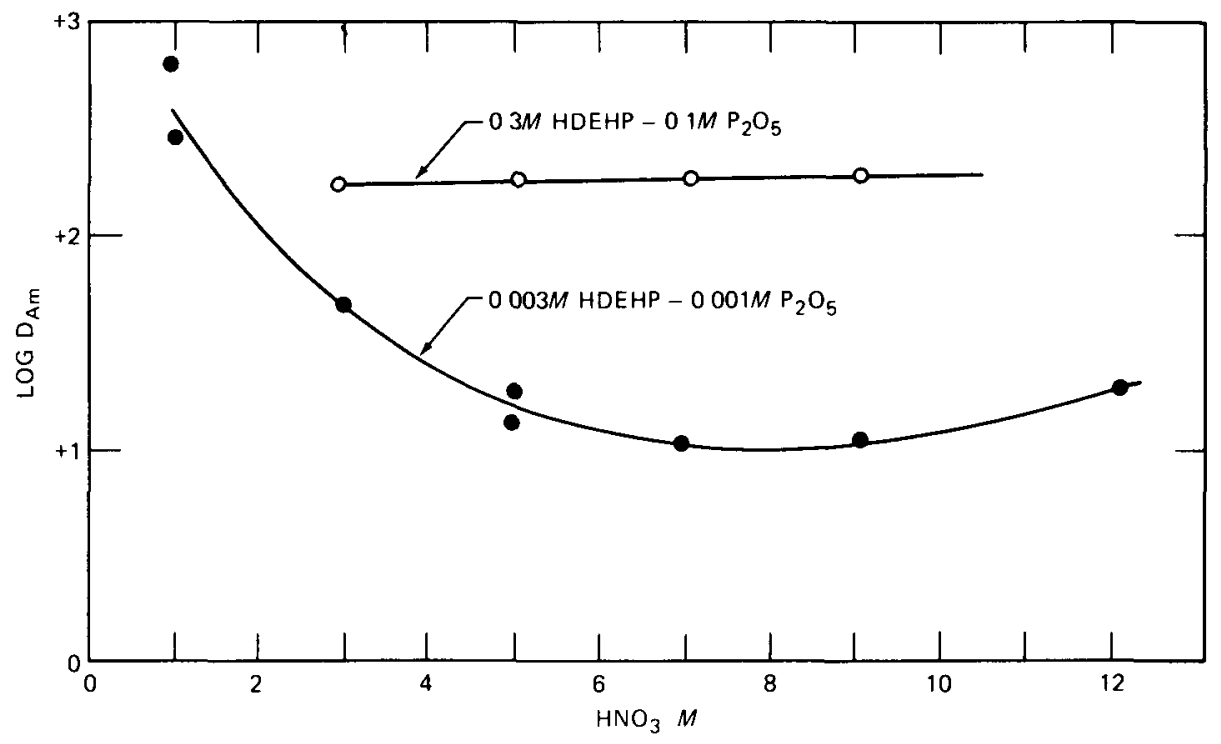

Fig. 520 Extraction of Am(III) by HDEHP- $\mathrm{P}_{2} \mathrm{O}_{5}$ solutions [From B F Myasoedov, M K Chmutova, N E Kochetkova, and G A Pribylova, ${ }^{172}$ Solvent Extraction of Trivalent Americuum from Acid Media, Radiochemical and Radioanalytical Letters, 14: 63 (1973) ]

extractive properties of $\mathrm{HDEHP}-\mathrm{P}_{2} \mathrm{O}_{5}$ mixtures decrease with time A satisfactory way of stripping metal values from the HDEHP $-\mathrm{P}_{2} \mathrm{O}_{5}$ extractant has not been reported

Synergistic and antagonistic effects in the extraction of Am(VI) and Am(III) by HDEHP-TBP solvents have been reported by Zangen ${ }^{122} 173$ and by Kolar1k ${ }^{174}$ In the system $003 M$ HDEHP $-01 M$ TBP $\ldots \mathrm{CCl}_{4}-005 M \mathrm{HNO}_{3}$ Zangen noted a syner gistic effect for the extraction of $A m(V I)$ and an antagonistic effect for Am(III) Kolarik notes also that TBP causes only an antagonistic effect in HDEHP extraction of Am(III) from perchlorate, citrate, and nitrilotriacetate solutions

Other Organophosphorus Acid Extractants Only HDEHP has found large-scale use for the recovery and separation of amencium, however much laboratory-scale work has been done to evaluate vanous other organophosphorus acids for therr ability to extract amencium from different aqueous media and to establish chemistry involved in such extraction systems Several interesting and relevant features of this laboratory work are mentioned here, a more complete description of these studies is provided in Ref 88

Monoacidic phosphonates are obtained by substıtutıng a phosphorus-bound alkyl or aryl group for an ester group of a monoacidic phosphate The former compounds, as shown first by Peppard, Mason, and Hucher, ${ }^{175} 176$ are considerably more powerful extractants for the actinides than are the corresponding monoacidic 
phosphates. Taking advantage of this greater extractive power, Baybarz, Leuze, and Weaver ${ }^{177,178}$ devised a countercurrent extraction process using a $1 M$ solution of HEHØР [bis(2-ethylhexyl) phenylphosphonic acid] in diethylbenzene as an extractant to separate americium and curium from transcurium elements contained in $1 M \mathrm{HCl}$. Americium and curium remain in the aqueous phase while the transcurium elements are stripped from the organic phase with $4 M \mathrm{HCl}$. Curium losses are about $0.1 \%$, and the decontamination factor of transcurium elements from americium is $\sim 10^{3}$. Routine use of this process at ORNL in actinide processing operations was precluded by the presence of zirconium in feed solutions because of corrosion of zirconium-based equipment. Zirconium is strongly extracted by HEHØP (Ref. 179); such extraction adversely affects the separation of americium and curium from transcurium elements.

Separation of lanthanides and actinides in the Talspeak process (compare pages 208 to 220) is smaller when HDEHP is replaced by the more powerful HEHØP (Ref. 151). For example, extraction by $0.1 M$ HEHØP in diisopropylbenzene from $1 M$ lactic solutions $0.04 M$ to $0.2 M$ in $\mathrm{Na}_{5}$ DTPA gives separation factors of 100 for cerium and europium over americium, but the neodymium/californium separation factor is only about one-half as large as that obtained with HDEHP.

Mason, Bollmeier, and Peppard ${ }^{\mathbf{8 0 . 1 8 1}}$ have used bis(2,6-dimethyl-4-heptyl) phosphoric acid, $\left[\left(i-\mathrm{C}_{4} \mathrm{H}_{9}\right)_{2} \mathrm{CHO}\right]_{2} \mathrm{PO}(\mathrm{OH})$, to preferentially extract $\mathrm{Am}(\mathrm{VI})$ and thus partition americium from lanthanides and trivalent actinides. They report that, in the system $\left.0.6 F \quad\left[i-\mathrm{C}_{4} \mathrm{H}_{9}\right)_{2} \mathrm{CHO}\right]_{2} \mathrm{PO}(\mathrm{OH})-n$-heptane- $0.025 F \mathrm{HNO}_{3}-0.025 F \mathrm{AgNO}_{3}-$ $0.185 F \mathrm{~K}_{2} \mathrm{~S}_{2} \mathrm{O}_{8}$, the extraction constant for oxidized americium is greater than 40 , whereas that for $\mathrm{Cm}(\mathrm{III})$ is $<10^{-5}$. Mason, Bollmeier and Peppard recommend the use of bis(2,6-dimethyl-4-heptyl)phosphoric acid as the stationary phase in extraction chromatography systems (compare page 255), but thus far no such application has been reported.

Much interest has been shown in the chemistry and reaction mechanisms involved in the extraction of Am(III) by mono-(2-ethylhexyl)-phosphoric acid $\left[\left(\mathrm{H}_{2}\right)\right.$ EHP].$^{143,145,166,182-188}$ This reagent has a much higher tendency to polymerize than HDEHP. In alcohols where $\left(\mathrm{H}_{2}\right)$ EHP is monomeric, Am(III) extraction follows the mechanism: ${ }^{186}$

$$
\mathrm{Am}_{(\mathrm{aq})}^{3+}+3\left[\left(\mathrm{H}_{2}\right) \mathrm{EHP}\right]_{(\mathrm{org})} \rightleftharpoons \mathrm{Am}(\mathrm{HEHP})_{3(\mathrm{org})}+3 \mathrm{H}_{(\mathrm{aq})}^{+}
$$

Rao, Mason, and Peppard ${ }^{183}$ give the following mechanism for the extraction of $\mathrm{Am}^{3+}$ by dimeric $\left(\mathrm{H}_{2}\right)$ EHP in hexone:

$$
\mathrm{Am}_{(\mathrm{aq})}^{3+}+2.5\left[\left(\mathrm{H}_{2}\right) \mathrm{EHP}\right]_{2(\mathrm{org})} \rightleftharpoons \mathrm{Am}(\mathrm{HEHP})\left[\mathrm{H}_{3}(\mathrm{EHP})_{2}\right]_{2(\mathrm{org})}+3 \mathrm{H}_{(\mathrm{aq})}^{+}
$$

Finally the extraction of Am(III) by $\left(\mathrm{H}_{2}\right)$ EHP in nonpolar diluents (e.g., $n$-hexane) can be represented as: ${ }^{182,184,185}$

$$
\mathrm{Am}_{(\mathrm{aq})}^{3+}+\left[\left(\mathrm{H}_{2}\right) \mathrm{EHP}\right]_{\mathrm{p}(\mathrm{crg})} \rightleftharpoons \mathrm{Am}\left[\mathrm{H}_{2 \mathrm{p}-3}(\mathrm{EHP})_{\mathrm{p}}\right]_{(\mathrm{org})}+3 \mathrm{H}_{(\mathrm{aq})}^{+}
$$


Because the extraction capacity of $\left(\mathrm{H}_{2}\right)$ EHP is greater than that of HEDHP, considerable effort has been expended in devising $\left(\mathrm{H}_{2}\right)$ EHP extraction processes for separating Am(III) from lanthanides. Systems studied in laboratory-scale batch and countercurrent tests involve the extraction of $\mathrm{Am}$ (III) from concentrated $\mathrm{LiCl}$ solutions ${ }^{189-191}$ and from $0.1 M$ to $10.3 M \mathrm{NH}_{4} \mathrm{SCN}$ media. ${ }^{166,185}$ Although excellent separations have been obtained in some cases, none of these $(\mathrm{H})_{2} \mathrm{EHP}$ extraction schemes have found any plant-scale use largely because of the required precise control of conditions.

In addition to those already cited, the following organophosphorus acids have also been used in laboratory-scale americium extraction studies: di[para(1,1,3,3-tetramethylbutyl)phenyl]-phosphoric acid $;^{145,146,192}$ di(hexoxymethyl)phosphoric acid; $;^{193,194}$ di-n-octylphosphoric acid; ${ }^{195}$ di-neooctylphosphoric acid; ${ }^{196}$ bis $(2,6$ dimethyl-4-heptyl)phosphoric acid; ${ }^{197}$ di- $n$-octylphosphinic acid; ${ }^{198,199}$ mono- $n$ octylphosphinic acid; ${ }^{200}$ 2-ethylhexylphosphinic acid; ${ }^{200} n$-octylphenylphosphinic acid; ${ }^{201}$ and cyclooctylphenylphosphinic acid. ${ }^{201}$

Amine Extractants. Nitrogen-based extractants, particularly tertiary amines and quaternary ammonium compounds, have been widely studied and used for separating and recovering americium and other actinide elements from aqueous media. General reviews of amine extractants and extraction chemistry have been written by Schmidt, ${ }^{202}$ by Coleman, Blake, and Brown, ${ }^{203.204}$ and by Müller. ${ }^{93}$

Tertiary Amine Salts. Paralleling the behavior of neutral monodentate organophosphorus extractants, tertiary amine salts extract $\mathrm{Am}^{3+}$ only poorly from concentrated $\mathrm{HNO}_{3}$ or $\mathrm{HCl}$ solutions but very strongly from concentrated nitrate or chloride solutions of low acidity (Fig. 5.21). Tertiary amine extraction of tracer amounts of americium from $\mathrm{HNO}_{3}$-metal nitrate [e.g., $\mathrm{Al}\left(\mathrm{NO}_{3}\right)_{3}, \mathrm{LiNO}_{3}$, and $\mathrm{Mg}\left(\mathrm{NO}_{3}\right)_{2}$ ] solutions has been investigated in detail as a function of type and concentration of metal nitrate ${ }^{105.106 .113 .123}$ amine type and concentra-

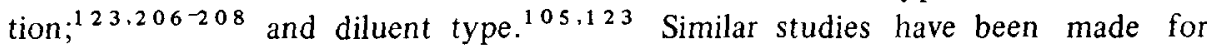
tertiary amine extraction of tracer americium from $\mathrm{HCl}-$ metal chloride solutions: type and concentration of metal chloride ${ }^{93,178,209-215}$ amine type and concentration; , 78,209,214-219a and diluent effects. $^{209,215,216}$ Results and findings of these studies are recounted in Refs. 88 and 95.

In tertiary amine extraction of americium from both nitrate and chloride solutions, $D_{A m}$ varies with the square of the amine concentration. ${ }^{178,205,206,209,214,216,218}$ From this extraction dependency, Marcus, Givon, and Choppin ${ }^{206}$ and Horwitz et al. ${ }^{205}$ assume that $\mathrm{Am}^{3+}$ is extracted from nitrate media as the complex $\left(\mathrm{R}_{3} \mathrm{NH}\right)_{2} \mathrm{Am}\left(\mathrm{NO}_{3}\right)_{5}$. In a similar fashion, Moore ${ }^{216}$ postulated that tertiary amines extract $\mathrm{Am}^{3+}$ from chloride solutions according to the reaction:

$$
2 \mathrm{R}_{3} \mathrm{~N}_{(\mathrm{org})}+2 \mathrm{H}_{(\mathrm{aq})}^{+}+\mathrm{AmCl}_{5(\mathrm{aq})}^{2-} \rightleftharpoons\left(\mathrm{R}_{3} \mathrm{NH}\right)_{2} \mathrm{AmCl}_{5 \text { (org) }}
$$




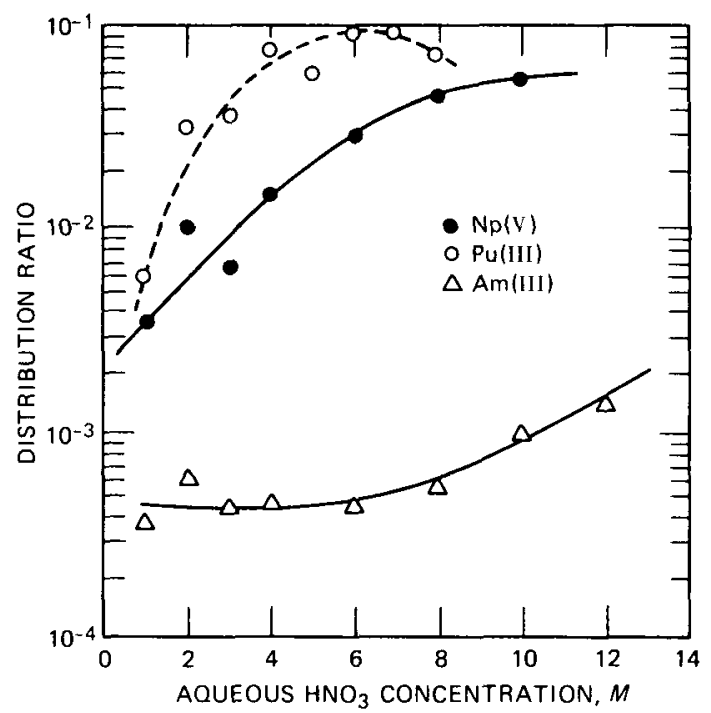

(a)

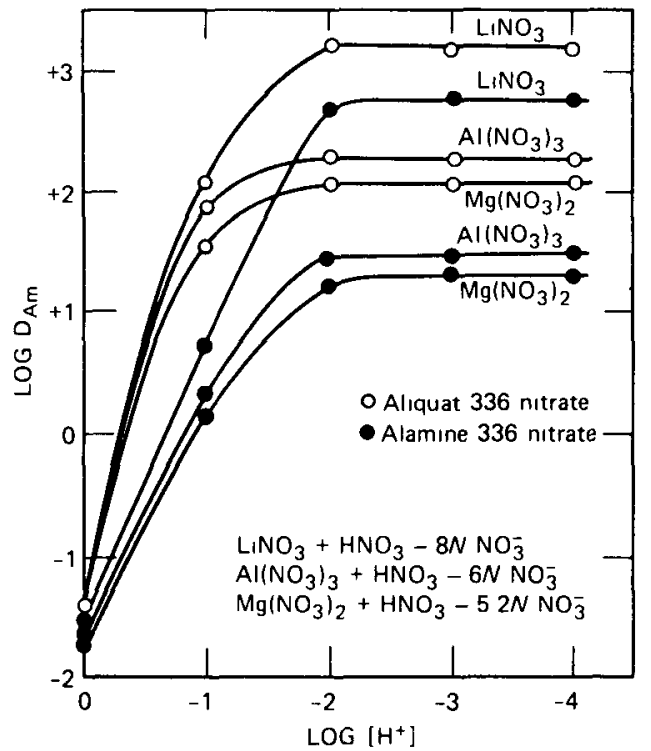

(b)

Fig. 5.21 Amine extraction of $\mathrm{Am}^{3+}$ from nitrate solutions. (a) Extraction from $\mathrm{HNO}_{3}$ solutions by 10 vol.\% tri- $n$-octylamine in xylene. [Adapted from W. E. Keder, J. C. Sheppard, and A.S. Wilson, ${ }^{207}$ The Extraction of Actinide Elements from Nitric Acid Solutions by Tri- $n$-Octylamine, Journal of Inorganic and Nuclear Chemistry, 12: 327 (1960).] (b) Extraction from $\mathrm{HNO}_{3}$-metal nitrate solutions by $0.59 \mathrm{M}$ Alamine $336 \cdot \mathrm{HNO}_{3}$ in disopropylbenzene and $0.39 \mathrm{M}$ Aliquat $336 \cdot \mathrm{NO}_{3} \cdot \mathrm{HNO}_{3}$ in xylene. [From E. P. Horwitz, C. A. A. Bloomquist, L. J. Sauro, and D. J. Henderson, ${ }^{205}$ The Liquid-Liquid Extraction of Certain Tripositive Transplutonium Ions from Salted Nitrate Solutions with a Tertiary and Quaternary Amine, Journal of Inorganic and Nuclear Chemistry, 28: $2313(1966)$.] 
Müller, Duyckaerts, and Fuger ${ }^{217}$ postulate that the complex extracted from chloride solutions is formed by association of the $\left(\mathrm{R}_{3} \mathrm{NH}\right) \mathrm{AmCl}_{4}$ complex with tertiary amine salts $\mathrm{R}_{3} \mathrm{NHCl}$; the resultant ionic quadrupoles

$$
\begin{array}{cc}
\mathrm{R}_{3} \mathrm{NH}^{+} & \mathrm{AmCl}_{4}^{-} \\
\mathrm{Cl}^{-} & \mathrm{R}_{3} \mathrm{NH}^{+}
\end{array}
$$

also contain two amine molecules per $\mathrm{Am}^{3+}$ ion.

Marcus $^{219}$ a has reported on results of studies of tri- $n$-octylamine extraction of macro amounts of $\mathrm{Am}^{3+}$ from $0.85 \mathrm{M} \mathrm{HCl}-9.45 \mathrm{M} \mathrm{LiCl}$ solutions. He observed coextraction of lithium with americium in a $1: 1$ mol ratio; lithium was not extracted in the absence of americium. To account for his results, Marcus suggested the following extraction mechanism:

$$
\begin{aligned}
\mathrm{AmCl}_{2(\mathrm{aq})}^{+}+2 \mathrm{Cl}_{(\mathrm{aq})}^{-}+\mathrm{Li}_{(\mathrm{aq})}^{+}+2\left(\mathrm{R}_{3} \mathrm{NHCl}\right)_{\mathrm{p}} \mathrm{R}_{3} \mathrm{NH}^{+} \mathrm{Cl}_{(\mathrm{org})}^{-} \\
\\
\rightleftharpoons\left[\left(\mathrm{R}_{3} \mathrm{NHCl}\right)_{\mathrm{p}} \mathrm{R}_{3} \mathrm{NH}\right]_{2} \mathrm{LiAmCl}_{6}(\text { org })
\end{aligned}
$$

Weaver ${ }^{8}$ mentions having heard doubts expressed about the coextraction of lithium and the validity of Eq. 5.15. In some recent related extraction studies, Harmon et al. ${ }^{219 \mathrm{~b}}$ observed that $1 M$ solutions of Adogen 464 (a quaternary ammonium salt available from Ashland Chemical Company) in xylene extract substantial amounts of lithium from $10 \mathrm{M} \mathrm{LiCl}$ solutions.

Distribution coefficients of $\mathrm{Am}^{3+}$ and other trivalent transplutonium elements from concentrated $\mathrm{LiCl}$ solutions are 150 - to $>1000$-fold higher than those of trivalent lanthanides (Fig. 5.22). This phenomenon was used by Moore $16,220,221$ in various analytical applications; it was also exploited by process chemists at ORNL in the development of the Tramex process ${ }^{123,178,209,215.222,223}$ for plant-scale separation of americium, curium, and other transplutonium elements from fission-product lanthanides and other contaminants.

The flow sheet in Fig. 5.23(a) illustrates the essentials of the Tramex process as originally devised, ${ }^{178}$ whereas that in Fig. 5.23(b) shows the particular Tramex process used in the Curium Recovery Facility at Oak Ridge to recover $35 \mathrm{~g}$ each of ${ }^{243} \mathrm{Am}$ and ${ }^{244} \mathrm{Cm}$ and about $25 \mathrm{~g}$ of ${ }^{242} \mathrm{Cm}$ in a highly pure form. ${ }^{150}$ The basic Tramex process [Fig. 5.23(a)] involves selective extraction of $\mathrm{Am}^{3+}$ and other transplutonium elements from $10 M$ to $11 M \mathrm{LiCl}-0.02 M$ to $0.25 \mathrm{M} \mathrm{HCl}$ into the hydrogen chloride salt of a tertiary amine in an appropriate diluent. The organic extract is scrubbed with a small volume of $11 M \mathrm{LiCl}-\mathrm{HCl}$ solution, stripped with $8 M$ $\mathrm{HCl}$, and discarded to waste without reuse. The strip product is scrubbed with amine extractant containing nitrous acid to improve decontamination from radioruthenium.

The chemistry involved in the Tramex process has been thoroughly worked out by ORNL chemists and engineers. ${ }^{123,178,209,215,223}$ Only highlights of this chemistry are mentioned here; much greater detail is provided in an article by Leuze and Lloyd. ${ }^{76}$ Distribution coefficients in the Tramex system, in agreement with the earlier 


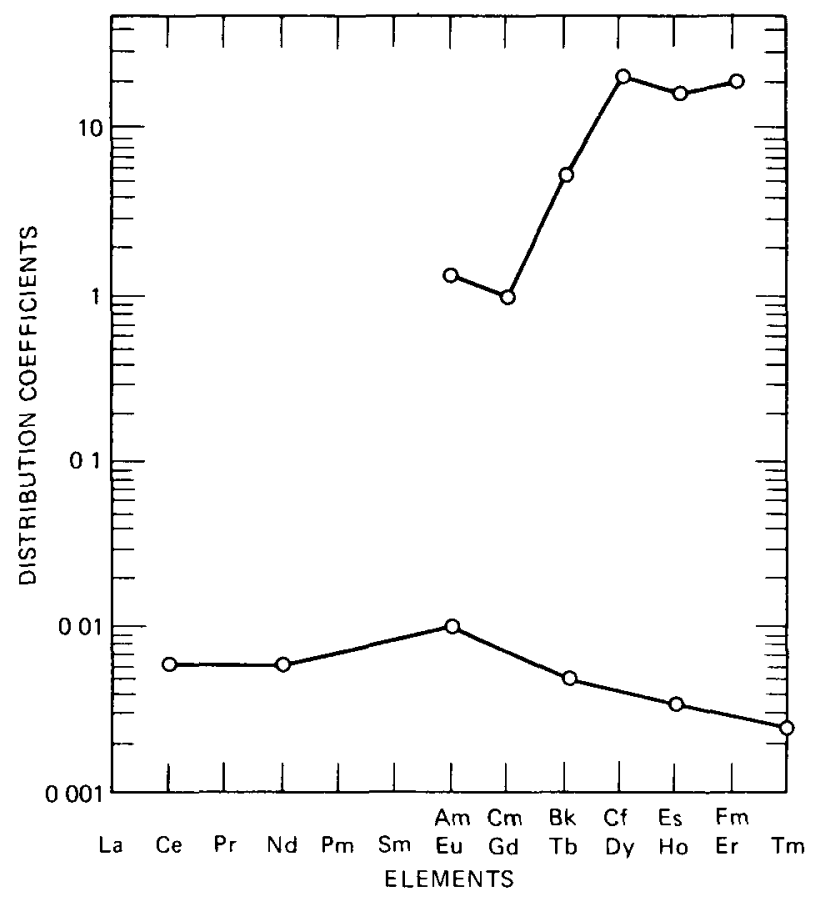

Fig. 5.22 Relative extractability of actınides and lanthanides from $10 M \mathrm{LiCl}$ solution. Extractant, $0.6 M$ Alamine $336 \cdot \mathrm{HCl}$ in diethylbenzene [From R D. Bdybarz, B S. Weaver, and H B. Kinser, ${ }^{209}$ Isolation of Transplutonium Elements by Tertiary Amıne Extraction, Nuclear Sctence and Engineenng, 17: 457 (1963).

discussion in this chapter, are directly proportional to the second power of the amine concentration and also highly dependent on the type of diluent. Various tertiary amınes were tested in laboratory-scale studies, but Alamine 336 (General Mills, Inc.) and Adogen 364HP (Archer Daniels Midland Company), both mixtures of octyl and decyl amines, because they are avallable in suitably pure form (particularly Adogen 364HP) in commercially avallable quantities, have been generally used in large-scale Tramex process operation. West and Navarez ${ }^{24}$ have published specifications for satisfactory tertiary amine extractants for use in the Tramex process. Because of its ready avalability, high flash point, and high distribution coefficients for actinides, diethylbenzene is a preferred diluent.

Extractability of the transplutonium and lanthanide elements into the Tramex process solvent is strongly dependent on the chloride concentrations of the aqueous phase. Distribution coefficients increase with increasing $\mathrm{LiCl}$ concentration and decrease with an increasing concentration of free $\mathrm{HCl}$. Mathematical representations for distribution data in the Tramex system have been derived by Roth and Henry 210 and by Agee and Roth. ${ }^{89}$ Aluminum chlonde is an effective salting agent in the 
Tramex process, but its maximum solubility in $10 M \mathrm{LiCl}$ is $0.2 M$ (Ref. 225). At these salt concentrations, $\mathrm{AlCl}_{3}$ will precipitate when the $\mathrm{HCl}$ concentration is $>0.05 M$. Actinide-lanthanide separation factors in the Tramex process are seriously compromised by the presence of nitrate in the adjusted feed; nearly comple te nitrate removal is thus required. The Tramex process provides excellent decontamination from rare earths, aluminum, strontium, and, in general, all those impurities which do not form extractable anionic chloride complexes. Ruthenium, zirconium, niobium, and iron are extracted and remain in the organic. Good ruthenium decontamination is difficult to obtain because of slow conversion of the extracted species to an inextractable one.

Predominant radiolysis effects in the Tramex process are rapid destruction of $\mathrm{HCl}$ and generation of a strong oxidant in $\mathrm{LiCl}$ feed solutions which results in poor decontamination from cerium since $\mathrm{Ce}^{4+}$ extracts along with the actinides. ${ }^{76,123,149,150,154,226}$ To counteract these effects, methanol is added to the feed to suppress the loss of $\mathrm{HCl}$, and 2,5-di-tert-butylhydroquinone (DBHQ), an organic-soluble reductant, is added to the Tramex process solvent to reduce any $\mathrm{Ce}^{4+}$ to $\mathrm{Ce}^{3^{+}}$(Ref. 150). In some early Tramex process operation [Fig. 5.23(b)], $\mathrm{SnCl}_{2}$ was added to the feed to insure the presence of trivalent cerium.

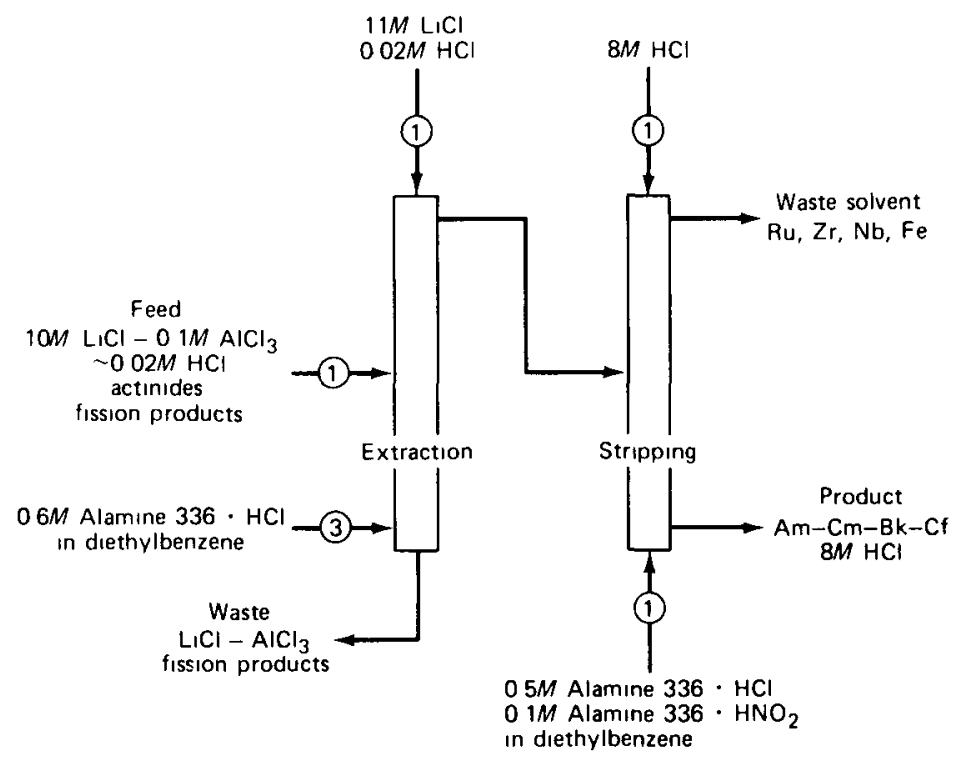

(a)

Fig. 5.23 Tramex process flow sheets. (a) As originally devised. (b) As used in the Curium Recovery Facility at Oak Ridge. [From R. E. Leuze and M. H. Lloyd, ${ }^{76}$ Processing Methods for the Recovery of Transplutonum Elements, in Progress in Nuclear Energy, Process Chemistry, Series III, C. E. Stevenson, E. A. Mason, and A. T. Gresky (Eds.), Vol. 4, page 549, Pergamon Press, Inc., New York, 1970.] See facing page for (b). 
The Tramex process has been used routinely since 1967 at the Transuranium Processing Plant (TRU) at ORNL as part of the processing sequence (Fig. 5.24) involved in the recovery and purification of transplutonium elements from highly irradiated (High Flux Isotopes Reactor and/or Savannah River reactors) aluminum-clad ${ }^{242} \mathrm{Pu}-\mathrm{Al}$ alloy, ${ }^{242} \mathrm{PuO}_{2}$, and ${ }^{243} \mathrm{AmO}_{2}-{ }^{244} \mathrm{CmO}_{2}$ targets. [The Pubex process referred to in Fig. 5.24 involves HDEHP extraction of plutonium and zirconium from the dissolver solution; the Cleanex process (compare pages 208 to 220) is an HDEHP extraction process performed to separate the transplutonides from metallic impurities, and, if necessary, to convert from a nitrate- to a chloride-based system.] At the TRU the Tramex process has been operated satisfactorily in continuous countercurrent

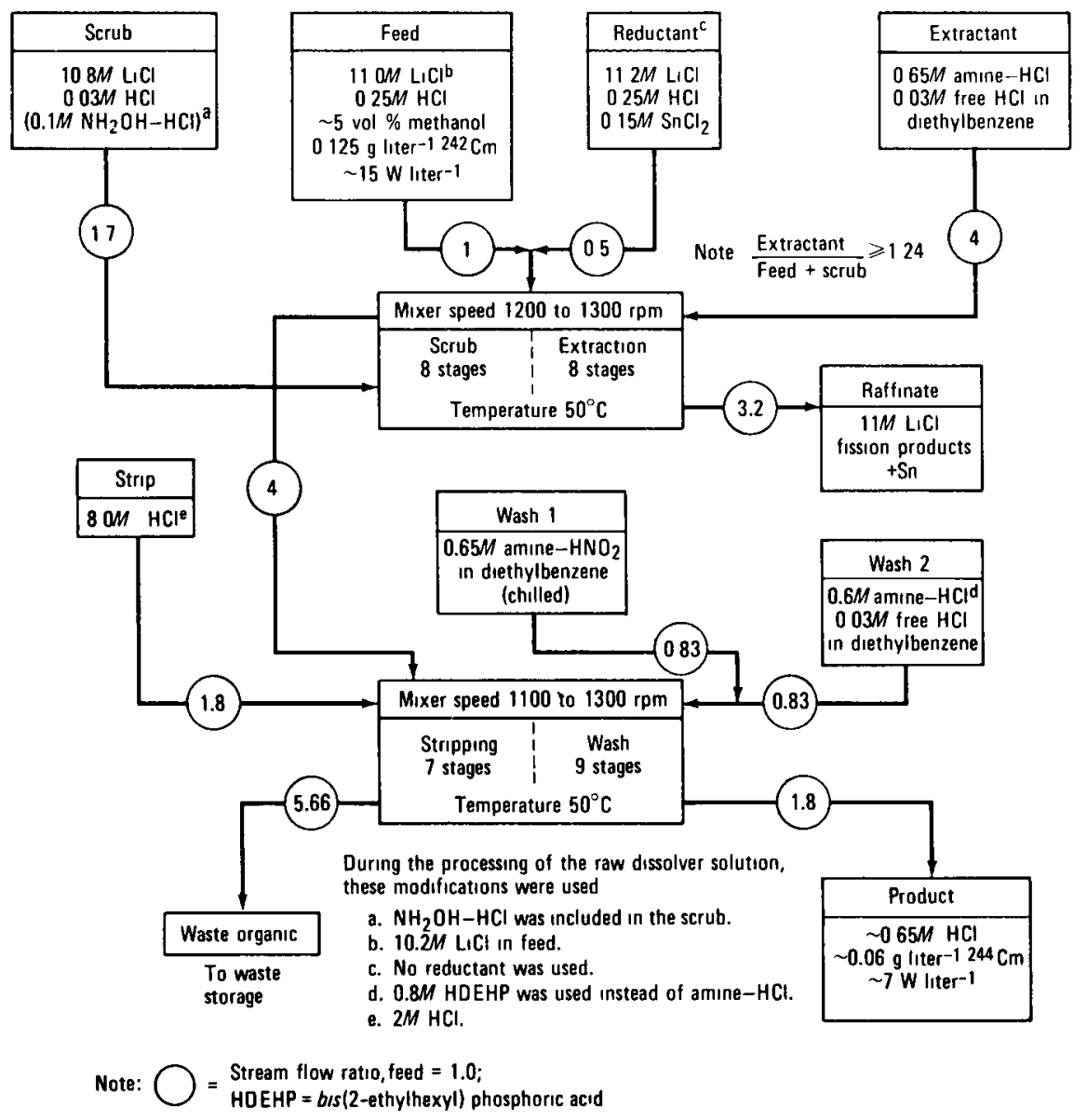

(b)

Fig. 5.23 (Continued; see facing page for caption.) 


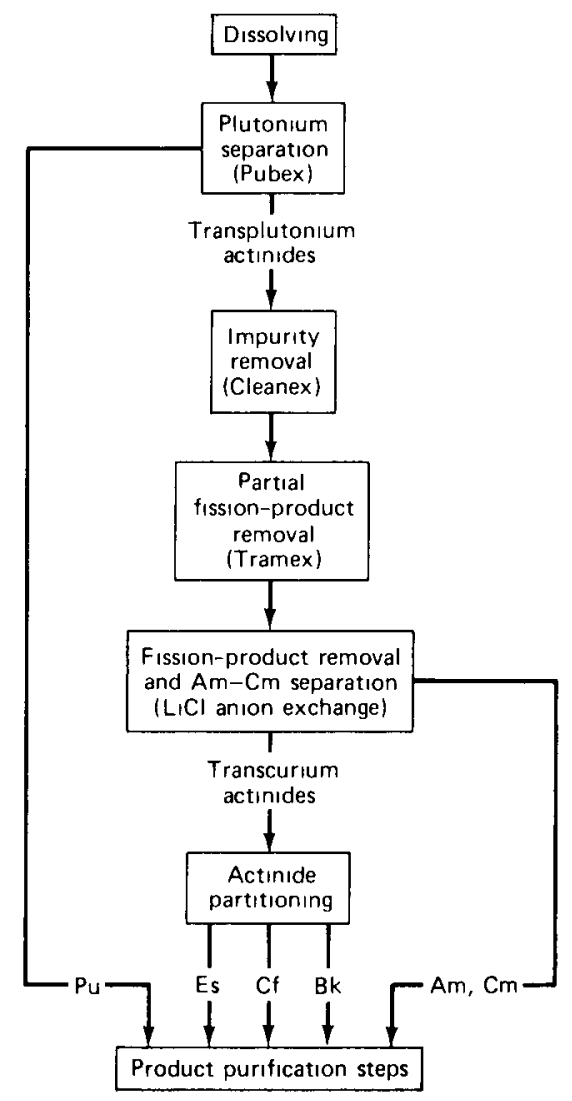

Fig. 5.24 Schematic of processing steps used in the Transuranium Processing Plant at Oak Ridge. Adapted from Ref. 66

equipment (pulse columns) constructed of Zircaloy under flow-sheet conditions very similar to those shown in Fig. 5.23(b) except for the substitution of DHBQ for $\mathrm{SnCl}_{2}$. Design details of the original pulse columns used in Tramex process operations are given in the paper by Leuze and Lloyd $;^{76}$ design changes made in second-generation Tramex process pulse columns are mentioned in Ref. 227. Continuous Tramex process operation has been generally satisfactory with feeds derived from $\mathrm{PuO}_{2}$ and $\mathrm{AmO}_{2}-\mathrm{CmO}_{2}$ targets. In the initial processing of ${ }^{242} \mathrm{Pu}-\mathrm{Al}$ alloy tubes irradiated at Savannah River, extensive carry-over of aluminum to the $\mathrm{LiCl}$ feed and attendant solids formation prohibited operation of the continuous Tramex process equipment; ${ }^{28}$ batch-type operation was necessary to process such feeds. Other details of the Oak Ridge experience with plant-scale Tramex process operation are provided in a paper by Bigelow, Chattin, and Vaughen. ${ }^{150}$

The Tramex process was also used for a time at the Savannah River Laboratory as part of the process sequence 29 carried out to produce and purify kilograms of 
${ }^{244} \mathrm{Cm}$ and ${ }^{243} \mathrm{Am}$. Savannah River Laboratory experience with continuous Tramex process operation in mixer-settlers has been summarized by Groh et al. ${ }^{105 a}$ and Prout et al. ${ }^{230}$ The two-cycle Tramex process flow sheet shown in Fig. 5.25 was initially satisfactorily demonstrated in laboratory-scale facilities with miniature mixer-settlers. [The actinide-lanthanide concentrate $\left(\sim 2 \mathrm{~g}\right.$ liter ${ }^{-1}{ }^{244} \mathrm{Cm}, \sim 0.9 \mathrm{~g}$ liter ${ }^{-1}{ }^{243} \mathrm{Am}, 6 M \mathrm{NO}_{3}^{-}$, and $0.4 M \mathrm{H}^{+}$) used as feed to the process derived from the prior batch TBP extraction operations described on pages 195 to 202; the Clanex process described later in this chapter was used as a head-end step to prepare chloride-based feed to the Tramex process.] Subsequently this solvent extraction process (Fig. 5.25) was applied in a large pilot production facility ${ }^{73}$ to purify $\sim 1.5 \mathrm{~kg}$ of ${ }^{244} \mathrm{Cm}$ and $\sim 0.7 \mathrm{~kg}$ of ${ }^{243} \mathrm{Am}$. Prout et al. ${ }^{230}$ state: "The ${ }^{244} \mathrm{Cm}$ produced met the radioactive purity specifications given in the initial report of this series (DP-1009). Although product quality was good, the rate of production was slow. The exacting analysis requirements for process control, and maintenance problems caused by the high concentrations of chloride in the extraction system, made continuous multicycle operation impractical ..." (author's italics). After their unpleasant and frustrating experience with a scaled-up Tramex process, the Savannah River group used a high-pressure displacement chromatographic cation-exchange process (compare pages 245 to 252$)$ to purify the remaining $(\sim 3 \mathrm{~kg}){ }^{244} \mathrm{Cm}$ and ${ }^{243} \mathrm{Am}$.

Nitrate ion in Tramex process chloride feedstock adversely affects the separation of actinides from lanthanides, as previously noted. A HDEHP solvent extraction process (Cleanex process) for converting from nitrate- to chloride-based systems has already been described (compare pages 195 to 202). The Clanex process (Fig. 5.26) is another such nitrate-to-chloride conversion process. In this process, americium, curium, and lanthanides in a $1 M$ to $2 M \mathrm{Al}\left(\mathrm{NO}_{3}\right)_{3}$ or a $7 M$ to $8 M \mathrm{NO}_{3}^{-}$[mixed $\mathrm{Al}\left(\mathrm{NO}_{3}\right)_{3}$ and $\left.\mathrm{LiNO}_{3}\right]$ solution are extracted into an $0.6 \mathrm{M}$ Alamine $336-\mathrm{HNO}_{3}-\mathrm{di}$ ethylbenzene solvent, scrubbed with $8 M \mathrm{LiNO}_{3}$, and stripped with $3 M$ to $8 M \mathrm{HCl}$. The strip product is scrubbed with $0.6 \mathrm{M}$ Alamine $336-\mathrm{HCl}-$ diethylbenzene to remove the last traces of nitrate. The rare earths coextract with the trivalent actinides, but most other contaminants are sufficiently inextractable that they remain in the aqueous raffinate. Applications of the Clanex process have been made both at Oak Ridge $^{76,231}$ and at Savannah River. ${ }^{76,105 a, 231}$

In other laboratory-scale investigations of tertiary amine extractants, Chmutova et al. ${ }^{232}$ have studied extraction of $\mathrm{Am}^{3+}$ and other trivalent transplutonide elements by mixtures of trioctylamine with TBP, tri- $n$-octylphosphine oxide, and triphenylphosphine oxide. The synergistic effect with such solvents is sufficient according to these Russian scientists to permit quantitative extraction of $\mathrm{Am}^{3+}$ from $1 M$ $\mathrm{HNO}_{3}-7 \mathrm{M} \mathrm{LiNO}_{3}$ solutions. Conversely Koehly, Madic, and Berger ${ }^{23}$ report that extraction of $\mathrm{Am}^{3+}$ from $\mathrm{LiNO}_{3}$ solutions by trilaurylamine nitrate solvent decreases when capric acid is added to the organic phase; the antagonistic effect of capric acid is accounted for by these workers on the basis of an addition reaction between one molecule of trilaurylamine nitrate and one capric acid dimer.

Koehly and Berger ${ }^{234}$ have studied the effects of aminopolycarboxylic acids (e.g., DTPA and EDTA) on the extraction of $\mathrm{Am}^{3+}$ and lanthanides from low-acid $\mathrm{LiNO}_{3}$ 


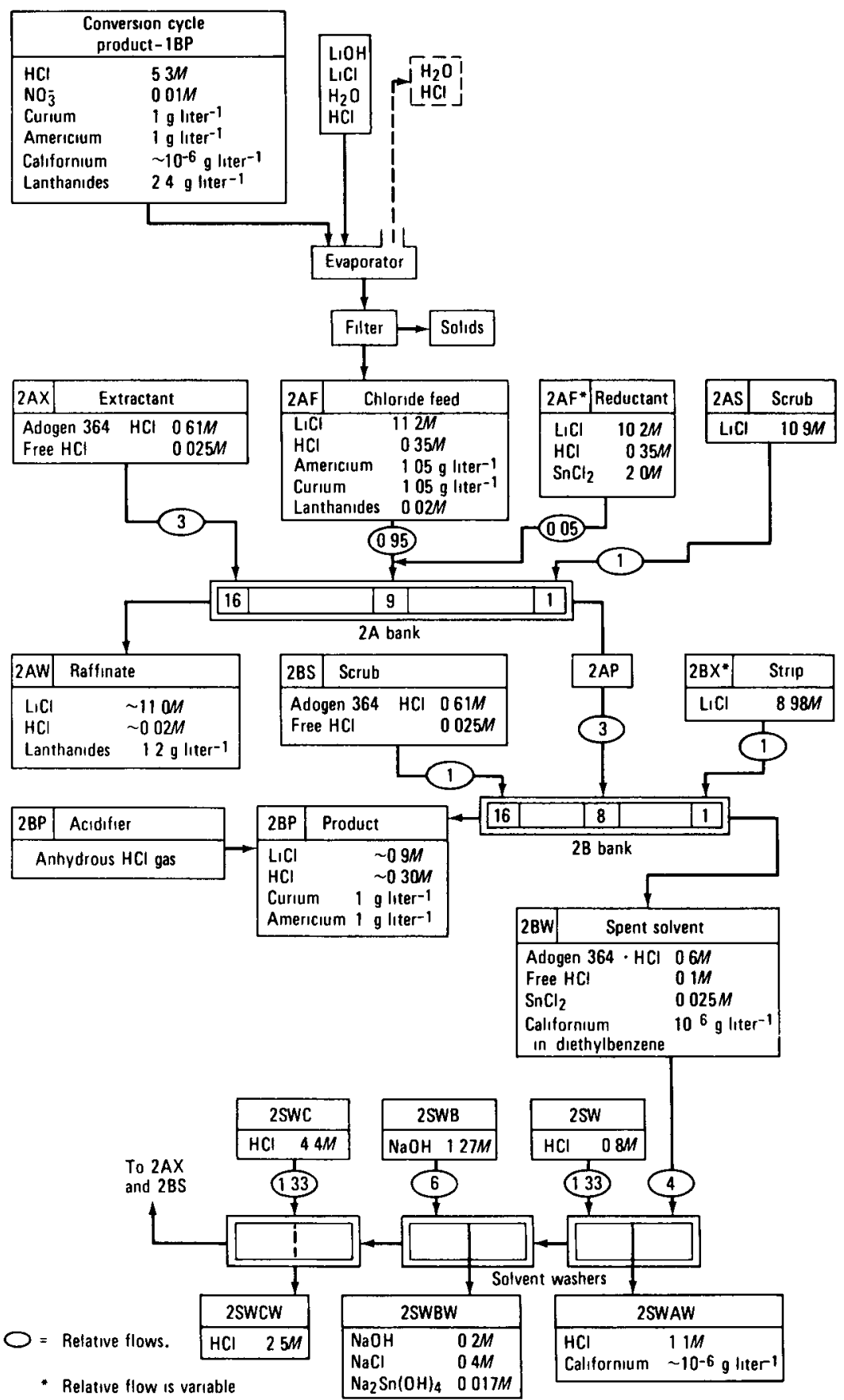

Fig. 5.25 Two-cycle Tramex process flow sheet used to recover amencium and curium at the Savannah River Plant. ${ }^{230}$ 


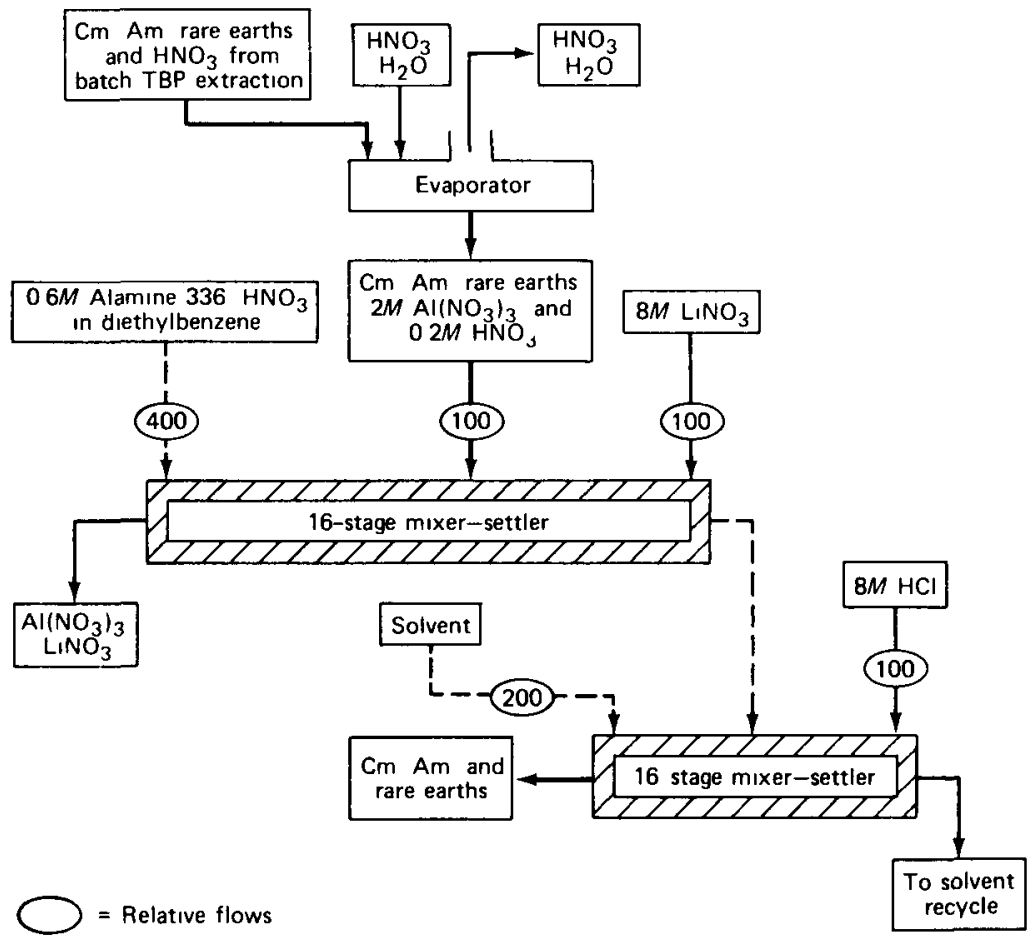

Fig. 5.26 Clanex process used for nitrate to chlonde conversion [From H J Groh, R $T$ Huntoon, C S Schlea, J A Smith, and F H Springer, ${ }^{105 a ~} 244 \mathrm{Cm}$ Production and SeparationStatus of the Plot Production Program at Savannah River, Nuclear Applicatıons 1· 327 (1965) ]

and $\mathrm{Al}\left(\mathrm{NO}_{3}\right)_{3}$ solutions by $064 M$ trildurylamine in a dodecane-chlorobenzene diluent, separation factors $\left(\mathrm{D}_{\mathrm{RE}} / \mathrm{D}_{\mathrm{Am}}\right.$ ) similar to those found (Table 5 5) in TBP extraction from similar solutions were observed Koehly and Berger used their data to devise countercurrent extraction processes for separating $\mathrm{Am}^{3+}$ from $\mathrm{Pm}^{3+}$ and $\mathrm{Cm}^{3+}$, these processes were subsequently satisfactonly demonstrated in miniature mixersettler tests with aqueous $\mathrm{LiNO}_{3}-\mathrm{DTPA}$ solutions containing milligram amounts of $241243 \mathrm{Am}$ and ${ }^{244} \mathrm{Cm}$ (Refs 234 and 235)

Moore $^{236}$ reported data for Alamine 336 extraction of $\mathrm{Am}^{3+}$ from $001 M \mathrm{HNO}_{3}$ solutions containing citnc, tartarıc, oxalıc, acetı, EDTA, or $\alpha$-hydroxyısobutyric acids

Weaver 237 made a brief companson of the extraction of Am(VI) and Am(III) from $\mathrm{LiNO}_{3}$ solution by Alamine 336 nitrate in disopropylbenzene At low nitrate concentrations, Am(III) was less extractable than Am(VI), but a difference in nitrate-concentration dependency reversed the preference at concentrations above $4 M$ $\mathrm{LiNO}_{3}$ 
Quaternary Ammontum Salts Quaternary alkyl ammonıum nitrate salts extract $\mathrm{Am}^{3+}$ considerably more efficiently from low-acid, highly salted aqueous nitrate solutions than do tertiary alkyl amines, as shown by the data of Horwitz et al 205 [Figure $521(\mathrm{~b})$ ] [Alıquat 336 is a mixture of trioctylmethyl- and tridecylmethylammonium salts made by General Mills, Inc ] Moore ${ }^{238}$ also studied the extraction of Am(III) from $\mathrm{LiNO}_{3}$ solutions, whereas Van Ooyen 239240 studied the extraction of $\mathrm{Am}^{3+}$ and other transplutonium elements from $\mathrm{LNO}_{3}$ solutions with trilaurylmethyl ammonium nitrate-xylene solutions Chudinov and Pirozhkov ${ }^{241}$ investigated the effect of the type of metal nitrate salting agent on the extraction of Am(III) by xylene solutions of tetraoctylammonium nitrate Collectively these studies show that $D_{A m}$ decreases rapidly at $\mathrm{HNO}_{3}$ concentrations much higher than $001 M$ because of the competition between excess $\mathrm{HNO}_{3}$ and the americium nitrate complex for the extractant, $D_{A m}$ also varies with diluent type and with the type and concentration of salting agent and appears to be a first-order function of quaternary ammonium extractant concentration The extracted species may be $\mathrm{R}_{4} \mathrm{NAm}\left(\mathrm{NO}_{3}\right)_{4}$, but Horwitz et al ${ }^{205}$ and others are quick to point out that this empirical formula may well be too simple to account for the extraction process The extraction sequence for trivalent actınıdes into either Alıquat $336 \cdot$ nitrate or trilaurylmethylammonium nitrate is $\mathrm{Cm}<\mathrm{Cf}<\mathrm{Am}<\mathrm{Es}$

Horwitz, Bloomquist, and Griffin ${ }^{24} 2$ included an extraction step with Aliquat 336 in the preparation of 20 to $30 \mathrm{Cl}_{1}$ of high-purity ${ }^{242} \mathrm{Cm}$ Ir adiated ${ }^{241} \mathrm{AmO}_{2}$ encapsulated in aluminum was dissolved in an $\mathrm{HNO}_{3}-\mathrm{Hg}\left(\mathrm{NO}_{3}\right)_{2}$ solution, a xylene solution of Aliquat 336 was used to extract curium and americium from the $\mathrm{Al}\left(\mathrm{NO}_{3}\right)_{3}$ solution and from certain fission products

Koch and Schoen ${ }^{243244}$ devised and tested on a laboratory scale a quaternary ammonium extraction process for the isolation of ${ }^{241}$ Am from aged plutonium scrap Feed for the extraction process is the americium-containıng raffinate resulting from anion-exchange recovery of the plutonium from a strong $\mathrm{HNO}_{3}$ solution This raffinate is concentrated by evaporation, residual plutonium and, if present, uranium are extracted with Aliquat 336 nitrate in an aromatic diluent The aqueous solution free of plutonium and uranium is adjusted to $7 M \mathrm{NH}_{4} \mathrm{NO}_{3}$ and $\mathrm{pH} 15$, and $\mathrm{Am}^{3+}$ is extracted with the Aliquat 336 solvent After the organic phase is scrubbed with $7 M$ $\mathrm{NH}_{4} \mathrm{NO}_{3}$, the purified americium is stripped with $3 M \mathrm{HNO}_{3}$ No large-scale application of this process has been reported

Advantages of a quaternary ammonium nitrate extraction process over other schemes (e $g$, Tramex process) for isolatıng trivalent actınide-lanthanide elements were discussed by Moore ${ }^{238}$ But again, no large-scale use of quaternary amines for the purpose has been made

Moore 245246 and later Gerontopulos, Rigali, and Barbano 247 found that the throcyanate salt of Alıquat 336 preferentially extracts actınides over lanthanides from moderately concentrated $\mathrm{NH}_{4} \mathrm{SCN}$ solutions Moore ${ }^{25}$ gives the order of extractability as $\mathrm{Cf}>\mathrm{Bk}>\mathrm{Am}>\mathrm{Cm} \gg \mathrm{Yb} \gg \mathrm{Tm}>\mathrm{Eu}>\mathrm{Pm}>\mathrm{Y}>\mathrm{Ce}>\mathrm{La}$ Gerontopulos et al report that distribution coefficients in this system are dependent on temperature, the presence of various contaminant anions, and the type of diluent but that 
separation factors between americium and rare earths remain relatively constant. Several process-scale applications of the Aliquat 336- $\mathrm{NH}_{4} \mathrm{SCN}$ system were suggested by Moore but none have been made.

Polish workers ${ }^{248}$ have reported on extraction of $\mathrm{Am}^{3+}, \mathrm{Cm}^{3+}$, and rare earths from $\mathrm{LiNO}_{3}-0.01 M \mathrm{HNO}_{3}$ solutions by chloroform solutions of cetyltrimethylammonium bromide and cetylpyridinium bromide. Zaman, Merciny, and Duyckaerts $^{249}$ investigated the extraction of americium-HEDTA complexes with Ali-

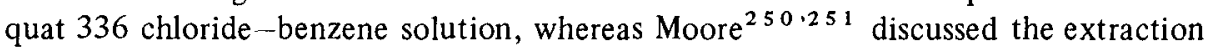
of-americium-HEDTA and americium-DTPA complexes with xylene solutions of Aliquat 336.

\section{ION-EXCHANGE PROCESSES}

\section{Introduction}

Ion-exchange processes-both cation and anion-are extensively used to concentrate, separate, and purify both micro and macro amounts of americium from a whole host of inert and radioactive contaminants, including, particularly, $\mathrm{Cm}$ (III) and lanthanides. A recent innovation for this purpose has been the application of very finely divided resins and high-pressure techniques. Feedstock for the americium ion-exchange processes derives usually from prior solvent extraction (see preceding section), pyrochemical (pages 185 to 187), and even precipitation (pages 190 to 194) schemes.

Ryan $^{252}$ has recently completed a comprehensive review of the chemistry and principles involved in the sorption of americium from various aqueous media by both organic and inorganic exchangers. Other authors have reviewed use of ion-exchange materials for the analysis of americium ${ }^{253}$ and for studies of americium complexes. $^{254}$ Rather than attempting to duplicate this excellent coverage, emphasis here is primarily on an account of the flow sheets, operating details, and performance of the ion-exchange processes used to routinely separate and purify kilograms of americium. Jenkins and Wain ${ }^{25}$ have recently authored a list of publications covering the use of ion exchange for recovering and purifying ${ }^{241} \mathrm{Am}$ and ${ }^{243} \mathrm{Am}$.

\section{Anion-Exchange Resin Systems}

Many different aqueous and mixed aqueous-organic media have been used in laboratory-scale studies of the absorption of americium by anion-exchange resins; results of these studies have been reviewed by Ryan. ${ }^{252}$ For routine, large-scale purification of americium, however, application of anion-exchange resins is limited to sorption from thiocyanate, chloride, and, to a smaller extent, nitrate solutions. 
Thiocyanate Solutions Americium(III) forms relatively strong complexes $\left[\mathrm{AmSCN}^{2+}, \mathrm{Am}(\mathrm{SCN})_{2}^{+}, \mathrm{Am}(\mathrm{SCN})_{3}\right]$ in concentrated aqueous thiocyanate solutions (compare Table 311 ) Thiocyanate species are sorbed on anion-exchange resins considerably more strongly 7256258 than are the corresponding lanthanide thiocyanate complexes, as illustrated by the distribution data plotted in Fig 527 Distribution coefficients and lanthanide-actinide separation factors decrease with an increase in temperature ${ }^{256}$ ( $F_{1 g} 528$ ), Ryan ${ }^{252}$ has pointed out that the europium results of Fig 2 of Ref 258 are incorrectly plotted a factor of 10 higher than the true values

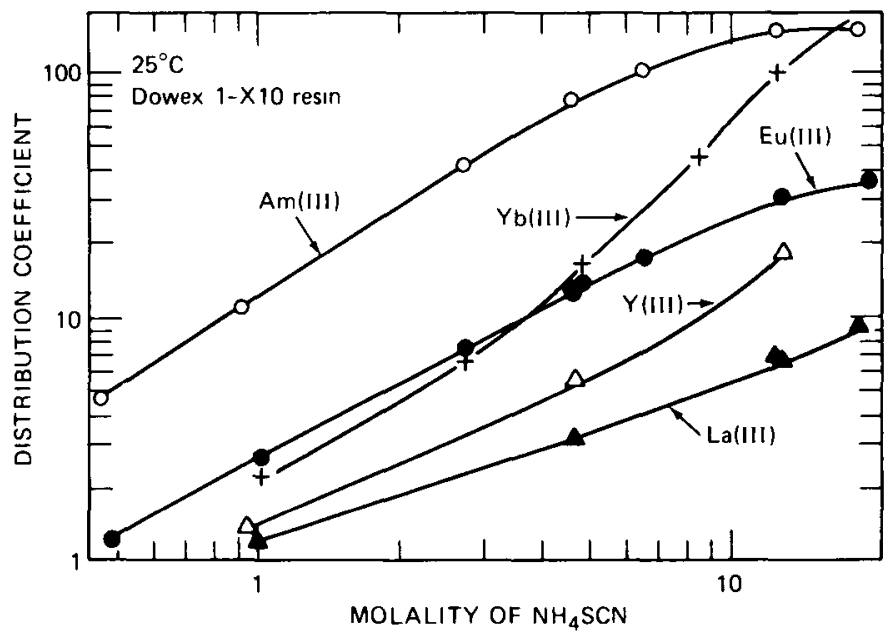

Fig. 5.27 Anion-exchange absorption of $\mathrm{Am}(\mathrm{III}), \mathrm{Lu}(\mathrm{III}), \mathrm{Yb}(\mathrm{III})$, and $\mathrm{La}$ (III) from aqueous $\mathrm{NH}_{4} \mathrm{SCN}$ solutions [t rom $\mathrm{J} S$ Coleman, L B Asprey, and $\mathrm{R} \mathrm{C}$ Chisholm, ${ }^{258}$ The AnionExchange Absorption of Americium, Yttrum, Lanthanum, Europium, and Ytterbium from Aqueous Ammonium Thiocyandte, Journal of Inorganic and Nuclear Chemtstry 31·1167(1969) ]

Much use has been made, particularly in the United States, of thiocyanate anion-exchange systems to purify americium from rare earths and other impurities Figure 529 detalls in schematic form the thiocyanate 1on-exchange process used at the Rocky Flats Plant for about 15 years (1960 to 1975) for routine purification of kllograms of ${ }^{241} \mathrm{Am}$ recovered from aged plutonium metal by the pyrochemical process discussed on pages 185 to 187 This purification scheme was developed originally by Coleman et al ${ }^{47259}$ and Keenan 260 at the Los Alamos Scientific Laboratory and applied there and also by Natto ${ }^{261}$ at the University of California, Lawrence Radiation Laboratory, for purification of milligrams of americium

Feedstock for the Rocky Flats thiocyanate 1on-exchange process is derived from prior aqueous processing of the $\mathrm{NaCl}-\mathrm{KCl}-\mathrm{MgCl}_{2}$ salt product of the pyrochemical process described on pages 185 to 187 For many years, as discussed on pages 190 to 194 , a hydroxide precipitation scheme was used to isolate and concen- 
trate americium from the chloride salt. The hydroxide precipitate was dissolved in nitric acid, and the resulting solution passes through a bed of Dowex 1 anion-exchange resin to remove the bulk of the plutonium. The $7 M \mathrm{HNO}_{3}$ effluent from the anion-exchange column, after dilution to about $0.4 M \mathrm{HNO}_{3}$ constituted feed to the thiocyanate process.

In the thiocyanate process, feedstock was loaded at $25^{\circ} \mathrm{C}$ and at a rate of about 100 liters $\mathrm{hr}^{-1}$ onto a 16.2 -liter bed of 50-100 mesh $\mathrm{H}^{+}$-form Dowex 50-X8 resin (column 1) to sorb and concentrate the americium and plutonium. Feed to this first column contained, typically, $0.02 \mathrm{~g} \mathrm{Am} \mathrm{liter}^{-1}$; $0.003 \mathrm{~g} \mathrm{Pu} \mathrm{liter}^{-1}$; and varying amounts of lanthanum, other rare earths, iron, magnesium, and other metallic impurities. After washing with water and $0.5 \mathrm{M} \mathrm{NH}_{4} \mathrm{SCN}$ to remove the major part of the iron [as the $\mathrm{Fe}(\mathrm{SCN})_{6}^{3^{-}}$complex], americium, plutonium, and rare earths were eluted with a $6 M \mathrm{NH}_{4} \mathrm{SCN}$ solution.

The $6 \mathrm{M} \mathrm{NH}_{4} \mathrm{SCN}$ eluate from the cation column, containing at this point approximately $1 \mathrm{~g} \mathrm{Am} \mathrm{liter}^{-1}$ and $0.1 \mathrm{~g} \mathrm{Pu} \mathrm{liter}^{-1}$, was loaded onto a 16.2-liter bed of 50-100 mesh SCN-form Dowex 1-X4 anion-exchange resin (column 2). To provide

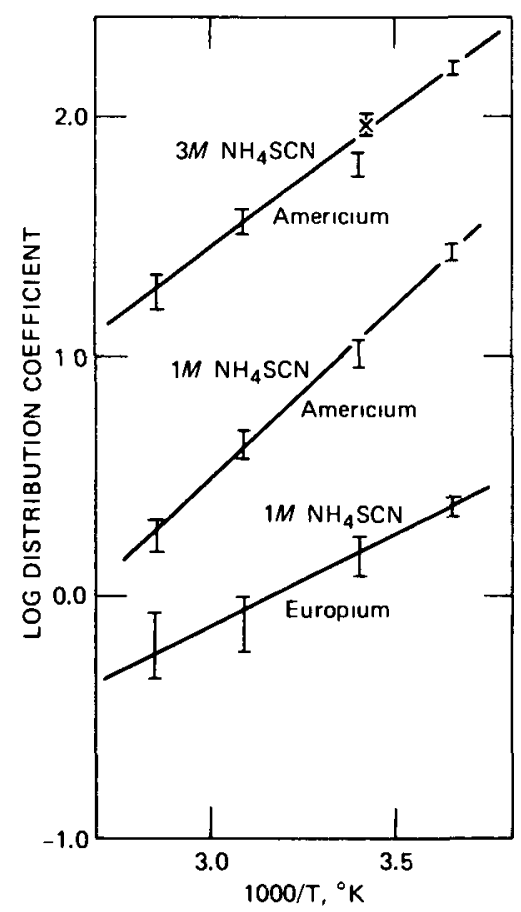

Fig. 5.28 Temperature dependence of distribution coefficients of Am(III) and Eu(III) into Dowex 1-X8 resin from aqueous $\mathrm{NH}_{4} \mathrm{SCN}$ solutions. [From J. L. Ryan, ${ }^{25} 2$ Ion Exchange, in Gmelins Handbuch der Anorganischen Chemie, Band 21, Transurane, Teil D2, G. Koch (Ed.), Verlag Chemie, G.m.b.H., Weinheim, Germany, 1974.] 


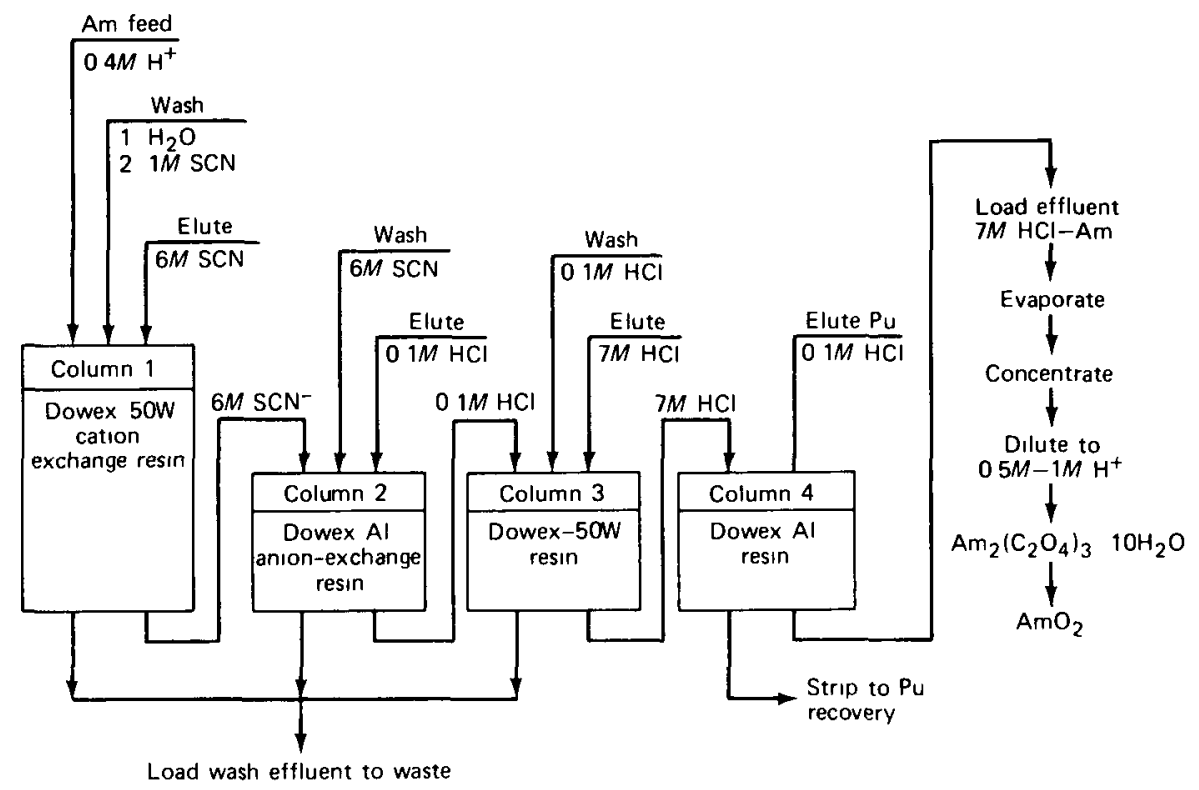

Fig 5.29 Rocky I lats thiocyandte ion exchange americium recovery process All columns are $152 \mathrm{~cm}$ in diameter

decontamination from cosorbed rare earths, the loaded resin bed was washed with several column volumes of $6 M \mathrm{NH}_{4} \mathrm{SCN}$ This sorption-wash sequence was the key element in the overall americium purification scheme, providing separation not only from rare earths but also from iron, magnesium, bismuth, copper, potassium, nickel, and zinc ${ }^{262} \mathrm{Na}^{2} \mathrm{O}^{261}$ and also Hagan and Miller ${ }^{263}$ have shown that some decontamination from aluminum and manganese is also obtained by washing the resin bed with a limited amount of $2 \mathrm{M} \mathrm{NH}_{4} \mathrm{SCN}$ after the lanthanides are removed

The amount of resin required to achieve essentially complete separation of americium from rare earths in the thiocyanate lon-exchange process depends on the rare earth/americium ratio For a lanthanide/americium ratio of $300 \quad 1$, about $30 \mathrm{ml}$ of resin per gram of lanthanide is required, ${ }^{47259}$ whereas a loading of about $15 \mathrm{~g} \mathrm{Am}$ liter ${ }^{1}$ resin can be used for the satısfactory purification of americium that is already largely free of rare earths 260

The final two ion-exchange columns in the Rocky Flats throcyanate process served to further concentrate the americium and separate it from plutonium To this end, americium and plutonium in the $01 \mathrm{M} \mathrm{HCl}$ solution resulting from elution of the first Dowex 1 resin bed (column 2) were loaded onto a second bed of Dowex 50 resin Subsequently americium and plutonium were eluted into a $7 \mathrm{M} \mathrm{HCl}$ solution, and the plutonium then preferentially sorbed onto a bed of Dowex 1 resin The effluent from the latter loading step containing purified americium was evaporated to yield a $6 \mathrm{M} \mathrm{HCl}$ solution containıng 25 to $30 \mathrm{~g} \mathrm{Am} \mathrm{liter}{ }^{1}$ from which the americium was precipitated, 
after adjustment of the acidity to $0.5 M$ to $1 M$, as the oxalate. The oxalate precipitate was calcined to yield high-purity $\mathrm{AmO}_{2}$.

Some additional details of the Rocky Flats thiocyanate ion-exchange process for purifying americium were given in a paper by Ryan and Pringle. ${ }^{262}$ Their report was published in 1960; however, Rocky Flats personnel state that the process was performed, with only minor modifications, much as outlined by Ryan and Pringle. Over 15 years' experience at Rocky Flats shows that the thiocyanate process can be operated successfully on a plant scale to purify americium from rare earths and other metallic impurities. Such experience has also disclosed several process disadvantages, including relatively low (60 to $70 \%$ ) overall americium recovery, production of troublesome free sulfur from alpha radiolysis of $\mathrm{SCN}^{-}$, and the general difficulties of handling and disposing of large volumes of viscous concentrated thiocyanate solutions. For these reasons the thiocyanate process has been replaced by a new cation-exchange process (compare pages 244 to 252 ) to recover and purify americium.

Enhanced anion-exchange resin separation of americium from rare earths can be achieved, according to Russian scientists, ${ }^{26-266}$ by adding various alcohols (methanol, ethanol, etc.) to aqueous $0.1 M$ to $1.0 M \mathrm{NH}_{4} \mathrm{SCN}$ solutions. Their results show that distribution coefficients of $\mathrm{Am}^{3+}$ increase much more rapidly than do those of lanthanides as the alcohol content of the solution increases. The nature of the resin phase complex in such systems is unknown; no large-scale use of such systems for purifying americium has yet been made.

Chloride Solutions. Distribution of Am(III) into anion-exchange resins is much higher from concentrated $\mathrm{LiCl}$ solutions ${ }^{267,268}$ than from concentrated $\mathrm{HCl}$ solutions. ${ }^{269,270}$ Moreover, Am(III) is sorbed much more strongly from concentrated $\mathrm{LiCl}$ solutions than are the lanthanides (Fig. 5.30a). Americium distribution ratios increase with increased $\mathrm{LiCl}$ concentration (Fig. 5.30b), whereas increased temperature enhances the separation of americium from rare earths (Fig. 5.31). Ryan ${ }^{25} 2$ states that about $10 M \mathrm{LiCl}$ appears to be optimum for actinide-lanthanide group separations, with poorer separation at lower concentrations and inconveniently long elution times at higher concentrations. Ryan has also questioned the basis for the hypothesis of Marcus ${ }^{219}$ that the complex species in the resin is $\mathrm{AmCl}_{4}$.

An LiCl-based anion-exchange process (Fig. 5.32) for separating multigram amounts of americium and curium from transuranium elements is routinely and successfully operated at the Oak Ridge TRU facility. ${ }^{271-273}$ Feedstock for this process is the chloride solution resulting from the Tramex process (compare pages 222 to 233). Satisfactorily pure actinide products are obtained by controlling the loading step (Fig. 5.32) so that the actinides load only onto the top $20 \%$ ( 5 to $15 \mathrm{~g} \mathrm{liter}^{-1}$ of resin average loading) of the resin bed. Following the loading step the resin bed is washed with 5 to 8 column volumes of $10 M \mathrm{LiCl}-0.1 M \mathrm{NH}_{2} \mathrm{OH} \cdot \mathrm{HCl}-5 \mathrm{vol} \%$ $\mathrm{CH}_{3} \mathrm{OH}$ to remove nickel and rare earths; hydroxylamine is used to maintain cerium in the trivalent state, whereas methanol ${ }^{76,226}$ is used to suppress the evolution of gas formed by radiolysis. The washed bed is then eluted, as shown in Fig. 5.32, with $\mathrm{LiCl}-\mathrm{HCl}$ solutions to obtain, sequentially, an americium-curium fraction, a 


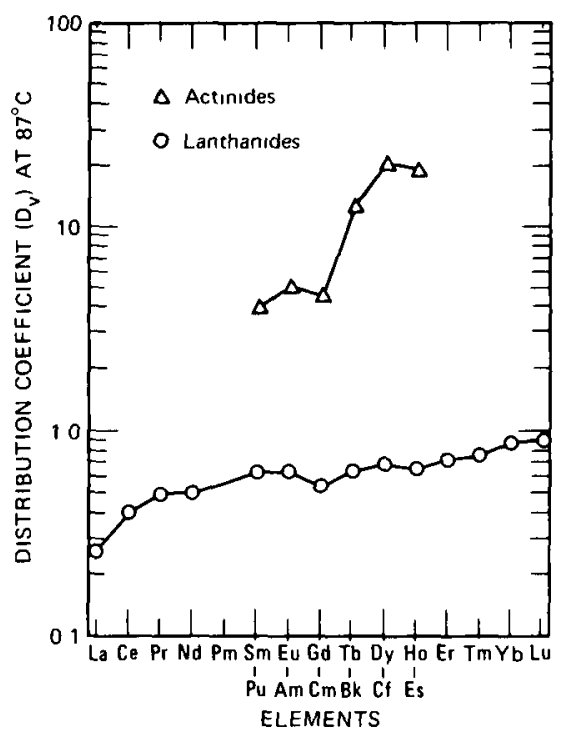

Fig. 5.30a Distribution coefficients of actınides and lanthanides in to Dowex 1-X8 resin from $10 \mathrm{M}$ LiCl. [From E K Hulet, R G. Gutmacher, and M. S Coops, ${ }^{26}$ Group Separation of the Actinides from the Lanthanides by Anion Exchange, Journal of Inorganic and Nuclear Chemistry, 17: 350 (1961) ]

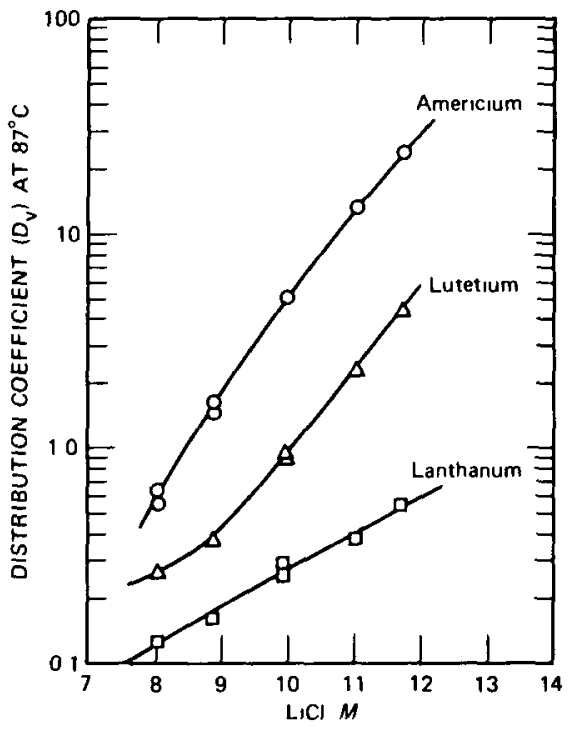

Fig. 5.30b Distribution of americium, lanthanum, and lutetium into Dowex 1-X8 resin as a function of $\mathrm{L} 1 \mathrm{Cl}$ concentration. [From E. K. Hulet, R G Gutmacher, and M. S. Coops, ${ }^{268}$ Group Separation of the Actinides from the Lanthanides by Anion Exchange, Journal of Inorganic and Nuclear Chemistry, 17: 350 (1961).] 


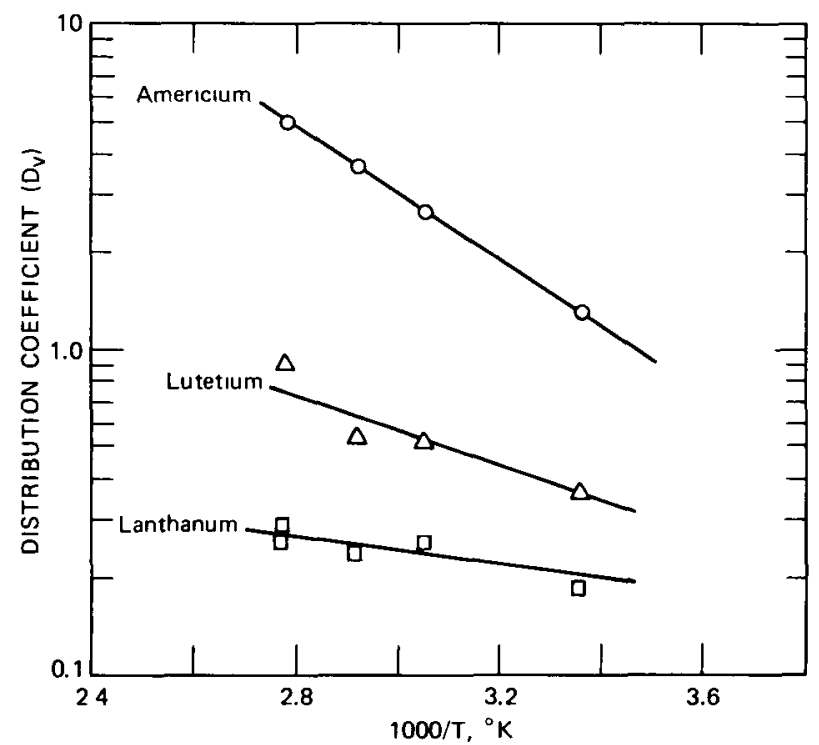

Fig. 5.31 Distribution of americium, lanthanum, and lutetium into Dowex 1-X8 resin from $10 M$ $\mathrm{LiCl}-0.1 \mathrm{M} \mathrm{HCl}$ as a function of temperature. [From E. K. Hulet, R. G. Gutmacher, and M. S. Coops, ${ }^{268}$ Group Separation of the Actinides from the Lanthanides by Anion Exchange, Journal of Inorganic and Nuclear Chemistry, 17: 350 (1961).]

curium-berkelium fraction, and a berkelium-californium fraction. Currently in the TRU facility, the LiCl-based process is operated as a conventional low-pressure ion-exchange process.

Chemists ${ }^{67,68,274}$ at the European Transuranium Institute in Karlsruhe have successfully applied the LiCl-based anion-exchange process to isolate the americiumcurium fraction from irradiated ${ }^{241}$ Am targets.

Morrow, ${ }^{275}$ Guseva and Tikhomirova, ${ }^{276}$ Orlandini and Korkisch, ${ }^{277}$ and Bochkarev and $\mathrm{Lbov}^{278}$ have all determined the distribution of $\mathrm{Am}^{3+}$ between anion-exchange resins and either $\mathrm{HCl}$ or $\mathrm{LiCl}-\mathrm{HCl}$ aqueous solutions containing varying amounts of ethanol, methanol, acetone and other water-miscible organic components. For several of these mixed solvent systems, americium distribution coefficients were higher than for the corresponding aqueous solutions; better americium-lanthanide separation factors were also observed in some instances. No plant-scale application of these mixed solvent systems to isolate or purify americium has been reported.

Nitrate Solutions. Paralleling behavior in chloride solutions (compare preceding section), $\mathrm{Am}$ (III) sorbs only slightly ${ }^{279}\left(\mathrm{~K}_{\mathrm{D}} \sim 15\right.$ at $\left.{ }^{280} 20 \mathrm{M} \mathrm{HNO}_{3}\right)$ onto anion-exchange resins from acidic nitrate solutions but moderately strongly $281-284$ from neutral solutions of various metal nitrates. Data for the uptake of americium by 


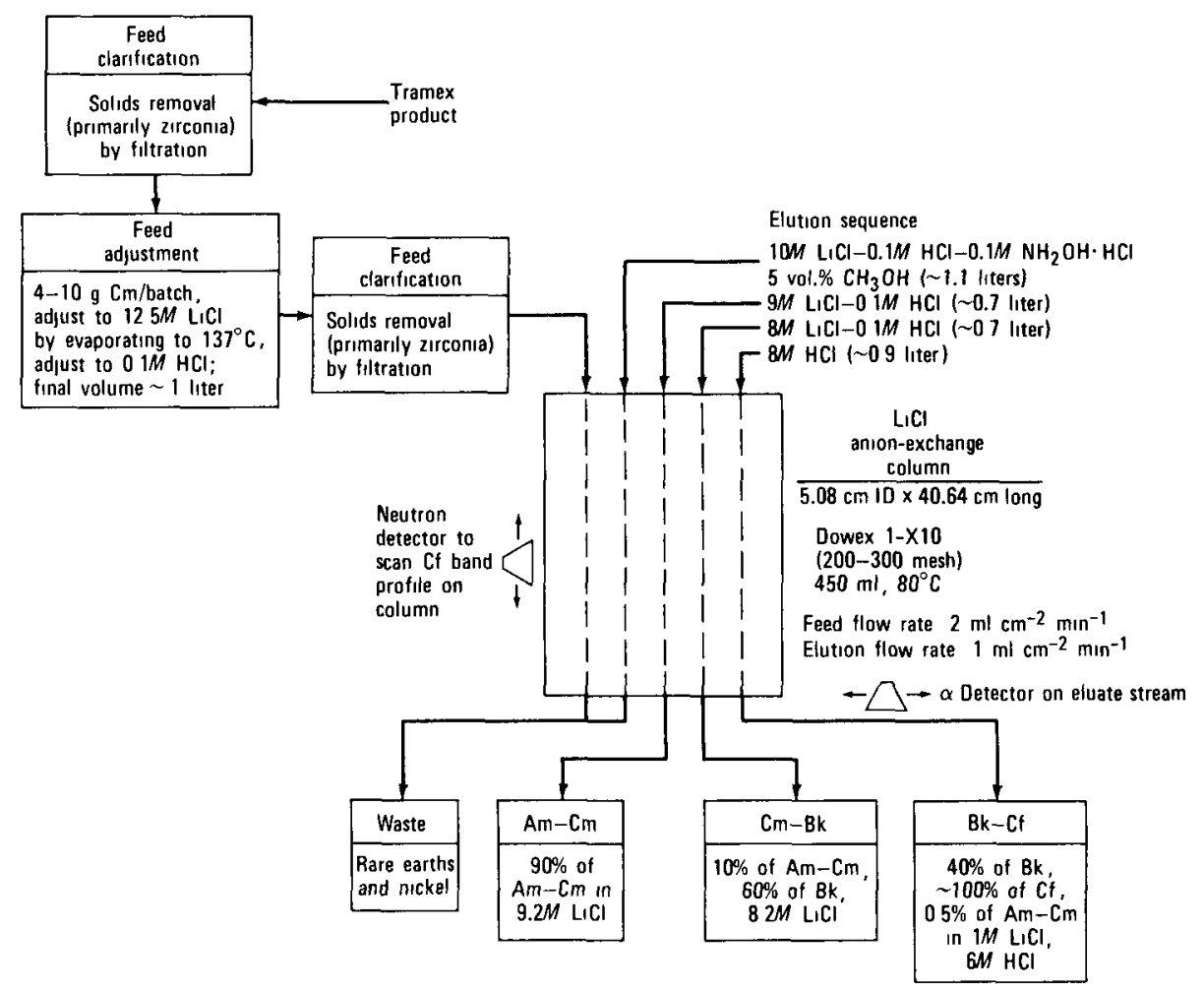

Fig. 5.32 $\mathrm{LiCl}$-anion exchange process flow sheet used in the Transuranium Processing Plant at Oak Ridge. [From R. E. Leuze and M. H. Lloyd, ${ }^{76}$ Processing Methods for the Recovery of Transplutonium Elements, in Progress in Nuclear Energy, Process Chemistry, Series III, C. E. Stevenson, E. A. Mason, and A. T. Gresky (Eds.), Vol. 4, page 549, Pergamon Press, Inc., New York, 1970.]

Dowex 1 resin from $3 M$ to $10 M \mathrm{LiNO}_{3}-0.05 M \mathrm{H}^{+}$solutions are ${ }^{285}$ shown in Fig. 5.33. Ryan ${ }^{252}$ observes that, with due regard to the effects attributable to variations in cross-linkage, Am(III) sorbs about equally well from $\mathrm{LiNO}_{3}$ and $\mathrm{Al}\left(\mathrm{NO}_{3}\right)_{3}$ solutions but less strongly from $\mathrm{Ca}\left(\mathrm{NO}_{3}\right)_{2}$ solutions. With Dowex 1-X8 resins, distribution coefficients of $\mathrm{Am}$ (III) from $\mathrm{LiNO}_{3}$ solutions decrease both with an increase in temperature and an increase in acidity above $\sim 0.01 M \mathrm{H}^{+}$(Ref. 285).

Contrary to results obtained with either chloride or thiocyanate solutions, distribution ratios of Am(III) from nitrate solutions onto anion-exchange resins overlap those of the lanthanides. Plant-scale use of nitrate-based anion-exchange systems for purifying americium has been largely precluded by the inability to obtain satisfactory decontamination from rare earths. Lloyd $d^{286}$ devised an anion-exchange process (Fig. 5.34) for recovering americium, curium, and rare earths from the nitrate waste solution resulting from processing of highly irradiated plutonium-aluminum 
alloys Although recoveries of $>95 \%$ were demonstrated in laboratory tests, only 30 to $40 \%$ of the amencium-curium was recovered when this process was scaled up for use at Oak Ridge Solids, mostly aluminum hydroxide, which formed during the feed preparation step, proved difficult to filter and restricted flow rates in the resin column Lloyd and Leuze ${ }^{287}$ state that this anion-exchange process (Fig 5 34) appears much more difficult to operate than the TBP extraction processes described earlier (compare pages 195 to 202 )

Lloyd and Leuze 287 also devised an alternate anion-exchange process for recovering americium and curıum from irradiated plutonium-aluminum alloys and for separatıng them from rare earths In this scheme (Fig 535 ), americium, curlum, and rare earths are sorbed on Dowex 1-10X resin from an $8 M \mathrm{LiNO}_{3}$ solution, followed by selective elution of rare earths with $10 \mathrm{M} \mathrm{LlCl}$ and elution of americium and curium with $1 M \mathrm{HCl}$ Subsequently Kingsley ${ }^{28}$ modified this process for the purification and concentration of americium recovered at Hanford (compare pages 202 to 205) To date, however, no plant-scale use has been made of the flow sheet shown in Fig 535

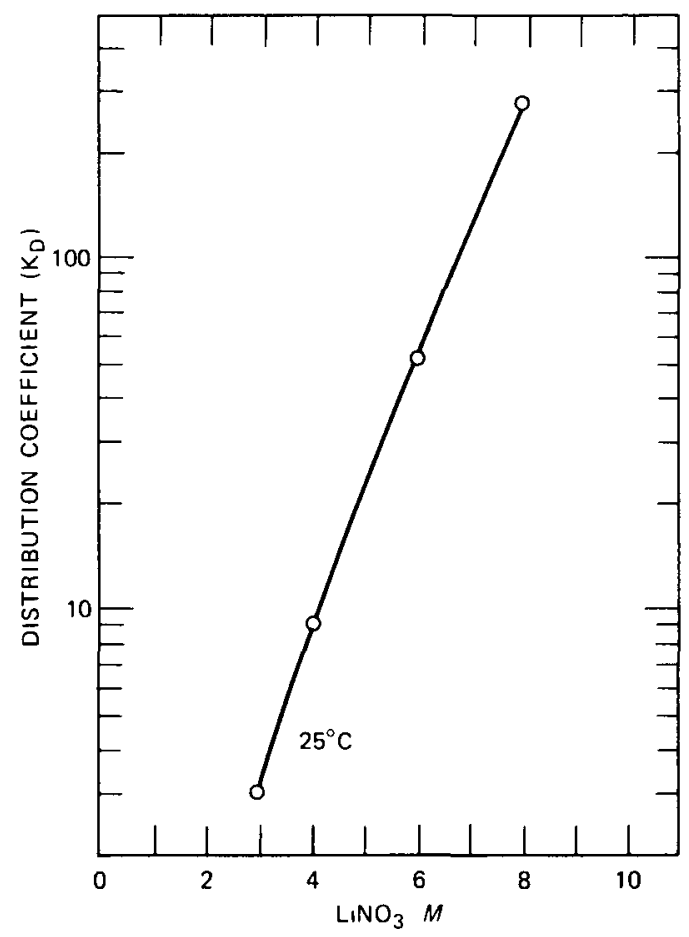

Fig. 5.33 Distribution coefficients of Am(III) between $\mathrm{LiNO}_{3}\left(0005 M \mathrm{H}^{+}\right)$solutions and Dowex 1-X8 resin [From S Adar, R K Sjoblom, $\mathrm{R} \Gamma$ Barnes, $\mathrm{P} R$ Fields, E K Hulet, and $\mathrm{H}$ D Wilson, ${ }^{285}$ Ion-Exchange Behavior of the Transuranium Elements in $\mathrm{LiNO}_{3}$ Solutions, Journal of Inorganic and Nuclear Chemistry, 25: 447 (1963) ] 


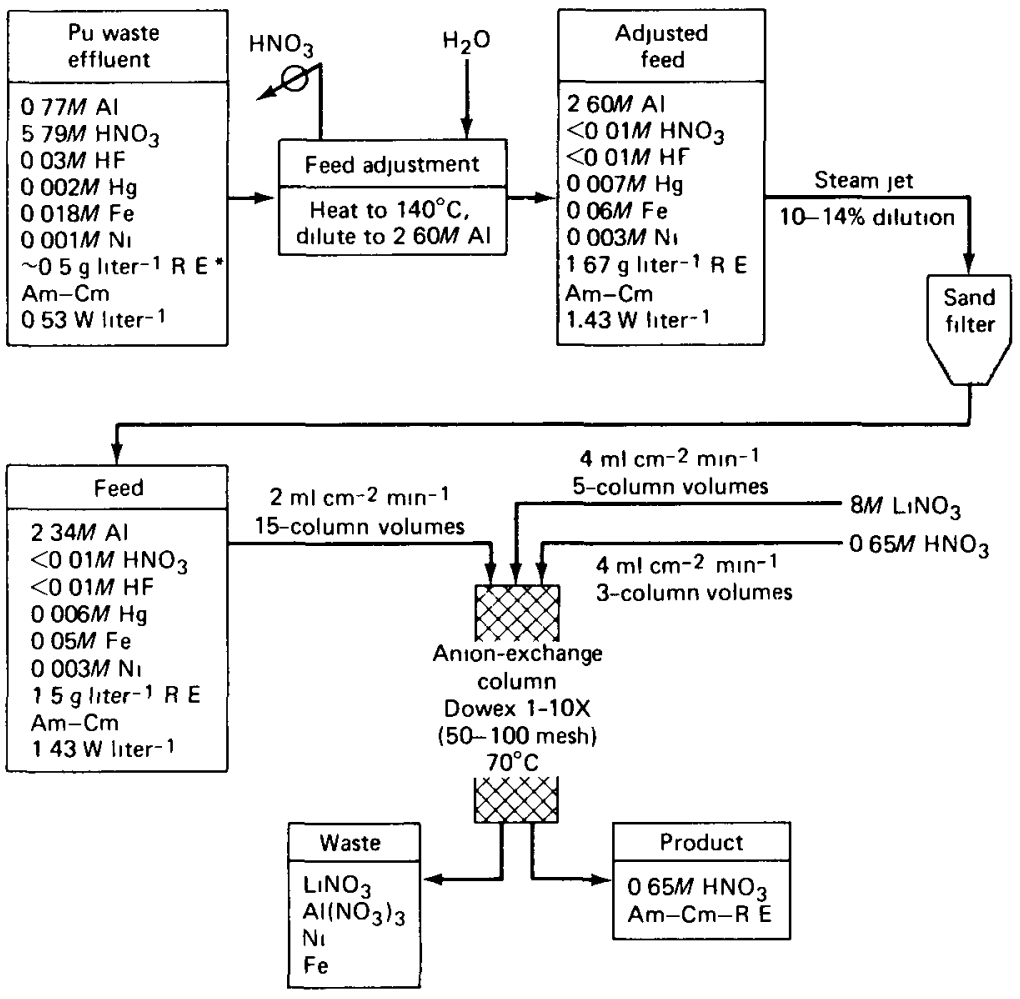

* $\mathrm{E} E$ = rare earths

Fig. 5.34 Anion-exchange process for recovering americium and curnum from $\mathrm{NO}_{3}$ waste from plutonium-alumınum alloy processing. [From M. H. Lloyd, ${ }^{286}$ An Anıon Exchange Process for Amerıcium-Curium Recovery from Plutonum Process Waste, Nuclear Science and Engineering, 17: $452(1963)$.]

Just as with chloride and thiocyanate solutions, anion-exchange resins sorb Am(III) much more strongly from mixtures of $\mathrm{HNO}_{3}$ or $\mathrm{LiNO}_{3}$ with metha$\mathrm{nol}^{283,289,290}$ and other organic solvents ${ }^{291}$ than from aqueous $\mathrm{HNO}_{3}$ and $\mathrm{LiNO}_{3}$ solutions. Russian scientists ${ }^{292}$ have made use of this fact to develop what they claim is a very efficient ion-exchange process for separating and purifying americium from irradiated plutonium targets. In their scheme trivalent actinides and lanthanides are loaded onto a strong base anion-exchange resin from $1 M \mathrm{HNO}_{3}$ in $90 \%$ methanol; inert iron and aluminum and fission-product cesium, strontium, zirconium, nobium, and ruthenium are not sorbed from this solution. Separation of rare earths from the americium and curium is accomplished by washing the former off with $0.5 \mathrm{M}$ $\mathrm{NH}_{4} \mathrm{SCN}-0.1 \mathrm{M} \mathrm{HCl}$ in $80 \%$ methanol (compare page 237). Americium and curium are then sequentially eluted with $0.5 \mathrm{MHNO}_{3}$ in $80 \%$ methanol. Lebedev, Myasoedov, and 


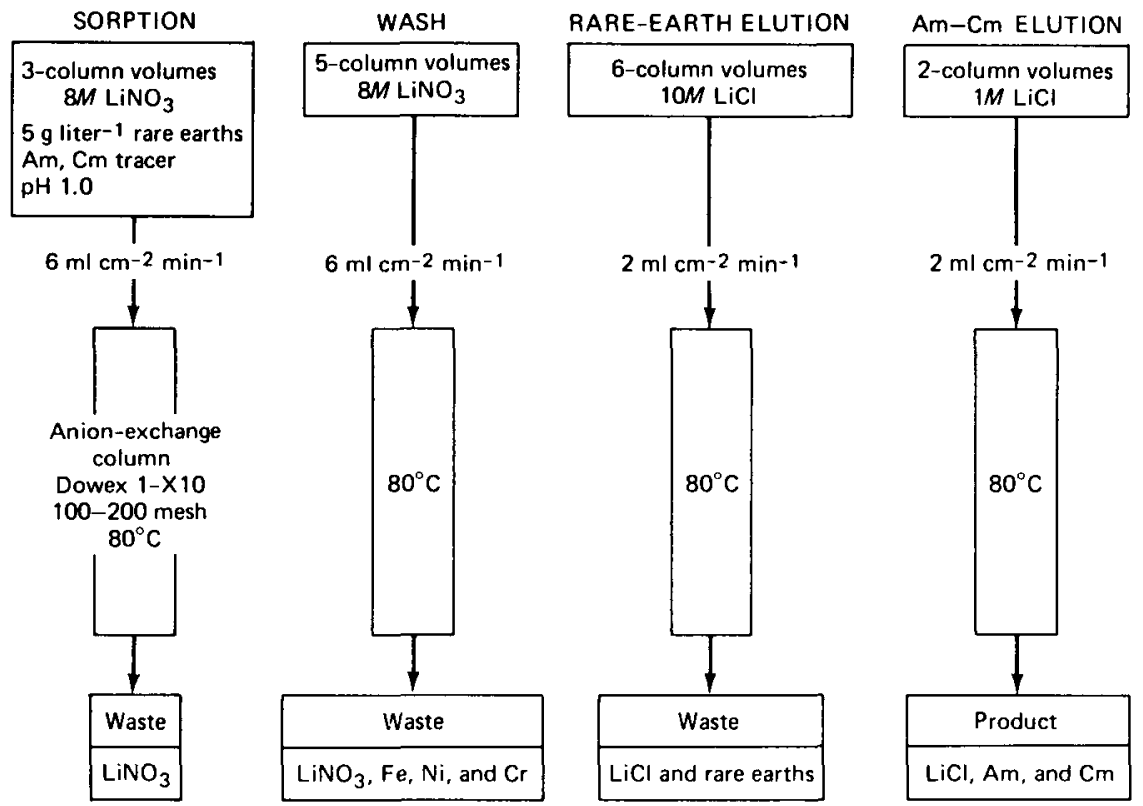

Fig. 5.35 $\mathrm{LiNO}_{3}-\mathrm{LiCl}$ anion-exchange process for separating americium and curium from rare earths. [From M. H. Lloyd and R. E. Leuze, ${ }^{287}$ Anion Exchange Separation of Trivalent Actinides and Lanthanides, Nuclear Science and Engineering, 11: 274 (1961).]

Guseva $^{292}$ state: "The described process of americium-curium recovery is highly convenient for use in laboratory-scale work. ... its obvious economic advantages and technological simplicity allow the expectation that the given method may be used on a larger scale."

Berger et al. ${ }^{159}$ and his fellow Frenchmen used a nitrate-based anion-exchange system to separate americium and curium previously recovered from irradiated plutonium-aluminum alloy (compare pages 208 to 220) by a Talspeak-type HDEHP extraction process. The $3 M \mathrm{LiNO}_{3}-0.065 M$ DTPA strip product (compare Fig. 5.18) from the HDEHP extraction step was adjusted to $6 M \mathrm{LiNO}_{3}$ and $0.1 M \mathrm{Al}\left(\mathrm{NO}_{3}\right)_{3}$, and the americium and curium were batch extracted into a $40 \%$ TBP-dodecane solvent. Transplutonium elements were stripped into $1 M \mathrm{HNO}_{3}$; an ethanolic (80 vol.\%) solution containing $1.33 M \mathrm{NH}_{4} \mathrm{NO}_{3}$ and $0.05 M$ to $0.1 M \mathrm{HNO}_{3}$ was prepared from the strip solution as feed to a bed of $200-400$ mesh Dowex 1-X8 resin. Subsequently curium was selectively eluted using an 80 vol.\% ethanol solution containing $1.33 \mathrm{M}$ $\mathrm{NH}_{4} \mathrm{NO}_{3}, 0.025 M$ DTPA, and $0.08 M \mathrm{HNO}_{3}$. Following removal of the curium, americium was eluted either with $1 M \mathrm{HNO}_{3}$ or a further portion of ethanolic $1.33 \mathrm{M}$ $\mathrm{NH}_{4} \mathrm{NO}_{3}-0.025 M$ DTPA- $0.08 M \mathrm{HNO}_{3}$ solution. This anion-exchange procedure permitted rapid and clean separation of milligram amounts of americium and curium. 


\section{Cation-Exchange Resin Systems}

General. Cation exchange resins sorb $\mathrm{Am}^{3+}$ very strongly from dilute acid solutions according to the reaction

$$
\mathrm{Am}^{3+}+3 \mathrm{HR} \rightleftharpoons \mathrm{AmR}_{3}+3 \mathrm{H}^{+}
$$

An important application of $\mathrm{Eq} 516$ is to simply concentrate $\mathrm{Am}^{3+}$ and other trivalent and tetravalent ions from acid solutions obtained in prior solvent extraction or precipitation processes and to separate them, at least partially, from monovalent and divalent impurities that have less affinity for the resin Instances of such use of cation-exchange resins in americium recovery and purification schemes will be discussed later

A combination of chromatographic elution techniques with cation-exchange resins provides a powerful and sophisticated tool for purifying americium from lanthanides and other trivalent actınides Elution chromatography involves the use of organic chelating agents to produce the largest possible difference in the distribution coefficients of the metal ions to be separated

Both elution-development and displacement-development (also known as barrierion or retaining-ion) chromatography have been used in cation-exchange separation and purification of americium Ryan ${ }^{252}$ points out that displacement-development chromatography is only capable of separatıng macro quantities, whereas, unless very large columns are used, elution-development chromatography is applicable only to the separation of tracer amounts Because of this limitation of the elution-development chromatographic method, its application to purification of americium is not discussed further here Helfferich ${ }^{293}$ has presented, in a comprehensive fashion, the theory of both the elution-development and displacement-development procedures

The basic principles of displacement chromatography have been stated by Ryan $^{252}$ as follows

In displacement development chromatography with a chelatıng agent, a macro-amount of the actinide or lanthanide is loaded onto the upper portion of a column, the rest of which initidly contains a restraining or barrier ion This ion is one which in the presence of the complexant exhibits a much lower distribution coefficient than the actinide or lanthanide ion Flution is carried out with a complexant of such strength and concentration of the free ligand that the $\mathrm{M}^{3+}$ distribution coefficients are very low This is normally achieved by neutralizing complexants to a higher $\mathrm{pH}$ than would be used for elution development with the same complexant Under these conditions the distribution coefficient of the $\mathrm{M}^{3+}$ is lower than that of the $\mathrm{NH}_{4}^{+}$or $\mathrm{Na}^{+}$ion used in the neutralization, and the $\mathrm{M}^{3+}$ is displaced with a self sharpening boundary An eluant concentration such that there is an excess of the trivatent ion in the resin is used. F or a mixture of actinides and/or lanthanides the reaction

$$
M_{a}(\text { Chelate })+M_{b} R_{3} \rightleftharpoons M_{b}(\text { Chelate })+M_{d} R_{3}
$$

occurs because of competition for the limited supply of the chelating agent Separation factors are related to complex formation constants in the same manner as discussed in the previous paragraph As the eluant redches the retaining or barner ion, it forms a stronger complex with it 
than with the dctinide or lanthanide, releasing the latter to be absorbed by the resin Since the complexants are weak dcids, $\mathrm{H}^{+}$ion is a satisfactory barrier ion unless the complex acid is not sufficiently soluble, in which case an appropriate metal ion is used The actinides and lanthanides develop into discrete bands or zones in direct contact with each other, the resin in the bands being principally in the actinide or lanthanide form The bands become resolved after a certain distance and travel with no further change after that

The effectiveness of chelating agents in cation-exchange displacement elution systems for americium purification is conveniently evaluated in terms of separation factors The separation factor between elements $a$ and $b$ is

$$
\alpha_{b}^{a}=\frac{\left(K_{D}\right)_{d}}{\left(K_{D}\right)_{b}}=\frac{\left(D_{V}\right)_{a}}{\left(D_{V}\right)_{b}}
$$

where $\mathrm{K}_{\mathrm{D}}=(\mathrm{mg} \mathrm{metal} / \mathrm{g} \mathrm{resin}) /(\mathrm{mg}$ metal $/ \mathrm{ml}$ solution $)$ and $\mathrm{D}_{\mathrm{V}}=(\mathrm{mg} \mathrm{metal} / \mathrm{ml}$ resin) $/(\mathrm{mg}$ metal $/ \mathrm{ml}$ solution). Separation factors are commonly referred to one actınide, e g, curnum $\left(\alpha_{\mathrm{Cm}}^{\mathrm{M}}\right)$ or one lan thanıde, e $\mathrm{g}$, gadolinıum $\left(\alpha_{\mathrm{Gd}}^{\mathrm{M}}\right)$

Distribution Coefficients Separation Factors Data for the distribution of $\mathrm{Am}^{3+}$ between cation-exchange resins and aqueous $\mathrm{HClO}_{4}, \mathrm{HNO}_{3}, \mathrm{HCl}, \mathrm{HF}, \mathrm{HBr}, \mathrm{HI}$, oxalate, acetate, phosphate, and sulfate solutions have been collected and interpreted by Ryan ${ }^{252}$ Much of this information was gathered to determine formation constants of complex species (Table 3 11) Not surprisingly, cation-exchange systems for large-scale separation and purification of americium use only $\mathrm{HNO}_{3}$ solutions as feeds Extensive use has been made of $\mathrm{HCl}$ solutions in cation-exchange systems for laboratory- and analytical-scale separation of americium from trivalent lanthanides, ${ }^{91} 269294297$ but no large-scale use has been made of such systems

Distribution coefficients for $\mathrm{Am}^{3+}$ into Dowex-50 resin remain ${ }^{280}$ very low and essentrally constant over the range $4 M$ to $11 M \mathrm{HNO}_{3}$ Even so, the results of Starik and Ginzburg ${ }^{280}$ indicate that, from $\mathrm{HNO}_{3}$ solutions, $\mathrm{Am}^{3+}$ sorbs slightly more strongly onto cation-exchange resins than do the lanthanides

Solutions of $\alpha$-hydroxycarboxylic and aminopolycarboxylic acids are commonly used to elute americium from cation-exchange resin. When these reagents are used in a displacement development elution system, they provide, as detaled on pages 245 to 252 , excellent separation of americium from trivalent lanthanides and other trivalent actinides Separation factors, $\alpha_{\mathrm{Cm}}^{\mathrm{Am}}$ and $\alpha_{\mathrm{Pm}}^{\mathrm{Am}}$, provided by some of these compounds are listed in Tables 5.9 and 510 Ryan's review ${ }^{25}$ furnishes additional information on the use of these organic chelating reagents in eluting transplutonium elements from cation-exchange resins.

Typical Cation-Exchange Americium Purification Processes. Simple Load-Elution Concentration Processes Relatively simple load-elute cation-exchange processes still find much use in concentrating (and purifying) americium from dilute feed solutions At Hanford, for example, such a process is used to concentrate americium and plutonium in the dilute product stream from the DBBP solvent extraction process (see pages 205 to 208) After this solution (containing, typically, $10^{-4}$ to $10^{-3} \mathrm{~g} \mathrm{liter}^{-1}$ each 
Table 5.9

SEPARATION FACTORS IN AMERICIUM CATION-EXCHANGE PURIFICATION SYSTEMS • ELUTION WITH $\alpha$-HYDROXYCARBOXYLIC ACIDS

\begin{tabular}{|c|c|c|c|c|c|c|c|c|}
\hline \multirow{3}{*}{$\begin{array}{c}\text { Chelating } \\
\text { agent }\end{array}$} & \multirow[b]{3}{*}{ Cation resin } & \multirow{3}{*}{$\begin{array}{l}\text { Solution } \\
\text { composition }\end{array}$} & \multirow[b]{3}{*}{$\mathrm{pH}$} & \multirow{3}{*}{$\begin{array}{c}\text { Temp., } \\
{ }^{\circ} \mathrm{C}\end{array}$} & \multicolumn{4}{|c|}{ Separation factors } \\
\hline & & & & & \multicolumn{2}{|c|}{$\mathrm{Am} / \mathrm{Cm}$} & \multicolumn{2}{|c|}{$\mathrm{Am} / \mathrm{Pm}$} \\
\hline & & & & & $\alpha$ & Ref. & $\alpha$ & Ref. \\
\hline Citrate & Dowex $50 \times 12$ & $025 \mathrm{M} \mathrm{NH}_{4}$ c1trate & 3.35 & $\begin{array}{l}25 \\
87\end{array}$ & $\begin{array}{l}1.18 \\
117\end{array}$ & $\begin{array}{l}295 \\
269\end{array}$ & 1.03 & 295 \\
\hline Gly colate & Dowex $50 \times 12$ & $0.25 \mathrm{M}$ glycolıc acıd & $\begin{array}{l}4.0 \\
4.0\end{array}$ & $\begin{array}{l}25 \\
87\end{array}$ & $\begin{array}{l}1.31 \\
1.24\end{array}$ & $\begin{array}{l}298 \\
299\end{array}$ & $\begin{array}{l}0.98 \\
0.92\end{array}$ & $\begin{array}{l}299 \\
299\end{array}$ \\
\hline AHIB* & $\begin{array}{l}\text { Dowex } 50-X 4 \\
\text { Dowex } 50-X 12 \\
\text { Zeokarb-225 } \\
\text { Dowex } 50-X 12\end{array}$ & $\begin{array}{l}0.5 M \mathrm{NH}_{4} \text { AHIB } \\
0.4 M \mathrm{NH}_{4} \text { AHIB } \\
0.4 M \mathrm{NH}_{4} \text { AHIB } \\
1.0 M \mathrm{NH}_{4} \text { AHIB }\end{array}$ & $\begin{array}{c}3.8-4.8 \\
40 \\
45-50\end{array}$ & $\begin{array}{l}25 \\
78 \\
77 \\
87\end{array}$ & $\begin{array}{l}139 \\
145 \\
138 \\
145 \\
1.41\end{array}$ & $\begin{array}{l}300 \\
301 \\
302 \\
301 \\
303\end{array}$ & 1.21 & 300 \\
\hline Lactate & Dowex $50-\mathrm{X} 12$ & $\begin{array}{l}037 M \mathrm{NH}_{4} \text { lactate } \\
0.4 M \mathrm{NH}_{4} \text { lactate } \\
04 M \mathrm{NH}_{4} \text { lactate } \\
1.0 M \mathrm{NH}_{4} \text { lactate } \\
0.4 M \mathrm{NH}_{4} \text { lactate } \\
027 M \mathrm{NH}_{4} \text { lactate }\end{array}$ & $\begin{array}{c}4.1 \\
4.0 \\
4.6 \\
30 \\
4.0-4.5 \\
42\end{array}$ & $\begin{array}{l}25 \\
87 \\
87 \\
87 \\
87 \\
87\end{array}$ & $\begin{array}{l}1.21 \\
1.23 \\
1.19 \\
1.27 \\
1.21 \\
1.16\end{array}$ & $\begin{array}{l}304 \\
269 \\
304 \\
305 \\
269 \\
303\end{array}$ & $\begin{array}{l}0.97 \\
\\
0.97 \\
0.97\end{array}$ & $\begin{array}{l}304 \\
304 \\
305\end{array}$ \\
\hline Tartrate & Dowex $50-\mathrm{X} 12$ & $\begin{array}{l}0.1 M \text { tartanc acid } \\
0.1 M \text { tartaric acid } \\
08 M \text { tartanc acid }\end{array}$ & $\begin{array}{l}4.0 \\
4.3 \\
2.8\end{array}$ & $\begin{array}{l}25 \\
87 \\
87\end{array}$ & $\begin{array}{ll}130 \\
107 \\
120\end{array}$ & $\begin{array}{l}304 \\
304 \\
304\end{array}$ & 0.89 & 304 \\
\hline
\end{tabular}

${ }^{* A H I B}=\alpha$-hydroxy sobuty nc acid

of americium and plutonium) is diluted with water to about $025 M \mathrm{HNO}_{3}$, it is then loaded at $25^{\circ} \mathrm{C}$ onto a 14-liter bed $(15 \mathrm{~cm}$ in diameter $)$ of $\mathrm{H}^{+}$-form Dowex 50-X8 cation-exchange resin Considerable decontamination from sodium, calcium, magnesium, and other divalent cations is obtained in this step. Subsequently the americium and plutonium are eluted either upflow or downflow with about 6 column volumes of $7 M \mathrm{HNO}_{3}$, the eluate containing roughly 2 to $4 \mathrm{~g} \mathrm{hter}^{-1}$ each of americium and plutonium is used as feed to final ion-exchange purification as described subsequently

A new ${ }^{311}$ cation-anion exchange process ( $F_{1 g} 5.36$ ) has recently replaced the hydroxide-precipitation (compare pages 190 to 194) and multistage thiocyanate 1on-exchange (compare pages 234 to 237) systems formerly used at the Rocky Flats Plant for recovering ${ }^{241} \mathrm{Am}$ from solutions of spent $\mathrm{NaCl}-\mathrm{KCl}-\mathrm{MgCl}_{2}$ salt residues In this new process, americium and plutonum in an $05 \mathrm{M} \mathrm{H}^{+}$feed solution containing, typically, $4 \mathrm{~g} \mathrm{Pu} \mathrm{liter}^{-1}$ and $04 \mathrm{~g} \mathrm{Am} \mathrm{liter}^{-1}$, are first loaded onto an 11-liter bed of 50-100 mesh Dowex 50-X8 resin. The loaded bed 1s washed with water and then eluted with 25 column volumes of $7 M \mathrm{HNO}_{3}$ [An earlier version of this separation process developed by Kudera and Guyer ${ }^{312}$ involved dissolving the $\mathrm{NaCl}-\mathrm{KCl}-\mathrm{MgCl}_{2}$ mixture in $0.35 \mathrm{M} \mathrm{HNO}_{3}$ and subsequently loading the americium and plutonium onto a cation-exchange resin ] 
Table 5.10

SEPARATION FACTORS IN AMERICIUM CATION-EXCHANGE PURIFICATION SYSTEMS: ELUTION WITH AMINOPOLYCARBOXYLIC ACIDS

\begin{tabular}{|c|c|c|c|c|c|c|}
\hline \multirow{2}{*}{$\begin{array}{l}\text { Chelating } \\
\text { agent* }\end{array}$} & \multirow[b]{2}{*}{ Cation resin } & \multirow[b]{2}{*}{ Solution composition } & \multirow[b]{2}{*}{$\mathbf{p H}$} & \multirow{2}{*}{$\underset{{ }^{\circ} \mathrm{C}}{\text { Temp., }}$} & \multicolumn{2}{|c|}{$\begin{array}{c}\text { Separation factor } \\
\mathrm{Am} / \mathrm{Cm}\end{array}$} \\
\hline & & & & & $\alpha$ & Refs. \\
\hline NTA & Dowex $50-\times 12$ & $0.001 M \mathrm{NTA}-0.1 M \mathrm{NH}_{4} \mathrm{ClO}_{4}^{\dagger} \dagger$ & 2.95 & 72 & 1.46 & 306 \\
\hline FDTA & Dowex $50-\mathrm{X} 12$ & $0.001 M$ EDTA $-0.1 M \mathrm{NH}_{4} \mathrm{ClO}_{4}$ & $\begin{array}{l}2-3.5 \\
2.35 \\
2.6\end{array}$ & $\begin{array}{l}25 \\
80 \\
80\end{array}$ & $\begin{array}{l}2.04 \\
1.1 \\
1.45\end{array}$ & $\begin{array}{c}307,308 \\
308 \\
308\end{array}$ \\
\hline NHEDTA & Dowex $50-\times 12$ & $0.001 M$ NHEDTA $-0.15 M \mathrm{KCl}$ & $\begin{array}{l}2.3 \\
2.3 \\
2.7 \\
2.7 \\
2.9 \\
2.9\end{array}$ & $\begin{array}{l}22 \\
80 \\
22 \\
80 \\
22 \\
80\end{array}$ & $\begin{array}{l}1.30 \\
1.30 \\
1.15 \\
1.25 \\
1.70 \\
1.30\end{array}$ & $\begin{array}{l}309 \\
309 \\
309 \\
309 \\
309 \\
309\end{array}$ \\
\hline DCTA & Dowex $50 \times 12$ & $0.01 M$ DCTA- $-0.1 M \mathrm{NH}_{4} \mathrm{ClO}_{4}$ & 3.0 & 25 & 118 & 310 \\
\hline
\end{tabular}

*NTA $=$ nitrilotracetic acid

EDTA = ethylenedia minetetracetic acid

NHLDTA $=N$-(2-hydrosyethyl)ethylenediaminetriacetic acid.

DCTA $=1,2$-didminocyclohexanetetradcetic acid

$\dagger 0.1 M$ glycolic acid also present.

In the anion-exchange portion of the new Rocky Flats americium purification process, the $7 M \mathrm{HNO}_{3}$ solution resulting from elution of the cation-exchange resin is passed through a bed of Dowex $1 . \mathrm{X} 4$ resin to sorb plutonium and separate it from americium. Americium in the $7 M \mathrm{HNO}_{3}$ effluent from the anion-exchange load cycle is contaminated with only small amounts of magnesium, potassium, sodium, and plutonium; no chloride ion is present. Double oxalate precipitation of americium from this solution yields, after calcination, $\mathrm{AmO}_{2}$ of a purity comparable to that obtained by the former thiocyanate ion-exchange process. The oxalate precipitation process involves evaporation of the $7 M \mathrm{HNO}_{3}$ load-cycle effluent to achieve a 10 -fold concentration, adjustment of acidity to $0.5 \mathrm{M} \mathrm{HNO}_{3}$, precipitation of $\mathrm{Am}_{2}\left(\mathrm{C}_{2} \mathrm{O}_{4}\right)_{3} \cdot 10 \mathrm{H}_{2} \mathrm{O}$, dissolution of the precipitate, and a second precipitation of americium oxalate.

Proctor $^{77}$ at the Rocky Flats Plant has also devised a cation-exchange procedure to recover and further purify americium from the $7 M \mathrm{HNO}_{3}$ load-cycle effluent stream obtained in the plutonium removal step. In this process, after acidity adjustment, all the metal ions in the feed are absorbed onto a bed of Dowex 50 resin. Following the loading step, the bed is washed with $0.1 M$ oxalic acid to remove $>99 \%$ of any iron, nickel, cobalt, and plutonium and about $60 \%$ of any aluminum with minimal $(<0.1 \%)$ loss of americium. The americium is then eluted with a $0.4 M$ citric acid ( $\mathrm{pH} 3$ ) solution; the alkali and alkaline earth elements remain on the resin in this step. Americium can be precipitated directly from the citrate eluant by adding oxalic acid. 


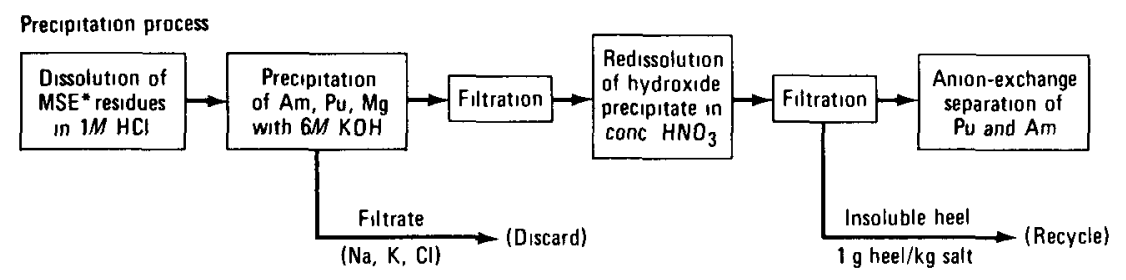

Cation-exchange process

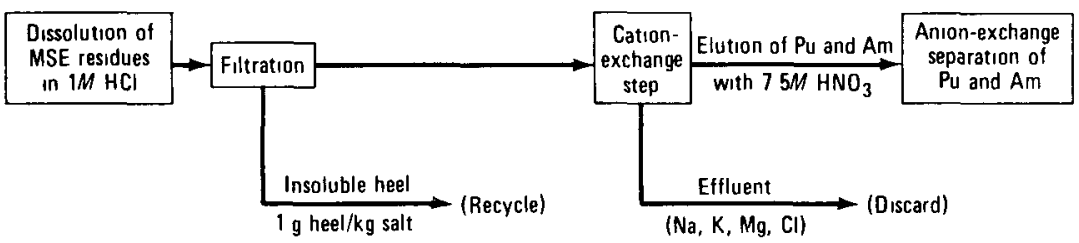

(a)

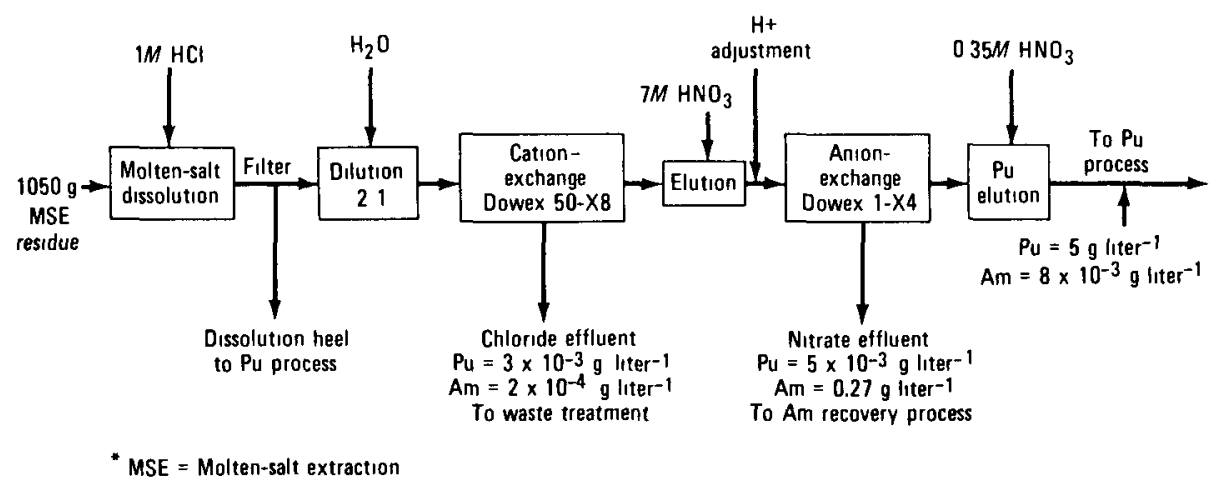

(b)

Fig. 5.36 New cation-exchange process used at the Rocky Flats Plant for recovering americium from molten-salt extraction process residues. (a) Ion exchange vs hydroxide precipitation head-end processes. (b) Ion-exchange process flow sheet. ${ }^{311}$

Preliminary laboratory-scale data indicated this cation-exchange process would recover $97 \%$ of the americium in the feed while generating only $40 \%$ of the waste produced by the thiocyanate process. When it was found that a double oxalate precipitation process could be used to purify the americium directly from the anion-exchange resin load-cycle effluent, this second cation-exchange purification cycle was unnecessary.

Americium recovery by the new cation-anion exchange process presently in use at Rocky Flats is considerably simpler than by the former precipitation-thiocyanate 
ion-exchange system. It is anticipated that this process simplification will be reflected in greater americium throughput and generation of a substantially smaller volume of aqueous waste more amenable (no thiocyanate) to treatment and disposition.

Haug $^{313}$ and others ${ }^{160.161}$ in Germany have developed a cation-exchange cycle for the concentration and decontamination of americium and curium present in the $0.05 M$ DTPA $-1 M$ lactic acid product solution resulting from prior HDEHP-TBP solvent extraction of actinides from Purex-process high-level waste (compare pages 208 to 220). Their scheme involves loading the americium and curium from the DTPA-lactic acid solution (adjusted to $\mathrm{pH} \mathrm{1.0)} \mathrm{onto} \mathrm{the} \mathrm{Dowex} \mathrm{50-X8} \mathrm{resin,} \mathrm{washing}$ the resin with several column volumes of $0.1 M \mathrm{HNO}_{3}$, and then eluting the americium and curium with $3 M \mathrm{HNO}_{3}$. In tracer-level tests, this purification scheme provided excellent decontamination of the americium and curium from DTPA, lactic acid, fission products, and other actinides.

Chromatographic Elution Schemes. In the past, $\alpha$-hydroxycarboxylic acids were used extensively as eluting agents in cation-exchange processes for the separation and purification of milligram and even gram amounts of americium. For example, Campbell $^{314}$ in 1956 purified $9 \mathrm{~g} \mathrm{Am}$ from kilograms of lanthanum by eluting the americium from a $25 \%$ loaded Dowex 50 resin column with $0.15 M$ citric acid $-0.1 M$ diammonium citrate- $0.3 \mathrm{M} \mathrm{NH}_{4} \mathrm{NO}_{3}$ solution at $\mathrm{pH}$ 3.3. Workers at LASL also successfully purified gram quantities of americium from kilograms of lanthanum by displacement elution at $25^{\circ} \mathrm{C}$ with $0.1 \%$ ammonium citrate, $\mathrm{pH} 8$ solution; the retaining ion was $\mathrm{H}^{+}$.

Both lactic and $\alpha$-hydroxyisobutyric acids provide better separation (Table 5.9) of americium from curium than does citric acid. Higgins and Crane ${ }^{267}$ devised an ion-exchange scheme to isolate and purify thousand-curie quantities of ${ }^{242} \mathrm{Cm}$ from irraulated ${ }^{241} \mathrm{Am}$ targets; one step in this process involved the use of lactic acid solution to selectively elute curium from a cation-exchange resin. Perdue and Hicks ${ }^{31} 5$ separated americium from cerium by selective elution of the former from Dowex $50 \mathrm{~W}$ resin with $1 M$ lactic acid adjusted to $\mathrm{pH} 2.97$ with $\mathrm{NH}_{4} \mathrm{OH}$. Both Russian ${ }^{25}$ and German ${ }^{316-318}$ workers have used $\alpha$-hydroxyisobutyric acid in chromatographic cation-exchange separation and purification of ${ }^{242} \mathrm{Cm}$ from solutions of neutron-irradiated ${ }^{241}$ Am targets. Using chromatographic elution from Dowex 50-X12 resin with $\alpha$-hydroxyisobutyric acid, Campbell ${ }^{319}$ demonstrated the use of high-pressure ion-exchange methods for the rapid separation of americium from curium. Burney and Harbour ${ }^{320}$ separated milligram quantities of ${ }^{252} \mathrm{Cf}$ from multigram quantities of ${ }^{244} \mathrm{Cm}$ and ${ }^{243} \mathrm{Am}$ using pressurized cation-exchange elution chromatography and $\alpha$-hydroxyisobutyric acid as the eluent.

Highly efficient displacement chromatographic separation schemes that use nitrilotriacetic acid and/or diethylenetriaminepentaacetic acid as eluents have been developed and applied in the last 10 years by Wheelwright at Hanford and by Hale, Lowe, and others at Savannah River to purify kilograms of americium from curium and lanthanides. For Dowex 50 resin, Wheelwright et al. ${ }^{321}$ report the following elution sequences: 
With DTPA,

$$
\mathrm{Zn}^{2+}, \mathrm{Pb}^{2+}, \frac{\mathrm{Er}^{3+}-\mathrm{Ho}^{3+}-\mathrm{Dy}^{3+}, \mathrm{Gd}^{3+}, \mathrm{Eu}^{3+}, \mathrm{Sm}^{3+}, \mathrm{Y}^{3+}, \mathrm{Pm}^{3+}, \mathrm{Nd}^{3+}, \mathrm{Pr}^{3+}, \mathrm{Ce}^{3+}, \mathrm{La}^{3+}}{\mathrm{Am}^{3+}}
$$

With NTA,

$$
\mathrm{Zn}^{2+},\left(\mathrm{Cm}^{3+}-\mathrm{Y}^{3+}\right), \mathrm{Gd}^{3+},\left(\mathrm{Eu}^{3+}, \mathrm{Am}^{3+}\right), \mathrm{Sm}^{3+}, \mathrm{Pm}^{3+}, \mathrm{Nd}^{3+}, \mathrm{Pr}^{3+}
$$

On the basis of these elution sequences, Wheelright ${ }^{321-324}$ successfully used a two-cycle cation-exchange process in conventional equipment to separate and purify $1 \mathrm{~kg}{ }^{241} \mathrm{Am}$ and ${ }^{243} \mathrm{Am}$, about $60 \mathrm{~g}{ }^{244} \mathrm{Cm}$, and $140 \mathrm{~g}{ }^{147} \mathrm{Pm}$ recovered (by solvent extraction techniques, compare pages 202 to 205) from 13.5 tons of blanket fuel elements of the Shippingport reactor. In this process, $\mathrm{Am}^{3+}$ and $\mathrm{Cm}^{3+}$ (contained in the dilute $\mathrm{HNO}_{3}$ feed solution) were initially loaded onto a $34.3-\mathrm{cm}$-diameter bed of $\mathrm{H}^{+}$-form Dowex 50W-X8 (50-100 mesh) resin. Subsequently the americium and curium were separated from promethium, other lanthanides, and other cosorbed impurities by displacement elution at $60^{\circ} \mathrm{C}$ through a series of seven $\mathrm{Zn}^{2+}$-form Dowex 50-X8 (50-100 mesh) resin beds with a 0.05M DTPA solution buffered to pH 6.5 with $\mathrm{NH}_{4} \mathrm{OH}$; the eluent was pumped through the column system at a flow rate of $4 \mathrm{ml}$ $\mathrm{cm}^{-2} \mathrm{~min}^{-1}$. The americium-curium product from the DTPA cycle was adjusted to $0.5 \mathrm{M} \mathrm{HNO}_{3}$ and loaded onto a 10.8 -cm-diameter bed of $\mathrm{H}^{+}$-form Dowex 50 resin. Separated and highly purified americium and curium fractions were obtained by americium-curium displacement elution at $60^{\circ} \mathrm{C}$ through a series of four $\mathrm{Zn}^{2+}$-form Dowex 50 resin beds with a $0.105 \mathrm{M}$ NTA solution buffered to $\mathrm{pH} 6.5$ with $\mathrm{NH}_{4} \mathrm{OH}$. Figure 5.37 illustrates simulated elution curves for Wheelwright's two-cycle americium purification process.

Ion-exchange technology developed by Wheelwright ${ }^{325}$ is currently used for the final purification of ${ }^{241} \mathrm{Am}$ recovered at Hanford by reprocessing of aged plutonium metallurgical scrap. Americium and plutonium in the $7 \mathrm{M} \mathrm{HNO}_{3}$ solution obtained in prior solvent extraction and ion-exchange (compare pages 202-204 and 245) steps are first separated by sorption of the plutonium on Dowex 1 resin. Subsequently the $7 M$ $\mathrm{HNO}_{3}$ waste stream containing the americium is diluted with water to yield a $1 M$ $\mathrm{HNO}_{3}$ solution containing 0.25 to $0.5 \mathrm{~g} \mathrm{Am} \mathrm{liter}^{-1}$. Americium in this feed is loaded onto a 10.8-cm-diameter bed of $\mathrm{H}^{+}$-form Dowex 50-X8 (50-100 mesh) resin and then eluted through a series of four $\mathrm{Zn}^{2+}$-form Dowex $50-\mathrm{X} 8$ resin beds with a $0.105 \mathrm{M}$ NTA solution buffered to $\mathrm{pH} 6.5$ with $\mathrm{NH}_{4} \mathrm{OH}$. Displacement elution is performed at $60^{\circ} \mathrm{C}$ at a flow rate of $8 \mathrm{ml} \mathrm{cm}^{-2} \mathrm{~min}^{-1}$. The center product cut from the final column contains 8 to $9 \mathrm{~g} \mathrm{liter}^{-1}$ of highly purified americium. Oxalic acid is added to this solution, and the resulting oxalate precipitate is calcined to $\mathrm{AmO}_{2}$. This ion-exchange scheme is used to purify about $1 \mathrm{~kg}^{241} \mathrm{Am}^{2} \mathrm{yer}^{-1}$.

Lowe, Hale, Hallman, and others ${ }^{308 \cdot 326-328}$ at the Savannah River Plant adapted Wheelwright's DTPA displacement elution scheme to pilot-scale operation in pressur- 


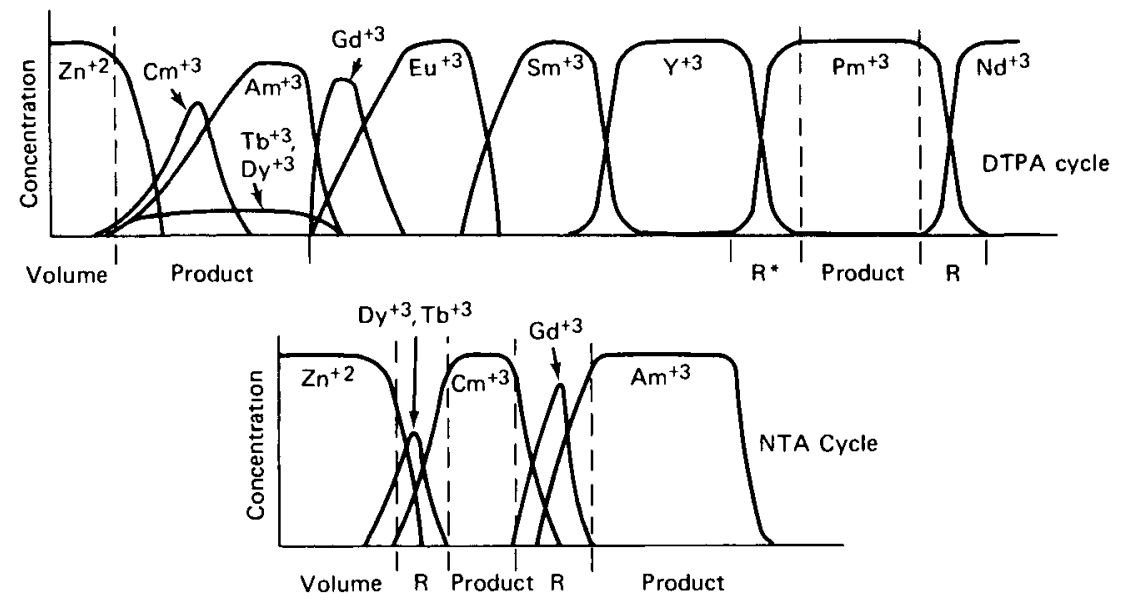

* $R$ denotes recycle solution for further product recovery.

Fig. 5.37 Typical elution curves for two-cycle chromatographic cation-exchange americium purification process. DTPA $=$ diethylenetriaminepentaacetic acid; NTA $=$ nitrilotriacetic acid. ${ }^{324}$

ized equipment. [Pressurization eliminates the bed disruptions caused by radiolytically produced gases in gravity-fed columns, and a severalfold increase in flow rate minimizes radiolytic resin degradation. Pressurization also allows the use of very finely divided resin, thereby improving sorption kinetics.] The pilot-scale system used by the Savannah River workers to successfully purify $3 \mathrm{~kg}{ }^{244} \mathrm{Cm}$ and ${ }^{243} \mathrm{Am}$ consisted of four columns constructed of $304 \mathrm{~L}$ stainless steel, Schedule 80 pipe; column diameters were nominally $10.2,7.62,5.08$, and $2.54 \mathrm{~cm}$, respectively, and each column was $122 \mathrm{~cm}$ long. All columns were filled with Dowex 50W-X8 (25- to 55- $\mu \mathrm{m})$ resin in the $\mathrm{Zn}^{2+}$-form. A typical batch of feed solution, obtained by prior solvent extraction (compare pages 202 to 205) processing of highly irradiated plutonium, contained $75 \mathrm{~g}$ ${ }^{244} \mathrm{Cm}, 24 \mathrm{~g}{ }^{243} \mathrm{Am}$, and $\sim 1.6 \mathrm{~mol}$ of fission-product lanthanides. After loading this feed onto the top 30 to $40 \%$ of the 10.2 -cm-diameter column, the americium, curium, and lanthanides were eluted at $70^{\circ} \mathrm{C}$ with a $0.05 \mathrm{M}$ DTPA solution adjusted to $\mathrm{pH} 6.0$ with $\mathrm{NH}_{4} \mathrm{OH}$. The desired elution rate of $16 \mathrm{ml} \mathrm{cm}^{-2} \mathrm{~min}^{-1}$ was obtained on each column without exceeding the design pressure of 1000 psig. A typical elution diagram for product fractions collected from the final $2.54-\mathrm{cm}$-diameter column is shown in Fig. 5.38. Hale and Lowe ${ }^{308}$ note that, because the curium/americium ratio in the feed to the pressurized ion-exchange system was $\sim 3: 1$, a large fraction of pure curium could be separated from both americium and lanthanides in a single DTPA ion-exchange cycle.

In further work at the Savannah River Plant, Kelly ${ }^{329}$ devised a pressurized cation-exchange system for separating and purifying ${ }^{244} \mathrm{Cm}$ and ${ }^{243} \mathrm{Am}$ from feed solutions with a lanthanide/actinide ratio of $\sim 17: 1$. This process was developed as part of a program to produce gram amounts of ${ }^{252} \mathrm{Cf}$ and was intended for use in the 


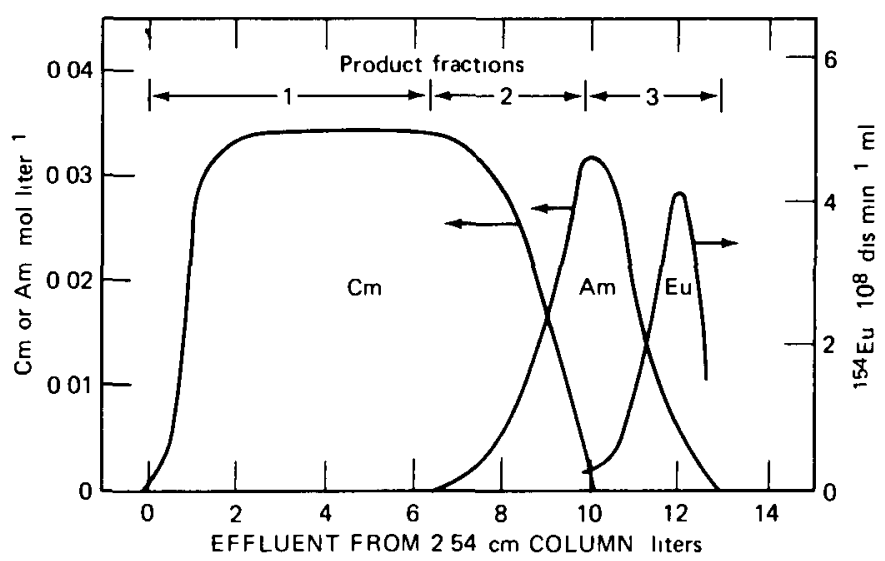

Fig. 5.38 Typical elution diagram for pressurized chromatographic ion-exchange separation of americium from curium Resin, Dowex 50W-X8, Eluent, $005 M$ DTPA at pH 60 [From J T Lowe, $\mathrm{W} \mathrm{H}$ Hale, $\mathrm{Jr}$, and $\mathrm{D} \mathrm{F}$ Hallman, ${ }^{326}$ Development of a Pressurized Cation Exchange Chromatographic Process for Separation of Transplutonium Actınides, Industrial and Engineering Chemistry, Process Design and Development, 10: 131 (1971) ]

Multipurpose Processing Facility constructed at the Savannah River Plant, no large-scale use of this ion exchange process has yet been made Wakat and Peterson ${ }^{3} 30$ have described an on-line radiochemical system for providing control information for pressurized cation-exchange chromatography processes

Specht, Schutz, and Born ${ }^{331}$ have reported on a laboratory-scale plant for separatıng $100 \mathrm{C}_{1}$ of ${ }^{242} \mathrm{Cm}$ from gram amounts of americium using high-pressure 1on-exchange chromatography Schutz, Specht, and Born used an $05 M \alpha$-hydroxyisobutyric acid solution adjusted to $\mathrm{pH} 365$ as the eluent

\section{Inorganıc Exchangers}

Several authors have reported results of studies of sorption of $\mathrm{Am}^{3+}$ from nitrate and chloride media by various inorganic exchangers (Table 511 ) Studied most intensively has been sorption of $\mathrm{Am}^{3+}$ by zirconium phosphate, distribution data for uptake at $75^{\circ} \mathrm{C}$ of $\mathrm{Am}^{3+}$ and other trivalent ions from nitric acid solutions are plotted in Fig 539 The order of the distribution coefficients of trivalent actinides and lanthanides into zurconium phosphate is the reverse of the order observed with a typical strong base resin exchanger, indicating that the phosphate groups probably replace part of the water in the hydration sphere of the 1ons ${ }^{332}$ Equilibrium in the zirconium phosphate $\mathrm{HNO}_{3}-\mathrm{Am}^{3+}$ system is established very slowly, even for tracer loading at $75^{\circ} \mathrm{C}^{332335}$, however, $>99 \%$ absorption of tracer $\mathrm{Am}^{3+}$ occurs in $15 \mathrm{~min}$ at $75^{\circ} \mathrm{C}$ 
Table 5.11

SUMMARY OF SORPTION OF Am(III) BY INORGANIC EXCHANGERS

\begin{tabular}{|c|c|c|}
\hline Exchanger & Media & Refs. \\
\hline Zirconium phosphate & $0.01 M-1.0 \mathrm{M} \mathrm{HNO}_{3}$ & $332-334$ \\
\hline Zurconium phosphate & $4 M-11 M \mathrm{LiCl}-0.01 M \mathrm{HCl}$ & 336 \\
\hline Zirconium phosphate-silicate* & $0.01 M-1.0 M \mathrm{HNO}_{3}$ & 335 \\
\hline Zirconium molybdate & pH 1-5 nitrate solutions & 333 \\
\hline Zurconium tungstate & $\mathrm{pH} 1-5$ nitrate solutions & 333 \\
\hline Zurconıum tungstate & $11 M \mathrm{LiCl}-0.01 M \mathrm{HCl}$ & 336 \\
\hline Zirconium oxide $†$ & $4 M-11 M \mathrm{LlCl}-0.01 M \mathrm{HCl}$ & 333,336 \\
\hline Ammonium phosphomolybdate & $10 M \mathrm{L1Cl}-0.01 M \mathrm{HCl}$ & 336 \\
\hline Permutit Decalso M-4 & $11 M \mathrm{LlCl}-0.01 M \mathrm{HCl}$ & 336 \\
\hline Linde Molecular Sieve X-13§ & $11 M \mathrm{LiCl}-0.01 M \mathrm{HCl}$ & 336 \\
\hline Linde Molecular Sieve AW $500 \S$ & $11 M \mathrm{LlCl}-0.01 M \mathrm{HCl}$ & 336 \\
\hline Chromatographic $\mathrm{Al}_{2} \mathrm{O}_{3}$ & $11 M \mathrm{~L} 1 \mathrm{Cl}-0.01 M \mathrm{HCl}$ & 336 \\
\hline \multicolumn{3}{|c|}{ 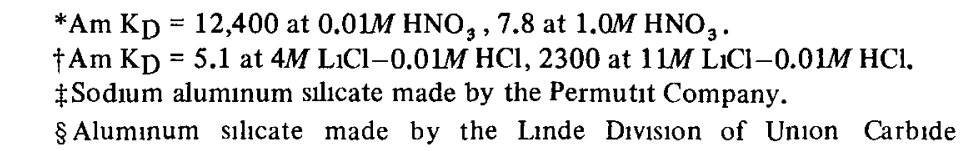 } \\
\hline
\end{tabular}

According to Ryan, ${ }^{252}$ several of the eluting agents previously used successfully with resin exchangers have been tested with zirconium phosphate Citrate, tartrate, and oxalate solutions dissolve zirconium phosphate, whereas $2 M$ lactate solutions at pH's 3 and 5 and a $15 M \alpha$-hydroxyisobutyrate solution at pH 42 do not elute trivalent actınides and lanthanides Concentrated mineral acids elute $\mathrm{M}^{3+}$ 1ons without separation Separation of americium from europium or cerium by elution from a zirconium phosphate column with a $10 M \mathrm{~L}_{1} \mathrm{Cl}$ solution $(\mathrm{pH} 2$ to 3 ) has been reported by ORNL workers 336

Uptake of $\mathrm{Am}^{3+}$ from nitrate solutions by zirconium molybdate is similar to that by zirconium phosphate With zirconium tungstate, $\mathrm{K}_{\mathrm{D}}$ 's for $\mathrm{Am}^{3+}$ and $\mathrm{Cm}^{3+}$ from $10 M \mathrm{~L} 1 \mathrm{Cl}-001 M \mathrm{HCl}$ are higher by a factor of 2 than for any of the lanthanides Absorption of $\mathrm{Am}^{3+}$ from $10 M \mathrm{LiCl}-001 M \mathrm{HCl}$ by ammonium molybdophosphate is farrly similar to that by zirconium phosphate. ${ }^{336}$ From the same chloride media, Permutit Decalso M-4 and Linde Molecular Sieves X-13 and AW 500 sorb Am ${ }^{3+}$ only weakly, whereas moderately strong absorption occurs with chromatographic alumina. 336

Both American ${ }^{337338}$ and Russian 339340 scientists have recently announced a new way of using a zirconium phosphate exchanger for separatıng americium from curium and other metal ions This method takes advantage of the fact that the singly charged $\mathrm{AmO}_{2}^{+}$ion is not sorbed by zirconium phosphate from dilute acid media Also, unlıke organic exchangers, the inorganic exchanger will not reduce the strongly 


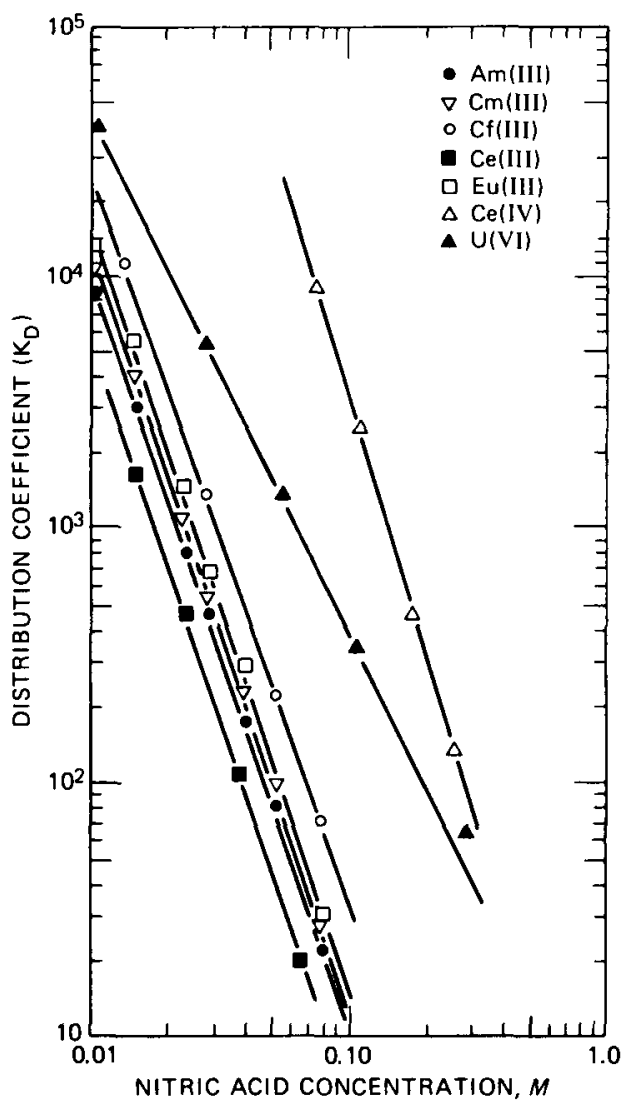

Fig. 5.39 Distribution coefficients $\left(\mathrm{K}_{\mathrm{D}}\right)$ for several ions onto amorphous zirconium phosphate $\left(\mathrm{PO}_{4} / \mathrm{Zr}=1.34\right)$ sorbent from $\mathrm{HNO}_{3}$ solution at $75^{\circ} \mathrm{C}$. [From E. P. Horwitz, ${ }^{332}$ The Sorption of Certain Transplutonium Ions on Amorphous Zirconium Phosphate, Journal of Inorganic and Nuclear Chemistry, 28: 1469 (1966).]

oxidizing $\mathrm{AmO}_{2}^{+}$. Shafiev, Efremov, and Andreev ${ }^{340}$ have recently separated milligram amounts of americium and curium on zirconium phosphate by sorbing curium preferentially from a $\mathrm{pH} 2.5$ solution containing $\mathrm{Am}(\mathrm{V})$ and $\mathrm{Cm}(\mathrm{III})$.

In the americium-curium separation scheme patented by Moore, ${ }^{338} \mathrm{Am}^{3+}$ in a $0.01 \mathrm{M} \mathrm{HNO}_{3}$ solution is oxidized to $\mathrm{AmO}_{2}^{+}$by heating at 80 to $90^{\circ} \mathrm{C}$ with $\left(\mathrm{NH}_{4}\right)_{2} \mathrm{~S}_{2} \mathrm{O}_{8}$; the oxidized solution is transferred to the zirconium phosphate exchanger, and the americium is eluted with $0.01 M \mathrm{HNO}_{3}$. If desired, a curium fraction can be eluted with $10 M \mathrm{HNO}_{3}$. The Russian procedure ${ }^{340}$ for separating americium from curium is essentially the same as that described by Moore, except for the use of $0.1 M \mathrm{HNO}_{3}$ to elute the $\mathrm{AmO}_{2}^{+}$. The Russian scientists note that, in some cases, the oxidized solution may contain some $\mathrm{AmO}_{2}^{2+}$ as well as $\mathrm{AmO}_{2}^{+} ; \mathrm{Am}(\mathrm{VI})$ is 
retained slightly more strongly than $\mathrm{Am}(\mathrm{V})$ but can be readily eluted with $0.05 \mathrm{M}$ to $0.15 \mathrm{M} \mathrm{HNO}_{3}$ solutions.

\section{Chelating Resins}

Ryan $^{252}$ observed that very little work has been done on the reaction of americium and other transuranium elements with chelating exchangers and gives reasons why this is so. Goya and $\mathrm{Lai}^{341}$ report a value of $\mathrm{K}_{\mathrm{D}}=1.3 \times 10^{4}$ for sorption of trace amounts of $\mathrm{Am}^{3+}$ from seawater into Chelex 100 resin. Myasoedov and Molochnikova $^{342}$ have used a chelating resin based on aminopolystyrene and Arsenazo I [2-arsonobenzene-(1-azo-2)-1, 8-dihydroxynaphthalene-3-6-disulfonic acid) to concentrate trace amounts of americium and curium and to separate them from plutonium and fission products. In this analytical procedure, $\mathrm{Am}^{3+}$ and $\mathrm{Cm}^{3+}$ are sorbed from a mineral acid solution of $0.1 N$ to $1 N$; after washing the chelating resin with $0.5 \mathrm{M}$ oxalic acid and $11 \mathrm{~N} \mathrm{H}_{2} \mathrm{SO}_{4}$, americium and curium are eluted with $2 \mathrm{M}$ ammonium citrate solution.

\section{EXTRACTION CHROMATOGRAPHIC PROCESSES}

Extraction chromatography (reversed-phase partition chromatography in some of the older literature) combines the best features of solvent extraction and chromatographic separations techniques. Extraction chromatographic systems involve a mobile liquid phase and a stationary liquid phase on an inert support; separations are achieved by taking advantage of the difference in the distribution of ions between the two liquid phases.

Systems that have been studied for extraction chromatographic separation of americium from rare earths, $\mathrm{Cm}$ (III), and other transplutonium elements are briefly described in Table 5.12. Not surprisingly, most of the systems investigated have used either HDEHP or Aliquat 336 as the stationary phase. For the most part, the extraction chromatographic procedures listed in Table 5.12 have been tested only with tracer amounts of americium either to investigate americium chemistry in such systems or to develop analytical procedures. A notable exception is the Aliquat 336 $\left(\mathrm{NO}_{3}\right.$-form)-kieselguhr system that has been used recently both in the United States $^{357}$ and in Europe 359,360 to separate milligram and even gram amounts of americium from curium.

\section{MISCELLANEOUS SEPARATION TECHNIQUES}

Many of the solvent extraction, ion exchange, and precipitation processes described earlier in this chapter are used, as noted previously, for large-scale separation and purification of americium in the United States and elsewhere. Various other 
Table 5.12

EXTRACTION CHROMATOGRAPHY SYSTEMS FOR AMERICIUM SEPARATION

\begin{tabular}{|c|c|c|c|c|c|c|c|}
\hline Carrier & $\begin{array}{l}\text { Mesh } \\
\text { size }\end{array}$ & Stationary phase & Eluent & $\underset{{ }^{\circ} \mathrm{C}}{\text { Temp., }}$ & Application & Refs. & 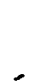 \\
\hline Kieselguhr* & $200-400$ & HDEHP & $0.5 M \mathrm{HCl}$ & 87 & $\begin{array}{l}\text { Separate Am(III) from } \\
\text { Bk and Cf }\end{array}$ & $343-345$ & \\
\hline Silica gel & $12-18 \mu$ & HDEHP & $0.74 M-1.02 M \mathrm{HCl}$ & 25 & $\begin{array}{l}\text { Distribution coefficient } \\
\text { data for Am(III) }\end{array}$ & 346 & \\
\hline Celite $545 \dagger$ & & 0.4M HDEHP-heptane & $0.1 N-0.6 N \mathrm{HCl}$ or $\mathrm{HNO}_{3}$ & $18-60$ & $\begin{array}{l}\text { Distribution coefficient } \\
\text { data for Am(III) }\end{array}$ & 347 & \\
\hline Celite $545 \dagger$ & $25 \mu$ & $8.82 \mathrm{wt} . \%$ HDEHP & $0.1 N-0.6 N \mathrm{HCl}$ or $\mathrm{HNO}_{3}$ & $25-75$ & $\begin{array}{l}\text { Separate Am(III) from } \\
\text { Cm(III) }\end{array}$ & 348 & \\
\hline Kieselguhr* & $100-400$ & HDEHP-xylene & $0.1 N-1 N \mathrm{HNO}_{3}$ & 20 & $\begin{array}{l}\text { Separate Am(III) from } \\
\text { La and other rare } \\
\text { earths }\end{array}$ & 349 & \\
\hline Filter Cel & $200-400$ & HDEHP & $0.3 N, 0.5 N$, and $2.1 \mathrm{NHNO}_{3}$ & & $\begin{array}{l}\text { Separate Am(III) from } \\
\text { Pm }\end{array}$ & 350 & \\
\hline KEL-F $\ddagger$ & $170-250$ & $10 \%$ HDEHP-heptane & $0.97 N-3.6 N \mathrm{HCl}$ & 20 & $\begin{array}{l}\text { Separate Am(III) from } \\
\text { Eu }\end{array}$ & 351 & \\
\hline Tee-Six & $70-80$ & 0.45 $M$ HDEHP-heptane & $\begin{array}{l}1 M \text { monochloroacetic acid- } \\
0.025 M \text { DTPA }\end{array}$ & 25 & $\begin{array}{l}\text { Separate } A m(I I I) \text { from } \\
\text { rare earths }\end{array}$ & 352 & \\
\hline Teflon-6§ & $60-70$ & $1 M$ HDEHP-heptane & $0.01 M \mathrm{HNO}_{3}$ & 25 & $\begin{array}{l}\text { Separate } A m(V) \text { from } \\
\text { Cm(III) }\end{array}$ & 353 & \\
\hline Celite $545 \dagger$ & $80-100$ & $1 M$ HDEHP & $0.1 M-2 M \mathrm{HNO}_{3}$ & 0.40 & $\begin{array}{l}\text { Study behavior of } \\
\text { Am(III), (V), and (VI) }\end{array}$ & 354 & \\
\hline Celite $545 \dagger$ & & $0.2 M$ HDEHP & $0.1 M \mathrm{HNO}_{3}$ & 25 & $\begin{array}{l}\text { Study extraction be- } \\
\text { havior of Am(VI) }\end{array}$ & 355 & \\
\hline
\end{tabular}




\begin{tabular}{|c|c|c|c|c|c|c|}
\hline Kieselguhr* & $100-400$ & Aliquat $336 \mathrm{q}-\mathrm{NO}_{3}$-form & $3.6 M \mathrm{LiNO}_{3}-0.01 M \mathrm{HNO}_{3}$ & $23-24$ & $\begin{array}{l}\text { Separate Am(III) from } \\
\text { Cm(III) }\end{array}$ & $\begin{array}{l}68,70 \\
239,240 \\
356-360\end{array}$ \\
\hline $\begin{array}{l}\text { Plaskon- } \\
\text { CTFE 2300 }\end{array}$ & & Aliquat $336-\mathrm{SCN}$-form & $0.1 N-0.6 \mathrm{~N} \mathrm{NH}_{4} \mathrm{SCN}$ & 25 & $\begin{array}{l}\text { Separate Am(III) from } \\
\text { rare earths }\end{array}$ & 361 \\
\hline Celite & $80-120$ & Aliquat $336-\mathrm{SCN}$-form & $\begin{array}{l}0.1 N-9 N^{N N_{4}} \mathrm{SCN}_{-} \\
0.002 N-0.1 \mathrm{NH}_{2} \mathrm{SO}_{4}\end{array}$ & 25 & $\begin{array}{l}\text { Separate Am(III) from } \\
\text { rare earths }\end{array}$ & 362 \\
\hline Paper & & $0.5 M$ tri- $n$-octylamine - xylene & $3 M \mathrm{LiNO}_{3}-0.02 M \mathrm{HNO}_{3}$ & 25 & $\begin{array}{l}\text { Separate Am(III) from } \\
\text { Cm(III) }\end{array}$ & 363 \\
\hline Paper & & $\begin{array}{l}0.02 M-0.18 M \text { HTTA } \dagger \dagger- \\
0.02 M \text { TOP } \ddagger \ddagger\end{array}$ & $0.05 M \mathrm{HCl}$ & 25 & Synergistic effect study & 364 \\
\hline Kieselguhr* & $100-400$ & $0.8 M$ TOPO $\& \S-x y l e n e$ & $0.1 M-1 M \mathrm{HNO}_{3}$ & 20 & $\begin{array}{l}\text { Separate Am(III) from } \\
\text { Eu }\end{array}$ & 349 \\
\hline
\end{tabular}

*Commercially available diatomaceous earth.

+Product of the Johns-Manville Company.

$\$$ Poly trifluoro- monochloroethylene.

§Polytetrafluoroethylene.

I General Mills, Inc.; mix ture of trioctylmethyl- and tridecylmethylammonium chloride.

**Trifluorochloroethylene made by the Allied Chemical Company.

$\dagger \dagger$ Thenoyltrifluoroacetone.

$\ddagger \ddagger$ Tri- $n$-octylphosphate.

$\S$ § Tri- $n$-octylphosphine oxide. 
schemes have been proposed and/or used from time to time for recovery, purification, characterization, or analysis of, generally, micro amounts of americium.

Bilal and others ${ }^{365-368}$ in Germany, principally at the Hahn-Meitner Institute, suggest that counterflow ion-migration procedures are applicable to the recovery and purification of americium from Purex-process high-level waste as well as irradiated ${ }^{241} \mathrm{Am}$ and ${ }^{243} \mathrm{Am}$ targets. These procedures involve a flow of a solvent counter to that of the ions of a mixture migrating in an electrical field; the velocity of this solvent compensates the mean migration velocity of the ions to be separated. The net result is to set up a stationary distribution of the mixture, within which the more rapid ions are transported upstream and the slower ions downstream. Separations of metal ions provided by counterflow ion-migration processes can be enhanced by the addition of ligands, which form complexes of different strengths with the various metal ions. In the favorable situation, one of the metal ions is converted to a neutral or anionic species, which is then transported out of the separation column by the counterflow liquid and is thus electrolytically extracted from the stationary mixture.

Counterflow ion-migration processes for separating large amounts of material are conveniently performed in troughs. ${ }^{367.368}$ Such troughs are divided by permeable diaphragms into compartments to avoid remixing caused by thermal convection and nonuniform flow profiles. Bilal et al. ${ }^{366}$ have described the successful application of the counterflow ion-migration technique to recover tracer amounts of ${ }^{241} \mathrm{Am}$ from synthetic denitrated Purex-process waste to which acetic acid had been added. Bilal et al. ${ }^{365}$ also applied this technique to cleanly separate americium and plutonium from a $2 \mathrm{M}$ acetic acid- $0.05 \mathrm{M} \mathrm{HNO}_{3}$ electrolyte containing $40 \mathrm{~g} \mathrm{Pu}(\mathrm{IV})$ liter $^{-1}$ and $0.15 \mathrm{~g} \mathrm{Am}$ (III) liter $^{-1}$.

The extraction of americium from dilute acetic acid solutions by sodium amalgam has been reported by Kobayashi and Saito. ${ }^{369}$ In their experiments, $0.4 M$ to $0.8 M$ acetic acid solutions containing about $1 \mathrm{~g} \mathrm{Am}^{3+} \operatorname{liter}^{-1}$ were contacted with sodium amalgam; 98 to $99 \%$ of the americium was in the amalgam phase. Most other actinide elements, as well as the lanthanides from lanthanum to europium, also extract under these conditions.

Other reported ${ }^{370}$ separation procedures include selective leaching of ${ }^{241} \mathrm{Am}$ from $\mathrm{PuO}_{2}$ powder by $1.2 \mathrm{M}$ formic acid at $90^{\circ} \mathrm{C} ; \sim 20 \%$ of the available americium extracts into the leach solution. Independent confirmation of this somewhat surprising leach behavior has not yet been reported. Zvarova, Zvára, and coworkers ${ }^{371-373}$ have separated microgram amounts of americium, curium, and plutonium by gas chromatography of the volatile chloride complexes formed by the reaction of $\mathrm{Al}_{2} \mathrm{Cl}_{6}$ vapor with solid actinide chlorides at 250 to $500^{\circ} \mathrm{C}$ (Fig. 5.40).

Paper electrophoretic procedures using $6 \mathrm{M}$ to $12 \mathrm{M} \mathrm{HNO}_{3}$ (Ref. 374), $\mathrm{HNO}_{3}-$ EDTA solutions (Ref. 375), $0.2 M$ citric acid (Ref. 376), and 0.07M $\alpha$-hydroxyisobutyric acid at $\mathrm{pH} 2.1$ (Ref. 377) have been described for separating Am(III) from $\mathrm{Cm}(\mathrm{III}), \mathrm{Ac}(\mathrm{III}), \mathrm{Pb}(\mathrm{II}), \mathrm{Th}(\mathrm{IV})$, and $\mathrm{Pu}(\mathrm{IV})$. So-called focusing electrophoretic techniques have been used to separate $\mathrm{Am}$ (III) and $\mathrm{Cm}$ (III) from $\mathrm{La}$ (III) and $\mathrm{Ce}$ (III) (Ref. 378), and to separate Am(III) from Cm(III) (Ref. 379); the latter separation was 


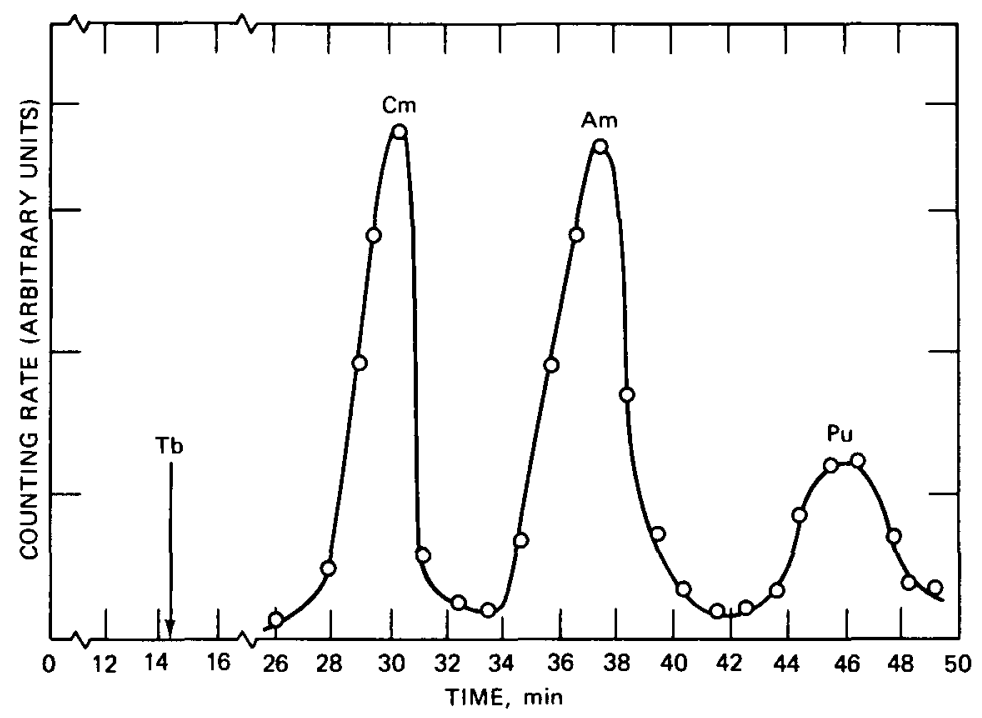

Fig. 5.40 Gas chromatographic separation of a mixture of chlorides of plutonium, americium, an curium. Glass capillary column $(2.5 \mathrm{~m}$ by $1 \mathrm{~mm}$ in inside diameter $)$ at $250^{\circ} \mathrm{C} ; \mathrm{Al}_{2} \mathrm{Cl}_{6}$ partial pressure, $\sim 100$ torrs; helium flow, $8 \mathrm{ml} \mathrm{min}^{-1}$. [From T. S. Zvarova and I. Zvara, ${ }^{371}$ Separation of Transuranium Elements by Gas Chromatography of Their Chlorides, Journal of Chromatography, 49: 290 (1970).]

accomplished in a sodium polyphosphate solution at $\mathrm{pH} 7.0$. Details of these electrophoretic methods are given in the text by Myasoedov et al..$^{95}$

Szeglowski and other Polish scientists ${ }^{380,381}$ have studied frothless ion flotation of anionic nitrate and citrate complexes of $\mathrm{Am}$ (III) from $\mathrm{LiNO}_{3}$ and citric acid solutions, respectively. Cetylpyridynium bromide in isooctyl alcohol was used as a cationic collector. Americium recovery by ion flotation increases with increased $\mathrm{LiNO}_{3}$ concentration but decreases linearly with increased citrate concentration. The Polish workers also studied the flotation of colloidal americium hydroxide from various aqueous solutions using sodium tetradecyl sulfate as an anionic collector; maximum recovery of americium was observed at $\mathrm{pH} 5$.

\section{REFERENCES}

1. J. L. Long, Recovery of Americium from Plutonium, U. S. Patent No. 3,460,917, August 1969.

2. J. B. Knighton, J. L. Long, R. C. Franchini, R. G. Auge, J. C. Brown, and F. G. Meyer, A Batch Two-Stage Countercurrent Mode for Liquid Plutonium-Molten Salt Extraction of Americium, USAEC Report RFP-1875, Rocky Flats Plant, Dow Chemical Company, July 1973. 
3 J Moseley and J B Knighton, Liquid--Liquid Extraction of Americium from Molten Plutonium Metal, USAEC Report RFP-1947, Rocky Flats Plant, Dow Chemical Company, August 1972

4 J L Long and C C Perry, Molten Salt Extraction of Americium from Plutonium Metal, Nucl Met, Met Soc AIME, 15: 385 (1969)

5 L J Mullins, J A Leary, and W J Maraman, Removal of Fission Product Elements by Slagging, Ind Eng Chem, 52: 227 (1960)

6 J B Knighton, J D Schilb, and J W Walsh, Separation of Rare Earths from Uranium and Plutonium by Molten Salt Extraction, in Chemical Engineering Division Summary Report, April-June 1962, USAEC Report ANL 6569, Argonne National Laboratory, August 1962

7 A R Teter, J L Long, R L Leggett, and C J Smith, Improved Resistance Furnaces for Molten Salt Extraction Processes, USACC Report RFP 1513, Rocky Flats Plant, Dow Chemical Company, August 1970

8 J B Knıghton, Dow Chemıcal Company, private communication, 1974

9 a L J Mullins, A J Beaumont, and J A Leary, Distribution of Americium Between Liquid Plutonium and a Fused Salt Evidence for Divalent Americium, I Inorg Nucl Chem 30: 147 (1968), also, USAEC Report LA-3562, Los Alamos Scientıfic Laboratory, May 1966

b J A Long and L J Mullıns, Divalent Americium in Molten Salt + Molten Plutonium Systems, J Chem Thermodyn 6. 103 (1974)

c W R Strickland, R G Auge, and J C Brown, Method of Precipitating Americium Oxide from a Mixture of Americium and Plutonium Metals in a I used Salt Bath Containıng $\mathrm{PuO}_{2}$, U S Patent No 3,804,939, April 1974

10 L J Mullins and J A Leary, Molten Salt Method of Separation of Americium from Molten Plutonium, U S Patent No 3,420,639, January 1969

11 G Landresse, Chemical Redctions in Fused Salts, Ind Chim Belge, 36: 843 (1971), also, USAEC Report RFP Trans-109, Rocky Hats Plant, Dow Chemical Company, 1972

12 R K Steunenberg, R O Pierce, and I Johnson, Status of the Salt Transport Process for Fast Breeder Reactor Fuels, in Symposium on Reprocessing of Nuclear Fuels, Ames, lowa, August 25-27, 1969, USAEC Report CONF 690801, pp 325-336, 1969

13 J B Knighton and R K Stuenenberg, Distribution of Transuranium Elements Between Magnesium Chloride and Zinc-Magnesium Alloy, J Inorg Nucl Chem, 271457 (1965)

14 J B Knighton and R K Steunenberg, Separation of Plutonium, Uranium, Americium, and I 1ssion Products from Each Other, U S Patent No 3,147,109, September 1964

15 S Lawroskı, J B Knıghton, and R K Steunenberg, Americium Curium Separation, U S Patent No 3,152,887, October 1964

16 Oak Ridge National Laboratory, Molten-Salt Reactor Processing, in Chemical Technology Division Annual Progress Report for Penod Ending May 31, 1969, USAEC Report ORNL-4422, pp 1-47, October 1969

17 M E Whatley, Molten Salt Processing and Preparation, in Molten Salt Reactor Program Semiannual Progress Report for Period Endıng August 31, 1969, USAEC Report ORNL-4449, p 214, Oak Ridge National Laboratory, February 1970

18 L E McNeese and L M Ferris, Molten-Salt Breeder Reactor Fuel Processing, Trans Amer Nucl Soc, 14:84 (1971)

19 L M Ferris, J C Mallen, J J Lawrance, F J Smith, and E D Nogueira, Equilibrium Distribution of Actinide and Lanthanide Elements Between Molten Fluoride Salts and Liquid Bismuth Solutions, J Inorg Nucl Chem, 32: 2019 (1970)

20 L M I erris, J C Malen, and F J Smıth, Chemistry and Thermodynamics of the Distribution of Lanthanide and Actinide Flements Between Molten LiF-BeF 2 and Liquid Bismuth Solutions, J Inorg Nucl Chem, 33: 1325 (1971)

$21 \mathrm{~J}$ C Malen and L M Ferris, Distribution of Transuranium Elements Between Molten Lithium Chloride and Lithum-Bismuth Solutions Evidence for Californum(II), Inorg Nucl Chem lett, 7:431 (1971) 
22 L M F erris, F J Smith, J C Malen, and M J Bell, Distribution of Lanthanide and Actınıde Elements Between Molten Lithium Halıde Salts and Liquid Bismuth Solutions, J Inorg Nucl Chem 34: 2921 (1972)

23 R H Moore and W L Lyon, Distribution of the Actinide Elements in the Molten System $\mathrm{KCl}-\mathrm{AlCl}_{3} \mathrm{Al}$, USAEC Report HW-59147, General Electric Company, Hanford Atomic Products Operation, October 1959

24 D E McKenzie, J W Fletcher, and $T$ Bruce, The Extraction of Plutonium from Plutonium Aluminum Alloys by Molten Bismuth, Canadian Report CRC 639, April 1956

$25 \mathrm{~J}$ Foos, Solvent Extraction of $4 \mathrm{f}-$ and $5 \mathrm{f}$-Serres Elements in Fused Salt Medium (Thesis), USAEC file No NP-18827, 1970

$26 \mathrm{~J}$ Foos and $\mathrm{R}$ Guillaumont, Solvent Extraction of $4 \mathrm{f}$ - and 5f-Series Elements from Alkalıne Molten Nitrates, Bull Soc Chım. Fr, 9· 3129 (1971)

27 a J Foos and R Gullaumont, Solvent Extraction from Molten Salts of Some 4f and $5 f$ Elements, in Proceedings of the International Solvent Extraction Conference The Hague Aprll 19231971 Vol 2, p 966, Society of Chemical Industry, London, 1971

b J Foos and R Gullaumont, Extraction par Solvent d'Elements cls et Transuraniens a Partir de Nitrates Alcalıns Fondus, $J$ Inorg Nucl Chem 36: 3833 (1974)

$28 \mathrm{~J}$ Foos and $\mathrm{J}$ Mesplede, Solvent Extraction from Molten Eutectic $\mathrm{L}_{1} \mathrm{NO}_{3}-\mathrm{KNO}_{3}$ of Some " $5 \mathrm{f}$ " Elements by Diphenyldiphosphine Dioxides and Tri-n-Octylphosphine Oxide, J Inorg Nucl Chem 34: 2051 (1972)

29 J Mesplede, Liquid-Liquid Extraction from Molten Alkalı Nitrates Containıng 4f and $5 \mathrm{f}$ Elements Usıng Diphosphıne Dioxıdes (Thesis), French Report I RNC-Th-368, 1972

30 Z Borkowska, S Gutnık, M Mielcarskı, and M Taube, Certain Physıcochemical Properties of Uranıum Chloride, Plutonıum Chlonde, Americium Chloride, and Curium Chloride in I used Salts, Nucleonika, 10(Suppl) 27(1965)

31 Yu A Barbanel, V P Kotlin, and V R Klokman, Absorption Spectra of Americrum(III) and Neodymıum(II) in Molten Pyridınıum and Alkalı Metal Chlorides, Radiokhımıa 15: 366 (1973), through Sov Radiochem (Engl Transl), 15: 368 (1973)

$32 \mathrm{R}$ A Penneman and $\mathrm{T} \mathrm{K}$ Keenan, The Radiochemistry of Americium and Curium, National Academy of Sciences-National Research Council, NAS-NS 3006, 1960

33 S G Thompson, L O Morgan, R A James, and I Perlman, The I racer Chemistry of Americium and Curium in Aqueous Solutions, in The Transuranium Elements, G T Seaborg, J. J Katz, and W M Manning (Eds.), pp 1339-1361, McGraw-Hill Book Company, Inc., New York, 1949.

34 B B Cunningham, The First Isolation of Americium in the Form of Pure Compounds, Microgram-Scale Observations on the Chemistry of Americium, in The Transurantum Elements, G T Seaborg, J J Katz, and W M Manning (Eds), pp 1363 1370, McGrawHill Book Company, Inc, New York, 1949

$35 \mathrm{~J} C$ Wallman, The First Isolation of the Transuranium Elements, $J$ Chem Educ 36: 340 (1959)

36 L B Werner, Method for Separation of Americium from Solutions Containing the Same, U S Patent No 2,577,097, December 1951

37 L B Werner, Radioactive Product and Method of Producing the Same, U S Patent No 2,554,476, May 1951

38 L B Werner, Precipitation Method of Recovering Element 95 from Contamınants, U S Patent No 3,551,119, September 1970

39 S G Thompson, Method of Obtaining Americium, U S Patent No 3,554,867, January 1971

$40 \mathrm{~J}$ Milsted, The Isolation of Americium, Britısh Report AERE-C/R-1 102, February 1953

41 P D Herniman, Separation and Purification of Milligram Quantities of Americium, Britısh Report AERE-C/R-1113, January 1953 
42 C R Hall and P D Hernıman, The Separatıon and Punfication of Amencium-241 and the Absorption Spectra of Tervalent and Quinquevalent Americium Solutions, $J$ Chem Soc, p 2214 (1954)

$43 \mathrm{~J}$ P Butler and J S Merritt, A Batch Process for the Recovery of $\mathrm{Am}^{24}{ }^{2}$ from Kilogram Amounts of Plutonium, Canadian Report CRC-661, August 1956

44 G N Yakovlev and V N Kosyakov, An Investigation of the Chemistry of Americium, in Proceedings of the Second United Nations International Conference on the Peaceful Uses of Atomic Energy, Geneva 1958, Vol 28, p 373, United Nations, New York, 1958

45 W J Maraman, A J Beaumont, E L Christensen, A V Hendrickson, J A Hermann, K W R Johnson, L J Mullins, and R S Winchester, Calcium Oxalate Carner Precipita tıon of Pu, USAEC Report LA-1692, Los Alamos Scientıfıc Laboratory, February 1954

46 F Weigel, The Isolation of Americium-241 in 100-Milligram Quantities from Large Amounts of Impurities, USAEC Report UCRL-3934, University of Calıfornı, Lawrence Radiation Laboratory, September 1957, also, Z Anorg Allg Chem, 294: 294 (1958)

47 J S Coleman, D E Armstrong, L B Asprey, T K Keenan, L E LaMar, and R A Penneman, Purification of Gram Amounts of Americium, USAEC Report LA-1975, Los Alamos Scientific Laboratory, November 1955

48 L B Asprey, S E Stephanou, and R A Penneman, Hexavalent Americium, $J$ Amer Chem Soc, 73: 5715 (1951)

49 S E Stephanou and R A Penneman, Observatıons on Cunum Valence States, A Rapid Separation of Americium and Curium, $J$ Amer Chem Soc 74: 3701 (1952)

$50 \mathrm{M}$ Ward and G A Welch, Oxidation of Americium to the Sexivalent State, $J$ Chem Soc p 4038 (1954)

51 A Chetham-Strode, Jr, The Determination of Amencium in Plutonium Product Solutions, USAEC Report HW 25205, General Electric Company, Hanford Works, August 1952

52 A Chetham-Strode, Jr, The Analytical Chemistry of Americium and Curium, USAEC Report AECD-3559 (HW-28277), General Electric Company, Hanford Works, June 1953

53 H W Miller, The Quantıtatıve Separation of Americium from Plutonium and Uranıum, USAEC Report HW-22267, General Electric Company, Hanford Works, October 1951

54 J A Hermann, Coprecipitation of the Transuranium Elements with the Rare Earths Coprecipitation of Americium with Lanthanum Oxalates, Diss Abstr, 16 1047 (1956)

55 J A Hermann, Coprecipitation of Am(III) with Lanthanum Oxalate, USAEC Report LA-2013, Los Alamos Scientıfic Laboratory, March 1956

56 J A Hermann, Separation of Americium from Lanthanum by Fractional Oxalate Precipitation from Homogeneous Solution, USAEC Report AECD-3637, Los Alamos Scientific Laboratory, July 1954

57 V I Grebenshchikova and R V Bryzgalova, Co-Precipitation of Am and Eu with Lanthanum Oxalate, Radiokhtmlya, 2: 152 (1960), through Radiochemistry, USSR (Engl Transl), 2: 152 (1960)

58 V I Grebenshchikova and V N Bobrova, Coprecipitation of Lanthanum, Cerium, and Americium with Potassium Sulfate, Zh Neorg Khtm 3: 40 (1958), also, USAEC Report AEC-TR-3682, May 1959

59 V I Grebenshchikova and N B Cherny avskaya, Coprecipitation of $\mathrm{Am}^{3+}$ with the Double Sulfate of Potassium and Lanthanum in Sulfuric Acid, Radıokhtmiya, 3: 650 (1961), through Sov Radio Chem (Engl Transl), 3: 142 (1961)

$60 \mathrm{~V} I$ Grebenshchıkova and $\mathrm{N} B$ Chernyavskaya, Isolation of $\mathrm{Np}^{4+}, \mathrm{Pu}^{4+}$, and $\mathrm{Am}^{3+}$ from Solutions by the Sulfate Method, Radıokhımıya 4 232 (1962), through Sov Radiochem (Engl Transl), 4: 207 (1962)

61 D L Bokowski, The Radiochemical Determination of Americium in the Presence of Plutonium in Unne, USAEC Report RFP-279, Rocky Flats Plant, Dow Chemical Company, 1961 
62 E N Jenkıns and G W Snedden, The Analysis of Urıne for Traces of Americium and Other Alpha Emitters, Britısh Report AERE-C/R 1399, November 1954

63 G N Yakovlev and D S Gorbenko-Germanov, "Coprecipitation of Amencium(V) with Double Carbonates of Uranium(VI) or Plutonium(VI) with Potassium, in Proceedings of the International Conference on the Peaceful Uses of Atomic Energy, Geneva, 1955, Vol 7,p 306, United Nations, New York, 1956

64 R S Pressly, Separation of Americıum and Promethium, USAEC Report ORNL 2202, Oak Ridge National Laboratory, March 1957, U S Patent No 2,893,827, July 1959

65 V I Kuznetsov and T G Akımova, Organıc Coprecıpıtants, Radıokhımıya 3737 (1961), through Sov Radiochem (Engl Transl) 3. 234 (1961)

66 L J Kıng, J E Bıgelow, and E D Collıns, Transuranıum Processing Plant Semiannual Report of Production, Status, and Plans for Penod Ending June 30, 1972, USAEC Report ORNL-4833, Oak Ridge National Laboratory, January 1973

$67 \mathrm{~W}$ Muller, F Maino, and J Cl Toussaint, Isolation of Amencium and Curıum from Irradiated ${ }^{24}$ Am Targets, Euratom Report EUR-4232, December 1968

68 K Buıss, W Muller, J Reul, and J C Toussaint, Separation and Purification of Americium on the Multigramme Scale, Euratom Report EUR 5040, October 1973

$69 \mathrm{G}$ A Burney, Separation of Americium from Curium by Precipitation of $\mathrm{K}_{3} \mathrm{AmO}_{2}\left(\mathrm{CO}_{3}\right)_{2}$, Nucl Appl 4: 217 (1968), also, USALC Report DP-1109, Savannah River Laboratory, February 1968

70 W Muller, F Mano, and J Cl Toussant, Processing of Imadiated ${ }^{241}$ Am Targets by Ion Exchange and Extraction, Euratom Report EUR-4409, January 1970

71 J Y Espie, B Poncet, and A Simon, Recovery of Trans-Plutonium Elements, French Report CEA-R-3744, March 1970

72 W D Burch (Comp), Transuranıum Quarterly Progress Report for Perıod Ending February 28, 1965, USAEC Report ORNL-3880, Oak Ridge National Laboratory, January 1966

73 A A Kishbaugh, H Bull III, G W Gibson, Jr, and L F Landon, Cunum Process Development IV Equipment Development and Testıng, USAEC Report DP 1146, Savannah River Laboratory, September 1969

$74 \mathrm{H}$ E Henry, Isolating Amencium and Curıum from $\mathrm{Al}\left(\mathrm{NO}_{3}\right)_{3}-\mathrm{NaNO}_{3}-\mathrm{HNO}_{3}$ Solutions by Batch Extraction with Tributyl Phosphate, USAEC Report DP 972, Savannah River Laboratory, 1965

75 W P Overbeck, C H Ice, and G Dessauer, Production of Transplutonium Elements at Savannah River, USAEC Report DP 1000, Savannah River Laboratory, 1965

76 R E Leuze and $\mathrm{M} \mathrm{H}$ Lloyd, Processing Methods for the Recovery of Transplutonium Elements, in Progress in Nuclear Energy, Process Chemistry, Series III, C E Stevenson, E A Mason, and A T Gresky (Eds), Vol 4, p 549, Pergamon Press, Inc, New York, 1970

77 S G Proctor, Dow Chemical Company, Rocky Flats Plant, private communication, 1974

78 F J Mıner and P G Hogan, Dow Chemical Company, Rocky Flats Plant, private communication, 1974

79 S G Proctor and W V Connor Separation of Cerium from Americium, J Inorg Nucl Chem, 323699 (1970)

80 S G Proctor, Preparation of High Purity Amencium Oxide, USAFC Report RFP 1857, Rocky Flats Plant, Dow Chemical Company, December 1972

81 S G Proctor, Rare Earth Removal from Amencium Oxıde, U S Patent No 3,723,594, March 1973

82 I N Zaozersku and P N Patkın, Rare Earth Elements, Academy of Sciences, Moscow, 1959 
83 S. G. Proctor, Recovery and Purification of Americium-241 from an AluminumAmenicium Oxide Mix̀ture, USAEC Report RFP-2206, Rocky Flats Plant, Dow Chemical Company, May 1974

84 R. S. Iyer and $\mathrm{P} \mathrm{R}$ Kamath, Separatıon of $\mathrm{B}_{1} \mathrm{PO}_{4}$ Carried Actınıdes by $\mathrm{B} 1 \mathrm{OCl}$ Precipitation, In Proceedings of the Chemistry Symposium, Chandigarh, India, September 23-26, 1969 (CONF-690916, Vol 2, pp 169-173)

85 C W Sill and R L Williams, Radiochemical Determınation of Uranium and the Transuranıum Elements in Process Solutions and Environmental Samples, Anal Chem, 41: $1624(1969)$

86 F L Ginzburg, T S Karantsevich, and V F Maksimov, Coprecipitation of Plutonium and Americium with Barium Sulfate, Radiokhimiya, 15:481 (1973), through Sov Radiochem (Engl Transl), 15: 487 (1973)

87 D N Bykhovskı and I. K Petrova, Role of Adsorption and Cocrystallization in Coprecipitation of Microamounts of Thorium(IV) and Americium(III) with Barium Oxalate, Radiokhimiya, 15: 605 (1973), through Sov Radiochem (Engl Transl), 15: 604 (1973)

88 B Weaver, Solvent Extraction in the Separation of Rare Earths and Trivalent Actinides, in Ion Exchange and Solvent Extraction, A Sertes of Advances, Vol 6, I A Marınsky and Y Marcus (Eds.), Marcel Dekker, Inc., New York, 1974

89 J E Agee and J A Roth, Solvent Extraction of Transuranium Elements, Separ Scl, 2: 563 (1967)

90 W Kraak, Extraction of Transplutonium Elements, Chem Weekbl, $61: 377$ (1965)

91 J Ulstrup, Methods of Separatıng the Actınide Elements, At Energy Rev , 4: 3 (1966)

92 R. Kroebel, Recovery of Transplutonium Elements, Chem Weekbl, 61: 389 (1965)

93 W Muller, The Extraction of Actınides by Alkyl-Substıtuted Ammonium Salts, Actinides Rev, 1: 71 (1967)

$94 \mathrm{R}$ D Baybarz, Recovery and Application of the Transuranium Elements ${ }^{237} \mathrm{~Np},{ }^{238} \mathrm{Pu}$, ${ }^{241} \mathrm{Am},{ }^{242} \mathrm{Cm},{ }^{244} \mathrm{Cm}$ and ${ }^{252} \mathrm{Cf}$, At Energy Rev , 8: 327 (1970)

95 B F Myasoedov, L I Guseva, I A Lebedev, M S Milyukova, and M K Chmutova, Analytical Chemistry of Transplutonium Elements, John Wiley \& Sons, Inc, New York, 1974

96 K A. Walsh, Extraction of Amencium Nitrate with Tributyl Phosphate, USAEC Report LA-1861, Los Alamos Scientıfic Laboratory, January 1955

97 T V Healy and H A C McKay, Complexes Between Tributyl Phosphate and Inorganic Nitrates, Rec Trav Chim, 75: 730 (1956)

98 G F Best, E Hesford, and H A C McKay, Tri-n-Butyl Phosphate as an Extracting Agent for Inorganic Nitrates VII, The Trivalent Actinide Nitrates, $J$ Inorg Nucl Chem, 12: 136 (1959)

99 V I Zemlyanukhin and G P Savoskina, Extraction of Amencium by Tributyl Phosphate, Radiokhımıa, 3: 411 (1961), through Radıochemistry (USSR), (Engl Transl), 3(4) 182 (1961)

100 V I Zemlyanukhın, G P Savoskına, and M F Pushlenkov, Complex I ormation of Americıum with Neutral Organophosphorus Compounds I, Radiokhimiya, 4: 570 (1962) through Sov Radiochem (Engl Transl), 4: 501 (1962)

101 E S Gureev, V B. Dedov, S M Karpacheva, I K Shvetsov, M N Ryzhov, P S. Trukchlayev, G N Yakovlev, and I A. Lebedev, Methods of Recovery and Some Chemical Properties of the Transplutonium Elements, in Progress in Nuclear Energy, Process Chemistry, Series III, C E Stevenson, E A Mason, and A T Gresky (Eds), Vol 4, p 631, Pergamon Press, Inc, New York, 1970

102 V I Zemlyanukhin, G P Savoskına, and M F Pushlenkov, Investigation of Complex Formation of Americium with Neutral Organophosphorus Compounds II, Radıokhımıya, 6: 694 (1964), through Sov Radiochem (Engl Transl), 6: 673 (1964) 
103 M C Thompson, Distribution of Selected Lanthanides and Actinides Between 30\% TBP in $n$-Paraffin and Vanous Metal Nitrate Solutions, USAEC Report DP-1336, Savannah River Laboratory, November 1973

104 J C Eargle, C W Swindell, and R I Martens, Large Scale Processing of Highly Irradiated Plutonium by Solvent Extraction and Ion Exchange, Ind Eng Chem., Process Design Develop , 6: 348 (1967)

105 a $H$ J Groh, R T Huntoon, C S Schlea, J A Smith, and F H Sprnger, ${ }^{244} \mathrm{Cm}$ Production and Separation-Status of the Pilot Production Program at Savannah River, Nucl Appl, 1: 327 (1965)

b D A Orth, J M McKibben, W E Prout, and W S Scotten, Isolation of Transplutonium Elements, in Proceedings of the International Solvent Extraction Conference, The Hague, Apnl 19-23, 1971, Vol 1, p 534, Society of Chemical Industry, London 1971

106 A L Boldt and G L Ritter, Recovery of Am, Cm, and Pm from Shippingport Reactor Fuel Reprocessing Wastes by Successive TBP and D2EHPA Extractions, USAEC Report ARH-1354, Atlantic Richfield Hanford Company, October 1969

107 F P Roberts and L A. Bray, Solvent Extraction of Transplutonium Elements from Redox Shıppıngport Waste, USAEC Report BNWL-CC-956, Battelle Memorial Institute, Pacific Northwest Laboratories, December 1966

108 C E Stevenson and D M Parge, Research and Development on Aqueous Processing, Reactor Fuel Process Technol, 11(4) 201208 (F all 1968)

109 F P Roberts and L A Bray, Recovery of Transplutonum Elements from Redox Waste, USAEC Report BNWL-CC-907, Battelle Memorial Instıtute, Pacıfic Northwest Laboratories, December 1966

$110 \mathrm{~J}$ Akatsu, Recovery of $\mathrm{Pu}$ and Am from Alpha-Bearıng Aqueous Wastes, Radıochem Radioanal Lett, 19:25 (1974)

111 R H Rainey, Development of the Amex Process for Amenclum Recovery, USAEC Report ORNL-1697, Oak Ridge National Laboratory, May 1954

112 J Stary, Separation of Transplutonium Elements, Talanta, 13: 421 (1966)

113 Y Marcus, M Givon, and M Shiloh, The Chemistry of the Trivalent Actinides in Aqueous Solution and Their Recovery, in Proceedings of the Third International Conference on the Peaceful Uses of Atomic Energy Geneva, 1964, Vol 10, p 588, United Nations, New York, 1965

114 W H Lewis, Amencium and Neptunium Recovery Processes, in Proceedings of the Second United Nations International Conference on the Peaceful Uses of Atomic Energy Geneva 1958, Vol 17, p 236, United Nations, New York, 1958

115 R E Leuze, Transuranic Studies-Status and Problem Statement, USAEC Report CF 59-4-108, Oak Ridge Natıonal Laboratory, April 1959

$116 \mathrm{G}$ Koehly and F Hoffert, Separation of the Actınide Group from That of the Lanthanides in Nitric Medium, in Semiannual Report of the Chemistry Department, Center for Nuclear Studies at Fontenay Aux-Roses, December 1966-May 1967, French Report CEA-N-856, also, USAEC Report ANL-Trans-628, Argonne National Laboratory, 1967

117 J M McKibben, H P Holcomb, D A Orth, W E Prout, and W C Scotten, Partitıonıng of Light Lanthanides from Actinides by Solvent Extraction with TBP, USAEC Report DP-1361, Savannah Ri' er Laboratory, August 1974

118 Oak Rıdge Natıonal Laboratory, Chemical Technology Divisıon, Annual Progress Report for Penod Ended August 31, 1960, USAEC Report ORNL-2993, September 1960

119 P. K Khopkar and P. Narayankutty, Extractıon of Americum(III) and Europium(III) from Throcyanate Solutions by Some Organophosphorus Extractants and Aliquat Thiocyanate, Indian Report BARC/I-135, 1971

$120 \mathrm{~N} M$ Isaak, P R Fields, and D M Gruen, Solvent Extraction of Actinides and Lanthanides from Molten Salts, J Inorg Nucl Chem, 21 : 152 (1961) 
121 Z. Borkowska, M Mielcarsk1, and $M$ Taube, High Temperature Organic Extraction of Uranium, Plutonium and Americium Fused Chlorides, J Inorg Nucl Chem, 26: 359 (1964)

122 M Zangen, Some Aspects of Synergism in Solvent Extraction III Am(III) and Am(VI) in Nitric Ac1d, J Inorg Nucl Chem, 28: 1693 (1966)

123 Oak Ridge National Laboratory, Chemical Technology Division, Annual Progress Report for Period Ended May 31, 1963, USAEC Report ORNL-3452, September 1963

124 V I Zemlyanukhın, G. P Savoskına, and M F Pushlenkov, Complex Formation of Nitrates of Transuranium Elements with Neutral Organophosphorus Compounds, Radio khimiya, 6: 714 (1964), through Sov Radiochem (Engl Transl), 6: 690 (1964)

$125 \mathrm{~J}$ C. Sheppard, The Distribution of $\mathrm{Am}^{3+}$ Between Xylene-DBBP Solutions and Nitrate Solutions, USAEC Report HW-81166, General Electric Company, Hanford Atomic Products Operation, March 1964

$126 \mathrm{~T} H$ Siddall, Extraction of Uranium and Other Actinides from Nitnc Acid by D1-n-butyl-n-butylphosphonate, USAEC Report DP-219, Savannah River Laboratory, June 1957

127 L. E Bruns, Geometrically Favorable Plutonıum Scrap Recovery Plant, in Preparatıon of Nuclear Fuels, Nuclear Engineenng, Part XVIII, Chemical Engneering Progress Symposium Series, No 80, Vol 63, pp 156-162, American Institute of Chemical Engneers, New York, 1967

128 L E Bruns, Plutonum-Uranıum Partitıoning by a Reflux Extraction Flowsheet, in Proceedings of the International Solvent Extraction Conference, The Hague, Aprl 1923 , 1971, Vol 1,p 186, Society of Chemical Industry, London, 1971

129 R S Kingsley, Solvent Extraction Recovery of Americium with Dibutyl Butyl Phosphonate, USAEC Report RL-SEP-518, General Electnc Company, Hanford Atomic Products Operation, June 1965

130 R S Kingsley and H H Hopkins, Jr, Solvent Extraction Recovery of Americium with Dibutyl Butyl Phosphonate, USAEC Report ISO-SA-7 (CONI-660320-16), Isochem, Inc , March 1966

131 C A Lorenzen and R I Speakman, Increased Plutonium and Americium Recovery by Continuous Solvent Extraction in the Waste-Treatment Facility, USAEC Report ARH-20, Atlantic Richfield Hanford Company, September 1967

132 I $\mathrm{N}$ Taylor, Jr, Flowsheet for Contınuous Solvent Extraction of Plutonium and Amencium in Waste Treatment $I$ acility, USAEC Report ARH-210, Atlantic Richfield Hanford Company, November 1967

133. G L Richardson, Americium Recovery by DBBP Solvent Extraction Pilot Plant Demonstration, USAEC Report BNWL-CC-1503, Battelle Memonal Institute, Pacific Northwest Laboratones, February 1968

134 a. G. L. Richardson and W W Schulz, Integrated LMFBR Aqueous Fuel Reprocessing Concepts, USAEC Report BNWL-CC-1939, Battelle Memorial Institute, Pacific Northwest Laboratories, January 1969

b W W Schulz and G. L. Richardson, Integrated Lanthanide-Actınide Solvent Extraction Process, USAEC Report BNWL-SA-3345, Battelle Memonal Institute, Pacific Northwest Laboratories, June 1970

135 V I Zemlyanukhın, G P Savoskına, and M F Pushlenkov, Study of the Complex Formation of Amencium with Disoamyl Ester Methylphosphinic Acid (DAMP), Radio khimlya, 4: 655 (1962), through Sov Radiochem (Engl Transl), 4: 579 (1962)

136. T. H Sidall III, Bidentate Organophosphorus Compounds as Extractants I Extraction of Cenum, Promethium, and Americium Nitrates, J Inorg Nucl Chem, 25: 883 (1963).

137. T. H Sidall III, Bidentate Organophosphorus Compounds as Extractants II Extraction Mechanisms for Cenum(III) Nitrate, J Inorg Nucl Chem, 26: 1991 (1964) 
138 T H Siddall III, Method of Extractıng Lanthanides and Actınıdes, U S Patent No 3,243,254, March 1966

139 W W Schulz, Bidentate Organophosphorus Extraction of Americium and Plutonium from Hanford Plutonium Reclamation Facility Waste, USAEC Report ARH-SA-203, Atlantic Ruchfield Hanford Company, September 1974, also, Trans Amer Nucl Soc, 21 262 (1975)

140 W W Schulz and L D McIsaac, Removal of Actınides from Nuclear Fuel Reprocessing Waste Solutions with Bidentate Organophosphorus Extractants, ERDA Report ARH SA-217 (CONF-750913-13), A tlantic Ruchfield Hanford Company, August 1975

141 F $E$ Butler and $R$ M Hall, Determination of Actınides in Biological Samples with Bidentate Organophosphorus Extractant, Anal Chem, 42: 1073 (1970)

142 J R Ferraro and D F. Peppard, Structural Aspects of Organophosphorus Extractants and Their Metallic Complexes as Deduced from Spectral and Molecular Weight Studies, $\mathrm{Nucl}$ Sct Eng, 16: 389 (1963)

143 J R Ferraro, G W Mason, and D F Peppard, Molecular Weight of Several Organophos phorus Acids, J Inorg Nucl Chem, 22: 285 (1961)

144 E S Gureev, V N Kosyakov, and G N Yakovlev, Extraction of Actinide Elements by Dialkylphosphoric Acids, Radiokhımıya, 6. 655 (1964), through Sov Radiochem (Engl Transl ), 6: 639 (1964)

145 D F Peppard, G W Mason, W J Driscoll, and R J Sironen, Acidic Esters of Orthophosphonc Acid as Selectıve Extractants for Metallıc Cations-Tracer Studies, $J$ Inorg Nucl Chem, 7:276 (1958)

146 G W Mason, S Lewey, and D F Peppard, Extraction of Metallic Cations by Mono-Acidic Orthophosphate Esters in a Monomerizing Diluent, $J$ Inorg Nucl Chem, 26• 2271 (1964)

147 S M Karpacheva and L V Ilozheva, Kinetics of Extraction of Amencium(III) from Perchlonic Acid Solutions by Bis-(2-ethylhexyl)phosphate in Decane, Radiokhtmiya 12: 460 (1970), through Sov Radlochem (Engl Transl), 12: 427 (1970)

148 G L Ritter and L A Bray, Solvent Extraction Process for Punfying Americium and Cunum, U S Patent No 3,463,619, August 1969

149 D E Ferguson et al, Chemical Technology Division Annual Progress Report, May 31, 1966, USAEC Report ORNL-3945, Oak Rudge National Laboratory, September 1966

$150 \mathrm{~J}$ E Bigelow, F R Chattin, and V C A Vaughen, Plant Practice in Solvent Extraction Processing of Alpha-Emitting Nuclides of High Specific Activity, in Proceedings of the Intemational Solvent Extraction Conference, The Hague, Apnl 19-23, 1971, Vol 1, p 507, Society of Chemical Industry, Lond on, 1971

151 B Weaver and F A Kappelmann, Preferential Extraction of Lanthanides over Trivalent Actinides by Monoacidic Organophosphates from Carboxylic Acids and from Mixtures of Carboxylic and Amınopolyacetıc Acıds, J Inorg Nucl Chem, 30. 263 (1968)

152 F. A Kappelmann and B S Weaver, Method for Separatıng Americium and Curium from the Lanthanide Rare Earths and Yttrium, U S Patent No 3,230,036, January 1966

153 B Weaver and F A Kappelmann, Talspedk A New Method of Separating Americium and Curium from the Lanthanides by Extraction from an Aqueous Solution of an Aminopolyacetic Acid Complex with a Monoacidic Organophosphate or Phosphonate, USAEC Report ORNL 3559, Oak Ridge National Laboratory, August 1964

154 R E Leuze, R D Baybarz, F A Kappelmann, and B Weaver, Behavior of the Transplutonium Elements in Solvent Extraction Systems, in Solvent Extraction Chemistry of Metals, H A C McKay, T V Healy, I L Jenkıns, and A Naylor (Eds), The MacMillan Company, London, 1966, p 423, also, USALC Report ORNL-P-1577, Oak Ridge National Laboratory, August 1965

155 W D Burch (Comp), Transuranium Quarterly Progress Report for Penod Ending November 30, 1964, USAEC Report ORNL-3847, Oak Ridge National Laboratory, September 1965 
156 K B Brown (Ed), Chemical Technology Division, Chemical Development Section C, Progress Report on Separations Chemistry and Separations Progress Research for January-June 1963, USAEC Report ORNL 3496, Oak Ridge National Laboratory, October 1963

157 K P Lunichkına and E V Renard, Extraction of Americium(III), Lanthanum(III), and Neodymum(III) from Lactic Acid Solutions by D1-(2-ethylhexyl)-phosphoric Acid in the Presence of Large Amounts of Rare Earth Elements, Radiokhtmiya, 15: 30 (1973), through Sov Radiochem (Engl Transl), 15: 28 (1973)

$158 \mathrm{~J} \mathrm{~J}$ Fardy and J M Pearson, Solvent Extraction of Trivalent Actinides and Lanthanides from a Mixture of Carboxylic and Amınopolyacetic Acids, J Inorg Nucl Chem, 35: 2513 (1973)

159 R Berger, G Koehly, C Musıkas, R Pottier, and R Sontag, Processing of Highly Irradiated Al-Pu Alloy, Nucl Appl Technol, 8: 371 (1970)

160 Z Kolank, G Koch, H H Kuesel, and J Fritsch, Separation of Americium and Curıum from Highly Radioactive Waste Solutions, German Report KFK-1553, l ebruary 1972

161 G Koch, Z Kolark, H Haug, W Hild, and S Drobnik, Recovery of Transplutonium Elements from Fuel Reprocessing High-Level Waste Solutions, in Symposium on the Management of Radioactive Wastes from Fuel Reprocessing, Paris, France, November 27December 1, 1972 (CONH-721107, pp 1081-1110), also, German Report KFK-1651, November 1972

162 G Koch, Method for the Separation of Amencium and Curum from Aqueous Solutions of Irradiated Fuels, German Patent No 1,813,441, June 1970

$163 \mathrm{G}$ Koch, Gewinnung der Actıniden aus dem HAW der WAK, in Project Actınıdes First Semi-Annual Report, 1972 PACT Report No 24, German Report KHK-1656, October 1972

164 G Koch, Recovery of By-Product Actınides from Power Reactor Fuels, German Report KFK-976, May 1969

$165 \mathrm{G}$ Koch, A Study on Americium/Cunum Recovery from Fuel Reprocessing High Level Waste Solutions, in Progress in Coordination Chemistry, M Cais (Ed), p 729, American Elsevier Publıshıng Company, Inc , New York, 1968

166 E S Gureev, V B Dedov, S M Karpacheva, I A Lebedev, M N Ryzhov, P S Trukhlyaev, I K Shvetsov, and G N Yakovlev, Extraction and Some Chemical Properties of Transplutomum Elements, in Proceedings of the Third International Conference on the Peaceful Uses of Atomic Energy, Geneva 1964 Vol 10, pp 553-560, United Nations, Geneva, 1965

167 P K Khopkar and P Narayankutty, Separation of Actınıdes and Lanthanıdes Usıng Di(2-ethylhexyl)phosphoric Acid, in Proceedings of the Nuclear and Radiation Chemistry Symposium, Poona, March 6-9, 1967 (CONH-670335)

$168 \mathrm{~K} \quad \mathrm{~B}$ Brown and $\mathrm{R}$ E Leuze, Development of Chemical Flowsheets for the Overall Process, in Transuranium Quarterly Progress Report for Penod Ending August 31, 1963, W D Burch (Comp), USAEC Report ORNL-3558, Oak Ridge National Laboratory, March 1964

$169 \mathrm{~K}$ Watanabe and C Sagawa, Separation of Plutonium and Curıum from Irradiated Americium by Solvent Extraction Using HDEHP, Nippon Genshıryoku Gakkatsh, 14326 (1972)

$170 \mathrm{C} T$ Lee, Study of the Separation 1 actor of Am-Cm in the D1-(2-ethylhexyl)orthophosphoric Acid Extraction System, Daehan Hwahak Hwoejee, 13: 205 (1969)

171 B F Myasoedov, M K Chmutova, N E Kochetkova, and G A Pribylova, Solvent Extraction of Trivalent Americium from Ac1d Media, Radtochem Radioanal Lett 14: 63 (1973)

172 B F Myasoedov, M K Chmutova, N E Kochetkova, and G A Pribylova, Extraction of Trivalent Transplutonium Elements and Europium by a Mixture of Di-2-ethylhexylortho- 
phosphoric Acid and Phosphorus Pentoxide from Strongly Acid Media, in Proceedings of the International Solvent Extraction Conference Lyon, France, September 8-14, 1974, CONF-740917, Vol 2, pp 1103-1108, Society of Chemical Industry, London, 1974

173 M Zangen, Some Aspects of Synergism in Solvent Fxtraction II Some D1-, Tr1- and Tetravalent Ions, $J$ Inorg Nucl Chem, 25·1051 (1963)

174 Z Koları, Acıdıc Organophosphorus Extractants XVI Effect of Tri- $n$-Butyl Phosphate on the Extraction of Some Metals by Di (2-ethylhexyl) Phosphoric Acid in $n$-Hexane, $J$ Inorg Nucl Chem, 34: 2911 (1972)

175 D F Peppard, G W Mason, and I Hucher, Acidic Esters of Phosphonic Acid as Selective Extractants for Metallic Cations-Selected M(III) Tracer Studıes, J Inorg Nucl Chem, 18. 245 (1962)

176 D F Peppard, G W Mason, and I Hucher, Mutual Separation of Cf and Cm with Actic Phosphonates, in Radiolsotopes in the Physical Sciences and Industry Conference Proceedings, Copenhagen, 1960, Vol II, p 541, International Atomic Energy Agency, Vienna, 1962 (STI/PUB/20)

177 R D Baybarz, Separation of Transplutonium Elements by Phosphonate Extraction, USAEC Report ORNL-3273, Oak Ridge National Laboratory, August 1962 also, $\mathrm{NuCl} \mathrm{Scl}$ Eng 17. 463 (1963)

178 R F Leuze, R D Baybarz, and B Weaver, Application of Amine and Phosphonate Extractants to Transplutonium Element Production, Nucl Scl Eng, 17: 252 (1963)

179 B Weaver, Enhancement by Zirconium of Extraction of Catıons by Organophosphorus Acids I Monoacidic Phosphonates, J Inorg Nucl Chem, 30. 2233 (1968)

180 G W Mason, A F Bollmeier, and D F Peppard, Partition of Oxidized Amencium from Actinides(III) and Lanthanides(III), J Inorg Nucl Chem, 32·1011 (1970)

181 G W Mason, A F Bollmeser, and D F Peppard, Separation of Amencium and Curium, U S Patent No $3,743,696$, July 1973

182 D F Peppard, G W Mason, W J Driscoll, and S McCarty, Application of Phosphonc Acld Esters to the Isolation of Certain Trans-Plutonides by Liquid-Liquid Extraction, $J$ Inorg Nucl Chem, 12: 141 (1959)

183 G S Rao, G W Mason, and D F Peppard, Extraction of Selected Metallic Cations by Di Acidic Phosphorus-Based Extractants, XPO(OH $)_{2}$, in a Ketone Diluent, $J$ Inorg Nucl Chem , 28. 887 (1966)

184 D F Peppard and G W Mason, Some Mechanisms of Extraction of M(II), (III), (IV), and (VI) Metals by Organophosphorus Extractants, Nucl Scl Eng, 16: 382 (1963)

185 G W Mason and D F. Peppard, Types of Acidic Organophosphorus Extractants and Their Applications to Transuranic Separations, Nucl Sct Eng, 17247 (1963)

186 Y Marcus and A S Kertes, Ion Exchange and Solvent Extraction of Metal Complexes, Wiley-Interscience, Inc, New York, 1969

187 D F Peppard, G W Mason, and R J Sironen, Isolation of Neptunium as a Mono-Octyl Phosphoric Acid Complex by Liquid-Liquid Extraction, J Inorg Nucl Chem 10: 117 (1959)

188 S Lewey, G W Mason, and D F Peppard, Comparative Extraction of Selected M(III) Cations by $\left(2-\mathrm{C}_{2} \mathrm{H}_{5} \cdot \mathrm{C}_{6} \mathrm{H}_{12} \mathrm{O}\right) \mathrm{PO}(\mathrm{OH})_{2}$ and $\left(2-\mathrm{C}_{2} \mathrm{H}_{5} \cdot \mathrm{C}_{6} \mathrm{H}_{12}\right) \mathrm{PO}(\mathrm{OH})_{2}, J$ Inorg Nucl Chem , 33: 2531 (1971)

189 R D Baybarz and R E Leuze, Separation of Transplutonıum and Rare Earth Elements by Liquid-Liquid Extraction, USAEC Report CF-60-3-32, Oak Ridge Natıonal Laboratory, June 1960

190 R D Baybarz and R E Leuze, Separation of Transplutonium and Rare Earth Elements by Liquid-Liquid Extraction, Nucl Scl Eng, 11.90 (1961)

191 R D Baybarz and R E Leuze, Process for Separatıng Americium and Curium from Rare Earth Elements, U S Patent No 3,079,225, February 1963 
192 D. F. Peppard, G W. Mason, and I Hucher, Stability Constants of Certain Lanthanide(III) and Actinide(III) Chloride and Nitrate Complexes, J Inorg Nucl Chem., 24: 881 (1962)

193 G W Mason, A. F. Bollmeier, and D. F Peppard, Diluent Effects in the Extraction of Selected Metallic Cations by Bis(hexoxyethyl)phosphoric Acid, J Inorg Nucl Chem., 29: 1103 (1967).

194 D F. Peppard, G. W Mason, and G Grıffın, Extraction of Selected Trivalent Lanthanide and Actınide Catıons by Bis(hexoxyethyl)phosphoric Acids, J Inorg. Nucl Chem, 27: $1683(1965)$

195 G. W Mason, N. L. Schofer, and D. F Peppard, The Extraction of U(VI) and Selected M(III) Cations by Bis-n-octylphosphoric Acid, J Inorg Nucl Chem., 32: 3899 (1970).

196 G. W. Mason, N L Schofer, and D. F. Peppard, The Extraction of U(VI) and Selected M(III) Cations by Bis-neo-octylphosphoric Acid, J Inorg Nucl Chem., 32: 3911 (1970)

197 D. F Peppard, G. W. Mason, A. F. Bollmeter, and S Lewey, Extraction of Selected Metallic Cations by a Highly Hindered (GO) ${ }_{2} \mathrm{PO}(\mathrm{OH})$ Extractant in Two Different Diluents from an Aqueous Chlonde Phase, $J$ Inorg Nucl Chem., 33: 845 (1971)

198 D. F. Peppard, G. W. Mason, and S Lewey, Di-n-Octyl Phosphinic Acid as a Selective Extractant for Metallic Cations Selected M(III) and M(VI) Tracer Studies, J. Inorg Nucl Chem, 27: 2065 (1965).

199. D F. Peppard, G. W. Mason, and S. Lewey, A Tetrad Effect in the Liquid-Liquid Extraction Ordering of Lanthanides(III), J Inorg Nucl. Chem, 31: 2271 (1969)

200 D. F. Peppard, G. W. Mason, and C. Andrejasich, Two Mono-Octyl Phosphinic Acids, (R) $(\mathrm{H}) \mathrm{PO}(\mathrm{OH})$, as Extractants for Metallic Cations Selected M(II), M(III), and M(VI) Tracer Studies, J Inorg Nucl Chem., 28: 2347 (1966)

201 G. W Mason, N. L. Schofer, and D. F Peppard, Two Octyl Phenyl Phosphinic Acids, (R) $\left(\mathrm{C}_{6} \mathrm{H}_{5}\right) \mathrm{PO}(\mathrm{OH})$, as Extractants for Selected $\mathrm{M}(\mathrm{III})$ and $\mathrm{M}(\mathrm{VI})$ Metallic Cations, $J$ Inorg Nucl Chem., 32: 3375 (1970).

202 V. S Schmidt, Amine Extraction, translated by J Schmorak, Israel Program for Scientific Translation, Jerusalem, 1971.

203 C. F. Coleman, Amine Extraction in Reprocessing, At Energy. Rev, 2: 3 (1964).

204. C. F. Coleman, C A. Blake, Jr., and K. B. Brown, Analytical Potential of Separations by Liquid Ion Exchange, Talanta, 9: 297 (1962).

205. E. P. Horwitz, C. A. A. Bloomquist, L. J. Sauro, and D J. Henderson, The Liquid-Liquid Extraction of Certain Tripositive Transplutonium Ions from Salted Nitrate Solutions with a Tertiary and Quaternary Amine, J Inorg Nucl Chem, 28: 2313 (1966).

206. Y. Marcus, M. Givon, and G. R. Choppin, Anıon Exchange of Metal Complexes. XIII. The Actınide(III)-Nitrate System, J Inorg Nucl Chem, 26: 1457 (1963), also, Israelı Report IA-783, October 1962.

207. W. E. Keder, J. C. Sheppard, and A. S. Wilson, The Extraction of Actınide Elements from Nitric Ac1d Solutions by Tri- $n$-Octylamıne, J Inorg Nucl Chem, 12: 327 (1960).

208. E. G. Chudinov and S. V. Pirozhkov, Investigation of the Influence of the Structure of Triaikylamine Nitrates on the Extraction Separation of Americium and Curium, Radiokhimiya, 13: 396 (1961), through Sov Radiochem. (Engl Transl), 13: 411 (1971)

209. R. D. Baybarz, B. S. Weaver, and H. B. Kınser, Isolatıon of Transplutonium Elements by Tertiary Amine Extraction, Nucl. Scl Eng, 17: 457 (1963).

210. A. J. Roth and H. E. Henry, Extraction of Americium-Curium-Europium from Lithium Chlonde-Hydrochlonc Acid by Tertiary Amines, J. Chem Eng Data, 10: 298 (1965)

211. A. Van Dalen, W. Kraak, J. Van Ooyen, P. Polack, and J C. Post, Transplutonıde Research, Final Report, Euratom Report EUR-2640.e, November 1965.

212. A. D. Gel'man, A. I. Moskvin, and P. I. Artyukhın, Composition and Dissociation Constants of $\mathrm{Pu}(\mathrm{V})$ and $\mathrm{Pu}(\mathrm{III})$ Complexes with Ethylenediaminetetraacetıc Acıd, At. Energ. (USSR), 7: 667 (1959), through Sov J. At. Energy (Engl. Transl.), 7: 667 (1959). 
213. G. Duyckaerts, J. Fuger, and W. Muller, L'Extraction Liquide-Liquide par le Chlorhydrate de Trilaurylamine, Euratom Report EUR-426.f, 1963

214 W Muller, J Fuger, and G. Duyckaerts, Complex Formation in Tertiary Amıne Extraction of Trivalent Metals, Euratom Report EUR-2196 e, 1964

215. R. D. Baybarz and B. Weaver, Separation of Transplutonium from Lanthanides by Tertiary Amıne Extraction, USAEC Report ORNL-3185, Oak Rıdge National Laboratory, December 1961

216. F. L. Moore, New Technıque for the Separation of Trivalent Actınide Elements from Lanthanide Elements, Anal Chem, 33: 748 (1961)

217 W Muller, G. Duyckaerts, and J Fuger, Mechanisms of Extraction of Transplutonium Elements by Trilaurylamine Hydrochloride, in Solvent Extraction Chemistry of Metals, H A. C McKay, T. B. Healy, I. L. Jenkins, and A. E Naylor (Eds), The Macmillan Company, London, 1966.

218 H. C. Jain and G. Duyckaerts, Extraction of ${ }^{241}$ Am from Concentrated Aqueous Chloride Solutions by Trilaurylamine Hydrochloride, Inorg Nucl Chem. Lett, 5: 553 (1969)

219 a Y. Marcus, Anıon Exchange of Metal Complexes XV. Anıon Exchange and Amine Extraction of Lanthanides and Trivalent Actınides from Chloride Solutions, $J$ Inorg $\mathrm{Nucl}$ Chem, 28: 209 (1966).

b H D Harmon, J. R. Peterson, W. J. McDowell, and C. F. Coleman, Phosphine Oxıde and Quaternary Ammonum Extraction of Amencium(III) from Concentrated Chloride Solutions, J Inorg. Nucl. Chem., 38: 155 (1976).

220. F. L. Moore, Rapid Removal of Transuranium Elements from Aqueous Solutions Prior to the Determination of Total Lanthanide Fission Products, Anal Chem, 37: 419 (1965).

221 F. L. Moore, Method for Separatıng Transplutonium Elements from Rare Earth Fission Products, U. S. Patent No. 3,178,256, April 1965

222. R. D. Baybarz, B. Weaver, and H. B. Kinser, Separation of Transuranium Elements from Rare Earths by Tertiary Amıne Extraction, Trans Amer Nucl Soc., 5: 17 (1962).

223. R. D Baybarz and H. B. Kinser, Separation of Transplutonium and Lanthanides by Tertiary Amine Extraction. II. Contaminant Ions, USAEC Report ORNL-3244, Oak Ridge National Laboratory, March 1962.

224. D. L. West and R. Navarez, Curum Process Development III-2. Identification of Solvent Degradation Products. USAEC Report DP-1016, Savannah Ruver Laboratory, November 1966.

225. K. B. Brown, Chemical Technology Division, Chemical Development Section C, Progress Report, July-December 1962, USAEC Report ORNL-TM-449, Oak Rıdge National Laboratory, April 1963.

226. R. D. Baybarz, Alpha Radiatıon Effects on Concentrated LiC Solutions Contaınıng HC, and the Use of Methanol as an Inhibitor of Acid Radiolysis, J. Inorg Nucl Chem, 27: 725 (1965).

227. W. D. Burch, J. E. Bigelow, and L. J. Kıng, Transuranium Processing Plant Semiannual Report of Production, Status and Plans for Penod Fnding December 31, 1968, USAEC Report ORNL-4428, Oak Ridge National Laboratory, November 1969.

228. W. D. Burch, J. E. Bigelow, and L. J. Kıng, Transuranıum Processing Plant Semiannual Report of Production, Status and Plans for Period Ending June 30, 1971, USAEC Report ORNL-4718, Oak Ridge Natıonal Laboratory, December 1971.

229. E. I. Eubanks and G. A. Burney, Curium Process Development. I. General Process Description, USAEC Report DP-1009, Savannah River Laboratory, April 1966.

230. W. E. Prout, H. E. Henry, H. P. Holcomb, and W. J. Jenkins, Cunum Process Development. II-2. Recovery of Cunum and Amencium by Solvent Extraction with Tertiary Amines, USAEC Report DP-1302, Savannah River Laboratory, December 1972

231. V. C. A. Vaughen and R. D. Baybarz, Curnum Processing Expenence, in Large Scale Production and Applications of Radioisotopes, Proceedings of the American Nuclear 
Society, Nationàl Topical Meetıng, March 21-23, 1966, Augusta, Georgla, USAEC Report DP-1066(Vol. 2), E. I. du Pont de Nemours \& Company, Inc , May 1966.

232 M K. Chmutova, B. F. Myasoedov, B Ya. Spivakov, N. W. Kochetkova, and Yu. A. Zolotov, Solvent Extraction of Transplutonuum Elements by Mixtures of Tri- $n$-Octylamine with Neutral Extractants from Nitrate Solutions, J Inorg Nucl Chem, 35: 1317 (1973)

233 G. Koehly, C. Madic, and R Berger, Capric Acld Effect on Actinide Extraction by Trilaurylammonium Nitrate, in Proceedings of the International Solvent Extraction Conference, The Hague, Apnl 19-23, 1971, Vol 1, p 768, Society of Chemical Industry, London, 1971

234 G. Koehly and R. Berger, Separation of Trivalent Actınide and Lanthanide Elements in Nitrate Medium, in Symposium on the Transuranium Elements, Liege, Belgium, April 21-22, 1969 (CONF-690426, pp 91-115)

235 Semiannual Report of the Chemistry Department, No 6, June-November 1968, French Report CEA-N-1148, June 1969

236. F. L. Moore, Liquid-Liquid Extraction of Metal Ions from Aqueous Solutions of Organic Acids with High-Molecular-Weight Amines, Anal Chem, 37: 1235 (1965).

237. B. Weaver, Extraction of Americium(VI), in Chemical Technology Division, Chemical Development Section C, Progress Report on Separations Chemistry and Separations Progress Research for January-June 1962, K B. Brown (Ed), USAEC Report ORNL3496, Oak Ridge National Laboratory, October 1963

238 F. L. Moore, Improved Extraction Method for Isolation of Trualent Actinide-Lanthanide Elements from Nitrate Solutions, Anal. Chem., 38: 510 (1966)

239 J. Van Ooyen, Quaternary Ammonum Nitrates as Extractants for Trivalent Actınides, in Solvent Extraction Chemistry, D Dyrssen, J.-O. Liljenzin, and J. Rydberg, (Eds.), John Wiley \& Sons, Inc, New York, 1967

240 J. Van Ooyen, Properties of Trilaurylmethylammonium Nitrate as an Extractant for Trivalent Actınıdes, Netherlands Report RCN-113, February 1970

241 E G. Chudinov and S. V. Pirozhkov, Effect of Cation of Saltıng-Out Agent on Separation of Trivalent Actınide Elements by Extraction with Amines, Radıokhımıya, 15: 18 (1973), through Sov Radlochem (Engl Transl) 15: 16 (1973).

242. E. P. Horwitz, C. A. A. Bloomquist, and H E. Gnffin, The Preparation of High-Purity ${ }^{242} \mathrm{Cm}$ in Multicurie Quantities, USAEC Report ANL-7569, Argonne National Laboratory, March 1969.

243. G. Koch and J. Schoen, Isolation of ${ }^{241} \mathrm{Am}$ from Plutonium Scrap by Extraction with Tricaprylmethylammonium Nitrate, German Report KFK-783, June 1968

244. G. Koch, Recovery of By-Product Actınides from Power Reactor Fuels, in Symposium on the Transuranium Elements, Liege, Belgium, April 21-22, 1969 (CONF-690426)

245 F. L. Moore, New Approach to Separation of Trivalent Actinide Elements from Lanthanide Elements Selective Liquid-Liquid Extraction with Tricaprylmethylammonium Thıcyanate, Anal Chem, 36: 2158 (1964).

246 F L. Moore, Method for Removing Lanthanides and Trivalent Actınides from Aqueous Nitrate Solutions, U. S. Patent No. 3,294,494, December 1966.

247 P. Th. Gerontopulos, L. Rigali, and P G. Barbano, Separation of Americium(III) from Lanthanides by Quaternary Ammonium Salt Extraction, Radıochim Acta, 4: 75 (1965)

248 Z. Szeglowskı, J. Mikulsı, K. A. Gavrilov, K Y. Bon, and O. S. Ik, Solvent Extraction of Actınide and Lanthanide Elements by Quaternary Ammonium Salts III Extraction of Lanthanide and Transplutonium Elements in the Systems CTMAB-L1NO ${ }_{3}$ and CPB$\mathrm{LiNO}_{3}$, Nukleontka, 17: 631 (1967).

249 N. Zaman, E. Merciny, and G. Duyckaerts, Extraction by Quaternary Ammonium Salts of High Molecular Weight Hydroxyethylethylenediaminetracetic Acid and Its Complexes with Trivalent Lanthanides and Actinides II Extraction of Americium and Curium, Anal Chim Acta, 56: 271 (1971). 
250. F. L. Moore, Liquid-Liquid Extraction of Anionic Amencium and Europium Complexes of Hydroxyethylethylenedıaminetracetıc Acıd and Diethylenetriamenepentaacetıc Acid, Anal Chem., 38: 905 (1966).

251 F. L. Moore, Method of Extractıng Soluble Metal Complexes Usıng Amıne Solvents, U. S. Patent No. 3,409,415, November 1968

252 J. L. Ryan, Ion Exchange, in Gmelins Handbuch der Anorganischen Chemie, Band 21, Transurane, Te1l D2, G. Koch (Ed.), Verlag Chemie, G.m.b.H., Weınheim, Germany, 1974

253. J. Korkisch, Modern Methods for the Separation of Rarer Metal lons, Pergamon Press, Inc, London, 1969.

254. A. D. Jones and G. R. Choppın, Complexes of Actınıde Ions in Aqueous Solution, Actinides Rev , 1: 311 (1969).

255 I. L. Jenkıns and A. G. Wam, Ion Exchange in the Atomıc Energy Industry with Particular Reference to Actinide and Fission Product Separations, Rep Progr Appl Chem, 57: 308 (1972).

256. J. P. Surls, Jr , and G. R. Choppin, Ion-Exchange Study of Thiocyanate Complexes of the Actınides and Lanthanides, J. Inorg Nucl Chem, 4: 62 (1957).

257 V. D. Dedov, V. V. Volkov, B. A. Gvozdev, V. A. Ermakov, I. A. Lebedev, V. M. Razbitnoı, P. S. Trukhlyaev, Yu T. Chuburkov, and G. N. Yakovlev, Preparation of ${ }^{24} \mathrm{Pu}$ and ${ }^{242} \mathrm{Cm}$ from Neutron-Irradiated ${ }^{241} \mathrm{Am}$, Radiokhtmiya, 7: 453 (1965), through Sov Radtochem (Engl Transl), 7: 452 (1965).

258. J. S. Coleman, L. B. Asprey, and R. C. Chisholm, The Anion-Exchange Absorption of Americium, Yttrium, Lanthanum, Europium, and Ytterbium from Aqueous Ammonium Thiocyanate, J Inorg Nucl Chem, 31 : 1167 (1969).

259 J. S. Coleman, R. A. Penneman, T. K. Keenan, L. E. LaMar, D. E Armstrong, and L B. Asprey, An Anion-Exchanger Process for Gram-Scale Separation of Americium from Rare Earths, J. Inorg Nucl Chem., 3: 327 (1956).

260. T. K. Keenan, Rapid and Efficient Purification of Americium, $J$ Inorg Nucl Chem, 20: 185 (1961).

261. K. Natto, A Method of Punfication of Amencium, USAEC Report UCRL-8748, University of Californa, Lawrence Radiation Laboratory, November 1959.

262. V. A. Ryan and J. W. Prngle, Preparation of Pure Amencium, USAEC Report RFP-130, Rocky Flats Plant, Dow Chemical Company, January 1960.

263. P. G. Hagan and H.W. Miller, Recovery and Prelıminary Purfication of Americium Obtained from Waste Material, USAEC Report RFP-442, Rocky Flats Plant, Dow Chemical Company, March 1965.

264. L. I. Guseva and G. S. Tikhomirova, Separation of Transplutonum Elements from Rare Earth Elements on an Ion-Exchange Resin in the System Ammonum ThiocyanateAlcohol-Water, Radiokhimiya, 10: 246 (1968), through Sov Radlochem (Engl Transl), 10: 233 (1968).

265. L. N. Moskvin and V. T. Novikov, Study of Anion Exchange of Ca, Eu, Tm, and Am in Aqueous Alcohol Solutions of Ammonium Thiocyanate, Radıokhımiya, 14: 106 (1972), through Sov Radiochem (Engl Transl), 14: 102 (1972).

266 L. I. Guseva and G. S. Tikhomirova, Isolatıon of Transplutonium Elements on Anıonites by Means of Aqueous Alcohol Solutions of Nitric Acld and Ammonium Thiocyanate, Radıokhtmiya, 16: 152 (1974), through Sov. Radıochem (Engl Transl), 16: 152 (1974).

267. G. H. Higgins and W. T. Crane, The Production and Chemical Isolation of Curium-242 in Thousand-Cure Quantities, in Proceedings of the Second United Nations International Conference on the Peaceful Uses of Atomic Energy, Geneva, 1958, Vol 17, p 245, United Natıons, New York, 1958.

268. E. K Hulet, R. G. Gutmacher, and M S Coops, Group Separation of the Actınides from the Lanthanides by Anıon Exchange, J Inorg Nucl Chem, 17: 350 (1961). 
269. S. G. Thompson, B. G. Harvey, G. R. Choppin, and G T. Seaborg, Chemical Properties of Elements 99 and 100, J. Amer Chem. Soc, 76:6229 (1954).

270 M. Ward and G. A. Welch, The Chlonde Complexes of Trivalent Plutonium, Americium, and Curium, $J$ Inorg Nucl Chem, 2: 395 (1956).

271. R. D. Baybarz and P. B. Orr, Final Purification of the Heavy Actinides from the First Four Campargns of the TRU Program, USAEC Report ORNL-TM-2083, Oak Ridge National Laboratory, November 1967

272 Oak Ridge National Laboratory, Chemical Technology Division Annual Progress Report for Period Endıng May 31, 1969, USAEC Report ORNL4422, October 1969

273 W. D. Burch, J. E. Bigelow, and L. J. Kıng, Transuranium Processing Plant, Semıannual Report of Production Status and Plans for Period Ending June 30, 1968, USAEC Report OR NL-4376, Oak Ridge Natıonal Laboratory, April 1969.

274 W. Muller, Die Gewinnung von Transplutoniumelementen aus Bestrahltem ${ }^{241} \mathrm{Am}$, Atompraxis, 15: 35 (1969).

275 R J. Morrow, Anion Exchange Separation Techniques with Methanol-Water Solutions of Hydrochlonc and Nitric Acids, J. Inorg Nucl Chem., 13: 1265 (1966).

276 L. L. Guseva and G. S. Tikhomırova, Sorption of Certain Transplutonium and Rare Earth Elements from Concentrated Solutions of Hydrochloric Acid in the Presence of Alcohol on a Catıon-Exchange Resın, Radiokhimiya, 14: 188 (1972), through Sov Radıochem (Engl Transl ), 14: 197 (1972).

277 K. A Orlandını and J. Korkısch, Anıon-Exchange Behavıor of Transplutonıum Elements and Lanthanides in Hydrochlonic Acid-Organic Solvent Mixtures, USAEC Report ANL-7415, Argonne National Laboratory, January 1968.

278 V. A. Bochkarev and A. A. Lbov, Sorption of Curium, Lanthanum, Erbium, and Ytterbium from Lithium Chlonde Solutions by AV-17 Anion Exchange Resin, in Soosazhente t Ad sorbitstya Radıaaktıv Elementov, p. 190, Izdatel'stvo Nauk, Moscow, 1965.

279. J P. Faris and R F. Buchanan, Anıon Exchange Charactenstics of Elements in Nitric Acid Medium, Anal Chem, 36: 1157 (1964).

280 I. E. Starik and F. G. Ginzburg, State of Microamounts of Radioelements in Dilute Solutions XVI. Investigation of the State of Americium by the Ion-Exchange Method, Radiokhtmiya, 3: 45 (1961), through Radiochemistry USSR (Engl Transl), 3: 49 (1961).

281 J. Danon, Anion-Exchange Studies with Actinium and Lanthanides in Nitrate Solutions, $J$ Inorg Nucl Chem, 7:422 (1958).

282 Y. Marcus and F. Nelson, Anion Exchange Studies XXV. The Rare Earths in Nitrate Solutions, J. Phys Chem, 63: 77 (1959).

283 W. Kraak and W. A. Van der Heıjden, Anıon Exchange Separatıon Between Americium and Curnum and Between Several Lanthande Elements, J Inorg Nucl Chem., 23: 221 (1961).

284 Y Marcus, M. Givon, and G. R Choppin, Anion Exchange of Metal Complexes--XIII The Actinıde(III)-Nitrate System, J. Inorg Nucl Chem., 25: 1457 (1963).

285. S. Adar, R. K. Sjoblom, R. F. Barnes, P. R. Fields, E. K. Hulet, and H. D. Wilson, Ion-Exchange Behavior of the Transuranium Elements in $\mathrm{LiNO}_{3}$ Solutions, $J$ Inorg Nucl Chem, $25: 447$ (1963).

286. M. H. Lloyd, An Anion Exchange Process for Amencium-Cunum Recovery from Plutonium Process Waste, $\mathrm{Nucl}$ Sct Eng, 17: 452 (1963).

287. M. H. Lloyd and R. E. Leuze, Anion Exchange Separation of Trivalent Actınides and Lanthanides, Nucl Sct. Eng., 11: 274 (1961)

288. R. S. Kingsley, A Multi-Column Ion Exchange Purfication-Concentration Process for Amencium, USAEC Report RL-SEP-729(Rev), General Electric Company, Hanford Atomic Products Operation, October 1965.

289 J. Hines, M. A. Wahlgren, and F. Lawless, Separation of Actinides with Nitric AcidMethanol and EDTA, in Proceedings of the 6th Symposium on Analytical Chemistry in 
Nuclear Reactor Technology, Gatlinburg, Tenn, October 9-11, 1962, USAEC Report TID-7655, p. 247, 1962.

290. V. A. Bocharev and E. N. Voevodin, Separation of Americium and Curium by Anion Exchange Using Solutions Containing a Mixture of Methanol and Nitric Acid as the Eluent, Radiokhimiya, 7: 461 (1965), through Sov Radiochem (Engl Transl), 7: 459 (1965).

291. D. C. Stewart, C. A. A. Bloomquist, and J. P. Faris, Nitric Acid-Organic Solvent Mixtures for Separations of Plus-Three Actinides on Anion Resins I. Survey of Solvents, USAEC Report ANL-6999, Argonne National Laboratory, 1965

292 I. A. Lebedev, B. F. Myasoedov, and L. I. Guseva, Use of Alcoholic Solutions for the Isolation and Punfication of Amencium and Cunum with Anion Exchangers, $J$ Radioanal Chem., $21: 259$ (1974).

293. F. Helfferich, Ion Exchange, McGraw-Hıll Book Company, Inc., New York, 1962

294. S. G. Thompson, A. Ghiorso, and G. T. Seaborg, The New Element Berkelium (Atomic Number 97), Phys Rev., 80: 781 (1950).

295. K. Street, Jr., and G. T. Seaborg, The Separation of Amencium and Curum from the Rare Earth Elements, J. Amer Chem. Soc, 72: 2790 (1950).

296 W. J. deWet and E. A. C. Crouch, A Sequential Analytical Scheme for the Carner-Free Separation of Microgram Quantities of Individual Fission Product and Actinide Elements from Highly Burnt-Up Fuels, J. Inorg Nucl Chem., 27: 1735 (1965).

297. K. Wolfsberg, W. R. Daniels, G. P. Ford, and E. T. Hitchcock, Punfication of Transplutonium Actinides Produced in Underground Thermonuclear Explosions, Nucl Appl., 3: 568 (1967).

298. S. G. Thompson, B. B. Cunnıngham, and G. T. Seaborg, Chemical Properties of Berkelıum, J. Amer Chem Soc, 72: 2798 (1950).

299. D. C. Stewart, Rare Earth and Transplutonum Element Separations by Ion Exchange Methods, in Proceedings of the International Conference on the Peaceful Uses of Atomic Energy, Geneva, 1955, Vol. 7, p. 321, United Nations, New York, 1956.

300 H. L. Smith and D. C. Hoffman, Ion Exchange Separations of the Lanthanides and Actinides by Elution with Ammonium Alpha-Hydroxy-Isobutyrate, $J$ Inorg Nucl Chem , 3: 243 (1956).

301. D. E. Armstrong L. B. Asprey, J. S. Coleman, T. K. Keenan, L. E. Lamar, and R. A Penneman, Ion Exchange Separation of Gram Quantities of Amencium from a Kilogram of Lanthanum, A. I. Ch. E. J., 3: 286 (1957).

302. J. Milsted and A. B. Beadle, Separation of Actınide Elements by Cation Exchange Usıng Alpha-Hydroxy Isobutync Acid, J. Inorg Nucl Chem, 3: 248 (1956).

303. I. Brandshtetr, T. S. Zvarova, M. Krzhıvanek and Ya. Maly, Chromatographic Separation of the Rare Earth Elements and Certain Actinides on Cation-Exchange Resins in the Presence of Radioactive Isotopes Coprecipitated with $\mathrm{LaF}_{3}$, Radiokhımya, 5: 694 (1963), through Sov Radiochem. (Engl Transl), 5: 655 (1963).

304. R. A. Glass, Chelatıng Agents Applied to Ion-Exchange Separation of Americium and Curum, J. Amer Chem. Soc., 77: 807 (1955).

305 L. Wish, E. C. Freiling, and L. R Bunney, Ion Exchange as a Separations Method. VIII. Relative Elution Positions of Lanthanide and Actınıde Elements with Lactic Acid Eluant at 87 ${ }^{\circ}$, J. Amer. Chem. Soc., 76: 3444 (1954).

306. S. H. Eberl and S. A. Alı, Ionenaustauschverhalten und Chelatbidung dreiwertiger Transplutoniumelemente bei Gegenwart Von Nitrilotriessig Saure und einigen iher Derivate, Z. Anorg. Allg Chem., $361: 1$ (1968).

307. J. Fuger, Ion Exchange Behaviour and Dissociation Constants of Americium, Curium, and Calıfornium Complexes with Ethylenediaminetetraacetic Acid, J. Inorg Nucl Chem, 5: 332 (1958). 
308. W. H. Hale and J. T, Lowe, Rapid, Gram-Scale Separation of Cunum from Americium and Lanthanides by Cation Exchange Chromatography, Inorg. Nucl. Chem Lett, 5: 363 (1969).

309. E. Merciny and G. Duyckaerts, Separation des Lanthandes et des Actindes sur Echangeur d'ıons par l'acıd Hydroxy éthylèné dıamınetrıacetıque. II. Étude de L'Influence du pH sur le Facteur de Séparation et sur L'Efficatité de la Colonne, J. Chromatogr., 26: 471 (1967).

310. R. D. Baybarz, Dissociation Constants of the Transplutonium Element Chelates of 1,2 Diamınocyclohexanetetraacetic Acid, J. Inorg. Nucl Chem., 28: 1055 (1966).

311. S. G. Proctor, Cation Exchange Process for Molten Salt Extraction Residues, ERDA Report RFP-2347, Rocky Flats Plant, Dow Chemical Company, March 1975

312. D. E. Kudera and R. H. Guyer, Plutonum and Americium Recovery from a Chlonde-Salt Matrix, USAEC Report RFP-1642, Rocky Flats Plant, Dow Chemical Company, June 1971.

313. H. O. Haug, Final Purification and Concentration of Americium/Curium Separated from High-Level Reprocessing Waste, J. Radioanal Chem., 21: 187 (1974).

314. D. O. Campbell, The Isolation and Purification of Amencium, USAEC Report ORNL-1855, Oak Ridge National Laboratory, April 1956

315. H, D. Perdue and H. G. Hicks, Ion Exchange Separation of Amencium and Curium, Anal Chem, 37: 1110 (1965).

316 G. Hohlein and H. J. Born, Ion Exchange Separation of Some Rare Earths and Actinides Under Optımum Conditions with $\alpha$-Hydroxyısobutyric Acıd, Radıochim. Acta, 8: 172 (1967).

317. G. Hohlein, H. J. Born, and W. Wenlander, Die Isolierung von ${ }^{242} \mathrm{Cm}$ aus Neutronenbestrahltem ${ }^{24}$ Am, Radtochim Acta, 10: 85 (1968).

318. G. Hohlein, H. Voller, and W. Weinlander, Verwendung von Amınex zur Trennung von Actıniden and Lanthaniden, Radiochim. Acta., 11:172 (1969).

319. D. O. Campbell, Rapid Ion Exchange Separations-Chromatographic Separation of Transplutonium Elements Using High Pressure Ion Exchange, Ind Eng. Chem, Process Design Develop , 9: 95 (1970).

320. G. A. Burney and R. M. Harbour, Separation of Milligram Quantities of $252 \mathrm{Cf}$ from Multigram Quantities of ${ }^{244} \mathrm{Cm}$ and ${ }^{243} \mathrm{Am}$, Radiochim Acta, 16: 63 (1971).

321. E. J. Wheelwright, F. P. Roberts, L. A. Bray, G. L. Ritter, and A. L. Boldt, Simultaneous Recovery and Purification of $\mathrm{Pm}, \mathrm{Am}$, and $\mathrm{Cm}$ by the Use of Alternating DTPA and NTA Cation-Exchange Flowsheets, USAEC Report BNWL-SA-1492, Battelle Memonal Institute, Pacific Northwest Laboratones, March 1968.

322. E. J. Wheelwnght, Ion Exchange Process for Recovernng Amencium and Curium, U.S. Patent No. 3,445,201, May 1969.

323. E. J. Wheelwnght, Ion Exchange-A Genenc Nuclear Industry Process for the Recovery and Final Punfication of Am, Cm, Pm, Sr, Pu, Np, Cs, Tc, Rh, and Pd, in Ion Exchange in the Process Industries, pp 202-208, London, Society of Chemical Industry, 1970

324. E. J. Wheelwright and F. P. Roberts, The Use of Alternating DTPA and NTA Cation-Exchange Flowsheets for the Simultaneous Recovery and Punfication of Pm, Am, and Cm, USAEC Report BNWL-1072, Battelle Memonal Institute, Pacific Northwest Laboratories, July 1969

325. E. J. Wheelwnght, Battelle Memoridl Instıtute, Pacıfic Northwest Laboratories, Richland, Washington, private communication, 1975

326. J. T. Lowe, W. H. Hale, Jr., and D. F. Hallman, Development of a Pressurnzed Cation Exchange Chromatographic Process for Separation of Transplutonium Actımdes, Ind Eng. Chem, Process Design Develop., 10: 131 (1971).

327. R. M. Harbour, W. H. Hale, G. A. Burney, and J. T. Lowe, Large-Scale Separation of Transplutonium Actınides by Pressunzed Cation Exchange, At. Energy Rev, 10: 379 (1972). 
328 W. H. Hale, Jr., and C. A. Hammer, Cation Exchange Elution Sequence with DTPA, Ion Exch Membranes, 1 : 81 (1972).

329. I. A. Kelley, Ion Exchange Process for Separating Americium and Curium from Irradiated Plutonıum, USAEC Report DP-1308, Savannah River Laboratory, November 1972.

330. M. A. Wakat and S. F. Peterson, On-Line Radiochemical Analysis for Controllıng Rapıd Ion Exchange Recovery of Transplutonum Elements, Nucl Technol, 17:49 (1973).

331. S. Specht, B. O. Schutz, and H. J. Born, Development of a High-Pressure Ion-Exchange System for Rapid Preparative Separations of Trans-Uranium Elements, $J$ Radioanal Chem., 21 : 167 (1974).

332. E. P. Horwitz, The Sorption of Certain Transplutonium Ions on Amorphous Zirconium Phosphate, J. Inorg. Nucl. Chem, 28: 1469 (1966)

333. W. J. Maeck, M. E. Kussy, and J E. Rein, Adsorption of the Elements on Inorganic Exchangers from Nitrate Media, Anal Chem, 35: 2086 (1963)

334. E. Akatsu, R. Ono, T. Tsukuechı, and H. Uchıyama, Radıochemical Study of Adsorption Behavior of Inorganic Ions on Zirconium Phosphate, Silica Gel, and Charcoal, J Nucl Scl Technol (Tokyo), 2: 141 (1965).

335. K. V. Baroukova and G. S. Rodionova, Sorption and Separation of Certain Transplutonium and Rare Earth Elements on a Zirconium Phosphate-Silicate Sorbent, Radiokhimiya 14: 228 (1972), through Sov Radiochem. (Engl Transl), 14: 237 (1972).

336. K. B. Brown, Chemical Technology Division, Chemical Development Section C, Progress Report for January-March 1962, USAEC Report ORNL-TM-181, Oak Ridge National Laboratory, July 1962

337 F. L. Moore, New Method for Separation of Americium from Curium and Associated Elements in the Zirconium Phosphate-Nitric Acid System, Anal Chem, 43: 487 (1971).

338. F. L. Moore, Separation and Recovery of Americium from Curum and Other Elements, U. S. Patent No. 3,687,641, August 1973

339. A. I. Shafiev, Yu. V. Efremov, V. M. Nikolaev, and G. N. Yakovlev, Separation of the Actinides and Lanthanides on Zirconium Phosphate II Separation of Americium(V), (VI), and Cunum(III), Radıokhtmiya, 13: 129 (1971), through Sov Radıochem. (Engl. Transl.), 13: 123 (1971).

340. A. I. Shafiev, Yu. V. Efremov, and V. P Andreev, Separation of Actinides and Lanthanides on Zirconium Phosphate IV. Separation of Milligram Amounts of Amencium and Cunum, Radiokhimiya, 15: 265 (1973), through Sov Radıochem. (Engl Transl), 15: 263 (1973),

341. H. A. Goya and M. G. La1, Adsorption of Trace Elements from Seawater by Chelex 100 , Report USNRDL-TR-67-129, U.S. Naval Radiological Defense Laboratory, September 1967.

342. V. P. Myasoedov and N. P. Molochnikova, A Procedure for Concentrating Americium and Curium Combined with Their Separation from Plutonium and Fission Products Using a Chelating Resın, J. Radioanal. Chem., 6: 67 (1970).

343. J. Kool, J. M. Gandolfo, N. Waechter, J. Wijkstra, R. Boden, R. Hecq, E. Vanhoof, and $M$. Leynen, Isolation of Microgram Amounts of Berkelıum and Calıfornıum from Irradiated Americium, Euratom Report EUR-2578.e, December 1965.

344. J, Koo1, R. Boden, and J. Wijkstra, Separation of Amencium (Curium), Berkelium and Californum by Extraction Chromatography, J Inorg Nucl Chem, 26: 2300 (1964)

345. J. Kool, Application of Extraction Chromatography in the Processing of Irradiated Amencium, Radiochim. Acta, 5: 91 (1966)

346. K. A. Gavrilov, E. Gvuzdz, J. Stary, and W. T. Seng, Investigation of the Solvent Extraction of Calıfornıum, Fermıum, and Mendelevium, Talanta, 13: 471 (1966).

347. E. P. Horwitz, C. A. A. Bloomquist, D. J. Henderson, and D. E. Nelson, The Extraction Chromatography of Amencium, Cunum, Berkelium, and Calıfornum with Di(2-ethylhexyl)-orthophosphonc Acid, J Inorg Nucl Chem., 31: 3255 (1969). 
348. E P Horwitz and C. A A. Bloomquist, High Speed-High Efficiency Separation of the Transplutonium Elements by Extraction Chromatography, J Inorg Nucl Chem, 35:271 (1973).

349 K. Watanabe, Separation of Americium and Some Rare Earths from Lanthanum by Reversed Phase Chromatography, J Nucl Scı Technol (Tokyo), 2: 45 (1965)

350 K. Watanabe, Separation of Promethium and Americium by Reversed Phase Chromatog raphy, J Nucl Scl Technol (Tokyo), 2: 112 (1965)

351 I. Stronskı, Untersuchungen uber die Trennung von einigen Lanthanıden und Actınıden mittels der Extractionschromatographe in System Di-(2athylhexyl)-orthophosphorsauresalzsaure, Radiochim Acta, 13: 25 (1970).

352 T. D. Filer, Separation of the Trivalent Actinides from the Lanthanides by Extraction Chromatography, Anal. Chem, 46: 608 (1974)

353 F. L. Moore, New Extraction Chromatographic Method for Rapid Separation of Americium from Other Transuranium Elements, Anal Chem, 40: 2131 (1968).

354 M. Hara and S. Suzukı, The Chemıstry of Amencium II. The Behavior of Am(III), Am(V), and Am(VI) in Column Chromatography, with Bis(2-ethylhexyl)phosphoric Acid Used as the Extractant, Bull Chem. Soc Jap, 47:635 (1974)

355 E. K Hulet, An Investigation of the Extraction Chromatography of Am(VI) and Bk(VI), J Inorg Nucl Chem 26: 1721 (1964)

356 E. P Horwitz, $\mathrm{K}$ A. Orlandinı, and C. A A. Bloomquist, The Separation of Americium and Curium by Extraction Chromatography Using a High Molecular Weight Quaternary Ammonium Nitrate, Inorg Nucl Chem Lett, 2: 87 (1966).

357 E. P. Horwitz, C. A. A. Bloomquist, K. A. Orlandını, and D. J. Henderson, The Separation of Milligram Quantities of Amencium and Curium by Extraction Chromatography, Radiochim Acta, 8: 127 (1967).

358 I. Stronski, Solvent Extraction and Separation of Some Lanthanides and Americium by Extraction Chromatography in the System Aliquat 336- $\mathrm{LNO}_{3}$ and $\mathrm{HNO}_{3}$, Chromatographa, 1: 285 (1969).

359 W. Muller, Extraction of Transplutonium Elements by Alkylammonium Salts, Angew Chem, 83: 625 (1971), through Angew Chem Int. Ed, 10: 581 (1971).

360. W Muller, Research on Transplutonium Element Chemistry at the European Institute for Transuranium Elements, in Symposium on the Transuranium Elements, Liege, Belgum, Aprl 21-22, 1969, Report CONF-690426, pp 169-191, 1969

361 F. A. Huff, Partition Chromatographic Studies of Americium, Yttrium, and the Rare Earths in the Tricaprylylmethyl-ammonium Thıocyanate-Ammonium Thiocyanate System, J Chromatogr, 27: 229 (1967).

362 P. G. Barbano and L. Rigali, Separation of Americium from Rare Earths by Reversed-Phase Partition Chromatography, J Chromatogr, 29309 (1967).

363. W. Knoch and H. Lahr, The Chromatographic Separation of Am-Cm on Paper, Radiochim Acta, 4: 114 (1965).

364. N. Cvjeticanın, Synergism in the Reversed-Phase Partition Chromatography of Americium, Cenum, and Lanthanum, $J$ Chromatogr, 34: 520 (1968)

365. B. A. Bilal, K. Metscher, B. Muhlıg, C. Reichmuth, and B. Schwarz, Application of Counterflow Ion Migration for Separation of Actinides, Chem Ing -Tech, 45: 841 (1973), through USAEC Report RFP-Trans-147, Rocky Flats Plant, Dow Chemical Company, 1973.

366. B. A. Bilal and B. Schwarz, Obtaning the Actinide Elements and Reusable Fission Products from the Waste Solution of Irradiated Nuclear Fuel by Means of Countercurrent Ion Migration, Radiochım. Acta, 18: 148 (1974), through USAEC Report AEC-tr-7535, 1972

367. K. Wagener, H D. Breyer, and B. A. Bllal, Countercurrent Electrophoresis, Separ Scl, 6: 483 (1971). 
368 B. A. Bilal and C. Reichmuth, Lanthaniden/Actınıden-Trennung mit Hilfe der Gegenstromelek trolyte, J. Inorg. Nucl. Chem, 34: 348 (1972).

369. Y. Kobayashı and A. Salto, Extraction of Thorıum, Neptunıum, Plutonıum, and Americium with Sodium Amalgam from Aqueous Solution, J Inorg Nucl Chem, 35: 3065 (1973).

370 H. Eschrich and L. Salomon, Study of the Leachıng of Plutonium Oxıde for the Elimination of Americium, Report ETR-276, European Company for the Chemical Processing of Irradiated Fuels, Mol, Belgium, February 1972

371. T. S. Zvarova and I. Zvára, Separation of Transuranium Elements by Gas Chromatography of Their Chlondes, $J$ Chromatogr., 49: 290 (1970).

372. T. S. Zvarova, Gas Chromatography of High-Bolling Metal Chlorides Usıng Aluminum Chlondes as Complex Former, Radiokhimiya, 15: 542 (1973), through Sov Radiochem (Engl Transl), 15: 546 (1973).

373 I Zvara, V. Alkhler, V. S. Belov, T S Zvarova, Yu. S. Korotkın, M. R. Shalaevskı1, V. A Shchegolev, and M Yussonnua, Gas Chromatography and Thermochromatography in the Study of Transuranium Elements, Radiokhimiya, 16: 720 (1974), through Sov Radio chem (Engl Transl)., 16: 709 (1974)

374. F. Clanet, J. Clarence, and M. Verry, Electrophoresis on Cellulose Acetate Paper in Strong Electrolytes and Concentrates. Equipment and Techniques, Determination of Electrophoretic Mobilities and Separation of Some Transuranium Elements in Nitrate Media, $J$ Chromatogr, 13: 440 (1964).

375. A. Van Dalen, W. Kraak, J. Van Ooyen, P. Polak, and J C. Post, Transplutontde Research, Euratom Report EUR-2640 e, November 1965

376. G. E. Ermolina and V.T. Kharlamov, Electrophoretic Separation of Amencium and Plutonium, Zh. Anal Khim., 28: 2246 (1973).

377 K. Backman, Trennung der Actınide durch Hochspannung-selektrophorese, Radıochım. Acta, 6: 62 (1966).

378 H. Y. Gee, A. H. Heımbuch, and M. W. Nathans, Separation of Americtum and Curium from Rare Earth Metal Carriers by Ion-f ocusing Electrophoresı, Anal Chem, 39: 98 (1967).

379. G. Marcu, Separation of ${ }^{152} \mathrm{Eu},{ }^{147} \mathrm{Pm},{ }^{241} \mathrm{Am}$, and ${ }^{246} \mathrm{Cm}$ Through Electrophoretic Focussing Using the Sodum Polyphosphate as Complexing Agent, Stud Univ BabesBolyat, Ser Chem., 11: 61 (1966).

380. Z. Szeglowsk1, M. Bittner-Jankowsa, J. Mikulsk1, and T. Machej, Frothless Ion Flotation of Some Trivalent Actınides, Nukleonika, 18: 307 (1973).

381. J. Stachursk1 and Z. Szeglowskı, Venfication of a Stochastic Model for a Frothless Solvent Ion Flotation Using Thulıum and Amencium, Separ Sct, 9: 313 (1974).

382. J. B. Knighton, R. G. Auge, J. W. Berry, and R. C. Franchini, Molten Salt Extraction of Americium from Molten Plutonium Metal, ERDA Report RFP-2365, Rocky Flats Plant, Rockwell International, March 1976 
Butler, J P, 189

Bykhovskı, D N , 194

Carn, A, 68

Campbell, D O , 249

Carlson, T A , 4

Carnall, W T , 6, 10, 84-85, 141, 151

Carvalho, R G, 102

Charvullat, J P , 132, 151, 163, 165-166

Chatt, J , 100

Chattın, $\Gamma \mathrm{R}, 211,228$

Chianızıa, R, 100

Chikalla, T D , 152-156

Chisholm, R C , 234

Chistyakov, V M , 70-71

Chmutova, M K , 14, 220, 229

Choppin, G R , 16, 99, 102, 106, 222

Christman, R P , 36

Chudinov, E G , 232

Clarke, R W , 14

Clayton, E D, 12-13

Cobble, J W , 55

Cohen, D , 13, 54, 77, 86, 166

Coleman, C $\mathrm{F}, 222$

Coleman, J S , 57, 61-64, 84-85, 140, 149, 234

Conner, W V , 123-124, 146

Conway, F G , 141

Coops, M S , 238-239

Coqblin, B , 126

Cornman, W R , 36

Crandall, J L , 29, 32

Crane, W T , 249

Cunningham, B B , 1, 55, 57, 62, 123-124, $142,153,155,189$

Damien, N , 69-70, 132, 156, 166

Danford, M D , 168

Darby, J B , Jr , 14

Dauben, C H , 142, 145, 153

David, F , 49, 127

Day, P P, 10

Dedov, V B , 196

Demine, D , 14

Désıré, B , 49

Drobnick, S , 217-218

Dumond, J W M , 10

Dunlap, B D , 13, 128

Duyckaerts, G , 224, 233

Dzkelepov, B S , 4

Eberle, S H , 103, 169

Efremov, Yu V , 254
Eicholz, G G , 32

E1ck, H A , 132, 138

Ellınger, F H , 129-130

Cl Raw1, H , 106

Ermakov, V A , 65-67, 70-72

Eyrıng, L , 55, 123, 152-153, 155-156

Faurcloth, R L , 152

Fang, D , 139

Fardy, J J , 213

Ferradinı, C , 16

Ferraro, J R, 208

Ferris, L M , 188

Fields, P R , 141, 151, 201, 241

Fletcher, J W, 188

Foex, M , 153, 154

Foos, J , 188, 201

Fowler, E E, 32

Fred, M , 6

Freeman, A J, 14

Frenkel, $\mathrm{V}$ Ya $, 52,61$

Fried, S , 78, 146

Friedman, H A , 49

Fuger, J , 44-45, 141-142, 153, 224

Gal, J , 11-12

Galleanı D'Agliano, E , 126

Garber, D I , 4

Gel'man, A D , 16, 86, 99

Gerontopulos, P Th, 232

Ghioroso, A , 1

Ginzburg, F L , 194, 245

Givon, M , 16, 51-52, 76, 99, 222

Goldanskı, V I , 15

Gorbenko-Germanov, D S , 140, 190

Gorsk11, A G , 77

Gourise, D , 64

Gove, N B , 4, 7

Goya, A A , 255

Graf, P , 78, 123

Griffen, H E , 232

Groh, H J , 229, 231

Gruber, J B , 141

Gruen, D M , 78, 201

Gullaumont, R , 49, 188, 201

Gunn, S R , 55, 57, 62

Gureev, E S , 196, 209, 211, 219

Guseva, L I , 14, 239, 243

Gutmacher, R G , 238-239

Guyer, R H , 246

Hadan, Z, 14

Hagan, P G , 236 
Haire, R. G., 146

Hale, W. H., Jr., 249-252

Hall, C. R., 189

Hall, G. R., 62, 74, 81, 83, 164

Hall, R. M., 208

Hall, R. O. A., 124, 126

Hallman, D. F., 250, 252

Hara, M., 53

Harbour, R. M., 249

Harmon, H. D., 224

Haug, H. O., 217-218, 249

Hauske, H., 142

Helfereich, F., 244

Helminski, E. L., 16, 32

Henderson, D. J., 223

Hennelly, E. J., 29, 33

Henry, H. E., 196, 225

Hermann, J. A., 190

Herniman, P. D., 74, 81, 189

Hesford, E., 197

Hicks, H. G., 249

Higgins, G. H., 249

Hild, W., 217,218

Hill, H. H., 126, 128

Hinchey, R. J., 55

Hindman, J. C., 64

Hoffert, F., 202, 205

Hogan, P. G., 193

Hollander, J. M., 4-6

Horwitz, E. P., 222-223, 232, 252

Howerton, R. J., 4

Hucher, I., 220

Hulet, E. K., 238-239, 241

Huntoon, R. T., 231

Hussonnois, M., 49

Hyde, E. K., 4

Ilozheva, L. V., 210

Isaak, N. M., 201

Iyer, R. S., 194

James, R. A., 1

Jenkins, I. L., 233

Johnson, K. W. R., 129-130

Jones, A. D., 16

Jones, L. H., 84-85, 99, 106

Jones, L. L., 107

Jove, J., 48, 165

Jullien, R., 126

Jyo, A., 65, 66

Kalvius, G. M., 13

Kamath, P. R., 194
Kanellakopulos, B., 132

Kappelmann, F. A., 211-215

Karantsevich, T. S., 194

Karapacheva, S. M., 196, 210

Karraker, D. G., 157, 168

Katz, D. J., 8, 14, 16

Keder, W. E., 223

Keenan, T. K., 15, 57, 61, 75, 84-85, 138-139, 141, 144-147, 189, 201, 219, 234

Keller, C., 11, 14, 32, 49, 53, 99, 101, 131, $139,146-147,149,152-153,157-159$, $161-163,169$

Kelley, J. A., 251

Kikindai, T., 49

Kingsley, R. S., 203, 241

Kinser, H. B., 225

Kishbaugh, A. A., 192

Knighton, J. B., 185-186

Kobayashi, Y., 258

Koch, C. W., 142

Koch, G., 215, 217-219, 232

Kochethova, M. E., 220

Koehly, G., 199, 202, 205, 216, 229, 231

Koiro, O. E., 52, 61

Kolarik, Z., 215, 217, 219-220

Konkina, L. F., 99

Korkisch, J., 239

Korotkin, Yu. S., 50-51

Kosyakov, V. N., 74, 82, 189, 209, 211

Kotlin, V. P., 77

Kramer, G. F., 125

Krot, N. N., 54, 57, 68-69, 84, 86

Kruse, F. H., 138, 141, 145, 147

Kudera, D. E., 246

Kuznetsov, V. I., 190

Lai, M. G., 255

Laidler, J. B., 142-143

Lam, D. J., 128-129, 131-132, 166

Latimer, W. M., 57-58

Lbov, A. A., 239

Leary, J. A., 47, 186-188

Lebedev, I. A., 14, 51-52, 61, 196, 241

Lederer, C. M., 4-6

Ledicotte, G. W., 32

Lee, C. T., 219

Legoux, Y., 127

Leuze, R. E., 16, 192-193, 199, 210, 221, $224,226,228,240-241,243$

LeVert, F. E., 16, 32

Lewey, S., 208 
Van Ooyen, J., 232

Varga, L. P., 75, 77, 79

Vasseur, C., 127

Vaughen, V. C. A., 211, 228

Vdovenko, V. M., 15

Viola, V. E., 4

Vodovatov, V. A., 143

Wade, W. Z., 123

Wain, A. G., 233

Wakat, M. A., 252

Wallman, J. C., 123-124, 189

Wapstra, A. H., 4, 7

Ward, J. W., 125

Warshaw, I., 153-154

Wasserman, N., 4

Watanabe, K., 219

Weaver, B., 16, 149, 195, 211-215, 221 , 224-225, 231

Weigel, F., 139, 142, 169-170

Werner, L. B., 80, 140, 189-190

West, D. L., 225

West, R., 32

Westrum, E. F., Jr., 55, 123
Wheelwright, E. J., 249-250

Williams, K. R., 106

Williams, R. L., 194

Wilson, A. S., 223

Wilson, H. D., 241

Wishnefsky, V., 142

Wolf, T., 123

Woods, M., 68

Yakovlev, G. N., 65, 74, 82, 140, 164,

189-190, 196, 209, 211

Yanir, E., 12, 51-52, 76

Zachariasen, W. H., 4, 8, 126, 138, 141, 150, $152-153,165$

Zaitsev, A. A., 58-60, 62, 68

Zaitsev, L. M., 16

Zaitseva, V. P., 65

Zaman, N., 233

Zamorani, E., 155-157

Zangen, M., 201, 219-220

Zaozerskii, I. N., 193

Zemylanukhin, V. I., 197, 204

Zvara, I., 258-259

Zvarova, T. S., 258-259 


\section{SUBJECT INDEX}

Acetate, 167

Acetylacetonate, 167

Alloys

See also Intermetallic compounds

with aluminum, 126

with beryllium, 127

with lanthanum, 128

with neptunium, 128

with plutonium, 129

with thorium, 130

Aluminate, 131

Amencium(II) ion

in aqueous solution, 47-49

in molten salts, 47

in solid compounds, 145

Americium(III) ion

calculated electronıc energy levels, 73

electrode potentials, $55-58$

hydrolysis of, 49-51

oxidation

of peroxydisulfate in $\mathrm{HNO}_{3}, 64-66$

by peroxydisulfate in $\mathrm{K}_{2} \mathrm{CO}_{3}$ solution, 67

paramagnetic susceptibility, 49

preparation in aqueous solution, 48

spectrum, in aqueous lithium solutions, 72-73

in ethanolic $\mathrm{HCl}, 72-73,77$
In fused $\mathrm{LiNO}_{3}, 72-73,78$

in $\mathrm{K}_{2} \mathrm{CO}_{3}$ solution, $72-73,76$

in $\mathrm{Mgl}_{2}$ solution, 72-73

in mineral acids, 72-76

in saturated KF solution, 72-73, 77

thermodynamic quantities, 55

Americium(IV) ion

autoreduction of, 60

calculated electronic energy bands, 75

disproportionation of, 60-62

electrode potentials, 55-58

preparation in aqueous solution, 48, 51-52

self-reduction of, in $\mathrm{H}_{3} \mathrm{PO}_{4}, 60$

spectrum, in $\mathrm{H}_{3} \mathrm{PO}_{4}$ solution, 75-76, 80

in $\mathrm{KF}$ solution, 75, 79

in $\mathrm{NH}_{4} \mathrm{~F}$ solution, 75, 78, 80

thermody namic quantities, 55

Americium(V) ion

calculated electronic energy bands, 77

disproportionation of, 62-64

electrode potentials, 55-58

oxidation of peroxydisulfate in $\mathrm{HNO}_{3}$ solution, 67

preparation in aqueous solutions, 48 , $52-53$

reduction, by $\mathrm{H}_{2} \mathrm{O}_{2}, 69$

by $\mathrm{Np}(\mathrm{IV})$ in $\mathrm{HClO}_{4}$ solution, 70

by $\mathrm{Np}(\mathrm{V})$ in $\mathrm{HClO}_{4}$ solution, 70-71 
by $\mathrm{Np}(\mathrm{V})$ in $\mathrm{Na}_{2} \mathrm{CO}_{3}$ solution, 71

by U(IV) in $\mathrm{HClO}_{4}$ solution, 71

self-reduction of, 59-60

spectrum, in $\mathrm{HCl}$ solution, 80-81

in $\mathrm{HClO}_{4}$ solution, $80-81^{\circ}$

in $\mathrm{H}_{2} \mathrm{SO}_{4}$ solution, 80

thermodynamic quantities, 55

Americium(VI) ion

calculated electronic energy bands, 79, 82

electrode potentıals, 55-58

preparation in aqueous solution, 48 , 53-54

reduction, in acıd peroxydisulfate solutions, 72

by $\mathrm{H}_{2} \mathrm{O}_{2}, 68$

by miscellaneous reagents, $68-69$

self-reduction of, 58-59

spectrum, in $\mathrm{CsOH}$ solution, 86

in mineral acids, 80, 82-83

in $\mathrm{Na}_{2} \mathrm{CO}_{3}$ solution, 85

in $\mathrm{NaOH}$ solution, 80,86

in $\mathrm{Na}_{4} \mathrm{P}_{2} \mathrm{O}_{7}$ solution, 84

thermodynamic quantities, 55

Americlum(VII) ion

preparation in aqueous solutions, 48,54

spectrum in $\mathrm{NaOH}$ solution, 84, 86

Americium sotope ${ }^{241} \mathrm{Am}$

avalability, from power reactors, $27-28$

from ${ }^{24}$ ' Pu decay, 24

critical mass, $12-13$

critical radius, $12-13$

decay scheme, 5

price, 24

production by ${ }^{241} \mathrm{Pu}$ decay, 23

target for production of ${ }^{242} \mathrm{Cm}, 33$

uses, table of, 30

Americium isotope ${ }^{243} \mathrm{Am}$

avallability from power reactors, $27-28$

decay scheme, 6

production from ${ }^{242} \mathrm{Pu}, 24$

target, for production of ${ }^{252} \mathrm{Cf}, 33-34$

for production of ${ }^{244} \mathrm{Cm}, 33-34$

Anion exchange

from aqueous nitrate solutions, 239-243

from $\mathrm{LiCl}-\mathrm{HCl}$ solutions, 239

from LiCl solutions, 237-238, 240

from methanolic nitrate solutions, $242-$ 243

from thiocyanate solutions, 234-237

Antimonides, 131-132

Arsenate, 132

Arsenıdes, 132
Benzoyltrifluoroacetonate, 168

Borate, 132

Bromides

dibromide, 138

tribromide, 138

Carbide, 139

Carbonates, 139-141

ammonium compound, 139

barium compounds, 140

calcium compound, 140

cesium compound, 139

potassium compounds, 139-140

rubidium compound, 140

sodium compounds, 140-141

Cation exchange

americium distribution ratios, 245

displacement chromatography, 244-245, 249-252

elution chromatography, 244

pressurized systems, 250-252

recovery processes, $245-252$

separation factors, $245-247$

Chlorides, binary

dichlonde, 141

oxychloride, 142

trichloride, 141-142

Chlorides, ternary

Am(III) compounds, 142-143

Am(V) compounds, 143

Am(VI) compound, 143-144

Clanex process, 229, 231

Cleanex process, 211

Complexes formed in solution

inorganic ligands, 99-100

kınetics of formation, 106

organic ligands, 100-102

tabulated formation constants, inorganic ligands, 87-90

organic ligands, $90-98$

thermodynamic functions, 102-106

Compounds

inorganic, table of, 133-137

organic, table of, 167

Critical mass, 12-13

Critical radil, 12-13

Curıum, separation from americium by extraction, with bis(2,6-dimethyl1-4-hexyl)phosphoric ac1d, 221 with bis(2-ethylhexyl)phosphoric acid, 219 
by extraction chromatography with Aliquat 336, 255-256

by gas chromatography of chlorides, 258-259

by nitrate-based anion exchange, 243 by precipitation with $\mathrm{K}_{5} \mathrm{AmO}_{2}\left(\mathrm{CO}_{3}\right)_{3}$, 190,192

by pressunzed cation exchange, $250-252$

by pyrochemical procedures, 187

separation factors for cation-exchange systems, 246-247

by sorption on zirconium phosphate exchanger, 253-255

Cyčlooc tatetraenate, 168

Cyclopentadıenide, 168

Dapex process, 210,213

Dipivaloylmethanato compounds, 168

Discovery, 1

Flectrode potentials

in $\mathrm{HClO}_{4}, 56-57$

in $\mathrm{H}_{3} \mathrm{PO}_{4}, 58$

in $\mathrm{NaOH}, 57-58$

Electron configuration, 7

Fluorides, bınary

spectra of, 144

tetrafluorıde, 146

trifluonde, 145

Fluorides, ternary

Am(III) compounds, 146

Am(IV) compounds, 147

Am(V) compound, 147

Formate, 169

Germanate, 147-148

Hexafluoroacetylacetonate, 169

Hydrides, 148-149

Hydroperoxide, 149

Hydroxides

Am(III), 149

Am(IV), 149-150

Hydroxyquinolates, $169-170$

Inorganic exchangers sorption of Am(III) by, 252-254 zirconium phosphate, 253-254

Intermetallic compounds

$\mathrm{Al}_{2} \mathrm{Am}, 126$

$\mathrm{AmBe}_{13}, 127$
AmB1, 127

$\mathrm{Co}_{2} \mathrm{Am}, 126$

$\mathrm{Fe}_{2} \mathrm{Am}, 126$

Ir $_{2} \mathrm{Am}, 128$

$\mathrm{Ni}_{2}$ Am, 128

$\mathrm{Os}_{2} \mathrm{Am}, 129$

$\mathrm{Pd}_{3} \mathrm{Am}, 129$

$\mathrm{Pt}_{2}$ Am, 129

$\mathrm{Pt}_{5}$ Am, 129

$\mathrm{Rh}_{2} \mathrm{Am}, 130$

$\mathrm{Rh}_{3} \mathrm{Am}, 130$

Iodides

dilodide, 150

oxylodide, 151

trllodide, 150-151

Ionization potentials, 4,8

Isotopes

See also Americium isotope ${ }^{241} \mathrm{Am}$ and Americium isotope ${ }^{243}$ Am

list of, 2-3

nuclear properties of, $2-3,7$

Lanthanıdes (separatıon from amerıcıum)

by Aliquat 336 extraction, 232

by anion exchange from $\mathrm{LiCl}$ solutions, 237,239

by anion exchange from thiocyanate solutions, 234-237

by bis(2-ethylhexyl)phosphoric acıd extraction, 211-221

by displacement chromatographic cation exchange, 249-252

by mono(2-ethylhexyl)phosphoric acid extraction, 222

by precipitation processes, 190

by pressurized cation exchange,

$$
\text { 250-252 }
$$

separation factors in cation exchange systems, 246

by Talspeak process, 211-214, 216-218, 221

by Tramex process, $224-230$

by tri- $n$-butylphosphate extraction, 198-202

Metal

phase transformations, 124

preparation of, 122-124

properties, physical, 124-125

table of, 125

Molybdates, 151 
Nitrate, 151

Nitride, 151

Organometallic compounds, 166-171

Oxalate, 170

Oxides, binary

dioxide, 153, 155-157

monoxide, 152

sesquioxide, 152,154

Oxides, ternary

with barium and strontium, 157, 159

with cunum, 159-160

with lithium and sodium, 157-158

with niobium, tantalum, and protactinium, 162

with zirconıum, hafnium, and thorium, 159-160

Oxychloride, 142

Oxylodide, 151

Oxy tellunde, 166

Perxenate, 166

Phosphate, 162

Phosphide, 163

Phthalocyaninato compound, 170

Pyndine carboxylates, 170-171

Radı

critical, 12-13

1onic, 4,8

metallıc, 4,8

Recovery

from aged plutonum metal, 185-187, 189,232

by amalgamation, 258

by anıon-exchange procedures, 233-243

by cation-exchange procedures, 244-252

at Hanford Plant, 196-197, 202-204, 207 , $210,212,245-246,249-251$

by ion flotation, 259

from irradiated ${ }^{241} \mathrm{Am}$ targets, 190, 239

from irradiated $\mathrm{Pu} \mathrm{Al}$ alloy, 188, 195 -

$196,199,214,216,240-242$

from $\mathrm{LlCl}-\mathrm{HCl}$ solutions, 200, 205, 237, 240

from Liquid-Metal-Cooled Fast Breeder Reactor fuel, 204

at Oak Ridge TRU Plant, 190, 192, 227$228,237,240$

by precipitation, of $\mathrm{Am}_{2}\left(\mathrm{C}_{2} \mathrm{O}_{4}\right)_{3}, 189$ $190,193-194,247,250$ of $\mathrm{AmF}_{3}, 189,191$

of $\mathrm{Am}(\mathrm{OH})_{3}, 189,191,193$

of $\mathrm{Am}_{2}\left(\mathrm{SO}_{4}\right)_{3} \cdot \mathrm{Na}_{2} \mathrm{SO}_{4}, 192$

of $\mathrm{K}_{3} \mathrm{AmO}_{2}\left(\mathrm{CO}_{3}\right)_{2}, 189$

of $\mathrm{K}_{5} \mathrm{AmO}_{2}\left(\mathrm{CO}_{3}\right)_{3}, 190,192$

of $\mathrm{K}_{8} \mathrm{Am}_{2}\left(\mathrm{SO}_{4}\right)_{7}, 189$

by Purex process waste, 197, 206, 215 219,249

by pyrochemical procedures, $185-189$

at Rocky Flats Plant, 185-186, 193-

194, 234-237, 246-249

at Savannah River Plant, 190, 192-193, 228-230, 250-252

by selective leaching from $\mathrm{PuO}_{2}, 258$

from Shippingport reactor fuel, 196-197, $199,210,212,249-251$

from slag and crucible waste, 197-198

by Tramex process, $224-229$

Scandate, 163

Selenıdes, 163

Separation

See also Recovery

by chelatıng 1on-exchange resins, 255

by counterflow ion migration, 258

from curum (see Cunum)

by extraction chromatography, 255-256

by gas chromatography of chlorides, 258 259

by inorgan1c exchangers, 252-255

from lanthanides (see Lanthanides)

by paper electrophoresis, 258-259

by precipitation processes, 190-194

by pyrochemical processes, 185-189

by solvent extraction methods, 195-233

by Talspeak process, 211-218, 221

by Tramex process, 224-231

Silıcates, 163

Solvent extraction [Am(III)]

by Alamine 336, 223, 225-226, 229, 231

by Alıquat $336,223,232-233$

by $b i s(2,6$-dimethyl-4-heptyl)phosphoric acid, 221

by bis(2-ethylhexylphenyl)phosphoric acid, 221

by $b i s(2$-ethylhexyl)phosphoric acid, 208-220

by dibutylbutyl phosphonate, 206-209

by dibutyl- $N, N$-diethylcarbamylmethylene phosphonate, 206-209

by dihexyl- $N, N$-diethylcarbamylmethylene phosphonate, 207-208 
by disoamylmethyl phosphonate, 205

by methyldibutyl phosphonate, 205

by mixtures of bts (2-ethylhexyl)phos-

phoric acid and $\mathrm{P}_{2} \mathrm{O}_{5}, 219-220$

by mono(2-ethylhexyl)phosphoric acid, 221-222

by quaternary amine salts, $224,232-233$

by tertiary amines, $222-231$

by tri- $n$-butyl phosphate, 188-189, 195-202

by tri-n-octyl amine, 223

by vanous organophosphorus acids, 222

-Solvent extraction [Am(VI)]

by Alamine 336 nitrate, 231

by bis(2,6-dimethyl-4-heptyl)phosphoric acld, 221

by bis(2-ethylhexyl)phosphoric acid, 219-220

by tri- $n$-butyl phosphate, 201-202

Spectra

absorption

see individual americium ions

emission, 6, 9-10

luminescence, 10
Mossbauer, 11-12

$\mathrm{X}$ ray, 10-11

Sulfates

of $\mathrm{Am}(\mathrm{III}), 164$

double, 164

Sulfides, 165

Talspeak process

distribution data, 214-215

reverse Talspeak-type processes, 214-216

Tellurides, 165-166

Thenoyltrifluoroacetonate, 171

Thermodynamic quantities, 55

Tramex process

chemistry of, 224, 226

distribution data, 225

Oak Ridge flow sheet, 224, 226-228

radioly tic efforts, 226

Savannah River flow sheet, 228-231

Tungstate, 166

Vanadates, 166

Zirconium phosphate exchanger, sorption of Am(III), 252-255

\section{NOTICE}

This book was prepared as an account of work sponsored by the United States Government. Neither the United States nor the United States Energy Research and Development Administration, nor any of their employees, nor any of their contractors, subcontractors, or their employees, makes any warranty, express or implied, or assumes any legal liability or responsibility for the accuracy. completeness or usefulness of any information, apparatus, product or process disclosed, or represents that its use would not infringe privately owned rights 


\section{ERDA SYMPOSIUM SERIES}

Avallable from the National Technical Information Service, U S Department of Commerce, Springfield, Virgınia 22161 (For foreıgn price add $\$ 250$ per publication)

Reactor Kınetics and Control (TID 7662) $1964 \$ 600$

Noise Analysis in Nuclear Systems (TID 7679) $1964 \$ 600$

Radioactive Fallout from Nuclear Weapons Tests (CONF 765) $1965 \$ 600$

Radioactive Pharmaceuticals (CONF 651111) $1966 \$ 600$

Neutron Dynamics and Control (CONF 650413) $1966 \$ 600$

Lumınescence Dosımetry (CONF 650637) $1967 \$ 600$

Neutron Noise, Waves, and Pulse Propagation (CONF-660206) $1967 \$ 600$

Use of Computers in Analysis of Experimental Data and the Control of Nuclear Facilities (CONF 660527) $1967 \$ 600$

Compartments, Pools, and Spaces in Medical Physiology (CONF 661010) $1967 \$ 600$

Thorium Fuel Cycle (CONF 660524) $1968 \$ 600$

Radioisotopes in Medicine In Vitro Studies (CONF 671111) $1968 \$ 600$

Abundant Nuclear Energy (CONF 680810) $1969 \$ 600$

Fast Burst Reactors (CONF 690102) $1969 \$ 600$

Bıological Implications of the Nuclear Age (CONF-690303) $1969 \$ 600$

Radiation Biology of the Fetal and Juvenile Mammal (CONF-690501) $1969 \$ 1000$

Inhalation Carcinogenesis (CONF 691001) $1970 \$ 600$

Myeloproliferative Disorders of Anımals and Man (CONF 680529) $1970 \$ 900$

Medical Radıonuclıdes Radıatıon Dose and Effects (CONF 691212) $1970 \$ 600$

Morphology of Experımental Respiratory Carcinogenesıs (CONF 700501) $1970 \$ 600$

Precipitation Scavenging (1970) (CONF 700601) $1970 \$ 600$

Neutron Standards and Flux Normalization (CONF 701002) $1971 \$ 600$

Survival of Food Crops and Livestock in the Event of Nuclear War (CONF 700909) $1971 \$ 900$

Bıomedical Implicatıons of Radıostrontıum Exposure (CONF 710201) $1972 \$ 600$

Radiation Induced Voids in Metals (CONF 710601) $1972 \$ 900$

Clinical Uses of Radionuclides Critical Comparison with Other Technıques (CONF 711101) 1972 $\$ 1360$

Interactive Bibliographic Systems (CONF 711010) $1973 \$ 760$

Radionuclide Carcınogenesis (CONF 720505) $1973 \$ 1360$

Carbon and the Biosphere (CONF 720510) $1973 \$ 1060$

Technology of Controlled Thermonuclear Fusion Experiments and the Engineerıng Aspects of Fusion

Reactors (CONF 721111) $1974 \$ 1660$

Thermal Ecology (CONF 730505) $1974 \$ 1360$

The Cell Cycle in Malignancy and Immunity (CONF 731005) $1975 \$ 1360$

Mammalian Cells Probes and Problems (CONF 731007) $1975 \$ 760$

Cooling Tower Environment-1974 (CONF 740302) $1975 \$ 1360$

Mıneral Cycling in Southeastern Ecosystems (CONF 740513) $1975 \$ 1360$

Radiation and the Lymphatic System (CONF 740930) $1976 \$ 900$

Atmosphere-Surface Exchange of Particulate and Gaseous Pollutants (1974) (CONF 740921) 1976 $\$ 1360$

Impact of Energy Production on Human Health An Evaluation of Means for Assessment (CONF 751022) $1976 \$ 675$ 


\section{ERDA CRITICAL REVIEW SERIES}

As a contınuing series of state-of the-art studies published by the ERDA Office of Technical Information, the ERDA Critical Reviews are designed to evaluate the existing state of knowledge in a specific and limited field of interest, to identify significant developments, both published and unpublished, and to synthesize new concepts out of the contributions of many.

\author{
SOURCES OF TRITIUM AND ITS \\ BEHAVIOR UPON RELEASE \\ TO THE ENVIRONMENT \\ December 1968 (TID 24635) \$600 \\ D. G. Jacobs \\ Oak Ridge National Laboratory

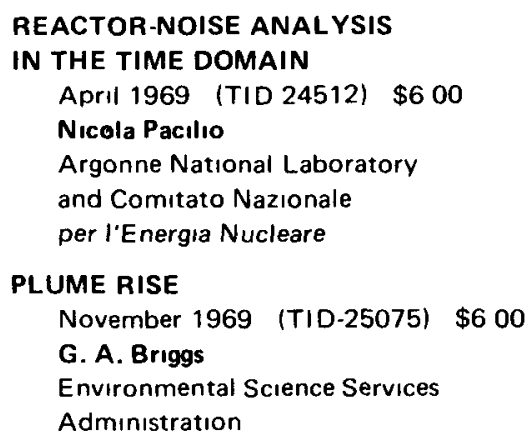

\section{ATMOSPHERIC TRANSPORT PROCESSES}

Elmar R. Reiter

Colorado State University

Part 1. Energy Transfers and Transformations December 1969 (TID 24868) \$600

Part 2 Chemical Tracers January 1971 (TID 25314) $\$ 600$

Part 3: Hydrodynamic Tracers May 1972 (TID-25731) $\$ 300$

\section{THE ANALYSIS OF}

ELEMENTAL BORON

November 1970 (TID 25190) $\$ 300$

Morris W. Lerner

New Brunswick Laboratory

\section{AERODYNAMIC CHARACTERISTICS OF ATMOSPHERIC BOUNDARY LAYERS \\ May 1971 (TID-25465) \$300 \\ Erich J. Plate \\ Argonne National Laboratory and Karlsruhe University}

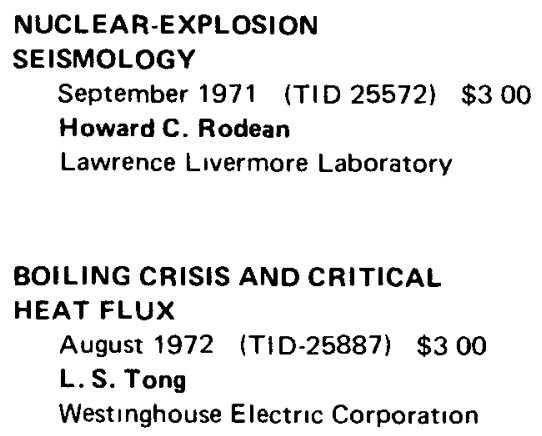

THE KINETICS OF THE OXIDATIONREDUCTION REACTIONS OF URANIUM, NEPTUNIUM, PLUTONIUM, AND AMERICIUM IN AQUEOUS SOLUTIONS

August 1975 (TID-26506) $\$ 545$

T. W. Newton

Los Alamos Scientifıc Laboratory, University of Calıfornıa

\section{PARTICLE-TRANSPORT SIMULATION WITH THE MONTE CARLO METHOD October 1975 (TID-26607) \$545 L. L. Carter and E. D. Cashwell \\ Los Alamos Scientific Laboratory}

\author{
THE CHEMISTRY OF AMERICIUM \\ October 1976 (TID-26971) $\$ 6.00$ \\ Wallace $W$. Schulz \\ Atlantıc Rıchfield Hanford Company
}

Avallable from the National Technical Information Service, U. S. Department of Commerce, Springfield, Virginia 22161. (For foreign price add $\$ 2.50$ per publication.) 